
D

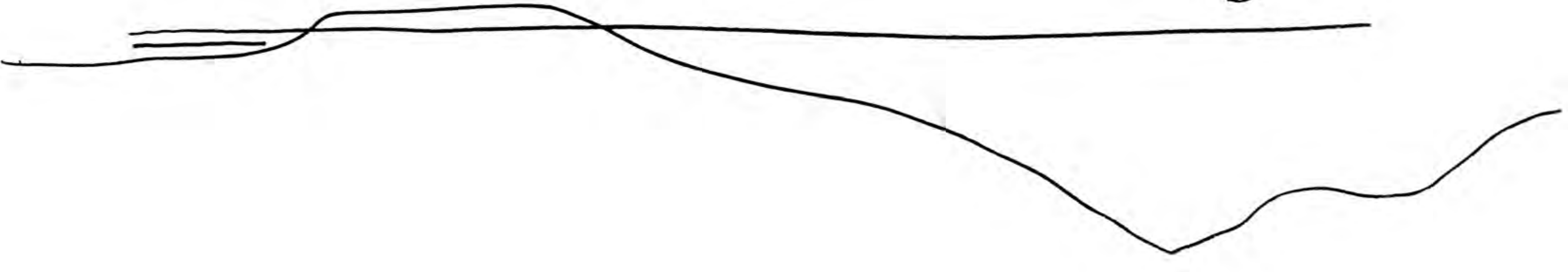


DESENHO E ESPAÇO CONSTRUIIDO: 


\section{RELAÇÕES ENTRE PENSAR E FAZER NA OBRA DE PAULO MENDES DA ROCHA}

TESE APRESENTADA A FACULDADE DE ARQUITETURA E URBANISMO DA UNIVERSIDADE DE SÃO PAULO PARA A OBTENÇÃO DO TITTULO DE DOUTOR EM ARQUITETURA E URBANISMO.

ÁREA DE CONCENTRAÇÃO:

HISTÓRIA E FUNDAMENTOS DA ARQUITETURA E DO URBANISMO

SÃO PAULO, FEVEREIRO, 2013.

EXEMPLAR REVISADO E ALTERADO EM RELAÇ̃̃O À VERSÃO ORIGINAL, SOB RESPONSABILIDADE DO AUTOR E ANUÊNCIA DO ORIENTADOR.O ORIGINAL SE ENCONTRA DISPONIVEL NA SEDE DO PROGRAMA.

SÃO PAULO, 28 DE JULHO DE 2013. 
PESQUISA, DESDE QUE CITADA A FONTE.

email: catheotondo@yahoo.com

Otondo, Catherine

O87d Desenho e espaço construído: relações entre pensar e fazer na obra de Paulo Mendes da Rocha / Catherine Otondo. - São Paulo, 2013.

$$
\text { XXX p. : il. }
$$

Tese (Doutorado - Área de Concentração: História e Fundamentos da Arquitetura e do Urbanismo) - FAUUSP.

Orientadora: Ana Maria de Moraes Belluzzo

1. Arquitetura moderna - Brasil 2. Desenho arquitetônico 3. Criação artística 4. Espaço (Estética) 5. Rocha, Paulo Archias Mendes I.Título 
PARA MEUS AMORES,

JORGE THOMAS, MARTIN E ANDRÉ 


\section{AGRADECIMENTO}

O espírito de trabalho em equipe sempre foi uma marca do ensino na FAU-USP, porém nunca pude imaginar que este sentido de coletividade fosse estar tão presente na elaboração de uma tese - que na minha imaginação era um trabalho feito predominantemente "em solidão". Por isso, meus primeiros agradecimentos vão para esta escola, de todos nós, que me permitiu conhecer e conviver com tantas pessoas especiais.

Gostaria de agradecer à Ana Belluzzo e à Paulo Mendes da Rocha. À Ana por sua orientação firme, corajosa, generosa, me apontou caminhos que eu não sabia existir. À Paulo Mendes da Rocha que literalmente me entregou a chave de seu escritório, me permitiu vasculhar suas gavetas e arquivos, e sobretudo, pelas nossas conversas distraídas pela tarde afora.

À banca de professores presentes nas qualificações: Prof. Dr. Arnaldo Martino; Prof. Dr. Carlos A.F. Martins, Prof. Dr. Luis Antônio Jorge e Prof. ${ }^{a}$ Dr. ${ }^{a}$ Regina Prosperi Meyer. Ampliaram os horizontes deste trabalho.

Aos professores das aulas de pós graduação, em especial: Prof. Dr. Agnaldo Farias, Prof. Dr. José Tavares Lira, Prof. Dr. Júlio Katinsky; Profa. Helena Ayoub, Prof. Dr. Marcos Acayaba, Profa Dr. ${ }^{a}$ Mônica Junqueira e Prof. Dr. Rafael Perrone.

À Sophia Telles, pela entrevista concedida, e pela iniciativa de abrir um espaço de estudos onde pudéssemos encontrar colegas pra refletir sobre os caminhos do nosso fazer.

Aos meus sócios, queridos, Jorge Pessoa e Marina Grinover que dividem comigo os sabores e dissabores desta profissão. E à equipe Base 3 que faz do nosso dia à dia uma grande diversão: Bhakta Kpra, Cadu Marinho, Fabiana Faroni, Fernando Túlio, Juliana Teixieira, Julie Trickett, Lívia Marquez, Marinho Velloso, Matheus Tonelli, Otavio Sasseron, Paula Saad, Patrícia Mieko, Rebeca Grinspum, Regis Sugaya, Thais Marcussi.

Aos amigos e colegas pelo apoio e afeto: Ana Paula Pontes, amigos da "Base Seis", Caio Faggin, Carolina Gimenez, Didiana Prata, Guilherme Pianca, Guilherme Wisnik, João Sodré, José Paulo Gouvêa (em especial pela parceria nas publicações), Juliana Braga, Marcella Faria, Martin Corullon, Martin Kohler, Michel Gubeissi, Milton Braga, Pedro Kok, Ricardo Bak Gordon, Silvio Oksman, Vinicius Andrade.

ÀDulcinéia CarmoPereiraeàElianeRamos Alves,zelosasguardiãsdoacervodeprojetosdePMR.

À Carla Zocchio pelo lindo projeto gráfico e à Nina Jacomini pela leitura atenta e correção ortográfica.

E à família pelo amor incondicional. À Teresa, mãe, que me fez conhecer o mundo das letras, e ao Bernard, pai, que me ensinou que a vida é uma aventura! 
Title: "Drawing and constructed space: The relationship between conception and production in the work of Paulo Mendes da Rocha".

This work presents a reflection on the formation of the architectonic work, based on the study of projects from the architect Paulo Mendes da Rocha's collection, aiming to relate two instances of the creative process: drawing and constructed space.

The act of drawing has been historically connected to the creative, technical, and institutional development of the architectonic craft. A drawing can be understood as a depository of multiple characteristics: mental and figurative, and it is present in various moments of the elaboration of an architectural project.

The study on Paulo Mendes da Rocha's work suggests a revision of the traditional concept of drawing applied to architecture schools, and it makes us search for new meanings for the complexity of the architectonic craft. Here, the drawing is connected to an ideation; it is a privileged instance where the action of the project's concept is materialized.

The direct examination of the works puts us face to face with the constructed space reality, and obliges us to elaborate new questions: how does the architect work with the matter, the technique and the program determinations? In other words, "how" does he become conscious or give shape to his thoughts?

The selected projects gathered in this research allow us to elaborate, from new parameters, an alternative comprehension to Paulo Mendes da Rocha's works, and they are at the same time associated with the continuous narrative that permeates his path, from the late 1950 s to the present time. 
O presente trabalho apresenta uma reflexão sobre a formação da obra arquitetônica a partir do estudo do acervo de projetos do arquiteto Paulo Mendes da Rocha, buscando relacionar duas instâncias do processo criativo: desenho e espaço construído.

A atividade de desenhar está historicamente aliada ao desenvolvimento criativo, técnico e institucional do fazer arquitetônico. O desenho pode ser entendido como algo que contém múltiplas naturezas: mental e figurativa, e está presente em vários momentos da elaboração de um projeto de arquitetura.

O estudo da obra de Paulo Mendes da Rocha sugere uma revisão do conceito tradicional de desenho aplicado às escolas de arquitetura, e nos leva a buscar novos sentidos para o desenho no fazer projetual, como um modo de alargar a percepção sobre o processo criativo, que traduz a complexidade do fazer arquitetônico. Aqui, o desenho está ligado à ideação, trata-se de uma instância privilegiada sobre a qual se materializa a ação do pensamento projetual.

O exame direto das obras nos coloca frente à realidade do espaço construído, e nos obriga elaborar novas perguntas: como o arquiteto opera com as determinações da matéria, da técnica e do programa? Por meio de quais ações projetuais o arquiteto transforma o espaço? Enfim, "como" ele toma consciência ou dá forma a seu pensamento?

As obras escolhidas para compor este trabalho permitem construir uma compreensão alternativa à obra de Paulo Mendes da Rocha a partir de novos parâmetros, e ao mesmo tempo se associam à narrativa contínua que percorre toda sua trajetória de trabalho, desde o fim dos anos 1950 até os dias de hoje. 


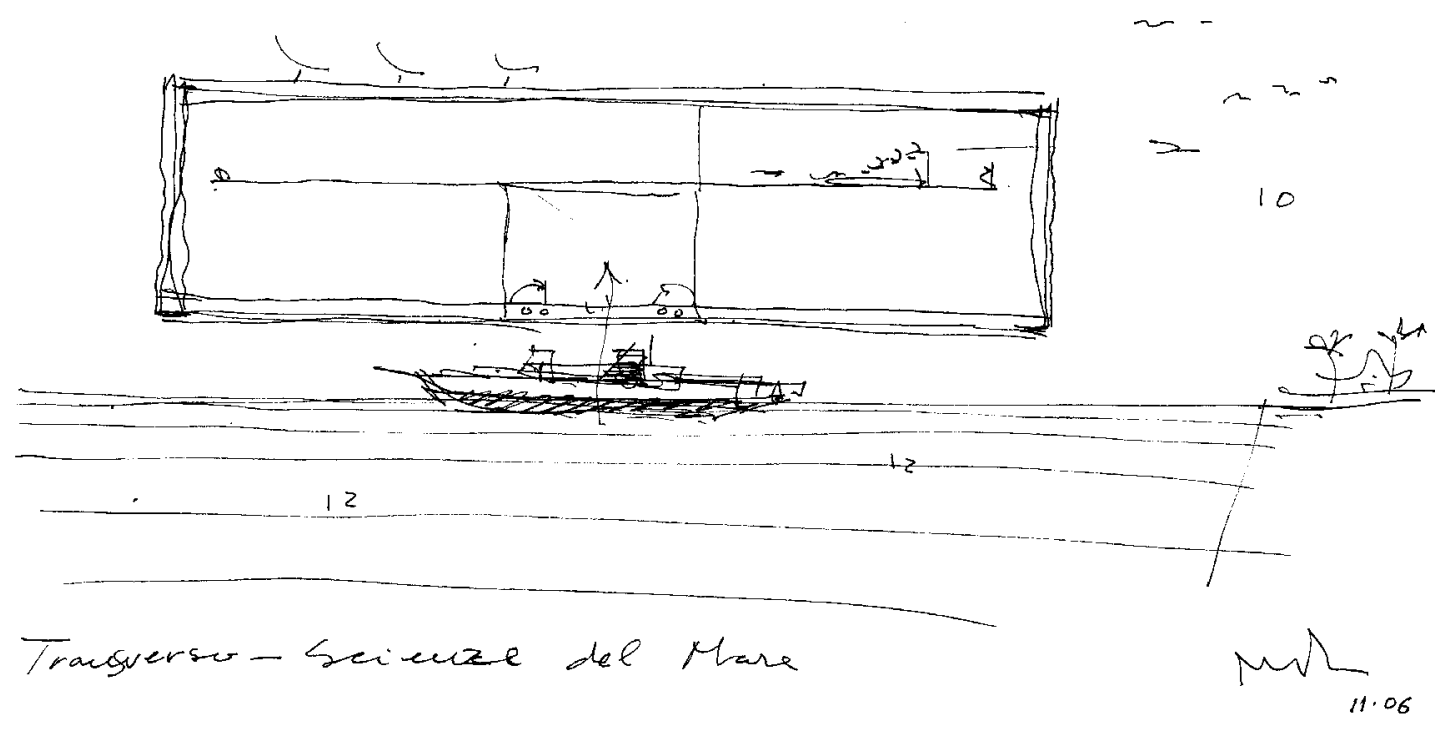

2006 - CENTRO DE CONVENÇÕES E SECRETARIA DO MAR (ERSU) CAGLIARI, SARDENHA, ITÁLIA 


\section{SUMÁRIO}

I INTRODUÇÃO

1.1 CORPUS: ABRINDO GAVETAS ................................................................................................... 16

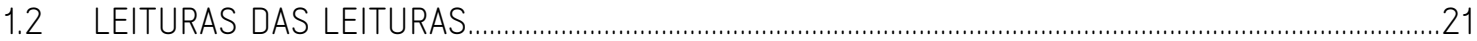

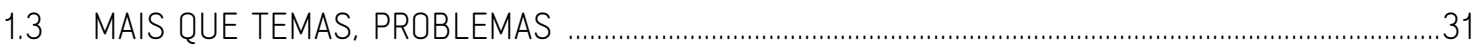

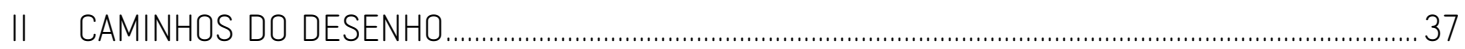

1958

GINASIO DO PAULISTANO: DESENHO DO EDIFÍCIO ……................................................................ 57

IV $1964-1970$

CASA BUTANTÃ E CASA MILLAN: O DESENHO DO LOTE ........79

4.1 CASA: ABRIGO DAS RELAÇÕES HUMANAS ……............................................................................8

4.2 FORMAR PELO CAVAR........ 90

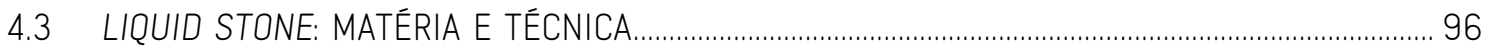

V $1974-1998$

CASA JUNQUEIRA E POUPATEMPO ITAQUERA: DESENHO DA CIDADE .........................................127

5.1 CASA JUNQUEIRA ............130

5.2 POUPATEMPO ITAQUERA

VI 2000-2008

CAIS DAS ARTES E MUSEU NACIONAL DO COCHES: O DESENHO DO TERRITÓRIO_.................167

6.1 CAIS DAS ARTES, VITORIA …………............................................................................... 174

6.2 MUSEU DOS COCHES, LISBOA …………................................................................................182

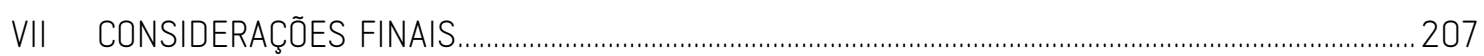

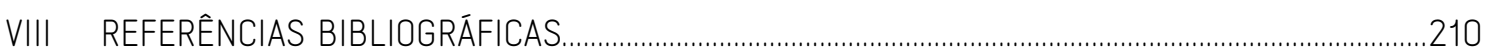

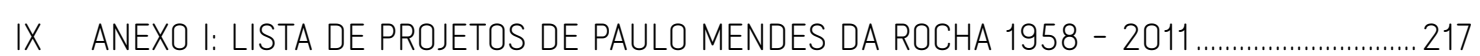





\section{INTRODUÇÃO}

SENNETT, Richard. O Artifice. São Paulo, Ed Record, 2009.

ibidem, p. 17 (grifo meu)

ibidem, p. 12
No recente livro de Richard Sennett, $\mathrm{O}$ artifice ${ }^{1}$, o autor inglês explora a tese do fazer como pensar. A partir da observação do trabalho do artífice, representado na narrativa ora por um cozinheiro ora por um luthier ou um arquiteto, Sennett revê a premissa da superioridade da cabeça sobre a mão na civilização ocidental e busca colocá-la em questão; tendo como teoria de partida a divisão política entre os homens definida por Hannah Arendt em A condição Humana.

Segundo a antropóloga alemã, também mestre de Sennett, nós, seres humanos, vivemos organizados em duas dimensões: a primeira delas ligada à tarefa de produzir coisas (Animal laborens) e a segunda, à tarefa de julgar e discutir o processo de produção (Homo faber), sendo evidente para Arendt a relação de superioridade da segunda sobre a primeira. Segundo o autor, estamos habituados a uma forma de vida tal que: “Enquanto o Animal laborens está fixado na pergunta 'Como?', o Homo faber pergunta 'Por quê?' É esta relação com o fazer que os distancia.

Arendt ilustra sua tese descrevendo como exemplo o processo de invenção da bomba atômica. Os técnicos que desenvolveram a bomba atômica em 1945, o fizeram aplicando de forma mais eficaz as leis da física. No entanto, foram os políticos americanos que, durante a Guerra Fria, vislumbraram o uso dessa arma como forma de opressão e destruição das nações inimigas ${ }^{3}$. Assim, segundo Arendt, a mente se ativa somente após o trabalho realizado; os engenheiros americanos não tiveram a dimensão da potência política daquilo que estavam construindo, a ideia de usá-la como opressão política nunca esteve presente no trabalho de concepção da bomba.

Contudo, para Sennett, esta divisão proposta não é satisfatória e lhe parece "falsa"; implica numa desigualdade, já que imputa ao Animal Laborens a incapacidade de pensar. Para o autor, pelo contrário, há pensamento no fazer, seja pela consciência do artesão quanto às possibilidades e virtudes de seu material de trabalho, seja pela convivência entre aprendizes em uma mesma oficina.

A partir de tal questionamento, sugere então um caminho intermediário para o entendimento da divisão das atividades sociais do homem, algo mais "equilibrado", onde “(...)o pensamento e o sentimento estão contidos no processo do fazer" ${ }^{4}$. 
Ao valorizar as atividades manuais, o autor aproxima cabeça e mão, o mundo das ideias e o mundo da ações e conclui que: “ (...) podemos alcançar uma vida material mais humana, se pelo menos entendermos como são feitas as coisas." 5 .

As atividades manuais, ainda segundo Sennett, fazem parte de nossa cultura material, e podem dizer muito a nosso respeito. A habilidade de fazer bem as coisas não é privilégio do artesão, personagem que praticamente desaparece no mundo industrial ocidental. Ela está no impulso, no desejo de fazer coisas de modo que cabeça e mão estejam relacionadas, quer seja um violino, um programa de computador ou um delicioso frango assado!' Para Sennett, o bom artífice "sustenta um diálogo entre práticas concretas e ideias; esse diálogo evolui para o estabelecimento de hábitos prolongados, que por sua vez criam um ritmo entre a solução de problemas e a detecção de problemas" .

O raciocínio que vamos adiante desenvolver está de acordo com esta visão. Pretendemos estudar a contribuição de Paulo Mendes da Rocha ${ }^{8}$, considerando que o modo como o arquiteto projeta e constrói revela seu pensar. Nosso interesse se fixa, portanto, em duas instâncias: desenho e espaço construído.

Quando iniciei o estudo sobre a obra de PMR, visava focalizar a singularidade de seus projetos e acreditava ser possível encontrá-la a partir de seu desenho particular. Razão pela qual, na primeira parte da pesquisa, nos dedicamos ao estudo da linguagem da arquitetura que compõe o acervo de projetos, localizado no seu escritório.

Ao final desta etapa, percebemos o valor e a função própria que o desenho ocupa em seu processo criativo. Notamos também o modo pelo qual o desenho atua neste processo, como não se encaixa nas atribuições comumente dadas ao desenho nos manuais de arquitetura. Descobrimos novos valores em seu particular ato de desenhar, que não eram levados em consideração. Daí a nova pergunta: o que move o desenho?

Para tanto, foi preciso ampliar nossa bibliografia a fim de atualizar conceitos que aprofundassem a noção de desenho, pois não era possível entendê-lo apenas como representação de um objeto a ser construído. Desenhar supõe pensar, é meio de manejar o espaço. O desenho pode nascer intuitivamente, ser posto a serviço da necessidade de articular diversas dimensões de um projeto e pode ser resposta ao desejo de movimento.

5 ibidem, p. 18

6 ibidem, p. 20

7 ibidem, p. 20

$\mathrm{O}$ autor continua a frase exemplificando que: "A relação entre a mão e a cabeça manifesta-se em terrenos aparentemente tão diferentes quanto a construção de alvenaria, a culinária, a concepção de um playground ou tocar violoncelo...”

8 A partir deste momento iremos abreviar o nome Paulo Mendes da Rocha com as iniciais: PMR 
9 JOBIM, Antonio Carlos “Corcovado" 1963

10 Refiro-me aos arquitetos que também foram ganhadores do Premio Pritzker: Norman Foster, Renzo Piano, Frank O. Ghery. Ao contrário destes, o arquiteto PMR mantém uma vida bastante "espartana":" não possui celular, site, carro...
Para nós, arquitetos contemporâneos cuja prática se desenvolve cada vez mais longe da prancheta e perto do computador, é importante compreender que o desenho tem um valor que caracteriza e determina o pensamento espacial do arquiteto, e por isso, seja ele feito à mão ou pela máquina, é necessário ter em mente a proeminência deste valor.

Não caberia fazer aqui um contraponto extenso entre mão x máquina, nem entraremos no mérito das diferenças entre obras de arquitetura realizadas a partir de desenhos feitos à mão ou digitais. Interessa compreender por hora que o uso de programas digitais na elaboração de projetos de arquitetura estabelece uma outra possibilidade de conceber espaços, e outro suporte para o pensamento.

Aquilo que podemos depreender por enquanto é que o ato de desenhar à mão permite ao arquiteto rever, reinventar e repensar sua ideia, em uma experiência onde mente e mão se relacionam diretamente, fisicamente. Um processo dinâmico que parece ter o tempo a seu favor. Um tempo que passa, um "tempo para sonhar”, e "muita calma para pensar"

Nos dias de hoje, o arquiteto PMR trabalha em um escritório “enxuto”, sem equipe de projetistas e sem computadores. Realiza poucos projetos ao mesmo tempo, o que lhe permite estabelecer uma relação próxima com a produção de cada um deles. Tem uma rotina de vida que em nada se assemelha à de seu pares contemporâneos, dos ditos arquitetos do "star system"10. Não se trata porém de imprimir-lhe uma imagem romântica do artífice, enaltecida por Sennett, do arquiteto que desenha solitário num canto escuro de seu ateliê.

É um arquiteto que desenvolve suas ideias num primeiro momento por meio de desenhos feitos à mão livre sobre papel manteiga ou elaborando maquetes de papel, outros suportes da mediação entre mente e mão: o momento preciso da concepção propriamente dita. Quando julga ter chegado a uma primeira síntese do projeto, PMR apresenta suas ideias à equipe de arquitetos que efetivamente irá desenvolver o trabalho. O desenho passa a desempenhar, então, um papel de comunicação entre os membros da equipe; tem uma função social, ele é a base da transmissão de informação, passa por ajustes, mudanças até vir a se realizar na obra construída.

Podemos perceber por este modo de trabalhar uma dupla natureza do desenho: uma no momento de concepção e outra de socialização da informação. Em seu livro Why architects draw (1994), o antropólogo americano Edward Robbins afirma que a 
complexidade da função do desenho de arquitetura manifesta-se por sua extraordinária habilidade de ser suporte material, que implica na criação e ao mesmo tempo na produção social do trabalho ${ }^{11}$.

Concordarmos com esta ideia: um desenho de arquitetura pode ter duas ou mais naturezas, o que importa esclarecer, então, é sobre qual delas estamos trabalhando.

Aqui, o desenho está ligado à ideação, projeção. Trata-se de uma instância privilegiada sobre a qual se materializa a ação do pensamento projetual.

Com o desenvolvimento dos estudos foi também possível compreender como o arquiteto atua sobre o espaço e como o espaço age sobre o arquiteto. Quer dizer: como a memória do espaço também faz parte de sua experiência, como mede o espaço com sua dimensão corporal, como reage às diferenças de luz e sombra e apreende assim, a escala do lugar.

O exame direto das obras nos coloca frente à realidade do espaço construído, e nos obriga a elaborar novas perguntas: como o arquiteto opera com as determinações da matéria, da técnica e do programa? Por meio de quais ações projetuais o arquiteto transforma o espaço? Enfim, "como" ele toma consciência ou dá forma a seu pensamento?

\section{1 - CORPUS: ABRINDO GAVETAS}

O extenso trabalho de estudo e documentação do acervo de desenhos de PMR situa o ponto de partida dessas reflexões. Além do convívio direto com o arquiteto e familiaridade com seus registros e notações - de grande valor para nosso trabalho -, pudemos gerar a produção de um arquivo de obras que foi apresentada em regime de mestrado, criando a oportunidade para o prosseguimento dos estudos em regime de doutorado.

Percebemos desde o início do levantamento que esta separação física dos arquivos tinha uma relação direta com o tipo de suporte e material gráfico de cada projeto, seja em termos cronológicos ou em termos de grau de seu desenvolvimento: os estudos e croquis estão nas gavetas, os projetos executivos, por serem mais volumosos em número de pranchas, estão nos tubos e os projetos mais recentes estão no

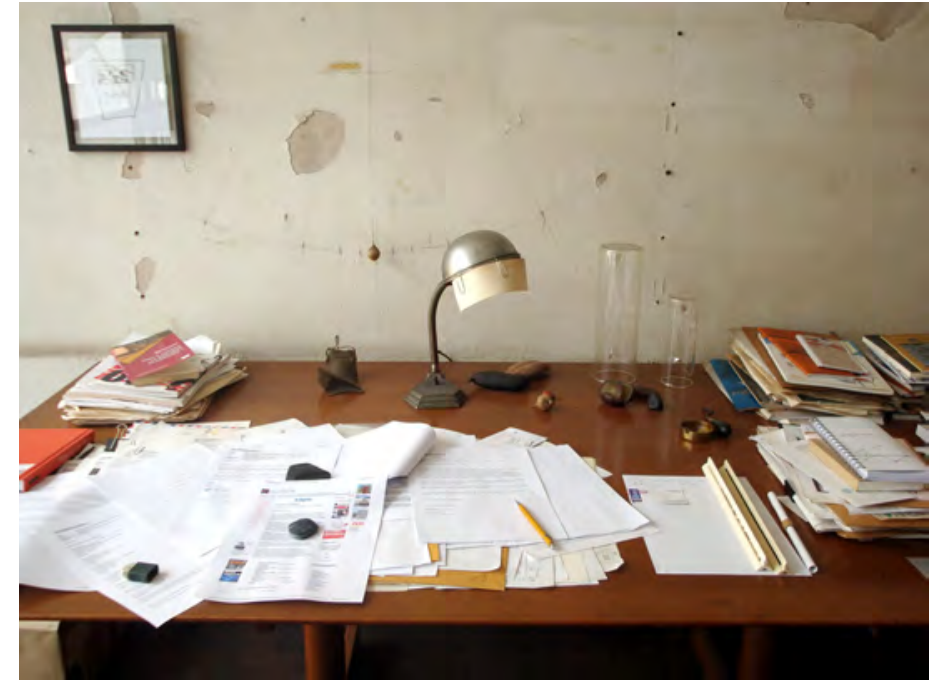

FIG. 01

MESA DE TRABAHO
11 ROBBINS Edward. Why architects draw. Cambridge: MIT Press, 1994. Nesta publicação o autor faz uma extensa pesquisa em onze escritórios de arquitetura contemporâneos sobre como o desenho "serve" à produção de projetos. A partir de perguntas como: "qual a função do desenho no processo de concepcão do desenho?; como e quando você desenha?; qual são os diferentes papeis que o desenho desempenha em relação a diferentes interlocutores tais como: engenheiros, clientes, apresentações publicas?(...)". Apesar do foco de sua pesquisa estar ligado aos diferentes modos da produção social do trabalho do arquiteto - um pouco distante do nosso propósito aqui - vale destacar a leitura dos capítulos referentes aos arquitetos Álvaro Siza e Renzo Piano. 
computador.

Constatamos que a estrutura de trabalho dentro do escritório de PMR sempre foi a mesma desde os primeiros anos de profissão: a equipe de arquitetos e estagiários variava de acordo com o volume de trabalho, os projetos eram desenvolvidos no escritório coordenados por PMR e João Eduardo de Genaro ${ }^{12}$. Primeiramente, o escritório ficava em uma sala alugada no edifício Conjunto Nacional na Avenida Paulista e em 1973, mudou-se para o edifício do IAB-SP ${ }^{13}$, onde está até hoje. A partir de 1974, a administração do escritório e catalogação dos projetos passou a ser feita de forma primorosa por Dulcinéia do Carmo Pereira, que é quem sabe até hoje onde tudo está.

Os projetos de grande escala, feitos até o início da década de 1990, estão bem guardados em tubos de papelão. São, na maioria, trabalhos que chegaram à fase de Projeto Executivo ou de projetos de escala que não foram construídos: Faculdade de Antropologia e Sociologia(1962), por exemplo, ou concursos, como Clube da Orla (1963). São, portanto, desenhos técnicos feitos em papel manteiga ou vegetal, à lápis e à nanquim.

Pudemos observar que as pranchas dos projeto executivos são bastante "limpas”, com poucas informações escritas, poucas cotas, uma marcação destacada dos eixos da estrutura, e uma clara preferência pelo desenho nas escalas menores ${ }^{14}$ e por detalhes em escala 1:1; todos feitos de maneira primorosa, revelando o rigor do arquiteto, inclusive na apresentação dos seus projetos.

O cuidado dispensado aos pormenores construtivos é uma característica dos projetos elaborados por PMR. O cuidado com as dimensões das peças de um guarda corpo, o fechamento das janelas, o pivô da porta. Enfim, trata-se de um arquiteto que tem prazer em desenvolver esses pequenos engenhos. Entretanto podemos considerar também, que no final da década de sessenta e durante a década de setenta a indústria da construção não estava tão desenvolvida como hoje, e era necessário desenhar tudo ${ }^{15}$.

Como se sabe, no ano de 1969, PMR teve seus direitos civis cassados pelo go-

12 O arquiteto João Eduardo de Genaro foi sócio de PMR entre os anos de 1958 a 1964.

13 IAB- SP: Instituto de Arquitetos do Brasil - Departamento de São Paulo, localizado na Vila Buarque região central da cidade.

14 O Projeto Executivo da casa Gerassi está desenhado em sete pranchas A1, com plantas na escala 1:25, poucas cotas e algumas indicações escritas. Ver publicação: Revista 1:100 n ${ }^{\circ}$ 45, Buenos Aires, 2008.

15 Era comum encontrar nos primeiros trabalhos vários detalhes construtivos 1:1, pregos, buchas e parafusos estão desenhados primorosamente à lápis, com as ranhuras representadas em uma delicada hachura vermelha. verno militar. O termo de cassação o proibia de lecionar na FAU e também de trabalhar para órgãos públicos. Existem dois paradoxos nesta questão que merecem ser destacados.

O primeiro é que PMR foi cassado no mesmo momento em que ganhou o concurso para o Pavilhão de Osaka, que seria a sede representativa do país na Exposição 
Internacional do Japão. Diante do constrangimento de ter o autor do projeto - que representaria o Brasil na Exposição - privado de seus direitos civis, o Governo Federal "acertou” os tramites necessários e PMR pôde viajar em segurança para o Japão com um passaporte diplomático, a fim de desenvolver o trabalho junto a uma equipe de arquitetos e engenheiros locais ${ }^{16}$.

O segundo paradoxo vem do fato de que mesmo durante os duros anos da ditadura, PMR realizou projetos importantes, inclusive para o poder público, sempre com a ajuda de amigos que estabeleciam parcerias a fim de viabilizar a participação do arquiteto nas concorrências. Ao analisarmos a lista de projetos ${ }^{17}$, veremos que de 1957 a 1970, PMR realizou 53 projetos e que de 1970 a 80, realizou 55, dos quais 22 eram encargos públicos.

Contudo, o que parece uma contradição, pode ser explicada nas palavras do arquiteto César Shundi, em sua dissertação de mestrado sobre a rodoviária de Jaú de Vilanova Artigas:

De um lado, se encontravam os interesses dos arquitetos e urbanistas, que há muito buscavam possibilidades de atuação de maior amplitude, realizando projetos públicos no âmbito da cidade. De outro, a necessidade dos governantes do país naquele instante, agindo pela mão forte da ditadura militar, em demonstrar avanços e realizar projetos. ${ }^{18}$

A partir dessa convergência de interesses, PMR, bem como Artigas, pôde realizar grandes projetos durante a década de 1970, como: Escola Jardim Calux (1972), Estádio Serra Dourada (1973) e CECAP Itatiba (1975).

Mesmo assim, os efeitos da cassação foram devastadores para a trajetória desses arquitetos, que devido a essa interrupção forçada, realizaram bem menos trabalhos do que suas capacidades produtivas permitiam.

Como meio de continuar trabalhando, PMR realizou diversos projetos residenciais: dos 272 projetos listados até agora, 62 são de residências, dos quais 26 apenas elaborados na década de 70.

Quando o arquiteto se refere aos projetos das casas unifamiliares, como veremos no capítulo IV, pondera que uma cidade contém na sua gênese a ideia do coletivo e, para tanto, a casa urbana é o edifício vertical, pois seria um absurdo pensar que todos os habitantes da cidade poderiam construir sua casa em um pedaço particular de terra. Assim, quando PMR afirma: “(...) como se as casas, no âmbito da cidade,

16 O projeto completo das formas e protensões foi realizado por uma equipe de engenheiros japoneses, a partir do pré-cálculo feito pelo engenheiro brasileiro Siguer Mitsutani. Os desenhos deste projeto executivo, em japonês estão guardados em tubo no escritório.

17 Ver Anexo 1.

18 IWAMIZU, César Shundi. A estação rodoviária de Jaú e a dimensão urbana da arquitetura. FAU-USP, São Paulo, 2008. p 142. 
19 Memorial de titulação FAU-USP, 1998. p. 2

20 Os escritórios e respectivos coordenadores que desenvolvem projetos atualmente para PMR são: Pedro Mendes da Rocha Arquitetos/Arte 3: Pedro Mendes da Rocha; MMBB: Ângelo Bucci (1996-2002),Fernando Mello Franco; Marta Moreira e Milton Braga; Piratininga: José Armênio Cruz; Escritório Paulistano de Arquitetura: Eduardo Colonelli e Silvio Oksman; Metro: Martin Corullon.

21 WISNIK, Guilherme. "Entrevistas con los estúdios colaboradores de Paulo Mendes da Rocha". Revista 2G. Revista 2G, n 45. Barcelona: Editorial GGili, 2008.p. 138 [Tradução minha]. fossem pedras de uma catedral da Idade Média (...)" ${ }^{\prime 19}$, parte da ideia de que a cidade se constitui a partir do desejo primordial do homem em morar ali, coletivamente, desfrutando da diversidade e imponderabilidade da vida urbana.

Nesse sentido, o desenho da casa urbana deve contemplar os recursos oferecidos pela cidade, e não mimetizá-la em uma escala privada.

Na década de 1980, com a abertura política, o arquiteto reorganiza seu escritório e realiza uma série de projetos que se tornaram emblemáticos em sua trajetória. Foi um período de intenso trabalho, mas também de profundas mudanças no ambiente intelectual no qual o arquiteto estava inserido. Trata-se de um momento de passagem, de transformação no pensar e fazer de PMR. O capítulo V contempla a reflexão sobre estas mudanças.

Em meados dos anos 1990, ao ser contratado para fazer a reforma da Pinacoteca do Estado, PMR desenvolve o projeto no canteiro de obras, onde passa grande parte de seu tempo. Nesse momento, os demais trabalhos que estavam em andamento no escritório eram de pequeno porte: projetos museográficos, cenários para teatro e para atendê-los, mantém uma equipe reduzida em seu escritório.

Em 1993, quando volta a trabalhar no escritório, ao fim da obra da Pinacoteca, encontra-se justamente no momento da troca da prancheta pelo computador.

$\mathrm{O}$ arquiteto toma a decisão consciente de não equipar seu escritório com tais tecnologias, dispensa sua equipe e passa a desenvolver seus projetos com escritórios parceiros - escritórios formados por ex-alunos e colaboradores antigos, como Eduardo Colonelli, do escritório Ricoy Torres, e Jose Armênio Cruz do Piratininga ${ }^{20}$ com os quais estabelece uma relação duradoura, cuja base é uma afinidade intelectual e uma proximidade geográfica, pois estão quase todos localizados na mesma rua da cidade. Segundo Jose Armênio: "A associação entre Paulo e seus colaboradores é, essencialmente, uma associação de ideias, uma construção do pensamento que se produz através das obras"21.

O escritório no IAB passa a ser então um lugar de estudo, leitura, reuniões, e onde o arquiteto recebe seus clientes, alunos e amigos visitantes.

Há com isso, sem dúvida, uma mudança estrutural na maneira como os projetos são desenvolvidos. Eles não ficam mais grudados na prancheta durante semanas, expostos ao olhar de seu autor, passam a ser feitos fora, nos escritórios de seus colaboradores, longe da presença diária de PMR. No entanto, os primeiros estudos de cada trabalho continuam a ser elaborados por ele sobre sua prancheta. 
A transformação na estrutura de produção do trabalho tem sim um reflexo na maneira como o arquiteto se relaciona com o mesmo. Primeiramente, há uma diminuição direta do tempo de convívio de PMR com o desenvolvimento do desenho, e também há uma mudança instrumental na hora de corrigir ou afinar o projeto, pois uma coisa é ver o projeto disposto ali na prancheta e outra é sentar ao lado de alguém olhando uma tela de computador ${ }^{22}$.

Outro ponto importante a assinalar, referente aos projetos desenvolvidos fora do escritório, é que "sobra” pouca documentação em papel como resultado desse processo, ao ponto de alguns trabalhos recentes, não terem o registro dos primeiros desenhos elaborados por PMR, o que torna difícil a tarefa de documentação. Sabemos da existência de desenhos feitos pelo arquiteto arquivados em alguns dos escritórios parceiros, mas o trabalho de pesquisa deste material ainda não foi realizado.

Assim, as relações de trabalho entre o arquiteto e os escritórios parceiros estabelecem uma nova instância do fazer. Trata-se ainda de um trabalho em equipe, mas a equipe, por ser de um escritório independente, possui um outro grau de autonomia em relação ao desenvolvimento do projeto. Veremos a seguir como esta relação se dá.

O caminho que o projeto percorre hoje pode ser descrito da seguinte maneira: há uma primeira fase de concepção feita "em solidão" no escritório, com base em modelos tridimensionais e desenhos feitos à mão livre. Nesta fase de concepção já existe um contato com o engenheiro, que dá uma primeira diretriz sobre o tamanho das peças estruturais, dos vãos, e ajusta com PMR como a estrutura vai "trabalhar". Neste momento, a ideia formadora do projeto já está dada.

A próxima fase, o desenvolvimento do projeto, é de certo a mais longa e penosa, pois entram os projetos complementares, os ajustes de orçamento e as modificações solicitadas pelos clientes. Neste momento o projeto está fora do escritório.

Cabe aos colaboradores de PMR coordenar essas acomodações, seguindo uma diretriz dada pelo arquiteto. Podemos verificar que existe uma cumplicidade na resolução dos problemas entre o arquiteto e seus parceiros. Segundo Martin Corullon, a dinâmica de trabalho estabelecida por PMR se assemelha a uma partida de xadrez, pois a cada etapa do trabalho, os arquitetos têm que raciocinar mantendo a tensão da "partida" até o xeque mate, num processo de "ação e reação" 23 .

22 Não podemos afirmar aqui, nem é o objeto deste estudo, se essa esta nova maneira de trabalhar transforma o projetar, e portanto o resultado final da obra arquitetônica.

23 A relação de trabalho entre o arquiteto e seus colaboradores incita vários outros questionamentos que infelizmente não cabem neste trabalho, mas que consideramos fundamental serem feitos. Para um início de pesquisa, indicamos a leitura da entrevista feita por Guilherme Wisnik com a maioria dos colaboradores, publicada na Revista $2 \mathrm{G} \mathrm{n}^{\circ} 45$. 
Podemos indicar então, que todos os projetos realizados posteriormente à finalização do projeto da Pinacoteca (1993) foram desenvolvidos fora do escritório de PMR, e que o arquivo de imagens, desenhos e maquetes está dividido entre o escritório parceiro e o do arquiteto.

\subsection{LEITURA DAS LEITURAS}

O arquiteto Paulo Mendes da Rocha realizou desde 1957 até 2011 aproximadamente, 270 projetos; a maioria deles divulgada em mais de 200 artigos para revistas e jornais brasileiros, 100 estrangeiros, além de 18 livros publicados. Destes livros, sete são monográficos, e somente três são publicações brasileiras.

Os primeiros artigos saíram simultaneamente à realização dos projetos: a cadeira Paulistano (1957) e a divulgação do projeto vencedor do concurso para a Assembleia Legislativa de Santa Catarina, ambos em 1957, pela revista paulista Acrópole $n^{\circ}$ 219 e 232 , respectivamente ${ }^{24}$.

A crítica e reflexão sobre arquitetura, entre as décadas de 1960 e 80 no Brasil, era feita de forma resistente em revistas especializadas, ou seja, haviam poucos livros publicados sobre o assunto, destacando-se as compilações feitas por: Yves Bruan ${ }^{25}$ : (Brasil Builds,1943), Henrique Mindlin (Arquitetura Moderna no Brasil,1956)26, e mais adiante já na década de 80, Marlene Milan Acayaba publicou sua dissertação, Residências em São Paulo (1947-1975)27.

A fim de preencher este vácuo editorial e organizar um material que auxiliasse a pesquisa acadêmica num momento em que a internet não existia, a professora Sophia da Silva Telles, junto à Faculdade de Arquitetura PUC de Campinas, fez entre os anos 1989-91 uma compilação de artigos sobre os arquitetos, Paulo Mendes da Rocha, Joaquim Guedes e Lina Bo Bardi. Este árduo trabalho consistiu em agrupar e reproduzir em xérox, artigos de jornais e revistas, nacionais e internacionais, e organizá-los em ordem cronológica. Sobre PMR, foram feitos dois volumes contendo mais de 150 artigos publicados entre 1957 e 1990. Durante muitos anos esta era a fonte mais completa de documentos sobre o arquiteto que se dispunha.

Curiosamente, o primeiro livro publicado sobre a obra de PMR foi realizado por uma editora estrangeira, a espanhola GGigli: Mendes da Rocha (1996), de autoria do crítico e historiador Josep Maria Montaner, em coautoria com Maria Isabel Villac. A relação completa das publicaçoes sobre a obra de PMR, separadas por
data e tipo de mídia, consta do Trabalho Programado 2 "O estado da questão" entregue à FAU-USP em 2009.

25 No livro de Bruand, estão publicados os seguintes projetos de PMR: Ginásio do Clube Paulistano, Residência Gaetano Miani, Residências no Butantã e Edifício Guaimbê.

26 O livro de Mindlin não publica nenhum projeto de PMR.

27 Estão publicadas no livro de Marlene Acayaba as seguintes obras: Residência no Butantã; Residência James Francis King e Residência Fernando Milan. 
A partir desta data, refletindo um impulso local na edição de livros nacionais sobre arquitetura, houve uma série de publicações sobre vários arquitetos, protagonistas de nossa cultura, que ainda não tinham sido devidamente "publicados". Vale destacar a série realizada pelo Instituto Pietro e Lina Bardi, conjuntamente com a editora Blau: Lina Bo Bardi (1993), Vilanova Artigas (1997), Affonso Reidy (2000), Lelé (2000).

Neste contexto, no ano 2000, surge a primeira monografia "completa” sobre a obra de PMR, realizada pela editora Cosac Naify, organizada por Rosa Artigas, com os projetos escolhidos pelo próprio arquiteto e três textos fundamentais escritos pelo mesmo.

Segue a esta publicação, o livro organizado pela professora suíça Annette Spiro, no qual apresenta uma ampla seleção de projetos (trinta e sete) e uma pequena análise do conjunto de realizações de PMR que não se atém a nenhum projeto em especial, mas cujo interesse está no modo como a autora localiza este conjunto a partir de uma visada europeia, sob a ótica da tradição clássica, apoiada nos estudos do crítico e historiador inglês Colin Rowe ${ }^{28}$.

Os trabalhos acadêmicos complementam e aprofundam temas levantados nas publicações e nos artigos de revistas ${ }^{29}$. Podemos identificar dois conjuntos de trabalhos acadêmicos: o primeiro que tem como foco principal a obra de PMR, como é o caso dos trabalhos de Ruth Verde Zein (2000), Maria Isabel Villac (2000) e Denise Solot (2004); e um segundo grupo no qual os projetos entram como exemplo de um tema mais amplo, como os trabalhos de Ivana Peters (2000), Myrna Arruda (2002) e Leandro Shenk (2004).

Desse conjunto, interessa-nos destacar os trabalhos do primeiro grupo. Em Ruth Verde Zein, o foco está no estudo historiográfico da formação e definição da Escola Paulista Brutalista entre os anos de 1960 e 70; para Maria Isabel Villac - que realiza sua tese em Barcelona - há uma busca da inserção da obra de PMR num contexto mais amplo, a cultura brasileira; e finalmente Denise Solot, um trabalho voltado para análise de obra - sob a orientação de Ronaldo Brito -, no qual elege a questão da técnica como tema de ligação entre as obras analisadas.

A seguir descreveremos cada um deles para situar nosso trabalho frente ao conjunto.

O trabalho de Ruth Verde Zein nos interessa na medida em que a autora propõe uma narrativa que busca encontrar um sentido para a Arquitetura Moderna local a

28 O texto de Annette Spiro nos intrigou particularmente por seu ponto de partida inusitado, procurando encontrar paralelismos entre os procedimentos projetuais de PMR e a tradição clássica. Por este motivo e por se tratar de um livro pouco acessível a nós, decidimos traduzir seu texto publicado na revista PÓS - Revista do Programa de Pós-Graduação em Arquitetura e Urbanismo FAUUSP. $n^{\circ} 25$, junho 2009.

29 Através da busca nas bibliotecas da USP, internet e no escritório do arquiteto, pudemos identificar 12 teses e dissertações cuja temática está direta ou indiretamente ligada a arquitetura de PMR; apenas quatro destas foram produzidas na Universidade de São Paulo. Não são muitas se compararmos ao número de trabalho registrados de outros arquitetos próximos, como: 15 sobre a obra de Lina Bo Bardi e 28 de Vilanova Artigas, para citar apenas alguns. 
30 ibidem, p. 384.

31 Segundo Hélio Piñon: "Não importa desmentir uma e outra vez, em suas escassas mas penetrantes confissões, aqueles que tratam de identificar essa produção como brutalismo que entrou para historia ha trinta anos...com o qual a conjuntura comercial procura compensar duas décadas de exibicionismo pós-modernista."

PIÑÓN, Helio. Paulo Mendes da Rocha, 2002. p. 13 partir da inauguração de Brasília, que identifica como sendo um momento de ruptura no desenvolvimento da arquitetura moderna no Brasil. Segundo a autora, a produção da Escola Paulista é o elo entre este momento de ruptura e o presente. Esta produção começa a realizar-se em meados da década de 1950 e teria se consolidado como escola na década seguinte, expandindo-se na década de 70. Para Ruth Zein, a obra de PMR é exemplar desse processo, pois passa por todos os momentos históricos discutidos em seu trabalho.

Desta maneira, a autora divide seu trabalho em duas etapas: na primeira, define as características e atributos da Escola Paulista e sua aproximação com o termo brutalista, relacionando aspectos formais, materiais, construtivos e discursivos. E no segundo momento, detém-se na compreensão desse período da história através da análise dos projetos residenciais de PMR, que segundo ela, congregam "alguns dos caros temas à Escola Paulista”.

A partir da comparação entre obras selecionadas para estudo, são estabelecidas características formais, espaciais e construtivas comuns a esta arquitetura que denomina Escola Paulista Brutalista. São realizações que têm como qualidade comum a preferência por blocos únicos destacados do chão, procura pela horizontalidade, e uso da estrutura em concreto armado protendido, "valorizando sua qualidade de manufatura" 30 .

Sobre as dificuldades de encerrar os termos desta escola, ou definir mais precisamente o que seria Escola Paulista Brutalista, Ruth Zein aponta três aspectos: o primeiro é que seus protagonistas não se reconheciam como parte de uma "escola"; o segundo, que esses arquitetos preferiam que suas obras fossem valorizadas pelos seus aspectos éticos, sociais e políticos, em detrimento das suas características formais e construtivas; e finalmente, por que tais arquitetos se expressavam mais através de suas obras que através de textos.

Ao definir o nome da Escola Paulista como brutalista, a autora dá um passo na contramão de muitos historiadores, e de autores como Helio Piñón e Rosa Artigas, por exemplo, que não aceitam o adjetivo brutalista, cuja origem vem da produção arquitetônica inglesa, para daquele conjunto de produções ${ }^{31}$.

Vale então destacar que vamos aceitar esta terminologia com reservas, pois não havia a rigor o projeto de constituição de uma escola, nem de um movimento ou manifesto. O termo Escola aqui pode ser entendido pelas afinidades de um proceder 
comum de arquitetos, que na sua maioria estavam relacionados à FAU-USP e mais particularmente, ao arquiteto Vilanova Artigas.

Tampouco podemos generalizar o termo Paulista, atribuído a um conjunto de realizações de um grupo particular de arquitetos. Porém, quando nos referimos à Escola Paulista somos capazes de reconhecer certo proceder projetual comum, com aparência estética das obras associadas ao uso do concreto bruto e aparente ${ }^{32}$, e sobretudo um procedimento projetual que se diferencia da arquitetura moderna carioca.

O trabalho de Maria Isabel Villac parte de outra preocupação, apesar de percorrer o mesmo caminho historiográfico que o trabalho de Ruth Zein. Villac aponta a construção da cidade de Brasília (1960) como o momento de ruptura de um movimento arquitetônico que se inicia com a chegada de Le Corbusier ao Rio de Janeiro em 1929 e com construção do Ministério de Educação e Saúde (1931).

Novamente, a Escola Paulista parece apresentar uma saída para o impasse histórico colocado pelo silêncio dos críticos diante da constatação da impossibilidade de Brasília servir de modelo para a arquitetura moderna e para a resolução dos conflitos sociais e culturais do país. Para a autora, a "Escola Paulista inaugura um laboratório construtivo de uma arquitetura adequada à realidade do país”33.

Sua tese admite a possibilidade da estruturação de um modelo de análise de obra cujo suporte seria a "mirada crítica" do sujeito em relação ao objeto. Nesta postura, daria-se a ação do arquiteto por meio de "arquitectogramas", entendidos como sendo a reunião de um conjunto de estratégias adaptáveis, procedimentos de transformação da natureza e um sistema de significados. Nas suas palavras: "a obra arquitetônica atualiza ritos, celebra gestos criadores e reitera criações exemplares" ${ }^{34}$. Para cada obra analisada, a autora busca encontrar procedimentos projetuais enquanto escolhas formais, estruturais e materiais. E sua análise também se estende quanto a inserção dessas obras em nossa cultura, relacionando-as com as vanguardas artísticas dos anos 1960 e com a tropicália.

O texto de Denise Solot, é elaborado a partir da análise de obra com enfoque na relação entre arte e técnica e, por conseguinte, na relação entre forma e estrutura. $\mathrm{O}$ argumento historiográfico descrito pela autora se assemelha ao das demais pesquisas, em que os arquitetos paulistas desenvolvem uma arquitetura em contraponto à de Brasília, uma arquitetura na qual as relações sociais e políticas estão voltadas para uma cidade que se faz a partir do pensamento coletivo.

Em sua opinião, o aspecto bruto dessa nova arquitetura vem da influência de Le

32 O Eng. ${ }^{\circ}$ Figueiredo Ferraz ( 1918-1994) ; e o Eng..$^{\circ}$ Roberto Zuccolo (1924-1967) foram os principais responsáveis pela introdução do uso do concreto protendido no país. Sobre, Zuccolo, PMR afirma: " ele foi um ilustre engenheiro do século XX, indispensável para todo o desenvolvimento das técnicas construtivas do país. Ele foi uma espécie de Eugene Freyssinet." In ROCHA, Paulo Mendes da. Encontros com Paulo Mendes da Rocha. p. 222.

33 VILLAC, Maria Isabel.p 8. Original em espanhol, tradução minha.

34 Ibidem, p. 75. Original em espanhol, tradução minha. 
35 A autora apresenta oito projetos num recorte que tem início na obra do Ginásio do Paulistano e termina na Praça do Patriarca.
Corbusier, não mais aquele que visitou o Brasil por primeira vez em 1929, mas aquele da capela Ronchamp (1955) e da Unidade de Marselha (1952). Por isso, a proximidade com o brutalismo inglês se daria pelo discurso, mais que pela plasticidade das obras.

Cada uma das obras escolhidas ${ }^{35}$ por Solot ilustra o encadeamento de sua narrativa, que oscila ora entre leituras mais próximas ao mundo das artes, ora ao mundo da técnica. E é sobre a discussão em torno deste último que o trabalho se destaca, pois a autora, como professora de escolas de engenharia, realiza explicações técnicas dos projetos bastante detalhadas.

Diante disso, podemos considerar que a nossa hipótese de trabalho sobre a obra de PMR complementa e amplia o conjunto de teses acadêmicas, na medida em que nos dispomos a apresentar um conjunto de reflexões sobre o fazer criativo do arquiteto PMR, com base no desenho e na experiência do espaço construído, que entendemos não ter sido o foco dos trabalhos apresentados até então.

Apesar da importância bibliográfica das teses descritas acima, foram alguns ensaios direcionados à análise de obra que se tornaram relevantes para a base teórica da presente tese.

O modo pelo qual autores como Flavio Motta, Sophia da Silva Telles e Guilherme Wisnik se aproximam das obras de PMR nos interessam, seja pelo modo como confrontam essa particular produção arquitetônica com outras disciplinas, tais como as artes plásticas, a filosofia e a música; seja pela precisão e clareza das ideias formuladas e ancoradas na experiência da obra. Com destaque, ainda, ao lirismo das frases curtas e poéticas do professor Flavio Motta, cujos ensaios analisaremos aqui com maior demora.

Consideramos que esses ensaios configuram um conjunto de ideias alinhadas, que podem ser compreendidos de forma relacional: aquilo que Motta estabelece como base ideal para a compreensão da obra de PMR nos anos 1970, Sophia Telles amplia nos anos 90 e Wisnik atualiza para nossos dias. Apesar da distância cronológica que separa os três autores, encontramos alguns pontos de tangência entres os textos, os quais procuraremos descrever a seguir.

O professor Flávio Motta escreveu dois ensaios específicos sobre a obra de PMR: "Paulo Mendes da Rocha"(1967), no qual faz um análise da Casa Butantã e “Arquitetura Brasileira para a Expo '70” (1970), onde reflete sobre o sentido cultural de um pavilhão brasileiro em Osaka. Com uma narrativa sintética, lança a base do 
que seria a reflexão crítica sobre a obra de PMR para as próximas décadas, inaugurando de maneira quase "visionária" o modo de considerar a arquitetura de PMR: descrevendo relações entre construção, natureza e técnica, e indagando o sentido do espaço arquitetônico como o lugar das relações humanas.

É reconhecida a proximidade intelectual e afetiva que existe entre Flavio Motta e PMR, iniciada nos tempos em que ambos eram professores da FAU_USP. Trata-se de uma relação de troca de ideias tão intensa que por vezes ao ler frases escritas pelo professor Motta, podemos achar que já ouvimos PMR dizer a mesma coisa ${ }^{36}$. Ao longo do tempo, conceitos levantados por Motta foram incorporados ao modo de pensar de PMR, como forma de explicar seu próprio trabalho.

O primeiro texto escrito por Flavio Motta, "Paulo Mendes da Rocha”, foi publicado em 1967 pela revista Acrópole e em 1973, em coletânea organizada pelo próprio autor, Textos Informes, publicada pela FAU-USP ${ }^{37}$.

Flávio Motta inicia seu argumento localizando o trabalho de Paulo Mendes em relação aos dois grandes mestres: Niemeyer e Artigas ${ }^{38}$. Afirma que o prestígio $\mathrm{da}$ arquitetura brasileira (da época) tira o foco da verdadeira função da arquitetura moderna, que não significava apenas uma modernização dos meios, mas uma ampliação do sentido do projeto em relação à sociedade e à natureza. Neste caso, a relação com a natureza não seria de domínio nem de subordinação, seria referencial, ou seja, o espaço criado pelo arquiteto é capaz de estabelecer o modo como nos relacionamos com o mundo ao nosso redor.

Sugere que a casa, portanto, seria o abrigo das relações sociais, com espaços "pessoais e impessoais". Trata-se de um lugar meio "favela racionalizada", que exige do seu morador uma nova maneira de viver, onde um aceita o convívio com o outro. Com isso, para Flavio Motta, o arquiteto concebe um espaço que se realiza pela experiência do viver: "É a proposta que pede resposta, por que é trabalho criador com sua implícita responsabilidade social”"39.

A partir daí vemos que Flavio Motta entende que o espectador participa da obra e não a contempla de longe; o espectador é parte fundamental do espaço, é ele quem lhe dá vida, dimensão, profundidade.

Flavio Motta supõe que a relação entre homem e objeto deva ser transformadora, dinâmica, cíclica. E finalmente, alerta para os perigos da "coisificação da vida", onde o objeto existe sem a projeção do homem: “...se os arquitetos, por reflexão, por experiência, por lá não se sabe mais o que, não se dispuserem realmente a projetar,
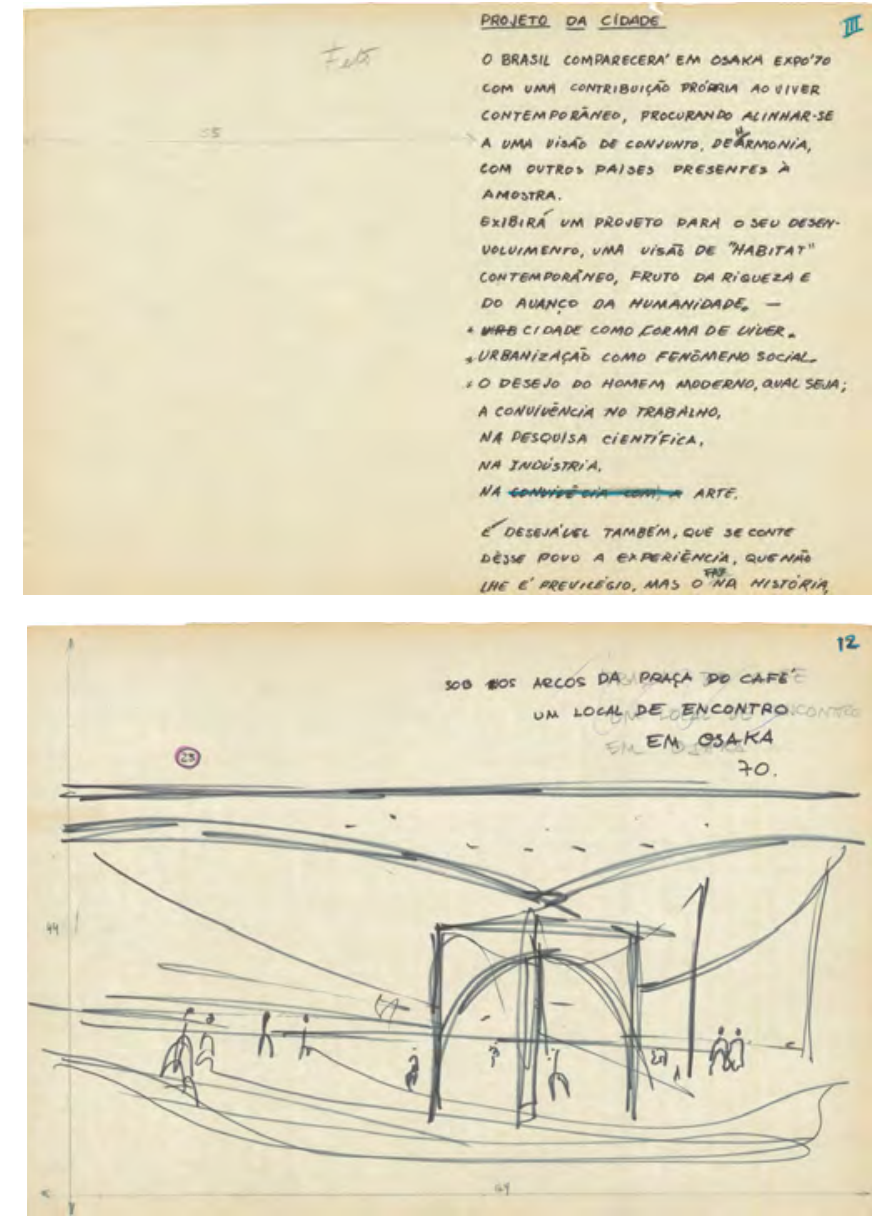

1970: PAVILHÃO DE OSAKA

DESENHO DE FLAVIO MOTTA, PARA O PROJETO MUSEOGRÁFICO DO PAVILHÃO ORIGINAL EM PAPEL MANTEIGA E CANETA HIDROGRÁFICA

36 Frequentemente o arquiteto menciona uma leitura que fez por indicação de Motta: Projeto e Utopia (1973) de Manfredo Tafuri, por exemplo.

37 FAU-USP: Faculdade de Arquitetura e Urbanismo da Universidade de São Paulo.

38 “(...)PMR encontrou em Niemeyer a tônica do confronto Arquitetura-Natureza, e em Artigas, Arquitetura- Sociedade." MOTTA Flávio. "Paulo Mendes da Rocha" in Textos Informes. São Paulo: FAU-USP, $2^{a}$ edição ampliada, 1973.p. 20.

39 ibidem, p. 21 

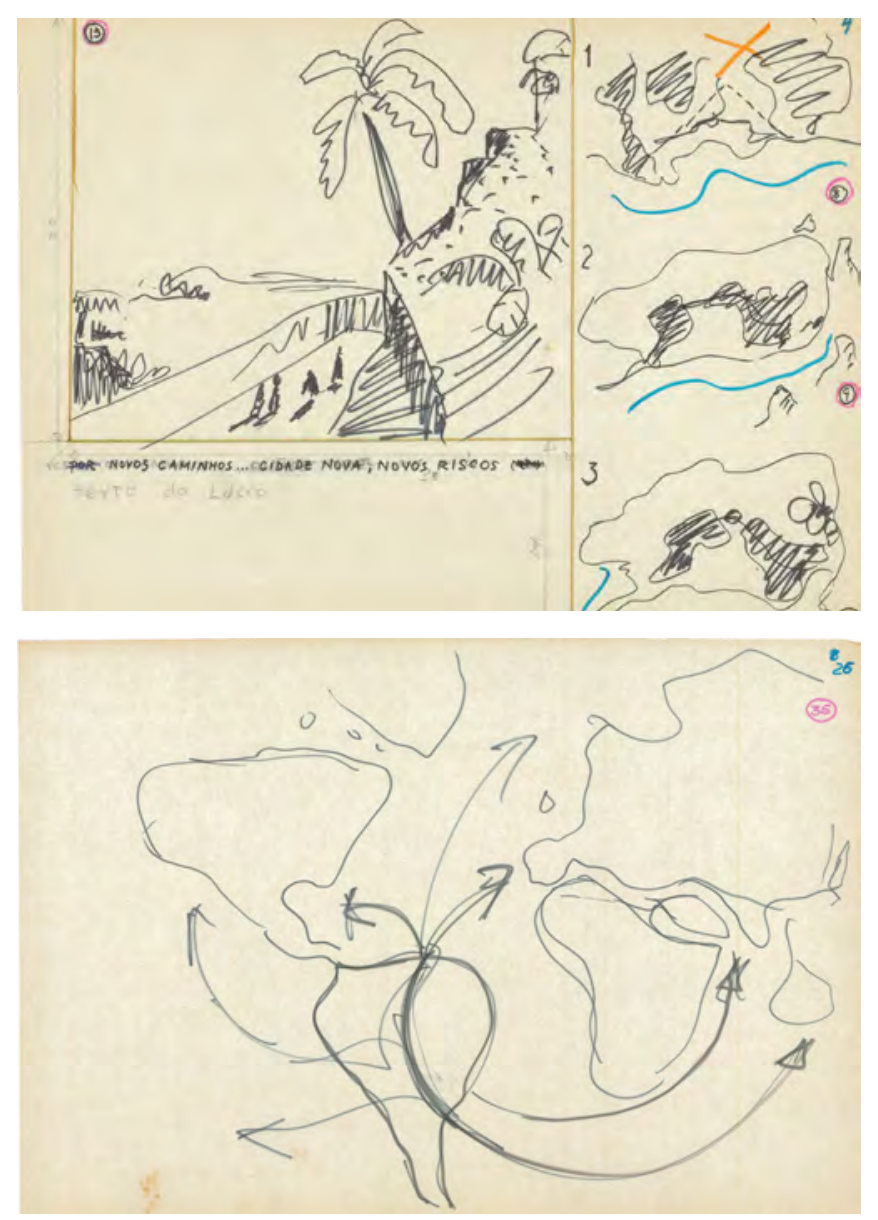

O DESENHO ACIMA REFERE-SE À UM PROJETO DESENVOLVIDO POR UMA EQUIPE DE ENGENHEIROS DA ESCOLA POLITÉCNICA DA UNIVERSIDADE DE SÃO PAULO, DO QUAL PARTICIPOU O PAI DE PMR: PAULO DE MENEZES MENDES DA ROCHA - CUJA PROPOSTA ERA CONSTRUIR UMA SERIE DE CANAIS FLUVIAIS ENTRE RIOS QUE CONSTITUIRIAM UMA CONEXÃO ENTRE AS BACIAS AMAZÔNICA E DO PRATA, POSSIBILITANTO A CRIAÇÃO DE UMA SEGUNDA COSTA BRASILEIRA. estamos destinados a viver em espaços cheios de coisas e vazios dentro de um "modus vivendi que pouco resta de "vivendi"” 40 .

No texto “Arquitetura Moderna para Expo' 70”, publicado na revista Acrópole e nos Textos Informes, Motta se preocupa em localizar o projeto do pavilhão para Osaka dentro de um quadro de realizações da arquitetura moderna estabelecido por Lucio Costa, Oscar Niemeyer e Vilanova Artigas, o que possibilitou a compreensão dessa arquitetura como representante da produção do país em uma feira internacional.

Antes de prosseguir com nossa reflexão, é preciso destacar que Flávio Motta teve participação ativa no projeto do pavilhão, não como arquiteto membro da equipe, mas como idealizador do projeto museográfico da exposição. "Em uma tarde", como nos conta PMR, Motta desenhou com canetas hidrográficas mais de 60 pranchas em formato A2, nas quais dispôs um panorama da cultura brasileira, abrangendo as artes plásticas, urbanismo, engenharia e arquitetura.

Para o autor, o Pavilhão não era apenas um envoltório para abrigar as "mercadorias” brasileiras, mas a representação de um conhecimento acumulado, contextualizado, que pudesse se colocar de forma universal e fraternal em relação aos edifícios vizinhos.

Em nenhum momento do texto, Motta se atém aos aspectos plásticos do pavilhão, ao contrário, diz que a construção não deve ser vista como um objeto de exuberância, exibicionista, dada sua técnica construtiva, mas algo que "constrói e amplia o conhecimento do homem e do mundo com o qual ele se faz, e por isso mesmo, também faz" ${ }^{\prime 4}$.

Visivelmente, a estrutura do pavilhão é imponente: pela grande cobertura de concreto armado e aparente ("como a FAU", segundo PMR), apoiada de um lado numa elevação ondulada do próprio terreno e de outro, em dois arcos entrelaçados. De modo poético, Motta conta, por exemplo, que a função dos arcos da Praça do Café não é ser mero apoio dos esforços mecânicos da laje de cobertura, constituem um lugar de convivência e a memória da beleza dos arcos na história da arquitetura.

A análise do autor destaca a importância do piso do pavilhão ser o mesmo asfalto de Osaka, que entra no espaço interno tornando-se nas palavras de Motta: “um caminho ininterrupto e sem barreiras, que ainda está na esperança de muitos (...). O chão acolhe suavemente o caminhante, e de maneira leve e delicada, a cobertura de concreto nervurada pousa sobre o terreno ondulado(...)"42. 
Entendemos que Motta decifra o sentido dessas formas e sua organização no tempo e no espaço com precisão e sabedoria . Como menciona bem Ana Belluzzo na seguinte passagem:

Sabe, como ninguém, considerar a obra de arte e ao penetrá-la em profundidade, como filósofo, desperta a sensibilidade e a reflexão de muitos interessados que não faltam ao seu redor (...) prepara sabiamente a perplexidade do observador diante da obra. Ele é capaz de torná-la um campo de indagações, detonadora de dúvidas e instigadora de novas vivências ${ }^{43}$.

Parece-nos inegável que o pensamento de Motta resistiu ao tempo e foi capaz de inspirar e amparar os estudos que vieram posteriormente, como é o caso dos ensaios que apresentaremos a seguir.

No início da década de 90, a autora Sophia da Silva Telles publica dois ensaios críticos fundamentais: "Museu da Escultura visto por Sophia Telles" (1990), no qual faz uma profunda análise de obra sobre o Museu da Escultura; e "A casa no Atlântico” (1995) uma introdução à seção Documento da Revista AU.

Nestes artigos, Sophia Telles recoloca a obra de PMR em discussão, após os anos silenciosos da ditadura, num momento de transição histórica, no qual estava posta em questão a retomada ou não da experiência da arquitetura moderna dos anos 1960 ou a aderência à novos caminhos. E quais seriam esses?

Segundo a autora nem a experiência pós-moderna (europeia e americana), nem o esforço do historiador Kenneth Frampton de valorizar arquitetura regionais foram ideias discutidas ou avaliadas no ambiente da arquitetura brasileira na época:

“... a crítica ao movimento moderno não se sustentaria se reduzida ao comentário maneirista (...) [enquanto] o regionalismo crítico, ideia corrente de Frampton ${ }^{44}$, só poderá ser instigante se compreendida no espectro amplo da cultura e não como simples atenção às condições objetivas da arquitetura. ${ }^{25}$.

Segundo Sophia, a obra de PMR possui um “rigor intimista”, próprio, por exemplo, da bossa nova, num tom rebaixado, menos monumental. Apesar da urgência dos compromissos políticos que contribuíam para a severidade dos projetos de arquitetura ligados à FAU_USP nos anos 1970, a obra de PMR escapa à polarização

43 BELLUZZO, Ana Maria M. "Falar em Flávio Motta é pensar em arte". Revista Caramelo 6 . São Paulo, FAU_USP, 1993. - p. 48.

44 Kenneth Frampton (1930), crítico e historiador inglês, estabelece o termo "regionalismo crítico é uma categoria que compreende a produção arquitetônica contemporânea a partir de valores universais, porém identificando seus vínculos com as realidades cultural, política e econômica onde são produzidas.

FRAMPTON, Kenneth. Modern Architecture, a critical history. Londres: Thames and Hudson, 1985.

45 TELLES, Sophia. "Museu Brasileiro da Escultura ". AU Arquitetura e Urbanismo, 1991. p. 51. 
46 Refiro-me a polarização que mobilizou a reflexão e produção arquitetônica da FAU USP nos anos $70 \mathrm{em}$ torno dos meios de produção da profissão do arquiteto. Um grupo de arquitetos cuja figura proeminente era Sergio Ferro defendia a ideia do arquiteto se envolver com a produção efetiva d construção. Para um conhecimento mais aprofundado da questão ver:

ARANTES, Pedro Fiori (org.) Sérgio Ferro: arquitetura e trabalho livre. São Paulo: Cosac Naifyy, 2006

47 TELLES, Sophia. "Museu Brasileiro da Escultura ", 1991 p. 50.

48 ibidem, p. 46

49 Imaginamos que neste ponto a autora esteja se referindo aos projetos elaborados por Le Corbusier a partir dos anos 1940 como a Unidade de Marselha (1947) e a capela de Ronchamp (1955).

50 Ao longo deste trabalho, realizei vários encontros com Sophia Telles. Percebi que muitas de suas ideias ecoavam em minha pesquisa, e que muitas delas eram desdobramentos de hipóteses colocadas em textos anteriores, ainda não publicados. Assim, decidi gravar uma pequena entrevista,durante a qual levantei três pontos de discussão que me pareciam importantes para o estudo da obra de PMR, e que precisavam ser registrados pela "voz" de Sophia Telles.

A primeira pergunta versa sobre as diferenças de uso do concreto bruto e aparente por arquitetos modernos; a segunda, sobre os conceitos de natureza, paisagem e território na obra de PMR; e finalmente, a última, sobre a relação entre arquitetura e a construção de cidades.

Diante do resultado, surgiu o interesse em publicar esta entrevista, mas isso ainda não foi feito. Portanto, sempre que me referir a algum trecho da entrevista, citarei: "Conversas com Sophia Telles". colocada entre canteiro e desenho ${ }^{46}$, e se traduz por uma relação mais afetiva em relação à história e à natureza. Retoma, assim, uma linha de pensamento proposta nos ensaios de Flavio Motta sobre o Pavilhão de Osaka.

A partir dessa reflexão, Sophia Telles coloca a obra de PMR em um outro lugar para a análise, mais independente em relação à obra de Vilanova Artigas, mais afastado dos rígidos pressupostos políticos, e “isento dessa culpa do canteiro" 47 .

Desta forma, a obra de PMR se caracteriza, segundo a autora, pelo modo singular pelo qual estabelece relações entre natureza e técnica, espaço e matéria, entre objeto construído e superfície do terreno. O Museu da Escultura se faz, segundo Telles, por uma sucessão de planos horizontais sobre um eixo vertical, configurando uma continuidade superficial entre interior e exterior: “O projeto destrói (...) a primeira impressão, a de uma superfície estática sobre a qual um objeto vem pousar." ${ }^{48}$. Num raciocínio distinto ao de Artigas e Niemeyer, que estabelecem a linha do horizonte como o lugar da tangência dos pontos de apoio.

Para compreender o modo como o arquiteto opera esta relação entre objeto e terreno, a autora destaca a importância da leitura corte transversal do Museu da Escultura, onde se vê a extensão do chão da rua para dentro do espaço interior. Deste modo, Sophia Telles elabora uma ideia que se torna chave para a compreensão da obra de PMR: a implantação de seus projetos no terreno se dá pela manipulação do desenho em corte e não pela planta.

Pudemos entender então, que na obra de PMR não existe a separação entre volume e superfície, como ocorre na obra de Niemeyer por exemplo, mas há uma extensão de planos constituindo uma unidade espacial ininterrupta.

Um último ponto que nos interessa destacar no texto de Sophia refere-se ao uso do concreto enquanto matéria bruta e aparente. Segundo a autora, PMR recupera o uso do concreto num sentido mais próximo à Le Corbusier (pedra bruta) ${ }^{49}$, portanto, de um modo distinto ao de Niemeyer e Artigas, cuja ênfase residia nas exploração das possibilidades estruturais e plásticas do material. O que interessa a PMR são as propriedades reversíveis do concreto, pelas quais ele pode reafirmar a continuidade espacial que se impõe no modo como ele implanta seus projetos.

Em “Conversas com Sophia Telles” (2010), a autora afirma que o raciocínio projetual de PMR não se faz a partir da junção de partes em vista de um todo, "ele pensa o concreto como uma matéria total" ${ }^{50}$. 
Entendemos, então, que seu raciocínio espacial se estende também para o modo como o arquiteto manipula a matéria, ou seja, não se trata de construir um objeto a partir de seus elementos construtivos (pilar, viga, fechamento), e sim constituir planos cuja função estrutural funde vários atributos em uma só peça: o fechamento da parede se estende até a viga de sustentação, que segue até a calha e se inclina na cobertura. Retomaremos esta ideia no capitulo IV.

O crítico e arquiteto Guilherme Wisnik, retoma as ideias sedimentadas por Sophia Telles e expande sua análise no sentido de fazer uma leitura mais transversal entre as obras, estabelecendo outro nível de relações. Assim, sua análise não se atém às particularidades de um ou outro projeto, como fizeram Flavio Motta e Sophia Telles, mas em uma visão mais geral da trajetória de PMR.

Em seus dois ensaios principais, "Nova cobertura da Praça Patriarca em São Paulo" (2002) $)^{51}$ e “Arquitetura do território" $(2008)^{52}$, seu interesse está em localizar a obra de PMR no mundo contemporâneo, procurando situá-la frente a outros campos do conhecimentos, como a sociologia, a música, as artes plásticas etc., sem se prender com intensidade aos procedimentos projetuais do arquiteto e suas estratégias formais.

O autor possui uma relação próxima ao trabalho de PMR, realizando publicações e escrevendo artigos sobre sua obra. Ao final do ano de 2012, foi curador de uma importante exposição das obras do arquiteto no Museu Vale em Vitória, Espirito Santo, intitulada: "Paulo Mendes da Rocha: a natureza como projeto".

Ao contrário da época na qual Sophia Telles publicou seus artigos, a obra de PMR desfruta nesse momento de uma condição de prestígio nacional e internacional bastante relevante. Isso permite com que Wisnik possa se ocupar de aspectos mais abrangentes da produção arquitetônica, como a relação com a natureza, a degenerescência das grandes cidades, o desequilíbrio natural do habitat humano.

Para Wisnik, a arquitetura de PMR pode ser pensada como uma metadisciplina (e não uma atividade multidisciplinar que busca apoio em outras disciplinas) que condensa vários modos do saber, capaz de formular perguntas sobre o destino das cidades e do homem.

Finalmente, o crítico retoma o binômio indicado por Motta e Telles, sobre as relações entre natureza e técnica. Aqui, natureza tomada não mais como um território natural, desocupado, mas o mundo edificado: "Seja em sitio urbanos, seja em meio à natureza, o projeto se lança como uma infraestrutura técnica que deve suportar uma ampla diversidade de usos, imprevisíveis e cambiantes." ${ }^{\text {33 }}$

51 WISNIK, Guilherme. "Nova cobertura da Praça Patriarca em São Paulo”. In wwrw.vitruvius.com. br, 01/12/2012.

52 WISNIK, Guilherme. “Arquitectura del territorio”. Revista 2G, Barcelona, 2008.

53 ibidem, p. 202. 
O exame desse conjunto de ensaios nos forneceu, então, um repertório conceitual a partir do qual avançaremos desenvolvendo os temas que nos parecem ser chave para nossa análise de obra: compreender o espaço como projeto social, relacionar natureza e técnica, observar a implantação dos projetos de PMR a partir de uma visão particular do território e assumir a cidade contemporânea como realidade edificada a ser reinventada.

\subsection{MAIS QUE TEMAS, PROBLEMAS}

Depois de um longo período mergulhados em gavetas, tubos, caixas e muito pó, no escritório de PMR, pudemos realizar uma primeira tentativa de ordenação crítica dos projetos. Fizemos um longo painel de desenhos no qual os trabalhos foram dispostos em seis categorias temáticas, em linha cronológica: 1958-2008 ${ }^{54}$. A ideia deste painel foi a de poder estruturar visualmente o conjunto de projetos estudados no tempo e no espaço, um panorama, enfim. Os temas surgiram a partir da percepção de diferentes questões tais como, técnica, relações com a cidade, os diferentes usos do concreto e do aço e a diversidade projetual das casas feitas da cidade ou na natureza.

A elaboração do painel foi um momento importante da pesquisa e nos permitiu a visualização de um conjunto amplo de projetos, além de verificar repetições de procedimentos, ver que algumas ideias vão se desenvolvendo ao longo do tempo até finalmente serem construídas.

Mas ao avançarmos na leitura das obras, e no sentido de cada categoria, vimos que nosso olhar escapava às linhas temáticas e se conduzia em movimento transversal a elas. Entendemos então que não era possível compreender a obra de PMR a partir de categorias ou temas, porque seu processo projetual não parte de uma ideia temática, ou de um assunto: a casa, a cidade, o museu, o concreto ou o aço, mas sim de um problema espacial, arquitetônico.

Não se trata também de uma arquitetura de soluções, ou seja, seu projeto não busca resolver problemas, mas apontá-los, pôr em evidência um outro modo de ver a vida, o real. Para Bérgson, tanto na Filosofia como em outras disciplinas, a verdade trata de "encontrar o problema e, por conseguinte pô-lo, muito mais que resolvê-lo ${ }^{55}$ ".

54 Este painel foi apresentado nas bancas de qualificação. Ele foi realizado em papel canson e lápis grafite, mede $1.00 \times 4.50 \mathrm{~m}$ e portanto de difícil reprodução digital. Ao lado uma imagem de um pequeno trecho do desenho.

A partir desta consideração, observamos que a maneira como PMR apresenta 
seus projetos se dá sobre a colocação de um problema, independente da escala, do programa, ou da localização da obra . Ou seja, o que vem primeiro é a pergunta, a questão, o discurso sobre o que fazer de modo oportuno.

O estudo da obra de PMR sugere ainda uma revisão do conceito tradicional do desenho aplicado em escolas de arquitetura, para tanto dedicamos um capítulo para esta reflexão. A análise dos sentidos do desenho não busca fornecer ferramentas operacionais para a análise de obra, mas alargar a percepção do processo criativo, construtivo que traduz melhor a complexidade do fazer arquitetônico.

Trata-se, portanto, de examinar a formação da obra, suas transformações no tempo. O formar. Perceber, enfim, o pensamento espacial de PMR tal como se expressa na arquitetura.

A escolha dos projetos foi feita a partir de dois critérios: o primeiro e mais direto é que os projetos fossem construídos, pois a hipótese desta tese coloca o pensamento e espaço vivido numa relação que demanda sua real verificação. Isso implica em dizer que visitamos pelo menos uma vez cada uma dessas obras.

O segundo critério refere-se ao tempo: pretendíamos com nossa seleção destacar projetos que pudessem de certo modo narrar a trajetória de trabalho de PMR como um todo, do início nos anos 1960 até os dias de hoje .

As sete obras escolhidas são analisadas em quarto capítulos dispostos numa sequência cronológica do Ginásio do Clube Paulistano (1958) até o Museu dos Coches (2008).

Deixamos de lado assim, algumas obras “primas” já bastante analisadas por outros autores, como o Museu da Escultura e a Pinacoteca, pois não nos interessava destacar feitos extraordinários, mas a possibilidade de construir uma narrativa contínua a partir da relação entre as obras, como elas conversam entre si, seus rebatimentos e distanciamentos.

Imaginamos desse modo então,criar uma nova maneira de refletir sobre o pensamento e obra de PMR, sua formação num tempo estendido, procurando perceber movimentos e mudanças, as inquietações e as particularidades do seu processo criativo que as vezes o brilho assertivo de uma obra prima poderia ofuscar.

A compreençao da obra é tecida, portanto, entre o desenho e o espaço construído no qual se sobrepõe o discurso, o exercício retórico que formula conceitos, que vão aderir à fantasia. 


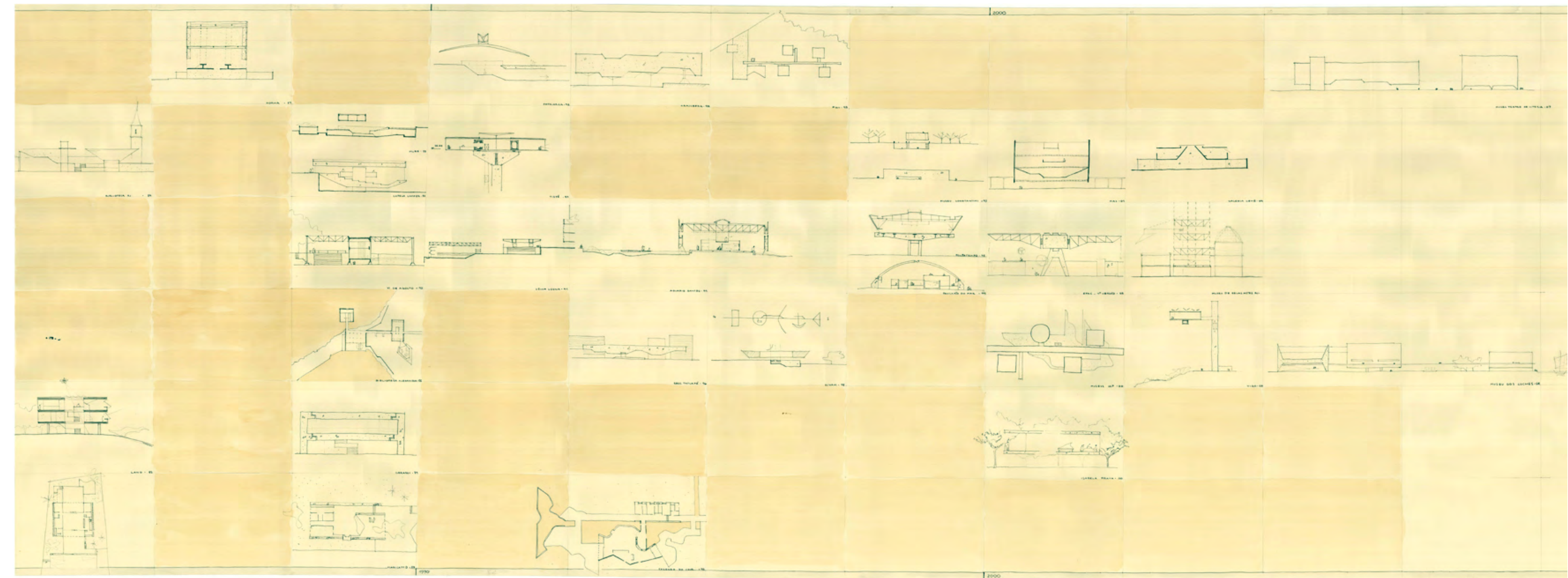

TRECHO DO PAINEL DE DESENHOS RELIZADO EM 2010, EM PAPEL CANSON, GRAFITE E AQUARELA.: 100 X 450 CM. PRIMEIRA TENTATIVA DE SINNTESE NA QUAL DIVIDI OS PROJETOS EM SEIS LINHAS "TEMÁTICAS" NA SEGUINTE ORDEM DE CIMA PARA BAIXO:

MOMENTOS DE INVENÇÃO; CAMINHOS DO CONCRETO; ESTRUTURAS HÍBRIDAS; PARA ALÉM DO LOTE; RESIDÊNCIAS URBANAS. CASAS NA NATUREZA. 



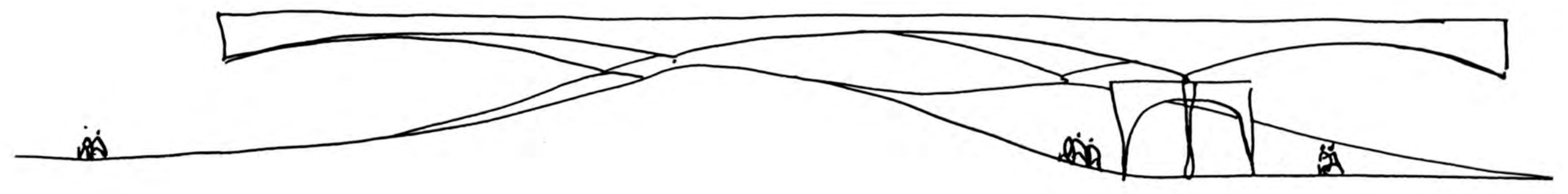





\section{CAMINHOS DO DESENHO}

"Aquilo que conecta pensamento com imaginação, imaginação com desenho, desenho com edificação, edificação com nossos olhos é projeção, ou o processo que escolbemos para modelar esta projeção (...)".

Robin Evans ${ }^{1}$

É com certa naturalidade que podemos relacionar as ações de desenhar e construir no campo da arquitetura, pois desde o Renascimento até nossos dias a atividade de desenhar é inerente à profissão do arquiteto. Pelo desenho, é que os arquitetos expressam e comunicam suas ideias. Por enquanto. ${ }^{2}$

O desenho, como sabemos, é a forma primitiva de expressão humana, assim como a escolha e a construção do abrigo do homem. Mas é somente a partir de meados do século XVI que o desenho torna-se um recurso de pré-visualização da construção. Mais que isso, torna-se um meio, um sistema, pelo qual os arquitetos passam a comunicar e ensinar ao outro aquilo que será construído.

Durante o Renascimento, através das realizações de Brunelleschi, Alberti e Rafael, principalmente, conforma-se o trabalho do arquiteto como aquele capaz de pré figurar uma ideia espacial e produzir desenhos num sistema gráfico que ilustra e comunica sua antevisão da construção.

Com o passar do tempo, a confiança no desenho como recurso para a realização do trabalho do arquiteto amplia-se de tal sorte que o valor de um arquiteto passa a ser dado pela virtude que possui em produzir um belo desenho. Ou seja, a representação gráfica ganha primazia até mesmo sobre o pensamento espacial.

Neste capítulo iremos traçar um breve percurso historiográfico a fim de apon-

1 EVANS, Robin. The Projective Cast Arquitecture and its three geometries. Cambridge, 2000. P. xxxi. (Tradução da autora.)

2 Há sem dúvida um desdobramento evidente desta afirmação que nos leva a perguntar: e o computador? Para melhor encadeamento de nossa reflexão não iremos abrir mais adiante esta discussão, o "Por enquanto" é um aviso que retomaremos ao assunto ao final deste capítulo. tar em passagens históricas, que vão desde o século XVI até nossos dias, os distintos papéis que o desenho assume no fazer arquitetônico.

Com isso desejamos consolidar um saber que nos permita ampliar a compreensão do desenho como algo que vai além da representação de uma ideia ou da orientação da construção. Veremos que imaginar, desenhar, construir e perceber são ações do 
Antes do surgimento da figura do "arquiteto" como conhecemos hoje, a condução de um processo construtivo cabia ao artesão (craftsman), cuja responsabilidade era comunicar oralmente aos seus aprendizes o modo de fazer. Tratava-se de um processo, portanto, empírico, cujos avanços se davam pela tentativa e erro. Havia sim desenhos no canteiro, mas estes se relacionavam à realização dos moldes das partes ornamentais de alguns componentes do edifício, como capiteis, frontispícios e cornijas.

A experiência descrita por Rafael em sua "Carta ao Papa Leão X sobre as ruínas de Roma” em 1519, ilustra como o autor apresenta ao Papa Leão X a necessidade da instauração de um sistema de representação gráfica que dê conta das complexas demandas de seu trabalho ( no caso, a recuperação das ruínas da cidade de Roma):

XVIII. Na minha opinião, há muitos que se enganam no que diz respeito a desenhar edifícios, e, em lugar de fazer o que pertence ao arquiteto, fazem o que pertence ao pintor. Direi, portanto, qual é o sistema que acho que se deva utilizar para que possamos entender exatamente todas as medidas e para que saibamos encontrar sem erros todos os membros dos edifícios. O desenho dos edifícios divide-se em três partes. A primeira delas é a planta, quer dizer, o desenho em plano; a segunda é o desenho da parede externa, com seus ornamentos; a terceira é a parede interna, também com seus ornamentos. A planta é aquela que ordena o todo do espaço plano do lugar a ser edificado, ou seja, o desenho da fundação de todo o edifício, quando ele está no nível do terreno. (...) Chama-se esse desenho de planta, porque, tal como o espaço que ocupa a planta do pé é a base de todo o corpo, assim essa planta é o fundamento de todo o edifício. ${ }^{4}$ (grifo meu)

Nota-se a preocupação do artista com o registro do edifício como um volume total e não mais com a representação de suas partes. Ou seja, o arquiteto passa a ser aquele que tem o controle mental de uma totalidade que ainda não existe como realidade.

Mais que uma ferramenta de comunicação do método construtivo de um edifício, o pensamento renascentista revela que há também uma dimensão ideal no de-

3 RAFAEL de Urbino; organizador Luciano Migliaccio. Cartas sobre Arquitetura. Campinas, 2010. p. 9.

Publicada pela primeira vez em português esta edição conta com distintas versões de dois documentos atribuídos a Rafael: a carta sobre a ruínas de Roma e "Carta de Rafael Castiglione sobre a Villa Madama”, ambas escritas em 1519.

4 ibidem, p. 51 




FIG. 02

RAFAEL, PROJETO PARA TERRAÇOS DE JARDINS VILLA MADAMA. ROMA, 1518

PLANTA: DESENHO EXECUTADO PRESUMIDAMENTE POR

ANTONIO DA SANGALLO ,ALUNO DE RAFAEL

5 VASSARI Giorgio, Vite, 1958. apud Eduardo Corte Leal CORTE-LEAL, Eduardo. O triunfo da virtude origens do desenho arquitetônico, 2001. p 59.

6 ibidem, p. 59.

7 Alberti, Leon Battista: De Re aedificatoria libri decem, 1452;

Palladio, Andrea: I quatro Libri dell'Architetura di Andrea Palladio, 1570; Scamozzi, Vincenzo: L'Idea dell'Architettura Universali di Vincenzo Scamozzi, 1615

8 Vale lembrar que nos Dez Livros de Vitruvius (1 a.C.) não havia ilustrações, nem tampouco no Tratado de Alberti original, que retoma a obra de Vitruvius como referência.

9 Em inglês, craft, também significa força, habilidade; e draft contém, além da ideia de esquema, a de porção, parte. http://michaelis.uol.com.br/moderno senho, ou seja, o desenho como um “juízo que se forma na mente”, nas palavras de Giorgio Vassari (1511-1574)5.

O desenho não só representa os aspectos constitutivos do edifício, mas se converte em suporte configurado por uma Idea, uma Ordem e uma "bela forma”. Giorgio Vassari indica, ainda, que se pode: "concluir que esse Desenbo outro não seja que uma aparente expressão e declaração de um conceito que se tem na alma, e daquele

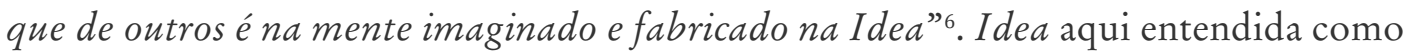
a razão do projeto, sua inteligência.

Diante disso, o desenho se torna o suporte da ação do arquiteto. E como tal, atua numa dupla dimensão do fazer: uma ligada à criação, ao mundo das ideias, e a outra focada nas questões dos códigos de representação e transmissão da informação para o canteiro de obra.

Interessa-nos aqui frisar a existência dessa dupla dimensão presente já nas origens da reflexão sobre o sentido do desenho para a arquitetura: uma ligada ao pensamento e outra à representação. Como veremos a seguir, as questões do desenho como linguagem acabam por prevalecer sobre as questões referentes à ideação.

A partir do Renascimento houve, portanto, uma ênfase na formalização de um código ou uma normativa gráfica, fundada nos princípios e valores estéticos da antiguidade clássica com base na obra de Vitruvius (1 a.C.). Proporção, harmonia, ritmo e beleza eram representados graficamente por figuras da geometria euclidiana: plano, linha, círculos, triângulos etc., constituindo um repertório figurativo que permanece ativo até o século XIX

A publicação e divulgação deste repertório deu-se na Europa já a partir do século XVI, sobretudo na Itália e na França, através da publicação dos Tratados de Alberti (1452), Palladio (1570) e mais adiante Scamozzi (1615). ${ }^{7}$ Ainda que em cada região as técnicas construtivas permanecessem vinculadas às condições materiais e técnicas locais, houve um processo de universalização de métodos da prática arquitetônica.

Os Tratados renascentistas apresentam por primeira vez proposições exibidas pelo desenho, ilustrando o como e o que fazer. ${ }^{8}$

Assim, representar graficamente uma ideia espacial torna-se uma ação intrínseca ao trabalho do arquiteto. Saber desenhar torna-se condição de saber projetar. Podemos dizer então que historicamente a figura do arquiteto vai se distanciando da imagem do artesão, o crafstman, como a extensão física do seu objeto de trabalho, e se aproxima à do desenhista, o drafstman ${ }^{9}$. 
Inquieta-nos, porém, o fato de que nessa trajetória a compreensão do desenho como norma ou como representação prevaleceu sobre sua dimensão criativa. As questões relativas à linguagem se sobrepõem às relativas ao pensamento. É como se parte de sua natureza fosse deixada à sombra.

Devemos atentar para o fato deque para compreender como pensa um arquiteto, como se dá seu processo de criação, temos que recuperar de certa maneira a dimensão do desenho como coisa mental e deixar um pouco de lado as categorias de análise ligadas ao código.

Ao final do século XVIII, os trabalhos de Giovanni Piranesi (1720-1788), Claude Ledoux (1736-1806) e Etienne-Louis Boullée (1728-1799) apresentam uma ampliação no repertório de soluções arquitetônicas, pois a configuração dos projetos não se refere apenas a uma edificação, mas à construção da cidade e sua pluralidade de funções; funções estas relacionadas ao desenvolvimento da indústria.

A indústria transformou não só as relações de trabalho e da família, mas também a vida urbana, promovendo novas atividades na cidade: de lazer, financeiras e administrativas. Para cada uma destas, desenvolveram-se "tipos” de edificações distintas, feitas de acordo com o programa que abrigavam: a Biblioteca, a Ópera, o Tribunal, a Casa da Moeda.

$\mathrm{Na}$ cidade grande, não é mais possível pensar na forma de cada edifício como algo único e singular, mas em tipologias que possam ser reproduzidas inúmeras vezes de acordo com a função urbana e o programa do edifício. Como afirma Giulio Carlo Argan: "O tipo não é modelo, mas um esquema que traz em si a possibilidade de variantes segundo as necessidades contingentes.” ${ }^{10}$ (grifo meu).

Ainda segundo o autor:

$\mathrm{Na}$ medida em que concebem a arquitetura como definição de objetos de edificação (e não mais como representação perspectivada e cenográfica do espaço), Boullée e Ledoux não projetam mais através de plantas e seções (sempre relativas a uma representação do espaço), e sim por entidades volumétricas, individuando nos sólidos geométricos a sintese entre a ideia e a coisa, isto é a forma típica por excelência ${ }^{11}$.

10 ARGAN, Giulio Carlo. Arte Moderna, 1992. p. 35,36. Texto referente às obras: "Projeto para o Cenotáfio de Newton" de Etienne Boullé, "Casa dos Guardas Campestres" de Claude Ledoux.

11 ibidem, p. 37 
12 Gaspard Monge (1746-1818) desenvolveu dentro da École Polythecnique de Paris os estudos sobre Geometria Descritiva, cuja ideia principal era que a configuração espacial não se dava mais a partir de uma linha do horizonte e um ponto de fuga, mas do rebatimento das figura em planos verticais dispostos de maneira perpendicular ao plano de base. Deste sistema derivou-se a axonometria.

13 Evans alerta que a Geometria é um conhecimento (uma ciência) que serve para medir coisas e não constituir espaços, que deve assumir uma presença na Arquitetura como a Matemática na Física, e o alfabeto nas palavras.

A Geometria não gera Arquitetura - os arquitetos não produzem geometria, eles a consomem, ela é um instrumento para sua produção. EVANS, Robin. The Projective Cast Arquitecture an its thres geometries, 2000. p. xxvi
Ainda no século XVIII, os estudos desenvolvidos nas recém criadas escolas de engenharia europeias, sobretudo acerca das propriedades físicas do cimento aliadas ao ferro, ampliaram os horizontes da construção civil, possibilitando a produção de sistemas estruturais capazes de vencer grandes vãos com peças industrializadas e complexas, nas quais um mesmo componente poderia absorver forças de compressão, tração e articulação.

As obras de arquitetura mais significativas do século XIX expressam essa aproximação entre ciência e construção. A torre de Gutave Eiffel (1887), o Salão de Leitura de Henri Labrouste (1858), ambos em Paris, e o Palácio de Cristal de Joseph Paxton em Londres (1851), são construções que expressam na sua forma o caminho das forças que sustentam o edifício, ainda que esteticamente estejam relacionadas a um repertório figurativo da antiguidade clássica.

É nesse ambiente de urgência e aceleração que surgem as primeiras formas de pensar e construir a partir do binômio ciência e arte, razão e emoção, que serão definidoras da produção arquitetônica da primeira metade século XX.

Apesar das intensas transformações nas dimensões ideais e formais no campo da arquitetura na passagem do século XIX para o XX, o sistema de representação gráfica dos projetos permanece o mesmo. Ou seja, o uso de plantas, cortes, elevações e perspectivas fundadas na geometria euclidiana é ainda o suporte instrumental para o desenho arquitetônico.

Segundo Robin Evans, apesar de tantas transformações ocorridas no campo da arquitetura, o sistema de representação dos projetos mantém-se “incontestado”. O autor destaca, porém, dois suportes gráficos que ganham valor no decorrer do desenvolvimento da arquitetura moderna do século XX.

O primeiro é a valorização do croquis como fonte de originalidade e meio investigativo do arquiteto. $\mathrm{O}$ croquis não como um primeiro impulso do artista, mas como ação projetual que contem a ideia.

O segundo é o uso de desenhos axonométricos que se desenvolveram a partir da geometria euclidiana, onde a equivalência métrica entre os três eixos, $\mathrm{x}, \mathrm{y}, \mathrm{z}$ tem o mesmo valor numérico, gerando um desenho espacial sem deformações, como ocorre na perspectiva renascentista com pontos de fuga ${ }^{12}{ }^{13}$.

Segundo Evans, seja pelo croquis ou pela axonometria, tais disposições gráficas são relativas ao processo criativo do arquiteto e não à representação da construção 
física da obra, elas se relacionam com o campo da imaginação e apresentam o modo particular como cada um configura seus projetos. Ou seja, pelo modo como o arquiteto apresenta sua ideia, é possível compreender como ele pensa espacialmente.

A partir desta compreensão, podemos relacionar o modo como o arquiteto desenha com seu modo de pensar e agir sobre o espaço. Robin Evans dá o nome a esta relação de "projeção"

Recentemente, o arquiteto espanhol Rafael Moneo reuniu em uma publicação intitulada Inquietação teórica e estratégia projetual o resumo de suas aulas, cujo tema é a análise de obra de oito arquitetos contemporâneos.

A inquietação do autor versa sobre a hipótese que as escolhas projetuais de cada arquiteto, desde o modo como ele desenha, a escolha de materialidades específicas até as técnicas construtivas, constituem uma estratégia de projeto particular de cada um.

Segundo Moneo, hoje não é mais possível traçar uma teoria que dê conta de uma ação projetual coletiva, com normas, programas e modelos comuns; faz-se então necessário conhecer cada uma dessas estratégias como uma chave fundamental para compreender as obras que os arquitetos contemporâneos realizam.

O termo 'estratégia' é entendido aqui como mecanismos, procedimentos paradigmas e artefatos formais que aparecem com insistência recorrente na obra dos arquitetos de hoje: entendo que os utilizam para configurar o construído ${ }^{15}$.

Moneo ainda afirma que na obra do arquiteto inglês James Stirling (1926-1992) é possível perceber quando o arquiteto concebe a partir da manipulação da planta ou do corte: "Tanto a maquete quanto os desenhos nos mostram como o fazer arquitetônico se converteu no fazer da planta (...). A arquitetura é, aqui, descrição deste [programa]por meio da planta" ${ }^{16}$. Ou ainda como Álvaro Siza, reconhece a realidade onde está inserido seu projeto e a manipula plasticamente através do corte transversal ${ }^{17}$.

Aquilo que nos interessa evidenciar a partir da leitura dos textos de Evans e Moneo é a consideração do desenho como algo próprio do processo de criação espacial. No cenário da arquitetura contemporânea, no qual o que prevalece é a individualidade e não a norma, torna-se indispensável reconhecer as particularidades de pensamento de cada arquiteto a fim de compreender os espaços que constroem. ${ }^{18}$

No processo dialético entre pensar e construir, entendemos que o desenho é também pensamento espacial, ele se forma na mente e não apenas figura no papel. É aquilo que põe em relação as distintas variáveis de um projeto em curso. É um meio plástico, móvel e flexível que encontra correspondência no manejo do meio espacial.

14 No texto original, Robin Evans usa o termo projection: "The distinction between composition and projection in architecture has its counterpart in mathematic geometry".

ibidem, p. xxxi.

15 MONEO, Rafael, Inquietação teórica e estratégia projetual na obra de oito arquitetos contemporâneos. São Paulo, 2009. p. 9

16 Ao analisar o projeto da biblioteca cientifica da Universidade do Sul da Califórnia (1988). ibidem, p. 47.

17 ibidem, p. 195. Ao descrever a obra do Restaurante Boa Nova em Leça Palmeira (1958-63), o autor afirma: "Trata-se de um projeto em que a manipulação do espaço prevalece. Daí a importância dos cortes, que permitem comprovar o uso hábil dos interstícios produzidos entre as coberturas".

18 Para o historiador Kenneth Frampton, em seu ensaio "Regionalismo Crítico", não é mais possível considerar a arquitetura ditada por soluções ou ideologias universalizantes. Para as questões globais, como o crescimento acelerado das cidades, o desequilíbrio ambiental, o arquiteto deve buscar elementos pré-existentes e regionais, "salientando determinadas condições dadas pelo site-specific", com uma visão critica do lugar.

Ver capítulo: "Critical Regionalism: modern architecture and cultural identity”, in FRAMPTON, Kenneth. Modern Architecture, a critical

bistory. Londres: Thames and Hudson, 1985. $2^{\mathrm{a}}$ edição. p. 327 (tradução da autora) 
Agora, a pergunta que temos que fazer é: como se dá este processo na obra de PMR? E mais ainda, o que move seu pensar?

A partir do estudo do acervo de projetos de PMR e do testemunho da concepção dos projetos do Cais das Artes (2007) e Museu dos Coches (2008), pudemos confirmar que as maquetes de papel e desenhos no papel manteiga são suporte material pelos quais o arquiteto realiza formalmente suas ideias.

Vimos que ao logo do processo de elaboração de um projeto o arquiteto realiza uma única maquete sobre a qual vai trabalhando e fazendo os ajustes necessários. $\mathrm{O}$ mesmo ocorre com o desenho no papel manteiga: não há uma profusão de papeis rabiscados até se chegar a uma conclusão, trata-se de um só desenho, em geral um corte, sobre o qual ele desenha várias hipóteses, apaga as antigas, num processo similar a uma lapidação.

Os traços sintéticos e precisos que qualificam esses suportes materiais indicam que o arquiteto desenvolve grande parte do desenho em sua mente antes de mesmo de dar-lhe forma no papel.

$\mathrm{Na}$ dimensão do pensamento, o arquiteto articula vários níveis de aproximação da questão pela escolha de alguns caminhos: a convocação do conhecimento acumulado sobre o assunto; a memória como referência espacial; e uma certeza singular daquilo que não quer fazer. Elementos que podemos conferir por meio do modo como ele se expressa sobre o processo de elaboração do projeto da Praça dos Museus da USP (2000):

(...) Vou explicar como se configurou com clareza na cabeça a solução que possibilita a você, lá pelas tantas, abrir a porta, chamar o calculista e os outros colaboradores para ajudar, expandir a ideia e chegar nas suas dimensões definitivas.

(...)Esses museus têm uma particularidade muito atraente: são museus de pesquisa, portanto frequentados por professores e cientistas. A convivência do público com esses cientistas, você pode imaginar o que é: não pode ser feita assim estabanadamente (...).

(...)Tem que arranjar uma espacialidade, uma museologia adequada para que ele possa exibir os resultados de sua pesquisa e permitir que outras pessoas desfrutem desse trabalbo. 
(...) Eupensei o seguinte: fazer um espaço elevado. Essa é a parte empírica do saber: o viaduto do Chá (1892), em São Paulo, é um espaço elevado (...). No nosso caso, imaginei que um espaço elevado poderia ser o saguão comum dos três museus (...).

(...) Assim, você vai juntando essas imagens e fazendo percursos na sua cabeça: a rua, o elevador, a entrada do volume do museu (...) e você vai se convencendo que não poderia ser de outro jeito. ${ }^{19}$

Portanto, aquilo que move o pensamento de PMR está de certo modo descolado das questões práticas ou funcionais das demandas do programa do projeto, parece ter início em outra dimensão de sentidos, como um saber em potência que sai do estado de inércia por uma ação intuitiva.

Henri Bergson adverte que aquilo que impulsiona o filósofo a dar sentido e direção ao seu pensamento é justamente a intuição e não a inteligência. A inteligência é a maneira humana de compreender o que há de estável e regular no real. Compreende o arranjo e o rearranjo das coisas, mas não aquilo que há no intervalo. A intuição, ao revés, é o modo humano de perceber a realidade pelo interior, "vinda do fundo". É reflexão que se principia numa especulação, que é a atenção que o espírito presta a si mesmo quando se fixa na matéria. A intuição é o "prolongamento ininterrupto do passado num presente que avança sobre o porvir" ${ }^{20}$.

A ciência se constrói pela inteligência e a filosofia pela intuição. O objeto da ciência é a matéria inerte que estabelece "relações de simetria, concordância e correspondência” sobre o mundo material ${ }^{21}$.Ela cria uma estrutura de pensamento a partir do intelecto e não do interior desta matéria.

Assim, a ciência produz um pensamento que é definitivo e abstrato, pois se apoia em conceitos cuja estrutura está distante do objeto que observa, porque não considera o seu movimento no tempo. Toma a matéria como objeto, a experiência como meio e a matemática como ideal. A filosofia, por outro lado, inclui um mundo “inacabado, mas deita raízes firmes no real.” "22, conclui Bergson.

A inteligência porém não cria, ela "combina e separa, arranja e desarranja, coordena" ${ }^{23}$, ela gera relações de simetria. A intuição engendra relações de sincronia, coincidência, numa trajetória que se faz por aproximações sucessivas.

19 ROCHA, Paulo Mendes da. Maquetes de papel, 2007. p. 30-34

20 BERGSON, Henri. O pensamento e o movente, 2006. p 29.

21 ibidem, p. 37.

22 H. Bérgson, ibidem, p. 49

23 ibidem,p. 153 

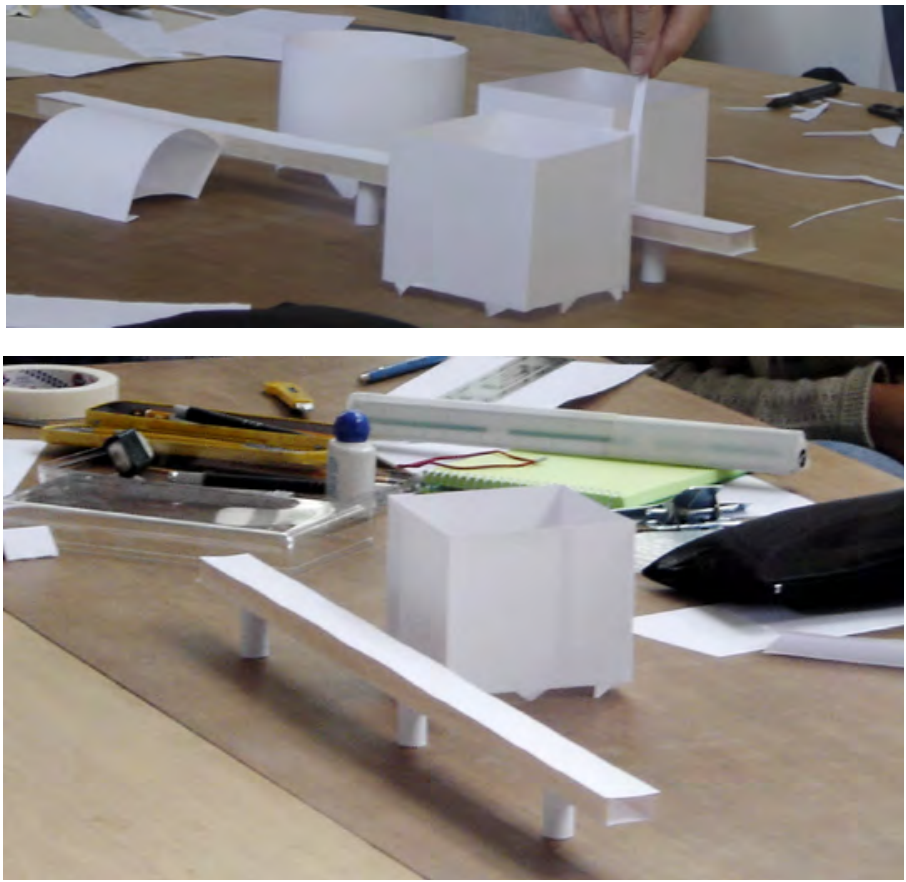

FIGS. 03 E 04

2000: MUSEUS DA USP 1 A. VERSÃO

MAQUETE DE PAPEL FEITA PELO AUTOR EM WORKSHOP REALIZADO NA

FUNDAÇÃO ARTIGAS, CURITIBA, 2008

24 Para Bergson, o espírito da síntese é uma potência mais alta que o espírito da análise, pois se trata de uma força do pensamento capaz de penetrar a fundo na coisa, no fato, e retirar dela aquilo que tem de significativo. ibidem, p. 237.

25 ARTIGAS Rosa (org). Paulo Mendes da Rocha, 2000,p. 72.

26 Segundo Frederic Worms, estudioso da obra de Bergson, existe em princípio, em cada filósofo, "coisas" que aprendemos com ("chez”) eles, enunciados ou teses que definem a particularidade de cada pensador. No caso de Bergson, segundo Worms, aprendemos sobre o duplo modo de surpresa e argumentação; suas três teses principais são: 1. "o tempo não é o espaço"; 2. o nada não existe; 3 . as diferenças entre moral e religião estão fundadas nas noções de fechado e aberto. Para nosso estudo, concentramo-nos na primeira tese expressa nos ensaios publicados no livro de Bergson O Pensamento e o Movente (2006). p. 15

WORMS, Frederic et RIQUIER, Camille. Lire Bergson,Paris, 2011. p. 15
Entendemos que para PMR, a configuração espacial não se dá pelo uso instrumental de um sistema de representação, nem pela aplicação de um glossário de figuras pré-estabelecidas.

Em seu processo criativo, quando na passagem da dimensão mental para a gráfica, há um momento de síntese ${ }^{24}$ no qual os diversos eixos de compreensão do problema arquitetônico se articulam numa configuração precisa e significativa. $\mathrm{Ou}$ seja, PMR não opera pela manipulação do desenho, para ele não é possível fazer um modelo ou um desenho pelo qual descobrirá uma espacialidade. "Minha arquitetura sempre foi inspirada por ideias, não evoca modelos (...), mas a habilidade do homem em transformar o lugar que habita, com fundamental interesse social (...)." ${ }^{25}$.

Quando examinamos seus desenhos em paridade à obra construída, percebemos que neste proceder tudo aquilo que se relaciona aos aspectos normativos do projeto, como o programa, a relação com o entorno, ao uso dos materiais, não estão explícitos nesta síntese (desenho). Por outro lado, o fato da obra ter sido executada nos permite comprovar como aquela síntese de fato se realiza espacialmente, com um programa, com um contexto e uma tectônica.

Isso nos indica que o processo criativo não se dá por uma trajetória fragmentada em etapas sucessivas: ideia/croquis/projeto executivo/obra. Não é linear. É uma totalidade que vai se transformando pela mudança, pelo movimento das ideias, pela ação do tempo.

Tempo que não pode ser medido por uma unidade de medida de minutos e segundos, mas tempo entendido como algo que age e transforma coisas.

Para desenvolver este conceito de tempo, voltamos a Bergson num preâmbulo talvez extenso, mas necessário ${ }^{26}$.

Para Bergson, tempo não é espaço, não podemos representá-lo como uma linha feita de momentos que se sucedem numa cronologia unidimensional, ele é móvel e tem duração. Quando pensamos no tempo, imaginamos logo quanto transcorreu: minutos, horas, anos, passado e futuro. O filósofo sugere que se encontre uma maneira precisa de compreender o tempo, tendo em vista não a somatória de unidades de medida, mas a sua relação com o real. É um tempo ao qual a ciência não pode atribuir medida, porque é aquele que temos que sentir e viver. 

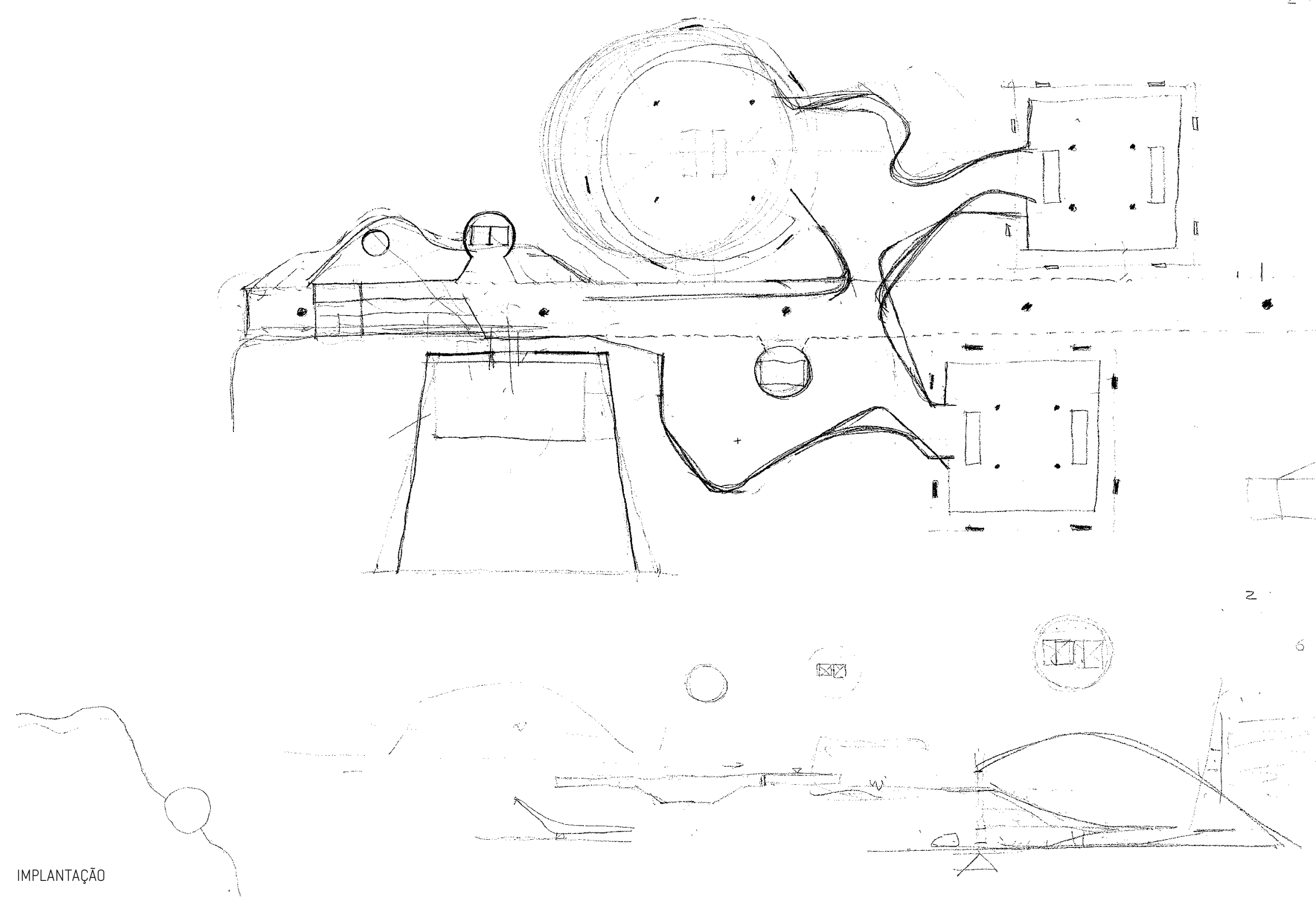

2000: MUSEUS DA USP, SÃO PAULO PRIMEIRA VERSÃO 


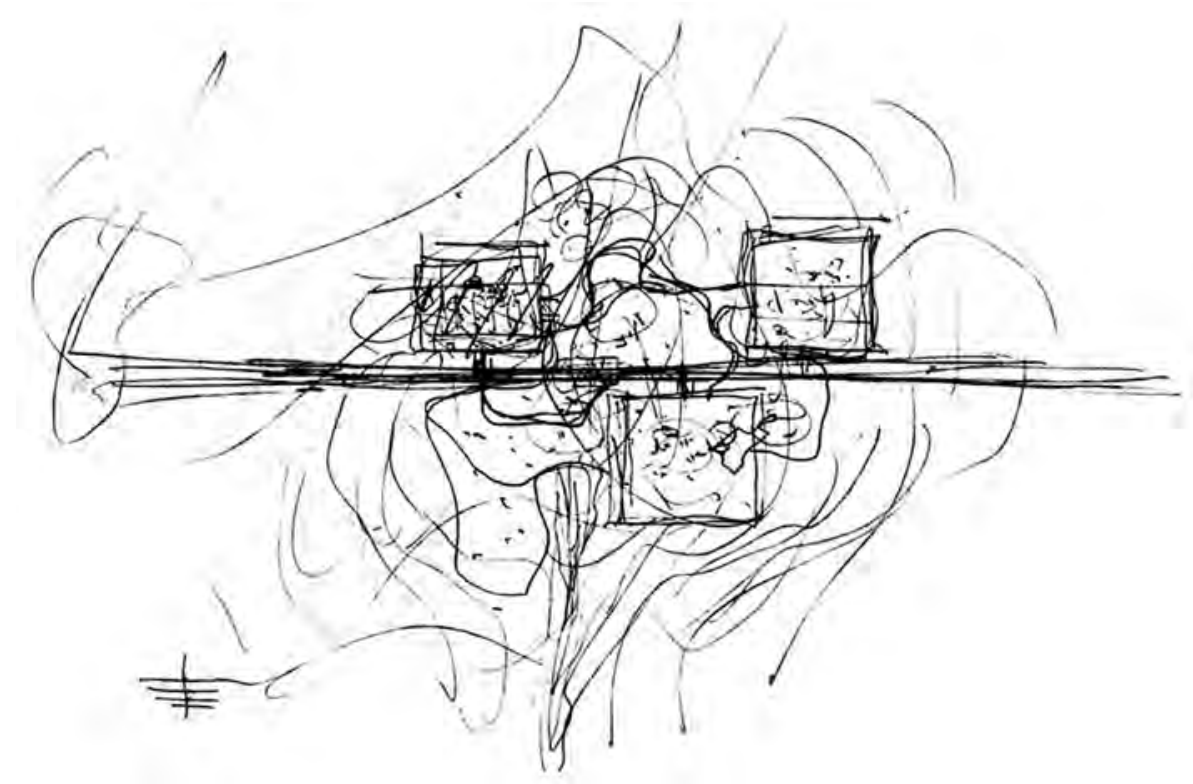

IMPLANTAÇÃO DOS VOLUMES DOS MUSEUS AO LONGO DA RUA ELEVADA

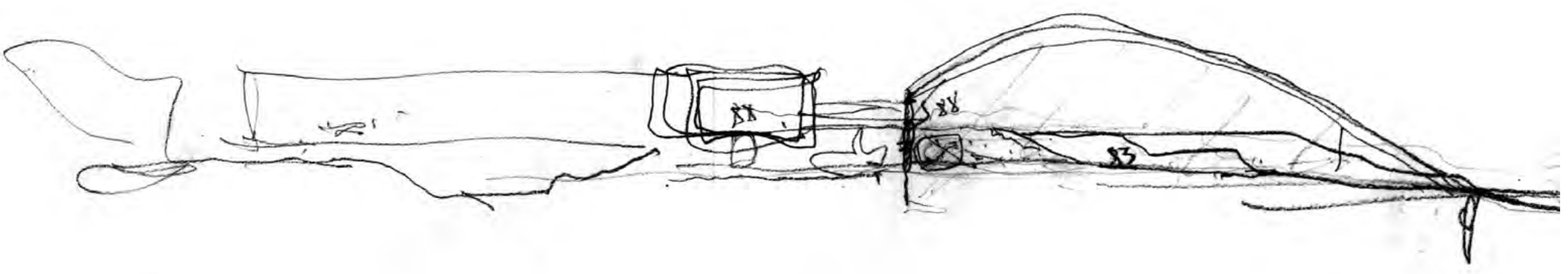

CORTE SOBRE O VOLUME DO ANFITEATRO 
Tempo $(\tau)$, tal como aprendemos na Matemática e na Física, é homogêneo e uniforme, tem uma relação vital com a medida, podemos atribuir-lhe um intervalo. Uma linha constituída de momentos postos lado a lado no espaço, que para Bergson "se dobra às exigências da linguagem esperando que se preste à do cálculo" 27 .

Essa noção de tempo espacial é, segundo o autor, desconectada de qualquer experiência concreta. A essência do tempo real é fluida, porém mensurável também. Aqui sua medida não se dá por símbolos, mas pela duração do tempo vivido, ele se constitui na dimensão da experiência.

O tempo real não é feito de imobilidades, mas de uma continuidade indivisível que se estende em partes distintas e justapostas. Nossa inteligência, porém, está habituada a guardar posições fixas de uma trajetória que transcorre no espaço, e as entende como sendo o real. No entanto, ainda segundo o autor, a trajetória não pode ser confundida com o trajeto, ou seja, a soma de infinitas imobilidades não é a representação real do movimento.

Sua proposta é entender o tempo real como algo indivisível e contínuo, e a forma de conhecer este todo é aquilo que Bergson define como sendo: “a atenção que o espírito presta à matéria” ${ }^{28}$. Um tempo que se estende, no qual o real e sua possibilidade se fazem ao mesmo tempo.

Assim, trata-se de um tempo que não é o do espaço (linha). É um tempo da vida, da percepção, da criação.

Para que serve o tempo real? Pergunta-se o autor. O tempo real é aquilo que impede que tudo se dê em um só golpe, ele retarda, elabora. Tempo compreende, portanto, ação.

Por mais que seja possível planejarmos uma ação futura, existe um tempo que separa nossa previsão de sua realização. Este tempo é necessariamente vivido por nós e não é possível encurtá-lo. É um tempo que se constitui pela experiência da duração.

O exemplo que ilustra essa imagem é o do açúcar que derrete na água. O tempo é agente desta ação (temps-vécu), é nele que se consuma o ato de diluir. Este tempo contém a ideia de uma possibilidade, de um devir ${ }^{29}$.

Por se tratar de uma visão na qual o movimento é aderente à realidade da vida, os tempos do passado, presente e futuro não podem estar alinhados numa sequência consecutiva, de causa e efeito. A ideia é que eles são momentos justapostos, nos quais o real e o possível se fazem ao mesmo tempo.

27 BERGSON, H. ibidem,. p. 9
28 ibidem, p 88.
29 Aqui é importante ressaltar que o tempo real não se confunde com a
duração real, justamente porque o tempo para Bergson contém a possiduração real, justamente porque o tempo para B
bilidade de um porvir, que ainda não se realizou. 


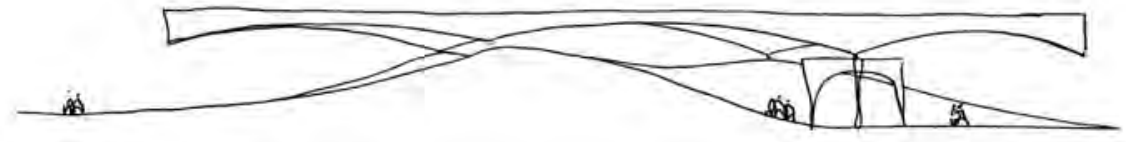

1970: PAVILHÃO DE OSAKA

ESTUDOS: ELEVAÇÃO

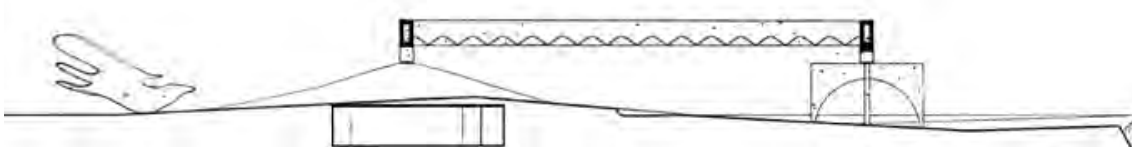

ANTE PROJETO, CORTE TRANSVERSAL

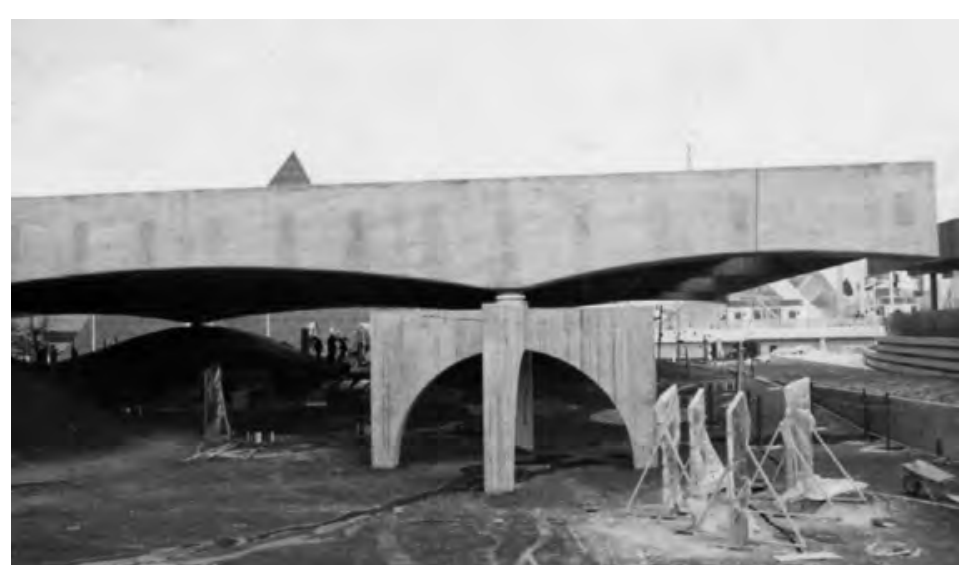

FIG. 05

EDIFÍCIO CONCLUÍDO

30 ibidem, p. 118.

31 ARGAN, Giulio Carlo. História da arte como história da cidade, São Paulo, 1995. p. 227.

32 BERGSON, H. ibidem, p. 118

33 BERGSON, H. ibidem, p. 155.
Com isso, o presente é uma possibilidade no real; aquilo que vivemos agora se fez possível num passado indefinido, mas que somente o presente pode reconhecer ali a sua possibilidade; o passado contém a pré-existência dessa possibilidade. "É preciso aceitá-lo: é o real que se faz possível e não o possível que se torna real.”30. Um historiador busca, por exemplo, no passado, aquilo que pode explicar a realidade de seu presente.

A extensão do presente no passado se dá até o momento em que o sentido do passado não é mais capaz de mover o presente. Quando nos lembramos de alguma coisa é porque ela ainda é capaz de mover nosso presente. Assim, o passado está aderido ao nosso presente, e aquilo que não tem aderência, se esquece. Ou seja, a lembrança é parte do presente; de um presente que dura.

A mesma extensão se dá em direção ao porvir, pois a sua possibilidade está contida no presente. Uma coisa só se realiza porque ela foi possível de ser pensada antes. Em arquitetura, essa transposição parece imediata: uma construção só pode ser realizada se ela foi pensada previamente, o desenho, o modelo, contêm necessariamente essa possibilidade do porvir.

O futuro, segundo Argan, leitor atento de Bergson, nada mais é do que um homem no presente e sua previsão, "ou mais exatamente, uma avaliação das possibilidades de duração e mudança” de uma situação atual ${ }^{31}$.

Quando o artista cria uma obra, elabora a ideia e a possibilidade da coisa, ao mesmo tempo. Para Bergson, o artista “cria o possível, ao mesmo tempo que o real quando executa a sua obra” ${ }^{32}$. Ou seja, o possível implica a realidade à qual ele corresponde.

Analogicamente, entendemos que o processo criativo de PMR se dá nessa dimensão do porvir, a ideia se realiza enquanto uma possibilidade do real, e portanto, o seu tempo não é o presente (resistente) e sim um futuro, mais amplo e livre. Por isso, numa primeira aproximação, temos a impressão (que às vezes se confirma) de que o arquiteto ao projetar não toma em conta aspectos que seriam aparentemente premissas do projeto, como programa, legislação, relação com os gabaritos vizinhos etc.

$\mathrm{O}$ artista, segundo Bergson, é aquele que nos faz ver aquilo que não conseguimos perceber. Somos capazes de compreender uma obra de arte na medida em que ela atinge os nossos sentidos, que estavam dentro de nós mas não haviam sido despertos: “assim como a imagem fotográfica que ainda não foi mergulhada no banho no qual irá ser revelada. O poeta é esse revelador.” ${ }^{33}$. Sua consciência é menos aderente à vida. 
As necessidades da vida prática limitam nossa capacidade de perceber, pois para que ela possa se estender, necessitamos estar menos preocupados em viver e mais “inclinados a contemplar”. Nossa ação está limitada por uma percepção utilitária da realidade, ela recorta aquilo que nos interessa de imediato; ao passo que o artista percebe as coisas como elas são, pelo prazer de contemplar ${ }^{34}$.

Nesse momento, podemos concluir que: intuir, inventar e contemplar são ações presentes no pensamento espacial de PMR. Trata-se de ações que qualificam sua projeção num modo particular de operar e transformar o espaço.

Espaço, não aquele medido em metros lineares ou quadrados, mas espaço com suas dimensões táteis, de luz e sombra, de compressão e extensão, ou seja, o espaço onde estamos e nos relacionamos com o mundo.

O físico e filósofo alemão Otto Bollnow (1903-1991), em seu livro Human Space (1963), procura estabelecer critérios coerentes para definir e mensurar o espaço, não por sua geometria mas por sua vivência. Seguindo os passos de Henri Bergson, dispõe-se a compreender o espaço a partir de sua duração e mudança, e não por categorias matemáticas de unidades espaciais.

O autor entende que o espaço, quando medido por unidades numéricas é homogêneo, infinito, uniforme e neutro, e defende que o espaço da experiência humana (espace-vecu) é plural, finito e relativo.

O eixo horizontal, por exemplo, não é um plano abstrato que define uma orientação, mas uma realidade tangível, "é o chão pelo qual eu estou de pé e que dá à minha vida uma base sólida" ${ }^{35}$.

Espaço, portanto, é um meio que estrutura relações, de suporte ou obstrução, e que se manifesta "por pronunciadas instabilidades" 36.

Mario Pedrosa também amplia a compreensão daquilo que entendemos por espaço em seu texto "Espaço e Arquitetura" (1952). Segundo o autor, estamos historicamente acostumados a compreender o espaço como algo bidimensional, num plano estático, e julgá-lo por seus atributos plásticos e não por seus valores relacionais entre dentro e fora, claro escuro, de uns com os outros.

A fim de podermos refletir sobre tais valores espaciais, afirma Pedrosa, é necessário aceitar o fato de que o espaço age sobre nós - "nosso espírito" - e que provoca reações sensoriais que vão além do olhar:

34 Identificamos que os momentos de contemplação realizam-se na obra de PMR pela figura de dois elementos arquitetônicos: os anexos e as

“janelinhas” - que aparecem discretamente aqui e acolá sem fazer muito alarde, mas quando nos damos conta estamos lá parados, contemplando pela pequena fresta aberta no concreto, o mundo lá fora. Apontaremos nas análises de obras estes momentos de contemplação.

35 BOLLNOW, Otto. Human Space. 2011. p. 47 (tradução da autora)

36 ibidem, p. 19 (tradução da autora). 
Ainda segundo Pedrosa, o método pelo qual conseguimos perceber essas dimensões é através do movimento. Movimento enquanto “o valor que o espaço representa para nós"38.

Diante disso, se o espaço não é coisa - cuja estrutura está no campo da realidade objetiva - percebemos a sua existência através daquilo que o conforma. E o que conforma o espaço é forma.

Para PMR, forma é resultante de uma antevisão, uma previsão daquilo que vai ser feito: "o homem sempre foi além da necessidade estrita que a forma poderia suprir, ou seja, além do seu conteúdo útil. Passou a projetar a visão que tinha de si mesmo nas formas" ${ }^{39}$.

Segundo o Prof. ${ }^{\circ}$ Franklin Martins, estudioso da obra de Bergson, a expressão do pensamento é Forma. Forma não como um esquema de representação da realidade, mas como formulação de um problema.

Com base nos conceitos discutidos acima, podemos reconhecer o modo particular como PMR se aproxima de uma questão projetual - ou de um problema, como expusemos acima. O que move a imaginação do arquiteto está além das questões práticas do projeto, ele busca pela intuição um sentido amplo para arquitetura, que em última instância é a construção dos espaços das relações humanas.

Por enquanto vimos como estas ideias se articulam no plano ideal, veremos nos capítulos seguintes a realidade dessas ideias na experiência do espaço construído.

Sendo assim, a atividade de desenhar está historicamente aliada ao desenvolvimento criativo, técnico e institucional do fazer arquitetônico. O desenho pode ser entendido como algo que contém variadas naturezas: mental e figurativa, e está presente em vários momentos da elaboração de um projeto de arquitetura: na concepção, na comunicação e na produção técnica do trabalho.

A dúvida colocada no início do texto - o tal "por enquanto" - recai sobre a

37 PEDROSA, Mario. “Espaço e Arquitetura”, 1953. p. 253.

38 ibidem, p. 252.

39 ROCHA, Paulo Mendes. in Paulo Mendes da Rocha, 2000. p. 73. pertinência de relacionar, nos dias de hoje, a habilidade de desenhar com a de pensar espacialmente, devido à introdução de programas de computador que permitem realizar modelos em três dimensões rápida e precisamente. 
Através de programas matemáticos cada vez mais complexos, tais ferramentas produzem modelos eletrônicos que simulam a realidade virtual pretendida.

Do mesmo modo como Alberti inventou um novo meio de representar aquilo que seria construído, os programas de computador estão transformando o modo como produzimos projetos de arquitetura. Assim como o drafstman (desenhista) se sobrepõe ao crafstman (artesão), poderíamos dizer que o draftsman submerge em relação ao "digitalman"? 40

A questão que podemos colocar por ora, é que ao contrapor o desenho feito à mão àquele produzido pelo computador a distância que separa a mão da mente parece maior.

Temos a sensação que a mão realiza um trabalho muito próximo do pensar, num processo de ação e reação quase que coincidentes, de um fazer e refazer e fazer de novo. Um desenho relacional, acumulativo, incompleto, que se apresenta em inúmeras possibilidades. É ainda uma experiência física, que imprime uma dimensão tátil ao pensar.

Já no $\mathrm{CAD}^{41}$ - programa mais difundido entre os escritórios de arquitetura esta dimensão tátil parece não existir. Basta dizer que para desenhar uma linha no computador é necessário fazer quatro comandos. Dentro da precisão e completude oferecida pelo programa, o espaço para este ir e vir da mente nos parece limitado. O desenho de computador apresenta uma realidade absoluta, fixa. Segundo Richard Sennett: "o que aparece na tela oferece uma coerência impraticável, composta de maneira unificada que nunca se verifica na visão física." ${ }^{\star 2}$.

Entendemos que aquilo que o desenho feito pela mão tateia, o desenho do computador simula. São experiências e procedimentos completamente diferentes.

Segundo Corte Leal, ao desenho - como ato de riscar no papel uma ideia - cabe a função de manter-se ativo como consciência crítica desse novo sistema de representação, a fim de pô-lo em causa enquanto meio de produzir espacialidades e não imagens ${ }^{43}$.

Por outro lado, é inegável a agilidade e precisão que esses programas trouxeram à produção técnica dos desenhos de arquitetura, uma realidade que não volta mais atrás. Ao invés de nos colocarmos numa posição nostálgica frente ao inevitável, propomos uma reflexão sobre qual seria hoje o papel do desenho no processo criativo do arquiteto.

40 De certo alguns arquitetos contemporâneos como Zaha Hadid, Daniel Liebeskind ou Frank O'Ghery produzem atualmente obras que sequer poderiam ser desenhadas no papel dada a sua complexidade material. O programa CATIA, desenvolvido originalmente para a indústria aeroespacial, foi usado pela equipe do Studio de Frank Gehry pela primeira vez para desenvolver o modelo do projeto do Pavilhão Olímpico de Barcelona. Ele consiste em construir uma superfície geométrica por meio de equações matemáticas, cujo desenho serve de molde para a produção industrial das peças que compõem tal superfície.

In LINDSEY, Bruce. Digital Gehry: material resistance/digital construction. Bael;Berlin;Boston: Birkauser, 2001

41 CAD- computer-asisted design.

42 SENNETT, Richard. $O$ artifice, 2009. p. 53

43 CORTE-LEAL, Eduardo. O triunfo da virtude: origens do desenho arquitetônico, 2001. p. 150 
No caso do trabalho de PMR, podemos afirmar com tranquilidade que o computador não faz parte de seu processo de criação. Mesmo havendo produção de modelos eletrônicos em seus projetos atuais, estes são realizados por suas equipes parceiras e não são instrumentos que participam da concepção dos projetos. As imagens em $3 \mathrm{D}$ servem à comunicação aos clientes, engenheiros e divulgação do projeto.

Diríamos até que o arquiteto nutre certa antipatia por esse recurso, pois afirma que tais imagens não representam aquilo que ele pensou. Como se PMR não reconhecesse sua arquitetura nessas imagens. Parecem-lhe falsas.

Para aqueles, como nós, condenados a desenhar no computador, resta manter a mão ativa, e uma visão crítica do alcance dos processos digitais na produção de projetos de arquitetura.
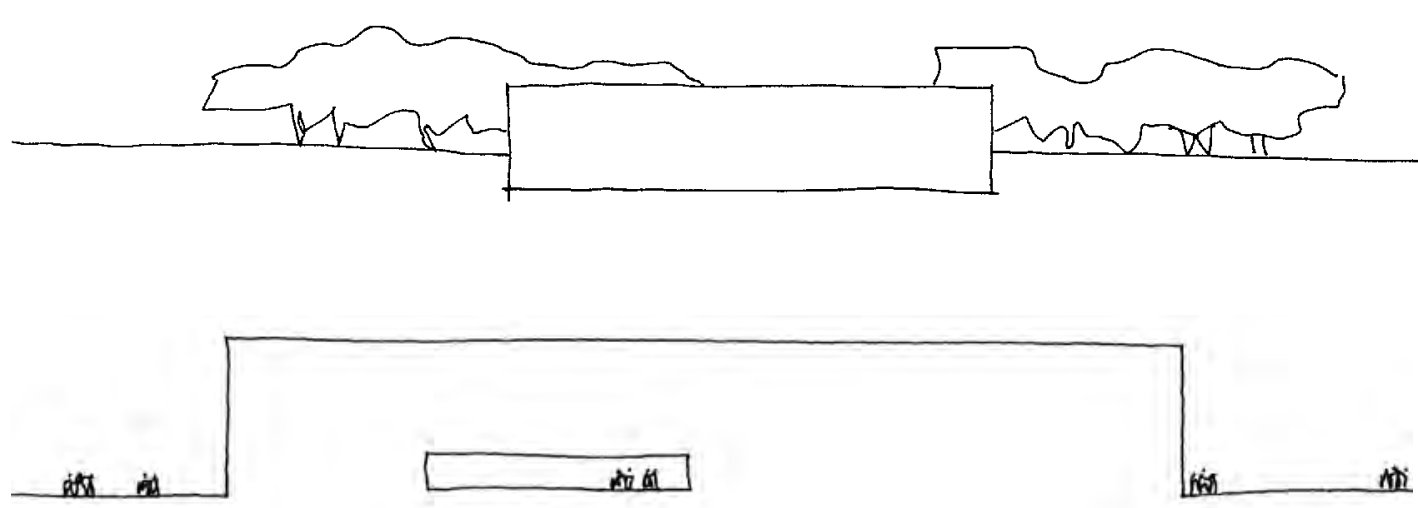

1997: CONCURSO PARA O MUSEU CONSTANTINI. BUENOS AIRES ELEVAÇÕES FRONTAL E LATERAL

S/ ESCALA 


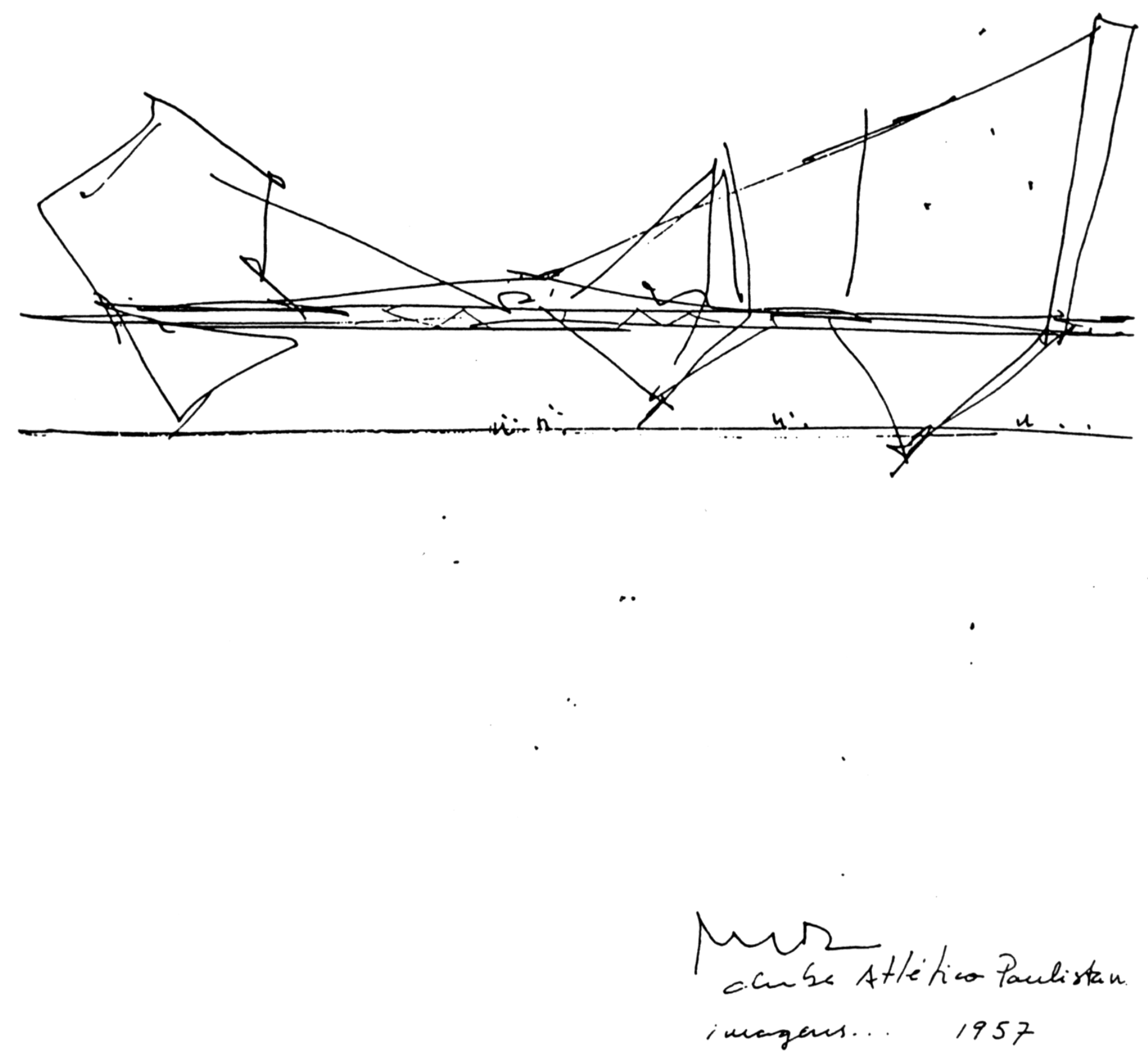

1958: GINĀSIO CLUBE PAULISTANO 



\section{1958 \\ GINÁSIO DO CLUBE PAULISTANO: \\ DESENHO DO EDÍFICIO}

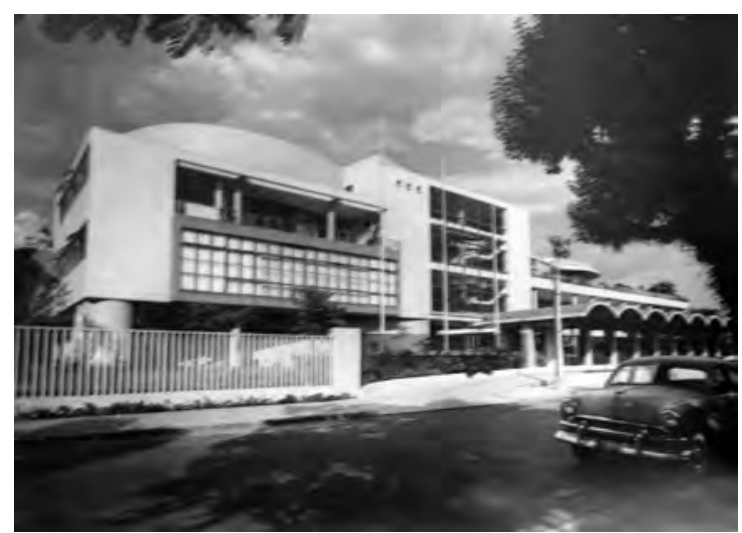

FIG 06

FOTO DA SEDE PRINCIPAL DO CLUBE, SOBRE A RUA HONDURAS PROJETO DE GREGORI WARCHAVCHIK, 1948

1 Este projeto foi realizado em 1957 , em parceria com o arquiteto Pedro Paulo de Melo Saraiva.

2 Por enquanto não encontramos nenhum desenho referente ao projeto do Concurso, baseamo-nos na descrição oral feita por PMR.
O ginásio do Clube Paulistano foi o primeiro projeto de grande porte concebido por PMR, o qual foi construído em 1958, apenas quatro anos após sua formatura como arquiteto. Antes disso, o projeto apresentado para o concurso Palácio Legislativo de Santa Catarina, ganharia, mas não seria desenvolvido ${ }^{1}$.

O projeto do Ginásio foi selecionado por meio de um concurso público e teve como membros do júri nomes importantes do cenário da arquitetura paulistana, como Rino Levi e Gregori Warchavchik, este último, aliás, autor da sede social do clube.

O concurso buscava soluções para a ampliação das novas instalações esportivas do clube, que incluía também uma escola primária (nunca construída). O terreno disponível para tal era toda a frente do quarteirão sobre a rua Colômbia, extensão da rua Augusta, que na época era uma das ruas comerciais mais importantes da cidade de São Paulo.

No projeto original apresentado para o concurso, PMR desenhou uma grande esplanada de 100 metros de comprimento, estendida ao longo de toda a rua Colômbia, a partir da qual se organizava o programa de demandas. Ao longo do desenvolvimento do projeto, a direção do clube decidiu diminuir o tamanho da intervenção e retirou a área da escola primária e alguns serviços do escopo do trabalho².

No ano de 1961, a construção do Ginásio é concluída e passa a ser publicada em revistas especializadas, o que contribui para a divulgação do nome de seu autor no cenário da arquitetura paulistana. Neste mesmo ano, o projeto do Ginásio do Paulistano recebe na IV Bienal de São Paulo o Grande Prêmio Presidência da República.

Trata-se, portanto, de um projeto marcante na trajetória do arquiteto, inaugural e contundente, que não se apresenta como uma realização frágil em termos projetuais, feita por um arquiteto recém formado. Veremos que à luz dos projetos posteriores, 
o Ginásio expõe e aponta caminhos que o arquiteto irá percorrer nos anos futuros. É como se este projeto contivesse a essência de um pensamento que permanece e se exprime em várias de suas realizações vindouras.

Podemos dizer, por hora, que o projeto do Ginásio do Paulistano contém os elementos fundamentais do pensamento projetual de PMR. O projeto traduz sua forma mentis, e é por isso que começamos por ele.

A análise deste projeto tem o propósito de apontar as origens e a potência do pensamento arquitetônico de PMR. A memória do projeto, como o desenrolar de um novelo de lã, traz frases que serão reditas, revela espacialidades que serão reconhecidas.

O desenho ao lado mostra um conhecido croquis feito pelo arquiteto, no qual podemos visualizar a síntese do projeto apresentado na ocasião do concurso. Notamos nesta imagem que o espaço destinado ao ginásio se apoia sobre uma linha que parece ser a linha do chão, que liga a rua Colômbia ao interior do clube. O memorial descritivo publicado por PMR na época aponta ser intenção do projeto que "a edificação não perturbe a serenidade e transparência do recinto (...) solta do chão criando uma praça aberta que garantiria a permeabilidade entre a rua e o interior dos jardins do clube." 3 .

Pela leitura do memorial descritivo e o desenho poderíamos inferir, à primeira vista, que a linha horizontal sobre a qual se apoia a estrutura principal do ginásio seria essa praça ao nível do chão, da rua.

O exame atento do projeto e as visitas à obra demonstram que aquela linha na verdade está suspensa do chão e conforma um patamar alto, ou uma "esplanada", como define PMR. Esta esplanada forma-se por um retângulo de $60 \times 80 \mathrm{~m}$, solto do chão a $2.90 \mathrm{~m}$ de altura ${ }^{4}$.

A superfície na base do desenho não seria então o chão ao nível da rua, mas sim o plano dessa esplanada, a partir da qual a espacialidade do Ginásio se realiza nos seus espaços internos e externos. Sobre ela, apoia-se a cobertura da quadra principal e abaixo dela estão os programas de apoio às atividades esportivas: vestiários, salas de ginástica, depósitos de material etc.

Tudo levaria a crer que com esse deslocamento para cima, a ideia inicial de estender a rua para o interior do clube se perderia. No entanto, quando visitamos o edifício construído e usando de um certo grau de abstração, pois esta esplanada hoje

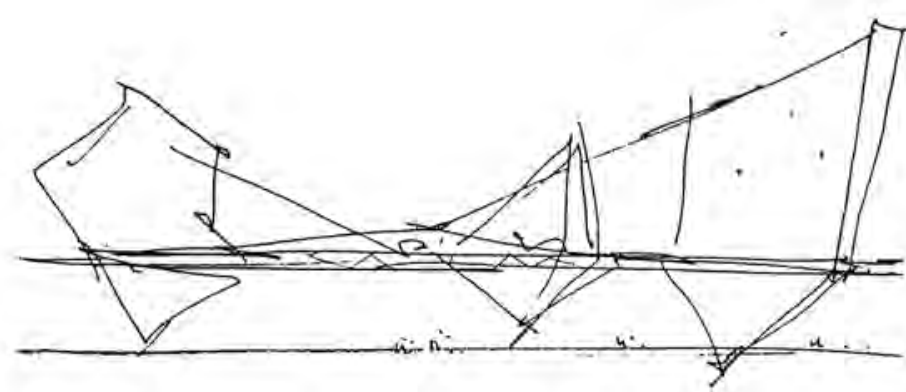

1958: GINÁSIO DO CLUBE PAULISTANO

SINTTESE DO PROJETO: SOBRE UM EIXO HORIZONTAL SE DESENVOLVE O ESPAÇO DO GINÁSIO COBERTO

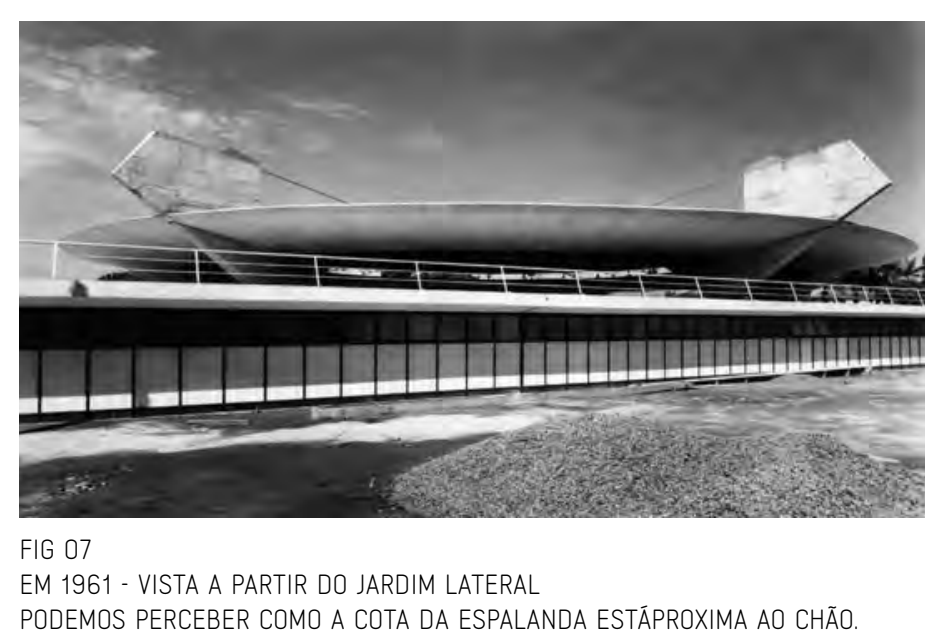

3 ROCHA, Paulo Mendes, "Ginásio Coberto do Clube Atlético Paulistano". Arquitetura. 1961, p.12.

4 Em conversa com o arquiteto, ele nos conta que o projeto original previa que a esplanada ficasse numa altura mais próxima à cota zero, numa relação de meio pé direito $(1.20 \mathrm{~m})$ em relação ao nível do jardim., mas que devido à altura elevada do lençol freático no terreno não foi possível realizar. No corte transversal A-B do projeto executivo publicado ao final do capítulo, notamos que há uma elevação do nível das quadras de tênis laterais, isso demonstra a preocupação do arquiteto em manter a cota de nível da esplanada o mais próxima do chão possível; não lhe interessava neste momento fazer da esplanada uma superfície muito destacada do chão, parece buscar uma continuidade entre os diferentes níveis. 


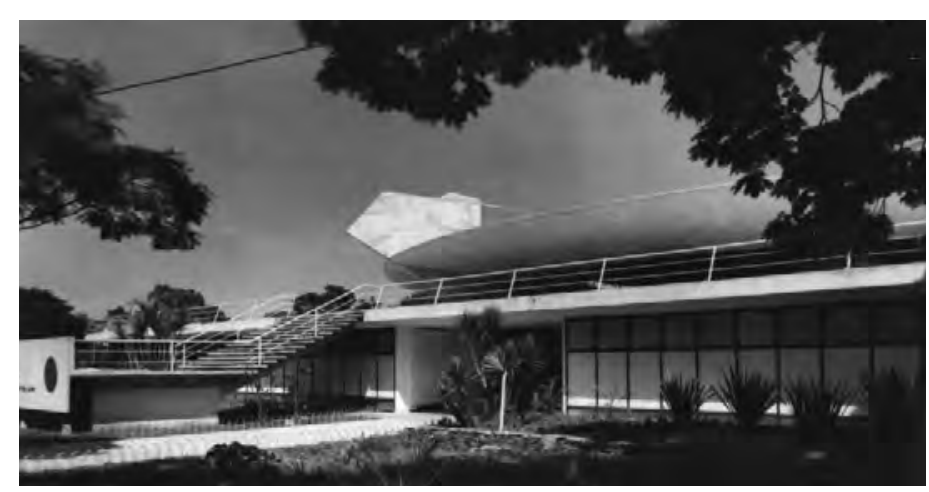

FIG 08

EM 1961 - VISTA INTERNA DA ESCADA DE ACESSO DOS JARDINS DO CLUBE Ã ESPLANADA.

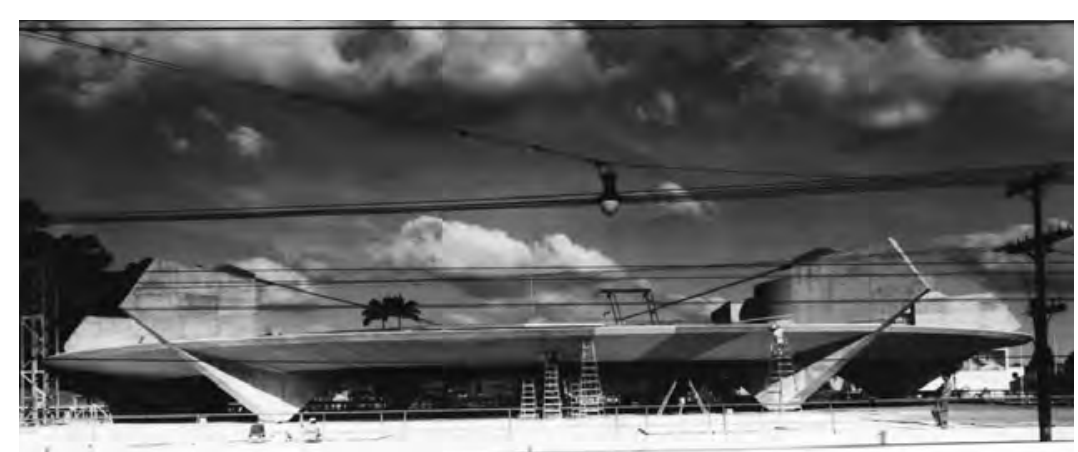

FIG 09

EM 1961 - VISTA INTERNA LATERAL DO JARDIM

5 Neste ponto distanciamo-nos da análise elaborada por Denise Chini Solot em sua dissertação sobre o Ginásio do Paulistano, quando afirma que a ideia de espaço de PMR coincide com a de Le Corbusier, que deriva do cubismo, "uma interpretação geometrizada do espaço natural de Braque e Picasso”. A projeção de PMR não se faz a partir da operação sobre um sólido, por deslocamentos ou translações volumétricas. Não é cubo, é plano. É Amilcar de Castro ou Richard Serra, se quisermos um paralelo com as artes plásticas.

SOLOT, Denise Chini. Paulo Mendes da Rocha: estrutura: o êxito da forma. Rio de Janeiro,2004. p. 38 está ocupada por uma coleção de "puxadinhos”, vemos que tal extensão permanece. A esplanada está numa cota muito agradável, próxima à rua, como uma varanda que junto à copa das árvores amplia a sensação de estarmos no meio de um jardim.

Imaginamos com facilidade um espectador saindo pelo alto da arquibancada, no meio do espetáculo, para fumar um cigarro, ele se apoia no guarda corpo e vê um amigo passando na rua e diz: “Entre que o jogo está ótimo!”. O que queremos confirmar é que a relação entre a esplanada e a rua se manteve, apesar da diferença de cotas que há entre ambas.

Para manter esta relação de proximidade, e garantir um pé direito adequado à quadra esportiva, o arquiteto reconstrói a cota zero de implantação do edifício: abaixa o piso da quadra central numa medida justa, que garante um acesso suave a ela por meio de rampas, e ao mesmo tempo aproxima a cota superior da esplanada do chão.

É pela ação de reconstruir a topologia do terreno que nasce, ou se desenvolve, toda a espacialidade do Ginásio. Esta ação tem importância fundamental para podermos entender a maneira como PMR engendra o espaço, e atua sobre ele, já no momento da implantação do edifício no lote. Não se trata de colocar uma volumetria imaginada sobre um terreno dado. Trata-se da invenção de sucessivas plataformas (ver Desenho 03 p.62), pelas quais as relações de dentro e fora, cheios e vazios se constitui, com uma riqueza espacial insuspeitada. O projeto surge a partir da transformação do próprio terreno.

Esse processo está presente em diversos projetos de PMR, como na Casa Butantã (1964), na Casa Fernando Millan (1970) e na Capela de Campos do Jordão (1988). Entretanto, no nosso entender, realiza-se de maneira radical na obra do Museu da Escultura (1988), onde o terreno e construção parecem se fundir em uma só coisa. Detalharemos no capítulo seguinte como isso ocorre nos projeto das residências citadas acima.

Compreendemos, então, que a ordenação espacial em PMR não se faz com base na demarcação de volume. O espaço é engendrado pela relação e extensão de planos horizontais. Não se aplica aqui a noção de objeto ${ }^{5}$.

O que significa trabalhar a configuração do terreno? Não é apenas refletir sobre a melhor maneira de implantar um edifício no lote. No caso do projeto de PMR, o chão ganha um sentido mais amplo, urbano, e onde se coloca espacialmente a fronteira entre o público e o privado. O enfrentamento da condição da vida urbana e a visão 
da cidade como abrigo das relações sociais, tornar-se-ão preocupações cada vez mais presentes em seus projetos, às quais oferece respostas particulares.

Podemos então notar que aquilo que impulsionou o projeto do Ginásio foi a possibilidade de alargar, estender, a vida da rua para o interior do edifício. E vice versa, estender o olhar do interior sobre a cidade. A linha horizontal do desenho nos revela o desejo desta continuidade, uma possibilidade que por enquanto figura apenas em sua imaginação.

O projeto se faz primeiramente pelo estabelecimento de dois planos: o do terreno reconstruído e o da esplanada sob e sobre a qual os espaços do edifício irão se expandir. A esplanada é o horizonte do desenho.

Abaixo do plano da esplanada, ficam os programas cuja exigência de pé direito é menor: salas de ginástica, vestiários, sanitários, lojas etc. Já a quadra central necessita de um pé direito maior (nove metros), além de visuais livres e inclinações específicas para as arquibancadas. A fim de articular tais especificidades, o arquiteto cria um vazio circular de $34 \mathrm{~m}$ de diâmetro no plano central da esplanada e uma cobertura suspensa em relação a ela, numa cota mais alta adequada aos jogos esportivos. A cobertura é leve e plana: uma estrutura metálica treliçada, revestida de chapas metálicas e no seu centro um foco de luz direta. Diferente, portanto, da figura de uma cúpula circular que geralmente cobre ginásios de esporte.

O plano da cobertura é sustentado por um conjunto de 12 cabos de aço que se juntam ao centro em um anel metálico (que funciona a tração). Nas pontas, os cabos estão presos dois a dois em seis pilares de concreto, cujo formato já podemos reconhecer no desenho. Estes pilares ganham uma figura inventada, resultante das múltiplas funções que o arquiteto condensou em sua estrutura, são pilares em forma de placas alongadas. Como contrafortes de concreto bruto e aparente.

Entre o plano da cobertura e o da esplanada há ainda uma marquise circular de concreto que percorre todo o perímetro do ginásio, sua função estrutural é ser o contraventamento dos seis pilares e o apoio de borda da cobertura metálica. Esta marquise fica, em relação ao plano da esplanada, apenas a 2,3 metros de altura, parte de sua circunferência cobre a arquibancada e parte sombreia a esplanada. Surge ali, entre os dois planos, um vazio de luz e um lugar que é dentro e fora ao mesmo tempo, uma transição.

Este espaço, ainda sem nome, é fundamental para que a continuidade entre os planos sucessivos de internos e externos se dê. Notaremos nas obras analisadas nos 


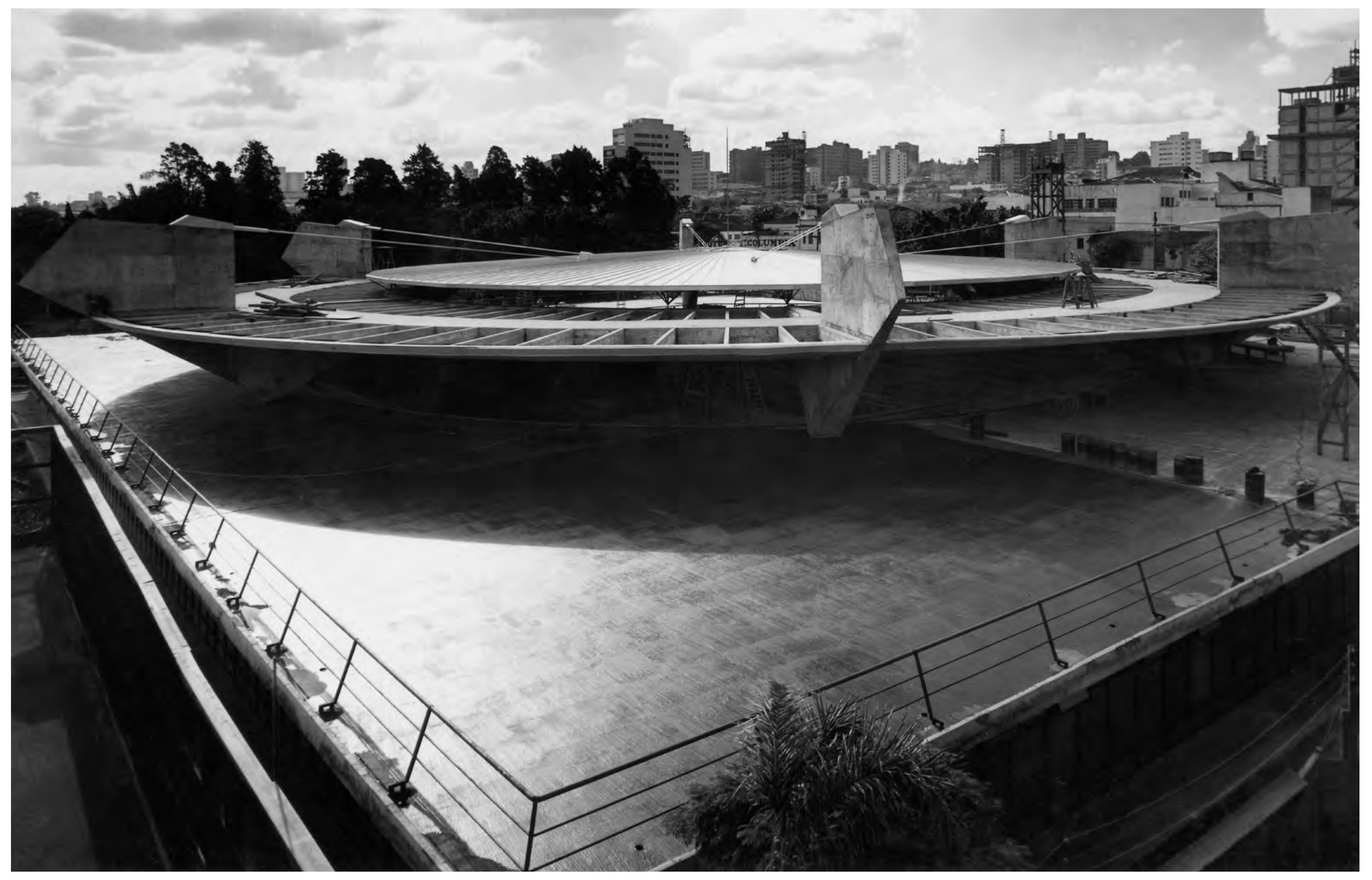


capítulos seguintes que PMR inventa com frequência espaços de transição, aos quais não podemos dar uma função programática, mas que é por eles que percebemos a unidade espacial de suas obras.

Sobre cada um dos contra fortes agem, portanto, dois tipos de força: são comprimidos por uma marquise de concreto e tracionados pelos dois cabos de aço que sustentam a parte central da cobertura. Toda esta carga chega a um ponto reduzido de apoio (1x.0.40m) na esplanada. Este ponto se articula por sua vez com um outro pilar de seção quadrada, que conduz a carga para a fundação. (Desenho. 04) ${ }^{6}$.

Assim, o princípio estrutural do Ginásio é composto por uma combinação de forças que une as propriedades de compressão do concreto armado e as de tração do aço num sistema complexo de transferência de cargas, onde cada peça tem uma função estrutural precisa, numa demonstração de rigor que se tornará expressão de sua obra.

Isso não quer dizer que o projeto se faz a partir de uma determinada escolha estrutural, nem tem a intenção de revelar as virtudes plásticas da matéria, no caso o concreto armado. Quando o historiador Josep Ma. Montaner afirma que o projeto de PMR parte de "uma fascinação pela engenharia e pela técnica", temos que ponderar que no nosso entender técnica aqui não é a expressão de uma tecnologia, ela tem um sentido distinto no projetar de PMR.?

Entretanto técnica também não é "instrumento que libera a forma”, como afirma a arquiteta Denise Solot”. ${ }^{8}$ Compreendemos que o que origina a forma não é dado pela vontade do arquiteto de se expressar pela técnica, nem por uma exigência plástica da matéria.

Propomos aqui um parêntese a fim de estendermos nossa compreensão sobre o conceito de técnica na obra de PMR. Além de nos auxiliar na análise da obra do Ginásio do Paulistano, é um conceito constante em suas entrevistas e textos, mais que isso, são ideias que também estruturam seu modo de pensar.

Podemos tomar por técnica aquilo que uma obra tem em comum com todas as outras. Segundo o filósofo Henri Bergson, a técnica é comandada pelas exigências da matéria, é repetição, fabricação e, deste modo, não é criação e sim o resultado de uma experiência acumulada. Sobre a técnica concentra-se a atenção do artista, a sua “intelectualidade”. Bergson esclarece ainda que: “Artesãos de nossas vidas (...) temos um interesse capital em nos familiarizar com a técnica de nossa ação, isto é, em extrair das condições nas quais esta se exerce tudo o que pode nos fornecer receitas e regras

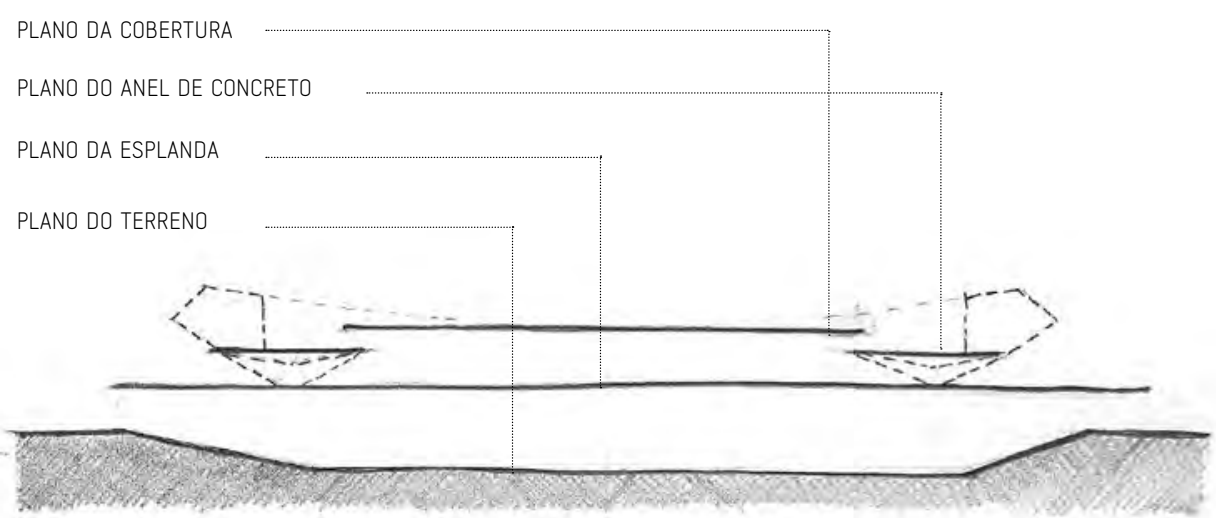

DESENHO 03

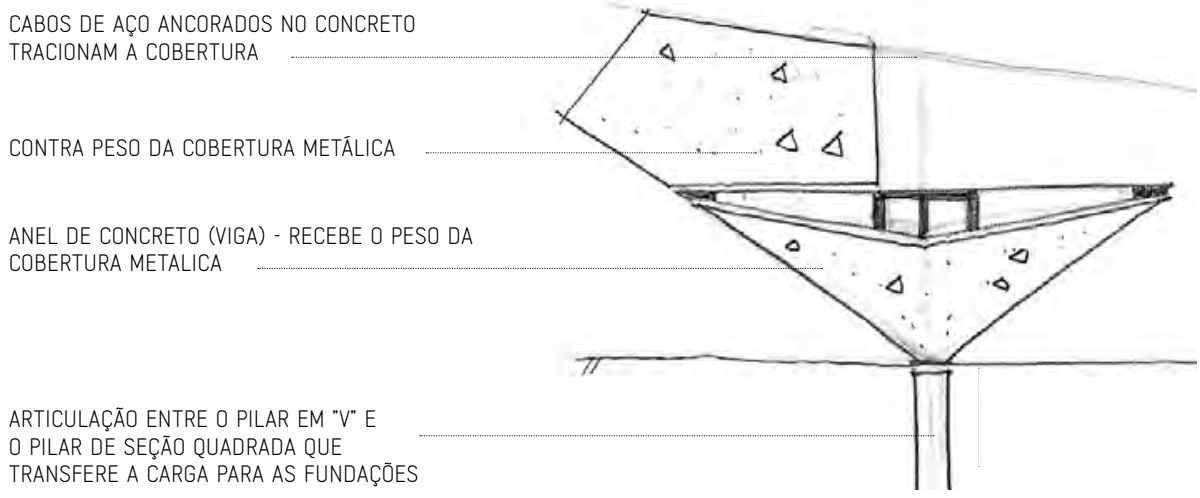

TRANSFERE A CARGA PARA AS FUNDAC̄̃ES

DESENHO 04

OS DESENHOS ACIMA, FEITOS POR MIM, ILUSTRAM ESQUEMATICAMENTE DUAS SITUAÇÕES APONTADAS NO TEXTO. O PRIMEIRO. DEMONSTRA OS DIFERENTES PLANOS SUCESSIVOS QUE CONFORMAM A ESPACIALIDADE DO EDIFÍCIO; E O SEGUNDO MOSTRA COMO $O$ FORMATO DO PILAR SE RELACIONA COM AS CARGAS DE FORÇA APLICADAS A ELE.

6 É curioso perceber como estes pilares quadrados "somem" no espaço e são difíceis de reconhecer nos desenhos executivos (VER CORTE A), pois eles estão escondidos entre as paredes dos vestiários que ficam abaixo do plano da esplanada. Com isso temos a sensação que os seis contrafortes se apoiam levemente no plano horizontal e não estão ancorados no chão.

7 MONTANER, Josep Ma. \&VILLAC Maria Isabel. Mendes da Rocha. Lisboa, 1996. p. 6

8 SOLOT, Denise. O êxito da técnica, 2004. p. 25. 


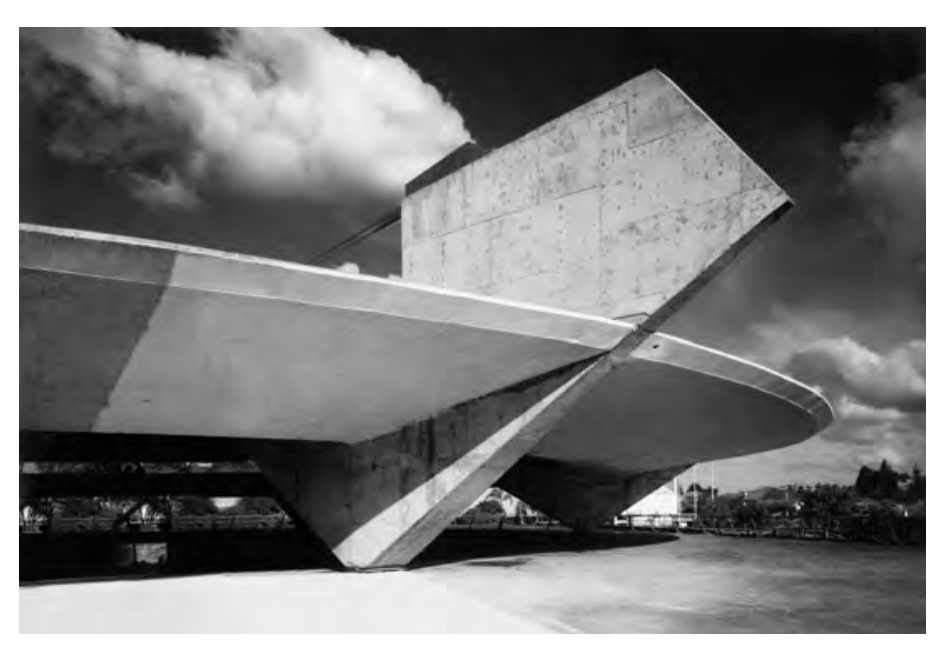

FIG 11

EM 1961 - CONTRA FORTE

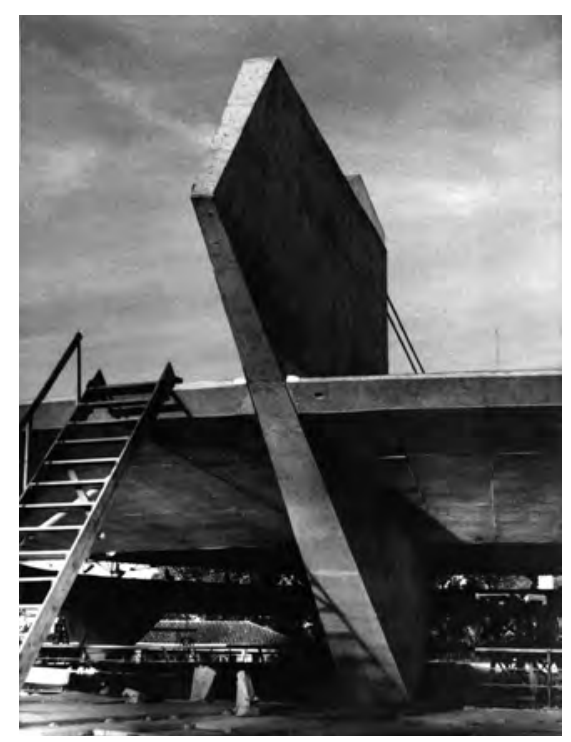

FIG 12

EM 1961 - APOIO DO CONTRA FORTE NA ESPLANADA

VEMOS OS PILARES EM "V" QUE SE AFINAM QUANDO CHEGAM NO PLANO DA ESPLANDANA: O ANEL DE CONCRETO DE 13 METROS DE LARGURA E ACIMA DESTE A PARTE TRINGLUAR DO PILAR CUJA MASSA ABSORVE O CONTRA PESO DO ESFORÇO DE TRAÇÃO REALIZADO PELOS CABOS DE AÇO QUE SUSTENTAM A COBERTURA.

9 BERGSON, Henri. O pensamento e o movente, 2006. p. 107 gerais sobre as quais se apoiará nossa conduta";; conduta como sendo o propósito de uma ação.

Nos projetos de PMR, técnica não se apresenta pela busca da esbeltez de um pilar, ou pela façanha de uma viga que vence grandes vãos, ou ainda pela espessura ínfima de uma parede de concreto. É um saber que está engendrado na experiência do arquiteto e surge como imaginação na possibilidade de um desenho ou de uma maquete de papel. Nas próprias palavras do arquiteto, é a "convocação de um saber". Entendemos que técnica no seu pensar se caracteriza pelo modo como mobiliza várias esferas do conhecimento: poesia, mecânica dos fluidos, escultura, geografia, campos que se articulam numa disposição espacial arquitetônica.

Voltando ao Ginásio Paulistano, constatamos que a qualidade espacial do Ginásio não é dada pelo modo como o arquiteto resolveu tecnicamente sua estrutura, é dada por um conjunto de determinações em diversos níveis de aproximação de um problema espacial, articulado previamente na sua mente, materializado pela armação rigorosa das peças e planos que conformam o espaço.

Cada um destes elementos (esplanada, pilares e o anel de concreto) são elementos arquitetônicos que congregam, num modo despojado e sintético, múltiplos atributos. A esplanada é praça, é a saída do Ginásio, é a extensão da rua, é o horizonte. O pilar é apoio, é a extensão do interior para o exterior, é a forma síntese do Ginásio. (Desenho 03 p.62).

Notaremos nas realizações posteriores ao Ginásio que o arquiteto desenvolve o gosto pela condensação. $\mathrm{Na}$ Casa do Butantã, por exemplo, a viga lateral será empena de fechamento, platibanda, beiral lateral, suporte da mesa de trabalho, da janelinha que se projeta para fora... Haja concisão!

Essa busca por concisão, que sem dúvida marca certa arquitetura moderna, se acentua no decorrer da trajetória do arquiteto. Torna-se um modus operandi do seu projetar. Há uma depuração daquilo que é supérfluo, um desejo de transformar o espaço com poucos elementos construtivos, poucas ações. Podemos dizer que a partir da obra do Ginásio a busca pela síntese se intensifica. Como veremos no capítulo VI, o arquiteto trabalha hoje apenas com retas e volumes puros: cubos e cilindros, numa economia "radical" de meios. Supomos que o projeto de Affonso Reidy para o Museu de Arte Moderna no Rio de Janeiro, realizado em 1954, possa ser visto como uma referência arquitetônica próxima à concepção do Ginásio do Paulistano. 
O espaço do Museu se configura por planos suspensos por uma sequência de 14 pórticos de concreto (bruto e aparente). $\mathrm{O}$ formato de cada pórtico segue uma tendência nominal que se desenvolveu na arquitetura moderna brasileira a partir da construção do Ministério da Educação e Saúde (1936), dada pelo afinamento na estrutura do pilar quando este chega ao chão, os conhecidos pilares em "v"10.

Como aponta Guilherme Wisnik: “esse projeto [o Ginásio do Paulistano] incorpora conquistas importantes da arquitetura feita no Rio de Janeiro, como a leveza dos apoios que se afinam ao tocar o solo (...)"11.

É importante destacar que tanto no Museu de Arte Moderna de Reidy como no Ginásio Paulistano está presente a ideia do espaço contínuo, sem barreiras, dada pela sucessão de planos "soltos" da estrutura principal, pelo modo ininterrupto como o pilar, a viga e a cobertura se fundem em uma peça aparentemente única (isto está evidente no Museu de Reidy) e pela propriedade plástica do concreto aparente, que permite dar um mesmo valor estético à frente e ao verso da construção. É exatamente nisso que reside a especial qualidade destes edifícios, que provoca um movimento que não cessa. Um “movimento de passagem”, tomando emprestada uma expressão do crítico Rodrigo Naves ${ }^{12}$.

A propriedade de fazer um espaço contínuo entre chão, parede, teto e mobiliário é realizável pelos atributos plásticos e físicos do concreto armado moldado em loco. Trata-se de uma matéria que se presta muito bem a essa intenção de projeto particular, pois pode ser pensada como massa moldável. Veremos no capítulo seguinte como não é possível agir da mesma maneira quando a matéria é o aço, o tijolo ou a madeira.

Por esse caráter de continuidade presente nas obras de PMR não é possível falar em composição quando estudamos estas obras. A operação projetual que faz o arranjo desses planos no espaço é articulação. Articulação e composição são duas ações projetuais distintas. Composição se dá por um raciocínio espacial que parte da combinatória de elementos arquitetônicos autônomos, partes pré-existentes reconhecíveis: pilotis + cubo + rampa + páteo ..., que juntos conformam um volume. Já a articulação se faz por um pensamento total do espaço, onde mal podemos identificar partes, pois os elementos estão arranjados de tal modo que um transforma o outro, como num móbile de Calder.

10 Vilanova Artigas em sua arguição memorial para o concurso de professor titular da Faculdade de Arquitetura e Urbanismo da USP, afirma a partir da arguição do professor Flávio Motta, que "o que me encanta é usar formas pesadas e chegar perto da terra e, dialeticamente, negá-las. Transformar minhas colunas numas coisas que se tornam para os olhos do engenheiro exigente uma coisa para dizer: 'Vai cair essa porcaria toda!'. Confesso-lhes que até agora nenhuma caiu, por causa da sabedoria que tenho de me fazer cercar por engenheiros inteligentes".

É interessante perceber que a partir de uma mesma ideia, de fazer "cantar os pontos de apoio” de Auguste Perret (1933), na arquitetura carioca predomina a questão plástica e em São Paulo, vem como um desafio para a engenharia.

ARTIGAS, Vilanova. Caminhos da arquitetura, São Paulo, 2004. p. 225

11 WISNIK, Guilherme. Estado crítico: à deriva nas cidades. São Paulo: Publifolha, 2009. p. 190.

12 No texto referente à obra de Amílcar de Castro, no qual encontramos várias relações de equivalência com a obra de PMR, Rodrigo Naves afirma que "aparentemente mais tradicional, a obra de Amílcar de Castro estabelece uma relação de maior altruísmo com o mundo. (...) seus trabalhos admitem - e, a bem dizer, instauram - um movimento de passagem que leva sempre à concretização de espaços situados para além de lugares magnetizados pela nossa presença (...)". NAVES, Rodrigo. A forma difícil. São Paulo, 1996. p. 246. 

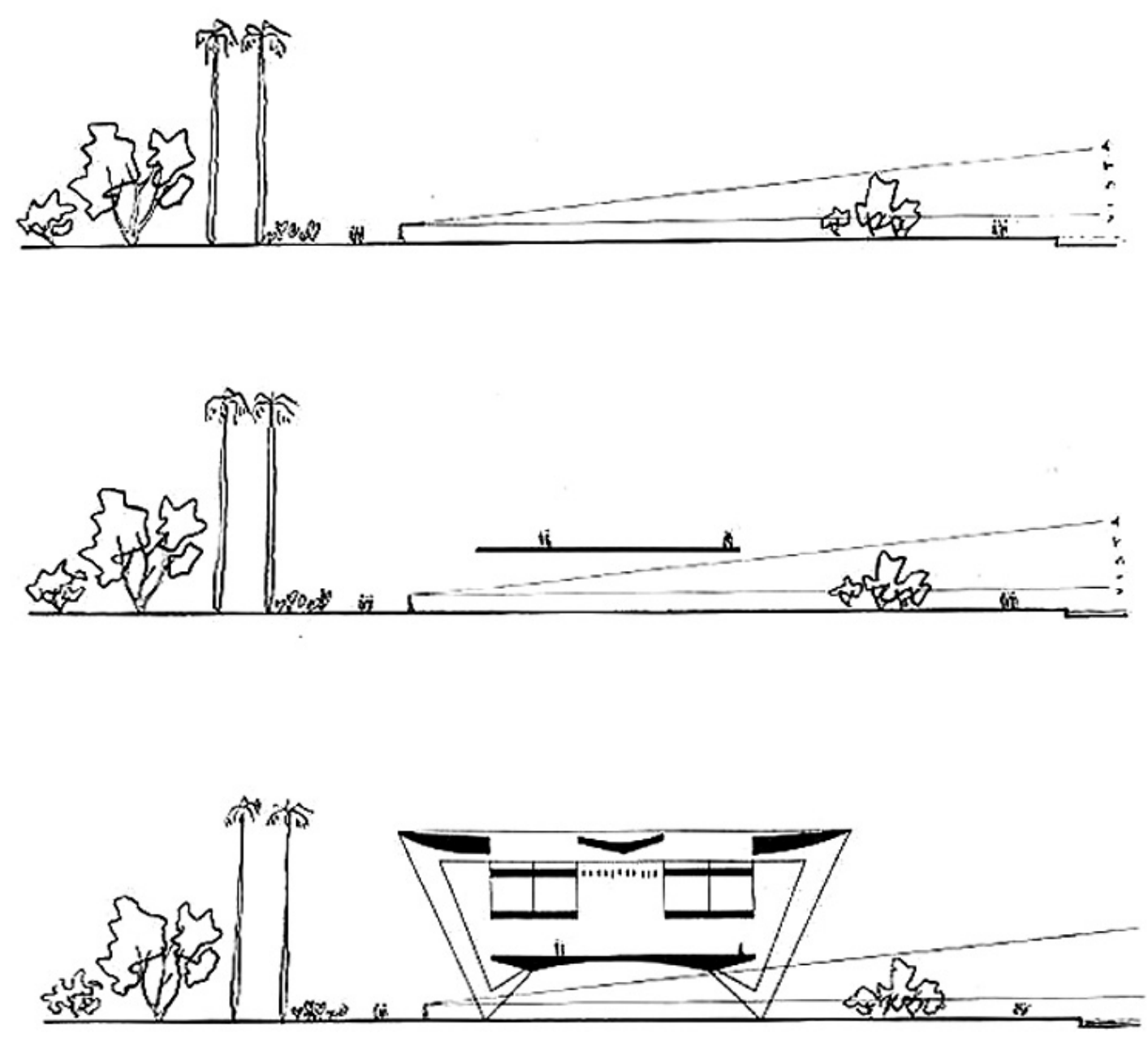

1954 - AFFONSO EDUSARDO REIDY. MUSEU DE ARTE MODERNA DO RIO DE JANEIRO. NESTES CROQUIS EXTRAÍDOS DO LIVRO DE S. GIEDION. AFFONSO EDUARDO REIDY - BAUTEN UND PROJEKTE 1960.VEMOS O PRINCIPIO DE ESTABELECIMENTO DE PRIVILEGIADA PARA A PAISAGEM DA BAITA DE GUANABARA. O EDIFİCIO, SE CONFIGURA A PARTIR DO ESTABELECIMENTO DESTA COTA IDEAL, E SE DESENVOLVE A PARTIR DELA, SEM OBSTRUIR A PAISAGEM. 
Ao observar o Ginásio, não podemos dizer que o espaço se fez pela soma da esplanada, dos seis contrafortes e da estrutura de sustentação da cobertura. O próprio desenho já nos mostra o pensamento totalizante.

Pudemos elencar até aqui algumas características do processo projetual do Ginásio, mas o que move o processo? O que o impulsiona?

Sabemos que o arquiteto não partiu de uma tipologia estabelecida para ginásios, pois não reconhecemos na volumetria do edifício construído um arquétipo de uma arena esportiva, um volume alto definido pelo formato das arquibancadas, de planta ovalada, fechado para a rua ${ }^{13}$. Nem tampouco percebemos que o foco do projeto está em atender às necessidades específicas do programa esportivo estabelecido pelo clu$\mathrm{be}^{14}$.

Compreendemos que o que move a ação do arquiteto é criar um espaço de característica urbana, que possa amparar ao mesmo tempo a vida da rua e as atividades esportivas do clube. $\mathrm{O}$ que determina o caráter do espaço são suas múltiplas possibilidades de uso, é o movimento erradio do espectador. Segundo suas próprias palavras, trata-se de uma arquitetura que "considera e ampara a imprevisibilidade das ações humanas." 15 .

Como vimos no capítulo anterior, o possível não é aquilo que ainda não se realizou, mas algo que se acrescenta à realidade: "É preciso aceitá-lo [diz Bergson]: é o real que se faz possível e não o possível que se torna real"16.

Assim, o arquiteto inventa uma nova forma para um ginásio esportivo, que não se remete nem a um tipo, nem a um programa de demandas determinado. Inventa algo que ainda não existe, uma possibilidade, um porvir.

Henri Bergson traz uma notável contribuição ao esclarecer que inventar é diferente de descobrir, pois só podemos descobrir aquilo que já existe; a invenção, "confere ser àquilo que não era, ela poderia não ter surgido nunca" ${ }^{17}$. Nesse sentido, para ele, o esforço da invenção é justamente suscitar um problema (como vimos no capítulo I) e criar os termos nos quais ele será posto.

Pudemos identificar por enquanto que o modo como PMR inventa se dá por aproximações sucessivas a um problema que ele formulou, colocado a partir de uma percepção, ou da consciência do real. Esta possibilidade se desenvolve na medida em que os vários eixos de compreensão do problema vão se articulando numa ação

13 Como é o caso, por exemplo, do Ginásio do Ibirapuera projetado por Ícaro de Castro Melo em 1957, para tomarmos um exemplo próximo cronologicamente à elaboração do projeto do Ginásio.

14 No curta metragem PMR 29', o arquiteto conta que em certa ocasião (não sabemos a data) o coreógrafo americano Merce Cunningham veio à São Paulo para escolher um teatro onde se apresentaria, animou-se com a possibilidade cênica do Ginásio do Paulistano cujas portas se abriam tão francamente para a rua. Segundo PMR, este episódio é uma demonstração de que a visão da arquitetura como algo que responde apenas às necessidades práticas do programa é limitante, pois justamente descarta a possibilidade do imprevisível, como este caso de se fazer um espetáculo de dança em uma quadra de basquete.

OTONDO, Catherine;BRAGA Juliana;GIMENEZ Carolina; GOUVEA José Paulo; SODRE João. PMR 29' - 29 minutos com Paulo Mendes da Rocha. Curta metragem, 2010.

15 ROCHA, Paulo Mendes. "Engendrando o Humano". Entrevista concedida à Revista Ide. São Paulo, 1998. p. 13.

16 BERGSON H. ibidem, 2006, p. 119.

17 BERGSON H. ibidem, 2006. p. 55. 

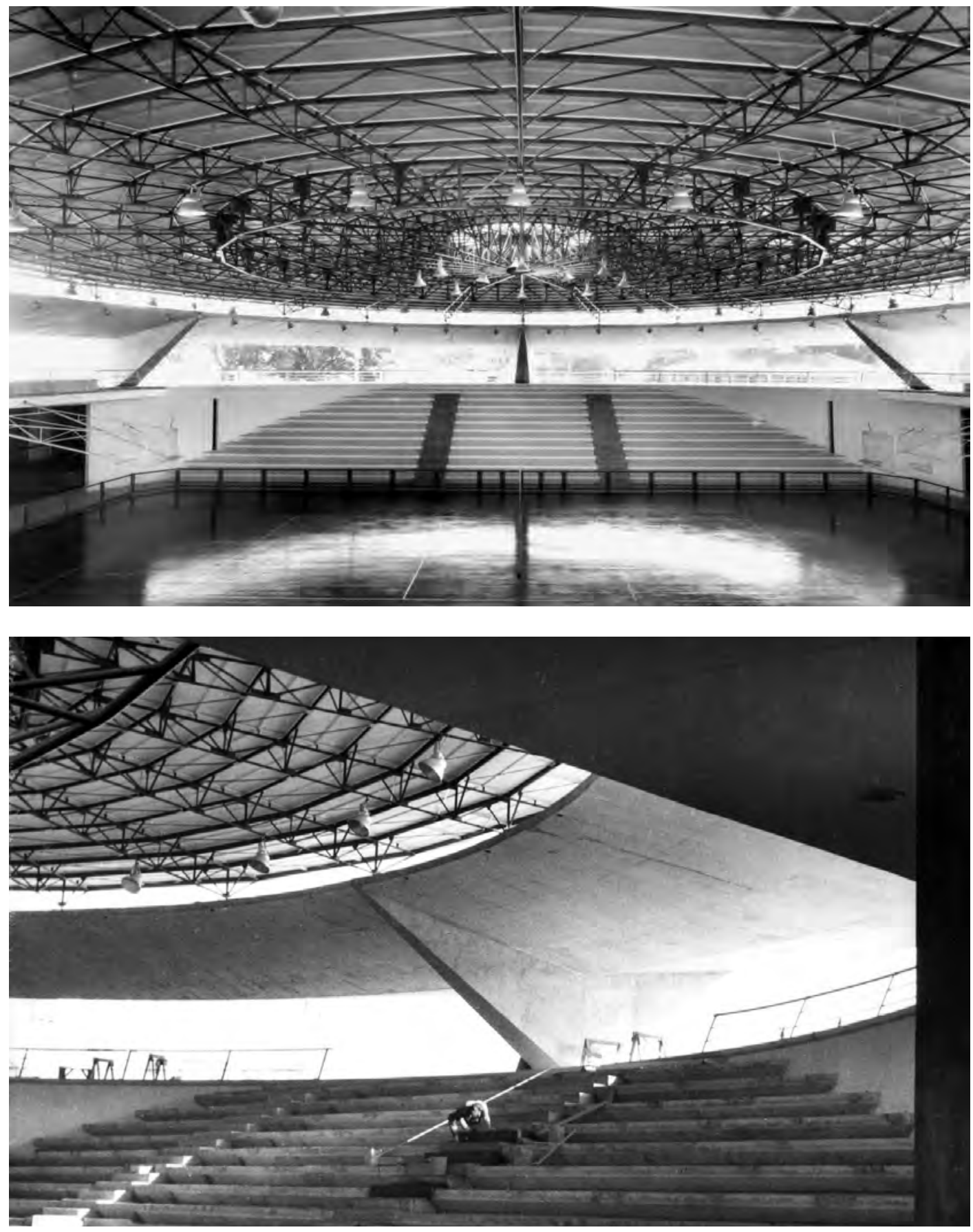


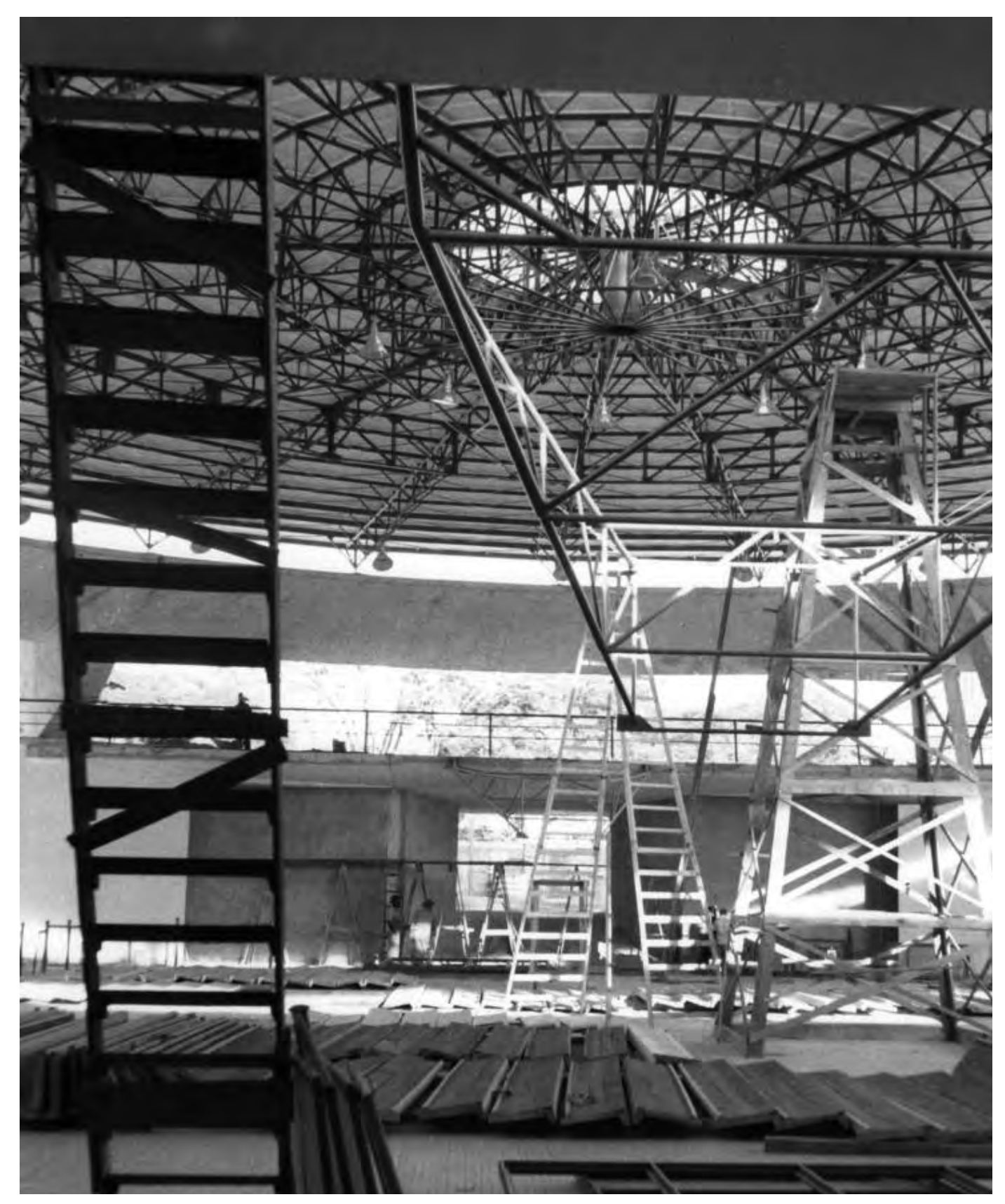

FIG 15

961 - VISTA INTERNA DO GINÁSIO POUCO ANTES DO TÉRMINO DA OBRA 


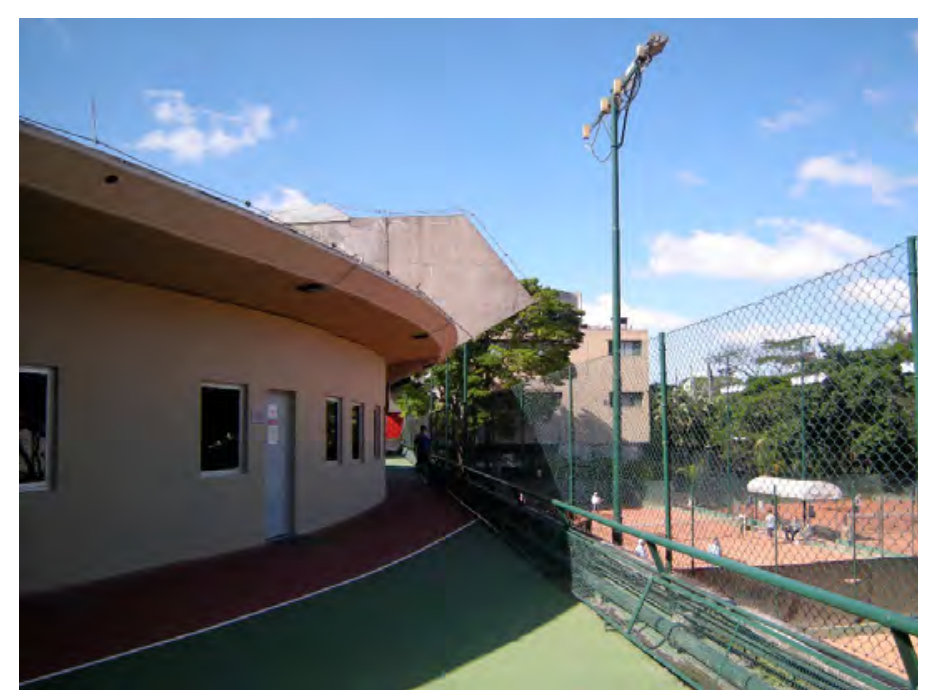

FIG 16

EM 2010 - VISTA DA ESPLANADA CERCADA POR UM ALAMBRADO E Ā ESQUERDA O FECHAMENTO EM ALVENARIA QUE FAZ COM QUE O ANEL DE CONCRETO "DESAPAREÇA".

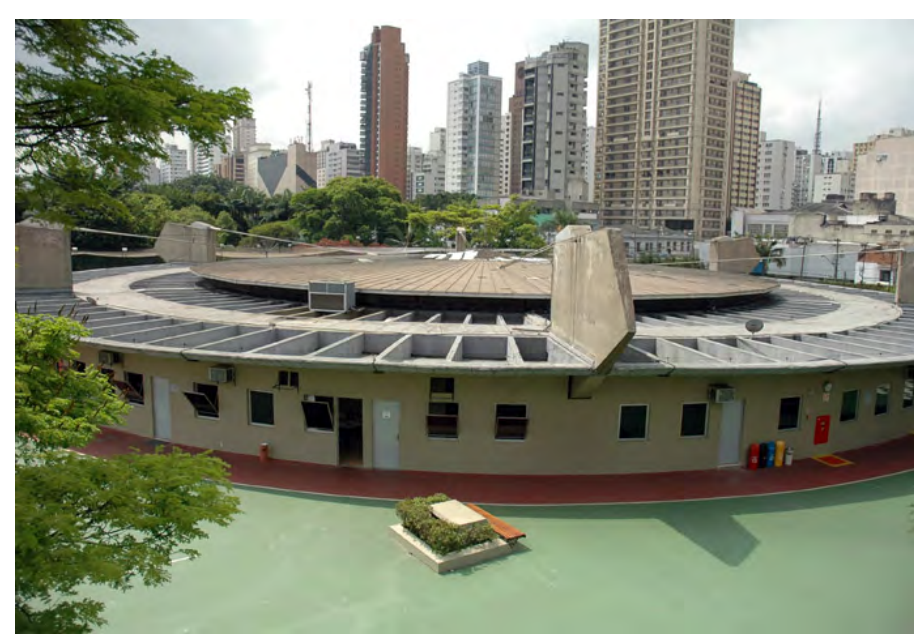

FIG 17

EM 2010 - 0 FECHAMENTO ATUAL INTERROMPE A CONTINUIDADE ESPACIAL ENTRE $O$ INTERIOR E $O$ EXTERIOR, E COM ISSO 0 ESPAÇO DA ESPLANADA PERDE SENTIDO, PARECE UMA SOBRA, ONDE DE CERTO MODO. DESAJEITADO, CONS-

TRUIU-SE UMA FLOREIRA E UM BANQUINHO, NUMA TENTATIVA "MAL A DROITT" DE REALIZAR UM AMBIENTE DE "PRAÇA". projetual desvinculada de um repertório formal ou de um programa pré-estabelecido.

Se observarmos como os desenhos do Ginásio são refeitos, verificamos que eles se modificam dos primeiros estudos até a construção da obra, constatamos que as mudanças naturais ao processo parecem escapar às exigências, ou acomodações da vida prática: compatibilização estrutural, de instalações, orçamentos, alterações de escopo, cronogramas. As mudanças se apresentam como momentos de uma mesma coisa que não se encerra no presente da obra concluída, mas permanece como obra em constante transformação.

Pela experiência de uso dos espaços, as pessoas acabam dando novas respostas ao espaço construído; a partir de suas vivências, deixam uma porta aberta ao imprevisível.

Quando andamos hoje pelo Ginásio, notamos que uma série de reformas (“puxadinhos") foram realizadas. O vazio de luz entre a esplanada e o anel de concreto, por exemplo, foi fechado com alvenaria, a própria esplanada cercada por um alambrado etc. Compreendemos, com certa melancolia, que a porta aberta ao imprevisível deixa também a possibilidade de se reconfigurar a ideia original, ameaçando sua própria integridade.

Neste sentido, as reformas provocam um sentimento contraditório, ao percebermos que apesar do espaço projetado há mais de cinquenta anos, ter sido transfigurado, sua essência está lá e move hoje com vigor a vida presente de seus habitantes. 


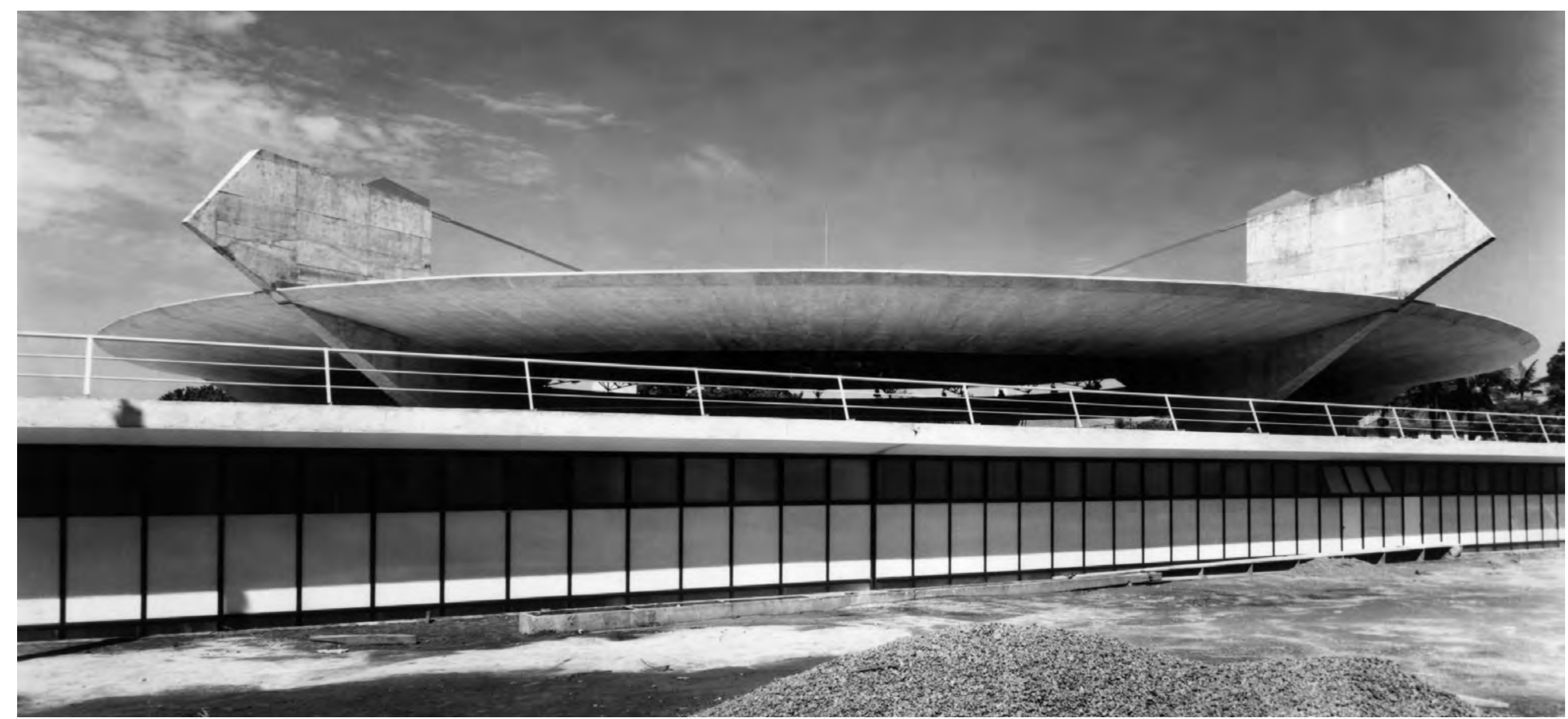

FIG 18

PUBLICACÃA DO PROJETO EXECUTIVO

FICHA TÉCNICA

GINÁSIO CLUBE ATLÉTICO PAULISTANO

RUA HONDURAS, 1400 - SÃO PAULO

DATA DO PROJETO:1958

DATA INITCIO DA OBRA: 1959

TÉRMINO DA OBRA:1961

ÁREA DO TERRENO: 40.654.98M2

ÁREA CONSTRUIDDA: 5.490,67M2

ARQUITETO COLABORADOR: JOÃO EDUARDO DE GENNARO

CÁLCULO DAS ESTRUTURAS DE CONCRETO ARMADO E DAS FUNDACÕES. ESCRITÓRIO TÉCNICO PAULO FRANCO DA ROCHA

CÁLCULO DAS ESTRUTURAS METÁLICAS: ESCRITÓRIO TÉCNICO ANDRATEL

TIPO DE CONTRATAÇÃO: CONCURSO 


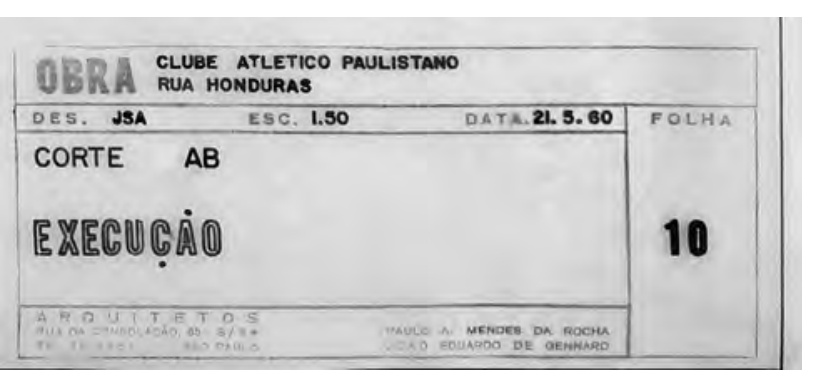

AMPLIAÇÃO DO CARIMBO ORIGINAL DAS PRANCHAS

O PROJETO EXECUTIVO ORIGINAL FOI REALIZADO A NANQUIM SOBRE PAPEL VEGETAL POSSUI APROXIMADAMENTE 30 PRANCHAS E ESTÁ ARMAZENADO EM TUBOS. POR CONTA DA PUBLICAÇ̃O DO LIVRO PAULO MENDES DA ROCHA PELA EDITORA COSAC NAIFY, O PROJETO FOI TODO REDESENHADO EM AUTOCAD. ALGUMAS DAS PRANCHAS ORIGINAIS DO PROEJTO EXECUTIVO FORAM DOADAS AO ACERVO DE PROJETOS DE ARQUITETURA DO MUSEU

GEORGE POMPIDOU, PARIS, E FORAM DIGITALIZADAS.

O CARIMBO AO LADO INDICA A DATA E A FASE DE PROJETO DOS DESENHOS A PRANCHA DA IMPLANTAÇÃO NÃO POSSUI CARIMBO NO ORIGINAL.

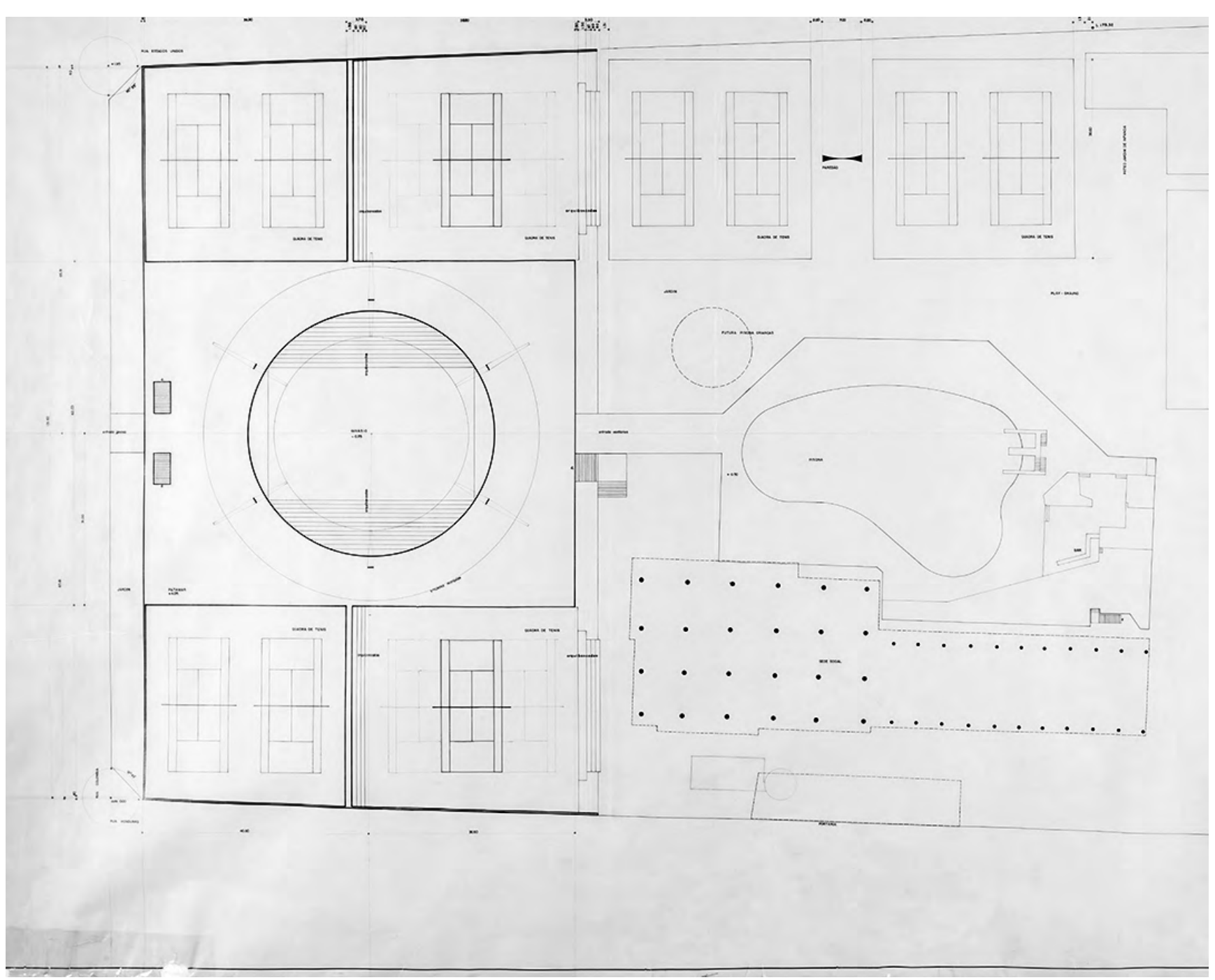

IMPLANTAÇÃO

S/ ESCALA 


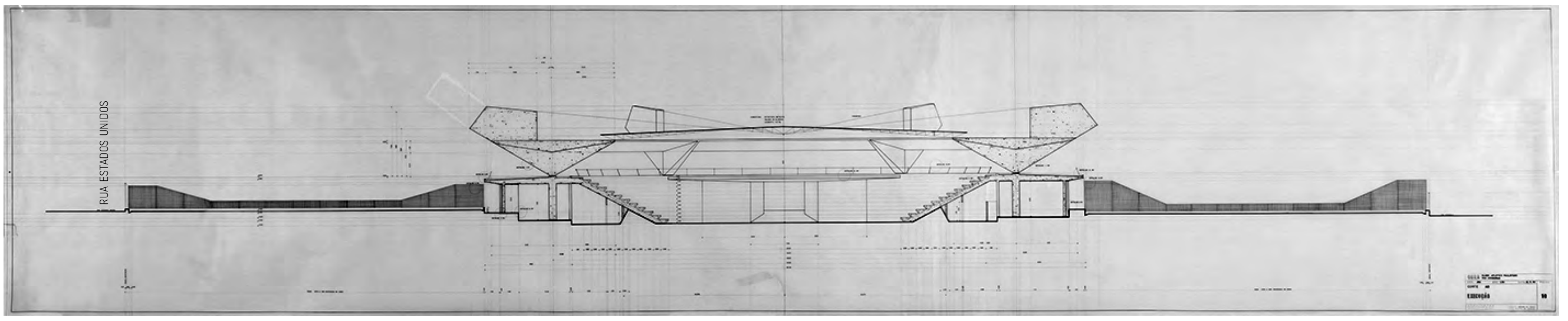

CORTE A-B

S/ ESCALA

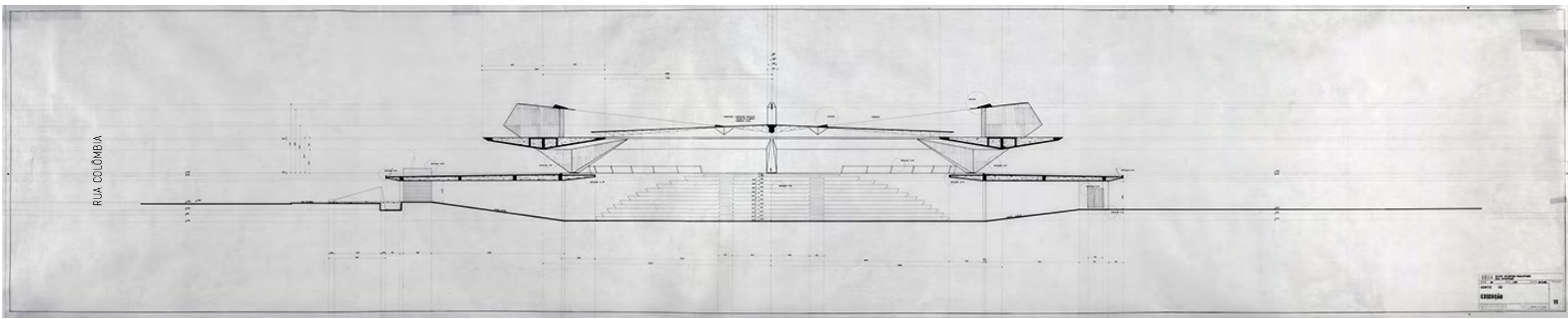

CORTE C-D

S/ ESCALA

OS DESENHOS ACIMA TÊM UM TAMANHO REAL DE 90X3.50M. O ARQUITETO

NOS CONTA QUE PARA NÃO TER QUE DIVIDIR O DESENHO EM DUAS PARTES

FEZ UMA MESA ESPECIAL PARA PODER DESENHAR ESTAS SECCÕES. 


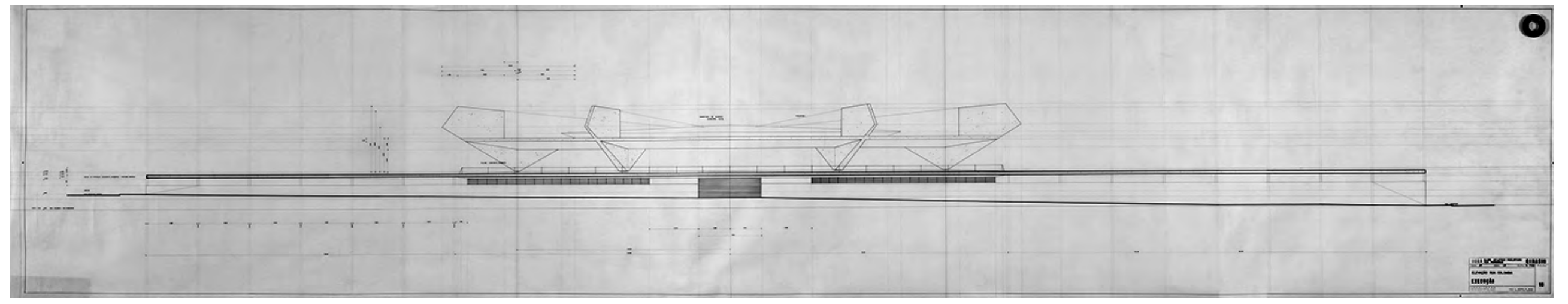

ELEVAÇÃO FRONTAL - RUA COLÔMBIA S/ ESCALA

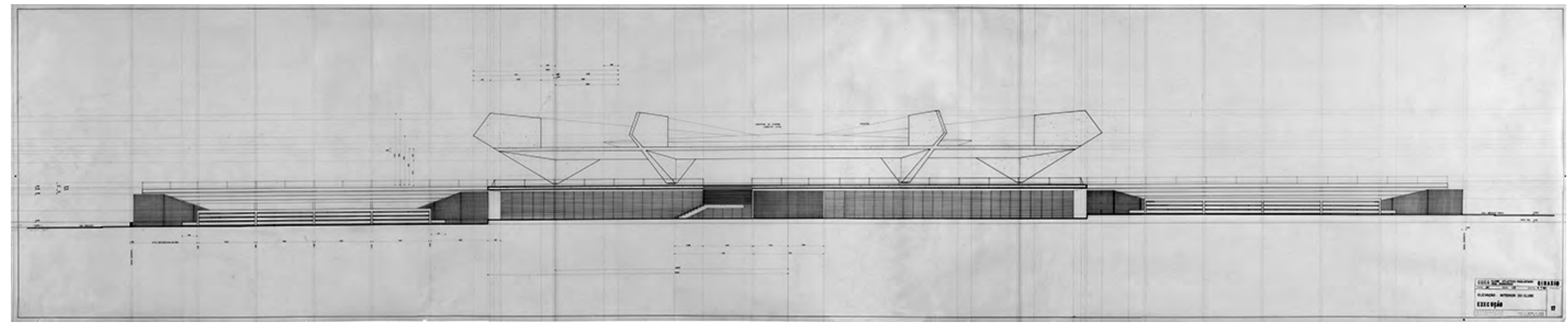

ELEVEÇÃO POSTERIOR - VISTA INTERNA DO CLUBE S/ ESCALA 


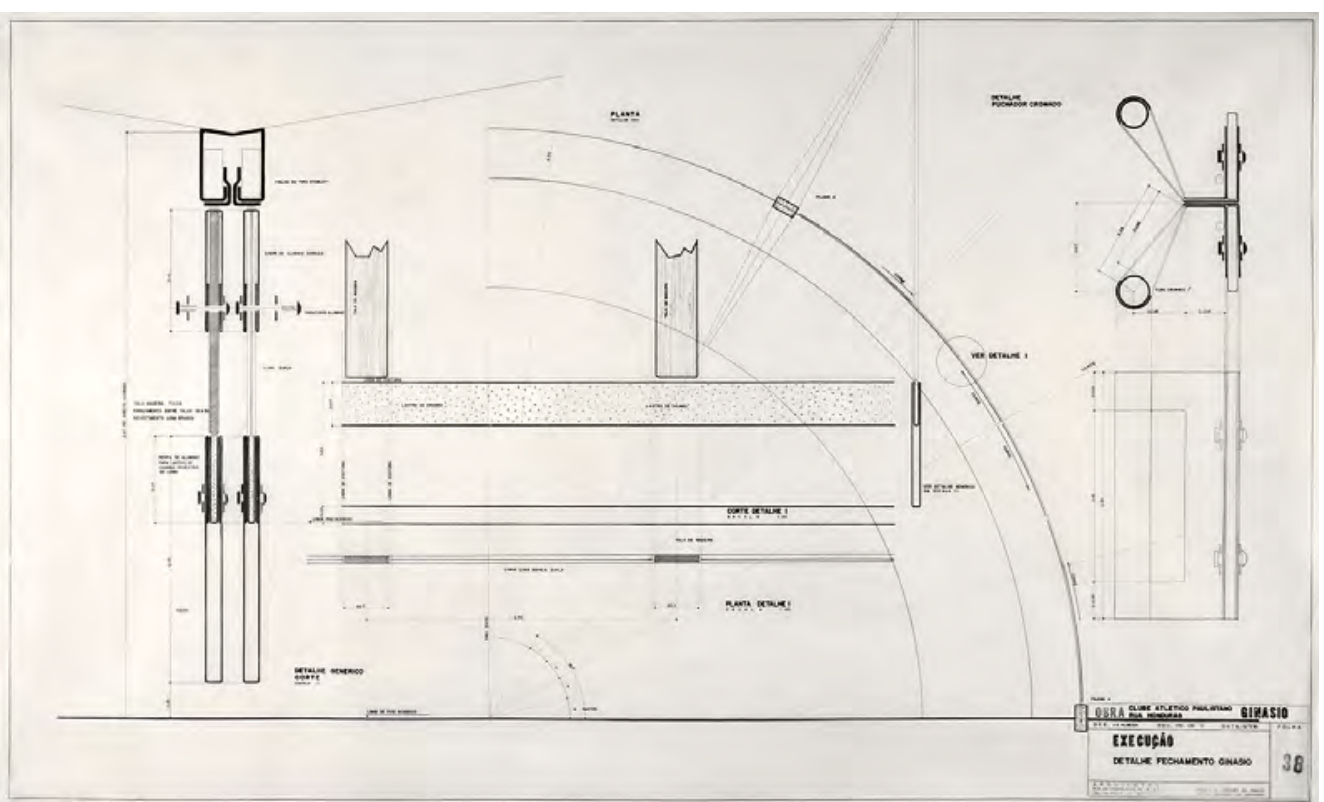

D DETALHE AO LADO MOSTRA UM SISTEMA DE FECHAMENTOS OUE

SERIA UTILIZADO PARA FECHAR O ESPAÇO ENTRE A ESPLANADA E O ANEL DE CONCRETO

ESTAS PORTAS NUNCA FORAM REALIZADAS E ANOS DEPOIS A DIREÇÃO DO CLUBE FECHOU ESTE VAZIO DE LUZ COM ALVENARIA, COMO VEMOS NAS FOTOS ATUAIS DO GINĀSIO.

S/ESCALA

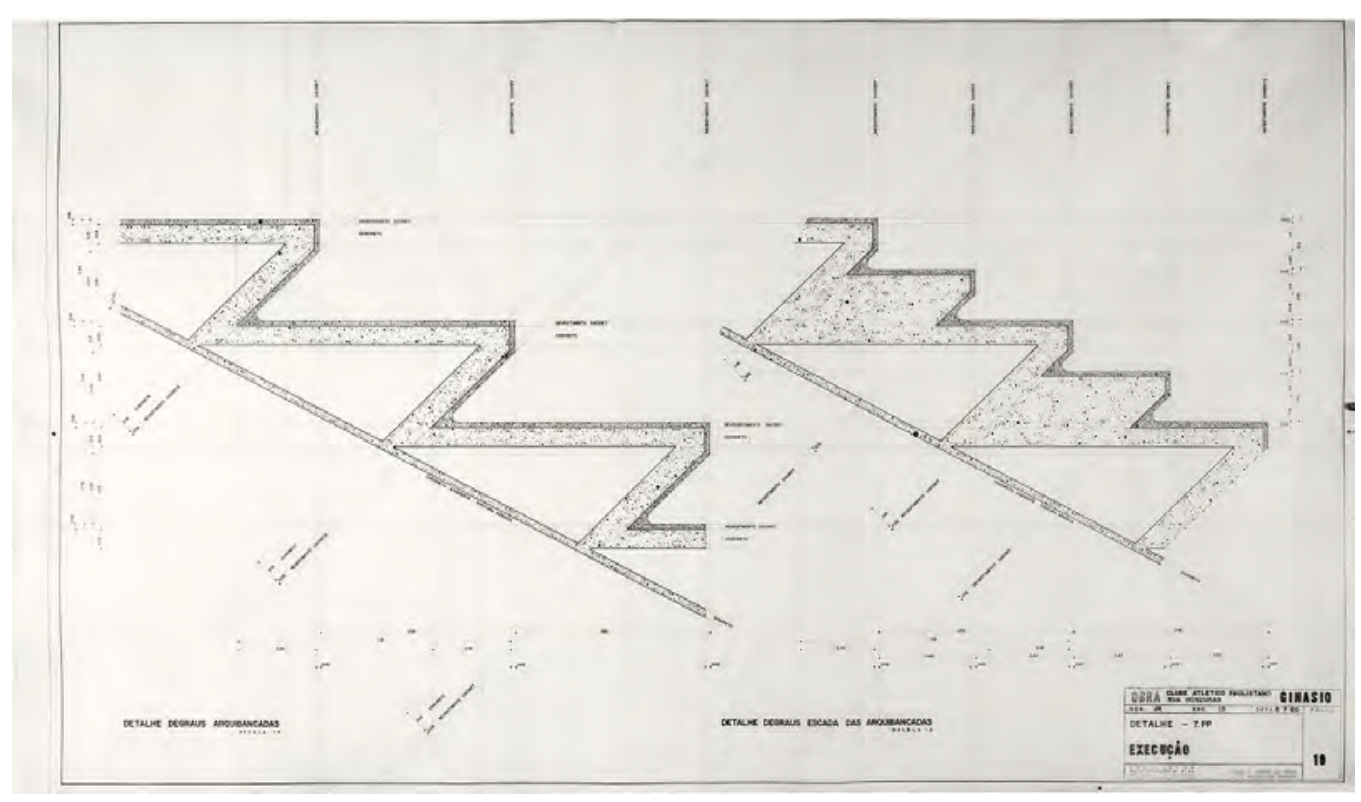

DETALHE DOS DEGRAUS DA ARQUIBANCADA S/ ESCALA 


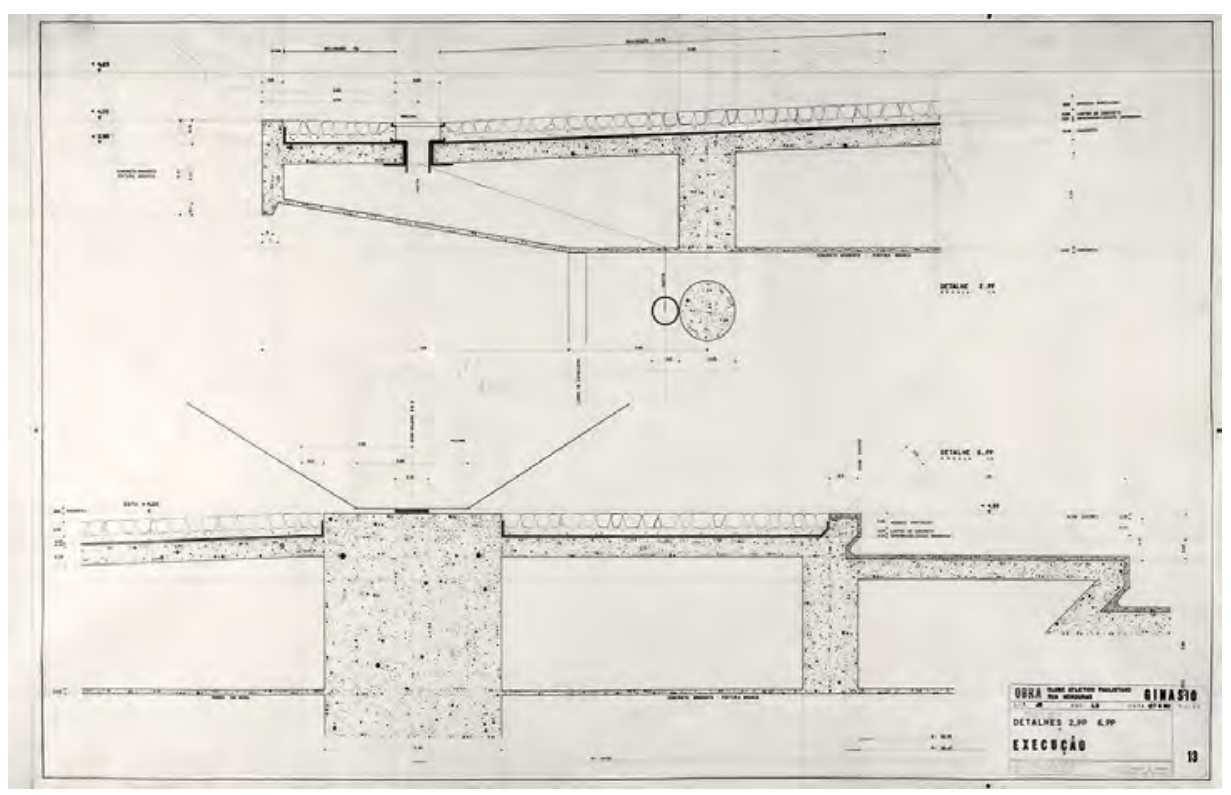

DETALHE DO ARRANQUE DO CONTRAFORTE SOBRE A ESPLANADA E DO ANEL DE CONCRETO, COM SUA IMPERMEABILIZAÇÃO E ESCOAMENTO DE ÁGUA.

S/ ESCALA

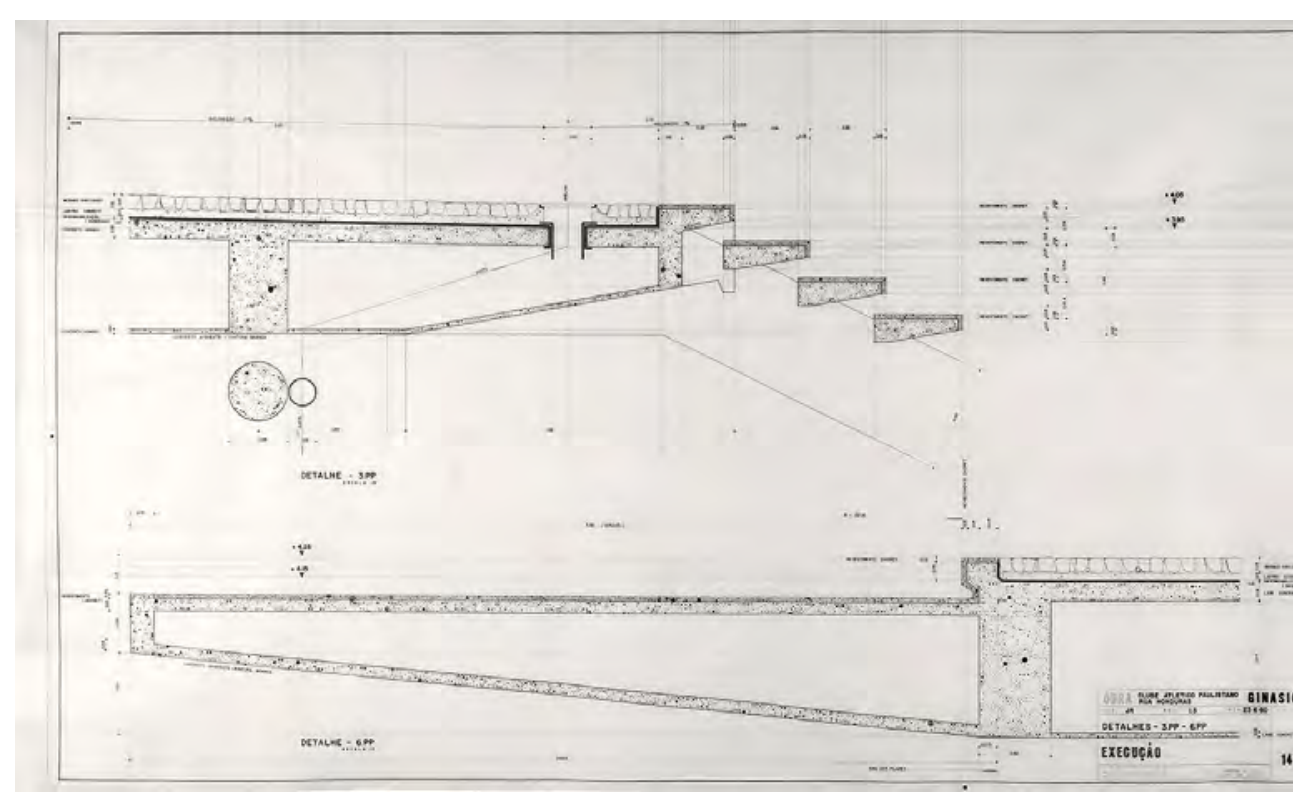

DETALHE DA ESCADA DE ACESSO À ESPLANADA E COBERTURA CIRCULAR DE CONCRETO S/ ESCALA 


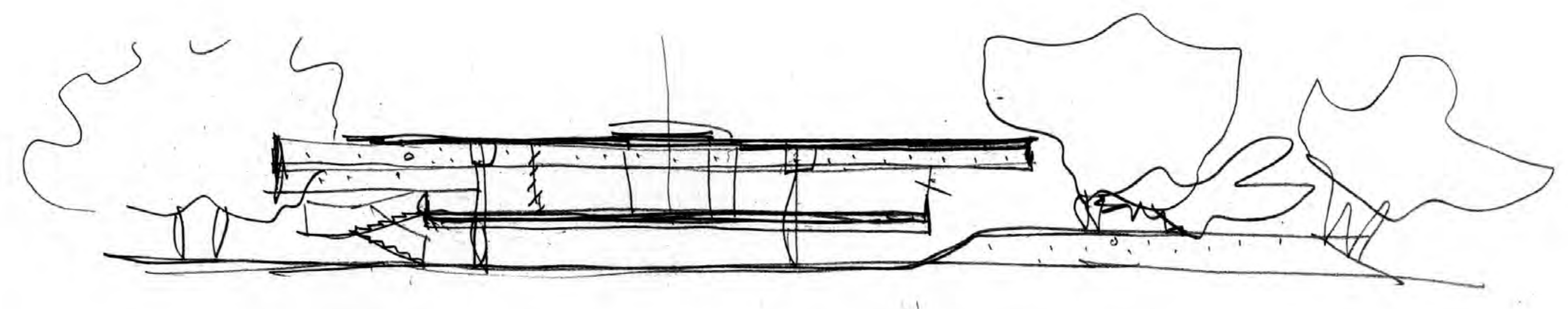

1964: CASA BUTANTÃ 


$$
\text { है }
$$



1970: CASA FERNANDO MILLAN 


\section{IV. $1964-1970$ CASA BUTANTÃ E CASA MILLAN: DESENHO DO LOTE}

"O homem move-se e actua no exterior de todas as coisas; está perpetuamente no lado de fora e, para penetrar além das superfícies é preciso que as rompa. O privilégio único da arquitetura entre todas as artes, seja edificando casas, igrejas ou naves, não é abrigar uma vida cômoda e rodeá-la de segurança, mas sim construir um mundo interior que dimensione o espaço e a luz segundo as leis de uma geometria, de uma mecânica e de uma óptica, necessariamente implícitas na ordem natural, mas em que a natureza não desempenha qualquer papel."

H. Focillon

1 FOCILLON, Henri. A vida das Formas seguido de Elogio da Mão, Lisboa, 2001. p. 39,40 .

2 Além das casas, contabilizamos 15 projetos de edifícios residenciais, dos quais 5 foram construídos.

3 Pelo ato de cassação, datado de 1969, o arquiteto foi afastado de seu posto de professor da Universidade de São Paulo e ficou impedido de participar de licitações e concorrências para órgãos ligados ao governo. Por uma

"ironia" da história, no mesmo momento PMR vence o concurso para a elaboração do projeto que representaria o Brasil na Exposição Internacional de Osaka no Japão.
No conjunto da obra do arquiteto Paulo Mendes da Rocha existem aproximadamente 60 projetos de residências unifamiliares, dos quais 23 foram construídos, principalmente entre as décadas de 1960 e 70.

Esse número refere-se à cerca de $1 / 4$ do total de projetos realizados pelo arquiteto entre os anos de 1958 a $2011^{2}$. Apesar de representar uma quantidade expressiva de trabalhos dedicados ao programa doméstico, por assim dizer, o arquiteto demonstra, como dissemos anteriormente, certa indignação quanto ao fato de que na cidade moderna ainda se venda um pedaço de terra para apenas uma família morar. Para PMR, a moradia unifamiliar deve estar disposta de modo adensado em edifícios de apartamentos que contém, por sua vez, o mínimo necessário para uma família realizar suas tarefas domésticas. As cidades existem para vivermos de modo coletivo, onde o espaço público tem preeminência sobre o espaço privado.

Diante disso, parece uma contradição essa intensa dedicação de PMR ao programa privado. No entanto, quando observamos atentamente a cronologia dessas realizações, vemos que a produção de projetos residenciais deu-se sobretudo durante o período da ditadura militar, durante o qual, como se sabe, o arquiteto teve seus direitos civis cassados pelo Estado ${ }^{3}$. Por esta razão não podia receber encomendas de trabalho vindas do poder público, direta ou indiretamente. 
Projetar casas, portanto, era aquilo possível de se fazer. É visível em sua trajetória que com o processo de abertura política do país, no início da década de 1980, a quantidade de projetos residências diminui consideravelmente. Basta dizer que nos anos 70 foram realizados 26 projetos de casas, na década de 80, oito, nos anos 90 , quatro, e em 2000, apenas três ${ }^{4}$.

Mas não era somente PMR que se dedicava ao projeto de casas, neste período houve expressiva produção de residências unifamiliar para uma classe social de alto poder aquisitivo em São Paulo5. Como vimos no capítulo I, essas obras se aproximam em termos de valor estético, formal e programático e fazem parte de um conjunto maior de realizações do grupo conhecido historicamente como Escola Paulista. Lembrando a caracterização feita por Ruth Verde Zein, são construções que se relacionam ao brutalismo corbusiano, cuja disposição espacial é dada por blocos únicos destacados do chão, pela procura de uma horizontalidade e pelo uso da estrutura em concreto armado protendido, "valorizando sua qualidade de manufatura"6.

Para nosso entendimento, mais do que identificar essas obras como sendo parte de uma escola, ou questionar seu atributo brutalista, interessa compreender como esses projetos permitiram ao arquiteto experimentar espacialidades, soluções formais e materiais, e o desdobramento desta experiência em projetos de maior escala.

O exame da trajetória completa dos projetos realizados por PMR nos permite afirmar que a experiência de projetar essas casas significou uma espécie de laboratório para o arquiteto, onde pôde ensaiar soluções, técnicas espaciais e matérias, que foram consolidando um modo particular de pensar e fazer projetos. As casas por sua escala reduzida, foram ideais para tais ensaios ${ }^{7}$.

Neste período de "reclusão", o arquiteto vai aos poucos formalizando alguns raciocínios projetuais que acabam por se tornar argumentos recorrentes em suas realizações futuras. Se, como vimos no capítulo anterior, o projeto para Ginásio do Paulistano transparece a forma mentis que atua no conjunto da obra de PMR, trata-se agora de constatar algumas ideias expressas em vários momentos de sua trajetória. São exemplares de uma "caligrafia".

A partir da análise de obra da Casa Butantã e Casa Millan, iremos apontar como esta "caligrafia" se manifesta espacialmente e quais ações projetuais formam esses espaços, não apenas como figuras geométricas, mas com valores de peso, densidade, equilíbrio, luz e movimento.
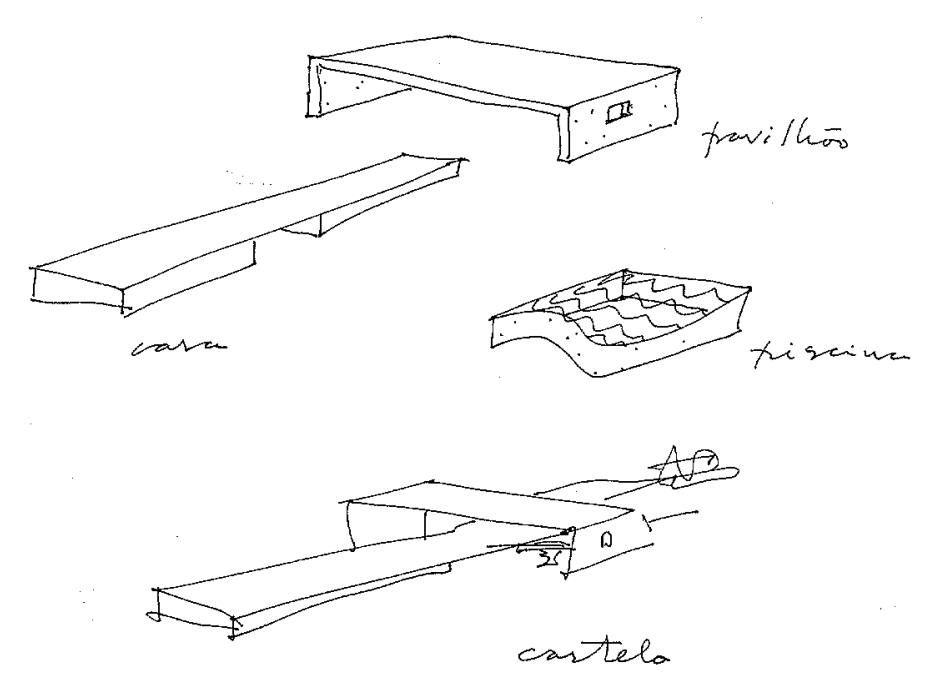

1988: CASA EM CATANDUVA

IMPLANTAÇÃO

S/ESCALA

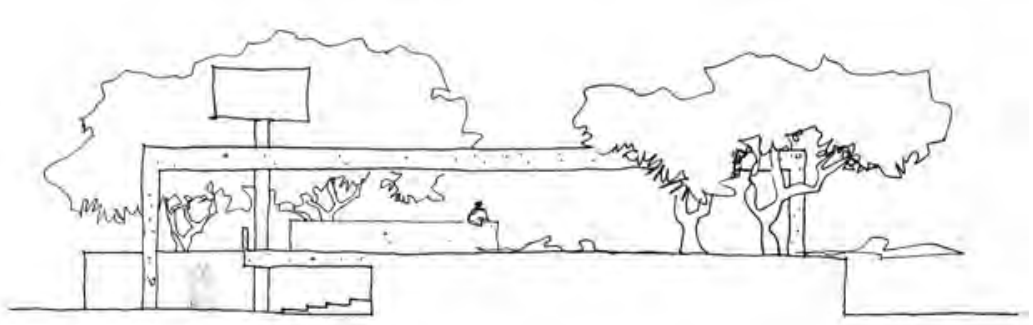

1988. CASA EM CATANDUVA.

ELEVAÇÃO

S/ESCALA

4 Ver lista de projetos: Anexo I.

5 A reunião destas obras pode ser vista no livro: ACAYABA, Marlene Milan. Residências em São Paulo (1947-1975). São Paulo, 1986.

6 ZEIN, Ruth V. Arquitetura brasileira, Escola Paulista e as casas de Paulo Mendes da Rocha. Porto Alegre, Dissertação de mestrado, Faculdade de Arquitetura da Universidade Federal do Rio Grande do Sul, 2000. p. 384

7 No projeto da Casa Silvio Bueno Netto (1978), por exemplo, o arquiteto desenha um pórtico de concreto que atravessa transversalmente o volume da casa; por este elemento - sem função aparente - se dá a passagem entre os espaços internos e externos da casa, estabelecendo uma relação de cheios e vazios dada pela articulação de três volumes: o corpo da casa, a varanda (formada pelo pórtico) e a piscina. Não é necessário grandes esforços de imaginação para reconhecer nesta solução espacial a origem do projeto para o Museu da Escultura (1988); relação feita inclusive pelos autores Sophia da Silva Telles em “Museu da Escultura” e Guilherme Wisnik em "Arquitetura do Território". 


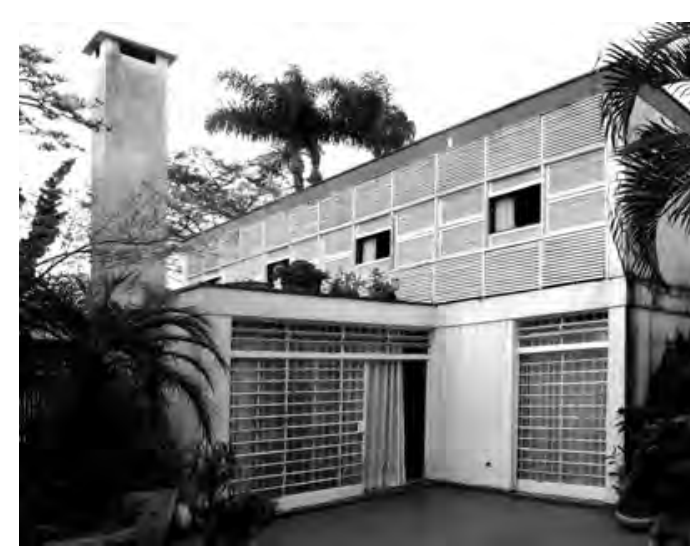

FIG 19

1960: CASA VIRGÍLIO LOPES DA SILVA, SP

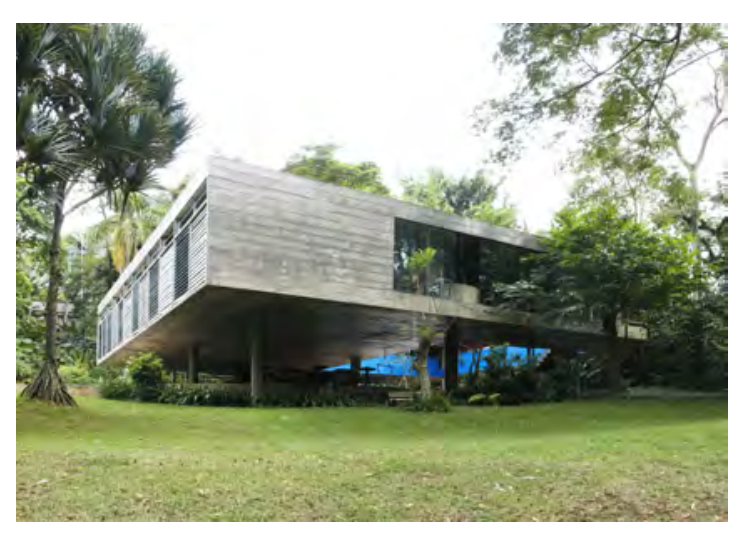

FIG 22

1972: CASA JAMES FRANCIS KING, SP

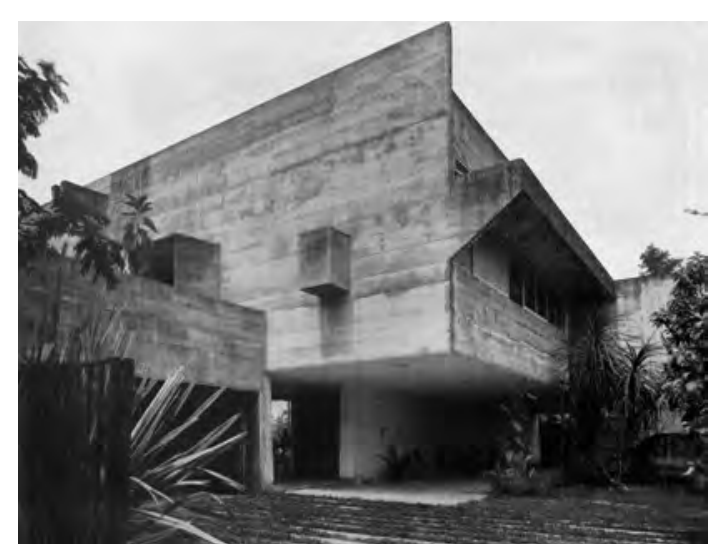

FIG 20

1961: CASA GAETANO MIANI. SP

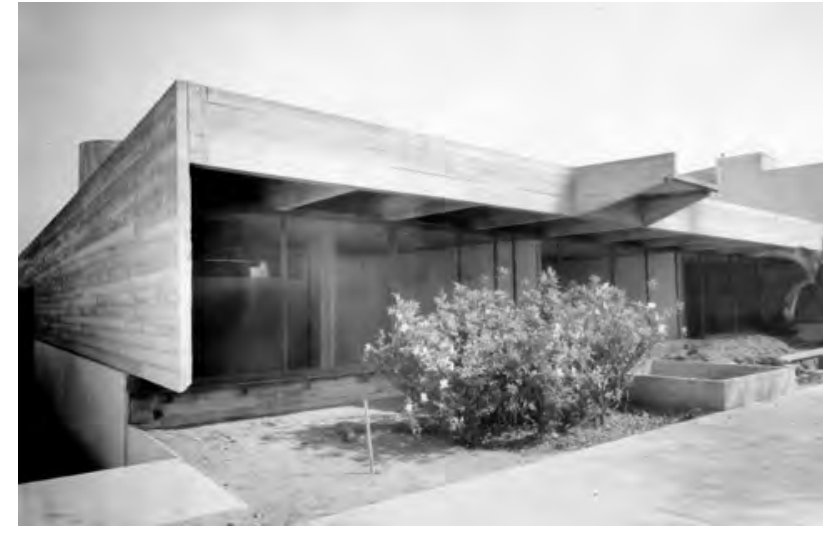

FIG 21

1964: CASA SILVIO ALBANESE, SP

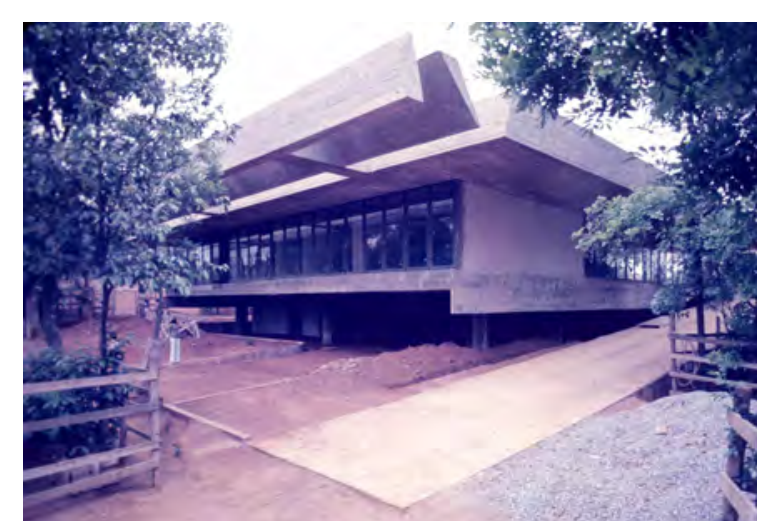

FIG 23

1973: CASA LYGIA E NEWTON CARNEIRO, SP

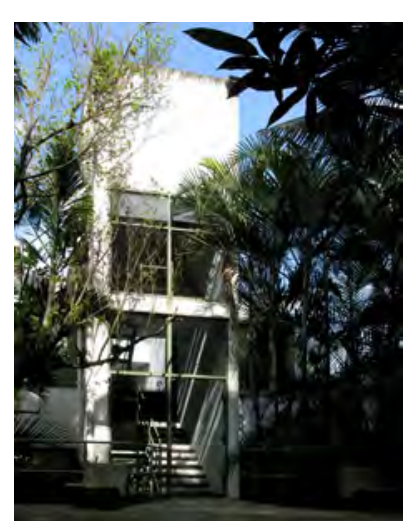

FIG 24

1977: CASA CORBETT. SP

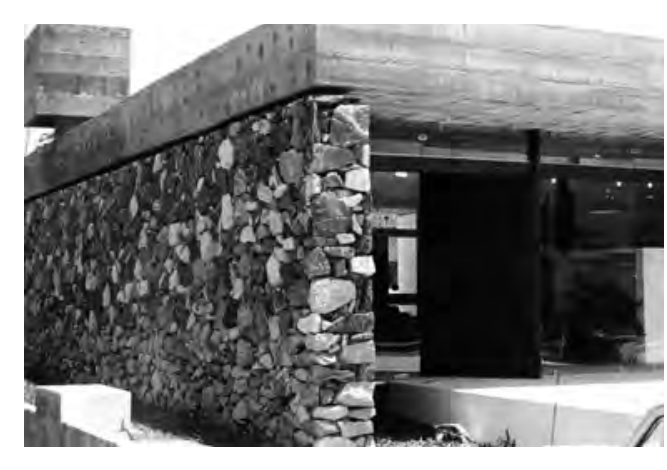

FIG 25

1973: CASA NABOR RUEGG, GUARUJÁ

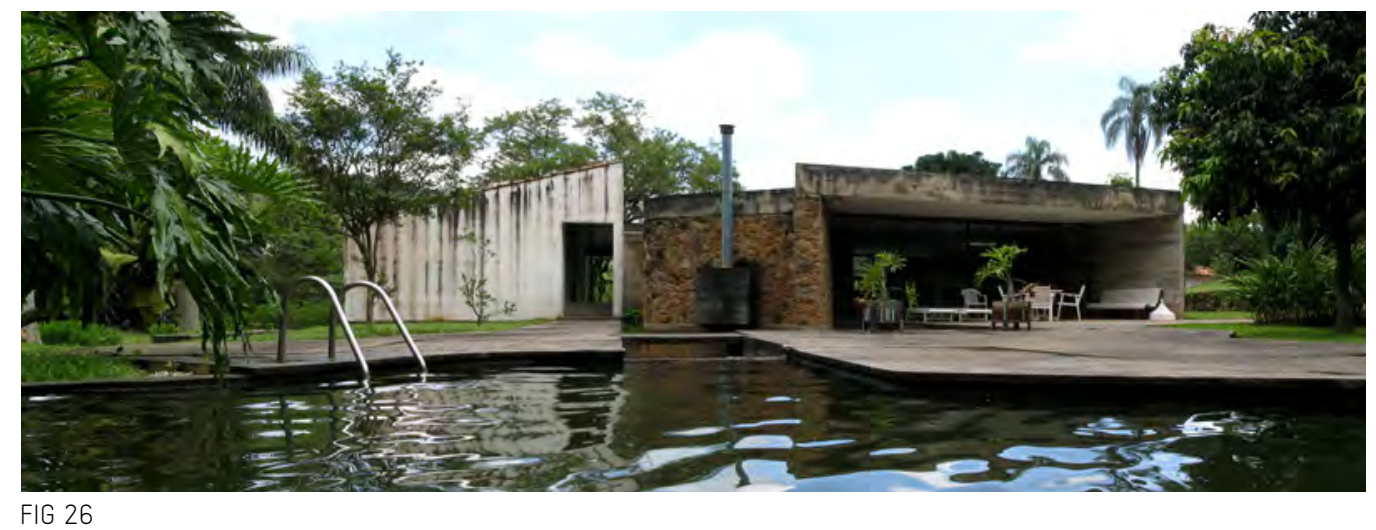

FIG 26

1995: FAZENDA DA CAVA, CABREÚVA

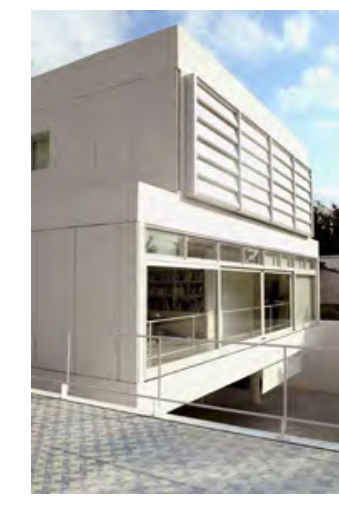

FIG 27

2000: CASA PRATA, SP
ESTAS IMAGENS MOSTRAM UMA VARIEDADE DE CASAS DESENHADAS PELO ARQUITETO AO LONGO DE SUA TRAJETORIA. VEMOS PELAS IMAGENS COMO O USO DO CONCRETO BRUTO E APARENTE VAI CEDENDO ESPAÇO A OUTROS MATERIAIS COMO A PEDRA E O ACCO.

SÃO CASAS POUCO PUBLICADAS, MAS QUE PERCEBEMOS EM TODAS ELAS DESDOBRAMENTOS DE SOLUČÕES ARQUITETÔNICA EM OUTROS PROJETOS DE MAIOR ESCALA, COMO VEREMOS MAIS ADIANTE. 
Ao longo deste trabalho, visitando várias casas projetadas por PMR, pudemos constatar que apesar da presença, da densidade, da estrutura de concreto aparente, da rigidez cartesiana na disposição do programa, a vida doméstica se instala dando cor e sabor aos espaços internos. Se, num primeiro momento as casas pareceram negar qualquer ideia de "conforto", tornando-as inóspitas - e de fato são concebidas assim - a vida do dia à dia dos seus ocupantes modifica e transforma o espaço conferindo-lhe ainda mais vigor.

Na Residência King (1972), por exemplo, encontramos uma mistura de móveis coloniais e ingleses que se distribuem pelo espaço desordenadamente. Já na casa Mario Masetti (1970) havia poucos moveis, mas muitas plantas sobre a grelha do chão. Constatamos, com certa surpresa, que apesar da relativa similaridade da disposição espacial dos ambientes e do uso predominante do concreto aparente, as casas nos pareceram muito diferentes entre si, justamente porque cada um vive à sua maneira. Como nos ensina Henri Focillon, "A vida é forma, e a forma é o modo de ser da vida"s.

As duas casas destacadas para objeto desta análise são exemplares da produção do arquiteto dos anos de 1960 e 70. Feitas predominantemente em concreto armado e aparente, os projetos confrontam o programa doméstico "burguês" da casa com vários quartos, banheiros, garagem e área de serviço, e apresentam uma disposição espacial que desafia modos tradicionais da vida privada.

A Casa Butantã (1962), na verdade são duas. Duas casas idênticas construídas em terrenos contíguos, localizados sobre uma pequena colina em frente à Casa do Bandeirante, no bairro do Butantã em São Paulo. No terreno próximo à esquina está a casa feita para a família do arquiteto, e no seguinte, a de sua irmã.

Existem pouquíssimas diferenças volumétricas e programáticas entre ambas, apesar disso, são construções bastante particulares que não têm como foco a industrialização do processo construtivo, ou seja, não há aqui a preocupação com o desenvolvimento de um modelo residencial a ser reproduzido. $O$ terreno foi pensado como um só, o que separa as casas é um jardim elevado e um muro baixo de concreto. Entre ambas há um túnel - divertido9 - que liga os dois pátios no nível da garagem. Para efeitos desta análise, concentraremo-nos na casa que foi destinada à família do arquiteto.

O projeto da Casa Millan (1970), foi encomendado ao arquiteto por um "azar" da vida. O proprietário do terreno era irmão do arquiteto Carlos Millan, que falece-

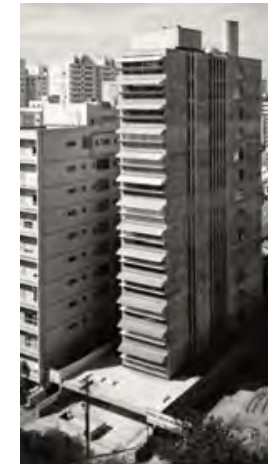

O ARQUITETO REALIZOU APROXIMADAMENTE 15 PROJETOS DE EDIFICIOS RESIDENCIAIS DOS QUAIS 5 FORAM CONSTRUITOS.

O ÚLTIMO EDIFICIO RESIDENCIAL CONSTRUÍDO FOI 0 CONJUNTO VALLECAS EM MADRID NA ESPANHA EM 2004

FIG 28

1962: EDIFÍCIO GUAIMBÊ, SP

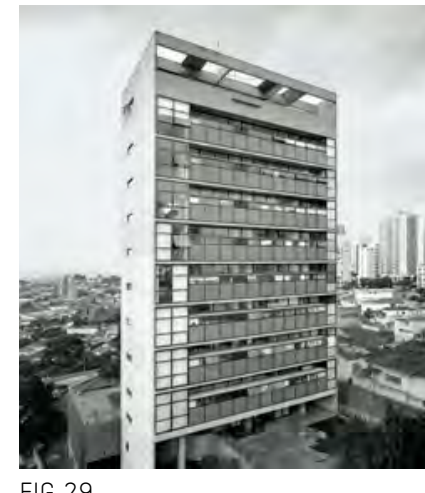

1984: EDIFÍCIO JARAGUA, SP

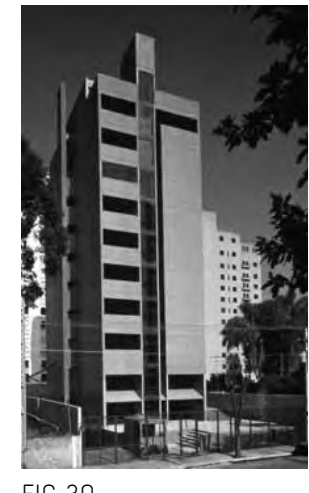

FIG 30

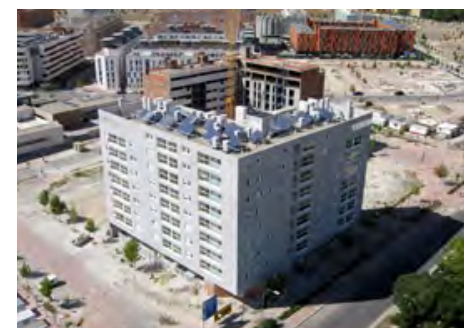

FIG 31

2004: RESIDENCIAL VALLECAS. MADRID

8 FOCILLON, Henri. A vida das Formas seguido de Elogio da Mão, 2001 p. 12

9 Eu sei que é divertido, pois - talvez seja necessário “confessar" - frequentei esta casa na minha infância. Ela era a sede do nosso clube da rua, onde brincávamos nos dias de chuva, onde aprendemos a patinar - pois o chão era lisinho - e onde, na brincadeira de esconde-esconde, eram oferecidos os lugares mais incríveis para se esconder (sendo o túnel um deles).

10 Arquiteto Carlos Barjas Millan (1927-1964) 




1964: CASA BUTANTÃ

PLANTA DO PRIMEIRO PAVIMENTRO

S/ ESCALA

POR ESTA PLANTA VEMOS CLARAMENTE A SEPARAÇÃO DAS TRÊS AREAS

APESAR DA RIGIDEZ COM QUE ESTAS FUNCÕES ESTÃO DISPOSTAS EM PLANTA, PODE-

MOS PERCEBER QUE AQUILO QUE AS DIVIDE SÃO ELEMENTOS LEVES, COMO PORTAS DE

CORRER OU AS PRATELEIRAS DA SALA.

NOTAMOS TAMBÉM A PROPORCĨO DO PATAMAR DA ESCADA DE ENTRADA QUE SE

ESTENDE PARA FORA DA PROJEÇ̃̃O DO BEIRAL, COMO QUEM BUSCA O SOL. AIT FAZ-SE 0

ALPENDRE DE ENTRADA DA CASA.

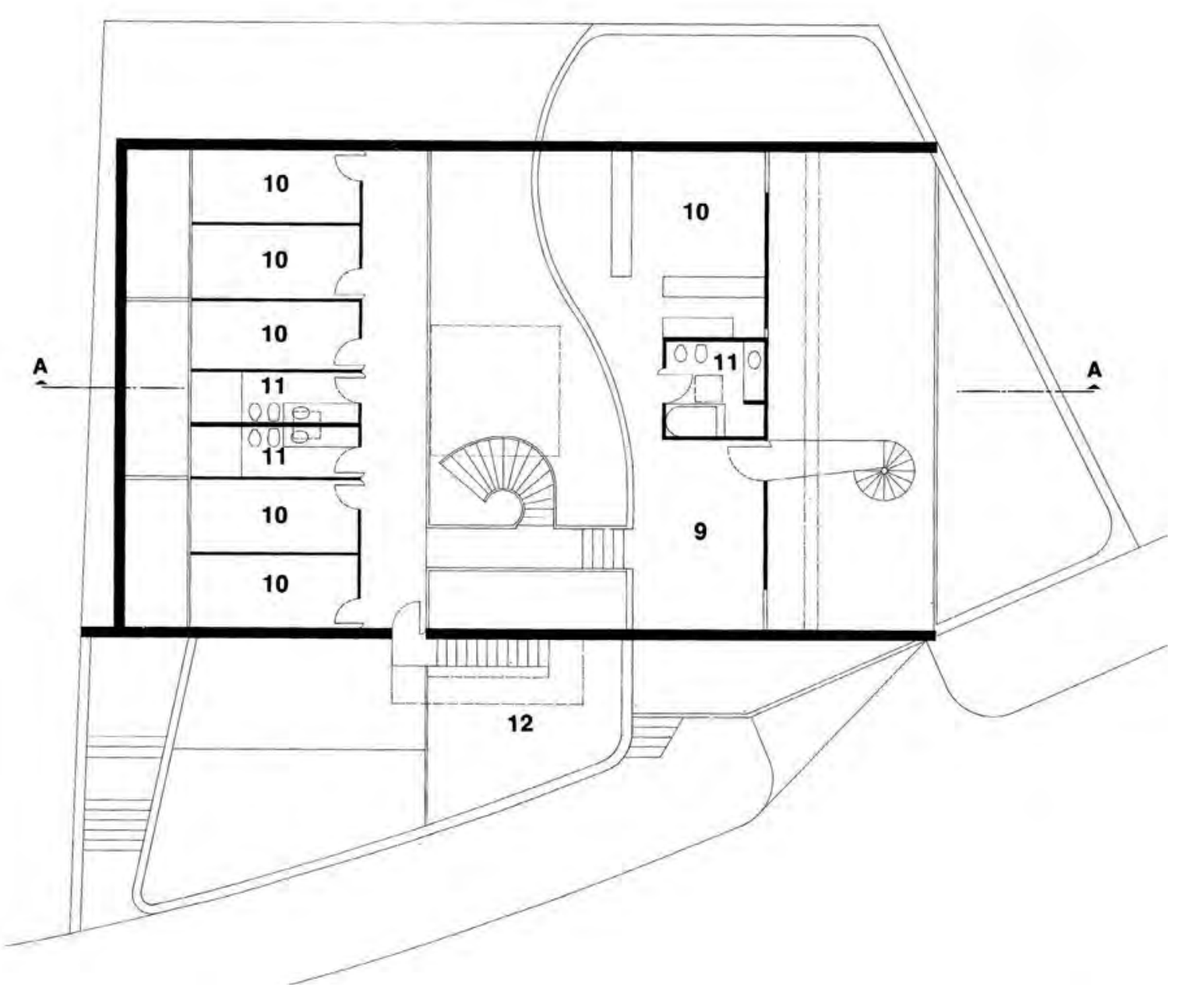

1970: CASA MILLAN

PLANTA DO SEGUNDO PAVIMENTRO

S/ ESCALA

A CASA MILLAN POR SER SOBRADO TERIA UMA DISPOSIÇÃO ESPACIAL MAIS SEGMEN TADA, MAS O VAZIO CENTRAL SOBRE A SALA FAZ COM QUE O PLANO DO TERREO E $O$ SUPERIOR FAÇAM PARTE DE UM ESPAÇO ÚNICO. 
ra, como sabemos, tragicamente em um acidente de automóvel em $1964^{10}$. PMR nos conta que realizou este projeto "em consternação" pela perda do amigo e colega de profissão, que se vivo seria obviamente o autor do projeto.

Recentemente, a casa foi adquirida por um galerista, também cliente de PMR, que realizou algumas reformas. A principal delas foi a transferência da cozinha, que estava localizada sob o volume dos quartos, para o pátio de entrada dos carros. Aqui, vamos analisar o projeto original, anterior às reformas.

Vamos a elas.

\subsection{CASA: ABRIGO DAS RELAÇÕES HUMANAS}

A função primitiva, original, de uma casa é a de abrigar. A casa carrega o sentido da permanência do homem na terra e de um mundo interior, em oposição ao caráter aberto e dinâmico do mundo exterior. Ela é o que permite ao homem deixar de ser nômade e se fixar no espaço natural.

Se pensarmos na construção física daquilo que conhecemos por casa, podemos dizer que ela se estrutura pelo menos por quatro elementos fundamentais: o teto, as paredes, portas e janelas. O teto realiza a metonímia da casa em si, é abaixo dele que nos escondemos e nos protegemos daquilo que vem de cima, da chuva à fúria dos deuses. As paredes ou os muros ${ }^{11}$ têm a função de nos separar do exterior; eles são o limite entre o dentro e o fora e contêm as aberturas das portas e janelas, para poder sair e olhar.

A armação desses quatro elementos estabelece um espaço interno, o lugar da vida íntima, mais que isso, é o repositório de nossas memórias, medos e alegrias, e que de tão particular, pode ser reconhecido pelo cheiro, pelos barulhos e pelas sensações de frio e calor.

A casa representa, assim, a antítese do mundo exterior, podendo ser mais ou menos permeável a ele; o caráter das relações entre o mundo público e o privado revela muito sobre as relações sociais, o que somos, o que queremos e como nos organizamos.

Para os gregos, por exemplo, a casa é o lugar da intimidade, onde as relações da vida privada, da família e do trabalho acontecem (oikos) num contraponto preciso à vida pública da polis; o limite entre ambos é claro e definido pela fachada frontal da casa ${ }^{12}$.

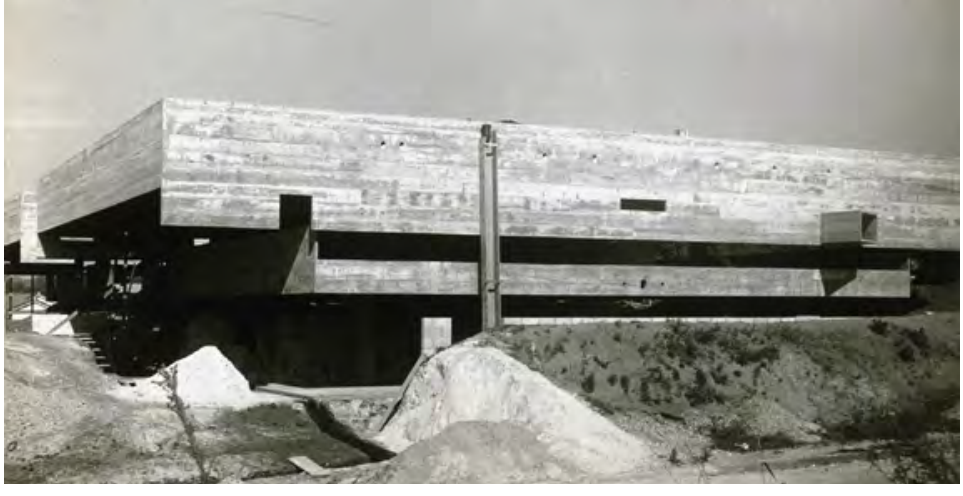

FIG 32

CASA BUTANTÃ

EM 1967. ENTRADA DA CASA. VEMOS O RECORTE DO TALUDE SOBRE O QUAL O VOLUME DA CASA PARECE TOCAR.
11 Muros com radical em latim vem do verbo munire, que significa fazer um trabalho de alvenaria destinado à proteção. In FLUSSER Vilém, Petite philosophie du design. 2002. p 82.

12 OTONDO, Catherine. "Espaços culturais na obra de Lina Bo Bardi - o caso do MASP". Trabalho de Iniciação Científica, orientador: Prof ${ }^{a} \operatorname{Dr}^{a}$ Otilia Beatriz Fiori Arantes. Faculdade de Arquitetura e Urbanismo da Universidade de São Paulo, 1992. Nesta pesquisa fizemos um estudo aprofundado dos livros de Hannah Arendt, $A$ Condição Humana, e Jurgen Habermas, Mudança estrutural na Esfera Pública, com a finalidade de estudar o sentido do espaço público na obra de Lina Bo Bardi. Retomei alguns conceitos desta pesquisa para escrever a passagem acima. 




FIG 33

EM 1967:FOTO TIRADA A PARTIR DA CASA DO BANDEIRANTE. VEMOS AS DUAS CONSTRUÇÕES E O TALUDE AJARDINADO QUE FUNCIONA COMO MURO DE DIVISA ENTRE AS DUAS CASAS E A RUA.

13 FLUSSER, VILEM. “La Maison: trouée comme le gruyère”, in Petite Philosophie du Design 2002. p 84.

14 Para o autor: "Os designers e arquitetos não devem mais pensar a casa em termos geográficos, mas topológicos: a casa não mais como uma caverna artificial, mas uma curvatura do campo relacional humano.”.

"Les designers et les architectes doivent penser désormais en termes non plus geographiques mais topologiques: la Maison non plus comme une caverne artificielle, mais comme une courbure du champ relationnel humain”, ibidem, p. 84. (tradução da autora).

15 PEDROSA, Mario. "Espaço e Arquitetura", in Dos murais de Portinari aos espaços de Brasília p. 254

16 MOTTA, Flavio L. "Paulo Mendes da Rocha”. in Textos Informes, 1973. p. 21
Segundo Habermas, em seu livro Mudança Estrutural da Esfera Pública, novos valores passam a diferenciar as esferas do público e do privado a partir do fim do século XVIII, com a ascensão da burguesia como classe dominante. Para o homem burguês, a preservação da intimidade impera sobre a vida pública e acaba por redefinir a espacialidade interna da casa, onde os locais de encontro da família diminuem, dando lugar às atividades de recepção das visitas - assim, a linha que divide o público do privado passa no meio da casa do homem.

Por este processo, a casa perde a solidez e opacidade de seus muros antigos, e traz a vida do mundo lá fora para dentro da sala, mas ainda mantém a esfera da intimidade, dos costumes, preservada.

A revolução tecnológica do século XX muda o sentido operacional da noção de abrigo: teto. Segundo Vilém Flusser o telefone, a televisão e o carro na garagem fizeram com que a casa parecesse um "queijo gruyère" de tão furada pelos "ventos que sopram da comunicação" ${ }^{13}$. Era necessário, então, pensar em um novo desenho para a casa, aberta, sem muradas sólidas, sem o medo do "lá fora". Ainda segundo Flusser, a casa deve ser o espaço do abrigo das relações humanas, sem hierarquias nem lugares para se esconder ${ }^{14}$.

Construtivamente, uma das grandes contribuições da arquitetura moderna ao campo da construção doméstica foi fazer com que a sustentação do teto não estivesse mais sobre os muros da casa; a laje plana do teto apoiada sobre um sistema de pilares e vigas libera a superfície do chão, que pode ser divida com maior liberdade. Com isso, os recintos internos ganham uma amplidão espacial e deixam de ser uma sequência de pequenos cômodos.

A casa moderna é como o homem que a habita, dinâmico e flexível. Sua qualidade plástica, segundo Pedrosa no texto "Espaço e Arquitetura" (1952), não é dada pelo ornamento pendurado nas paredes, mas pelas relações de planos e volumes que se interpenetram ${ }^{15}$.

As casas Butantã e Millan foram feitas para este homem moderno. Nos espaços internos, a separação entre as funções de estar, trabalhar e dormir é feita por elementos leves, ou por deslocamentos verticais ao nível do chão. Como indica Flavio Motta em seu texto "Paulo Mendes da Rocha", são espaços onde temos que aceitar o convívio com os demais, "dentro de novas e procuradas condições de respeito humano." ${ }^{\text {. }}$.

Primeiramente, veremos como o arquiteto organiza os espaços internos das duas casas, e num momento seguinte veremos por quais operações projetuais ele con- 
figura o terreno para implantar a edificação, estabelecendo uma nova proposição entre a esfera doméstica da casa e a cidade.

Na Casa Butantã, a planta é organizada como se fosse uma casa térrea, num rigor "miesiano", onde todo o programa (exceto as áreas de serviço) está disposto em setores bem determinados.

O volume da casa é constituído por apenas seis superfícies justapostas em comprimento, altura e largura que encerram um espaço interior único, total, com duas faces transparentes e duas opacas, um piso único de madeira e um teto plano perfurado por claraboias transparentes.

A porta de entrada, localizada justo após o último degrau da escada, abre-se para um espaço "sem nome", uma espécie de varanda fechada que se estende por toda a extensão da casa e para a qual se abrem todos os quartos e a cozinha. Nesta varanda há uma longa bancada de concreto e sobre ela estão a máquina de costura, os brinquedos, os livros que não cabem nas prateleiras, a roupa que será distribuída pelos quartos, o correio e as chaves do carro. Nas extremidades da varanda, há duas “janelinhas de contemplação" uma ao mesmo nível do tampo da mesa da copa e outra na ponta oposta da casa, por onde vemos quem vem da rua.

Os quartos estão no meio da casa, sem janela. (Sem janela?). Dentro deles há vários ambientes: o de estudo, o de dormir, o de se trocar e o de se banhar. Tudo em sequência, num espaço único iluminado generosamente por uma claraboia no teto. A janela aqui fica no teto.

Do lado de lá dos quartos está a sala, que possui a mesma extensão da varanda, porém mais profunda. Na sala estão os ambientes de estar, estudo e de comer. Tudo nela é de concreto: a mesa de jantar, as prateleiras, a mesa de trabalhar, a lareira e os sofás.

Ao contrário de uma casa "tradicional”, não há uma diferença estética entre frente e fundo, o mesmo caixilho que fecha a frente fecha o fundo, ambos sombreados por uma pérgula de concreto. Nas laterais opostas, as empenas de fechamento da casa são superfícies de concreto bruto com poucas aberturas, dadas pelas janelinhas mencionadas anteriormente e por um vão de luz que se forma inesperadamente entre o peitoril de bloco e a empena de concreto. A janela neste caso fica no plano horizontal, como um tampo de mesa iluminado.

O sentido de totalidade espacial pode ser percebido, de modo mais direto, pelo chão de tábua corrida que percorre a casa inteira, da cozinha ao banheiro, da sala ao corredor.

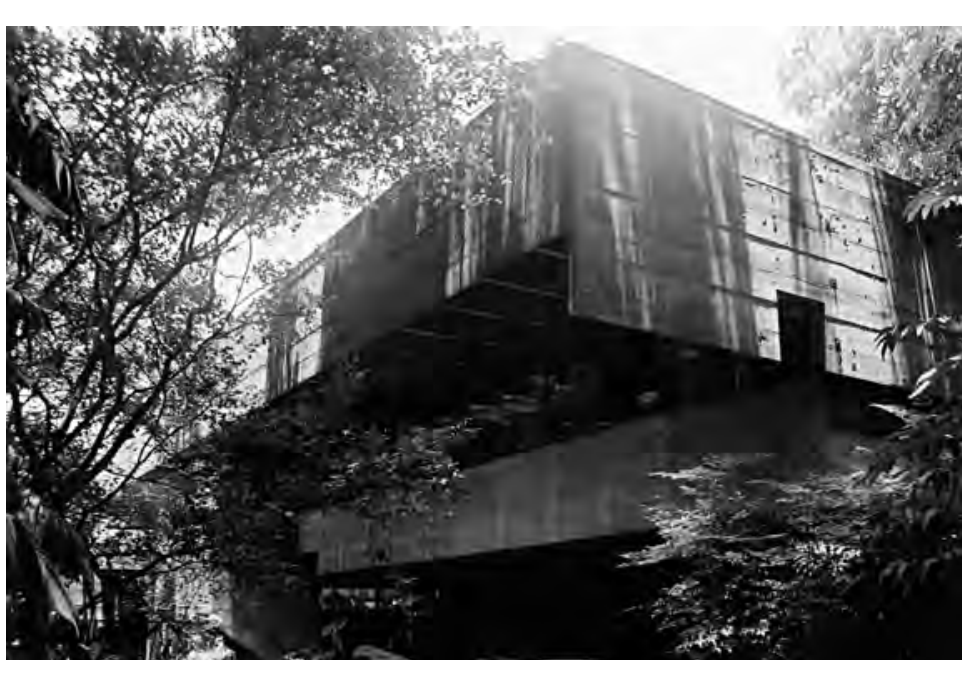

FIG 34

FACHADA DO JARDIM - VISTA DA VARANDA PELO LADO DE FORA

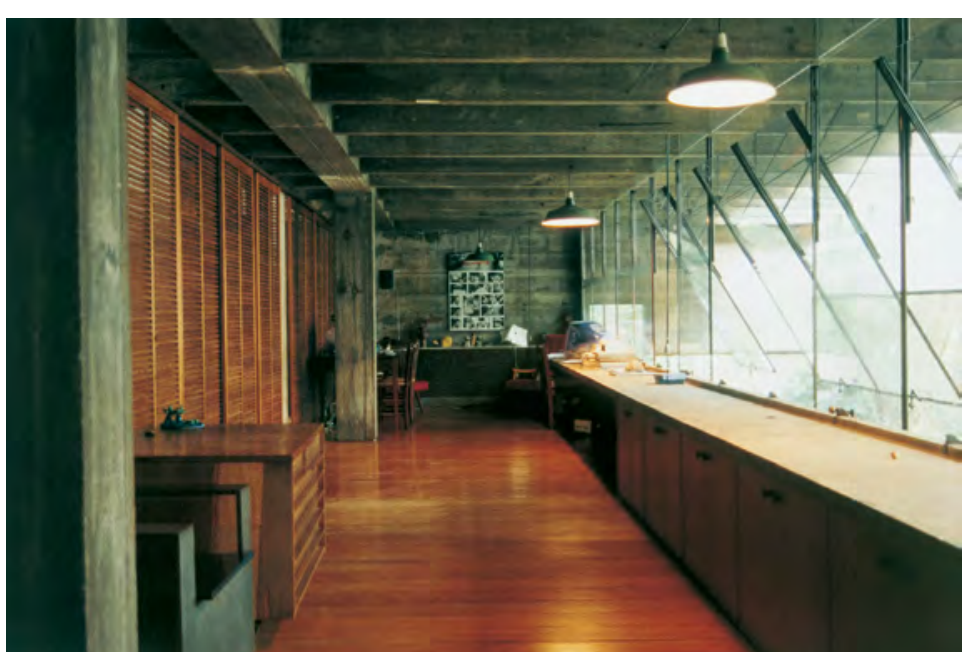

FIG 35

O FECHAMENTO DAS PORTAS DE CORRER DOS QUARTOS NÃO CHEGA ATÉ O TETO, O QUE FAZ COM QUE TENHAMOS UMA PERCEPÇÃO TOTAL DO ESPAÇO DETO, O QASA.

À DIREITA, VÊ-SE A BANCADA DE TRABALHO, ESTUDOS E APOIO DAS COISAS DO DIA A DIA. 


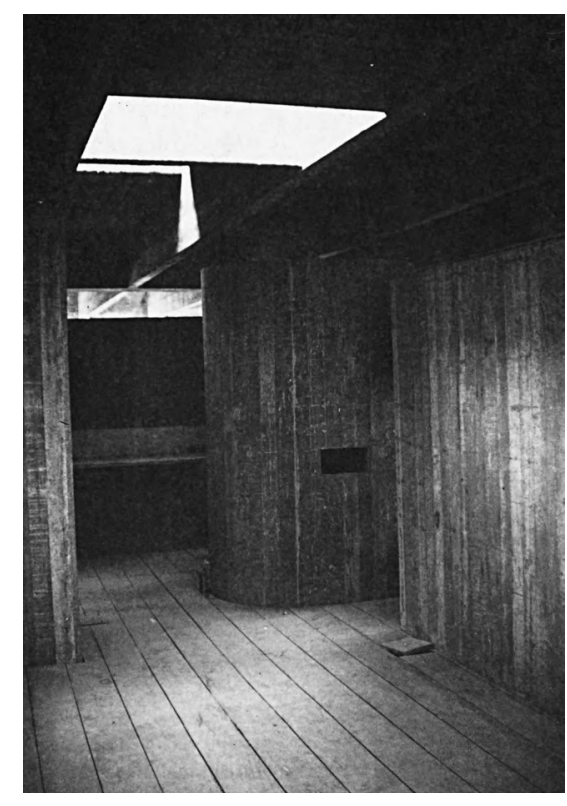

FIG 36

EM 1967: JANELA NO TETO CLARABOIA DOS QUARTOS
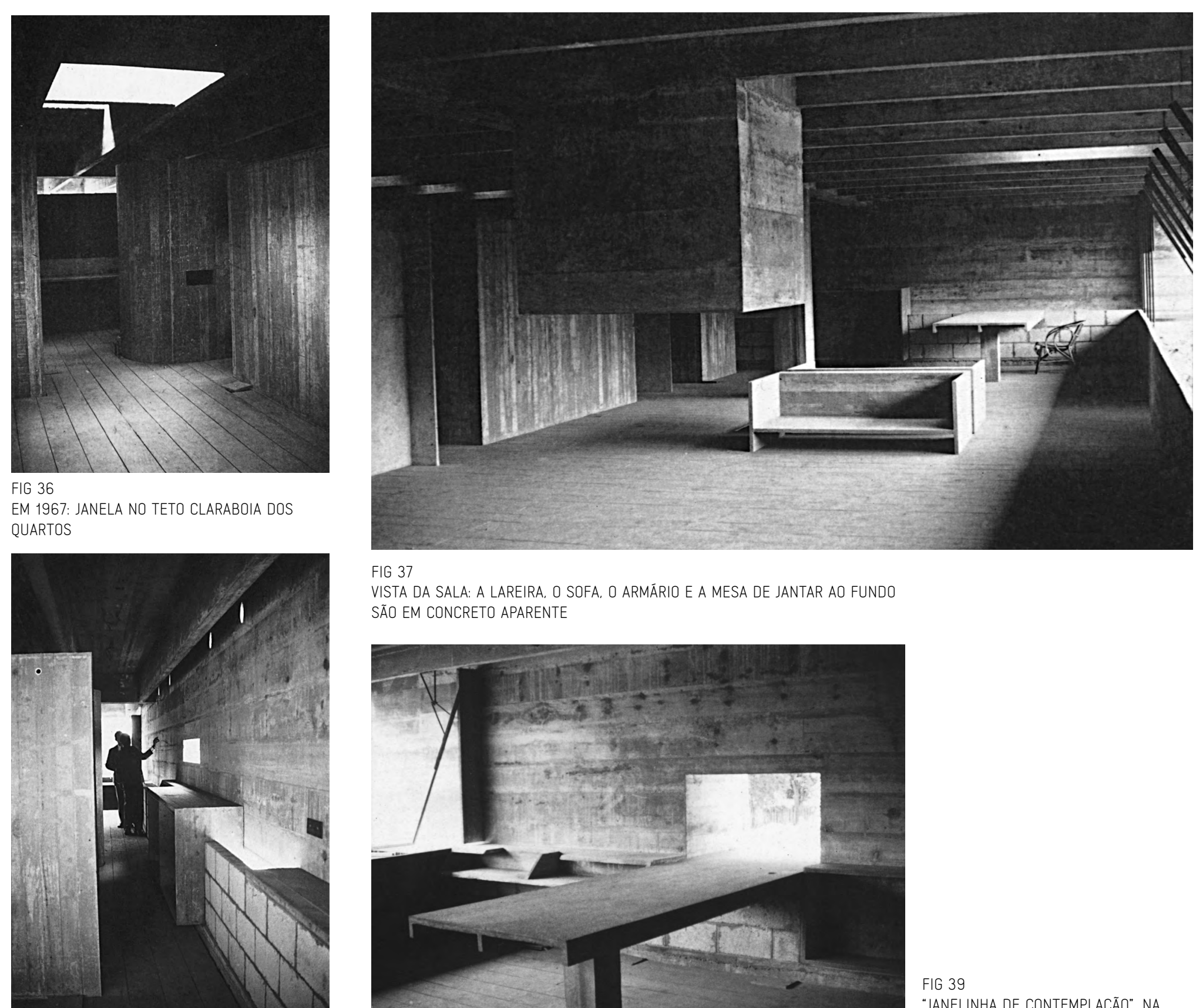

FIG 37

VISTA DA SALA: A LAREIRA, O SOFA, O ARMÁRIO E A MESA DE JANTAR AO FUNDO SÃO EM CONCRETO APARENTE

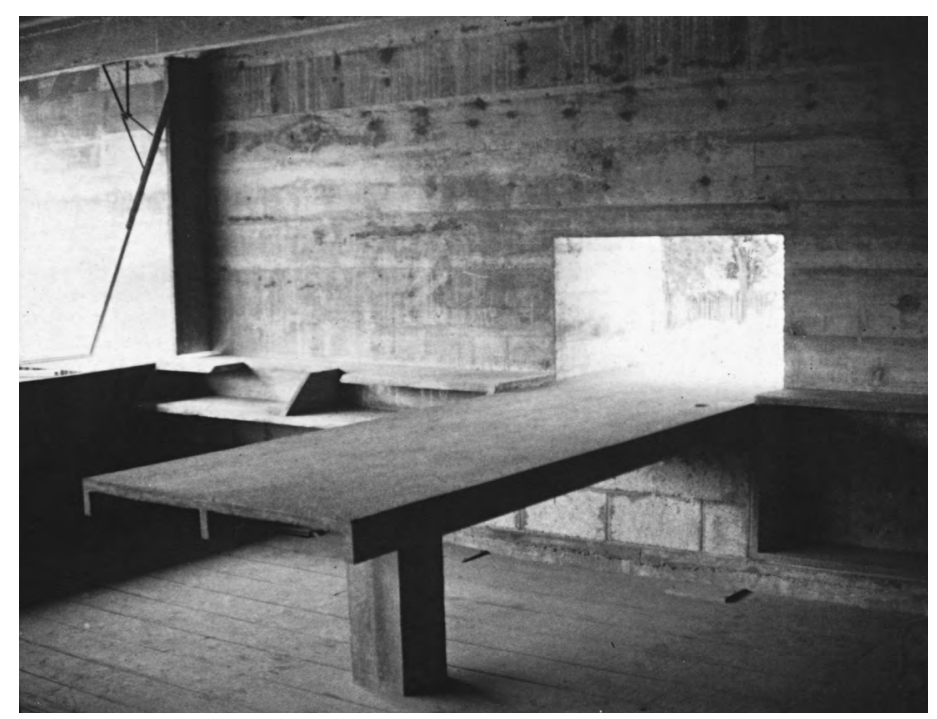


As paredes internas não vão até o teto. Quase não existem portas, as poucas que há fecham os quartos e são todas iguais (madeira com veneziana). Num simples correr de portas, os quartos, a sala e a varanda transformam-se em um único espaço, permitindo um movimento pela casa que não cessa, pois não existem corredores sem saída nem salinhas fechadas. A rigidez das funções domésticas, determinada de modo tão preciso na planta, parece se dissolver com um simples correr de portas.

Assim, com poucos meios, o arquiteto realiza uma proposição espacial completamente nova, num modus vivendi sem hierarquias familiares, e descarta a rigidez funcional de cada ambiente, o que obriga ao desapego das coisas. Lembrando Flavio Motta em seu texto "Paulo Mendes da Rocha", o autor afirma que: "O homem acumula coisa até virar coisa” e com isso “encurtam o mundo”, cabe então ao arquiteto projetar espaços que se "atirem contra o imobilismo [das coisas]"17.

O desenho das plantas, cortes e elevações da casa são relativamente "simples" de compreender, feitos por figuras geométricas reconhecíveis (quadrados e retângulos), mas sabemos que o espaço construído é muito mais complexo que a somatórias dessas superfícies.

A diferenciação de valor e sentido entre aquilo que nos informa a planta desenhada e o espaço percebido surpreende-nos a cada vez que visitamos uma obra de PMR, e compreendemos assim que só é possível ter a consciência do espaço projetado pela sua vivência. Já dizia Mario Pedrosa: o que dá o sentido ao espaço moderno é sua pluridimensionalidade dada pela fusão das suas "dimensões, luz, temperatura etc. $(\ldots){ }^{18}$.

$\mathrm{Na}$ Casa Millan, a ordenação espacial se dá por uma operação projetual inversa. Se na casa Butantã o arquiteto cria uma superfície plana solta do chão, neste caso ele cava toda a dimensão do terreno e aloja a casa no seu interior. A casa, assim, não é um volume sobre o terreno, mas a própria reconstrução deste.

Por esta operação, radical, o arquiteto cria um volume fechado, sem janelas para a rua, onde a luz natural principal vem de uma imensa claraboia de vidro $(4.00 \times 4.00 \mathrm{~m})$ localizada no centro do espaço da sala, fazendo com que a espacialidade da casa se aproxime da ideia de uma caverna. Nela percebemos a densidade do concreto, pesado, opaco e úmido.

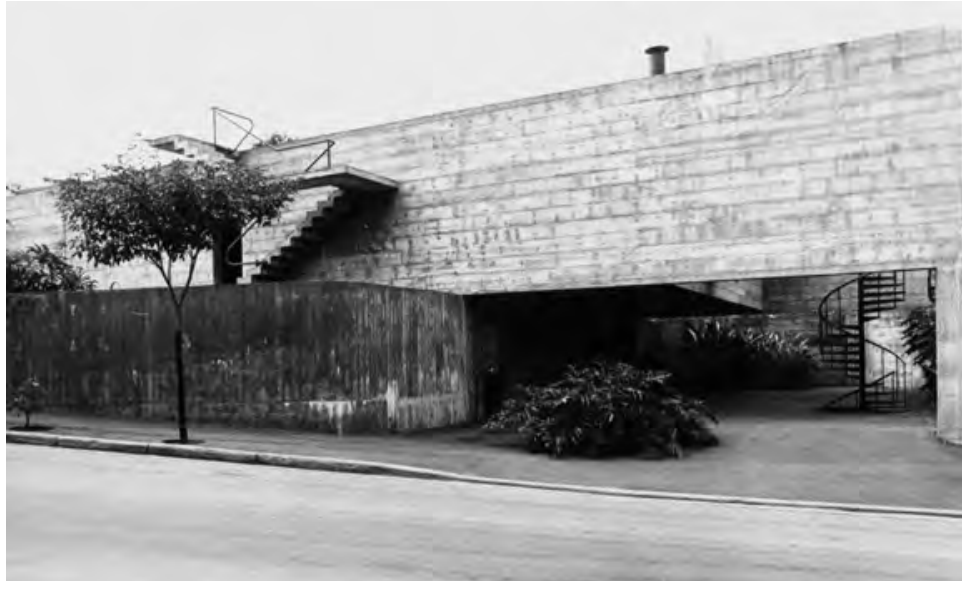

FIG 40

1970: CASA MILLAN

O PISO DE ASFALTO QUE ENTRA DENTRO DO PATIO INTERNO. A ESCADA HELICOIDAL QUE FAZ A LIGAÇÃO EXTERNA DIRETA ENTRE O PAVIMENTO DO SUB SOLO E O SUPERIOR: A ESCADINHA DE CONCRETO QUE SAI DO JARDIM ONDE ESTÁ A PISCINA, QUE DA RUA NÃO SE VÊ., E CHEGA ATÉ A COBERTURA.

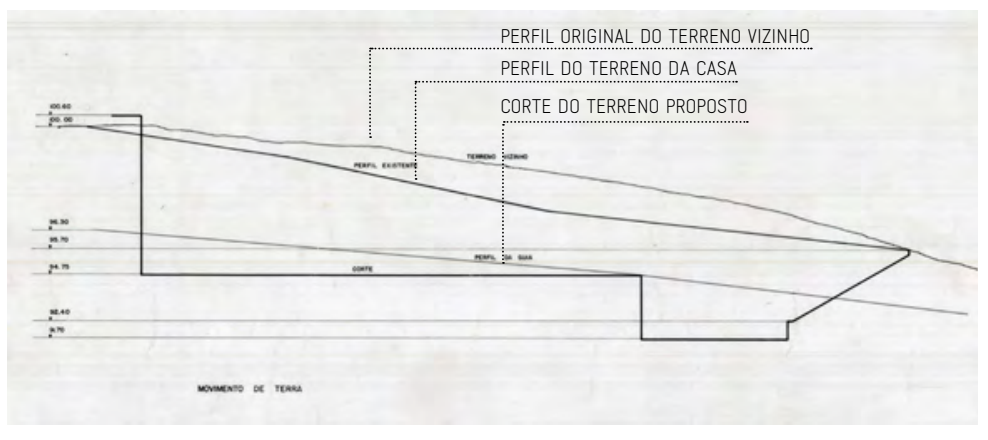

CASA MILLAN

CORTE TRANSVERSAL ESQUEMÁTICO DO MOVIMENTO DE TERRA. S/ ESCALA 


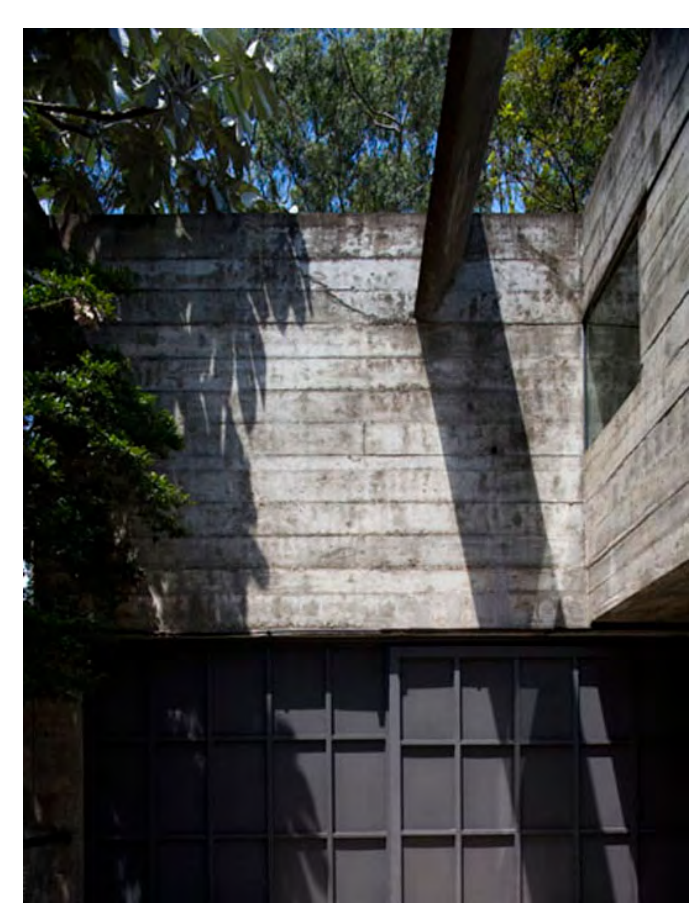

FIG 41

VISTA DO PÁTIO INTERNO. NO ALTO, A DIREITA, VEMOS O BRISE QUE PERCORRE TODA A EXTENSÃO LATERAL DA CASA. O PORTÃO AO FUNDO NÃO FAZ PARTE DO PROJETO ORIGINAL.

19 O brise do átrio da Casa Millan não tem uma função de quebra-sol fundamental, até porque a empena que ele protege tem poucas aberturas. Tem, no nosso entender, uma função reguladora do espaço, ele atrai nosso olhar para o alto e com isso compreendermos a escala daquele lugar.

Neste sentido, pode ser visto como um embelezamento ou como esclarece Henri Focillon, um "capricho linear que se oculta para atingir um fim secreto, elabora-se uma nova dimensão, que não é movimento nem profundidade, e que nos leva à ilusão".

FOCILLON, Henri. 2001, p. 35

20 A entrada da casa no projeto original era na feita por uma escada enterrada no lado oposto ao da garagem. A ideia do arquiteto era que quando os empregados da casa tivessem terminado o trabalho, eles sairiam por esta porta de entrada, passariam pela calçada para entrar de novo na casa pela garagem, que dá acesso aos aposentos de serviço, dando uma sensação ao empregado que o trabalho e a sua casa estavam em lugares distintos. Com a nova reforma, esta entrada foi fechada e o pátio de serviço transformou-se em entrada da casa.

21 PMR nos conta em tom de divertimento que imaginava um pedestre andando na rua quez de repente recebe um jorro d'água vindo do alto, que não é chuva, mas o espirro das braçadas "da turma" na piscina.
Aqui, a separação entre as funções domésticas se dá pela diferença de nível entre os pisos. No piso térreo estão a sala e a cozinha, e por uma escada helicoidal, situada no centro do espaço central da casa, chega-se ao nível dos quartos, separados por um vazio. No corte longitudinal, lê-se claramente esta distribuição espacial.

Nesta casa, os espaços são de fato escavados no desnível do terreno. Para garantir a chegada de luz natural aos ambientes, o arquiteto desenha planos de luz na cobertura que iluminam a sala e a cozinha. A iluminação dos quartos menores é feita de maneira indireta: a luz que vem de cima, para iluminar a cozinha, reflete nas paredes de divisa da casa e entra nos quartos. Somente o quarto maior recebe luz natural direta, vinda do pátio de entrada.

Tal pátio, cuja função original é destinada ao abrigo de carros, ganha um lugar de destaque na casa. Devido a sua grande escala e magnitude, transforma-se em lugar de entrada da casa. É também um espaço cujo nome nos escapa, suas paredes altas de concreto aparente conferem certa imponência e nossos olhos buscam o céu, onde encontramos, lá no alto, "voando”, uma peça de concreto, feita para ser um brise. Mais que isso, o brise encerra e dá escala imponente ao lugar, como uma régua ${ }^{19}$. Com isso, aquilo que deveria ter um caráter de "fundos" no programa, ganha predominância como frente ${ }^{20}$.

As relações entre dentro e fora da casa também são muito particulares: o piso da rua de asfalto se estende para dentro da casa sem barreiras. $O$ jardim que tradicionalmente fica na extensão da sala aqui se encontra no piso superior, cujo acesso se dá através de uma pequena porta, localizada no corredor de acesso aos quartos. O jardim é, portanto, uma plataforma elevada do chão, alta em relação à cota da rua. Neste lugar o arquiteto encaixou também a piscina, cujo muro de contenção é o muro da divisa da casa ${ }^{21}$, e uma pequena escada que nos leva à cobertura; ali há uma lamina d'água que é de fato a proteção mecânica da laje, mas também abriga plantas e peixes, formando um recinto de calma e contemplação.

Por esta disposição espacial, a casa quase não possui um "lá fora”, é tudo dentro. A luz natural é, deste modo, o grande agente do espaço e vem por várias direções e gradientes: ou é intensa e direta no centro da sala, ou é refletida nos muros de concreto. O espaço que percebemos é, então, valorizado por esse gradiente de luz e sombra, e como é de se esperar, quando a janela do teto se “apaga” à noite, prevalece a sombra sobre todo o seu interior. $O$ desejo do arquiteto em construir um espaço total surge neste projeto pelo espaço vazio que envolve os volumes soltos do chão, 
onde estão os quartos. Como vemos pelo corte longitudinal, trata-se de um vazio que percorre toda a extensão da casa, dentro e fora dela.

O espaço construído revela-se como uma coisa só, a passagem por entre os lugares internos se faz em um movimento contínuo e fluido. São espaços flexíveis, com diferentes funções e que configuram uma unidade. Aquilo que se faz mais perceptível é a variação de luz - mais do que uma mudança dos usos funcionais da casa -, dividindo o espaço da casa em lugares onde há muita luz ou nenhuma.

Entendemos que nas duas casas o raciocínio projetual de PMR avança na direção de criar espaços internos flexíveis, com diferentes funções e que configuram uma unidade; o contrário de uma casa "tradicional", onde cada atividade doméstica (comer, estar, dormir) corresponde a um tipo de espaço, com características físicas correspondentes à sua função, que se traduz materialmente nos diferentes revestimentos, no tamanho das janelas e qualidade de luz.

Nas duas casas o piso é um só, as janelas são todas iguais e o material de dentro e fora da casa é o mesmo: concreto bruto e aparente. Esta continuidade material também colabora para o sentido de unidade do espaço interno.

Vimos ainda que a passagem entre os diversos ambientes das casas se faz de maneira fluida, sem abrutamento; entendemos que esta fluidez ocorre pela existência de espaços aos quais não conseguimos conferir um uso determinado - os tais espaços "sem nome", como dizia Flavio Motta ${ }^{22}$ - que atuam como um amalgama que tudo junta; são lugares onde a indeterminação prevalece sobre a ordem, e assim, transforma o modo de vida de seus moradores.

A seguir veremos que este particular raciocínio extrapola a lógica do volume e põe em evidência a maneira como o arquiteto agencia a implantação da casa no terreno.

\subsection{FORMAR PELO CAVAR}

A primeira ação que o arquiteto praticou nos terrenos vazios das casas Butantã e Millan foi a de cavar, constituindo uma nova topologia sobre a qual viria a implantar o volume das casas no lote.

Os cortes nos informam, já nos primeiros estágios do projeto que o acerto do terrapleno seria uma grande questão do trabalho, de um modo ainda mais presente que no projeto do Ginásio do Paulistano. 


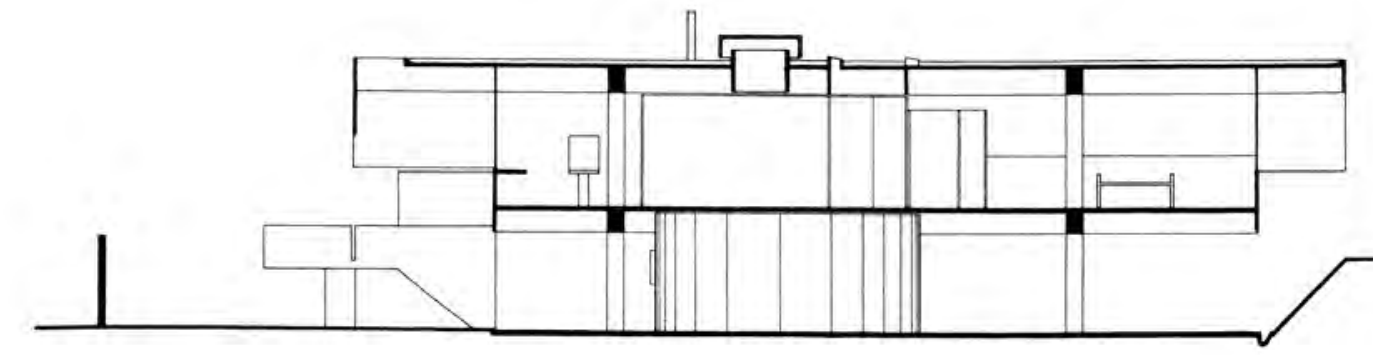

S/ ESCALA

O VOLUME DA CASA ESTÁ SUSPENSO DO CHÃO, APOIADO EM PILARES AFASTADOS

DAS EMPENAS LATERIAS. CONFERINDO UMA LEVEZA AO CONJUNTO.

O TALUDE CONFORMA O ESPAÇO DO TÉRREO COMO UMA PAREDE DE TERRA.

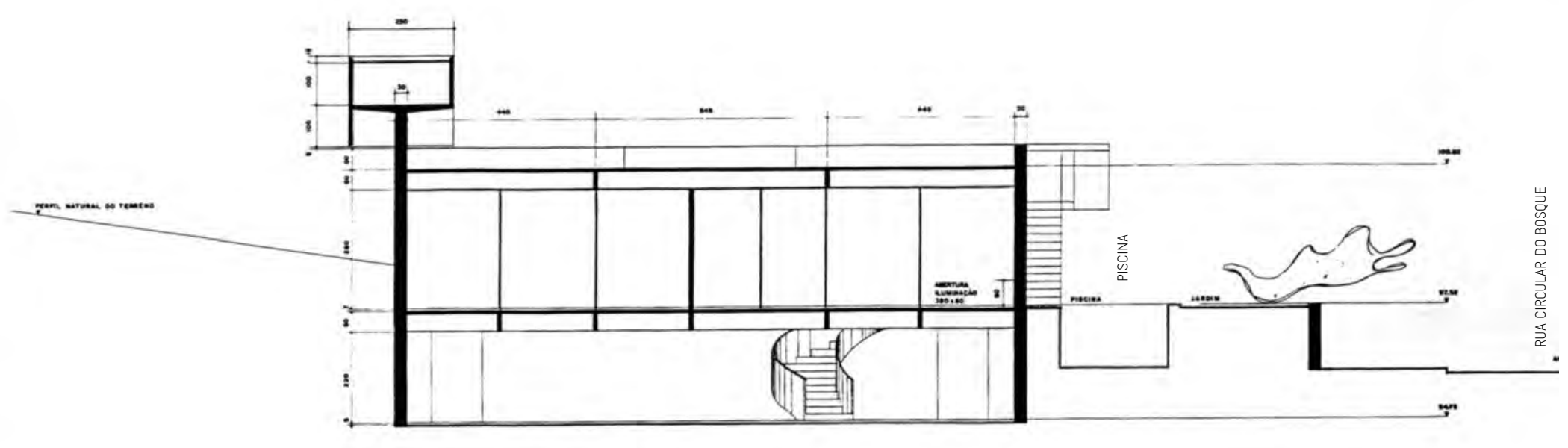


Na Casa Butantã, a cota mais alta do terreno fica elevada a aproximadamente $2.00 \mathrm{~m}$ de altura, em relação à esquina. Desta massa de terra, o arquiteto retira parte do miolo central, gerando um vazio dentro do qual ele implanta a casa, mas deixa uma porção perimetral de terra e conforma um talude ajardinado que faz as vezes de muro de divisa.

O volume da casa, suspenso por quatro pilotis, quase toca o jardim e pela fresta de luz deixada entre a terra e a casa, temos a impressão que esse flutua. Criam-se assim três planos sucessivos: o térreo, o jardim e o piso da casa propriamente dito. Aquilo que conecta os três é uma escada externa larga ${ }^{23}$, com um amplo patamar intermediário, que faz as vezes do alpendre de entrada, outra referência à casa Bandeirista situada logo em frente.

Já na Casa Millan a operação é ainda mais radical, pois o terreno possui uma diferença de nível entre a rua e o fundo do lote de aproximadamente sete metros. A cota de implantação do térreo é a mesma da rua, acarretando um movimento de terra de grandes proporções.

No vazio escavado, o arquiteto encaixa o volume da casa, que neste caso não se configura por planos articulados como na Casa Butantã, mas por uma casca de concreto aparente dentro da qual se dispõe o programa da casa. O que se vê da rua é apenas uma empena de concreto sem janelas, solta do chão. São poucos elementos arquitetônicos que indicam estarmos diante de uma casa. Não há portas nem janelas, somente duas superfícies de concreto e uma escada escultural que parece voar entre um plano e outro.

A massa de concreto reconstrói no vazio cavado uma nova espacialidade, deixando para trás qualquer vestígio do terreno natural. É somente possível reconhecer a topografia pré-existente quando observamos a diferença de cotas de nível da casa em relação aos seus vizinhos.

Assim, o modo pelo qual o arquiteto realiza esta operação se dá pela remoção de matéria ao invés de adição. Ele retira a terra para encontrar, no seu negativo, o vazio que precisa.

Uma operação que encontramos também, por exemplo, na obra do escultor americano Michael Heizer quando cava no deserto de Nevada (EUA)uma fenda na terra. A obra do artista surge pela remoção da matéria ao invés da acumulação; pelos cortes que realiza na terra, pode sentir a magnitude das paredes profundas e do vazio.

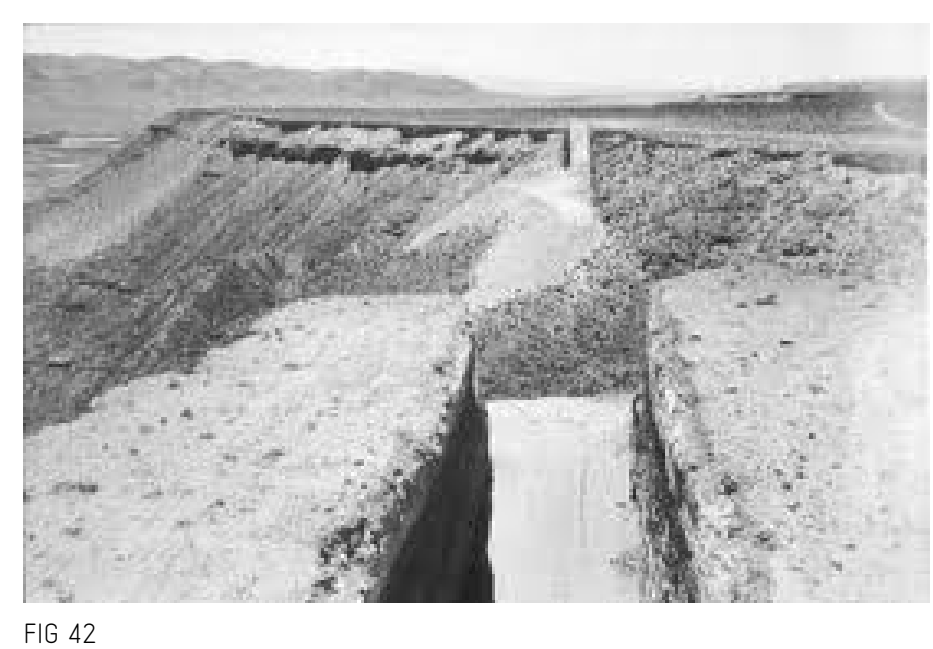

M. HEIZER: 1969: DOUBLE NEGATIVE, - NEVADA, ESTADOS UNIDOS

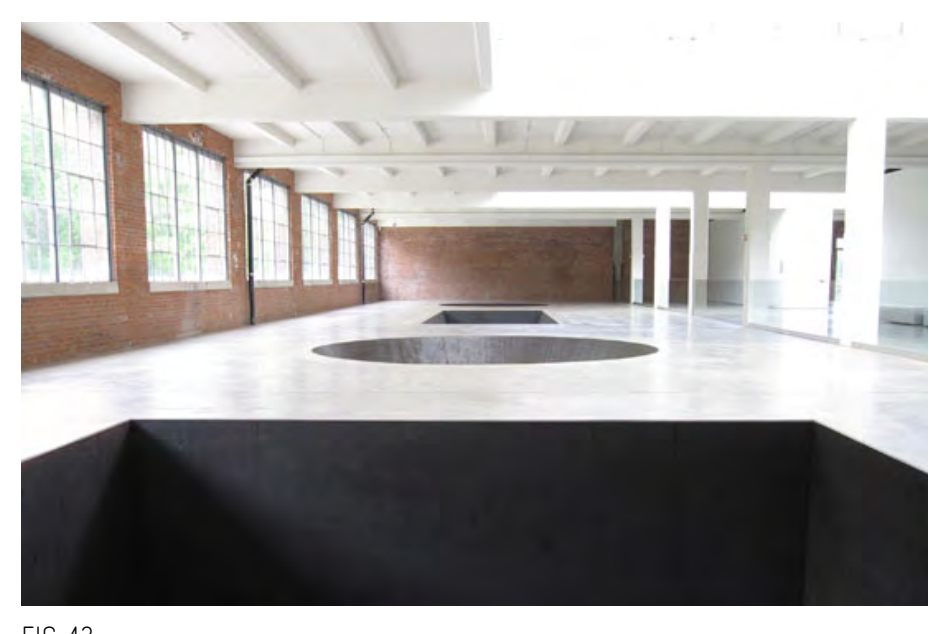

FIG 43

M. HEIZER: 1967/2002 NORTH, EAST, SOUTH, WEST DIA FOUNDATION, NOVA YORK, ESTADOS UNIDOS.

O ARTISTA AFIRMA QUE SUAS ESCULTURAS SÃO SOBRE O NADA, RETIRA A MATERIA PARA ENCONTRAR ESTE VAZIO, "NOTHINGNESS".

23 As escadas representam elementos importantes na arquitetura de PMR.Ao contrário da obra de outros arquitetos paulistas, nas quais predomina o uso da rampa, em PMR as rampas são raras e a escada assume um protagonismo particular, com um desenho elaborado. Torna-se assim mais que um lugar de passagem, mas de estar também. Ver p. 103. 
$24 \mathrm{O}$ arquiteto nos conta que por questões contratuais com as construtoras, houve um lapso de tempo entre as duas etapas da construção, e portanto, durante meses, o que se viu no terreno foi uma peça de concreto cercada por mato, como num terreno baldio. Ver no curta metragem PMR 29' o depoimento sobre processo construtivo do Museu.
Podemos ainda chamá-las de esculturas quando a ausência prevalece sobre a presença? O vazio central da Casa Millan também remete a esta ausência.

Há, portanto, uma identificação total entre a construção do terreno e a da casa, que impossibilita a leitura de um sem o outro. Por isso, não podemos pensar nesta construção como um objeto autônomo, que "pousa” na linha imaginária do horizonte. Aqui não há pouso, há um alojar, pôr em abrigo.

Ao pensarmos de modo comparativo em algumas obras do arquiteto Oscar Niemeyer, perceberemos como seus projetos estabelecem uma outra relação com a linha do horizonte, que se dá pela tangência. Os volumes parecem apenas tocar a superfície do chão em um ponto, sem alterar sua configuração.

Se, por absurdo, imaginarmos a possibilidade de um guindaste gigante içar o Museu de Arte contemporânea de Niterói, e pousá-lo em outra pedra, a pedra original permaneceria quase intacta, sem rastros do Museu. Mas o mesmo não ocorreria com a Casa Millan - nem tampouco com o Museu da Escultura, projeto no qual PMR retoma a mesma ação -, pois ao ser arrancada de seu terreno original, deixaria marcado no solo o molde daquilo antes estava ali.

Aliás, no projeto do Museu da Escultura, o próprio processo de construção demonstra esta operação. Como se sabe, o lote do Museu está numa esquina em declive em relação aos fundos e sua porção maior, na cota mais alta relativa à avenida principal. Já nos primeiros estudos, o arquiteto desenhou o Museu em dois níveis, uma praça na cota mais alta, sobre a qual implanta uma marquise no sentido perpendicular à avenida, e abaixo dessa acomodou as salas de exposição, anfiteatro e administração .

Ao iniciar as obras, decidiu-se por construir primeiramente a marquise de concreto, aproveitando a altura do terreno para escorar a peça, o mais próximo do chão possível, diminuindo a elevação do escoramento e facilitando a concretagem deste elemento de 60x12m. E assim foi feito. Uma vez concluída a execução da marquise, escavou-se a terra sob ela para a construção do espaço museológico propriamente dito ${ }^{24}$.

Ora, este procedimento surgiu necessariamente na fase de concepção do projeto, quando o arquiteto desenhou os apoios da marquise a certa distância das paredes diafragma dos salões de exposição no subsolo, de sorte que não houve interferência de cargas entre as duas fundações.

Vemos que o desenho do terrapleno se configura no início da ideação do projeto, participa da formação do Museu. É a partir do redesenho do terreno que se 

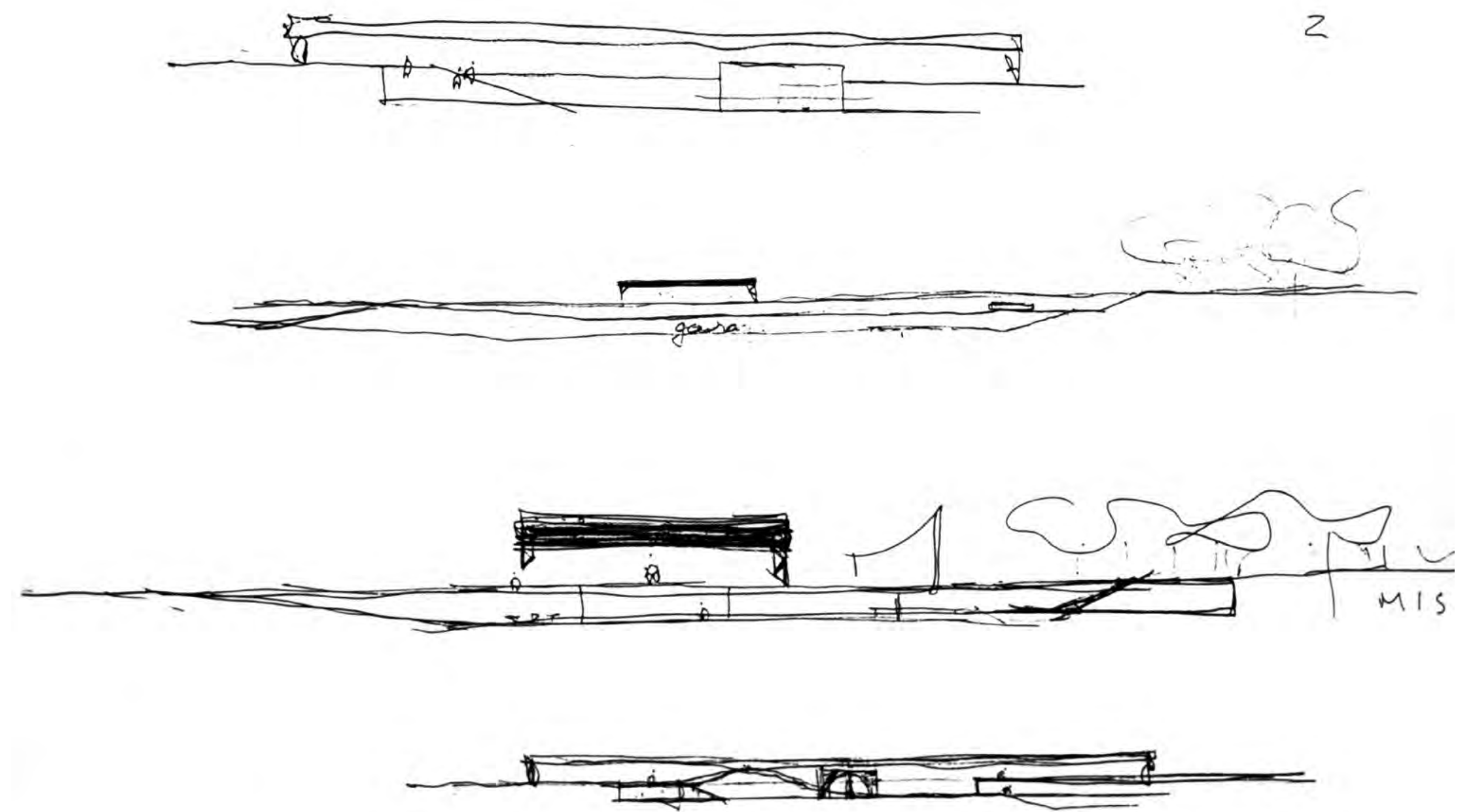

1988 - ESTUDOS PARA O MUSEU BRASILEIRO DA ESCULTURA, SP

ENQUANTO PMR REDESENHA O TERRENO NA BUSCA DE VAZIOS QUE ORDENEM O ESPAÇO.

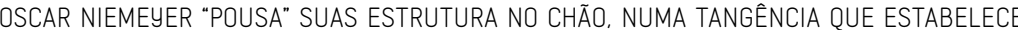

COM O HORIZONTE UMA RELAÇÃO DE FIGURA E FUNDO, O QUE NÃO OCORRE NO PROJETO DO

MUBE, POR EXEMPLO 


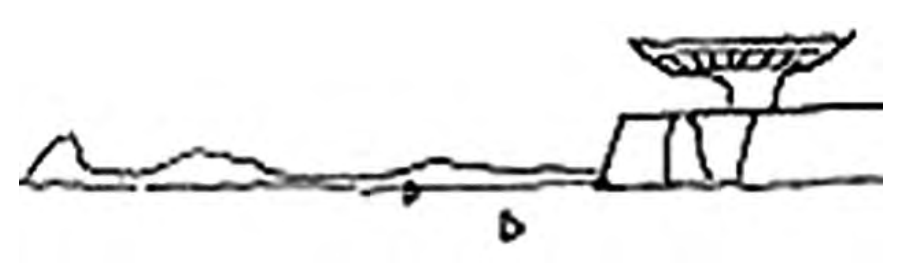

O. NIEMEYER: 1996 MAC, NITERÓI

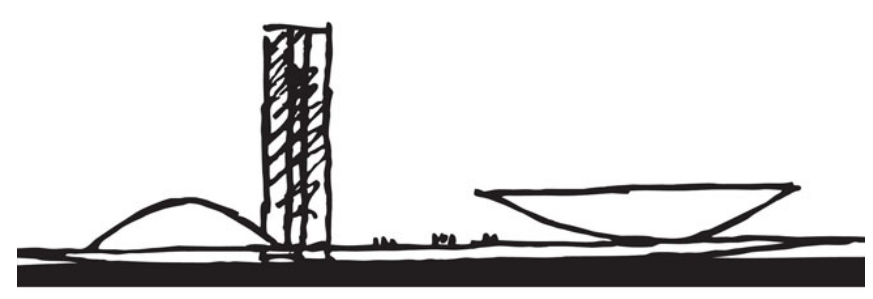

O. NIEMEYER: 1960 PALÁCIO DO CONGRESSO, BRASÍLIA



O. NIEMEYER: 1960 PALÁCIO DA ALVORADA, BRASÍLIA

25 TELLES, Sophia. "Museu Brasileira da Escultura". AU Arquitetura e Urbanismo, 1990. p 47.

26 "O Museu Brasileiro de Escultura (...) é de fato a construção de uma geografia natural”. PIÑON, Helio. 2002, p. 8,9.

27 Na casa Millan, o chão de asfalto da rua entra na casa. Hoje, após a reforma não podemos mais perceber esta continuidade pois há um portão que fecha o pátio para a rua. conformam as relações de dentro e fora, cheios e vazios. Relações que nos guiam pelo passeio da praça até a entrada das salas expositivas e do anfiteatro. Como indica Sophia Telles: "uma superposição de níveis que traz o solo para o interior do projeto numa sutil relação entre proximidade e distância." 25 .

Voltando às casas, entendemos que neste processo a ação de “cavar” não pretende construir uma nova geografia, num contraponto entre razão e natureza ou uma "geografia artificial” como define Helio Piñon. ${ }^{26}$

Não se trata tão pouco de ato político daquele que marca simbolicamente o chão com a cruz, como realizou Lucio Costa em Brasília; nem há uma busca pela monumentalidade, como em Niemeyer quando pousa seus palácios no cerrado ou na encosta da baia de Niterói; a seu modo, PMR funde objeto construído e relevo numa só coisa, numa contração entre forma e fundo, como um “contra-relevo”.

Decorre daí a dificuldade de atribuir a esta arquitetura um caráter monumental. Não tem pedestal, como em Giacometti, onde base e figura são um só. Assim o próprio chão vira coisa, num contínuo. Pensar o chão, como o escultor pensa a base, é próprio ao seu processo de projeto.

A paisagem nessa configuração não existe como algo sobre a qual o edifício se coloca, não é suporte para o objeto, edifício e chão formam uma única totalidade que se manifesta em relações pouco contrastantes ou definidas entre dentro-fora, cima-baixo, perto e longe, luz e sombra.

Quando o arquiteto estabelece valores equivalentes entre exterior e interior anula as distâncias entre os mundos privado e público, numa ação que revela o desejo do arquiteto de criar um espaço urbano sem limites, onde o chão da casa é o mesmo da cidade ${ }^{27}$.

Cavar faz parte da poesia de sua obra e neste sentido, ela se realiza transformando aquilo que é contingente do lugar em outra coisa, terreno e casa ao mesmo tempo, num deslocar de massas, de terra e concreto.

Essa ação torna-se constante na projeção de PMR. Através dela estabelece-se não só as relações entre forma e espaço, mas também correspondências entre cidade, território e natureza, como veremos no capítulo VI.

Dessa maneira, o que trans-forma o espaço nas Casas Butantã e Millan, é a ação sobre a superfície de um chão, que se desdobra numa sucessão de planos dispostos num contínuo que não cessa. São obras como nos ensina Giulio Carlo Argan ao descrever a obra de dois artistas construtivos, Anton Pevsner e Naum Gabo : "fundadas 
no território da topologia, ramo da geometria que pensa as formas como uma progressão no tempo; que definem o devir, e não mais o ser do espaço." ${ }^{28}$.

O conceito de forma como progressão do tempo contém a ideia de algo que é transitivo e não fixo ${ }^{29}$,que se apreende pela passagem do tempo e do espaço. Forma, segundo Bergson, é uma realidade, uma consciência do tempo, um "instantâneo de uma transição", não como uma tradução da realidade, mas sim como expressão de uma intuição da passagem do tempo ${ }^{30}$.

Para a análise que estamos construindo, entende-se forma como aquilo que contém uma ação sobre um conjunto de determinações. Ação que se dá num tempo continuo.

A forma do pilar, então, é resultante do encontro em sincronia de um saber técnico com uma intenção de projeto na qual este pilar não é apenas o suporte de uma série de esforços físicos, mas é aquele que também ordena e qualifica o espaço. Portanto, forma transforma o espaço, conforma.

Quando Argan descreve a estrutura de tubo de aço da cadeira de Marcel Breuer (Cesca), em seu livro Walter Gropius (2005), também faz essa distinção entre matéria e forma. Para ele, não se trata da transformação da matéria em forma por meio de um processo industrial: "o ponto de partida já é uma forma (o tubo metálico), o processo é construção formal: da unidade à complexidade, por meio de projeções sucessivas.” ${ }^{31}$.

Se forma, como vimos, é a realidade da matéria, resta entender agora de que matéria estamos falando. É o que faremos a seguir.

\subsection{LIQUID STONE: MATÉRIA E TÉCNICA}

the more interesting works in concrete are often those that recognize concrete's ambiguous nature: it can be both liquid and solid, smooth and rough, backward and advanced, worthless and precious (...)

Adrian Forty ${ }^{32}$

Talvez não exista um material que seja mais identificado com a origem e o desenvolvimento da arquitetura moderna do que o concreto armado bruto e aparente. Como sabemos, o uso do concreto em edificações data desde a construção da cidade de Roma, mas é somente na virada do século XVIII com a evolução tecnológica e

28 ARGAN, Giulio Carlo. Arte Moderna. 1992,p. 454.

29 No dicionário de Abbagnano, o termo forma aparece sobretudo a partir da definição Aristotélica:

“(...) forma é causa ou razão de ser da coisa, aquilo em virturde do que uma coisa é o que é; é ato ou atualidade da coisa, por isso o princípio e o fim do seu devir(...) ABBAGNANO, Nicola. Dicionário de Filosofia. São Paulo, 1998. p. $468-470$.

30 BERGSON, Henri. O pensamento e o movente, 2006. p. 10.

Quando Bergson relaciona o real com estados de transição, esclarece que a realidade não é uma somatória de estados imóveis, é fluxo, é continuo de duração, "é a própria mudança”.

31 parágrafo segue: "por esse caminho, o móvel se integra à arquitetura, não mais entendida como representação estática e plástica de um espaço definido, mas como a dimensão das infinitas possibilidades da vida". ARGAN, Giulio Carlo, Walter Gropius e a Baubaus, 2005. p. 65

32 FORTY, Adrian. “ The material without history” in Liquid Stone. 2006. p. 34.

Tradução do trecho: os trabalhos mais interessantes em concreto em geral são aqueles que reconhecem a natureza ambígua do concreto: ele pode ser líquido e sólido, macio e áspero, avesso ou reverso, sem valor ou precioso. (tradução da autora). 
33 Em 1747, é inaugurada em Paris a École Nationalle des Ponts et Chaussées, considerada a primeira escola de engenharia civil do mundo, e responsável pela formação de grandes nomes da engenharia civil europeia, tais como Eugene Freyssinet (1879-1962) que teve como professor Etienne Louis-Boulée (1728-1799).

PICON Antoine. "Architecture and Technology: two centuries of reative Tension”, in Liquid Stone. 2006. p. 8

34 O engenheiro Frances François Hennebique (1842-1921) patenteou em 1892 um dos primeiros sistemas construtivos em concreto armado, amplamente difundido não só na Europa como nas colônias inglesas e francesas. ibidem, p. 12

35 No original: "Concrete also presents yet another dichotomy, allowing for the transgression of the limit between technical and 'artistic' buildings". ibidem, p.24. industrial desenvolvida na Europa, que o concreto armado passa a ser uma matéria de uso constante no campo da construção.

Foi pelas mãos dos iluministas que surgiram as primeiras experiências de combinação entre concreto e aço, que tinha a função de compensar a fragilidade do concreto comum para os esforços de tração. Deste modo, o concreto armado é um produto de laboratório, cuja performance estrutural é representada por uma fórmula matemática.

Até então, tecnologia e engenharia não eram saberes distintos da arquitetura. A partir da segunda metade do século XVIII é que a engenharia ganha autonomia em relação à arquitetura, sobretudo na França e na Inglaterra ${ }^{33}$.

O saber construir em concreto armado passa a depender então de uma formação técnica que não estava mais associada nem ao ofício do construtor nem ao do arquiteto. $\mathrm{O}$ concreto armado é matéria que precisa da intermediação intelectual de um cálculo elaborado, ao contrário do tijolo e da pedra, que permitem certo grau de empirismo. Trata-se de um processo pelo qual se avalia o peso e as medidas adequadas dos componentes: aço, cimento e agregado, para determinado fim. Tais materiais não tinham valor para o construtor se ele não possuísse este saber tecnológico e a patente que o permitisse usar tal tecnologia ${ }^{34}$.

O avanço do uso do concreto armado na Europa pré-industrial se deu, portanto, na mesma proporção que o desenvolvimento industrial e tecnológico, e passou a ser usado em larga escala nas obras de infraestruturas como pontes, viadutos, reservatórios de água etc.

Em seu texto "Modern Architecture and the saga of concrete", o arquiteto e historiador Jean Louis Cohen aponta para o fato de que o uso do concreto armado ampliou algumas dicotomias no campo da arquitetura. A primeira delas, e mais evidente, é o distanciamento entre aquilo que define a prática profissional de arquitetos e engenheiros. Como vimos acima, o desenvolvimento das tecnologias ligadas ao concreto armado colocou os engenheiros em uma posição de destaque em relação ao construir, pois o desenho do edifício era antes de mais nada o desenho de uma estrutura calculada.

A segunda dicotomia, e talvez menos perceptível, torna possível analisar a obra de um arquiteto moderno pelo modo como ele projeta seus edifícios em concreto armado, permitindo uma "transgressão do limite entre edifícios técnicos e artísticos" 35 . Na obra de Auguste Perret, Cohen reconhece um repertório vindo das construções 
de pontes e viadutos. Já na obra de Le Corbusier, ele distingue a influência das superfícies parabólicas desenhadas por Eugene Freyssinet (inventor do concreto protendido) e o hangar de Orly ( 1917)..$^{36}$

Esta distinção nos interessa pois reconhecemos que nas casas de concreto armado, o arquiteto PMR usa o material de modo particular, o que define e marca seu projetar.

Se continuarmos na linha de pensamento de Jean Louis Cohen, podemos assinalar, por exemplo, a distinção entre o uso do concreto armado na obra de Niemeyer e PMR. Se pensarmos na obra do MAC em Niterói, de Niemeyer, há uma linha contínua que delimita o perfil do volume, como um skyline do edifício. Nada deixa ver o concreto, as superfícies são contínuas, uniformes, lisas e pintadas de branco.

No caso das casas Butantã e Millan, o concreto também é usado como uma matéria total: está na estrutura principal, nos fechamentos e até no mobiliário. Mas ao invés da linha, PMR constrói grandes planos separados pela criação de um vazio entre eles. Ou seja, podemos reconhecer visualmente um jogo de armar dessas peças gigantes. Sophia Telles nomeia, com propriedade, tais encontros como "articulações disjuntivas"37.

Assim, se para Niemeyer o concreto é matéria líquida, e escorre obediente dentro de fôrmas curvas e finas, para PMR o concreto é solido, uma peça bruta précalculada juntamente aos engenheiros e que condensa várias funções estruturais em um só elemento. Se em Niemeyer a matéria ganha aparência lisa e macia, em PMR, revela-se rugosa e áspera.

Nas casas Butantã e Millan, como vimos, o concreto armado é também matéria que está em todos os lugares, no chão, na parede e no sofá; o caráter do espaço é dado pelo concreto. É interessante observar o desenho ao lado e perceber que tudo o que está desenhado ali é de concreto: o muro do fundo, as lajes dos dormitórios, a escada e o brise.

O concreto armado, neste sentido, se presta muito bem ao raciocínio espacial de PMR, pois como se trata de matéria sem avesso, as relações entre dentro e fora, peso, densidade e cor ficam equivalentes, e daí temos a sensação de unidade espacial. O contraste ou a graduação vem apenas pela incidência da luz natural, seja refletida nos grandes beirais que conformam a sala e a varanda, seja pela incidência direta das claraboias, ou ainda pela inusitada luz verde refletida do jardim, que entra pela fenda deixada entre a empena superior de concreto e o peitoril da parede, na Casa Butantã.

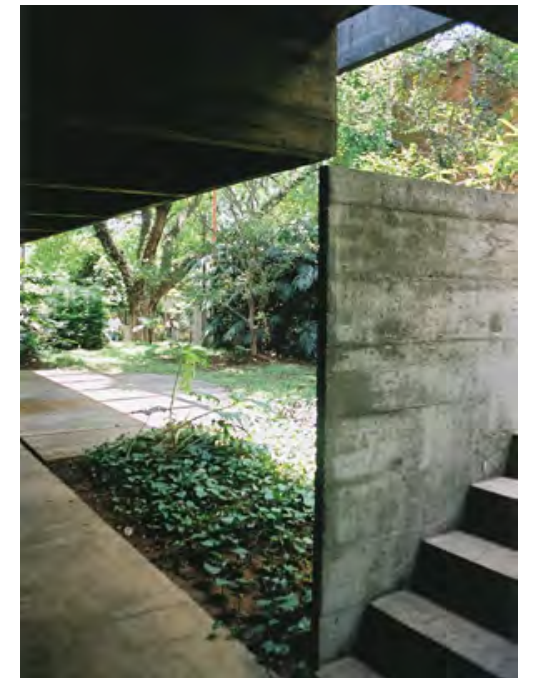

FIG 44

CASA BUTANTÃ

EXEMPLO DE "ARTICULAÇÕES

DISJUNTIVAS"

SEGUNDO SOPHIA TELLES
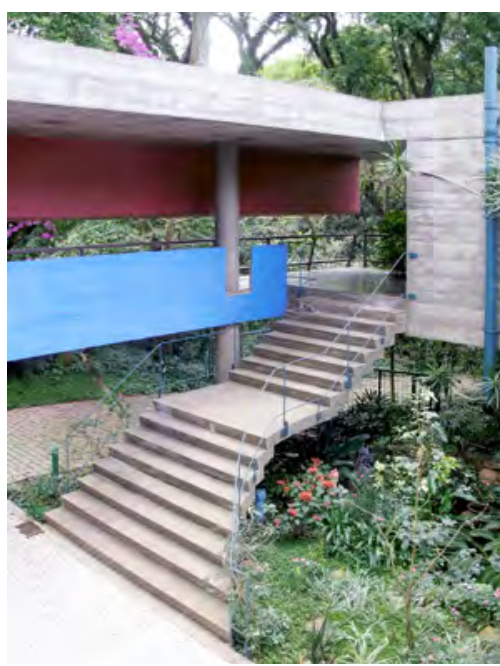

FIG 45

1972: CASA JAMES KING

36 No decorrer no texto, o autor segue esta argumentação comentando a obra de alguns arquitetos modernos. Ao se referir a Oscar Niemeyer, afirma que: "Concrete allowed for the introduction of elegance and fantasy in programs dealing with political representation".

Trad.: "O concreto permitiu [a Oscar Niemeyer] introduzir em seu trabalho elegancia e fantasia em programas relacionados a instituições políticas (tradução da autora). ibidem, p. 30

37 TELLES, Sophia. “Conversas com Sophia”. São Paulo, 2010. Entrevista a Catherine Otondo 
38 Evidente que no processo construtivo das casas estudadas, há aspectos bastante artesanais no que se refere à construção das fôrmas de madeira e na inexistência de processos industrializados no canteiro. $\mathrm{O}$ que estamos afirmando é que o processo criativo de PMR não contempla a manualidade. Como, por exemplo, o faz Lina Bo Bardi no projeto do SESC Pompéia, onde podemos reconhecer na textura do concreto, no revestimento de pedrinha a estampa da mão de quem o fez.

39 Paulo de Menezes Mendes da Rocha (1887-1967) foi engenheiro naval responsável pela construção de obras de infraestrutura de canais e açudes no Nordeste do Brasil. Em 1939, ingressa como professor da Escola Politécnica da Universidade de São Paulo, tornando-se catedrático no ano seguinte.

40 Frequentemente, PMR refere-se à experiência de ter sido professor assistente de Vilanova Artigas como sendo sua segunda formação, que lhe deu uma ampla dimensão do alcance cultural e social da arquitetura.

41 ROCHA, Paulo Mendes da. Wisnik, Guilherme org. Encontros com Paulo Mendes da Rocha.Rio de Janeiro, 2012. p. 72.

42 BRUAN, Yves. Arquitetura contemporânea no Brasil. São Paulo: Perspectiva, 1981.

43 Hoje, pelas novas normativas de cálculo estrutural, muitas das estruturas projetas naquele tempo não poderiam ser realizadas. Por exemplo, o pilar tem que ter uma seção mínima de $25 \mathrm{~cm}$, há normas mínimas para a espessura de recobrimento do ferro, o que faz com que a espessura das lajes seja maior etc.
Entretanto, como o concreto é matéria pouco reflexiva, os espaços internos são feitos predominantemente de sombras, com alguns feixes diretos de luz.

Uma obra pensada em concreto armado passa necessariamente pela mediação de um engenheiro calculista que prefigura a execução das peças de concreto, sejam elas industrializadas ou moldadas em loco. Uma parede de alvenaria, em princípio não precisa desta mediação. No caso de PMR, notamos que a interlocução com os engenheiros se dá já nos primeiros momentos da concepção.

Desse modo, o raciocínio que molda a matéria na obra de PMR é tributário da engenharia, e não de uma tradição manual, do tijolo, da pedra. Aqui não há nada de artesanal ${ }^{38}$

A engenharia enquanto disciplina quase sempre fez parte da vida do arquiteto, desde a infância quando viajava com seu pai para visitar as obras de portos, eclusas e canais $^{39}$. E também em sua "segunda formação" ${ }^{40}$, quando se aproxima de Vilanova Artigas e passa a integrar um grupo de arquitetos paulistas que em suas palavras: "vinculou com muita nitidez a questão da criatividade com sua essencialidade racional, técnica e cientifica." ${ }^{41}$.

$\mathrm{O}$ uso intenso do concreto armado nas obras dos arquitetos paulistas nas décadas de 1960 e 70 levou a uma caracterização desta arquitetura como sendo "brutalista”, conforme já mencionamos.

O primeiro crítico a fazer a relação entre o brutalismo europeu e a arquitetura paulistas foi Yves Bruand ${ }^{42}$ em seu compendio sobre arquitetura contemporânea no Brasil. No livro, o autor distingue duas "tendências arquitetônicas": uma ligada ao brutalismo inglês e outra à obra de Le Corbusier (sobretudo a partir do projeto da Unidade de Marselha). E conclui que em São Paulo predomina a influência deste último na figura e obra do arquiteto Vilanova Artigas.

Para nós, o caráter dessas obras nada tem de bruto, ao contrário, são o resultado de um desenho associado a um raciocínio estrutural no mais alto grau de sofisticação, que levam ao limite as propriedades físicas do material ${ }^{43}$. Esbeltez, leveza e equilíbrio eram atributos que os arquitetos buscavam em suas obras. São obras vigorosas, mas não necessariamente de aparência grosseira.

Mais do que ficar buscando justificativas para as relações entre o brutalismo paulista e o europeu, interessa-nos apontar o que se destaca no caso paulista. Em nosso entender, o que é único neste caso é justamente essa interlocução entre arquitetos e engenheiros; os arquitetos paulistas se beneficiaram muito da experiência profissional 
de engenheiros brasileiros que tiveram uma formação na Europa, como Figueiredo Ferraz, calculista do MASP, Roberto Zuccolo, responsável pela difusão do uso do concreto protendido, e no caso de PMR, Siguer Mitsutani, que calculou a grande maioria de suas obras, como o Pavilhão de Osaka (1970) e as casas que estamos apresentando neste capítulo. Assim, mais que brutalista, trata-se de uma manipulação do concreto com alto grau de precisão e cálculo; uma arquitetura (fazendo uma anedota) "calculada”.

Provavelmente, é por esta aproximação com o campo da engenharia que a noção de técnica ${ }^{44}$ se associa à obra desse arquiteto. Entendendo técnica como sendo o modo pelo qual o artista (trans)forma a matéria e dá ordem às relações espaciais.

É oportuno lembrar que de acordo com Henri Focillon, na obra de arte podemos entender técnica como uma ação que contém dois sentidos, o primeiro se refere ao conjunto de métodos, ou procedimentos de um ofício; o segundo, ao modo pelo qual o artista faz viver as formas na matéria, como ele "ataca” a matéria. De grande interesse para nossos estudos esta noção ativa da técnica ${ }^{45}$.

Segundo PMR, os arquitetos devem abordar a questão técnica como quem anula as distâncias entre humanismo e tecnologia, filosofia e matemática, razão e imaginação ${ }^{46}$.

Pudemos observar ao longo deste trabalho que o arquiteto se encanta com o engenho das coisas, seu mecanismo, como elas são feitas. Percebemos este encantamento refletido no cuidado com o detalhamento expresso nos seus primeiros projetos executivos, nos detalhes 1:1: do pivô da porta de entrada da Casa Butantã, no fecho das janelas e em tantos outros. Se por um lado são detalhes construtivos necessários de serem feitos - compensando a falta de industrialização no país - por outro eles nos revelam o cuidado do arquiteto com a escala do pequeno, a minúcia e a precisão, que sem dúvida qualificam seu fazer ${ }^{47,48}$.

Quando, posteriormente, elaborou o projeto da Casa Gerassi, em 1989, o arquiteto a princípio não se animara com a demanda de ainda ter que desenhar casas. Porém, desta condição adversa, resolveu construir a casa em um sistema pré-fabricado de concreto, em geral utilizado para edificar galpões industriais.

O terreno em questão fica em um bairro nobre da cidade de São Paulo. A casa - cujo desenho executivo foi realizado em apenas sete pranchas desenhadas a mão se constituía em um plano elevado, sobre pilotis, que deixava o terreno, plano, todo livre. A estrutura era feita por um jogo de armar de peças pré-industrializadas que seriam montadas no terreno.

44 Segundo Josep Maria Montaner, a obra de PMR parte "da fascinação pela engenharia e pela técnica (...)”. MONTANER, Josep Maria e VILLAC, Maria Isabel. Mendes da Rocha. Barcelona e 1996. p. 6.

45 FOCILLON, Henri. A vida das Formas seguido de Elogio da Mão, 2001 p. 61.

"Somos assim levados a ligar à noção de matéria a noção de técnica, que na verdade de modo algum são separadas. (...) É que a técnica é susceptível de numerosas acepções: podemos considerá-la como uma força viva, ou como uma mecânica, ou ainda simples adorno. Nunca a consideraríamos um automatismo do 'ofício', nem uma curiosidade ou receita de uma determinada 'culinária', mas sim uma poesia toda feita de ação e, para manter nossa terminologia, mesmo naquilo que tem de incerto e de provisório, o instrumento das metamorfoses." (grifo meu).

46 ARTIGAS, Rosa (org.) Paulo Mendes da Rocha, 2000. p. 72.

47 Tais detalhes foram desaparecendo de suas pranchas, talvez pelo modo apressado que fazemos projetos hoje em dia, talvez pelo fato de nossa indústria ter se desenvolvido a tal ponto que não são mais necessários.

48 Ver curta metragem PMR 29' 29 minutos com Paulo Mendes da Rocha, 2010. 


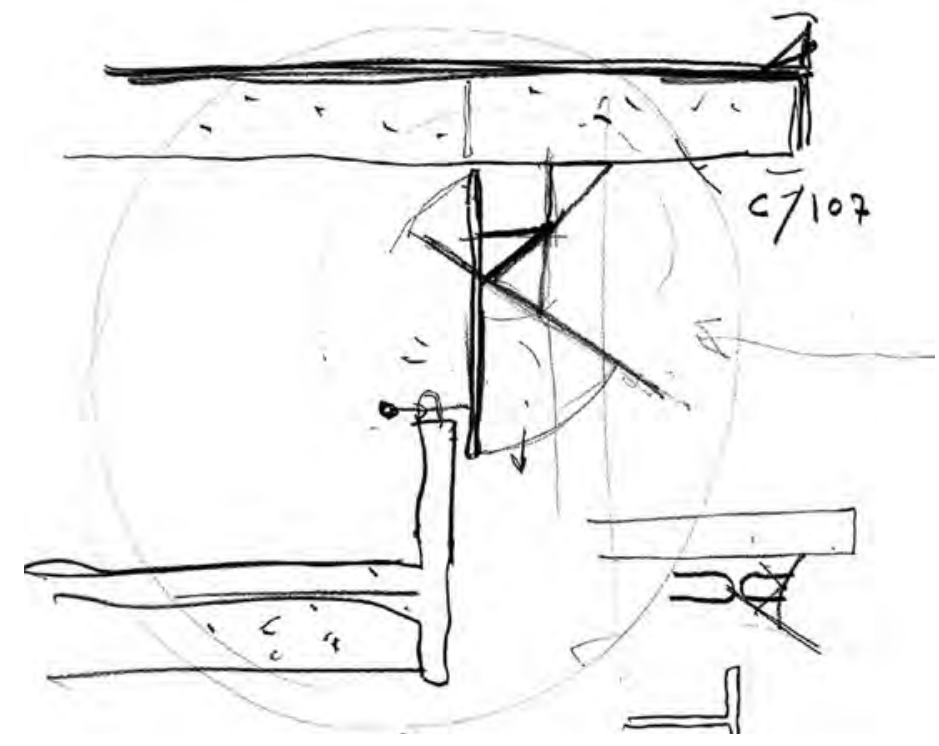

CASA BUTANTÃ

ESTUDOS PARA O SISTEMA DE ABERTURA DAS JANELAS

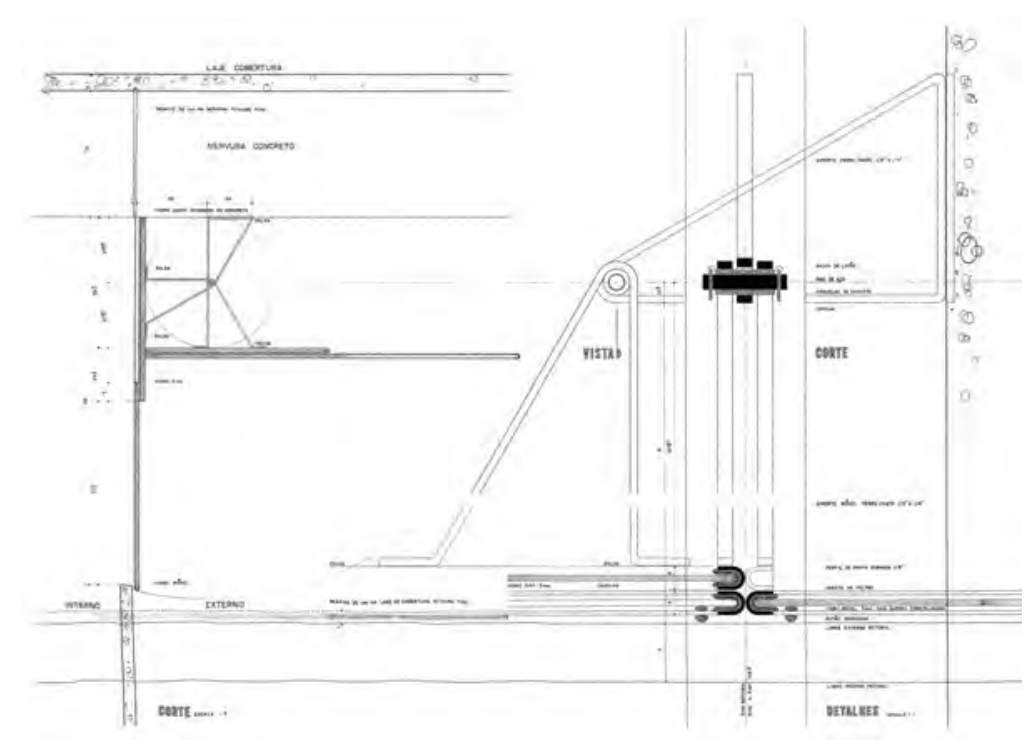

CASA BUTANTÃ

DETALHE CONSTRUTIVO DO SISTEMA DE ABERTURA DAS JANELAS S/ ESCALA

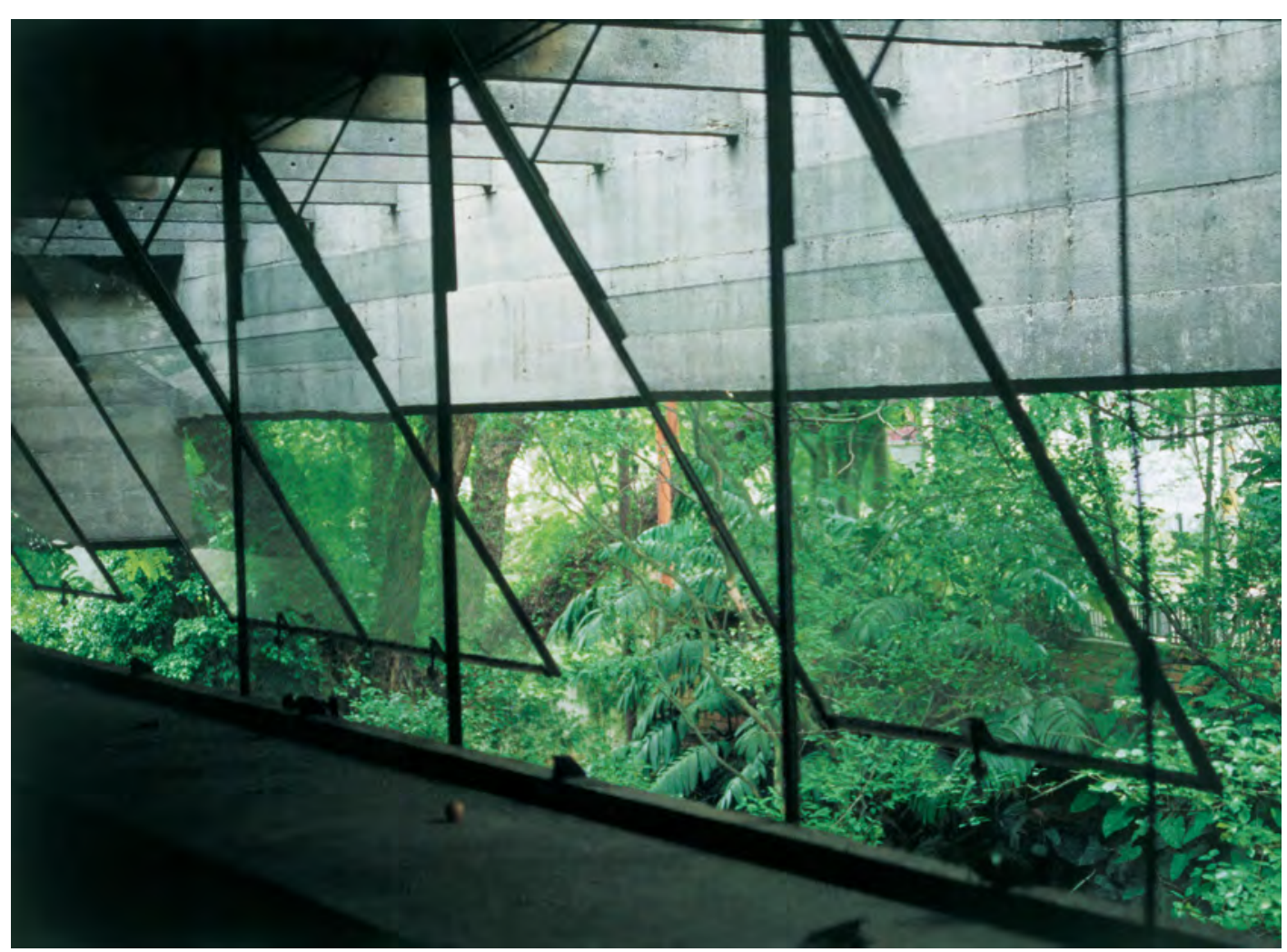

FIG 46

CASA BUTANTÃ

JANELAS IGUAIS: VARANDA FRONTAL E SALA 
Tão logo o guindaste começou a montar as peças houve um protesto dos vizinhos na rua, reclamando que ali era um bairro residencial e não poderia haver comércio. Ou seja, pelo modo como aquilo estava sendo construído não poderia ser casa! Tal espanto causado na vizinhança trouxe grande satisfação ao arquiteto, gerando um incômodo frutífero, na compreensão do que poderia ser o processo construtivo de uma casa num país com déficit habitacional como o nosso.

Ao revelar tais contrassensos por meio da realização do projeto, exibia-se, para PMR, o verdadeiro êxito da técnica. Técnica como instrumento de mudança das relações entre o homem e a natureza das coisas.

As casas analisadas neste capítulo são para nós exemplares da realização de um pensamento espacial que vai se consolidando no decorrer da trajetória deste arquiteto.

São obras nas quais PMR consegue formalizar um modo particular de pensar o espaço, que não estava presente em suas primeiras realizações, incorporando ao seu desenhar questões que expandem o campo da própria arquitetura, e que se amplia para um pensamento sobre a cidade, o homem e a natureza.

Estamos nos referindo à consolidação de procedimentos, modos do fazer e não à cristalização de conceitos ou formulações doutrinarias. A preocupação do arquiteto está em outro plano neste momento.

Essa ampliação da compreensão sobre o "fazer arquitetônico" surge, em certa medida, da aproximação com arquiteto Vilanova Artigas ${ }^{49}$, por conta do ambiente de reflexão que havia em torno da FAU-USP e dos arquitetos ligados ao IAB, e se incorpora com extrema naturalidade ao seu modo de fazer projetos ${ }^{50}$.

A partir da experiência de construir casas em concreto armado, PMR consolida um modus operandi que passa a ser causa e razão do seu pensar, qualificando o modo como elabora seus projetos, age sobre o espaço e se apropria de uma técnica, transformando o programa de demandas em um problema espacial.

49 Segundo depoimento de PMR: "Eu, particularmente, tive muita felicidade, porque lá pelas tantas ele (Artigas) me convidou para trabalhar na FAU (1959), como professor assistente. $\mathrm{E}$ eu, que não conhecida com muita profundidade tudo isso, entrei numa fase de grande espanto e descoberta, e devo muito da minha formação a esta convivência.” In “Aprendendo com Artigas”. ROCHA, Paulo Mendes da. Encontros com Paulo Mendes da Rocha. Rio de Janeiro, 2012. p. 73.

50 Sophia Telles afirma que a arquitetura de PMR é a que melhor formaliza o discurso de Artigas, contendo uma "elegância espacial impar." in TELLES, Sophia. "Conversas com Sophia”. São Paulo, 2010. Entrevista a Catherine Otondo. 


\section{ESCADAS}

AO CONTRÁRIO DA MAIORIA DOS ARQUITETOS DA ESCOLA PAULISTA, PMR DESENHOU POUCAS RAMPAS EM SEUS PROJETOS. PREDOMINAM AS ESCADAS, COM SEU DESENHO APURADO, MEDIDAS GENEROSAS. CONSTRUIIDAS TANTO DE FERRO COMO EM CONCRETO MOLDADO

FIG 47

CASA BUTANTÃ

A ESCADA COMO ALPENDRE DA ENTRADA
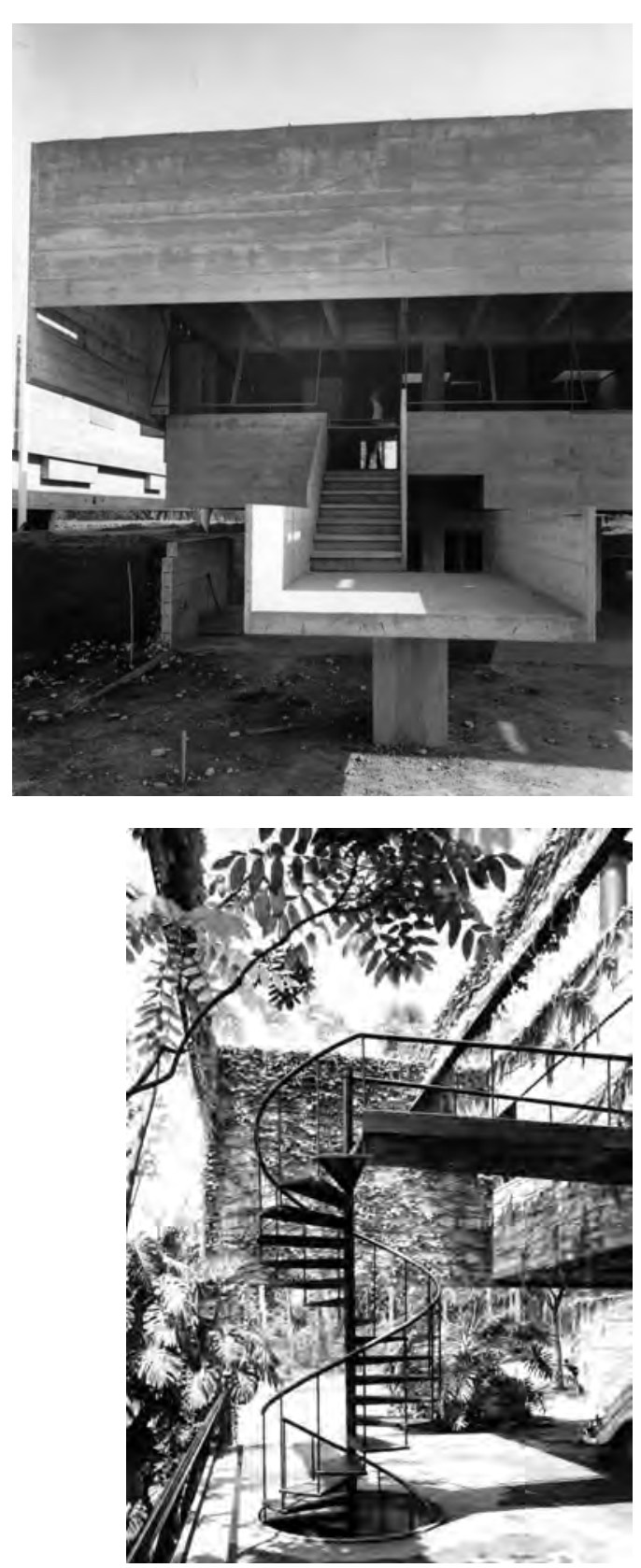

FIG 49

CASA MILLAN

ESCADA NO PATIO INTERNO

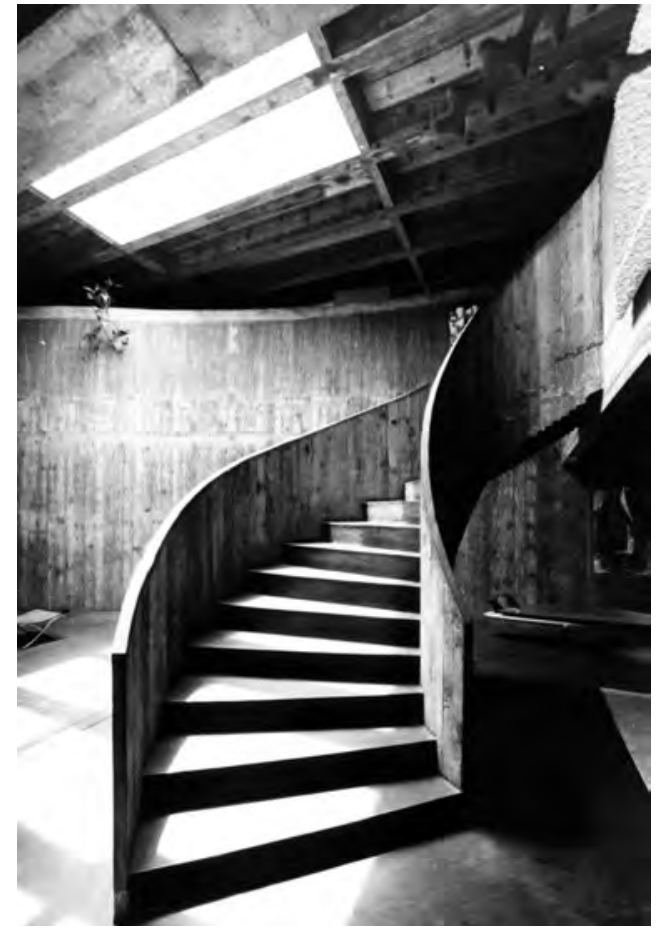

FIG 48

CASA MILLAN

VAZIO CENTRAL. ESCADA EM CONCRETO QUe CHEga nO MEIO DA SALA. NO ALTO, VEMOS PARTE DA CLARABOIA DE VIDRO, FONTE UNICA DE LUZ NATURAL PARA TODA A SALA.

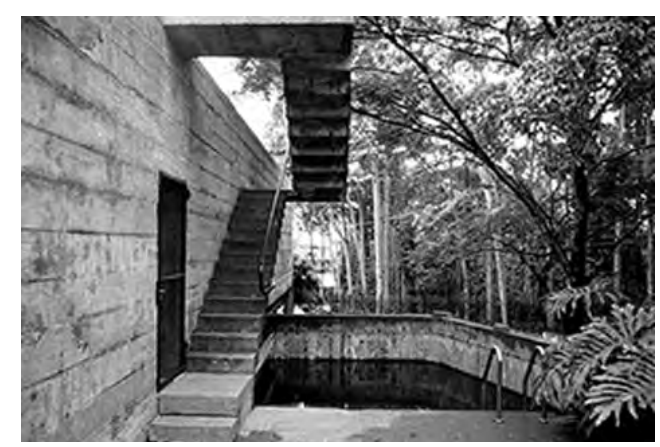

FIG 50

CASA MILLAN

JARDIM: PISCINA E ACESSO À COBERTURA 



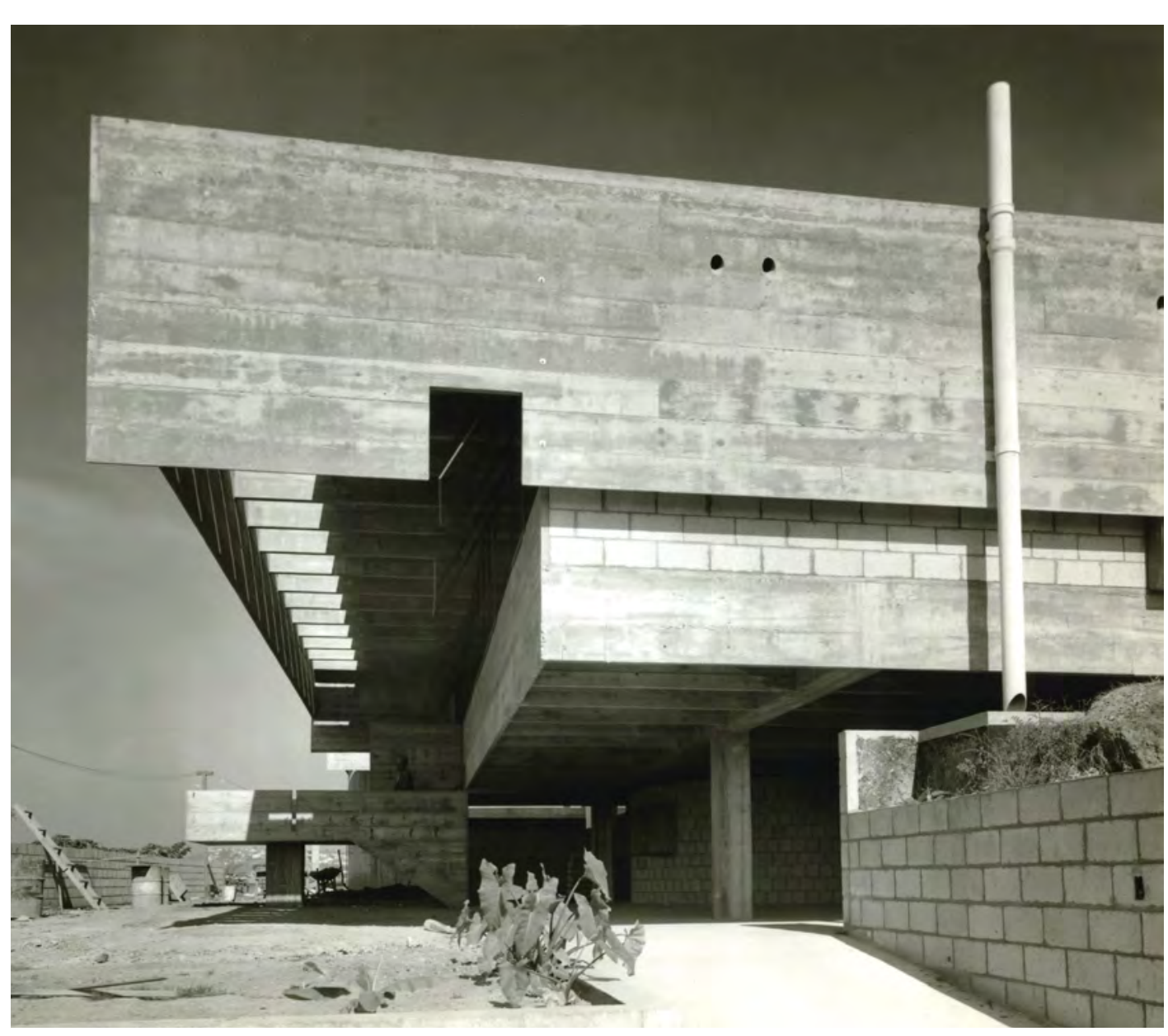

FIG 51

CASA BUTANTÃ

RUA ENGENHEIRO JOÃO DE ULHÔA CINTRA, 26 - SÃO PAULO

DATA DO PROJETO: 1964

CONCLUSÃO DA OBRA. 1967

ÁREA DO TERRENO: $760,00 \mathrm{M}^{2}$

ÁREA CONSTRUÍDA: $276,00 \mathrm{M}^{2}$

COLABORADORES: ARQUITETO JOÃO EDUARDO DE GENNARO

CÁLCULO DAS ESTRUTURAS DE CONCRETO ARMADO E DAS FUNDAC̄̃̃ES: CONSCAL CONSULTAS E CÁLCULOS LTDA.

ENG. RESPONSÁVEL. SIGUER MITSUTANI

CONSTRUTORA: CENPLA-CONSTRUÇÕES, ENGENHARIA E PLANEJAMENTO LTDA.

ENG. RESPONSÁVEL: OSMAR AUGUSTO SOUZA E SILVA 



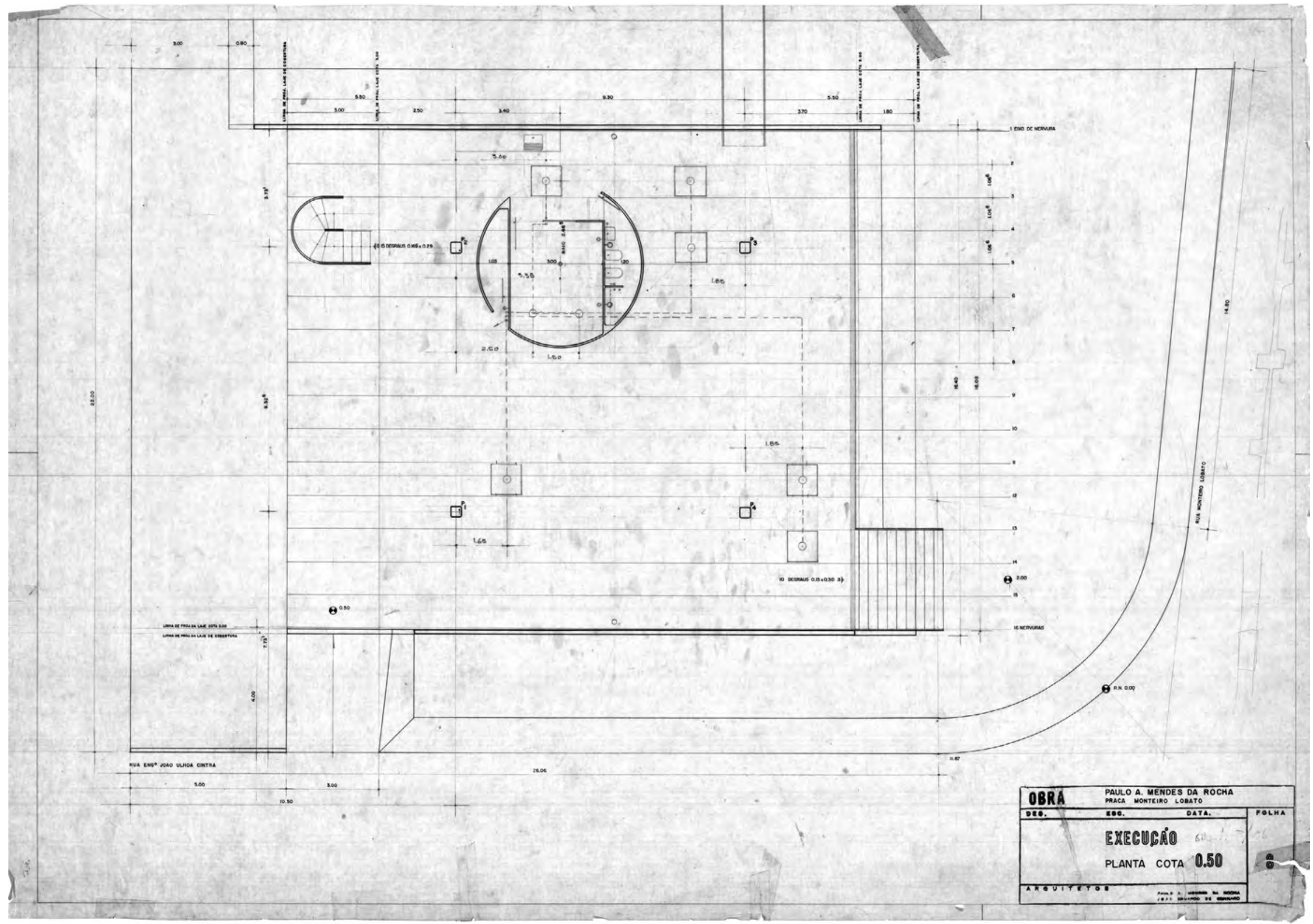

PLANTA DO TÉRREO

S/ ESCALA

PODEMOS PERCEBER QUE O DESENHO DA ESCADA FOI ALTERADO JÁ NA FASE DO PROJETO EXECUTIVO 







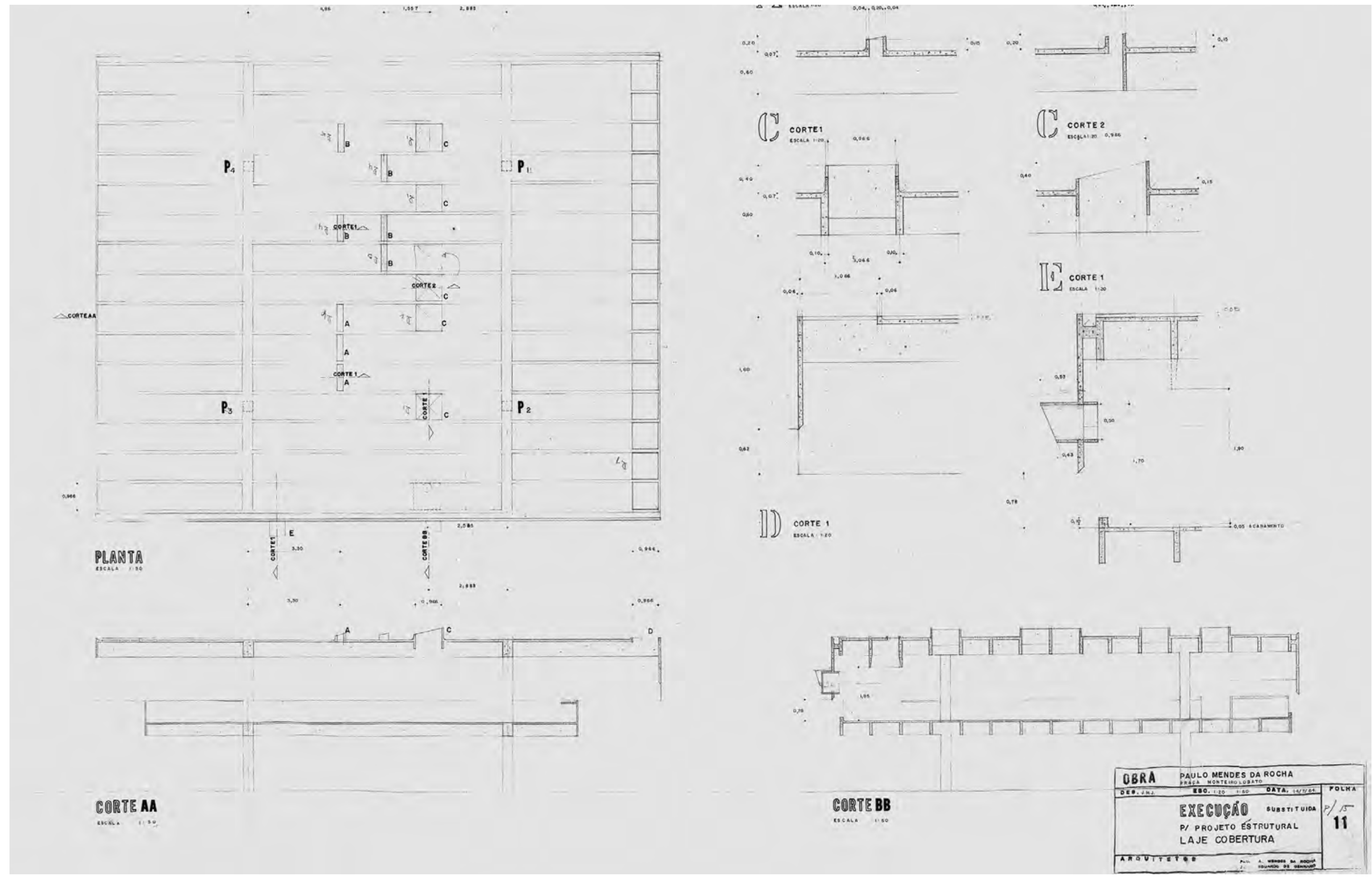

PLANTA DE COBERTURA, CORTE AA, BB E DETALHES CONSTRUTIVOS S/ ESCALA 


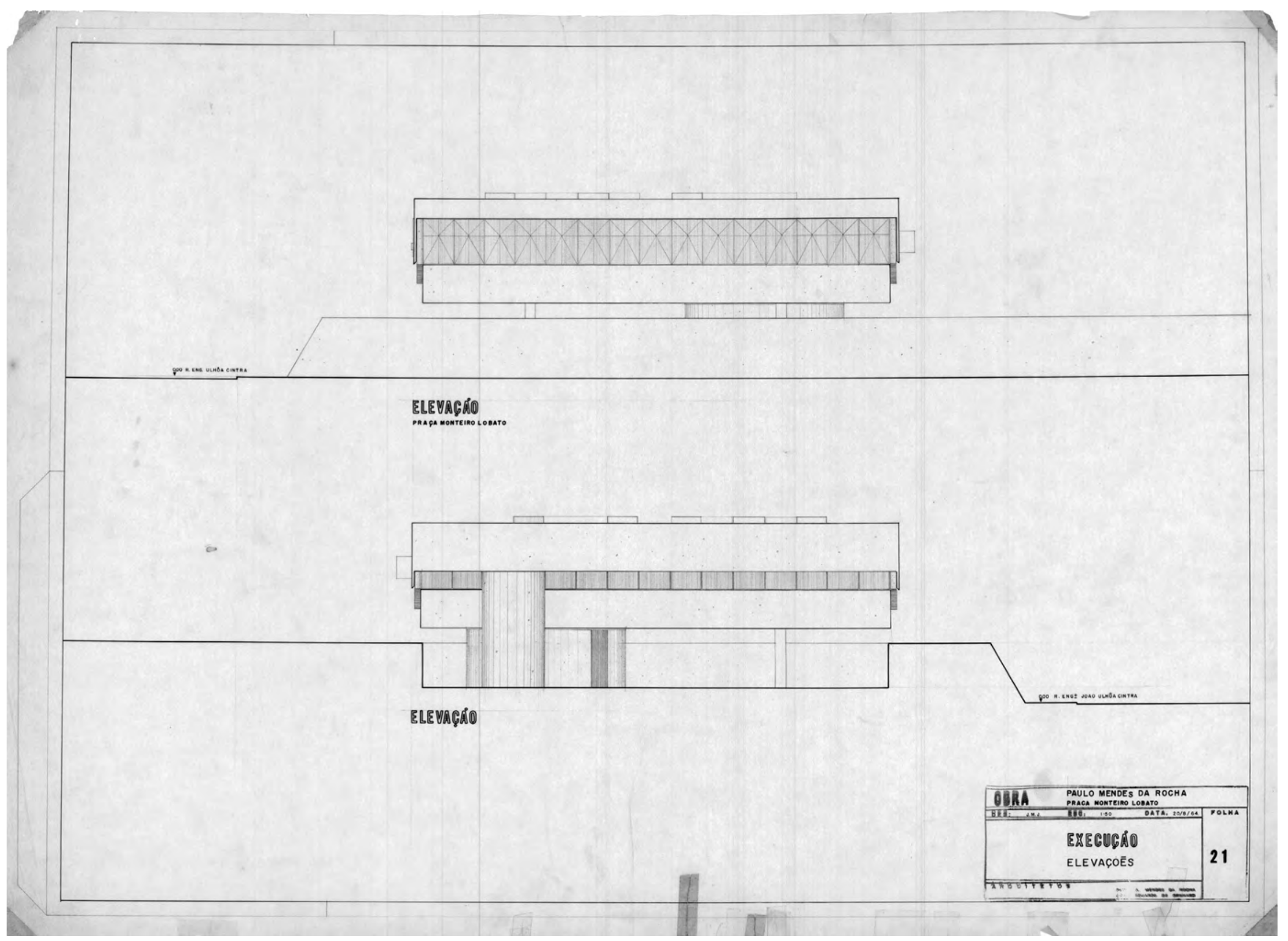

ELEVAÇ̃̃ES FRONTAL E POSTERIOR S/ ESCALA 


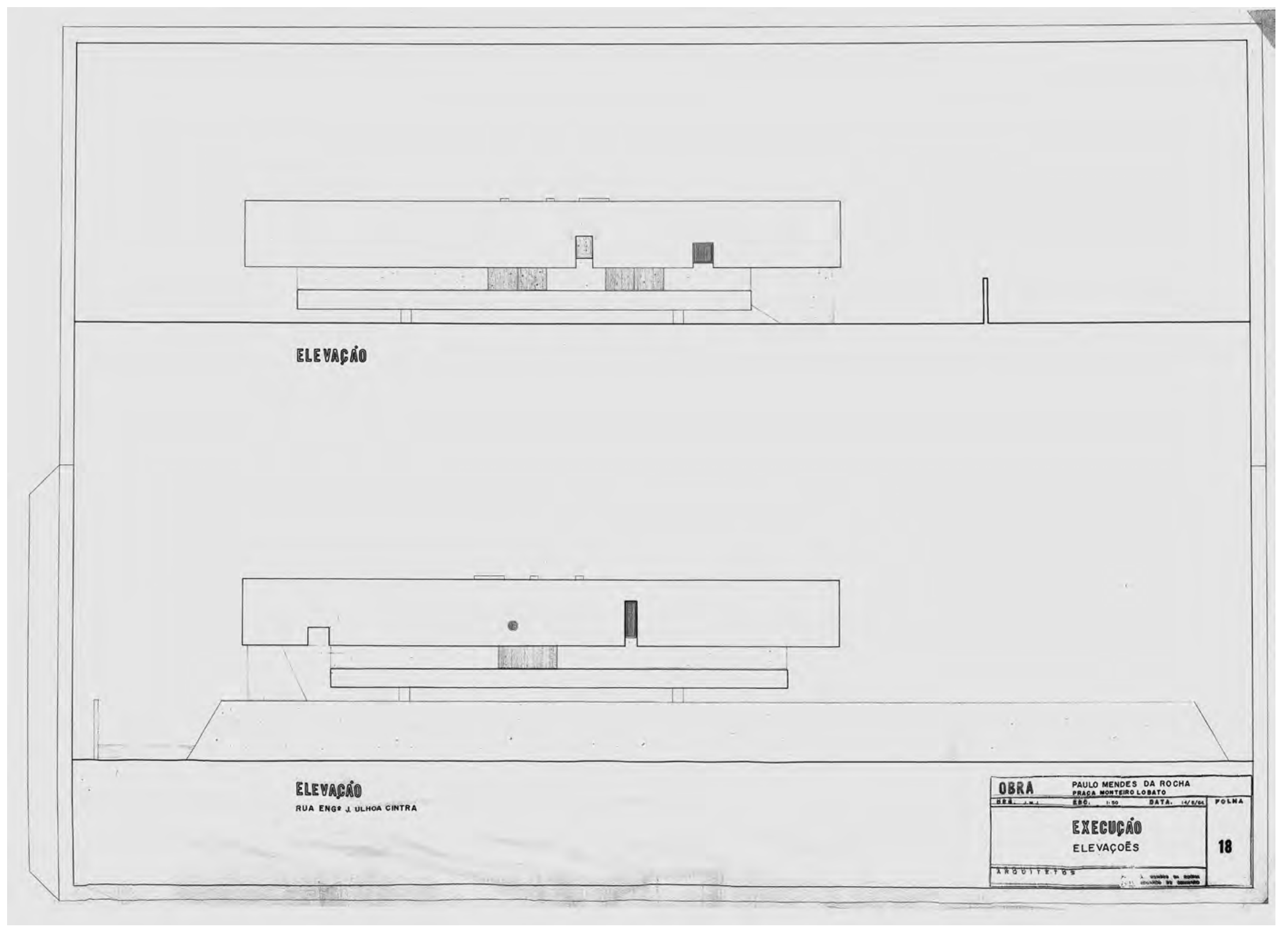

ELEVAÇÕES LATERAIS

S/ ESCALA 


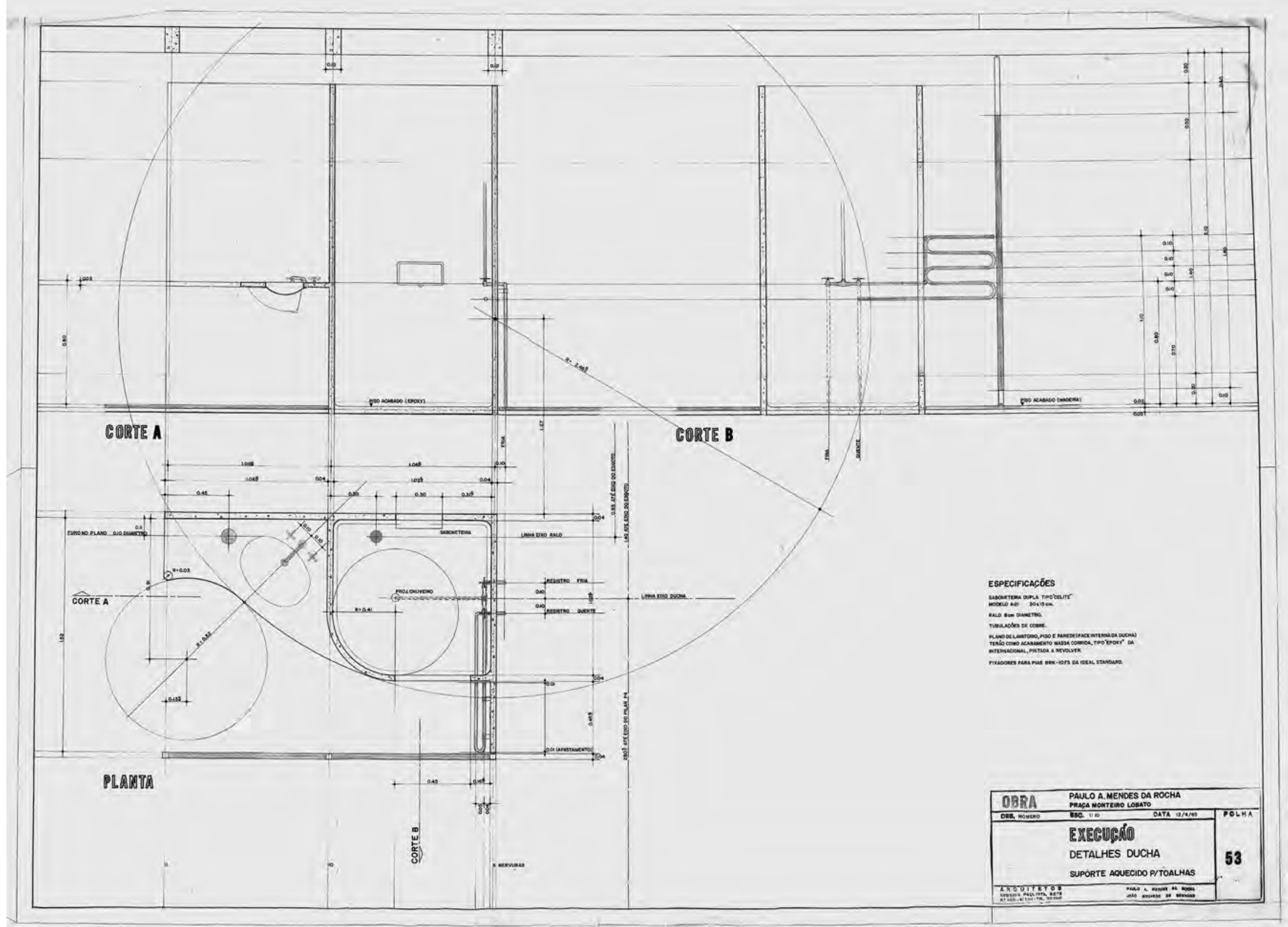

DETALHAMENTO: BANHEIROS 


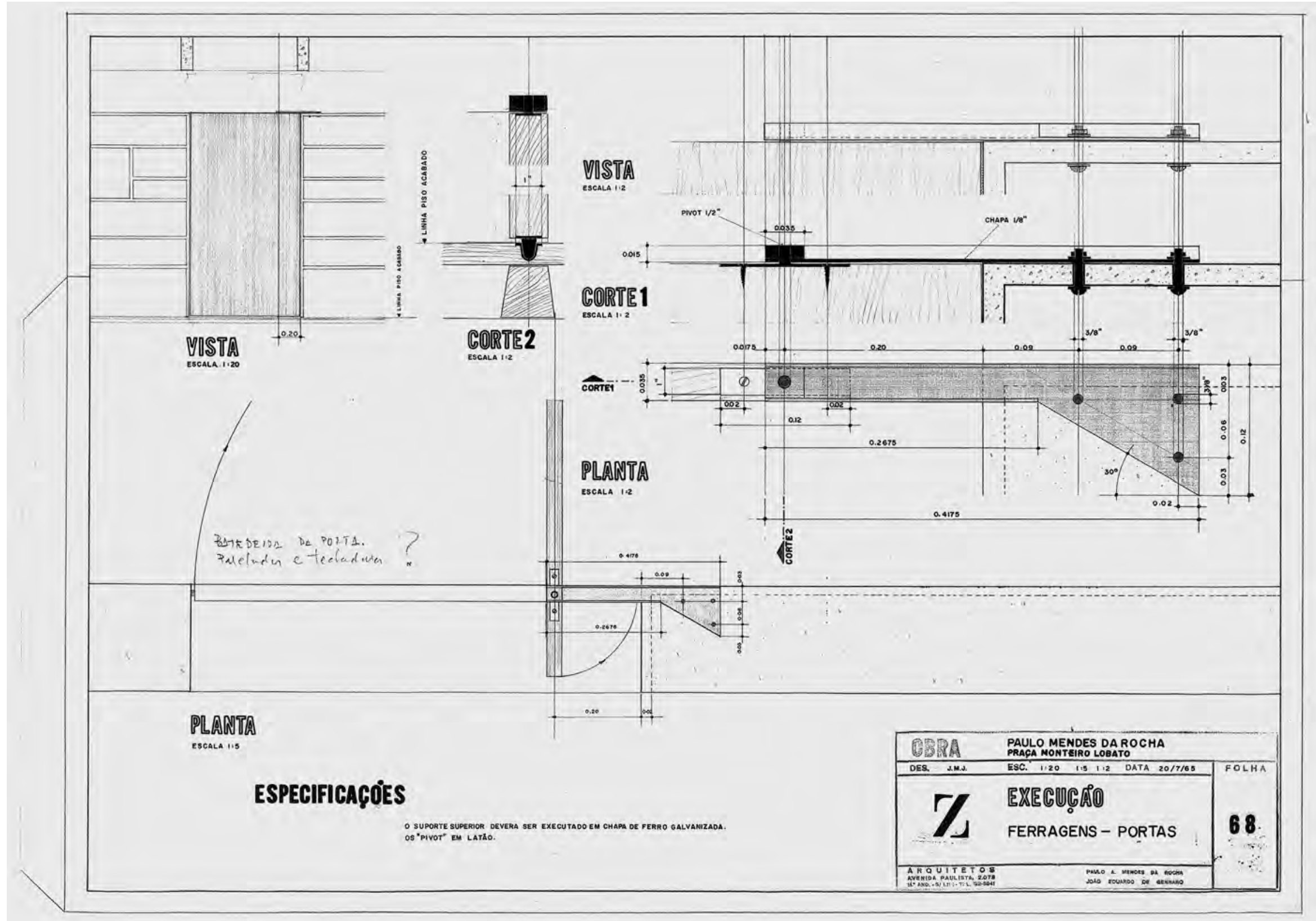

DETALHAMENTO: PORTAS 



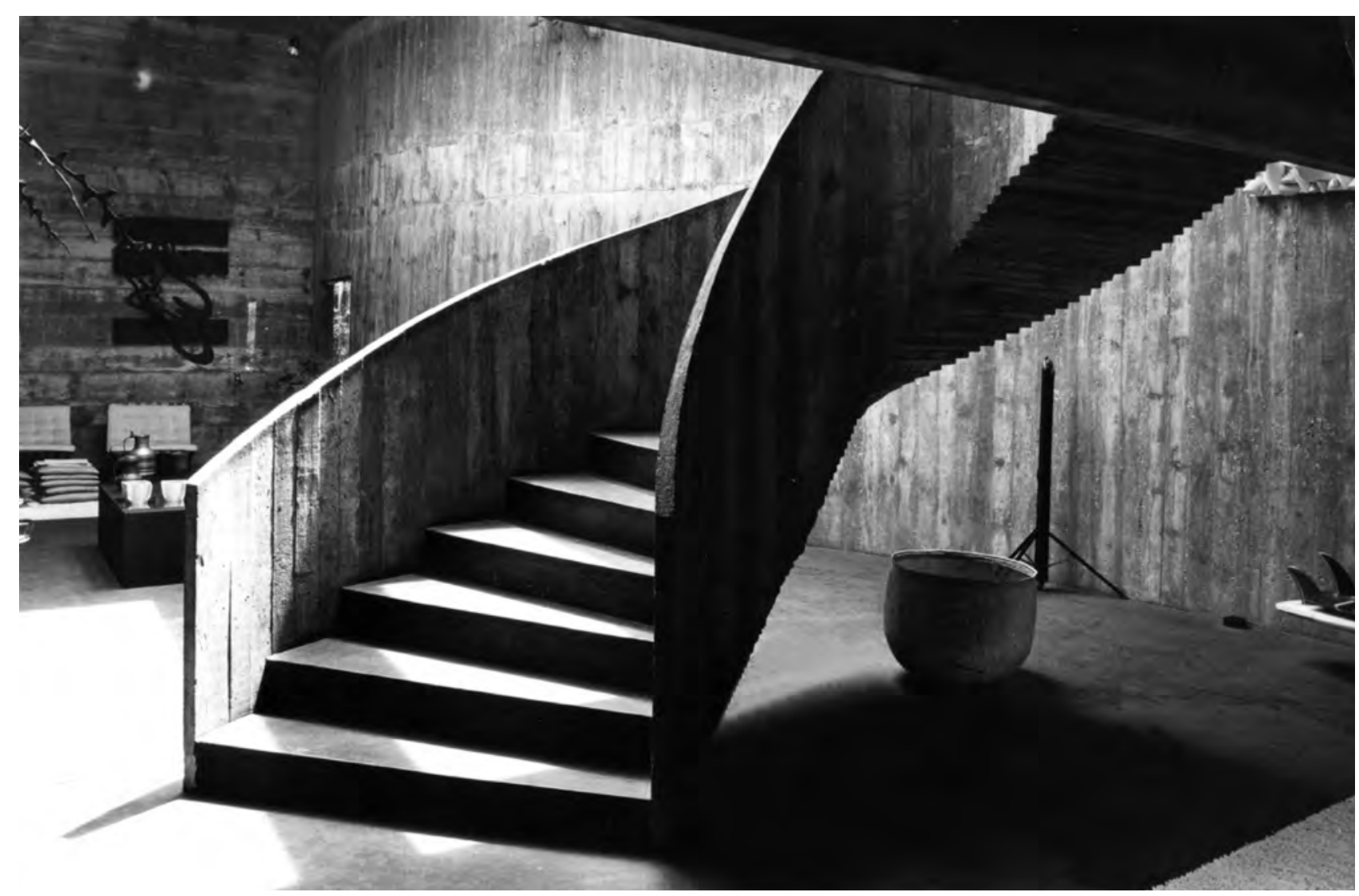

FIG. 52

CASA MILLAN

AVENIDA CIRCULAR DO BOSQUE, 628, SÃO PAULO

ÁREA DO TERRENO: $628,56 \mathrm{M}^{2}$

ÁREA CONSTRUIIDA. $314.28 \mathrm{M}^{2}$

DATA DO PROJETO: 1970

DATA TÉRMINO DA OBRA: 1974

CÁLCULO DAS ESTRUTURAS DE CONCRETO ARMADO E DAS FUNDACÇ̃ES: CONSCAL CONSULTAS E CÁLCULOS LTDA.

ENG. RESPONSÁVEL: SIGUER MITSUTANI

CONSTRUÇÃO: CENPLA - CONSTRUÇÕES. ENGENHARIA E PLANEJAMENTO LTDA.

ENG. RESPONSĀVEL: OSMAR AUGUSTO PENTEADO DE SOUZA E SILVA 



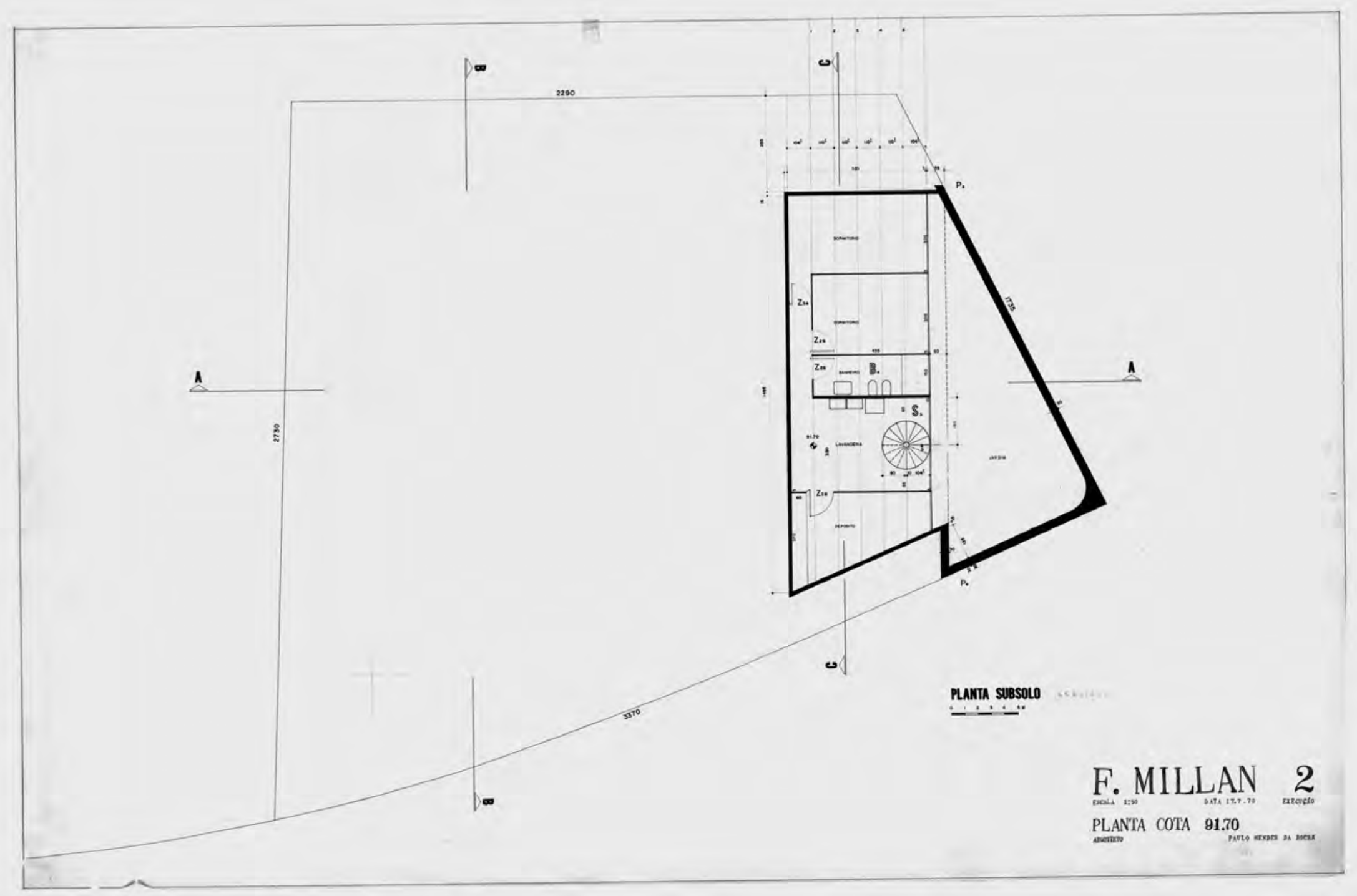




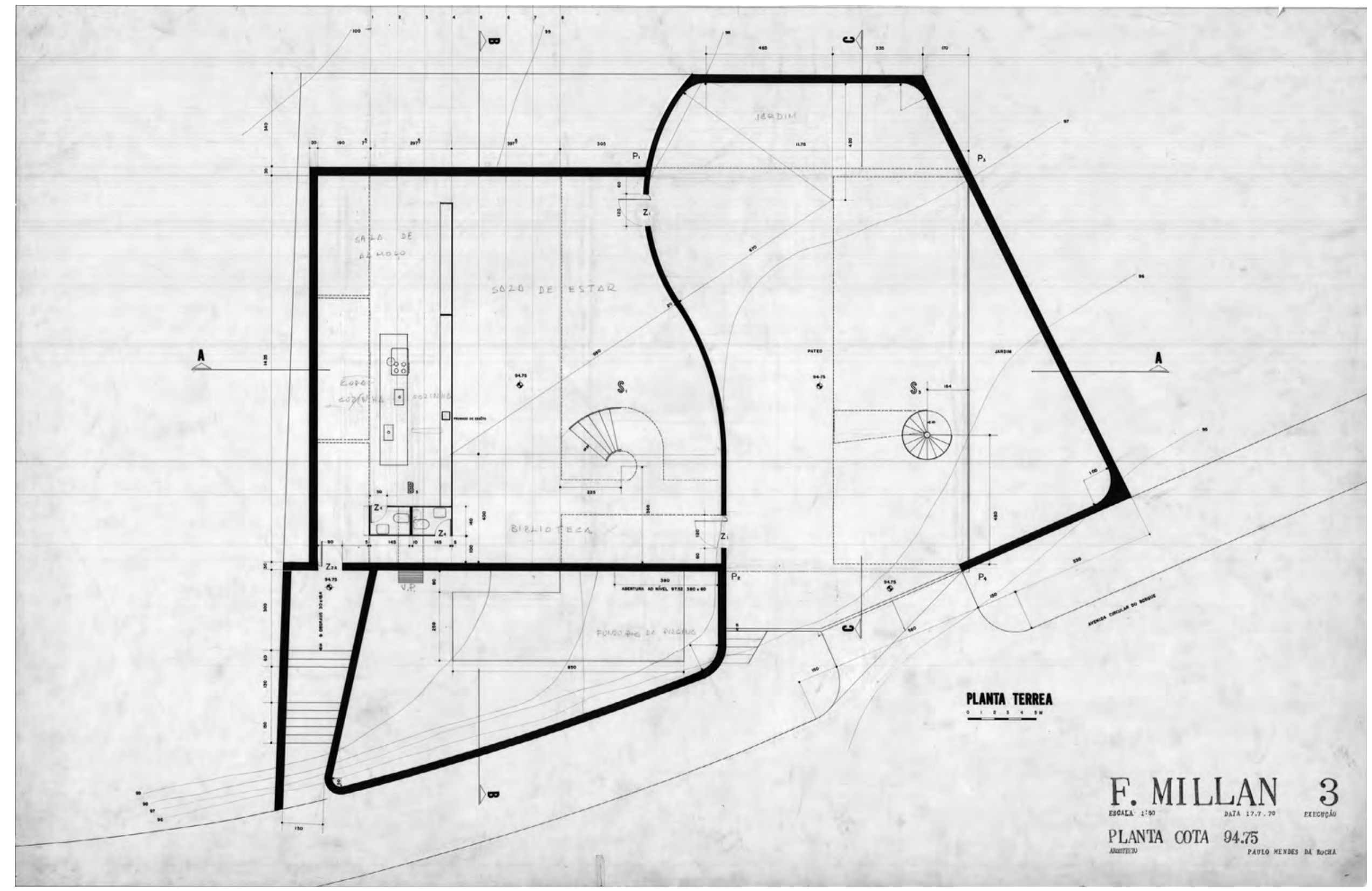




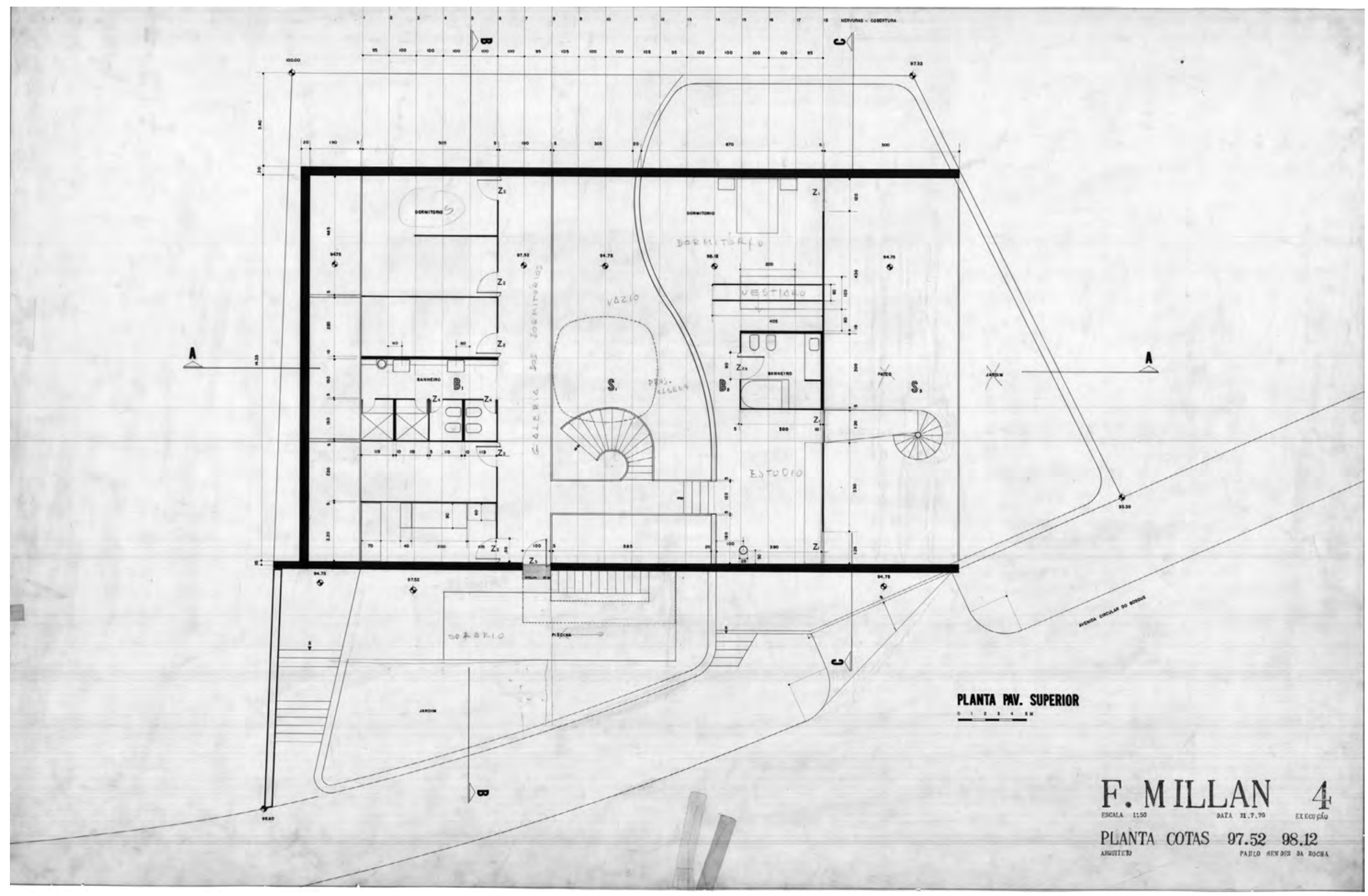




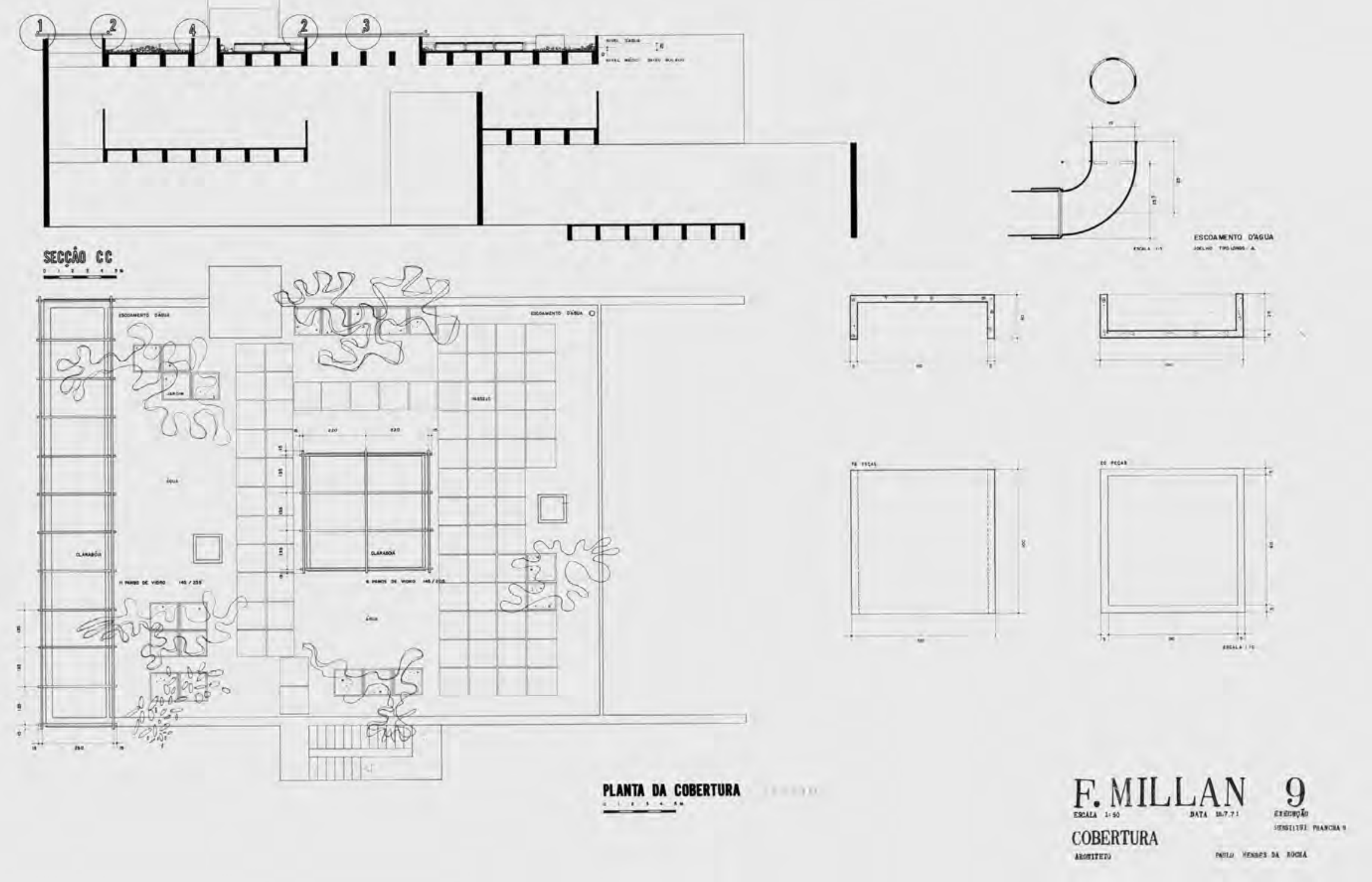




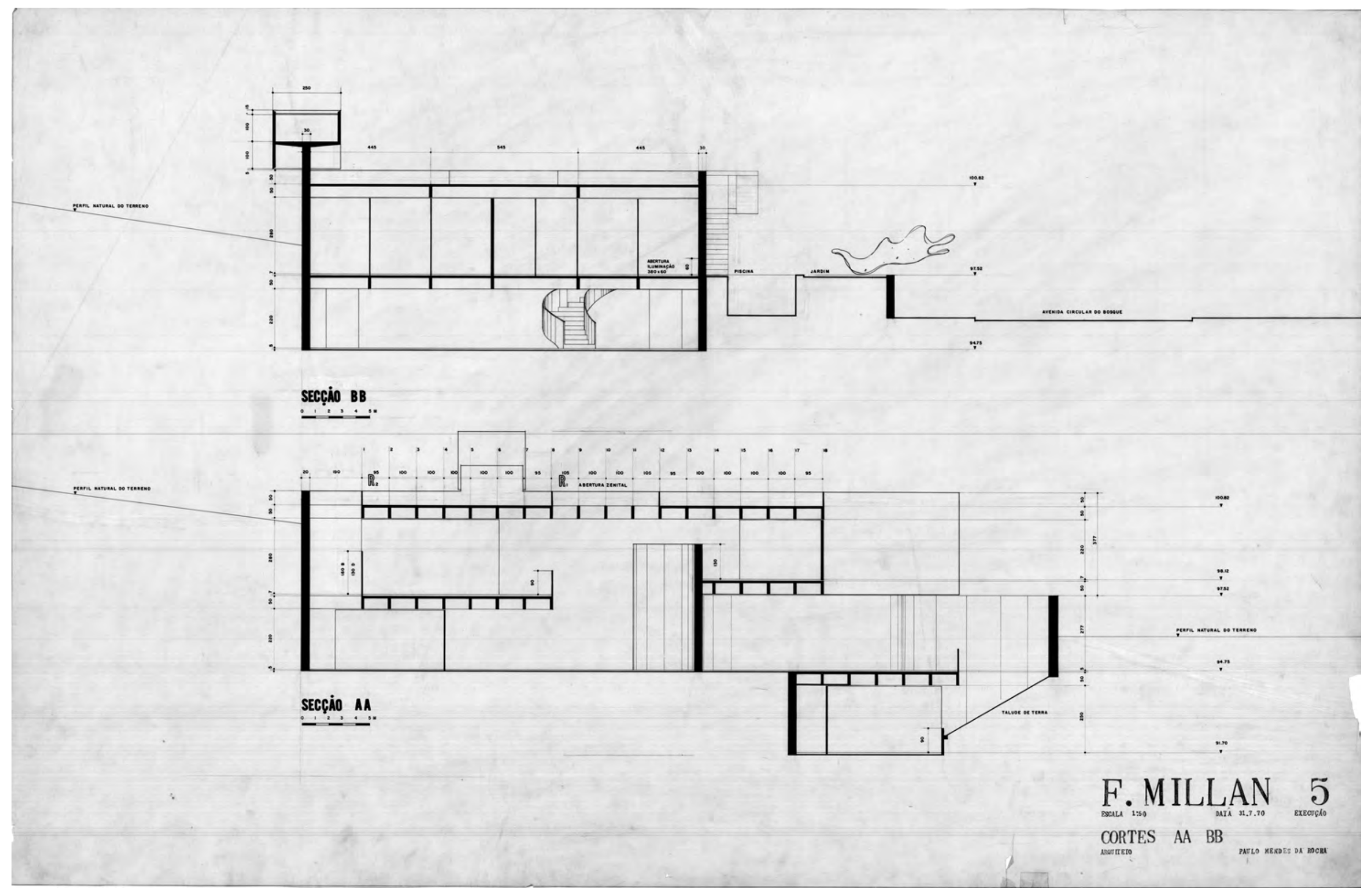






DETALHES CONSTRUTIVOS: GUARDA CORPO DA ESCADA DO JARDIM 

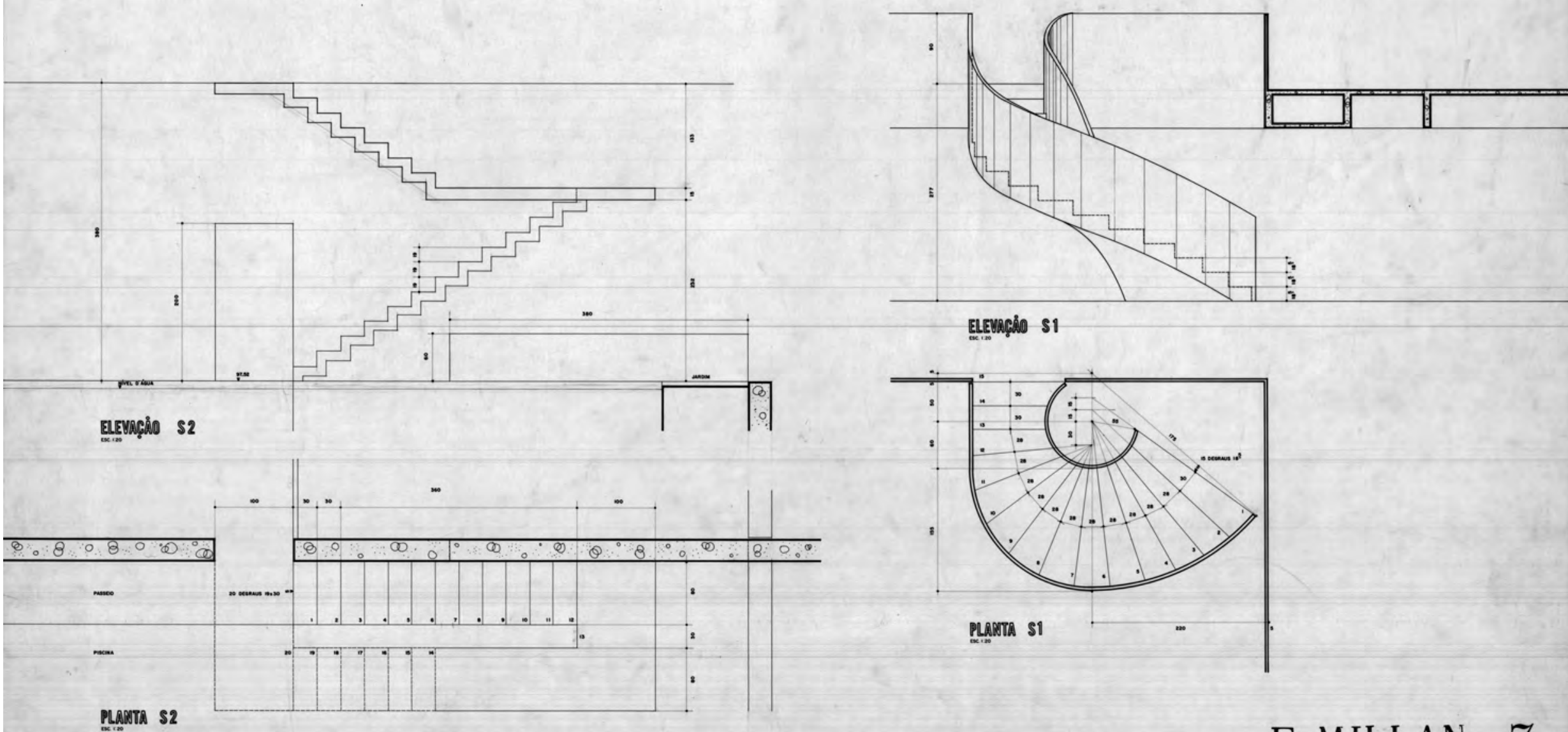

F. MILLAN 7 ESCADAS S1 S2

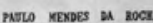




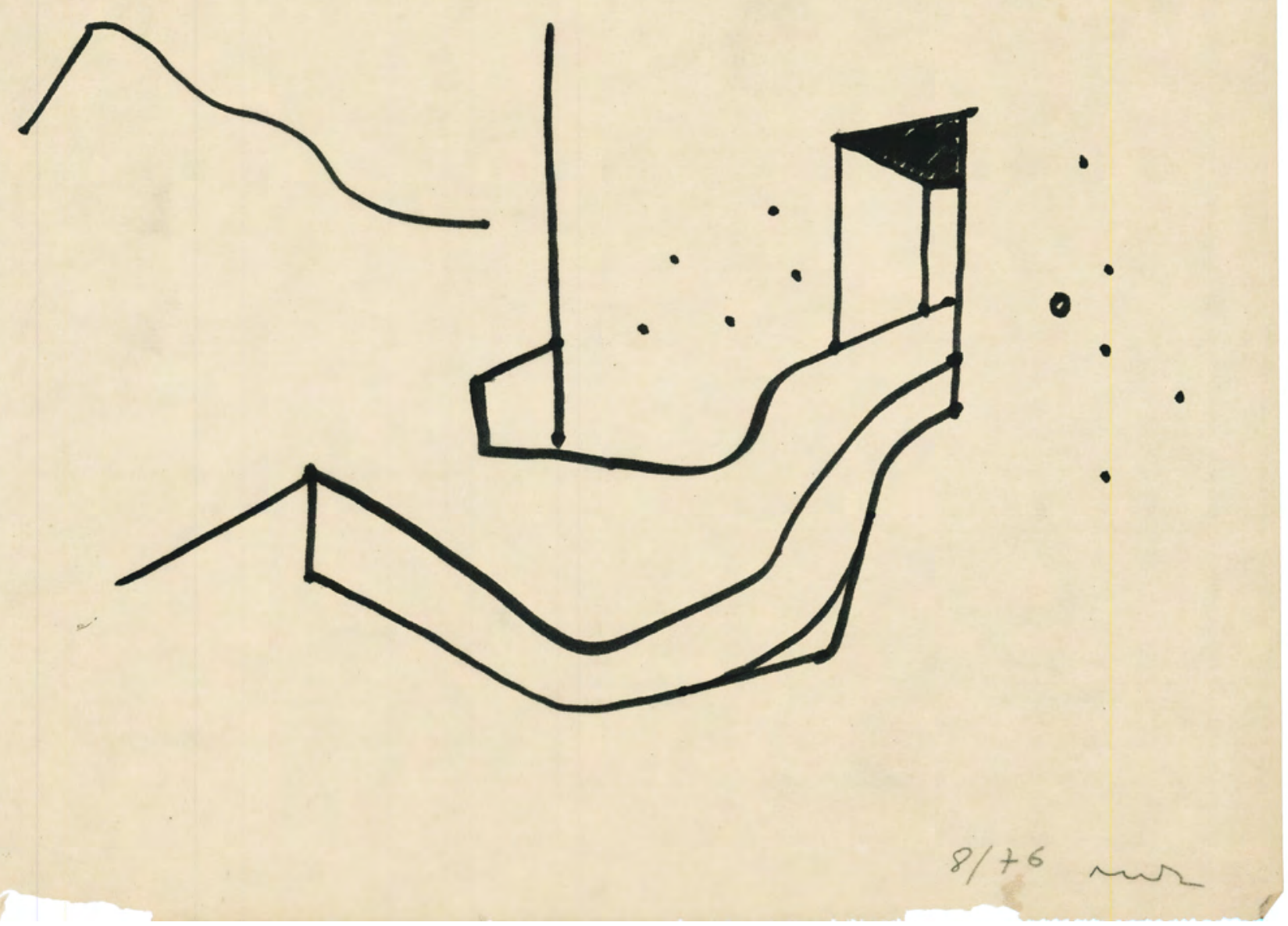

1976: CASA JUNQUEIRA 




1998: POUPATEMPO ITAQUERA 



\section{V: $1974-1998$ \\ CASA JUNQUEIRA E POUPATEMPO}

"já não nos cabe mais pensar em villes radieuses, em arrasar o espaço. Hâ necessidade de manter a propriedade já tida como memória absoluta (...) como desenho arquitetônico, para men gosto atualmente, que extravasa o edifício mas passa a ser o desenho ambiental em que cada aspecto do espaço existente, com sua linguagem, ainda que um tanto bumilde, possa conviver com as formas altamente necessárias do ambiente histórico (...) com uma racionalidade típica de Terceiro Mundo, como o nosso, que não pode se dar ao luxo de construir uma quarta cidade - já que a primeira foi feita de taipa; a segunda de tijolos; $e$ a terceira nós a fizemos de concreto armado."

Vilanova Artigas

1 ARTIGAS, Vilanova. Caminhos da arquitetura. p. 194 e 195

2 Nos principais livros publicados os projetos são em geral dispostos de maneira cronológica ou programática, mas a nenhum deles é conferido um lugar de destaque por representar uma dúvida ou uma investigação fora da "consistência formal" do conjunto de suas realizações.

3 Estou me referindo ao painel de desenhos realizado em 2010, apresentado sumariamente no primeiro capítulo desta tese.
No início deste trabalho tínhamos algumas certezas que hoje, com o avanço do tempo, não se confirmam. Felizmente! Uma destas certezas referia-se ao caráter constante e linear que parecia definir o conjunto de projetos de arquitetura de PMR.

Ao começarmos a examinar o acervo de projetos do arquiteto não podíamos supor que o desenvolvimento do seu trabalho viria se revelar, não a partir de uma cadência regular, comumente apresentada nas publicações sobre sua obra², mas através de momentos de inflexões e de dúvida, e por transformações. Na primeira tentativa de organizar um panorama geral da arquitetura de PMR, compreendíamos este conjunto como sendo bastante homogêneo ${ }^{3}$.

Estas bifurcações, porém, são comuns na biografia de artistas e arquitetos. Podemos observar na obra de Vilanova Artigas a distância formal e espacial que separa o Terminal de Londrina (1950) e a Estação Rodoviária de Jaú (1973), ou em Lina Bo Bardi do MASP (1968) ao SESC Pompéia (1977), ou ainda em Le Corbusier antes e de depois da Unidade de habitação de Marselha (1946).

No caso da obra de PMR, tais inflexões pareciam ficar mais escondidas.

Ruth Verde Zein diz, em sua dissertação, não haver na trajetória de PMR nenhuma evidente "descontinuidade formal ou conceitual", mas uma sutil transforma- 
ção a partir do momento que realiza o projeto do Museu da Escultura (1988): "É o mesmo arquiteto, com a mesma linguagem mas algo de imponderável se altera, mais na sua obra que no seu discurso, pois não se alinha com os debates formais da pós-modernidade mas permite-se cada vez mais uma complexidade explicita" ${ }^{4}$.

A partir do olhar mais próximo, entendemos que essa "transformação” ocorre sobretudo em meados da década de 1980, como aponta Ruth Zein, mas não é tão sutil, nem ocorreu por "questões imponderáveis". Como expressamos anteriormente, nesta década sucedem alguns eventos que, combinados, alteram o ambiente intelectual, político e social no qual o arquiteto estava engajado, e tem uma implicação direta em seu pensar e fazer:

A anistia política em 1980, que devolve os direitos civis ao arquiteto, permitindo que enfim possa exercer a profissão legalmente; a morte prematura de Vilanova Artigas (1985), seu grande interlocutor, a quem atribuía sua "segunda formação"; a volta melancólica de PMR à FAU_USP, onde não encontra mais o ambiente do debate vigoroso que deixara em 1964.

É preciso lembrar que neste momento a questão que mobilizava o campo da arquitetura no cenário internacional era a revisão do projeto da arquitetura moderna a partir de estratégias operativas sobre o legado da Arquitetura Clássica, movimento conhecido como pós-modernismo.

Aqui no Brasil esta questão teve pouco eco, seja pela urgência que havia em se reestruturar institucionalmente o país depois de tantos anos de repressão, seja simplesmente, como afirma Sophia Telles, pela inexistência de uma tradição clássica local sobre a qual tais operações projetuais poderiam ser realizadas ${ }^{5}$.

Segundo Carlos Martins, era o momento, antes de mais nada, de compreender as razões de nossa modernidade: "cabe preguntarse como ha sido posible crear, en tan corto tiempo, una cultura arquitetónica. $Y$, ineluctablemente, eso significa preguntarnos, cómo y porqué ha sido perdida de manera casi tan igualmente rápida"6.

Esse conjunto de fatores tem impacto direto sobre a vida do arquiteto, pois no momento em que ele precisa recolocar-se profissionalmente, o ambiente intelectual e produtivo da arquitetura encontrava-se completamente alterado.

Notamos que PMR toma duas atitudes conscientes neste momento: a primeira é buscar encargos públicos e mais complexos, deixando os encargos privados, portanto as casas, para um segundo plano; e a segunda, já em meados da década de 90 , é alterar sua maneira de produzir projetos, quando desmobiliza sua equipe de colaboradores

4 ZEIN, Ruth V. Arquitetura brasileira, Escola Paulista e as casas de Paulo Mendes da Rocha. Porto Alegre, 2000. p. 160.

5 TELLES, Sophia. "Conversas com Sophia”, São Paulo, 2010. Entrevista a Catherine Otondo.

6 MARTINS, Carlos. "Hay algo de irracional... - apuntes sobre la historiografia de la arquitectura brasileña”. Revista Block, número 4, dezembro. Buenos Aires, 1999. p. 8-9.

“cabe perguntar-se como foi possível criar, em um tempo tão curto, uma cultura arquitetônica. E, inevitavelmente, isso significa perguntarmo-nos como e por que se perdeu de maneira quase tão igualmente rápida." (tradução livre da autora). 


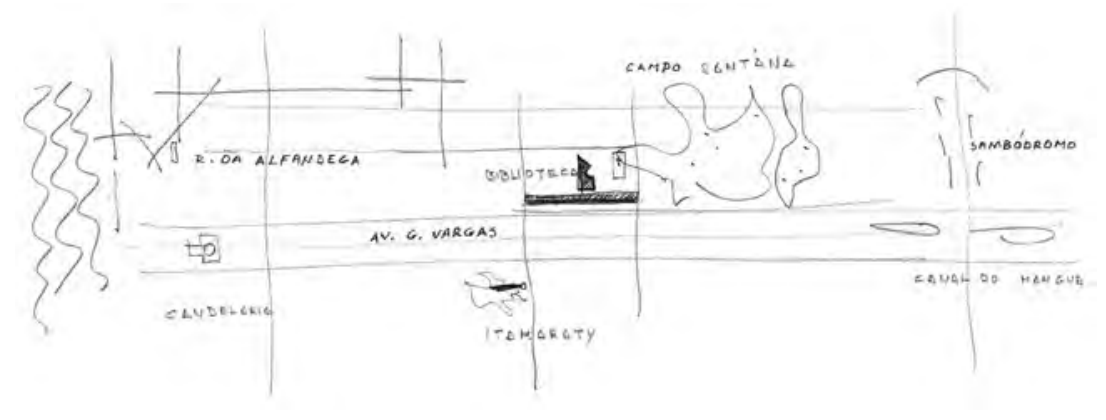

1984 - CONCURSO BIBLIOTECA DO RIO DE JANEIRO IMPLANTAÇÃO

S/EXC

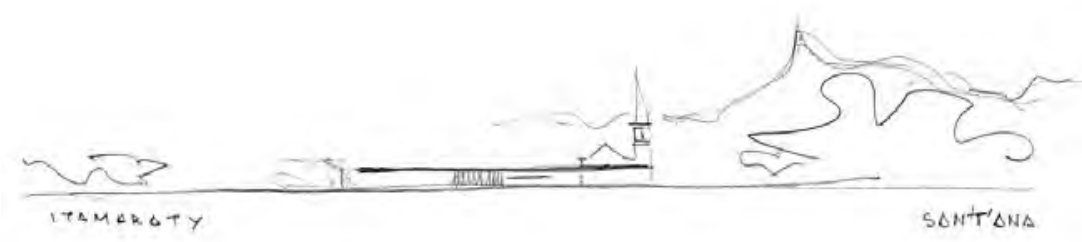

ELEVAÇÃo

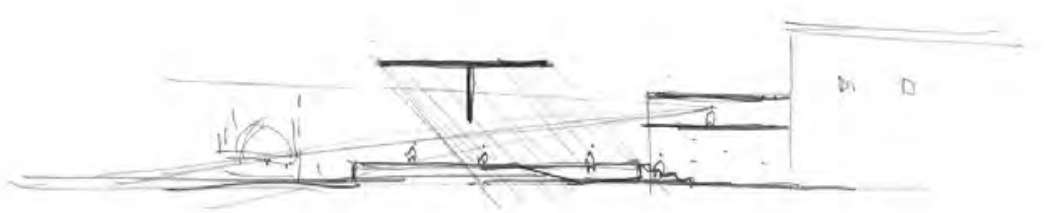

CORTE

7 Segundo PMR em depoimento à revista $2 \mathrm{G}$, ampliar seu escritório demandaria, em suas palavras: "uma organização de caráter empresarial, e que desvia dos problemas essenciais, porque no fundo, fazemos do trabalho um motivo de reunião". Revista $2 \mathrm{G}, \mathrm{n}^{\circ}$ 45. p. 135. e passa a trabalhar por meio de parceria com escritórios de jovens arquitetos. Tal atitude evita trazer para dentro de seu escritório uma grande equipe que demandaria certo esforço de gestão, e sobretudo, evita ter que lidar diretamente com a passagem do meio de produção de desenhos na prancheta para o computador?

Neste capítulo nos interessa destacar obras nas quais percebemos tais mudanças de postura, recuos, e experiências com novos materiais. Ou seja, pequenas ações que se tornarão determinantes para o momento seguinte, os anos 2000.

As décadas de 1980 e 90 parecem ter sido um período de inquietação na razão e no espírito do arquiteto, notadamente anos muito produtivos, nos quais vários de seus projetos foram construídos e premiados no Brasil e no mundo. Tais como: Edifico Jaraguá (1984); Loja Forma (1987); Museu da Escultura (1988); Capela São Pedro (1988); Casa Gerassi (1989) e os encargos públicos: Praça Patriarca (1992); Pinacoteca do Estado(1993); e Terminal de Ônibus D. Pedro II (1996).

Apesar dos projetos citados acima constituírem um corpo de realizações reconhecido publicamente como um agrupamento de “obras primas" (por que não?), escolhemos para objeto de nossa análise obras que pudessem nos revelar momentos de transição, as passagens.

A obra da Casa Junqueira (1976) é exemplar neste sentido por se tratar do último projeto residencial do arquiteto, construído ainda predominantemente em concreto aparente, podemos considerar esta casa como sendo o fim de uma série. Mais que isso, a obra aponta para caminhos que serão desenvolvidos nas décadas seguintes, é a preparação do porvir, pois nela estão contidas experiências projetuais e espaciais que irão ressurgir nos projetos da Biblioteca do Rio de Janeiro (1984 não construído) e do Museu da Escultura (1988).

O interesse despertado pelo projeto do Poupatempo Itaquera (1998) está no fato de ser um encargo público para um edifício novo de dimensões em escala metropolitana. Com um programa de demandas que se relaciona diretamente com as questões infra estruturais da cidade - e não mais do lote -, uma vez que se situa junto à linha de trem e metrô da periferia da cidade de São Paulo.

Neste projeto veremos com clareza que o desenho das estruturas de concreto e de aço tem protagonismo "equivalente", parece que pela primeira vez PMR encontra meios de expressar as qualidades físicas e plásticas do aço e do concreto numa combinatória mais equilibrada. 
Assim, trata-se de um capítulo sobre passagens e mudanças. Passagens políticas, urbanas e culturais. Passagem do mundo moderno ao contemporâneo. Mudanças que sem dúvida movem o pensamento e o espírito deste arquiteto.

\section{1: CASA JUNQUEIRA: O FIM DE UMA SÉRIE}

A Casa Junqueira não é uma casa que possui uma grande biblioteca, ela é uma biblioteca, que ao fundo, enterrada, tem como anexo uma casa.

O cliente deste trabalho, ilustre advogado e professor da Faculdade de Direito de São Paulo, encomendara um projeto cujo programa de demandas era uma casa “comum” - em um lote de um bairro nobre da cidade de São Paulo - que pudesse abrigar sua biblioteca, com um acervo de aproximadamente dez mil exemplares.

Já nos primeiros desenhos, notamos que o foco do projeto está na biblioteca, deixando a parte doméstica da casa em segundo plano. Uma inversão programática na qual o que deveria ser anexo vira corpo principal e vice versa.

A casa/biblioteca realiza-se, assim, em dois volumes, uma opção rara até aqui. O sólido maior na frente, solto do terreno, comporta a biblioteca, e um volume rebaixado em relação ao nível da rua, atrás, para as dependências domésticas.

O volume da biblioteca é formado por um pórtico de concreto que sustenta, por meio de pendurais de aço, um sólido de faces irregulares no seu vazio. As distâncias entre as faces do sólido e as paredes do pórtico são variáveis, uma mais larga onde está a escada principal de acesso ao recinto da biblioteca, e uma estreita, quase espremida, por onde se dá a entrada de quem vem de dentro da casa. $\mathrm{Na}$ face frontal há uma parede de concreto inclinada, pintada de um rosa-lavado, sem aberturas, e ao fundo, uma curva delicada conforma o núcleo hidráulico e as aberturas para o teto jardim, que cobre a casa localizada mais abaixo.

O pórtico com suas empenas paralelas e o volume da biblioteca com faces irregulares se articulam deixando vazios de luz e sombra. Há momentos em que os dois parecem apenas se tocar, e outros nos quais eles se afastam. As janelas surgem entre os planos que não se tocam, são aberturas oblíquas à vista externa, que produzem no volume interior uma atmosfera introspectiva na qual o assunto principal são os livros.

Assim, o pórtico e o volume da biblioteca são dois elementos autônomos que se juntam pelo vazio de luz.

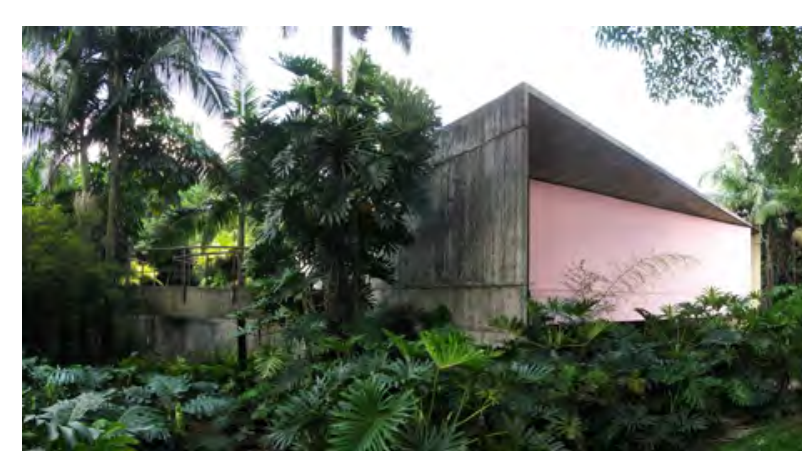

FIG 53

CASA JUNQUEIRA

VISTA FRONTAL

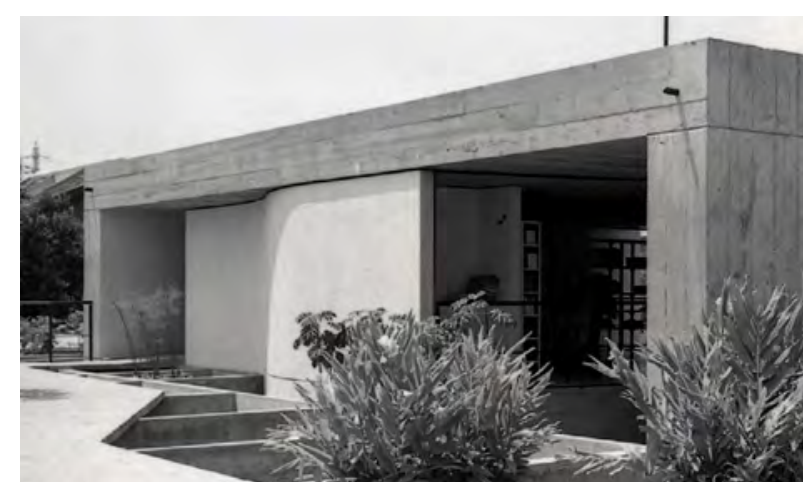

FIG 54

VISTA POSTERIOR DA BIBLIOTECA

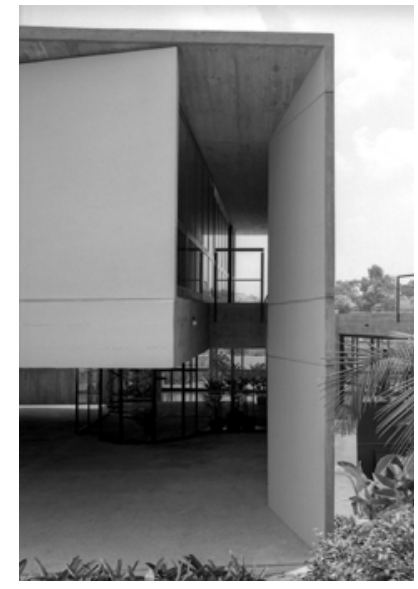

FIG 55

VISTA FRONTAL DA BIBLIOTECA, NOTA-SE O CAIXILHO LATERAL DA BIBLIOTECA.

RECEBE UMA LUZ REFLETIDA DA EMPENA DE CONCRETO. 


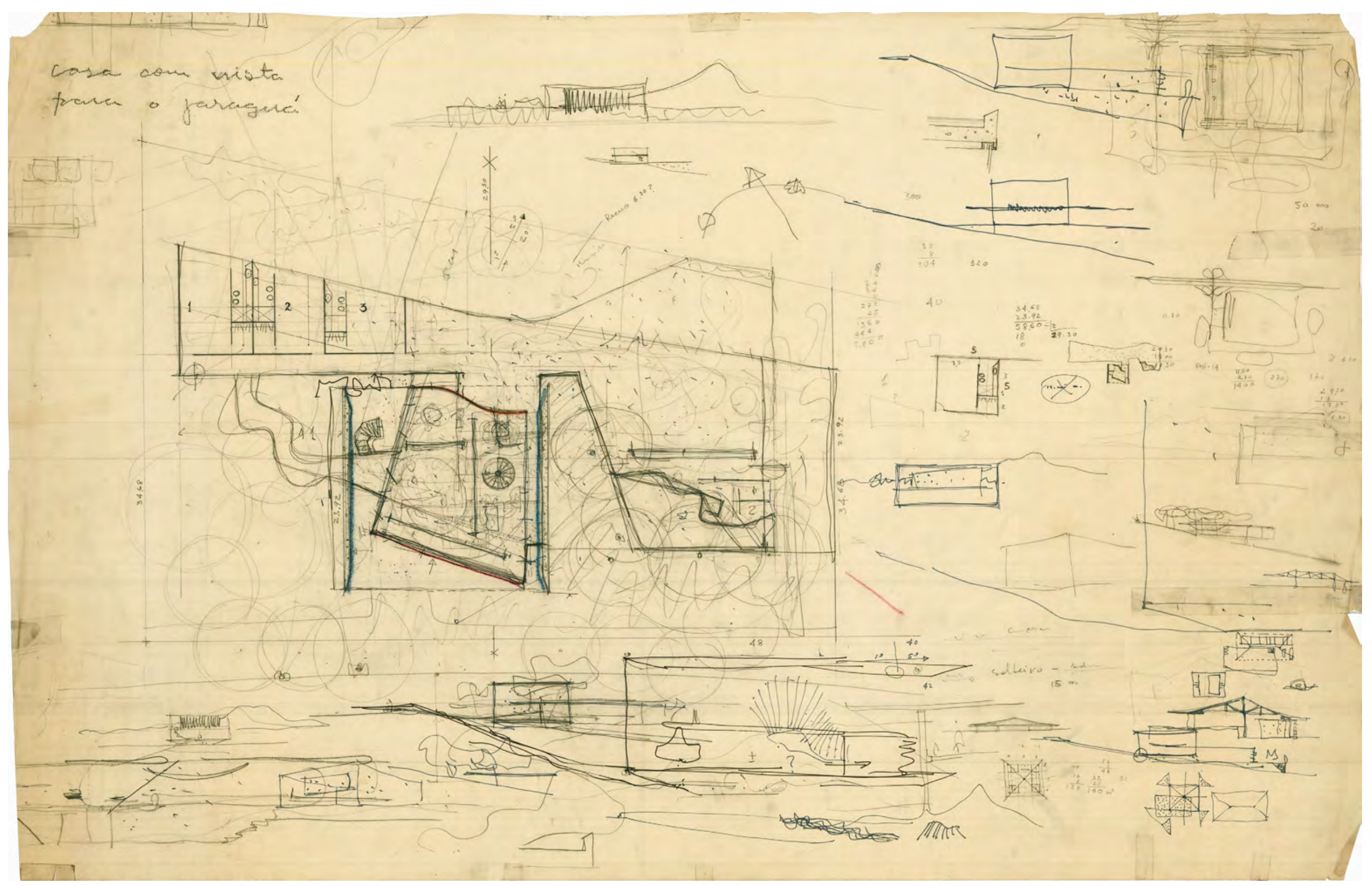


Apesar do caráter introspectivo do espaço interno, o arquiteto parece disfrutar desta disposição espacial criando pequenas passagens para o jardim, pintando a face interna do pórtico de concreto de amarelo, como se fosse um raio de sol refletido, num jogo lúdico entre cheios e vazios.

Sob o pórtico da biblioteca é que se faz a entrada da casa propriamente dita, que até então não aparece em nosso campo de visão. O piso sobre o qual se apoia o pórtico é um plano liso de concreto que começa na rua e termina em um plano vertical, que descobrimos depois ser a parede do corredor dos quartos. Onde seria a junção dos dois planos, o arquiteto cria um espelho d'água e com isso, eles parecem não se tocar ${ }^{8}$. O piso está à sombra e a parede do fundo à luz. O contraste entre luz e sombra, somado ao reflexo da água no plano vertical, e a sublimação do ângulo reto entre o piso e a parede do fundo, por uma superfície reflexiva e móvel, dão um caráter magnífico ao lugar.

Diante disso, não sabemos se estamos dentro da casa, da biblioteca, ou ainda no jardim ou no passeio. Esta entrada é um daqueles lugares "sem nome”, cuja indeterminação nos faz mover com curiosidade para dentro.

Dentro, o programa da casa distribui-se em um prisma de faces irregulares, semienterrado no chão em relação à rua. De um lado estão os três quartos e de outro, separados por um grande hall de entrada, está a sala, a cozinha e os serviços.

A maior parte das aberturas dos ambientes internos se volta para os fundos do lote, ou seja, possuem uma única fonte de luz, o que confere aos quartos e à sala um ar sombrio, agravado pelo fato de estarem a meio nível abaixo da cota do térreo.

A cobertura da casa está no mesmo nível que o piso da biblioteca - repete-se aqui a solução da Casa Millan de fazer a piscina no pavimento superior. À diferença desta, a piscina aqui está no meio de uma laje jardim e seu acesso não está nem próximo aos quartos nem à sala. A água do recinto da piscina se espalha pela laje, num espelho d'água, sobre o qual andamos, pisando em placas de concreto que parecem florescer acima do nível d'água, como as pedras do rio. Nesta água com peixes e plantas, forma-se o grande jardim da casa.

A água enquanto elemento arquitetônico assume neste projeto uma função importante: ora desconecta planos, como vimos acima, evitando a tangência do plano vertical com a linha horizontal, ora conecta programas como a piscina, o jardim, o passeio que se transforma em passarela e entra na biblioteca. Ou seja, o que junta é o mesmo que separa. Talvez neste aparente paradoxo resida a sensação de continuidade

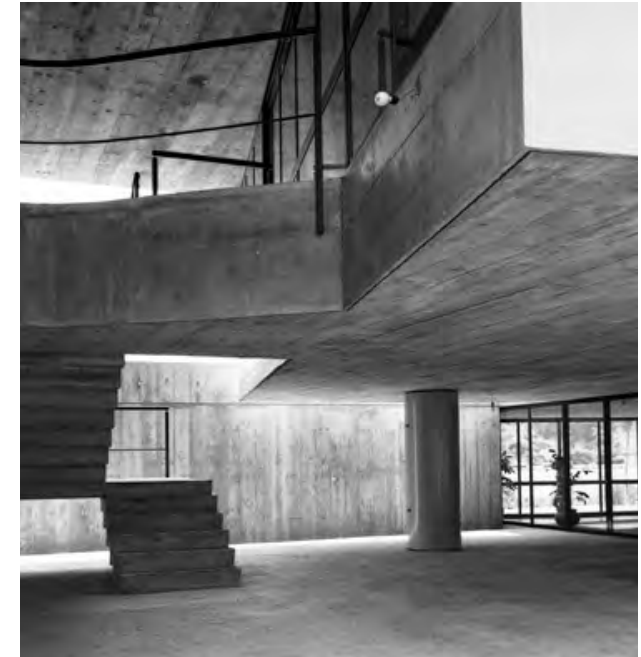

FIG 56

ENTRADA DA CASA À DIREITA E ESCADA DE ACESSO Ã BIBLIOTECA AO FUNDO, A PAREDE DA CASA QUE NÃO ENCOSTA NO PISO DA GARAGEM. POIS HÁ ALI UM ESPELHO D'AGUA.

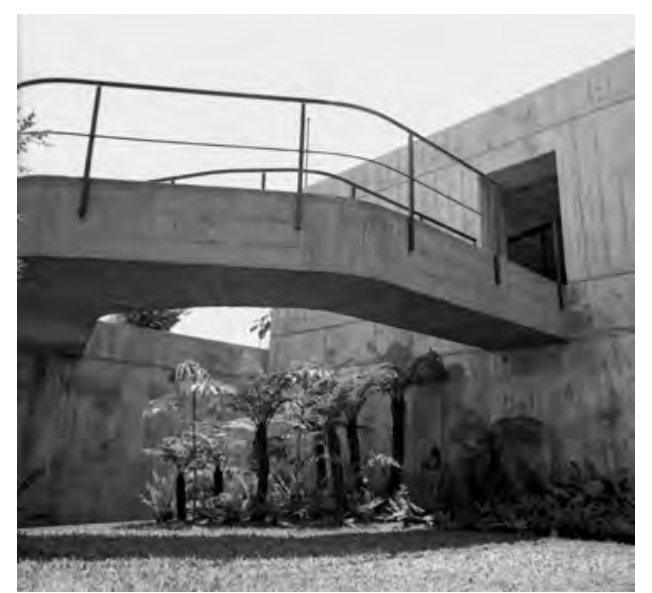

FIG 57

PASSARELA DE CONCRETO QUE LIGA A BIBLIOTECA AO JARDIM SOBRE A LAJE.

8 Como uma "articulação disjuntiva” como define Sophia Telles. (Ver capítulo IV). 


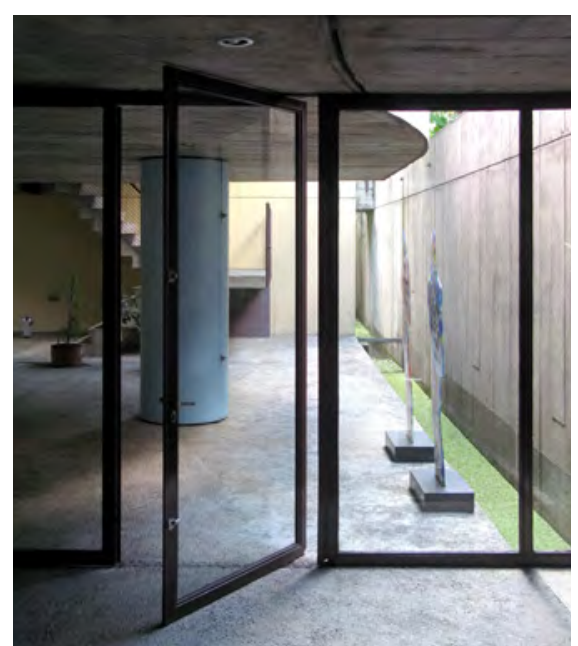

FIG 58

ESPELHO D'ÁGUA NO ENCONTRO DO PISO DA GARAGEM E DO MURO DE FUNDO DA CASA

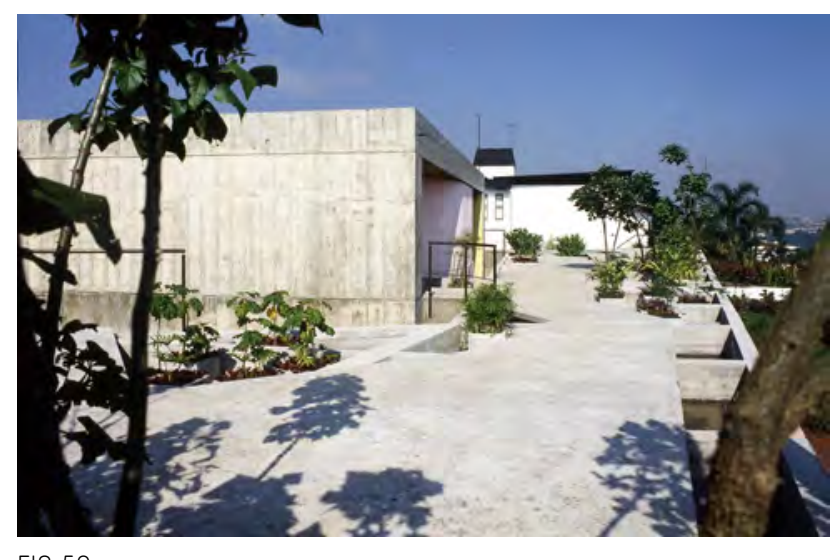

FIG 59

VISTA DA LAJE JARDIM

9 É curioso perceber como nos projetos das casas a piscina e o jardim raramente estão relacionados à sala. A piscina é um elemento que aparece em lugares inesperados, depois de uma porta como acontece na Casa Millan, ou longe da casa como acontece na Casa King, ou ainda de modo mais curioso no meio do patamar da escada como na Casa Corbett.

10 Topografia é ciência ligada à geografia que investiga os acidentes geográficos, e topologia é ciência ligada à matemática que investiga a formação de superfícies elásticas e trata os objetos pelas relações que têm entre si. Em geral, PMR refere-se ao termo topografia, mas entendemos que o conceito de topologia também se aplica muito bem a seu pensamento. que percebemos entre os dois volumes que foram pensados separados (a casa e a biblioteca), mas que constituem uma só totalidade.

O uso da água torna-se frequente nos projetos de PMR a partir de então, não só como elemento de proteção mecânica das lajes de cobertura de casas, mas como elemento organizador do espaço.

Apesar do jardim de águas ser um ambiente que se sobressai no projeto, sobretudo quando observamos o desenho de implantação, ele não está ligado diretamente a nenhum espaço interno da casa como seria de se esperar. Tanto a sala como os quartos se abrem para pequenos pátios confinados, que não têm relação física nem visual com o ambiente da piscina e dos jardins suspensos?.

A ideia moderna de integrar espaços naturais externos e internos está expressa de modo exemplar na arquitetura de Frank Lloyd Wright quando faz dos ambientes internos uma extensão do jardim numa continuidade sem barreiras.

Num movimento contrário à Wright, a continuidade que interessa ao arquiteto PMR é de outra natureza, ela está na continuidade do terreno em relação à rua, ao público. O jardim pertence a uma ordem espacial destacada dos espaços internos, é elemento que organiza a disposição do mundo exterior ao redor da casa, não é para por mesinha e ficar tomando café. Nesse sentido, não há estar no jardim. O que há é o estabelecimento de um plano contínuo que busca dissolver os limites do lote na trama urbana.

Deste modo a implantação da Casa Junqueira se faz pelas mesmas estratégias projetuais apresentadas no capítulo anterior: a configuração original do terreno é transformada por ação que integra o chão e a casa numa unidade espacial; realiza assim uma nova topografia, uma topologia ${ }^{10}$ constituída a partir de parâmetros que vão além das exigências funcionais do universo doméstico.

$\mathrm{Na}$ contraposição de valores, entre dentro e fora, anexo e corpo principal, luz e sombra, casa e cidade, percebemos que a biblioteca é o centro da casa em torno do qual os demais ambientes gravitam numa notável relação de inferioridade.

A biblioteca parece ter vida própria em relação à casa, cujo papel é de constituir apenas um volume que ampara e faz um contraponto com o pórtico de concreto da biblioteca. Pudemos perceber que o programa de usos do "anexo da biblioteca" poderia ser qualquer outro, escola, escritório, mas a questão aqui é que se trata de uma casa. Uma casa que não quer ser. 
Apesar de considerar a Casa Junqueira como sendo uma das mais belas casas projetadas por PMR, devo confessar que é um dos espaços mais perturbadores que visitei. Em todas as outras casas que estive ${ }^{11}$ pude reconhecer nelas as múltiplas possibilidades de acomodação de uma vida doméstica, independente dos gostos, tradições e costumes de seus habitantes. Embora a predominância do concreto bruto nas paredes e da aparente rigidez espacial, havia nelas uma generosidade capaz de abraçar esta multiplicidade. Na casa Junqueira, de fato, a disposição espacial interna da casa não apresenta esta generosidade, são espaços incômodos, frios e com pouca luz, difíceis de serem vividos.

Com esta casa, que não quer ser casa, o arquiteto encerra um ciclo: das casas de concreto aparente; depois desta, haverão poucas - nenhuma em concreto aparente e nenhuma, sinto, tão intrigante!

Observamos que no decorrer da década de 1980 há um certo distanciamento ou descompromisso de PMR com o programa doméstico, que se reflete numa busca de projetos cujo o foco está em outras questões, mais amplas e complexas, relativas à construção de um projeto não mais individual e sim coletivo.

Nos quase vinte anos que separam a construção da Casa Junqueira e o Poupatempo, PMR trabalhou intensamente em projetos de várias escalas, em encargos públicos e privados. Como dissemos, recebeu prêmios, participou de exposições como a X Documenta de Kassel (1987), montou exposições e fez até cenários para óperas ${ }^{12}$.

Desta maneira, a situação profissional que PMR vivenciou no final da década de 1990 parece muito distante daquela do início da década anterior. Veremos a seguir como na obra do Poupatempo novas questões se colocam e como o arquiteto reage a elas.

11 Durante a pesquisa visitei 17 casas.

12 As informações sobre estes trabalhos constam da Lista de Projetos, Anexo I. 
ÁGUA; ELEMENTO ORGANIZADOR DOS ESPAÇOS EXTERNOS:

a ÁGUA APARECE NOS PRIMERROS PROJETOS DE PMR COMO ELEMENTO DE PROTEÇÃO MECÃNICA DAS LAJES DE COBERTURA DAS CASAS. AOS POUCOS GANHA PREDOMINÂNCIA EM SEU PROJETO

EM OUTROS USOS VOLTADOS PARA O AGENCIAMENTO DOS ESPAÇOS EXTERNOS. O DESENHO DAS

SUPERFICIES DE ÁGUA DEFINEM CAMINHOS, LUGARES DE ESTAR, DILUI FRONTEIRAS ENTRE DEN-

TRO E FORA, E COFERE UM SENTIDO LÚDICO AO PROJETO.

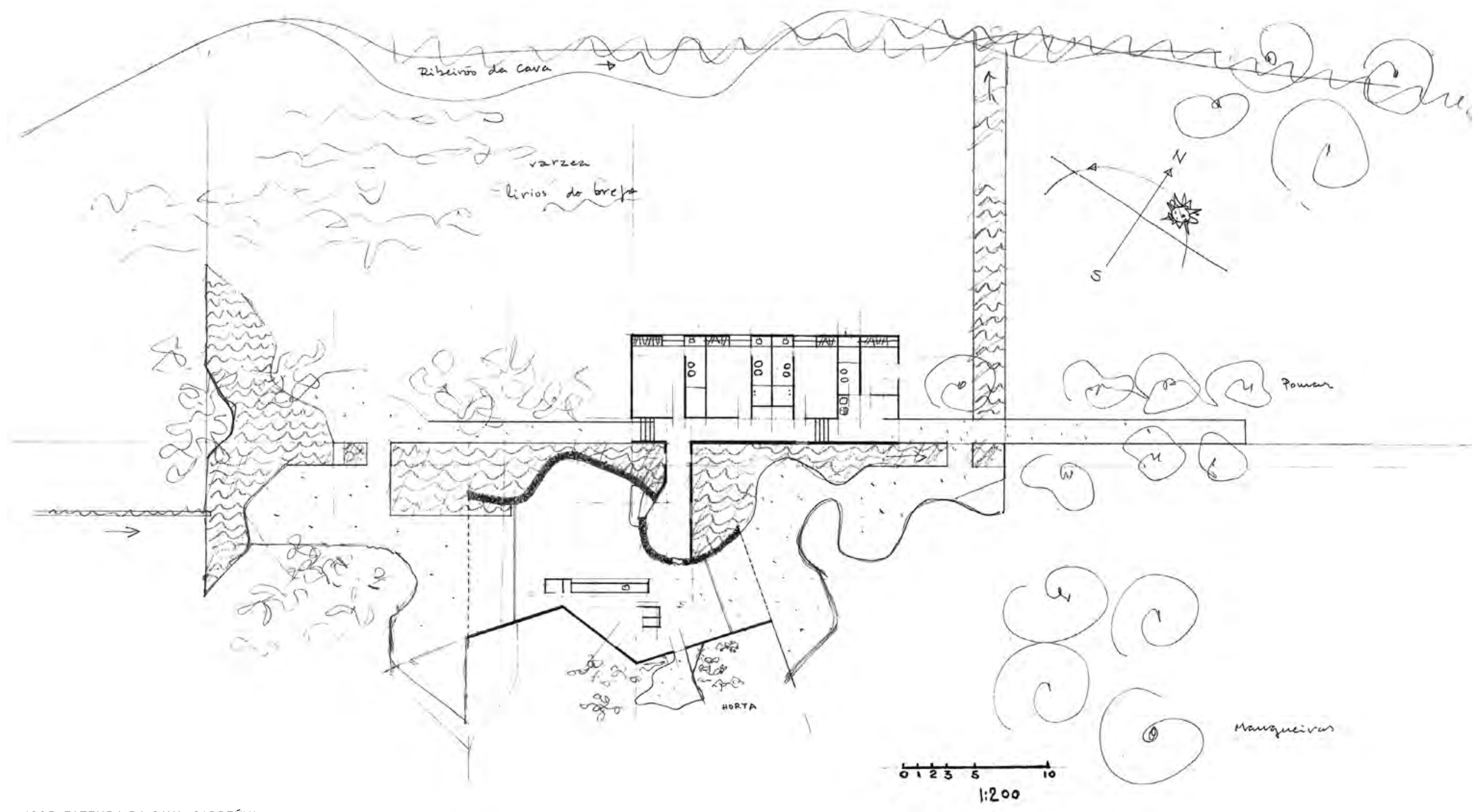

1995: FAZENDA DA CAVA, CABREÚVA

IMPLANTAÇÃO 
AP

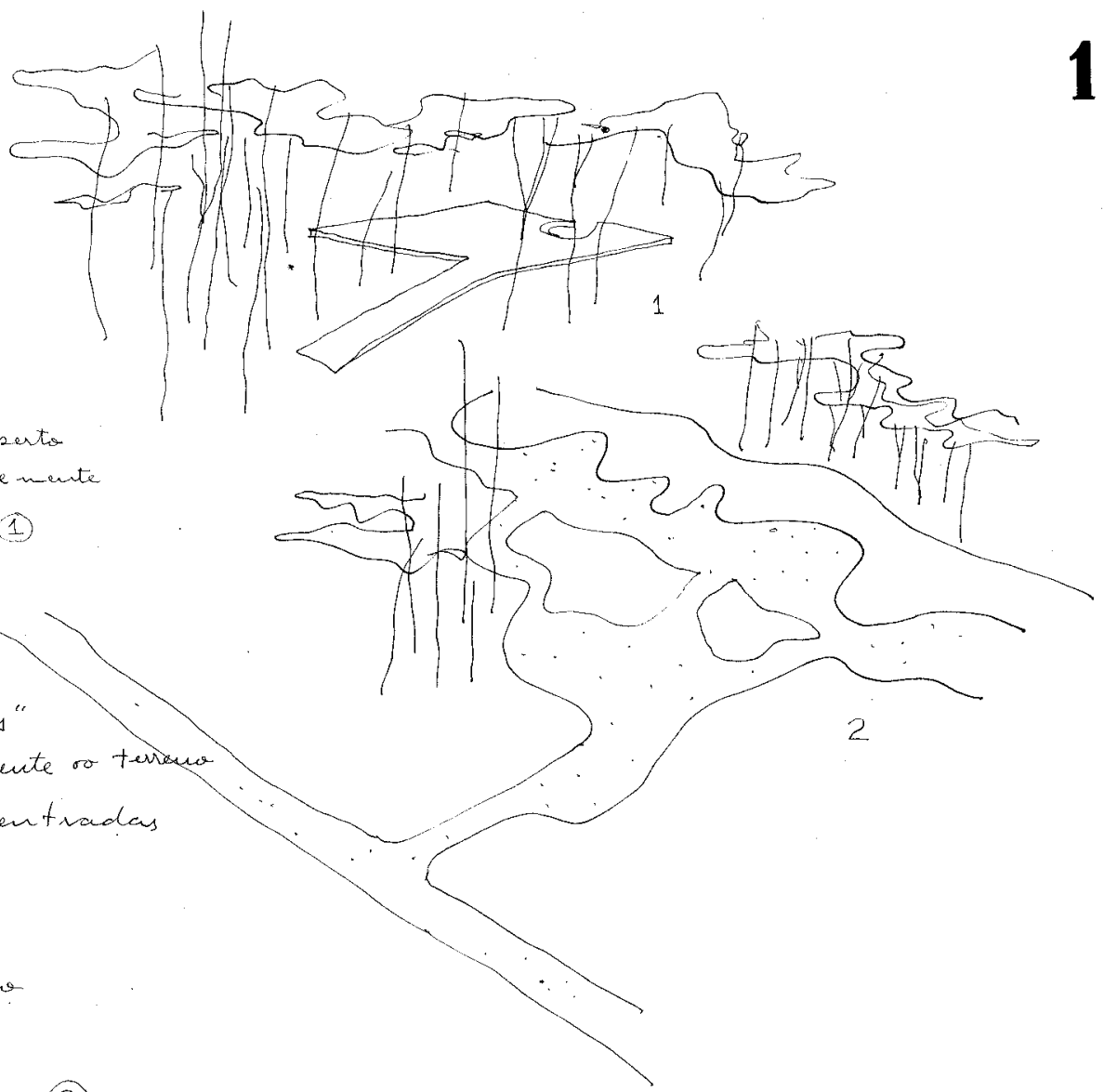

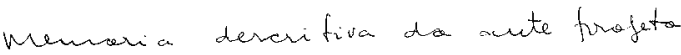
da casa de tygia carmciro:

Sna carra é unva situcacion variante

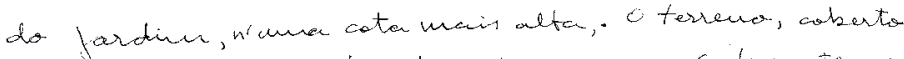
de vegetacers mativa é muito a tracente e Sufticiente mente

grande parca se pencar assim.

As asvares deveño. ficar, o mais possivel,

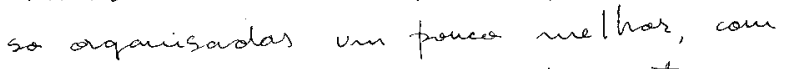
plantio de especies de sub-mata e caminhos revertidas de "mostaico portugues" ma cor branca que derde a calcada em frente oo terrour buaroi a fooles as sifwanger que o fropeto exige. entradas de pedestres, entrada de carros, de servicio e até a cura area maior: praia e fircina, wo extremo

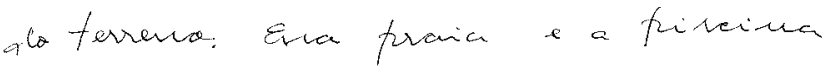
serois tambern nevestidos do mesme (2) moravion branco.

A pirscivas, é cur elemento de guande improstancia mo trofeto re var de urm extrecura ov antro de terrence porem con frofurdiolades variareris,

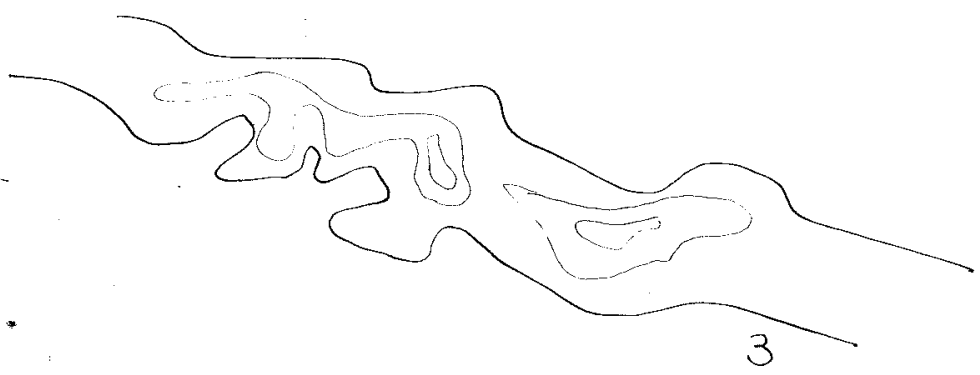
conco un ria

1973: RESIDÊNCIA LYGIA E NEWTON CARNEIRO, SÃO PAULO

136 


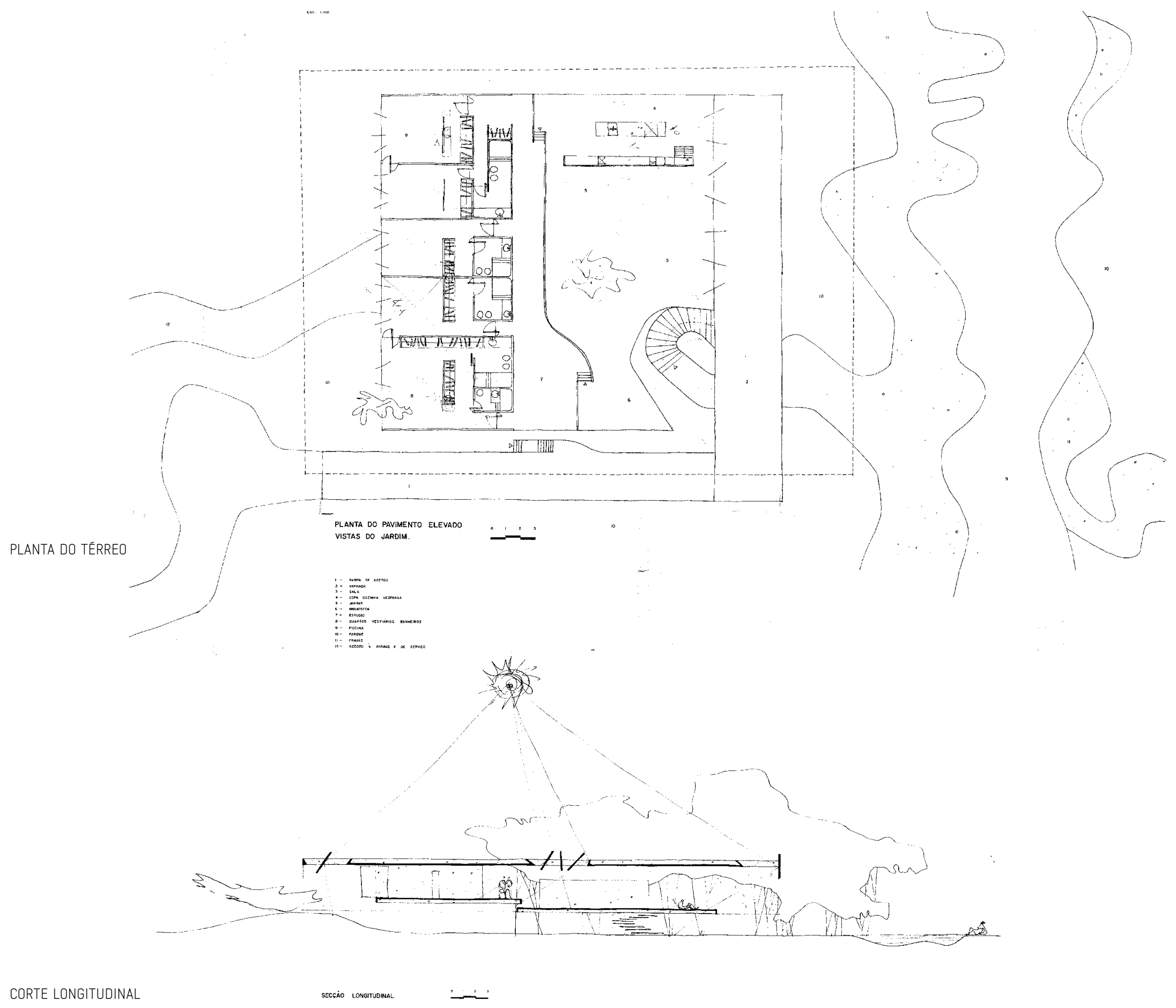




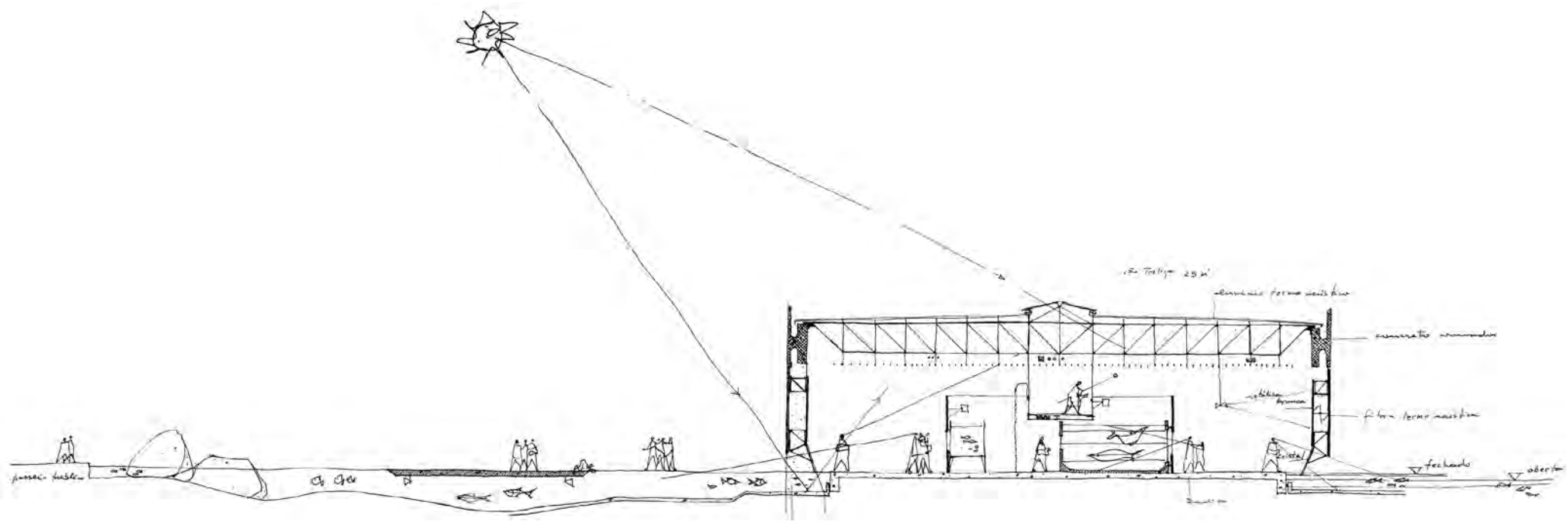

1991: AQUÁRIO MUNICIPAL DE SANTOS. SANTOS ESTUDOS: CORTE TRANSVERSAL 


\subsection{POUPATEMPO ITAQUERA}

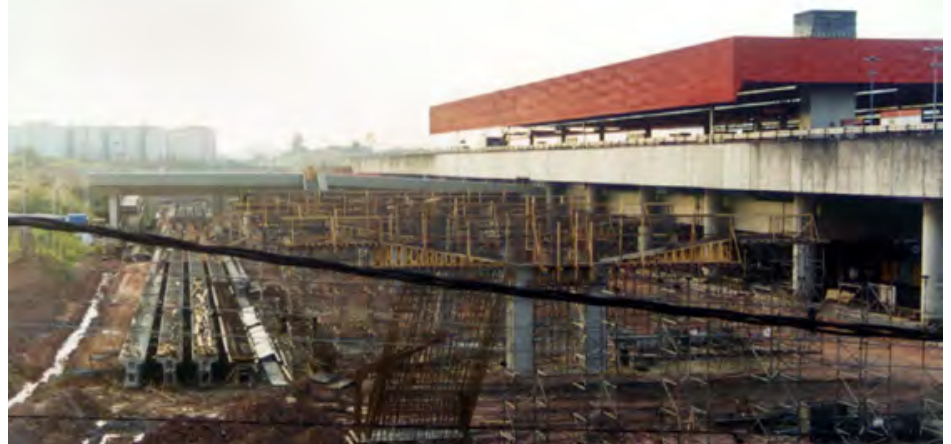

FIG 60

POUPATEMPO ITAQUERA

A ESQUERDA ESTÁ O LUGAR DE IMPLANTAÇÃO DO POUPATEMPO, CUJA IMPLANTACCÃO SE FEZ CONSIDERANDO A PASSARELA DE CONCRETO EXISTENTE, SEM QUE

FOSSE DEMOLIDA. À DIREITA A ESTAÇÃO DE TREM-METRO CORINTHIANS-ITAQUERA.

13 "Uma cidade para nós é o seu passado; para eles é antes de tudo um porvir; aquilo que eles apreciam nela é tudo que ela ainda não é, e tudo aquilo que ela pode ser.

...É que o passado, nestas cidades que vão depressa, que não são construídas para envelhecer e que progridem como exércitos modernos, encerram ilhas de resistência, que elas não podem destruir, não se manifestam como em nosso caso, pelos monumentos, e sim pelos resíduos". (tradução da autora)

Este artigo Jean Paulo Sartre escreveu juntamente com "New York ville colonialle" por ocasião de sua viagem aos Estados Unidos nos anos 19451946, quando visitou as cidades de Nova York e Chicago. Para o autor estes lugares residuais eram os trilhos de trem abandonados de Nova York, o metrô aéreo e barulhento no centro de Chicago, um canal fluvial sem calçada a dois passos do arranha céu mais alto do mundo.

SARTRE, Jean-Paul. "Villes d'Amerique". in Penser la ville: choix de textes philosophiques. Bruxelas, 1989. p. 404-405.

14 Ignasi de Solá-Morales define estes lugares residuais como "terrain vagues": vazios urbanos, obsoletos, imprecisos, indefinidos, sem limites determinados.

SOLA-MORALES, Ignasi de. Territórios. Barcelona, Gustavo Gilli, 2002. p. 184.

15 A área de um Poupatempo é de aproximadamente $10.000 \mathrm{~m}^{2}$, nele estão instalados órgãos municipais estaduais e federais tais quais: Procon, TSE, $\mathrm{CNH}$, e Registro Geral.
Une ville pour nous, c'est surtout un passé; pour eux, c'est d'abord un avenir, ce qu'ils aiment en elle, c'est tout ce qu'elle n'est pas encore, c'est tout ce qu'elle peut être.

...C'est que le passé, dans ces villes qui vont vite, qui ne sont pas construites pour vieillir et qui progressent comme des armés modernes, en encerclant de îlots de résistance qu'elles ne peuvent pas détruire, ne se manifeste comme chez nous, par des monuments, mais par des résidus.

Jean Paul Sartre ${ }^{13}$

A zona leste da cidade de São Paulo, onde está o Poupatempo Itaquera, foi uma das áreas periféricas da cidade que mais cresceu a partir da década de 1980 em termos populacionais e da expansão da mancha urbana. $\mathrm{O}$ resultado desta rápida ocupação é um misto de densos aglomerados habitacionais e terrenos vagos, sem qualquer infraestrutura urbana; são lugares abandonados pelo Estado, a espera de um futuro que nunca chega ${ }^{14}$.

O local originalmente destinado ao Poupatempo era um destes "terrenos residuais”, entre duas alças de uma avenida. Ao visitar o lugar, PMR percebe a importância de conferir a este extraordinário equipamento infra estrutural uma conexão com o tecido urbano, mesmo que frágil, de modo efetivo, o que não ocorreria estando no lote proposto.

Sugere então ao contratante da obra (Governo do Estado de São Paulo) que o Poupatempo seja construído em outro terreno, mais próximo à estação de trem Corinthians-Itaquera a centenas de metros dalí. Aponta como ideal o lugar disponível ao lado oposto da linha férrea, em relação à plataforma de chegada dos trens.

Através da possibilidade de realizar uma conexão direta com a estação de trem, o arquiteto cria a oportunidade de conferir um endereço ao Poupatempo e potencializa a articulação de uma região periférica da cidade ao tecido urbano da cidade formal.

O programa de um Poupatempo ${ }^{15}$, como se sabe, é o de concentrar em um único recinto vários serviços públicos, a fim de desembaraçar vida do cidadão. 
A demanda espacial para este tipo de serviço exige ambientes extensos e livres, com circulações amplas para dar conta de um grande público de aproximadamente dez mil pessoas/dia ${ }^{16}$.

A unidade do Poupatempo Itaquera foi a primeira concebida a partir de um projeto arquitetônico novo - as unidades feitas até aquele momento foram instaladas em construções já existentes. Havia, portanto, como questão inicial do trabalho a preocupação em conceber um edifício cujo sistema construtivo pudesse ser repetido em outros terrenos.

Seria necessário pensar também na questão dos fluxos de chegada ao Poupatempo. Por estar tão próximo a um sistema de transporte do porte do trem e do metrô, o arquiteto priorizou a chegada ao Poupatempo pela estação e não pela rua. Assim, o pavilhão seria elevado do chão na mesma cota da passarela que faz a transposição da linha férrea, que estendida faria uma ligação direta entre a estação e o Poupatempo. A passarela é hoje a principal porta de entrada do lugar.

Estas ações articuladas: a escolha do terreno, de uma tipologia (pavilhão) e a necessidade de conceber um sistema construtivo industrializado definem o modo pelo qual o arquiteto se aproxima do projeto. Mas o que ocorre sobretudo no momento da elaboração deste projeto em particular é uma outra compreenção do arquiteto de como enfrentar o território loteado.

Motivado pelas novas funções da cidade contemporânea, surgem premissas de projeto que evidenciam a necessidade de contrariar o desenho do lote, que estava configurado com uma divisão de propriedade arbitrária a qual não pode mais servir de parâmentro para se pensar os problemas da metrópole.

A partir de então o arquiteto aprofunda sua concepção do terreno urbano, passando a não tomar como premissa de projeto a configuração da cidade pré existente, transgredindo sua ordem na divisão dos lotes, estruturas viárias e gabaritos. Colocando novos parâmentros para contruir a cidade sobre ela mesma.

Embora, os desenhos apresentados nas pgs. 142 e 143, não explicitem as questões destacadas acima diretamente, eles nos ajudam a compreender os caminhos percorridos pelo arquiteto e o seu processo de escolha das soluções formais que já contemplam as determinações previamente articuladas.

No Desenho 01, reconhecemos primeiro a estrutura similar adotada no Terminal Rodoviário de Goiânia (1985), o que nos indica o desejo de fazer uma única estrutura capaz de conter a área necessária para abrigar todas as atividades do Poupatempo. Um pavilhão.

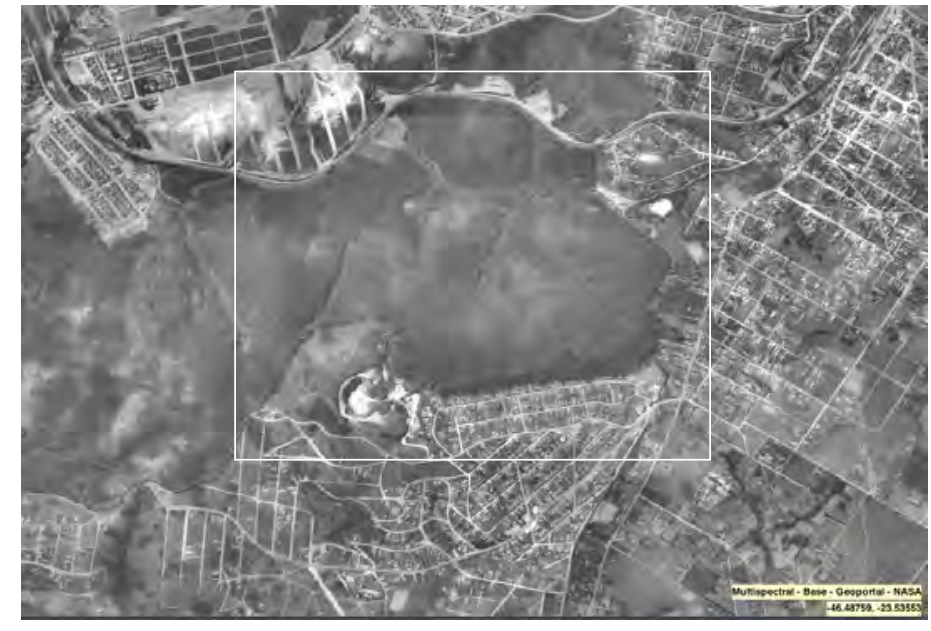

FIG: 61

BAIRRO DE ITAQUERA, 1958

FONTE: WWW.GEOPORTAL.COM.BR

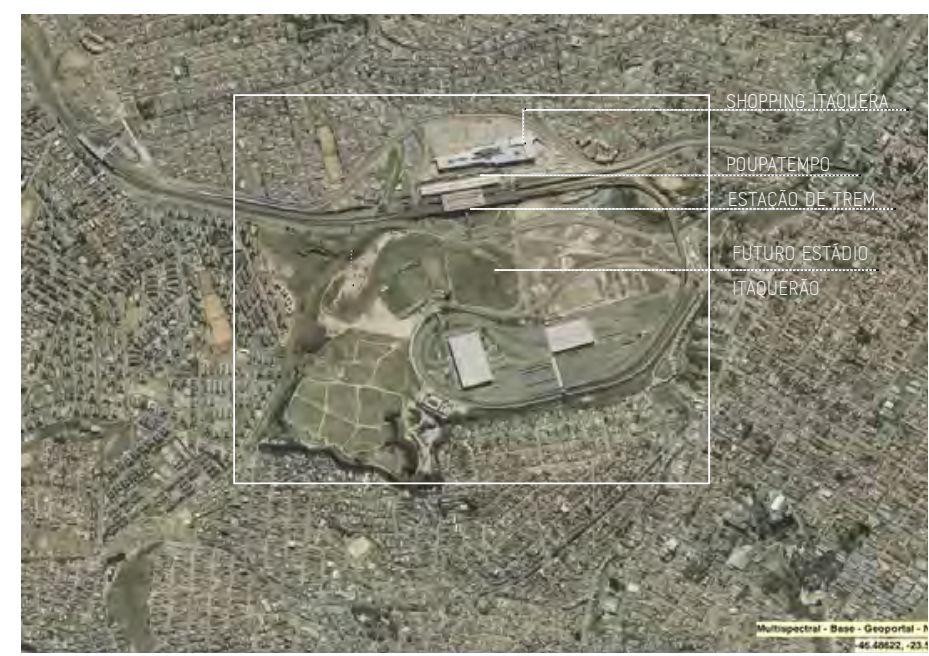
FIG: 62

BAIRRO DE ITAQUERA, 2008

FONTE: WWW.GOOGLEMAPS.COM.BR

16 Hoje o Poupatempo Itaquera atende 12.000 pessoas/dia! http://www.pou patempo.sp.gov.br/dados_est 


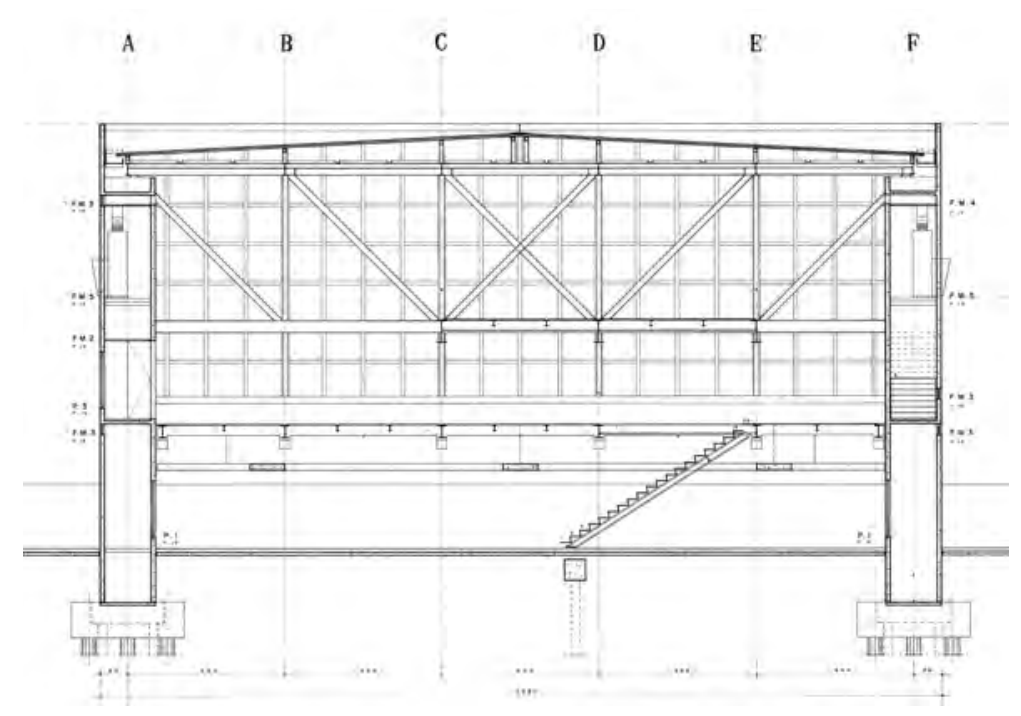

1987: LOJA FORMA

CORTE LONGITUDINAL

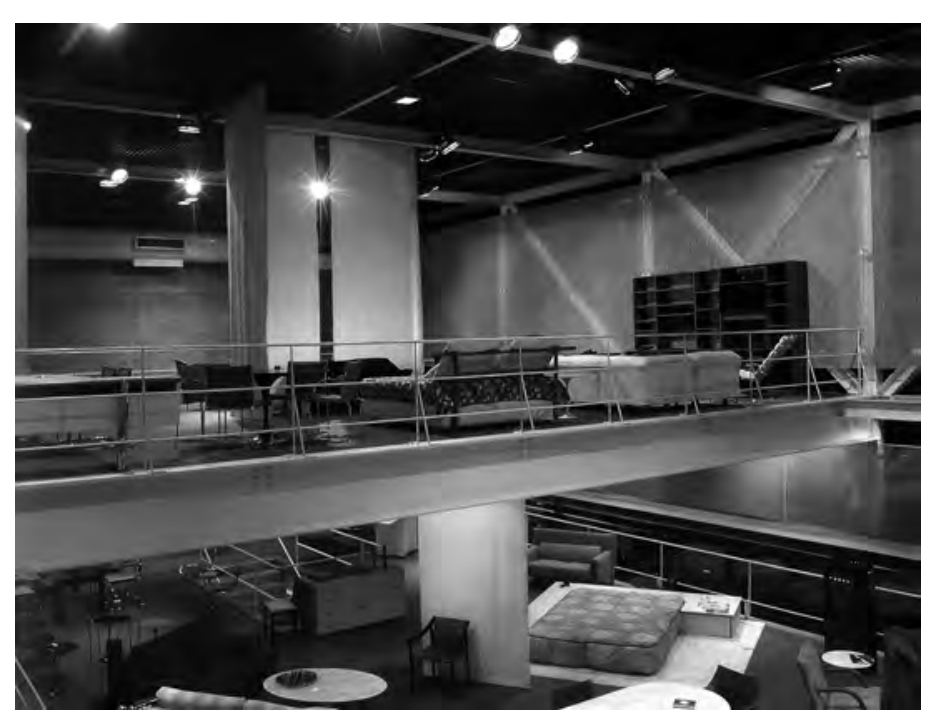

FIG: 63

LOJA FORMA: VISTA INTERNA
No entanto, a necessidade de ser um pavilhão elevado torna difícil adotar o mesmo partido da rodoviária, a menos que se eleve a cobertura para que o volume interno tenha um pé direito duplo, numa estrutura similar ao projeto para o Aquário de Santos (1991). Desenho 02.

Como o programa deveria estar todo numa mesma cota - da passarela de acesso do trem -, o térreo de fato não precisaria ser ocupado e pôde ficar livre para estacionamentos e áreas de apoio.

Surge então a ideia de fazer uma plataforma elevada sobre a qual se apoiaria uma grande cobertura contínua que encerraria o volume. Uma cobertura curva, um arco metálico leve apoiado em uma estrutura independente do concreto. Desenho 03

Estabelecem-se neste momento duas estruturas: uma de concreto, densa, pesada, que sustenta as cargas dos grandes vãos e o plano da plataforma; e outra, leve, luminosa, toda em aço, que faria a cobertura, vedos e aberturas.

Logo o desenho de uma cobertura curva foi abandonado e vemos que a ideia desenvolveu-se em torno de uma cobertura mais angulosa; nas pontas do volume surgem desenhos de pórticos de concreto com pilares triangulares, figura bastante presente no repertório de PMR. Desenho 04

O pavilhão assume a mesma conformação de uma estação de trem. Uma plataforma de concreto de 300 metros de comprimento, apoiada sobre um conjunto de pilares centrais, dispostos dois a dois a cada 20 metros aproximadamente.

Nas duas pontas, encerrando o volume, aparecem dois pórticos maciços de concreto aparente bruto, em oposição às empenas laterais que se realizam por superfícies de aço e vidro, leves e transparente.

O desenho da empena de aço requer atenção, pois ao contrário do concreto que pode ser pensado como uma superfície única, homogênea, de aparência igual tanto no interior como no seu exterior, o aço exige um desenho mais particularizado de cada uma das peças que constituem a treliça.

Nas empenas laterais, por exemplo, há uma estrutura que se projeta para fora do volume central recebendo uma luz que vem de cima, esta superfície inclinada é a grande janela do edifício que recebe a luz refletida do sol e permite a entrada de ar de forma cruzada evitando o uso de ar condicionado no recinto principal.

Como dissemos anteriormente, desenhar para o concreto não é o mesmo que desenhar para o aço. Na trajetória de PMR notamos por primeira vez esta diferença no projeto da Loja Forma, realizado em 1987. 
DESENHO 01: PRIMEIROS ESTUDOS. PÓRTICOS QUE LEMBRAM A ESTRUTURA DA RODOVIÁRIA DE GOIÂNIA (1985).

DESENHO 02: ESTUDO PARA ELEVAR O PAVILHÃO DO CHÃO. ESTRUTURA EQUIVALENTE AO PROJETO PARA O AQUÁRIO DE SANTOS. (1991)
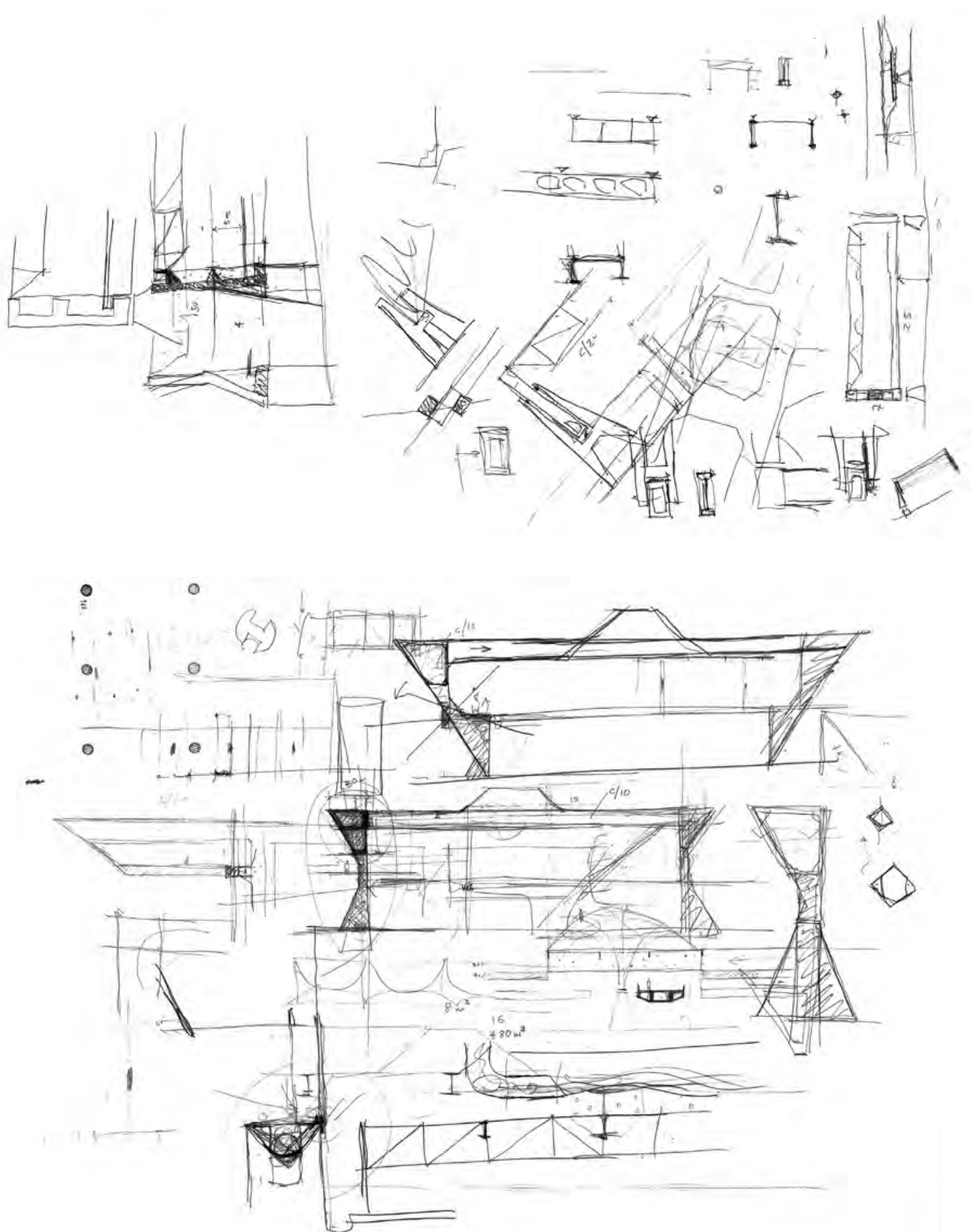


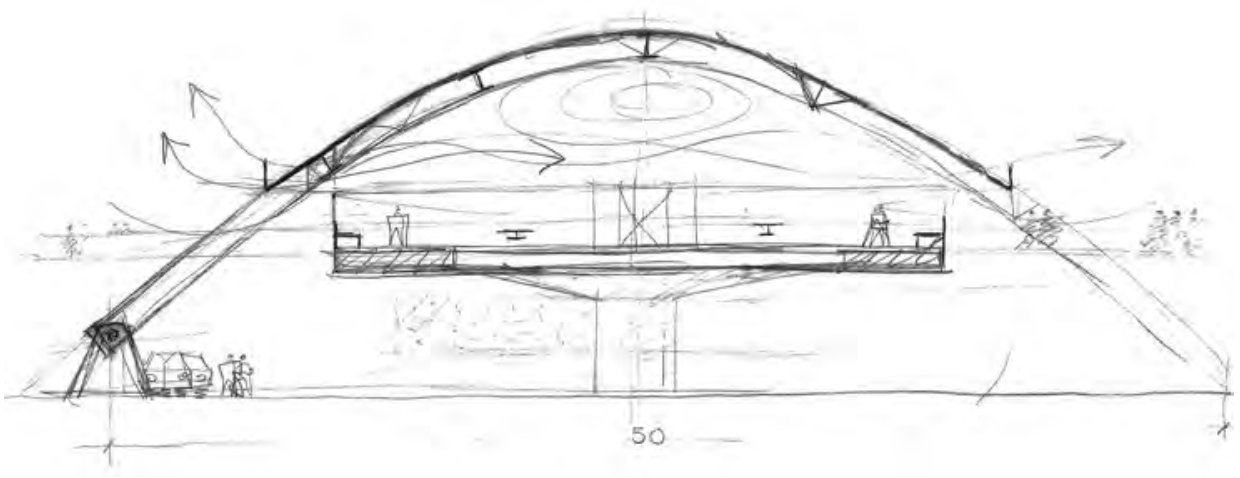

DESENHO 03: COBERTURA CURVA. NUM PRIMEIRO MOMENTO ANCORADA NO CHÃO E EM SEGUIDA SOBRE UMA PLATAFORMA.

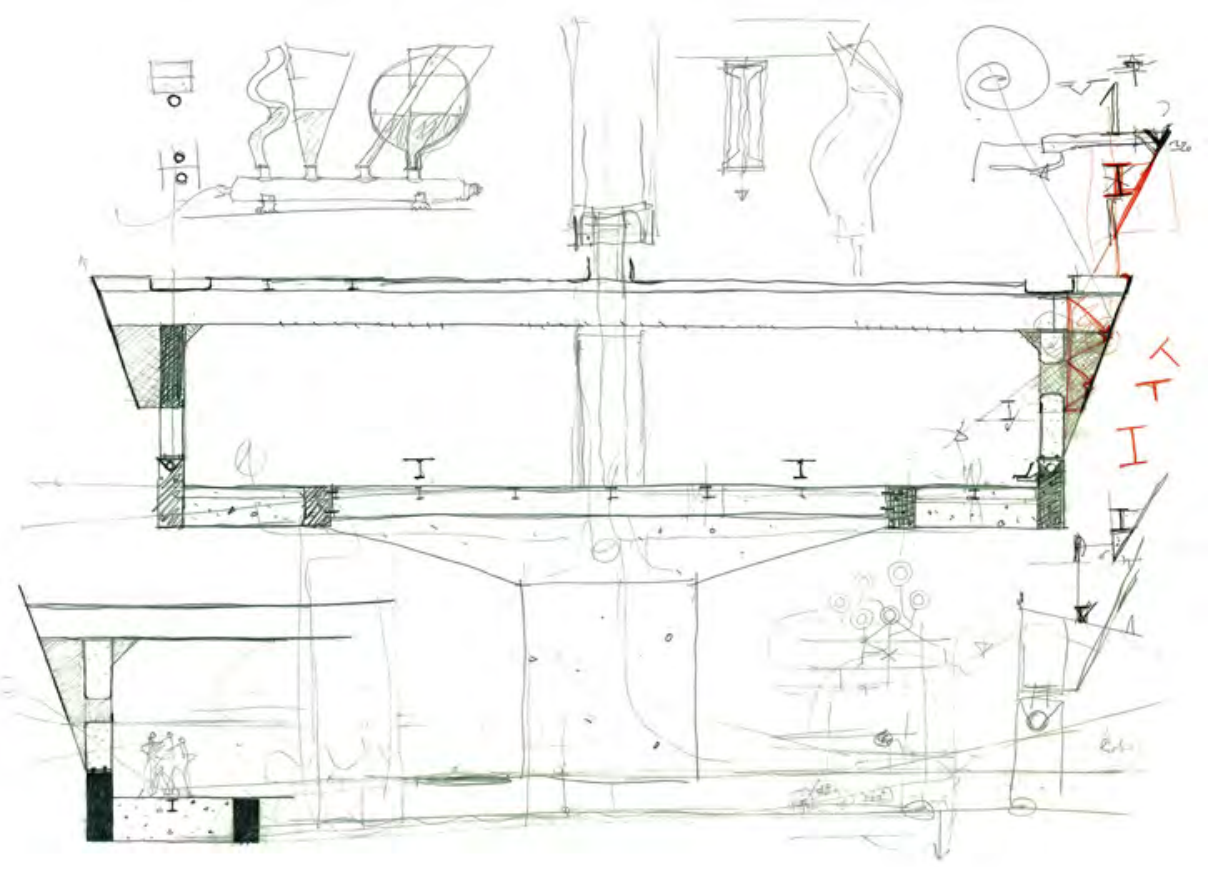

DESENHO 04: PRIMEIRAS FORMALIZAÇÕES DA SOLUÇÃO ADOTADA.
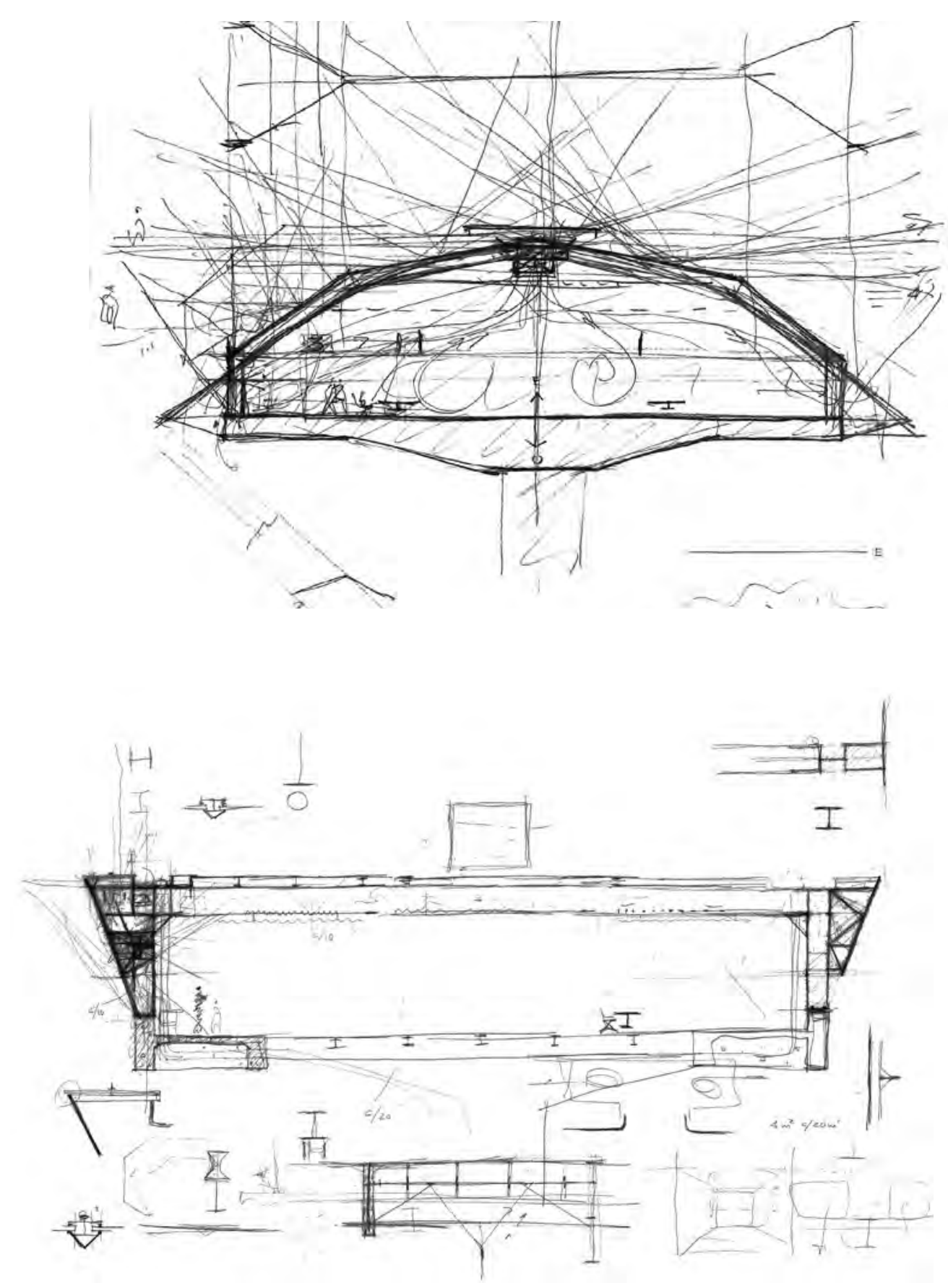
A Loja Forma retoma uma volumetria análoga à da biblioteca da Casa Junqueira, um volume suspenso do chão, apoiado em duas empenas laterais de concreto. $O$ fechamento frontal e de fundos do volume da Loja é feito por duas superfícies lisas e leves compostas de placas por alumínio.

A sensação que temos dentro deste espaço é completamente diferente da biblioteca da Casa Junqueira, onde o concreto domina todas as faces internas do recinto. $\mathrm{Na}$ Loja, perde-se a noção de continuidade e da constrição de meios que o concreto permite. $\mathrm{O}$ aço se desenha por uma infinidade de linhas multidirecionais. $\mathrm{Na}$ biblioteca, temos a impressão de estabilidade e permanência, na loja, de movimento e fluxo.

No projeto do Poupatempo percebemos que o arquiteto segue empregando o concreto e o aço, conferindo a cada matéria um desempenho específico. De modo equivalente ao da Loja Forma, o concreto está na superestrutura que sustenta o volume principal e o aço estrutura a fachada, as aberturas e o espaço interior.

Para quem estava habituado à generosidade de manuseio do concreto, desenhar para o aço manifesta-se como um grande desafio, pois se trata de um material que não admite imprecisões, e que tem um comportamento estrutural e físico que dificulta a constrição de meios que o concreto permite. Ou seja, para o concreto pensa-se em grandes planos contínuos. Para o aço não, pensa-se em fragmentos, em vetores de força, linhas, nós, onde cada elemento tem uma função única e precisa.

Talvez a experiência mais radical, na trajetória de PMR, em usar o aço como matéria total esteja no projeto para o pórtico da praça do Patriarca, realizado em 1992.

O projeto original da Praça continha dois momentos: a criação de uma marquise para a descida à Galeria Prestes Maia, localizada sob a praça, e a instalação de uma cobertura curva continua, nas duas calçadas do Viaduto do Chá. Para o arquiteto, a graça do projeto estaria em realizar uma estrutura capaz de comunicar as duas margens do vale do Anhangabaú. Sem sua completa realização, a cobertura da Praça parece ter ficado sem muita proporção, pois perdeu justamente sua extensão até o outro lado do viaduto, e passou a se relacionar somente com os limites construídos ao seu redor, criando uma situação urbana de não pertencimento, parece estar fora de escala.

Fica evidente pelas dimensões da cobertura que o foco de PMR não estava em dar sentido àquela nova praça. Trata-se de uma estrutura que existe apesar da Praça, ela não se relaciona com seus limites, tem uma proporção grande demais para cobrir a escada rolante - demanda original do projeto - e tampouco está próxima o suficiente das elevações dos edifícios que conformam a Praça, ao ponto de tocá-las ou criar uma situação de tensão entre o novo e o velho ${ }^{17}$. 144

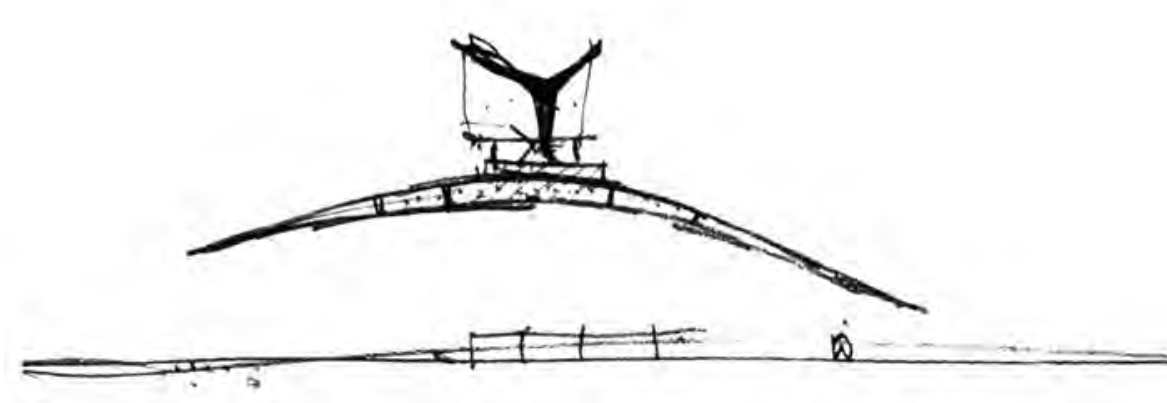

1992: PRAÇA DO PATRIARCA

ESTUDOS

DESENHO DO PÓRTICO METÁLICO DA PRAÇA



PRAÇA DO PATRIARCA: ESTUDOS

CORTE LONGITUDINAL SOBRE O VIADUTO DO CHÁ

17 Neste sentido, não estou de acordo com a colocação de Guilherme Wisnik sobre o projeto: "Realizando uma leitura da cidade, o projeto é um inteligente comentário sobre o desejo de não confinamento dos seus espaços, definindo, ao mesmo tempo, na escala local, uma praça aberta que pode ser lida como um átrio para a igreja". Pois entendo que o projeto de PMR não contempla está escala local, nem funciona como um átrio para a Igreja que esta fora do eixo do pórtico; é como afirma o próprio Wisnik no mesmo artigo, "um objeto ensimesmado".WISNIK, Guilherme. "Nova cobertura da Praça Patriarca”, 2002. 


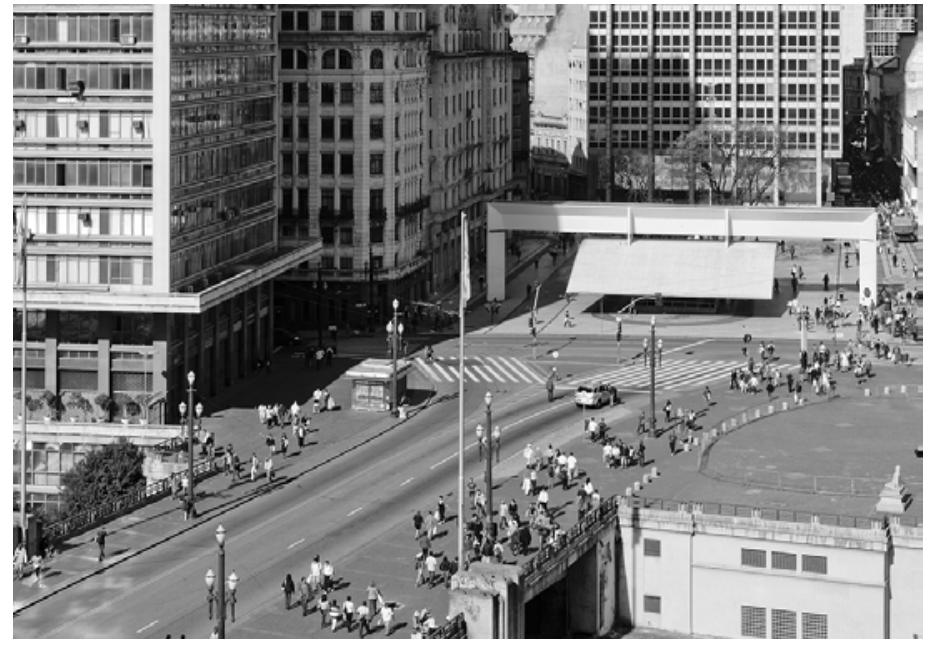

FIG: 64



FIG: 65

18 PMR usa esta expressão para defini-la. ARTIGAS, Rosa (org.) Paulo Mendes da Rocha. p. 215.

19 Vale destacar que durante a construção, as fundações foram feitas $50 \mathrm{~cm}$ abaixo do nível projetado, fazendo com que a ponta inferior da aba ficasse mais baixa em relação ao chão da Praça do que previsto. Houve também dificuldade em se locar os pórtico, dada a grande quantidade de infraestrutura de abastecimento de água, luz e gás que passam no subsolo deste lugar.
Aqui, o arquiteto parecia estar mais atento às possibilidades plásticas do aço: a curva, o balanço, a leveza da cobertura que parece voar, a dobradura das chapas que conformam o pórtico. Vemos o cuidado com que desenha os conectores entre a estrutura principal e a asa de aço, como atributos que o arquiteto vai conferindo à matéria ao desenhá-la.

Trata-se, portanto, de um "artefato" 18 , um objeto metálico que pousa no meio da Praça, a nosso entender, sem prestar muita atenção aos seus vizinhos, à escala e ao uso dos edifícios ${ }^{19}$. O pórtico parece não pertencer àquele lugar, mas em que medida contraria a atual funcionalidade da praça, observada por tantos críticos?

Anos depois, quando realiza o projeto do Poupatempo, vemos que a busca pela expressão plástica do aço permanece ativa, mas numa medida menor. $\mathrm{O}$ aço entra como uma estrutura secundária que preenche o vazio criado pelo concreto, mas ao contrário da Loja Forma, o aço aqui tem um desenho mais apurado; aparece nas empenas luminosas que fecham o espaço e no belíssimo desenho dos condutores de água pluvial, aplicados aos contrafortes que encerram a volumetria do pavilhão.

De novo a água surge numa condição lúdica do projeto. Como se estivesse desfrutado das virtudes da sua própria invenção, o arquiteto desenha um condutor em chapa de aço dobrada, branca, luminosa, que conduz o caminho das águas da chuva, fixo nas empenas de concreto aparente como uma escultura, um Amílcar de Castro.

Assim, o arquiteto parece ter encontrado o ponto de equilíbrio entre concreto e aço no contraste entre peso e leveza, opacidade e luz, solidez e fragilidade.

Ao colocarmos lado a lado as obras da Casa Junqueira e o Poupatempo fica evidente como os procedimentos projetuais são distintos, tanto quanto ao uso da técnica mas também seu sentido urbano (ação sobre o terreno).

Em dois extremos podemos dizer que na Casa Junqueira há uma transformação completa do terreno, ele está totalmente incorporado à construção, de modo que não é mais possível reconhecer um sem o outro. Neste sentido, o projeto do Museu da Escultura - que deriva diretamente de um raciocínio experimentado na Casa Junqueira - é a realização máxima deste pensamento.

No Museu, os espaços exteriores se fundem aos interiores. A matéria concreto aparente é total, não há hierarquias de peso e densidade, é tudo uniforme. O chão da praça também é único, igual dos dois lados da marquise, que está lá não como um portal que anuncia uma novidade do outro lado, mas como uma peça reguladora do espaço. É por ela que percebemos o desnível entre as cotas da Avenida Cidade Jardim e Alemanha, é por ela que entendemos que o horizonte não está lá, mas aqui. 
Já no Poupatempo temos a situação inversa, há uma total preservação do terreno, que permanece, quase que in natura, colocando em um plano distinto a articulação entre os espaços. Vemos pelos desenhos de concepção como o foco está no volume suspenso, na sua forma e não na sua relação com o chão.

Aqui a operação de cavar, de retirar a terra, de trabalhar com a topografia do terreno, dá lugar à operação de expansão da superfície, do plano. E o pavilhão apenas toca o chão.

Mesmo assim pelo modo como o edifício se instala no tecido urbano, conectado à estação de trem, o lugar antes de caráter indeterminado, vague, ganha nova orientação, que se amplia para outras direções. Basta dizer que se seguiu à construção do Poupatempo um Shopping Center (Itaquera), cuja entrada principal é feita pela extensão da mesma passarela do Poupatempo. E atualmente, está em construção no mesmo eixo um estádio de futebol que abrigará jogos para a Copa do Mundo 2014.

Sob o volume suspenso, o chão fica livre, uma sombra. No projeto original, neste térreo, haveria uma lanchonete e alguns serviços de apoio, hoje há um estacionamento e depósitos. Este lugar permanece com a sensação de ser "terra de ninguém", toda vida ativa que percebemos ocorrer no nível das passarelas flutuantes se dissolve neste ainda lugar sem desenho.

Ao contrário das obras que vimos até então, com esta estratégia de estabelecer um outro nível de conexão entre os edifícios, o plano do chão perde força e não faz parte da configuração o espaço. Temos a sensação de um certo abandono melancólico, por parte do arquiteto, daquilo que fica lá embaixo. Retomando, é como se para o arquiteto, a condição desastrosa da cidade contemporânea, não conferisse premissas de projeto válidas, se faz necessário então ultrapassá-las.

O que interessa frisar ainda é que há mudança de escala dos trabalhos realizados por PMR, o campo de ação do arquiteto também se expande, não se trata mais de pensar o lote e sua relação estendida com a rua, mas sim a escala da cidade, do urbanismo, em grandes porções territoriais.

É necessário portanto compreender as implicações dessa mudança de escala: do desenho do lote para o desenho da cidade.

Segundo Argan, o pensamento moderno do fim do século XIX, acerca do desenvolvimento das cidades, fez-se sobretudo a partir da disciplina do Urbanismo e não da Arquitetura. O campo de ação do Urbanismo extrapola os limites da cidade, seu objeto é a existência humana, em todas as suas dimensões. Assim, o Urbanismo "se propõe a estruturar o mundo inteiro" 20.

146

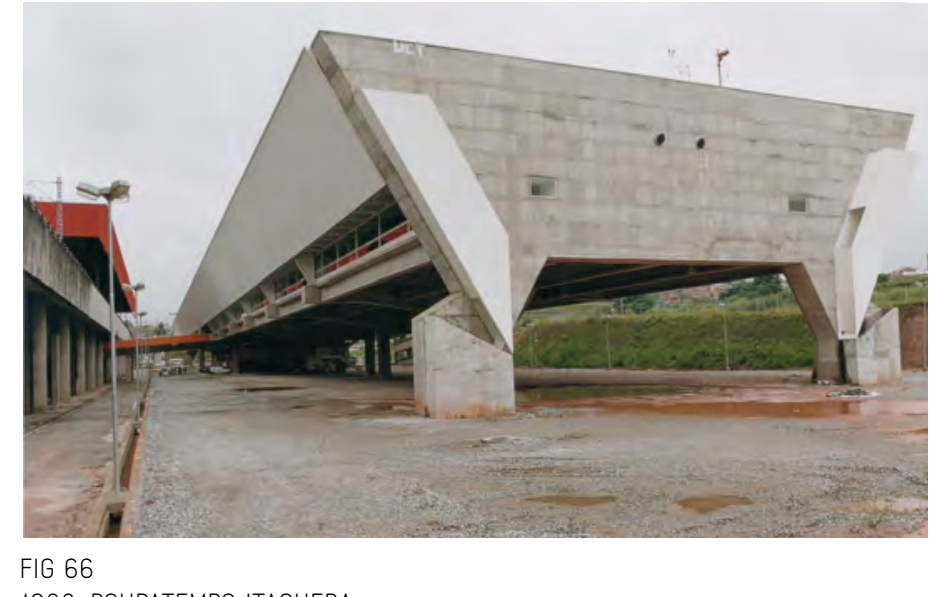

1988: POUPATEMPO ITAQUERA

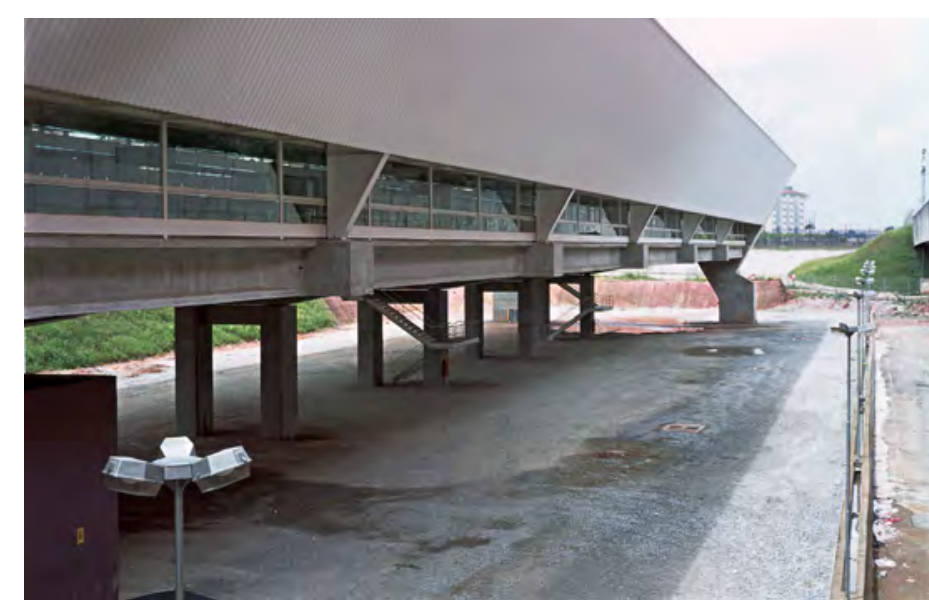

FIG 67

20 ARGAN, Giulio Carlo. História da arte como história da cidade. São Paulo: Martins Fontes, 1995 p. 212. 


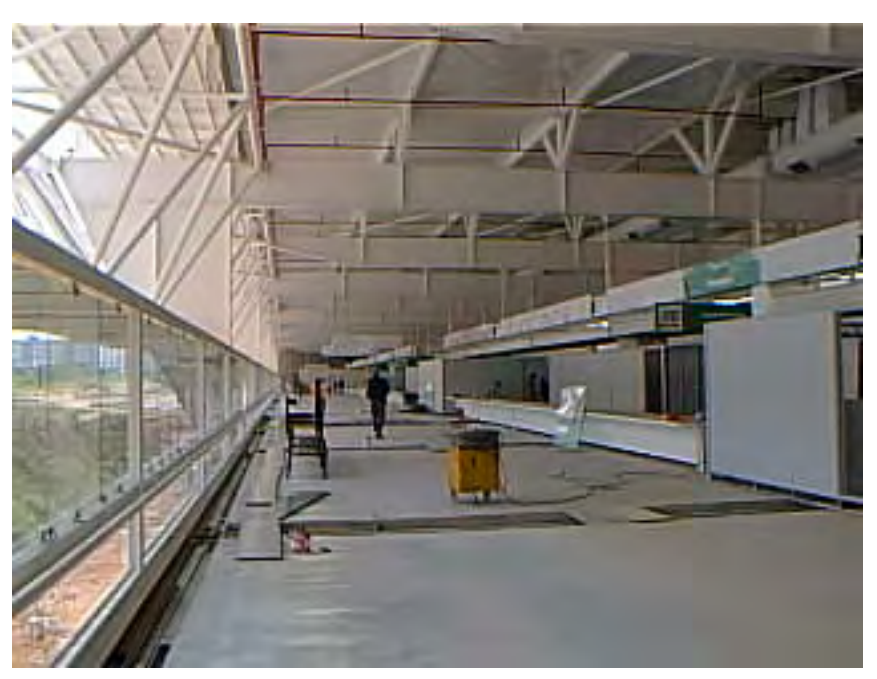

FIG 68

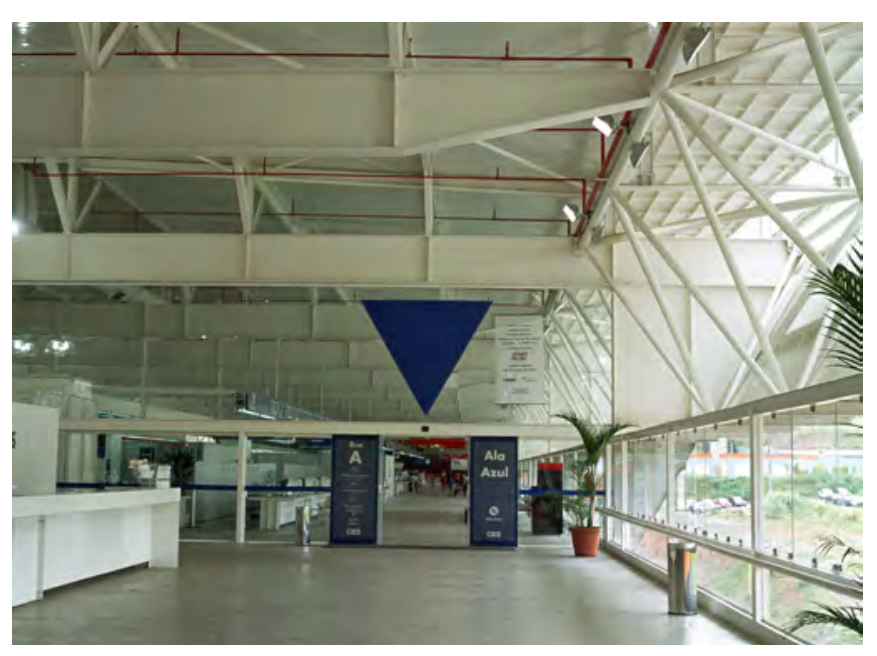

FIG 69

O Urbanismo enquanto disciplina “integral” reduz, para o autor, o mundo todo à esfera do habitável e assim construção e natureza são conceitos que passam a se relacionar de forma integrada e não mais contraposta. O campo de ação do Urbanismo, portanto, é determinado pelas características físicas do lugar, sua geografia, e dimensões históricas, econômicas e sociais.

Ou seja incorpora-se ao campo construtivo da Arquitetura as questões da natureza. E como se daria tal inclusão?

Segundo Carlos Martins, - em seu posfácio para a edição brasileira de Precisões de Le Corbusier - o arquiteto suíço considera as particularidades do lugar como "elemento central do raciocínio projetual”, restabelecendo a relação entre arquitetura e natureza, não mais sobre uma base de "domínio ou sujeição, mas de interação de uma estratégia projetual, que ele [Le Corbusier] chama de 'composição atmosférica'”21, criando uma relação de reunião entre obra construída e paisagem.

Uma composição contrastante, quando vemos os croquis feitos por ele (Le Corbusier) em 1929 para a cidade do Rio de Janeiro, nos quais reconhecemos os dois mundos: a cidade proposta organizada em uma imensa lâmina e a existente com suas edificações, as montanhas, o mar...

Em relação à obra de PMR, entendemos que ela se aproxima mais da concepção mais totalizante como colocada por Argan; não haveria portanto um desejo de contraste, ou composição, pois no caso deste arquiteto natureza não é um mundo a parte, ou um fundo sobre o qual se coloca uma figura. O modo como pensa sobre o universo das coisas naturais, ou o mundo não construído, reflete-se em seus desenhos de cidade de outra maneira, como por exemplo na cidade Tietê (1980).

Este projeto começa com um sobrevôo de helicóptero no qual PMR deveria apontar uma situação geográfica favorável para a implantação da nova capital do Estado de São Paulo. Escolhe um lugar não por seu valor simbólico como em Brasília, mas estrutural, num ponto equidistante entre o porto de Santos e o rio Paraná. A cidade estaria entre duas ferrovias e uma rodovia (SP-320), e às margens de um alargado do rio Tietê, "uma albufeira”, que conforma uma represa que seria em seu projeto a porção central do desenho da cidade, integrando as estruturas de transporte hidroviário, rodoviário e de trem, entre a costa do oceano Atlântico e o interior do país.

Neste projeto não encontramos um desejo de uma fundação simbólica, mas a instalação de cidade no território. Não há no desenho da cidade de Tietê nenhum caráter "palaciano" ou institucional, mas uma visão sistêmica de agenciamento dos

21 CORBUSIER, Le. Precisões. Posfácio de Carlos A. Ferreira Martins "Uma leitura crítica”. São Paulo, Cosac Naify, 2004. p. 278. 


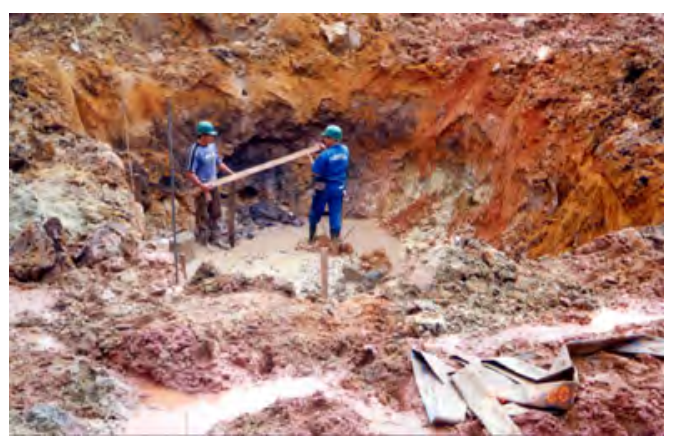

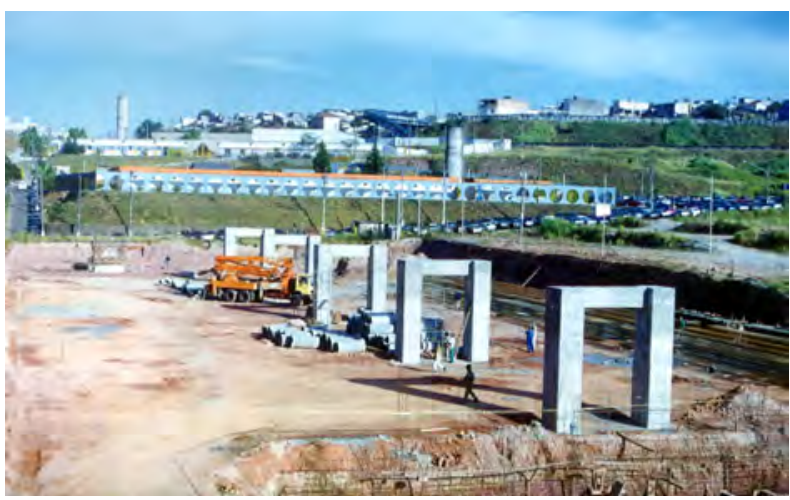

FIG 71



FIG 72

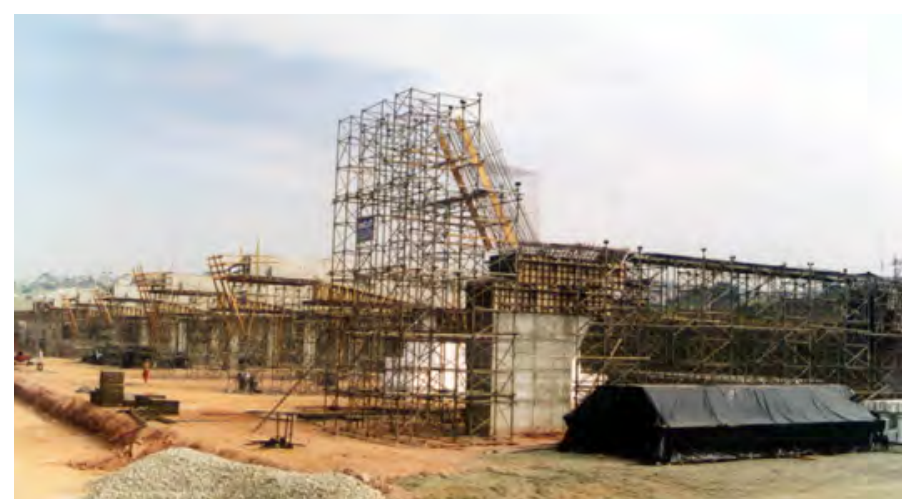

FIG 73



FIG 74 

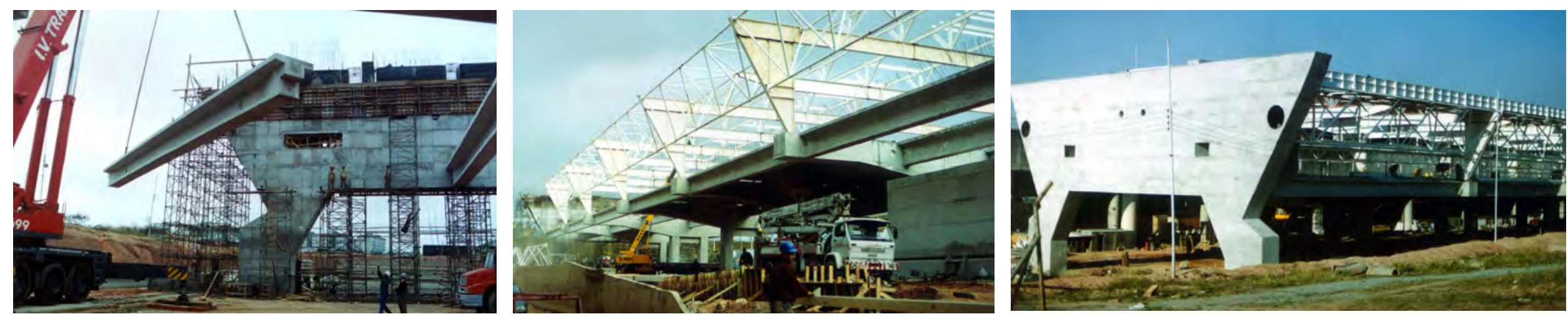

FIG 76

FIG 78

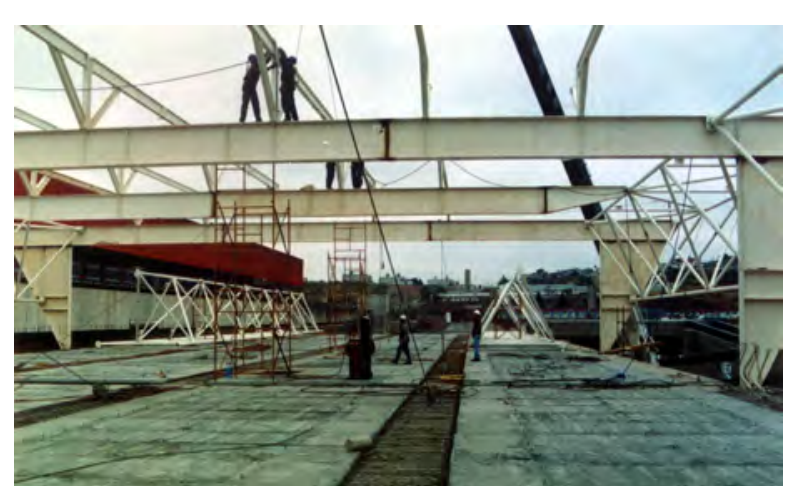


recursos naturais: canais, portos, ferrovias, como suporte para o desenvolvimento da nova capital.

Daí, podemos entender a aproximação com o campo da Geografia, como um dado de projeto para PMR. Geografia, não pela descrição das formas naturais, mas como valor quantitativo para seu projeto. A extensão dos rios, a força dos ventos, as distâncias entre os mares. Trata-se de uma disciplina que amplia os horizontes da arquitetura, conferindo novas dimensões ao seu projetar, que no imaginário particular deste arquiteto tem a extensão do continente americano.

Em suas palavras: "Nossos olhos se voltam para a ideia de construir as cidades americanas na natureza, estabelecendo novos raciocínios sobre o estado das águas, das planícies e das montanhas, a espacialidade de um continente."22.

Portanto, o que define o caráter do terreno onde se implanta o Poupatempo não são as dimensões do seu lote, nem seus acidentes geográficos, mas o fato de se tratar de uma porção de terra situada na periferia da cidade, cujas contingências fundamentais são por exemplo: possuir uma conexão direta com um sistema de transporte público de dimensões metropolitanas, ser um equipamento público onde o cidadão se credencia para viver em sociedade.

Se ainda na Casa Junqueira, percebemos ainda que a dimensão de trabalho de PMR está atrelada ao pensamento do lote, já no Poupatempo, isso não ocorre mais, não se trata mais de ocupar-se com a continuidade, mas de ultrapassá-la. A ênfase do projeto revela com toda clareza a relação com o fluxo de transformação da cidade. É uma obra que supera os limites do lote e atinge múltiplas relações cruzadas. E em última análise atravessa a cidade nas condições que ela está configurada, com todos os desajustes que ela conservou.

Portanto para nós o tratamento dado ao lote no projeto do Poupatempo é chave para se compreender as passagens as quais nos referimos no inicio do capítulo. E como veremos ele será fundamental para estabelecer as bases dos projetos que virão.

Ao final da década de 1990, ou seja, 20 anos depois de ter recuperado seus direitos civis, o arquiteto encontra-se em uma situação profissional bem diversa daquela do começo da década de 1980.

Apesar da crise econômica que castigou o país nestes anos, PMR teve uma quantidade regular de trabalho, sobretudo na esfera dos encargos públicos. Além disso, projetos como o Museu da Escultura e da Pinacoteca do Estado, tiveram uma grande

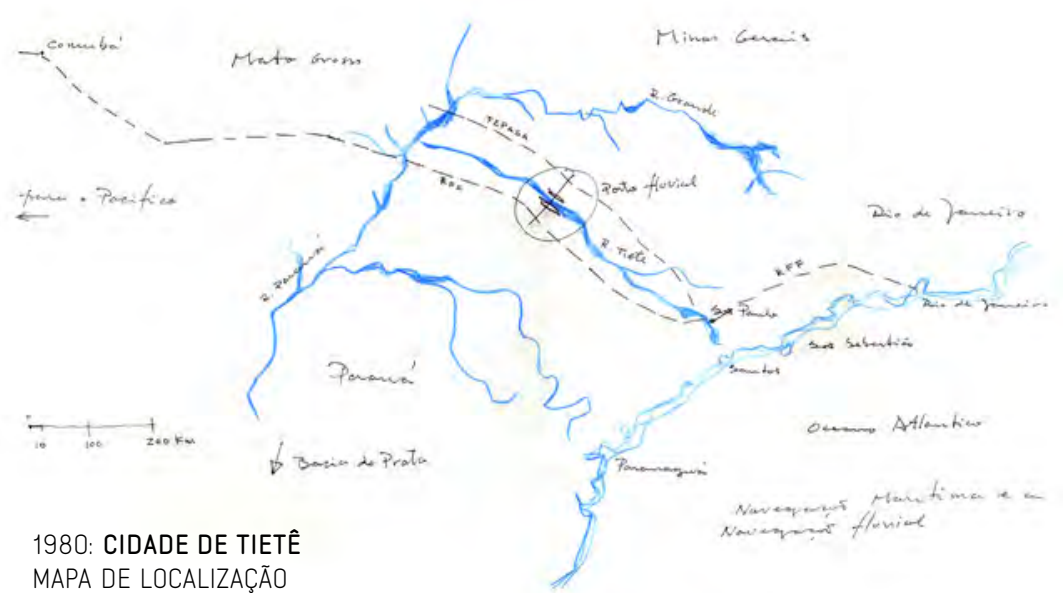

MAPA DE LOCALIZAÇÃO
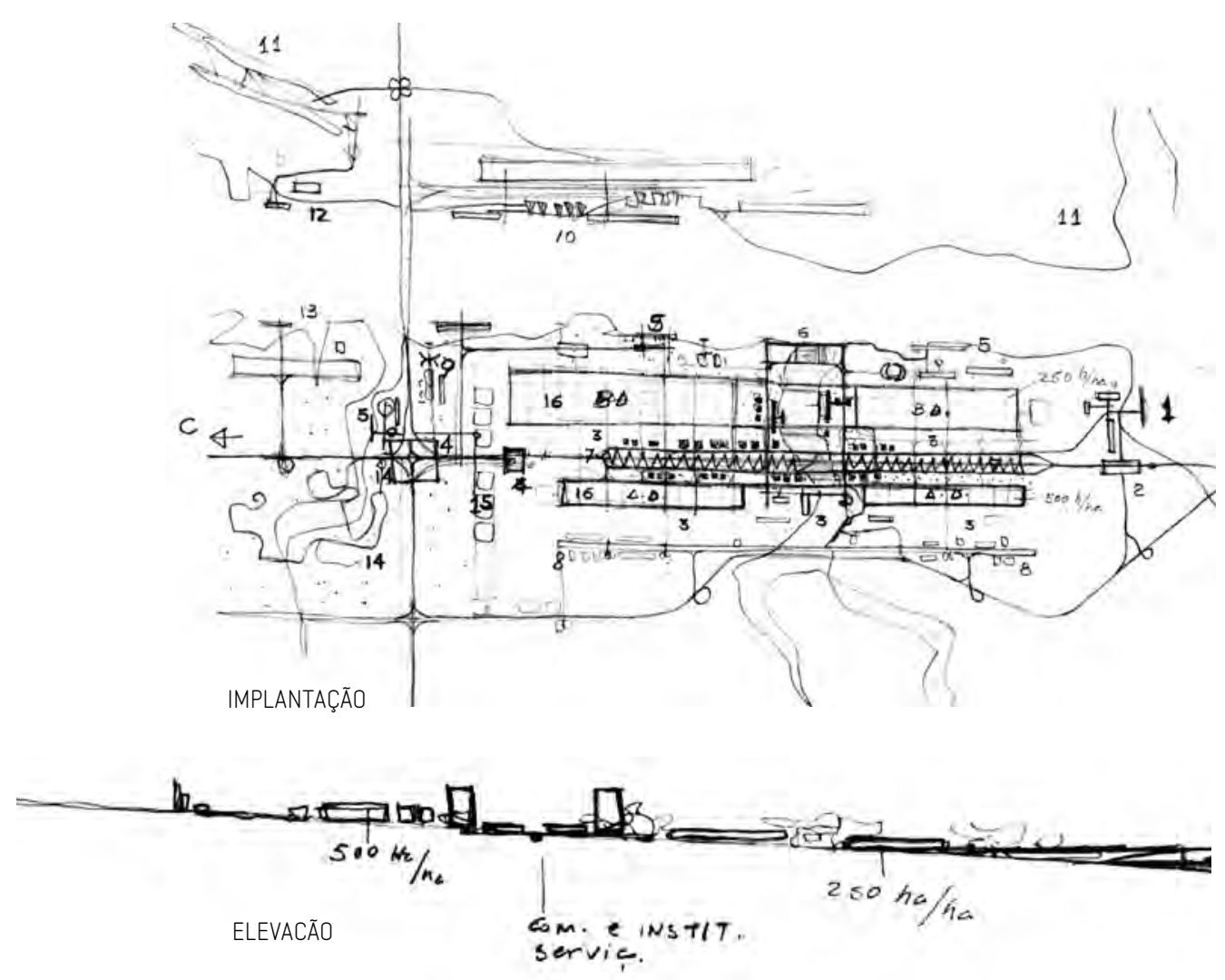

22 ARTIGAS, Rosa (org.) Paulo Mendes da Rocha. São Paulo, Cosac Naify, 2000. p. 16. 
projeção na mídia nacional e internacional, conferindo ao arquiteto inúmeras premiações e participações em Bienais de Arquitetura na condição de convidado especial23.

Ainda que os encargos tenham se tornado cada vez mais complexos, o modo de trabalho escolhido pelo arquiteto, após o término da obra da Pinacoteca em 1993, mostra-se produtivo e de acordo com sua vontade de não se tornar um gerenciador de um grande escritório de arquitetura.

Certamente, se fosse outro seu desejo, poderia ter retomado seu escritório com uma notável equipe interna, mas isso significaria agenciar uma mudança tecnológica considerável, e se tornaria além de arquiteto um administrador; atividades que não caberiam ao seu modo de trabalhar. Sem a pressão de ter que sustentar uma complexa estrutura de trabalho, e gozando de prestígio e reconhecimento profissional, o arquiteto parece sentir-se livre para escolher apenas trabalhos que lhe tocam o espírito.

Tais escolhas estão em geral relacionadas com a possibilidade de refletir sobre um campo imaginário cada vez mais expandido, amplos horizontes territoriais, não apenas na esfera do objeto arquitetônico.

Sua busca afirma-se no sentido da concepção de espaços com base nos de ideais de democracia e igualdade social, com a consciência de que não podemos construir o habitat humano consumindo os recursos naturais do planelta como se fossem infinitos.

Inicia-se assim em meados dos anos 2000 uma outra fase: a das grandes obras les grands travaux, tomando emprestado uma expressão usada por Carlos Martins no posfácio citado anteriormente.

Veremos no capítulo seguinte como PMR não volta mais para a escala do particular, do pequeno e da casa. Mesmo realizando projetos menores, seu imaginário está num lugar do tamanho da América, dos rios, das planícies e da possibilidade de criar um mundo equilibrado e de paz.

Em suas próprias palavras:

23 1994: Sala especial na V Bienal de La Habana, Cuba; 1997: Sala especial na X Documenta de Kassel; 1998 ;Prêmio especial I Bienal Ibero-americana, Madrid; 2000: II Prêmio Mies van der Rhoe para Arquitetura latino-americana, pelo projeto da Pinacoteca do Estado.

24 ARTIGAS, Rosa (org.) Paulo Mendes da Rocha. São Paulo, Cosac Naify, 2000. p.174.
Agora, estamos diante da completa arquitetura das cidades, da construção da paz, e superação da pobreza e da miséria. Uma virtude nova, possivel na consciência mundial, sobre o estado do homem, dos conhecimentos, da nova condição da natureza. ${ }^{24}$ 


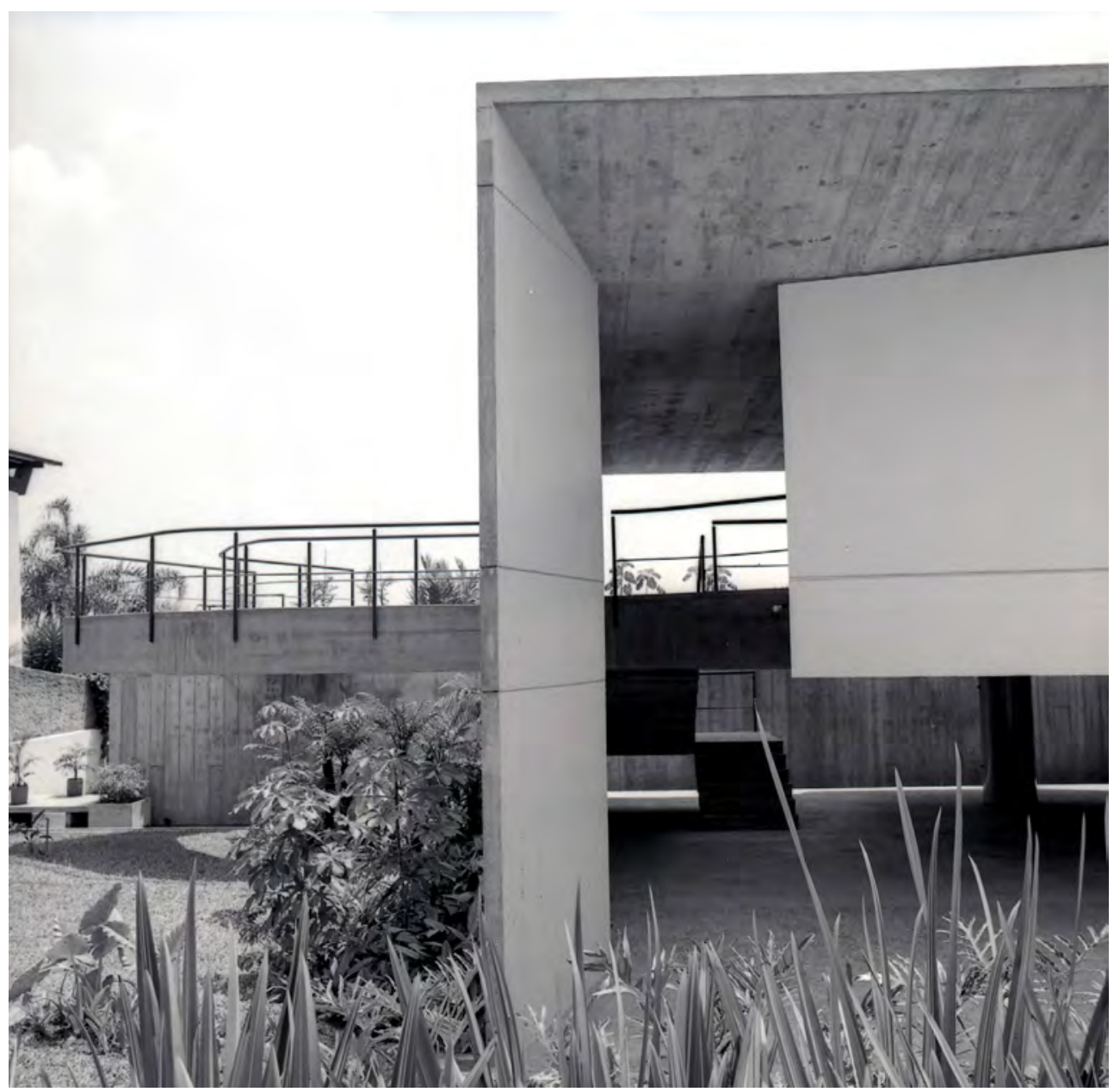

FIG 79

CASA JUNQUEIRA

RUA GUAONEES, 144 - SÃO PAULO

ÁREA DO TERRENO: $1407.00 \mathrm{M}^{2}$

ÁREA CONSTRUIIDA: $677.22 \mathrm{M}^{2}$

DATA DO PROJETO: 1976

DATA TÉRMIO DA OBRA: 1980

COLABORADORES: ARQUITETO ROBERTO LEME FERREIRA

CÁLCULO DAS ESTRUTURAS DE CONCRETO ARMADO E DAS FUNDAÇÕES: CONSCAL - CONSULTAS E CÁLCULOS LTDA ENGENHEIRO RESPONSĀVEL: SIGUER MITSUTANI

CONSTRUÇÃO: CENPLA - CONSTRUÇÕES ENGENHARIA E PLANEJAMENTO LTDA.

ENG. RESPONSÁVEL: OSMAR AUGUSTO PENTEADO DE SOUZA E SILVA 


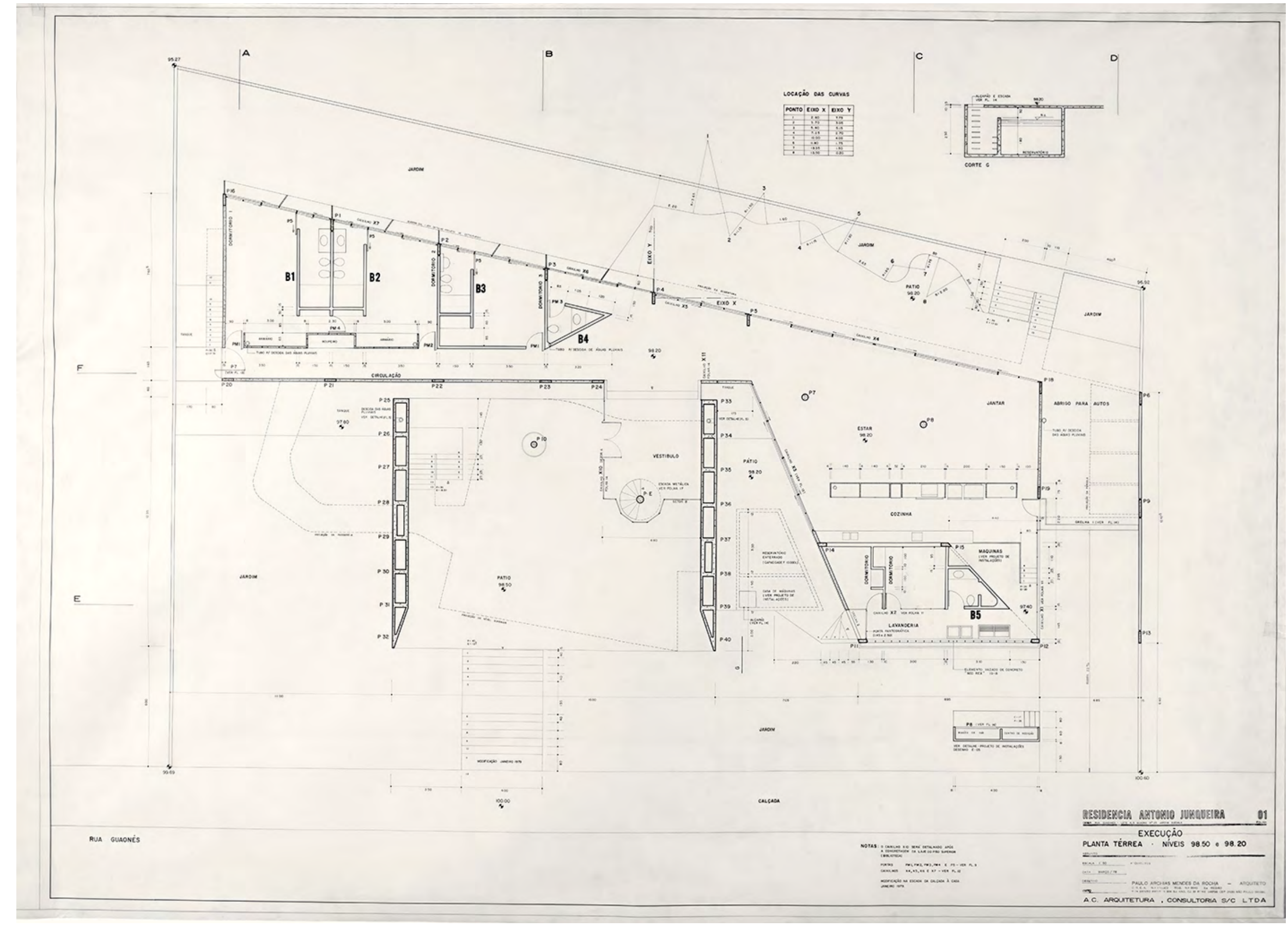

PLANTA DO TÉRREO 


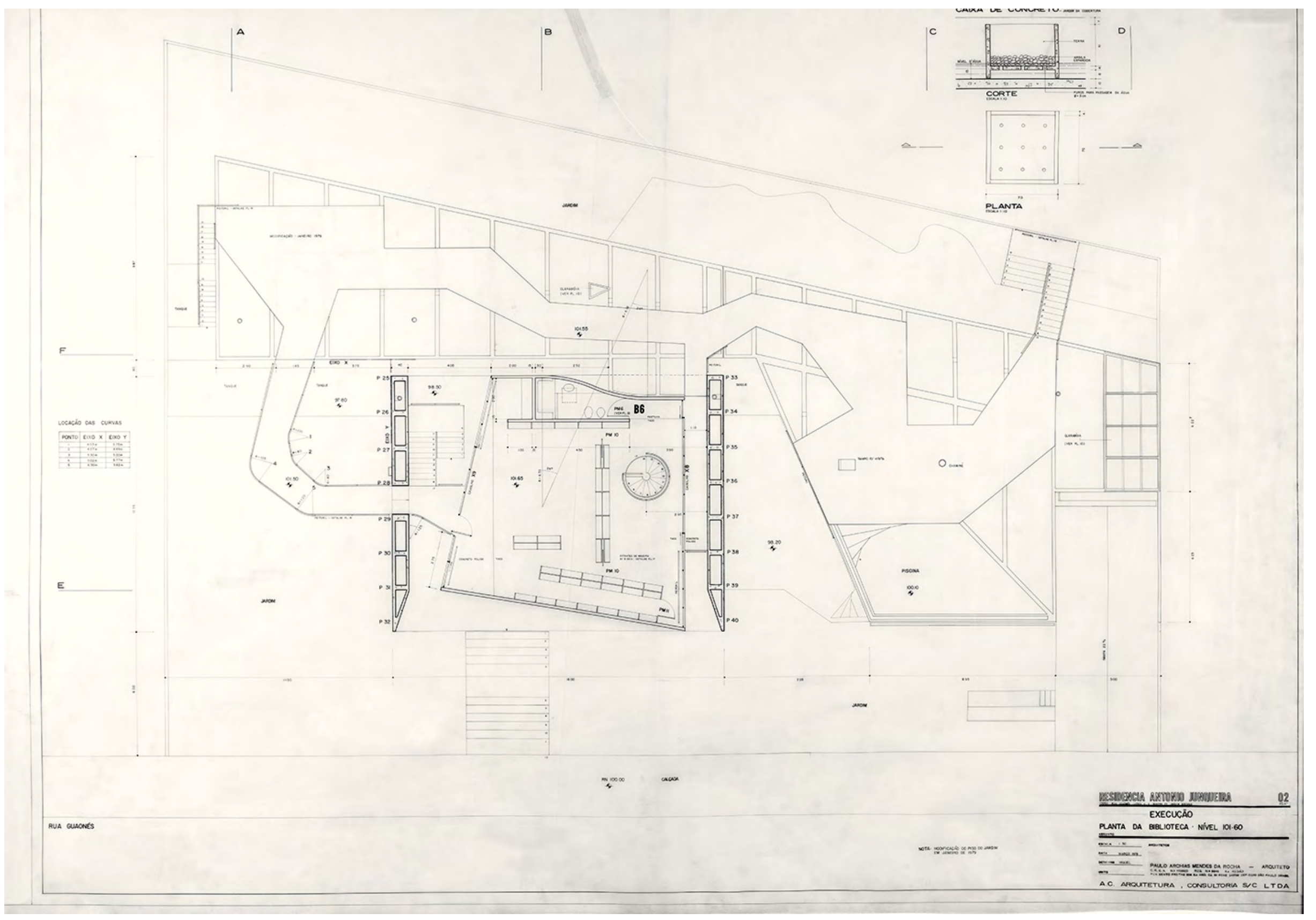

PLANTA DO PAVIMENTO SUPERIOR -PLANTA DA BIBLIOTECA E LAJE JARDIM QUE COBRE A CASA S/ ESCALA 


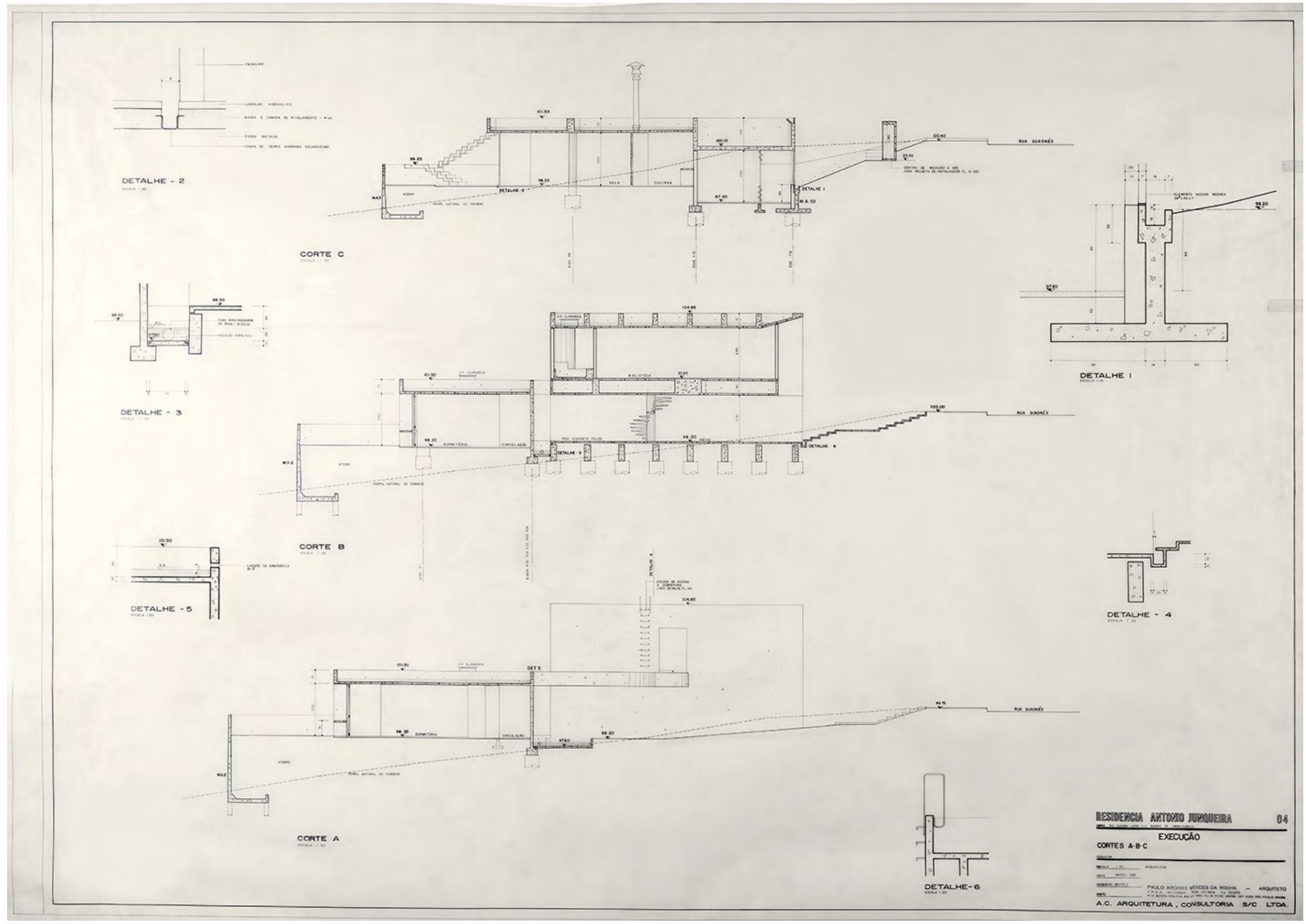




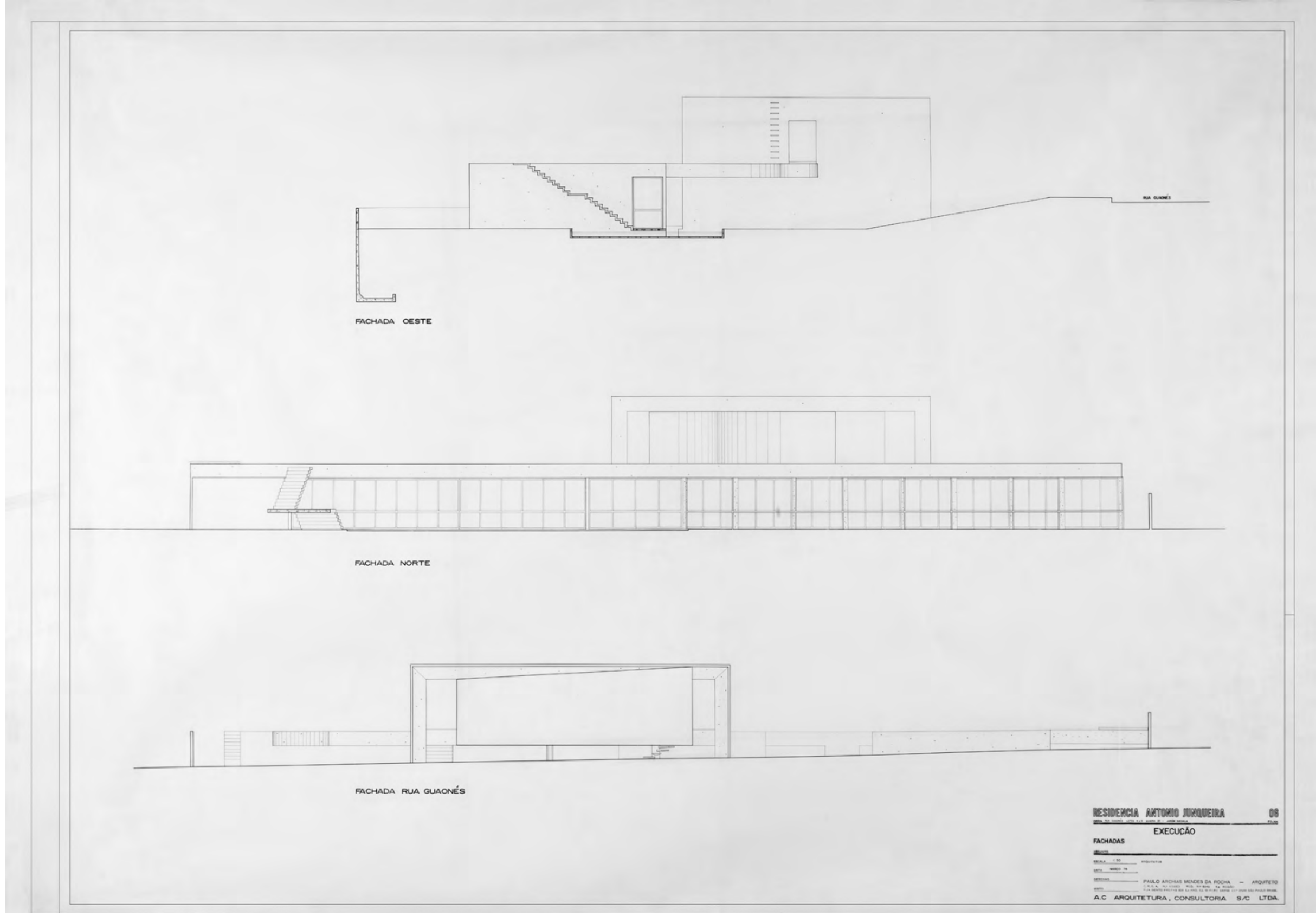




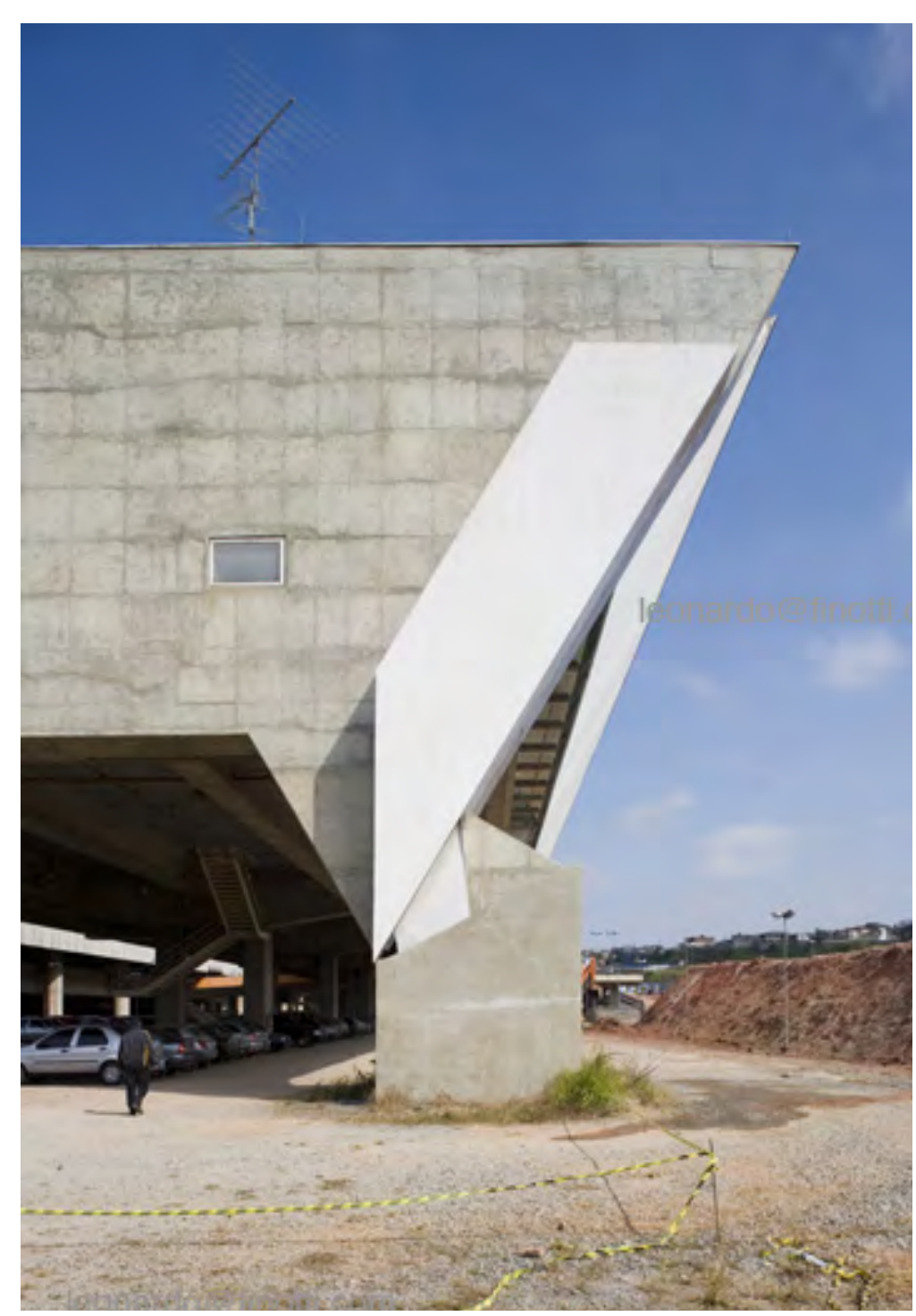

FIG 80

POUPATEMPO ITAQUERA

AV. DO CONTORNO, 60, SP

ANO DO PROJETO: 1998

ANO DO TÉRMINO DA OBRA: 1999

ÁREA CONSTRUIIDA. $10.100 \mathrm{M}^{2}$

ESCRITÓRIO COLABORADOR: MMBB ARQUITETOS

PROJETO DE ESTRUTURA: JORGE ZAVEN KURKDJIAN 
SHOPING ITAQUERA



PROJETO DESENVOLVIDO COM MMBB ARQUITETOS EM AUTOCAD.

\begin{tabular}{|c|c|c|}
\hline \multirow{2}{*}{\multicolumn{3}{|c|}{ 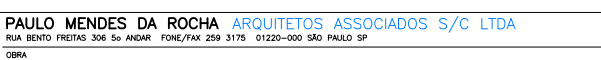 }} \\
\hline & & POUPATEMPO UNIDADE ITAQUERA \\
\hline $\begin{array}{l}\text { FrseA } \\
\text { PROJETO EXECUTVO }\end{array}$ & 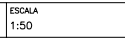 & |atery \\
\hline $\begin{array}{l}\text { OUATIO } \\
\text { CASTELO DE CONCRETO } \\
\text { CONDUTOR DE AGUAS PLUVIAIS }\end{array}$ & DET253 & 1 \\
\hline Fisponsest & 蓶 & \\
\hline
\end{tabular}




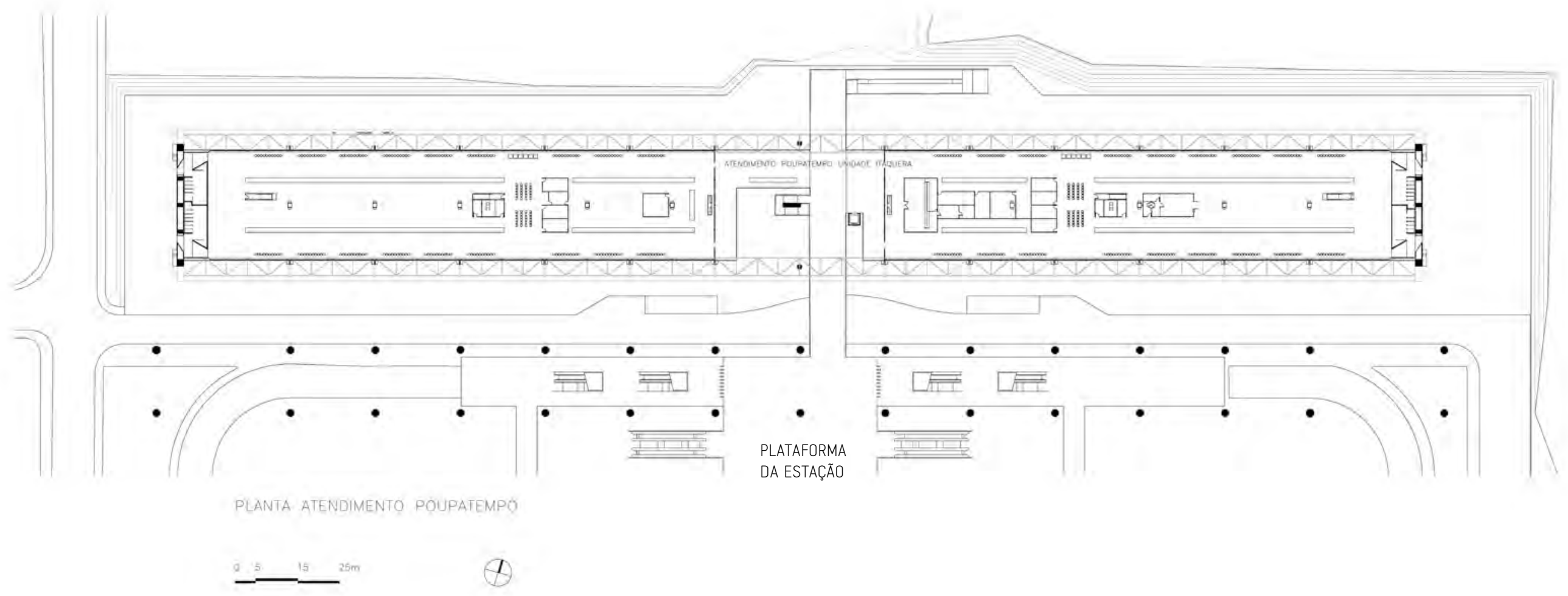








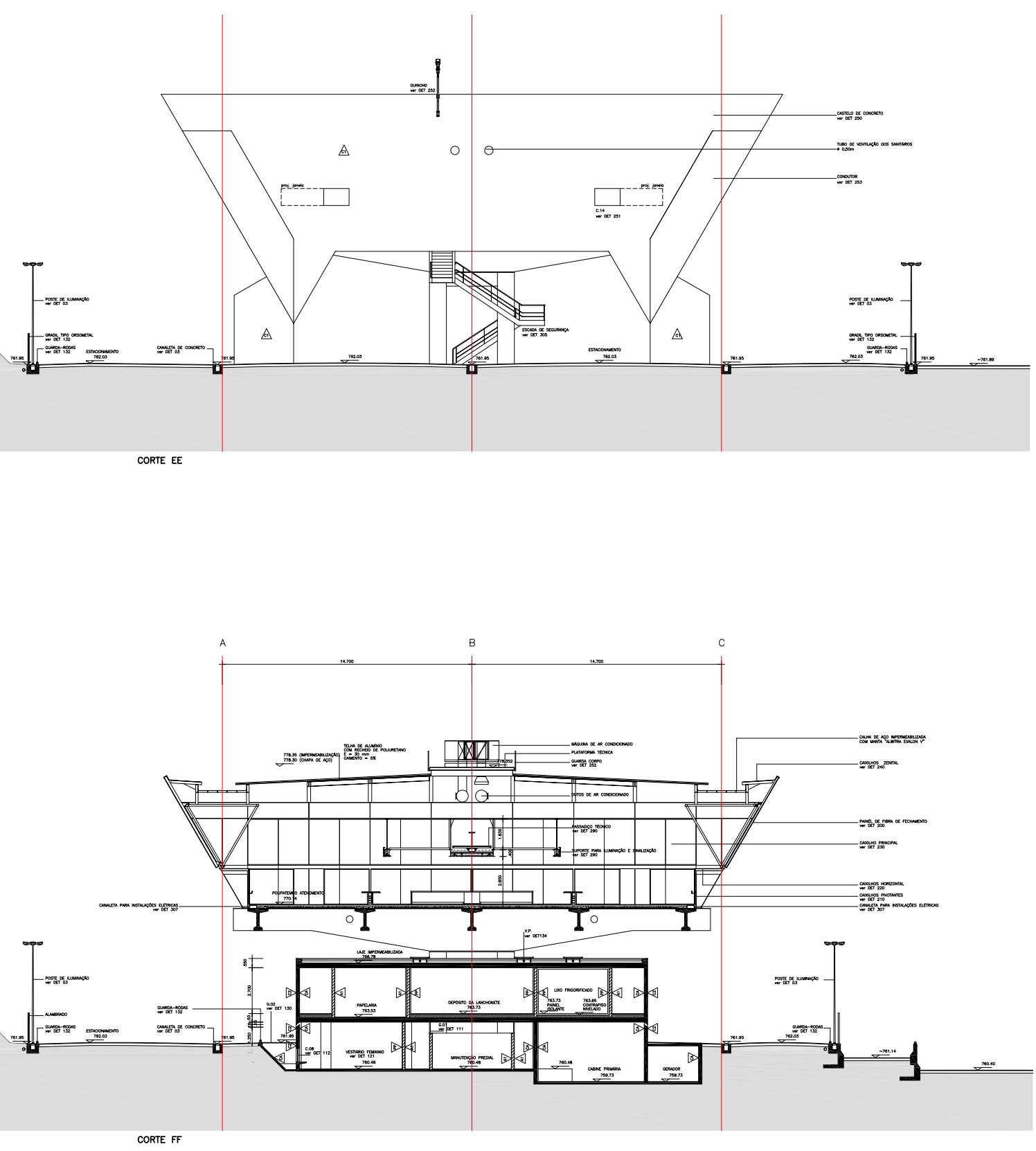

CORTE TRANSVERSAL E ELEVAÇÃo LATERAL 




PLANTA DO CONOUTOR
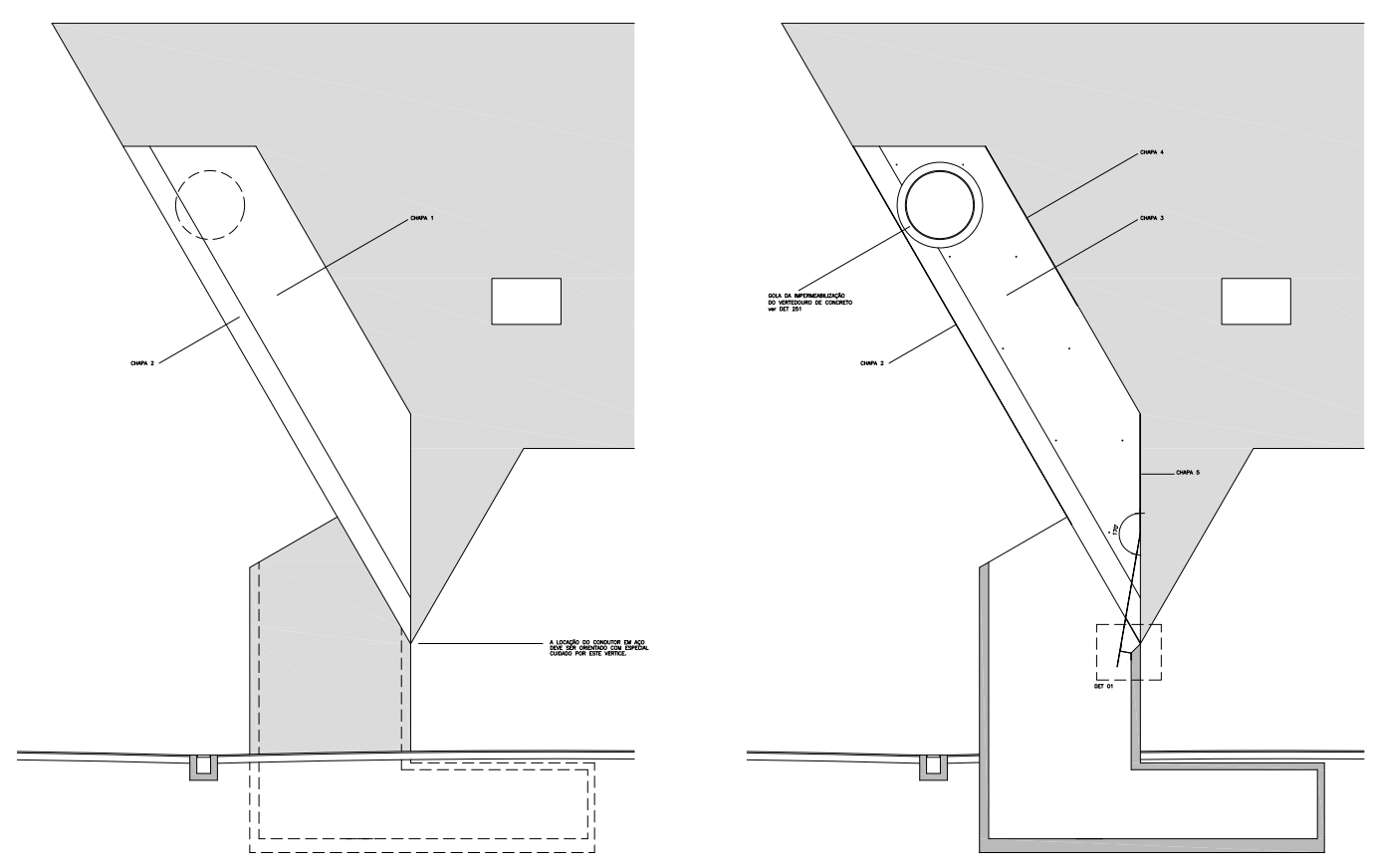

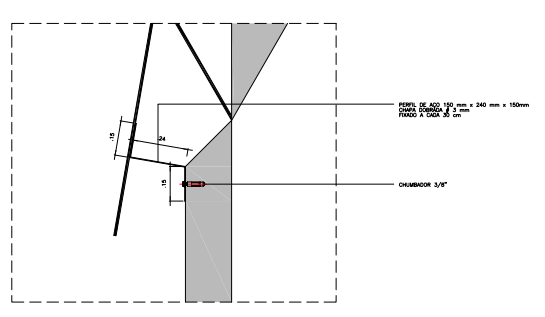

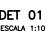

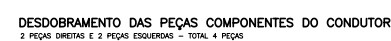

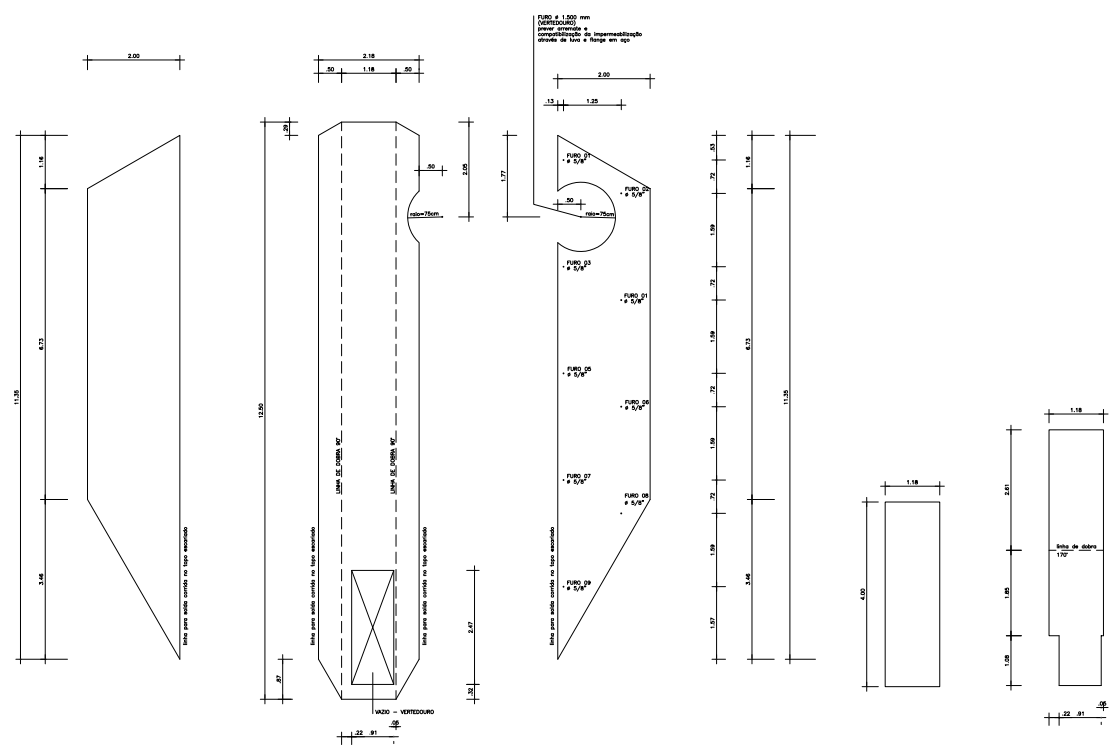



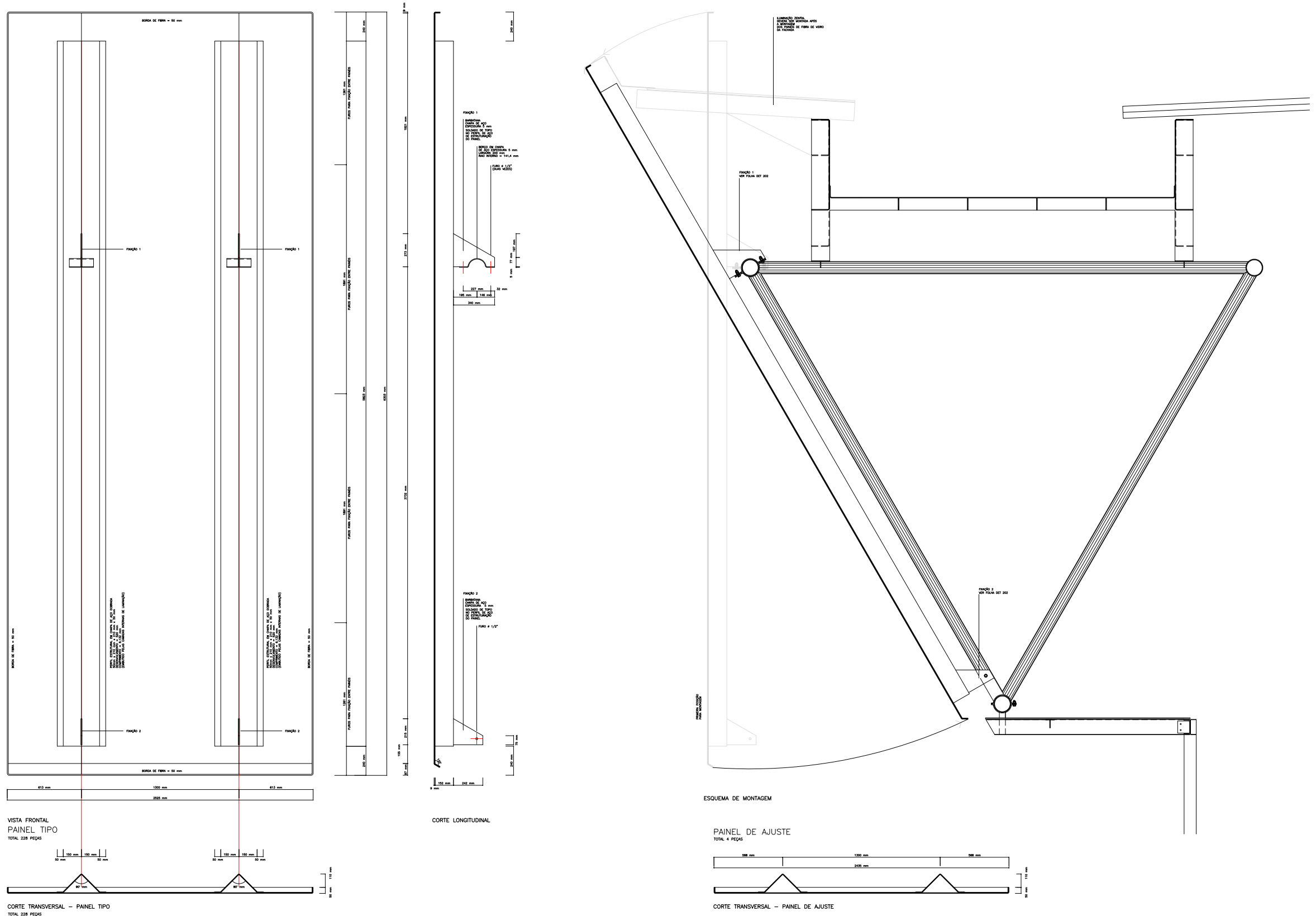

DETALHE: PAINEL DE FECHAMENTO LATERAL E CALHA S/ ESCALA 


$$
\pm \square
$$




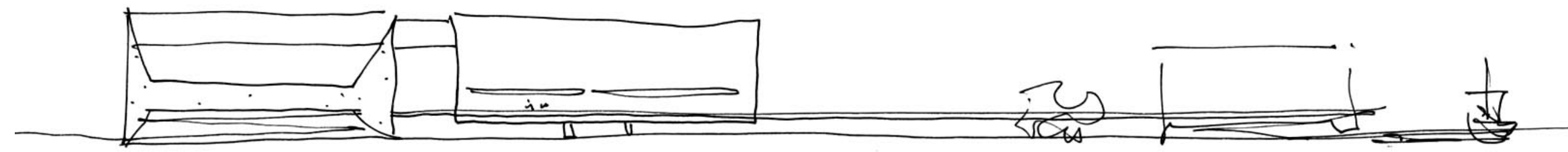

2008 MUSEU DOS COCHES 



\section{2000-2008 \\ CAIS DAS ARTES, MUSEU DOS COCHES: O DESENHO DO TERRITÓRIO}

"O território é o lugar em que desembocam todas as ações, todas as paixões, todos os poderes, todas as forças, todas as fraquezas, isto é, onde a história do homem plenamente se realiza a partir das manifestações da sua existência"'.

Milton Santos

A complexidade dos diversos sistemas que determinam o caráter da cidade contemporânea põe em causa a relação entre arquitetura e cidade. A realidade material da cidade vai, hoje, muito além da sua dimensão construída, dos seus marcos históricos e lugares simbólicos.

A cidade contemporânea se configura por um conjunto complexo de sistemas que constituem a vida metropolitana: transportes, telecomunicações, entretenimento, serviços, consumo etc. Não é mais uma cidade local e singular, mas global onde o trabalho está no setor de serviços e não na indústria, e os meios de produção não são mais mecânicos e sim digitais.

Esta cidade, que cresce em ritmo acelerado, perde rapidamente suas fronteiras, sua forma estável, suas raízes (genius loci), e se determina pela fluidez dessas diversas dimensões sistêmicas.

Tal condição interfere no campo de ação do arquiteto, porque a cidade é agora um corpo móvel, de grandes extensões territoriais e em constante transformação; para atuar sobre este ambiente é necessário então estabelecer novos critérios de desenho.

Sobre a realidade densa e complexa da metrópole, cabe ao arquiteto revelar ou estabelecer um conjunto de valores ou fenômenos que configuram contornos sobre o qual se dará sua ação projetual. Passam a ser questões para a arquitetura neste mundo

1 SANTOS, Milton. "O dinheiro e o território" in Território, territórios: ensaios sobre o ordenamento territorial, 2011. p. 13. 
Nesse sentido, a noção de território permite uma primeira aproximação ao novo fenômeno: a relação entre arquitetura e cidade não é mais dada pela ligação do edifício à rua e o lote, mas por um recorte, uma porção de terra e suas contingências físicas e sociais. $\mathrm{O}$ constante emprego deste conceito em textos de arquitetura e urbanismo nas últimas décadas, incluindo naqueles que se referem à obra de $\mathrm{PMR}^{2}$, indicaria o território como sendo um campo ampliado de ação que se sobrepõe à própria noção de cidade.

Quando PMR faz referência ao conceito de território em seu discurso, existem duas ideias que predominam: primeiro, território como uma ampla porção espacial que ultrapassa os limites da cidade, a “América”. E segundo, território como o lugar a ser construído para o habitat humano a partir da consciência dos seus recursos naturais sobretudo do movimento das águas dos rios como vias de conexão entre lugares, fonte de energia natural, lazer etc.; ou seja uma visão de equilíbrio entre ocupação e desenvolvimento. ${ }^{3}$

Como podemos perceber, por exemplo, no projeto realizado durante um seminário para a Baía de Montevidéu (1998) o arquiteto destaca a configuração morfológica da baía enquanto elemento capaz de reestruturar o centro histórico da cidade:

O problema urbano era evidente: a cidade inteira, em suas comunicações, tinha que girar em torno da baia, tendo-a como um entrave a ser superado. A intenção do projeto foi justamente inverter o problema, fazer a cidade dirigirse a ela de modo concêntrico... ${ }^{4}$

A partir deste conjunto de informações, o arquiteto concebe a baía como uma praça de água: "animada, como uma São Marcos inundada", numa visão "veneziana" da relação entre homem e natureza. Redesenha as margens com uma geometria ortogonal, no seu centro há uma ilha quadrada que abriga um teatro. E assim, reconfigura as margens da cidade que passa a ter as águas da baía como frente e não mais como fundos.

Entretanto território é um conceito que abrange questões que vão além das dimensões físicas do lugar, e por isso é tradicionalmente estudado tanto na Geografia como nas Ciências Sociais, e mais recentemente na Arquitetura. Por este motivo, antes de começarmos a usar esta noção, e com o objetivo de ampliar a discussão propomos uma pausa para compreender como arquitetos e geógrafos entendem o conceito de território.

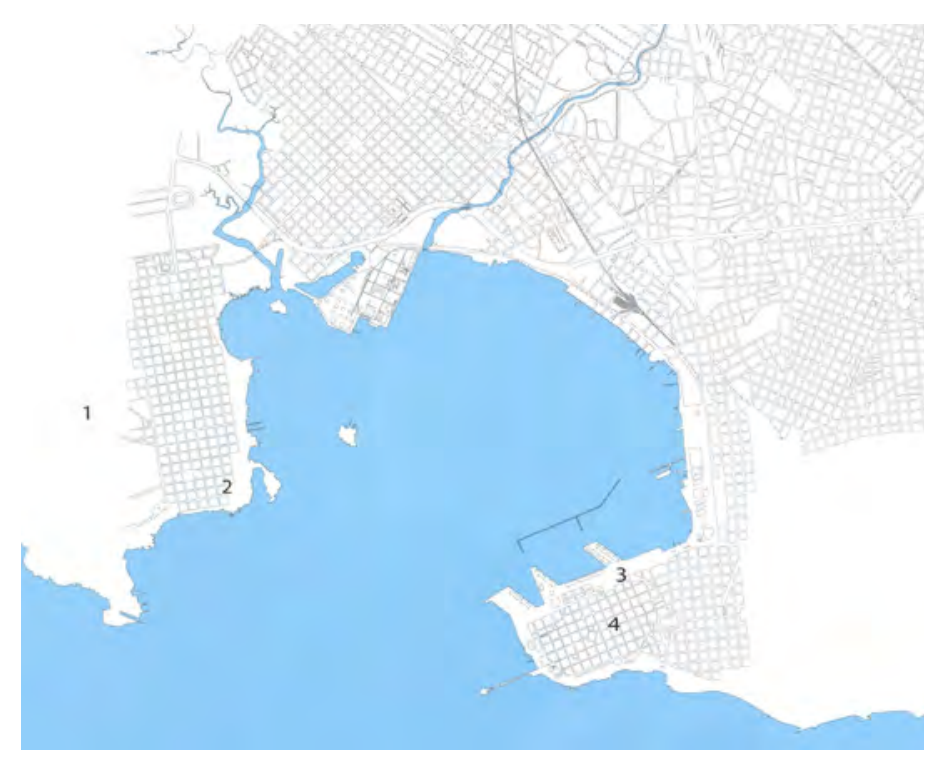

BAíA DE MONTEVIDÉU: CONFIGURAÇ̃̃o EXISTENTE
2 O título do texto de Guilherme Wisnik para a revista internacional 2G é: "Paulo Mendes da Rocha: arquitetura do território", 2008.

"Construir el territorio no es ocuparlo sino inventarlo". Maria Isabel Villac em sua tese La construcción de la mirada - Naturaleza, ciudad y discurso en la Arquitectura de Paulo Archias Mendes da Rocha, 2002. p. 226.

"Você tem muitas obras construídas, como casas e escolas, mas suas imagens são geográficas: a configuração do território de um modo novo". Pergunta de Jupira Corbucci e Sophia Telles na entrevista "Consolidar um lugar”, 2000 in Encontros com Paulo Mendes da Rocha. p. 94.

3 "Nossos olhos se voltam para a ideia de construir as cidades americanas na natureza, estabelecendo novos raciocínios sobre o estado das águas, das planícies e das montanhas, a espacialidade de um continente(...)". ARTIGAS, Rosa (org.) Paulo Mendes da Rocha, 2000. p. 15.

4 ibidem. p. 218

5 ibidem p. 220. 


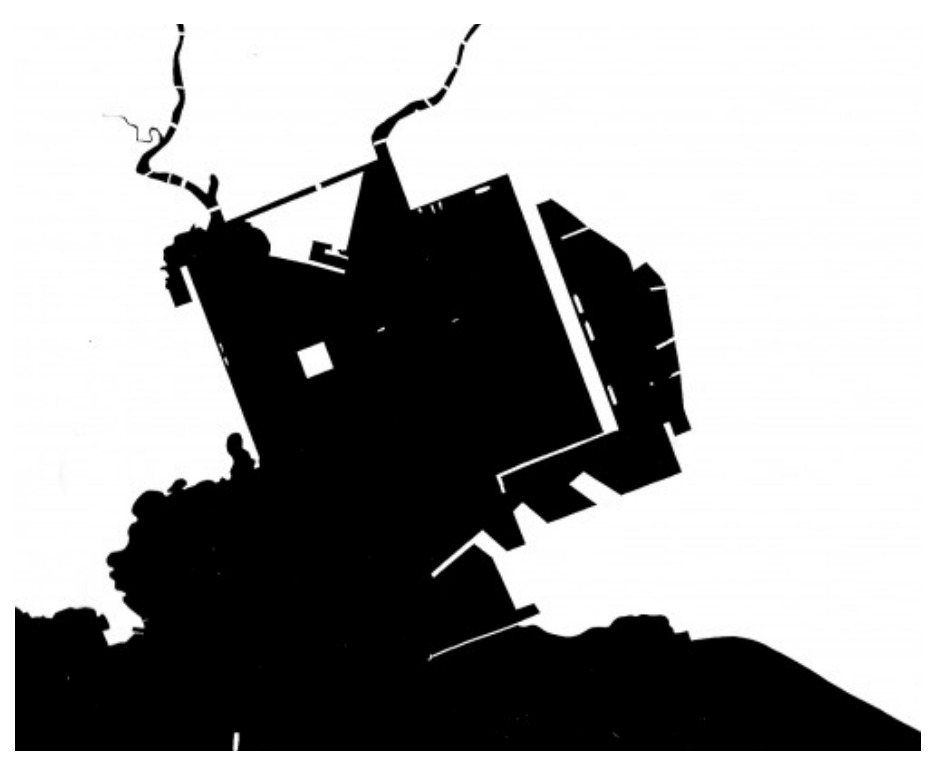

1998: BATIA DE MONTEVIDÉU

CROQUIS DO PROJETO PROPOSTO PARA A BAIA, ONDE NOTA-SE A RECONSTITUICCÃO DAS BORDAS, CONFORMANDO UMA "PRAÇA INDUNDADA".

O QUADRADO BRANCO AO CENTRO SERIA UMA ILHA ONDE HAVERIA UM TEATRO.
6 GREGOTTI, Vittorio. Território da arquitetura. São Paulo, 2001. p. 65

7 PIÑÓN, Helio. Paulo Mendes da Rocha, 2002. p. 8. O título da introdução do livro é: "Quando o projeto revela a Geografia oculta".

8 MOTTA Flávio. "Paulo Mendes da Rocha” in Textos Informes. 1973. p. 21.
A primeira evidência a destacar é que território não é coisa, é conceito. Cidade é coisa: uma realidade material definida e concreta; enquanto que se entende território como um conjunto de relações físicas e sociais, em um determinado espaço. Possui, assim, uma dimensão ligada aos recursos da natureza e da produção, mas também uma dimensão ideal e simbólica.

O arquiteto Vittorio Gregotti, por exemplo, em seu livro Território da Arquitetura (1972), considera que para projetar sobre "conjuntos ambientais" de ampla escala, ou seja que vão além dos limites da cidade, é necessário encontrar novas ferramentas de projeto, o que busca nas relações com outras disciplinas, tais como: Planejamento, Paisagismo (landscape), e a Geografia. Essa “ampla escala” à qual o autor se refere seria a natureza, a paisagem, o território; tudo aquilo que não é cidade. Coloca as duas realidades, cidade e natureza, em contra ponto, como coisas bem distintas, e daí a necessidade de se buscar novas ferramentas projetuais: “(...) de que modo nossa percepção da paisagem se converte em percepção estética, de que modo se adquiri consciência da qualidade figurativa da paisagem?(...)”。.

É preciso ressaltar que Gregotti escreve a partir de uma percepção de cidade europeia (italiana), que historicamente teve seus limites bem demarcados por muralhas e fortificações. Ou seja território, neste caso, parece ser tudo aquilo que não é cidade.

Já para o arquiteto espanhol Hélio Piñon, PMR possui uma "obsessão pela geografia enquanto forma natural e em relação à qual o projeto adquiri sentido." (grifo meu).

Assim como Gregotti, Piñon entende que nas relações entre arquitetura e natureza, é preciso recorrer à Geografia como disciplina que oferece ao arquiteto ferramentas para projetar sobre um universo distinto da cidade; o território seria este outro lugar.

Por outro lado, vale retomar o ensaio de Flavio Motta sobre a Casa Butantã (1970), no qual afirma que a casa: “ É arquitetura que tenta 'pousar', sem violentações, diante desse homem deformado e transformado no nosso Brasil Central, desse homem mais próximo à Geografia do que à História, que lembra mais a árvore do cerrado do que a Alvorada do Palácio."».

Entendemos a partir da citação acima que o que deforma o homem venha talvez pelo modo desigual como o Brasil foi ocupado desde sua colonização, ou seja a arquitetura se defronta, não com uma natureza desconhecida, mas com um "subdesenvol- 
vimento machucado", em todas as escalas. Aquilo que o autor relaciona, e determina como campo de ação ampliado da arquitetura está no binômio espaço e sociedade, e não arquitetura e natureza. Por isso, é mais Geografia que História.

Tal aproximação com a Geografia pode assumir por vezes um viés equivocado ou exagerado, pois entendemos que não é pela Geografia que o projeto de PMR ganha sentido. Como vimos anteriormente, a Geografia não é disciplina operativa, e sim informativa, ao dispor no presente, aquilo que caracteriza morfológica e socialmente o lugar. $\mathrm{O}$ arquiteto transforma uma condição existente em problema de projeto, em problema espacial. Segundo PMR: "Antes de construir, o homem escolhe um lugar, onde antevê uma situação arquitetônica sobre o espaço."10 - entendemos que a razão da "escolha do lugar" é dada por uma consciência espacial e social do lugar.

Ao nos aproximarmos da obra de PMR, entendemos que Geografia como disciplina vai muito além dos aspectos formais da natureza, e revela as condições de nossa existência sobre esse espaço desigual e de escala continental. É a partir de tais contingências que o arquiteto articula sua proposta.Portanto território não pode ser apenas o distinto da cidade, mas uma extensão espacial, com seus usos e memórias.

Avançamos, então, nossa pesquisa dentro da disciplina da Geografia e encontramos na publicação Território territórios, organizada por Milton Santos, uma série de ensaios de pesquisadores, na sua maioria geógrafos, que buscam refletir sobre as diversas possibilidades de aproximação entre espaço e sociedade.

No ensaio do geógrafo Rogerio Haesbaert, o autor descreve diversas compreensões que a noção de território pode conter, admite que vivemos um tempo de múltiplas proposições teóricas e que a noção de território pode ser vista através de várias lentes, tais como:

- Perspectiva materialista: relações entre território e natureza: o território como, fonte de recursos, o lugar das relações econômicas, de produção;

- Perspectiva idealista: relações entre território e cultura, incorpora uma dimensão ideal ao espaço, reforçando seus valores simbólicos e de representação;

- Perspectiva política: território e integração social: prioriza as relações de poder e de controle e ordenamento pelo Estado-nação moderno;

- Perspectiva histórica: o território e as relações sociais; ${ }^{11}$ 
Como vimos território é valor, um valor relacional.

Porém, para Haesbaert o principal debate no campo da Geografia contemporânea são os processos de desterritorialização: "Desterritorialização como domínio das redes, dos fluxos, da mobilidade"12; sob a perspectiva de relacionar território e a ideia de "rede". ${ }^{13}$ E ponta como evidência desse processo: a perda das referências espaciais concretas, do sentido de lugar, a perda de poder político ligado à ideia de Estado-nação, e ainda a perda da localização econômica dada pelas grandes corporações internacionais.

Segundo Milton Santos (1996), desterritorialização é estranhamento, é mudança:

"Hoje, a mobilidade se tornou praticamente regra. O movimento se sobrepõe ao repouso. A circulação é mais criadora que a produção. Os homens mudam de lugar, como turistas ou como imigrantes. Mas também os produtos, as mercadorias, as imagens e as ideias. Tudo voa." ${ }^{\prime 14}$.

Apesar das intrigantes questões que este debate levanta, não é tempo de entrar mais na especificidade de cada uma destas relações. Contudo esta pausa nos fez ver como a noção de território não pode ser dada como um valor absoluto, ou ainda como uma nomenclatura que resume tudo aquilo que não é cidade, nem natureza. É preciso admitir a complexidade de sentidos do território e suas múltiplas dimensões, inclusive àquelas ligadas à ideia de desterritorialização.

$\mathrm{Na}$ obra de PMR percebemos que o arquiteto se aproxima deste conjunto de questões a partir de meados da década de 1990, mais precisamente quando realiza o projeto para o Concurso da nova Faculdade Getúlio Vargas (1995). Sobre um lote na periferia da cidade de São Paulo, em declive, coberto por uma mata, o arquiteto propõe uma rua aérea que conecta diversos pavilhões "flutuantes", que tocam o chão em poucos e precisos pontos.

Essa estratégia projetual se apresenta novamente em projetos como: Centro desterritorialização é aquele que propõe a emergência de uma sociedade 'em rede' (Castells, 1996) em detrimento de uma sociedade 'territorial' Castells contrapõe um 'espaço de fluxos' a um espaço de lugares'”. ibidem, p. 57

14 SANTOS, Milton. A natureza do Espaço: técnica e tempo, razão e emoção, 2006. p. 327 (1998); a primeira versão para os Museus da USP, São Paulo (2000); e o projeto para a Universidade de Vigo, Espanha (2003). Nenhum deles construído.

Em todos eles, a ideia fundamental é criar uma estrutura principal de circulação, em geral aérea, que ordena os fluxos nos diferentes espaços. Como uma veia que ali- 


\section{NOVAS ESTRUTURAS ESPACIAIS}

ESTES PROJETOS APRESENTAM-SE A PARTIR DE UMA NOVA ESTRATÉGIA PROJETUAL CUJA "VEIA" É DADA PELA CIRCULAÇ̃̃o AÉREA
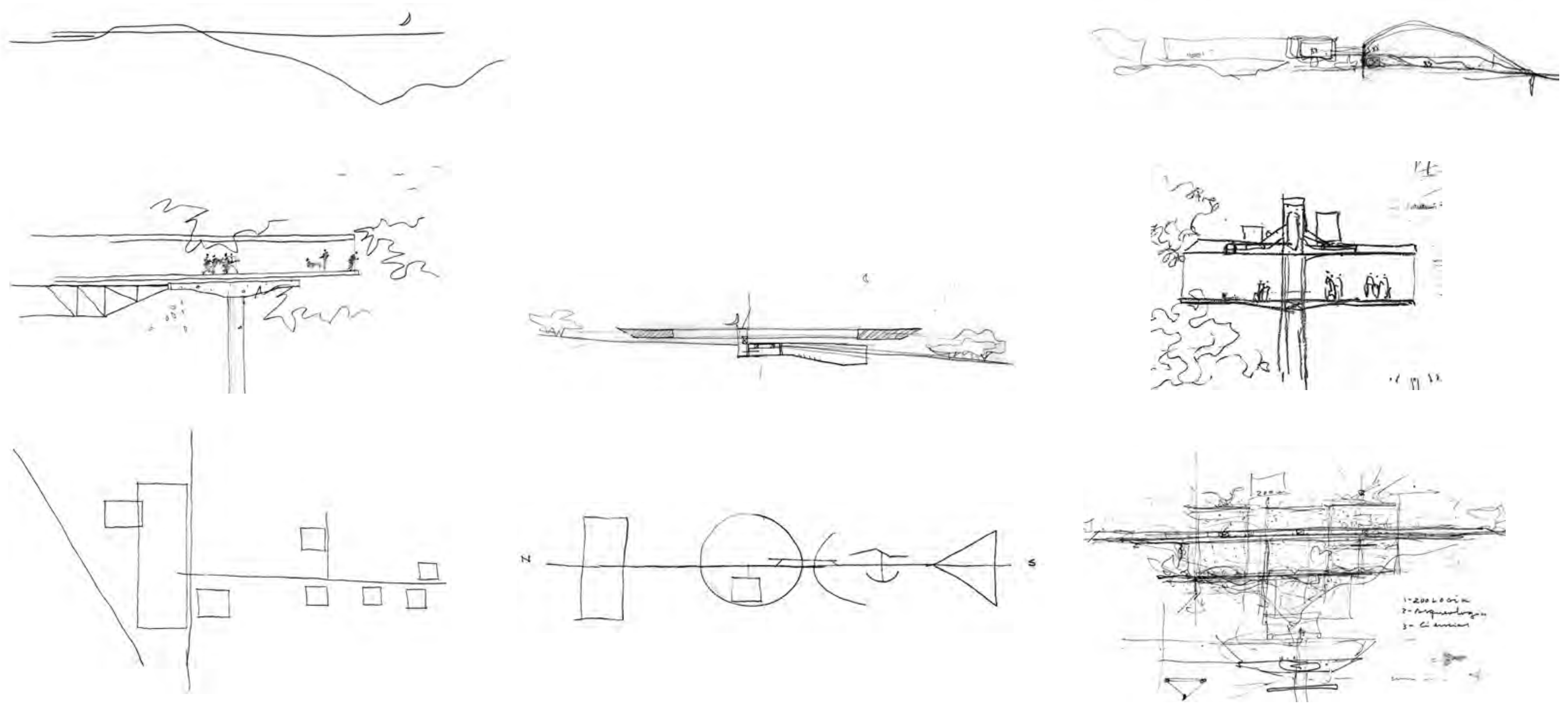


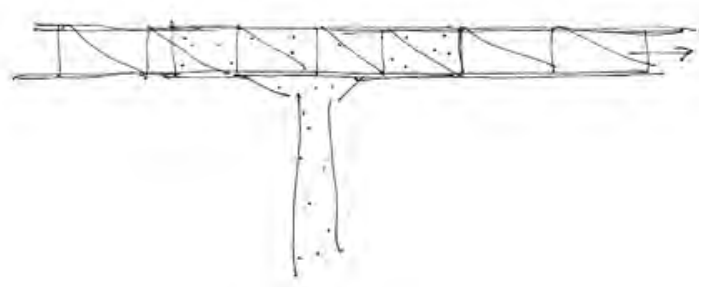

2
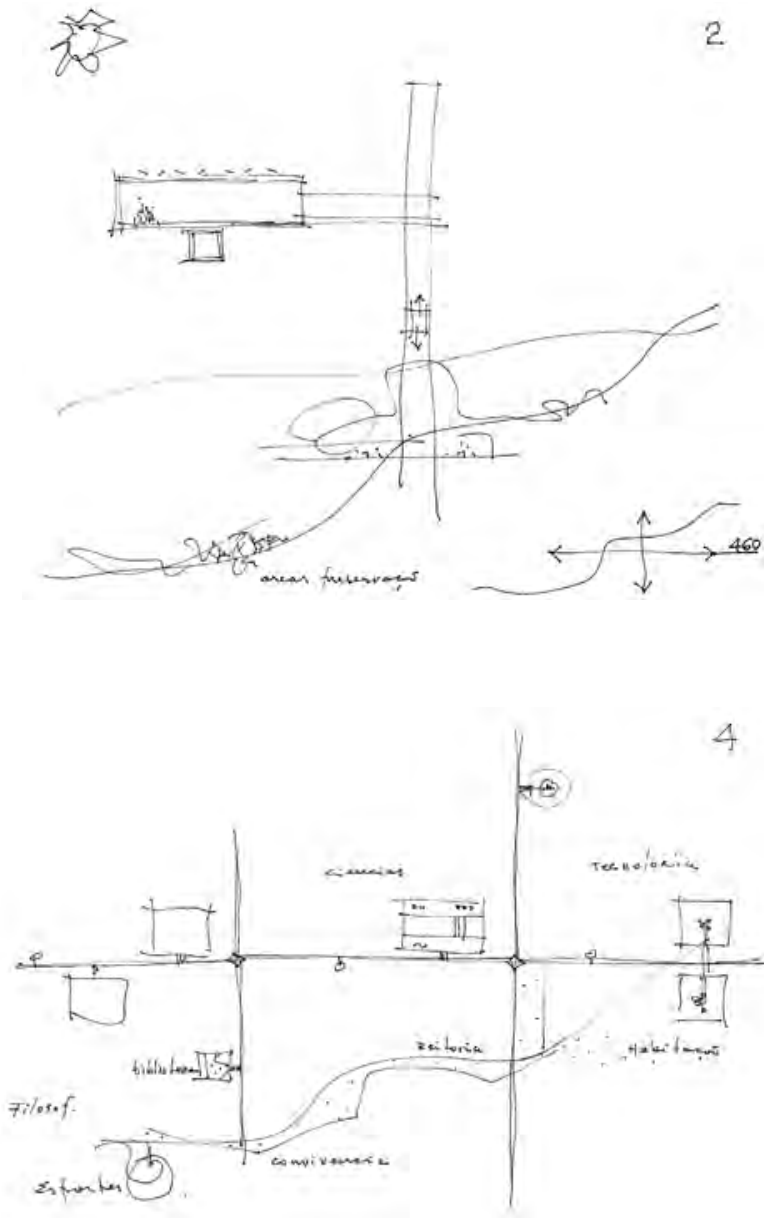

menta e sustenta essa arquitetura aparentemente desconexa do chão, desterritorializada, como uma alternativa ao real. Tais estruturas flutuantes parecem ter em relação à existente uma ligação paradoxal de certo abandono do real - quando estabelece um outro patamar de articulação entre os espaços- e de transformação, pois cria uma estrutura que modifica o real, faz ver diferente aquilo que já havia, em outro enquadramento.

Este raciocínio espacial se expande inclusive para projetos ainda maiores como os apresentados para os Jogos Olímpicos de Paris (2000) e a postulação da cidade de São Paulo para os Jogos de 2016 (2000). Na cidade de Paris, propõe que os pavilhões de esporte, suspensos do chão, estejam sobre um eixo perpendicular ao Canal fluvial Saint Denis, e com isso articula o programa com o resto da cidade, pelas águas. Em São Paulo, num projeto que toma em conta toda a cidade, é também pelas guas que o programa ganha sentido, neste caso, propõe que o rio Tietê seja o grande eixo articulador de todas intervenções urbanas realizadas para abrigar os jogos na cidade.

Se o projeto do Poupatempo introduz as questões da cidade contemporânea com toda clareza, como vimos no capítulo anterior, é também por meio dele que se revela a chave para a realização dos projetos recentes que reiteram um outro modo de projetar. Um novo fazer. Um caminho original para enfim entrar nos projetos dos Museus.

O Cais das Artes e o Museu dos Coches são dois museus “irmãos” separados pelo oceano Atlântico, duas estruturas similares: sólidos puros, soltos do chão, que se articulam por passagens aéreas. Dois programas equivalentes: em Vitória, um museu e um teatro e em Lisboa, um museu para o singular acervo de coches de Portugal.

A implantação dos museus estabelece uma relação aberta com o terreno, sem barreiras, que toca o chão apenas quando estritamente necessário.

As especificidades do acervo de obras de cada um dos museus parecem estar em um plano secundário na configuração do projeto, seja para um acervo de arte contemporânea que ainda não está formado, em Vitória, ou para os coches portugueses. 


\subsection{CAIS DAS ARTES, VITÓRIA ${ }^{15}$}

"Localizado na Enseada do Suá, numa extensa esplanada aterrada em frente ao canal que conforma a ilha de Vitória, o projeto faz um elogio desse território construido pelo monumental confronto entre natureza e construção, numa cidade cotidianamente animada pela presença do porto, no constante e enérgico trabalho das docas." ${ }^{16}$.

Paulo Mendes da Rocha

No ano de 2008, quando iniciamos a pesquisa sobre a obra de PMR, o arquiteto estava começando a elaborar o projeto para o Cais das Artes, localizado na Baía do Suá, em Vitória. Não era a primeira vez que fazia um projeto para a cidade, em 1991 havia feito um estudo para o Museu Krajcberg e em 1993, concebido o Plano Urbanístico para a Baía de Vitória, no qual propunha um novo uso para as margens do canal.

Sendo sua cidade natal, Vitória faz parte das memórias de infância do arquiteto. Ao longo da elaboração do projeto, não raro afloravam recordações desta época, dos tempos de escola, das brincadeiras na praia e das histórias de família ${ }^{17}$.

Ao descrever uma abertura na empena do Museu, lembra, por exemplo, que no morro para o qual esta janela se abre, as pessoas costumavam colher mariscos e aquecê-los em braseiros dentro de um baldinho, e comiam lá mesmo!

O terreno do Cais das Artes está localizado a beira do canal que dá acesso ao Porto de Vitória, num lugar privilegiado da Baía do Suá. Sua frente, com trezentos metros de comprimento, dá vista ao Morro do Convento onde figura uma construção jesuíta, marco histórico da cidade. Esta porção da cidade, de ocupação recente, configura um entorno bastante rarefeito, com pequenas casinhas do outro lado da rua e a duas quadras já na avenida principal surgem os primeiros edifícios altos, que completam a paisagem.

O movimento das grandes embarcações no canal estreito constitui um espetáculo a parte. Não será difícil perceber porque a vida do canal, o ir e vir dos barcos, irá dominar o sentido do projeto, mais que a configuração urbana ao seu redor ${ }^{18}$.

O programa do Cais das Artes prevê a construção de um museu de $10.000 \mathrm{~m}^{2}$, um anexo administrativo, e um teatro de ópera de aproximadamente 700 lugares. Foi



FIG 81

VISTA A PARTIR DO MORRO DO CONVENTO, DO OUTRO LADO DO CANAL

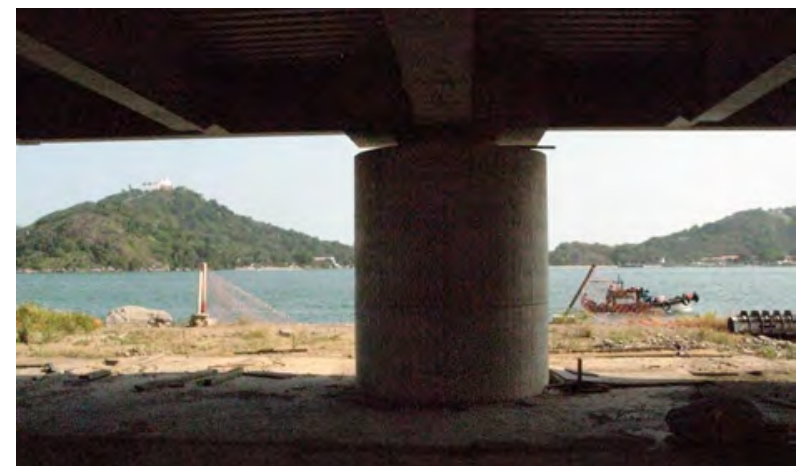

FIG 82

SOB O VOLUME DO MUSEU.

15 A obra do Cais das Artes encontra-se neste momento parada, com promessas do governo do estado de prosseguir em breve. Atualmente, o volume do edifício administrativo está quase terminado, o do museu tem sua volumetria externa realizada, mas não as lajes intermediárias e o teatro está parcialmente executado, mas não podemos ainda ver o sentido total de sua volumetria.

16 ROCHA. Paulo Mendes. Memorial de apresentação do projeto.

17 Uma dessas histórias: sua avó costumava fazer sorvetes de fruta, caju, manga... e para que sorvete tivesse tempo de congelar antes que as crianças afoitas abrissem a geladeira ela ficava na cozinha fazendo crochê esperando o doce endurecer. Em um dado momento dizia, está pronto! Ou seja, a lembrança de PMR é que ela media o tempo pela quantidade de crochê que havia feito!

18 Como parte da maquete, PMR confeccionou alguns navios cargueiros, feitos primorosamente com papel colorido, em tamanhos diferentes, de origens distintas do globo, os navios gregos e russos. 


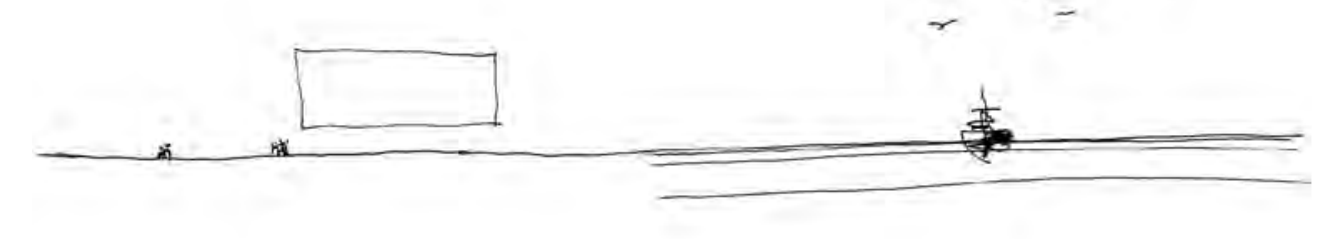

- mommental confrouto natoreze e construcōo. necte levgar, sugere os edificios suppeusos no ar as aisuais hivres edesimfudidas, fran a paisagen $<$ a espetráculo los traballos no var

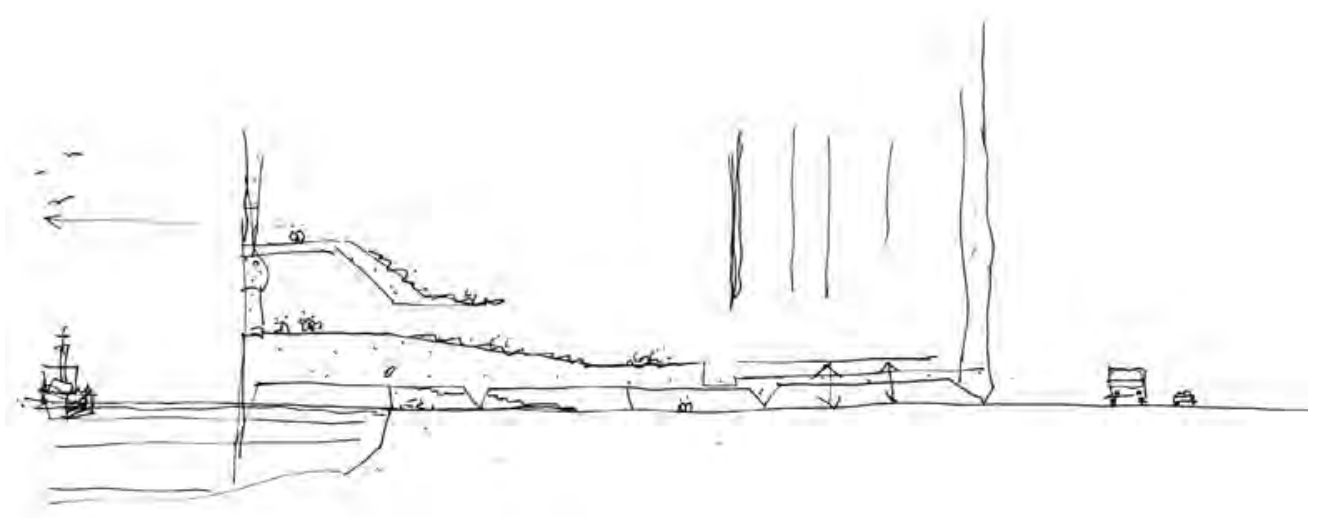

No teatio, o solo infuropio frava

comstrucios abaito do nivel do war exige que se eleve os miveis do fraber e platicia.

pran alofar os en barramentos e nuaquinainias de atroio la tralea.

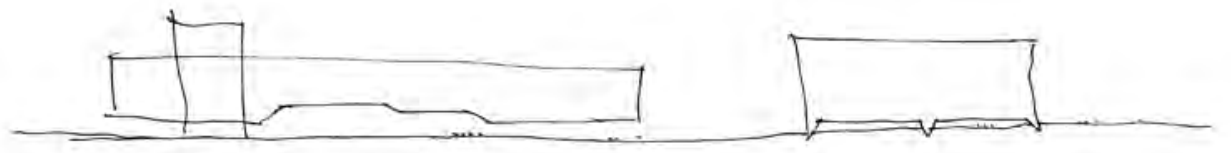

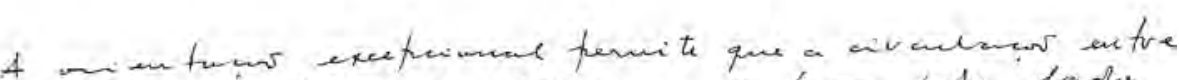



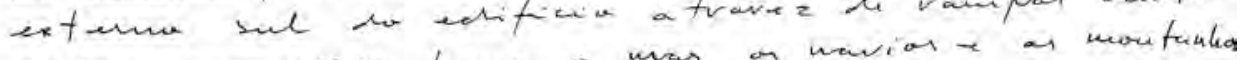
de vila velthe.

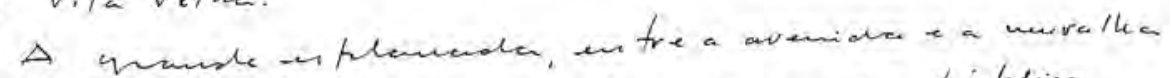

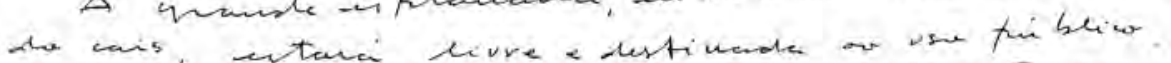

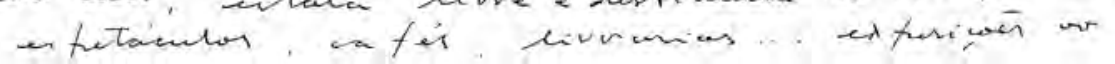
an livere.

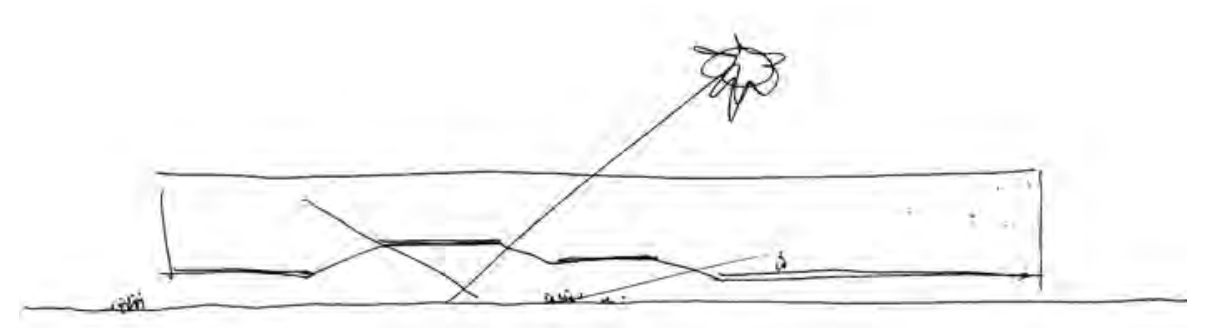

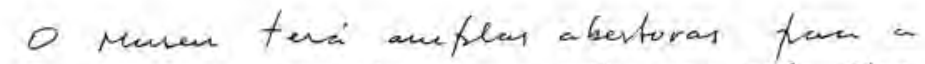
traca sem incidencia livete do sol. Unea luminosidade refletida do solo e una visos dor eventor exfermos, no ales da frace. 

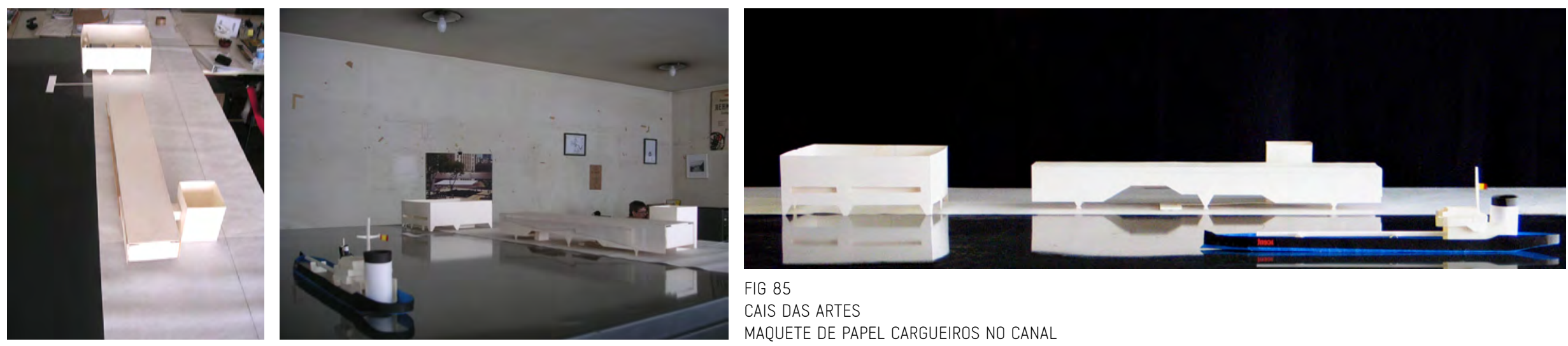

FIG 85

CAIS DAS ARTES

MAQUETE DE PAPEL CARGUEIROS NO CANAL

FIG 83 E FIG 84

AIS DAS ARTES

MAQUETE DE PAPEL SOBRE A MAPOTECA: IMPLANTAÇ̃̃̃O

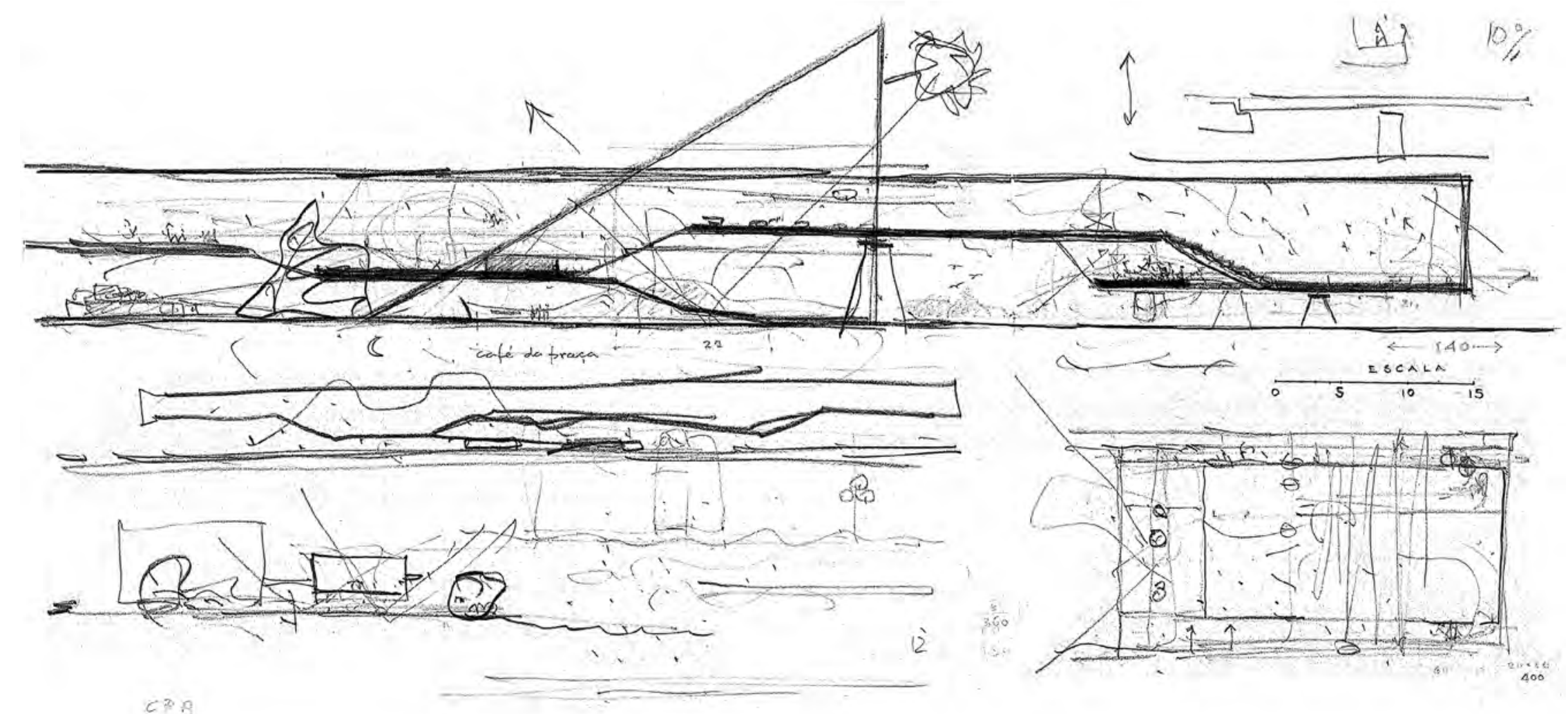

FIG OO E FIG OO

CAIS DAS ARTES

ESTUDOS: CORTE TRANSVERSAL 


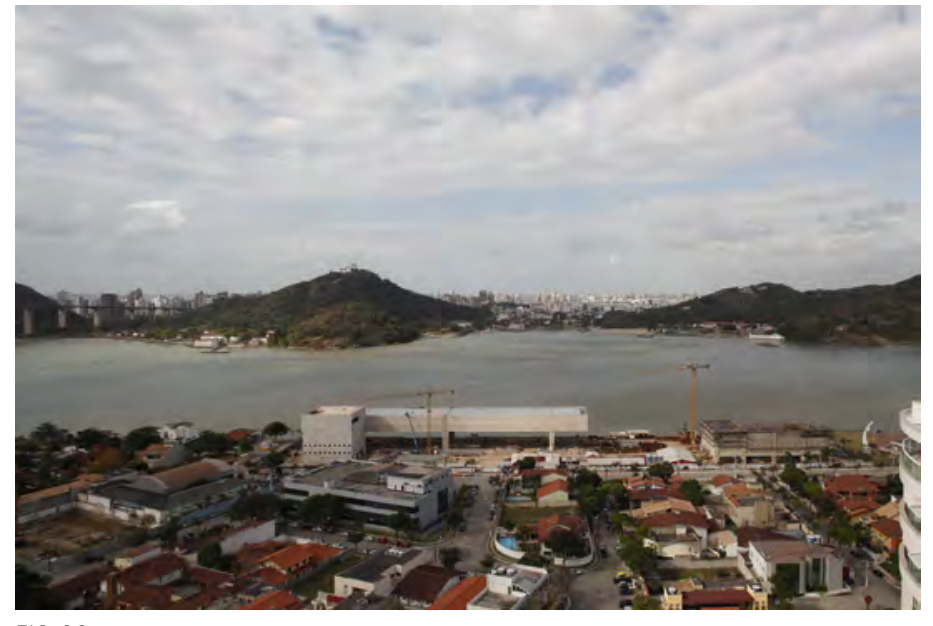

FIG 86

19 Para o projeto do Teatro havia um também umpequeno desenho feito na lousa.

20 Houve em certo momento a intenção de se fazer um estacionamento, que tinha sua configuração definida e já estudada em outros projetos: um cilindro de rampa contínua que neste caso estaria implantado sobre as águas do canal.

21 Certo dia, ao chegar ao escritório, notei que a implantação estava toda invertida. Achei que era engano, mas ao perguntar à Dulcinéia (secretária administrativa de PMR desde 1974) o que havia acontecido, ela me confirmou: "Foi o Dr. Paulo que mudou, ficou melhor assim!".

22 Em uma de nossas conversas, PMR explica sua decisão: "O Museu está a oito metros da linha d'água e a vinte da calçada porque a esplanada do Museu para o cais perderia sua força, ao passo que para a cidade ela cria um respiro numa avenida marcada por um alinhamento de prédios". A distância entre os volumes é de 50 metros, segundo Paulo, uma distância boa para que o transeunte veja o céu. No meio deste quadrado virtual, ele pensava fazer um rebaixo no chão de aproximadamente 10x10. Este furo teria um fundo de pedras, as mesmas do encabeçamento do cais, conectado com o canal por meio de uma tubulação larga no subsolo, o suficiente para que peixes e caranguejos possam passar por ela, criando um espelho d'água que se enche de acordo com a maré! a partir de um corte longitudinal do Museu e de uma maquete feita de papel, colada na mapoteca, que PMR concebeu o projeto sozinho, em aproximadamente um mês.

Cada uma destas ferramentas - corte transversal e maquete de papel - serviram como suporte para diferentes demandas do projeto. Sobre o corte na escala 1:200, desenhou o museu, a disposição espacial do programa, as circulações, aberturas e a estrutura: duas empenas de concreto de $144 \mathrm{~m}$ de comprimento, apoiadas em três pilares, com um balanço na ponta de $18 \mathrm{~m}$ de cada lado - um terço do vão principal, como convém para este tipo de estrutura ${ }^{19}$.

Sobre a maquete - feita em escala 1:300 - o arquiteto trabalhou a implantação das construções no terreno. Um fio de linha de costura preso nas duas laterais da mapoteca representava o limite do terreno, com beira no canal.

O projeto compreende três volumes diferentes, um para cada uso: museu, administração e teatro. É a partir da maquete que PMR se relaciona com a totalidade do projeto.

A volumetria de cada edifício foi definida rapidamente pelo arquiteto, como nos projetos anteriores, todas formas simples: para o teatro, um cubo de concreto de 60 metros de lado, apoiado parte no terreno, parte na água; para o museu, um volume retangular com sua face inferior irregular, composta de trechos de retas de distintos tamanhos; e para a administração, um cubo mais alto que se conecta com o museu por meio de uma passarela ${ }^{20}$.

O acerto da disposiçao espacial destes sólidos no território deu-se em processo mais lento. Como peças de um móbile, os volumes pareciam flutuar sobre o terreno, buscando uma posição de equilíbrio entre eles.

Tendo sido concebidos soltos do chão, mostrou-se tentador experimentar as diversas possibilidades de arranjo daquelas formas no espaço e explorar as diferentes configurações territoriais entre elas. Ao deixar os volumes bem próximos, por exemplo, entre eles formavam-se pequenas frestas entre eles que "lembram Veneza" dizia PMR; ou ao contrário, ao afastar o Museu da rua frontal, criava-se uma grande esplanada para a cidade, e o volume do Museu então se aproximava dramaticamente da linha d'água ${ }^{21}$.

Durantes dias, observei como o arquiteto movia as peças sobre o plano da mapoteca e de repente, como se o vento houvesse parado de soprar, fixou-as no chão como se elas tivessem encontrado seu lugar ${ }^{22}$. 
O arranjo escolhido pelo arquiteto evidentemente privilegia a relação com a água, o canal e o ir e vir dos cargueiros, numa atitude afirmativa sobre as virtudes do movimento portuário para a vida da cidade ${ }^{23}$.

Os turistas - no imaginário de PMR - viriam pela água em pequenas navetas, que atracariam sob a plateia do teatro, a qual teria os pilares de uma das empenas apoiados diretamente sobre a água.

Ao visitar a obra, fica clara a assertiva desta opção, pois nossos olhos são imediatamente atraídos para a beira do canal. Antes de entrar dirigimo-nos à água, para ver os barcos e a margem do lado de lá, e só depois nos reencontramos diante do museu. A cidade parece que ainda não chegou nesta margem do canal. A rua que dá acesso ao Cais das Artes é uma via estreita com pequenas casinhas térreas e pouco movimento de carros e pedestres. A cidade que dará vida ao museu e ao teatro ainda está por vir.

O Cais das Artes, portanto, será um equipamento cultural que trará “animação" para esta porção da cidade. Uma ação política, que conhecemos bem, dada pela instalação de museus como âncora de revitalização urbana. Lembrando o texto de Otília Arantes "Novos Museus" (1993), constatamos como tal política ainda vigora:

Não se trata apenas de uma metáfora da politica cultural francesa, [referindo-se ao Centro Cultural Beaubourg] mas de um verdadeiro emblema das políticas de animação cultural promovidas pelos Estados do capitalismo central, em função das quais mobilizam o atual star system da arquitetura internacional, no intuito de criar grandes monumentos que sirvam ao mesmo tempo como suporte e lugar de criação da cultura e reanimação da vida pública. ${ }^{24}$

No Cais das Artes, o que marca o chão não deriva de uma operação de cavar, e sim do desenho da sombra dos edifícios elevados que se reflete sobre a superfície da praça. A superfície do chão ganha um tratamento homogêneo, é a simples extensão das calçadas para dentro do lote. É um espaço onde a sensação de expansão se sobrepõe à de confinamento. Talvez porque o plano do terreno permaneça como é, in natura, ao contrário do Museu da Escultura, onde o exterior e interior parecem ser parte de uma mesma coisa. No Cais das Artes, predomina a presença do sólido como objeto autônomo sobre a superfície do terreno.

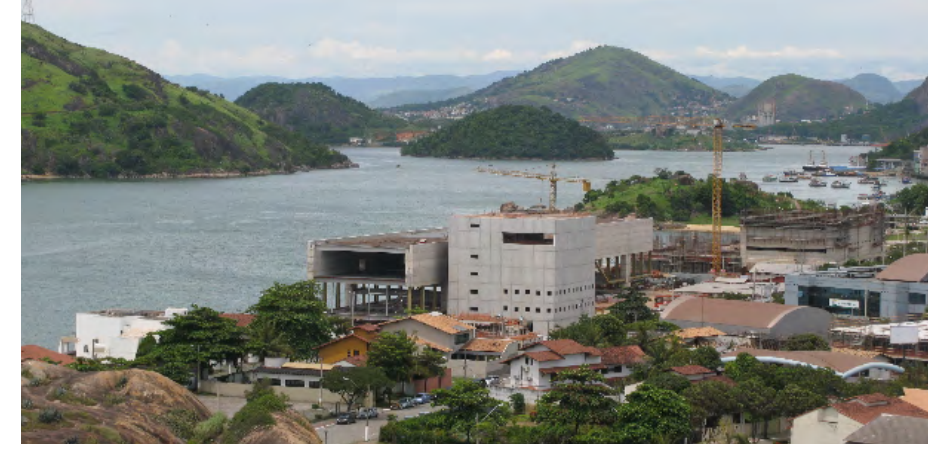

FIG 87

VISTA A PARTIR DO VIADUTO QUE ATRAVESSA O CANAL

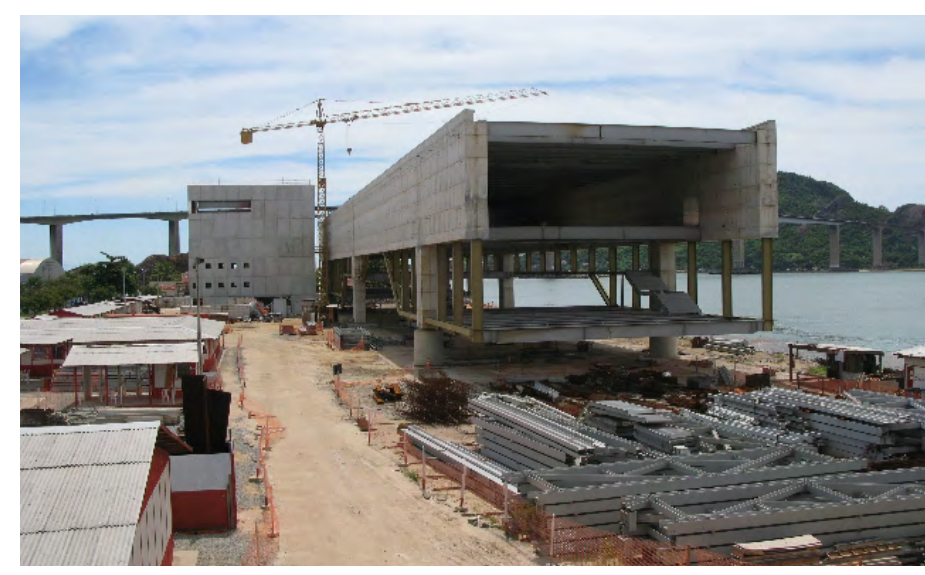

FIG 88

FOTO DA OBRA EM DEZENBRO DE 2011
23 Com o desenvolvimento do porto de Tubarão localizado na porção continental do município de Vitória, cogitou-se por parte do governo desativar o porto da cidade, devido ao baixo calado do canal e sua estreita dimensão, que impede a entrada de navios de grande porte.

24 ARANTES, Otília B.F. O lugar da Arquitetura depois dos Modernos, 1993. p. 240. 


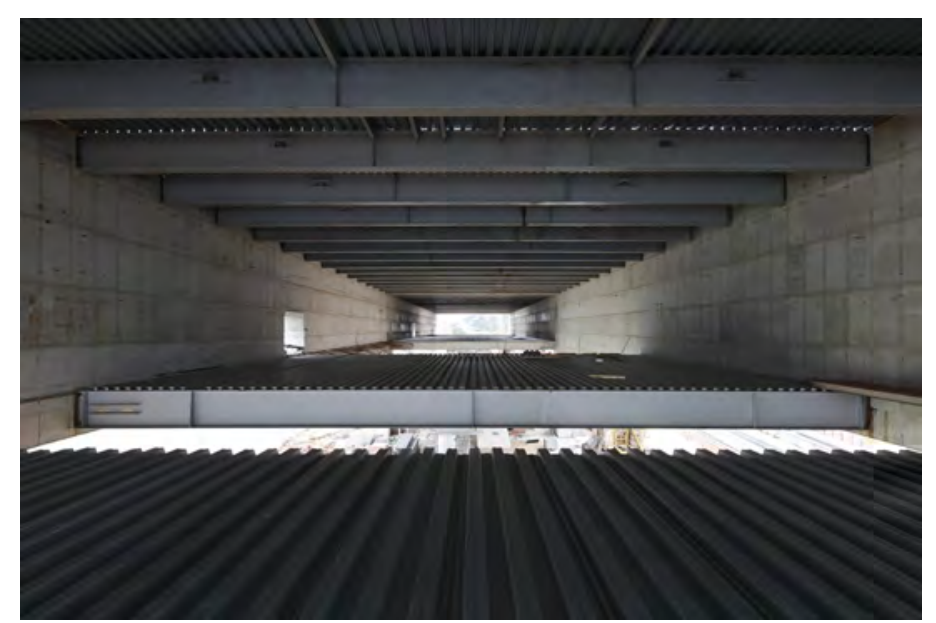

FIG 89

IMAGEM INTERNA DO PAVILHÃO DE EXPOSIÇÕES
Nos três volumes a relação com o exterior é dada por aberturas ortogonais desenhadas nas superfícies maciças das empenas de concreto: janelas e não planos de vidro. Esta atitude surpreende por dois motivos: primeiro porque a transparência entre interior e exterior em seus projetos precedentes era dada pela constituição de superfícies de vidro contínuas, então o que se via era um plano transparente e não a figura de uma janela; e em segundo lugar, porque dada a exuberância visual do lugar, seria de se esperar a presença de grandes planos de vidro para o canal.

O único plano de vidro que há no museu é uma grande superfície de vidro inclinada, que relaciona o espaço interno dos salões de exposição com o plano do chão. Trazendo, segundo o arquiteto, uma luz refletida para seu interior.

O museu foi concebido como um pavilhão de exposições - como o edifício da Bienal de São Paulo - e não tem um acervo específico - sabe-se vagamente que receberá um acervo de arte contemporânea. Assim o que ordena o espaço não é uma coleção particular, como veremos no Museu dos Coches, mas o percurso, como se passeia pelos diversos andares. Aqui novamente o arquiteto desenha a circulação com todo cuidado: a entrada do museu se faz por uma grande rampa cujo patamar intermediário é quase uma praceta (8x8metros); as lajes intermediarias que configuram os salões de exposição, apoiam-se somente nas empenas laterais e portanto parecem pairar no vazio do volume do pavilhão, sem se tocar, deixando vazios intrigantes entre elas. Para ir de um andar ao outro temos que "sair" do volume principal e tomar as escadas que estão "fora” do museu, num pequeno volume em projeção, ao qual PMR nomina de "cristaleira", pois no desenho original era toda de vidro.

Os volumes do museu e do teatro se sustentam por estruturas similares àquelas desenvolvidas no projeto do Poupatempo: uma superestrutura feita em concreto moldado em loco com fechamentos laterais feitos por grandes treliças metálicas. A diferença aqui é que para o recobrimento das empenas o arquiteto optou por fazer placas de concreto pré-fabricadas.

$\mathrm{O}$ aço nesta obra não tem quase presença material, ele está na estrutura que fixa as lajes de piso e nas treliças principais, mas por fora tudo é concreto. Um concreto menos bruto, liso, feito de placas pré-moldadas em fôrmas de aço, que se penduram uma a uma na estrutura metálica, deixando uma pequena junta entre elas, que confere à fachada o desenho de uma quadrícula ortogonal. Com isso, o concreto assume uma textura menos contínua (como a das casas) e mais fragmentada, menos áspera e mais 


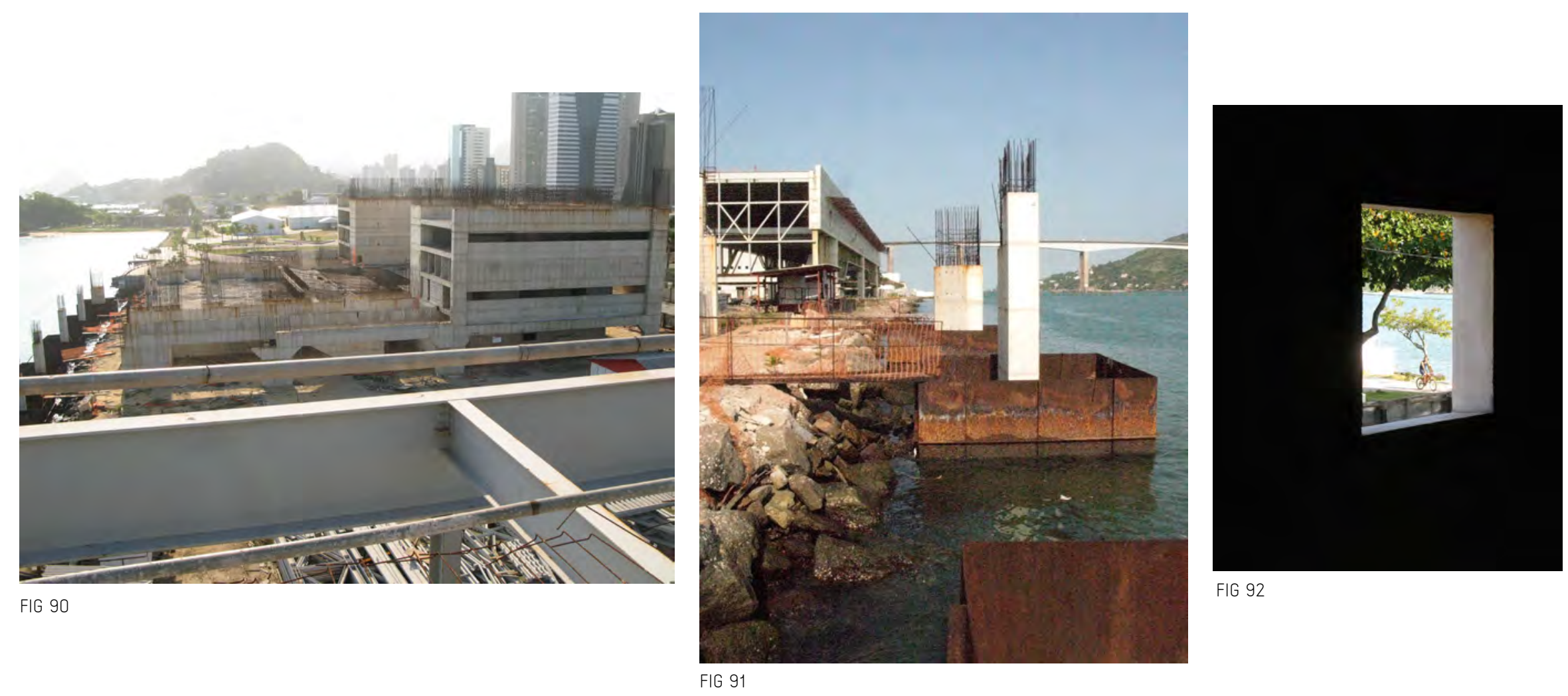



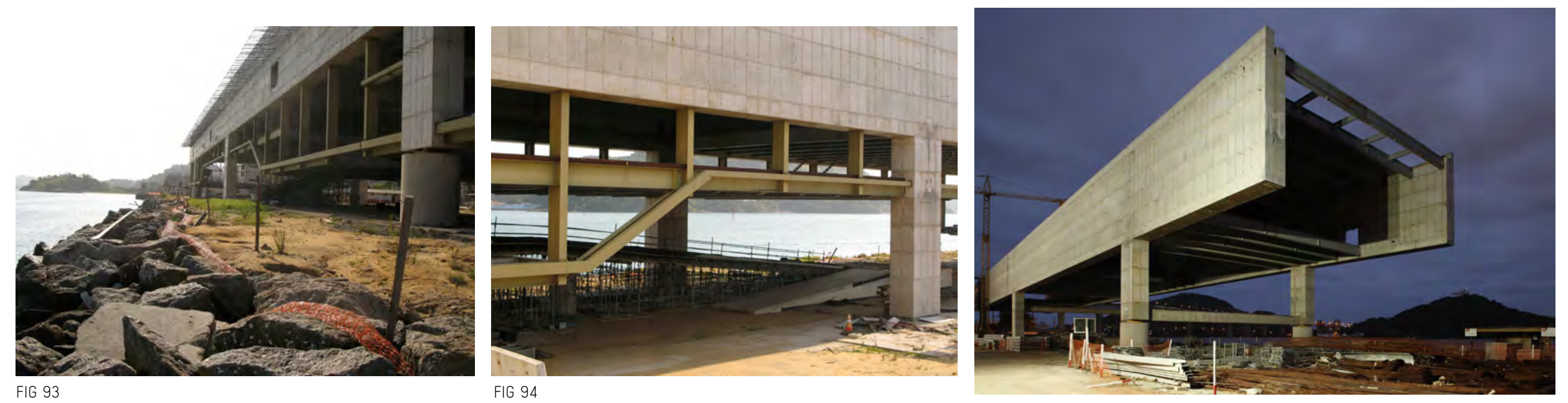

FIG 95 
lisa. Como se o concreto tivesse perdido sua propriedade "líquida". A ação sobre a matéria, neste sentido, parece menos manual.

A localização do Cais das Artes é ainda periférica em relação ao centro da cidade. Ali, onde a vida ainda não pulsa, a vibração vem sem dúvida do movimento dos barcos cargueiros, dos pequenos pesqueiros que param à margem do canal, das pessoas pescando, da vista do Morro do Convento do outro lado.

Com certeza o arquiteto enxerga nestas atividades valores que poderiam potencializar uma transformação daquele lugar. É por meio desta potência, dada pela vida animada das margens do canal, que PMR imagina uma possível transformação da cidade ao seu redor.

\subsection{MUSEU DOS COCHES, LISBOA}

Lembro-me do espanto de PMR ao receber o catálogo com os coches que estariam no museu. Como fazer um espaço para objetos tão sui generis? Uma de suas primeiras inquietações era como expor os coches sem um artefato estranho que o mantivesse equilibrado. Não poderia ser a escultura de um cavalo, nem um objeto esdrúxulo. Ponderou que a parte mais bonita das carroças são as ferragens, os arreios que amarram o cavalo, e que se elas fossem dispostas sem apoio pareceriam sem sentido, murchas, caídas; por que não fazer um suporte de aço que recebesse estes equipamentos, um objeto como se fosse o cavalo de Dali?

Outra condição que o intrigou foi a do movimento das rodas, que ao rodarem rapidamente fazem desaparecer a linha dos aros radiais: então, segundo PMR, por que não fazer no chão uma fresta milimétrica a fim de destacar as rodas do solo e assim, através de uma engenhosidade mecânica fazer com que elas girem permanentemente? Imaginou, ainda de um modo poético, que cavalos corressem livres pelo jardim e os pedestres do lado de fora em caminhos protegidos. Transformando o acervo em evento, acontecimento! ${ }^{25}$

Havia, portanto, um problema expográfico que incidiu sobre a solução espacial do projeto. Diferentemente do Cais das Artes, o desenho do Museu nasce a partir do acervo dos coches.

O terreno destinado ao novo Museu não está em uma esplanada, mas em um lote localizado num enclave urbano, entre a rua da Junqueira e a Ladeira d'Ajuda, no



FIG 96

IMAGEM DO ATUAL MUSEU DOS COCHES

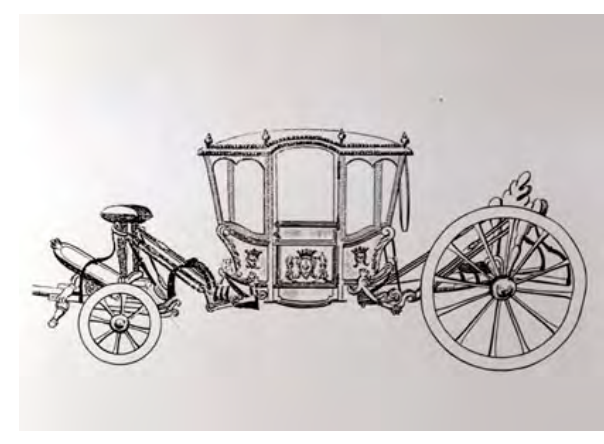

NO ATUAL MUSEU DOS COCHES AS PEÇAS ESTÃO EXPOSTAS EM UM GRANDE SALÃO ONDE TUDO BRILHA, CHÃO PAREDES E TETO. CONSTRUITDO EM 1786. POR INICIATIVA DE D. JOÃO VI (AINDA INFANTE). O EDIFICO TINHA A FUNÇÃO DE PROMOVER JOGOS EQUESTRES PARA DESFRUTE DA FAMIILIA REAL. HTTP://WWW.MUSEUDOSCOCHES.PT 
$\int_{\text {Afude }}$

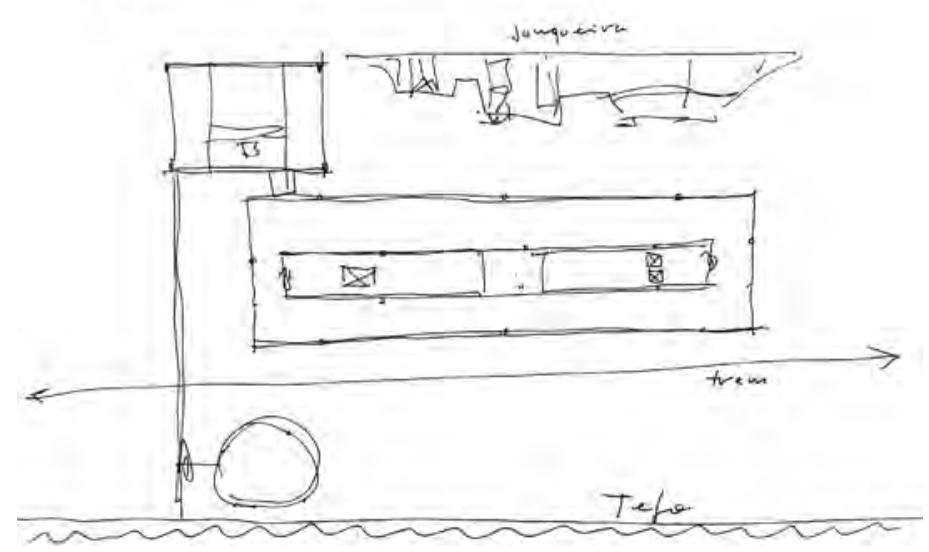

MUSEU DOS COCHES: ESTUDOS IMPLANTAÇÃO

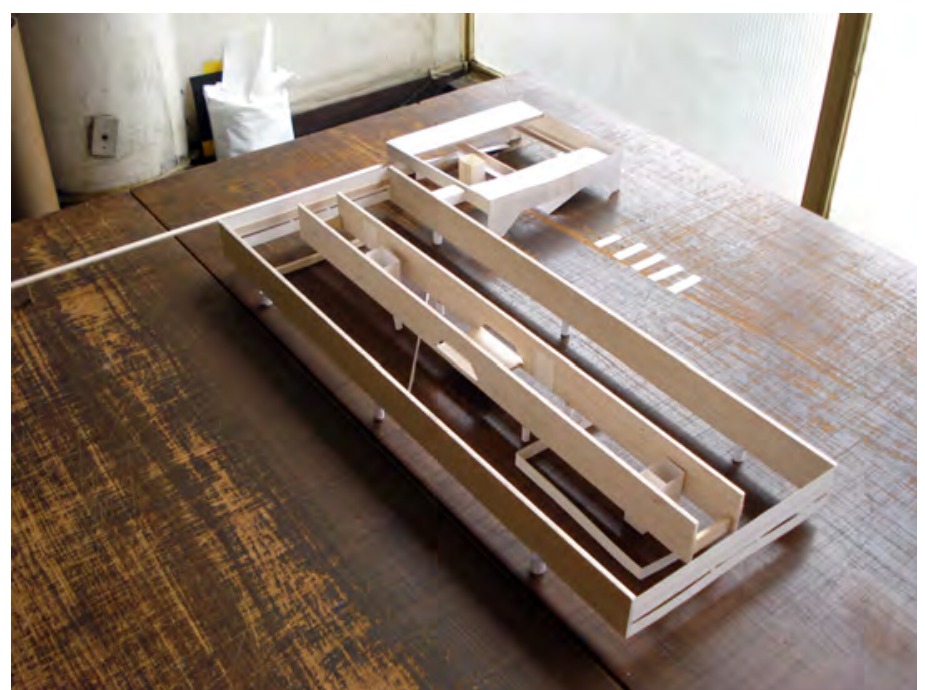

FIG 97

MUSEU DOS COCHES: ESTUDOS

MAQUETE DE PAPEL SOBRE A MESA DE TRABALHO DE PMR.

26 Projeto de intervenção urbana: "Frente Ribeirinha Ajuda-Belém".

27 Depoimento apresentado na Câmara Municipal de Lisboa em 6/09/2011: vimeo.com $/ 29315650$ bairro de Belém, , onde antigamente estavam instaladas as oficinas gerais do Exército.

A ideia da transferência do acervo dos coches para um novo espaço faz parte de um grande projeto de transformação urbana na região ribeirinha da cidade de Lisboa $^{26}$, integrando os vários equipamentos culturais existentes - Mosteiro dos Jerônimos, Centro Cultural de Belém (do arquiteto Vittorio Gregotti), Museu da Marinha e a própria Torre de Belém - numa estrutura contínua dada pelo projeto de reurbanização das margens do rio Tejo.

O terreno de $12.000 \mathrm{~m}^{2}$ disponibilizado para o novo museu tem como frente as avenidas marginais Índia e Brasília, e um conjunto de linhas de trem, que uma vez transpostas chega-se às margens do rio Tejo. De um dos lados do terreno há uma sequência de parques públicos que terminam no Centro Cultural de Belém (projeto de Vitorio Gregotti, 1993), e de pequenos casarios ao longo da Rua da Junqueira, que conformam de modo irregular os fundos do lote.

Neste caso, não se trata de pensar o confronto "monumental” entre as águas do rio e a construção, como no Cais das Artes, mas o confronto "monumental" entre a pré-existência e o novo.

Para o arquiteto, o desafio deste projeto estava em propor algo que considerasse a riqueza patrimonial da cidade, como quem segundo ele "coloca um acorde que só aumenta a mesma sinfonia" ${ }^{27}$. Não se trata aqui, portanto, de fazer um contra ponto entre o novo e o velho, mas de reconhecer as virtudes do lugar e potencializá-las espacialmente.

Curiosamente, o raciocínio espacial que o arquiteto constrói para a instalação do Museu dos Coches segue a mesma linha do Cais das Artes: desenha volumes suspensos separados de acordo com seu programa interno e interligados por passagens aéreas, deixando o térreo livre para uma grande praça pública, de novo sem barreiras nem fronteiras.

Apesar do térreo ser livre, parte de sua área é ocupada com funções do Museu, mais ligadas ao dia a dia da cidade: a loja, o café e a oficina de manutenção dos coches, toda envidraçada, que traz para o público, uma intrigante visão das "entranhas do Museu”.

$\mathrm{O}$ acesso público às salas de exposições se da por meio de dois gigantes elevadores, que pousam no meio da praça.

Assim, o térreo revela-se mais construído que o Cais das Artes. Entretanto, como o entorno é mais densamente ocupado, seja pela disposição espacial do casario ao fundo, pelo movimento barulhento das marginais ou pela monumentalidade do 
Jardim dos Jerônimos ao lado, os espaços vazios da praça ganham uma importância fundamental, não só em relação ao lote, mas a todo entrono imediato do Museu. É uma praça inscrita no tecido urbano, o arquiteto cria vazios intersticiais no meio do lote, e com isso desmancha a sua geometria.

Trata-se de uma opção projetual oposta, por exemplo, ao Centro Cultural de Belém, de Gregotti, onde os vazios estão intramuros. Mais que isso, uma opção pouco vista na cidade, como uma visão estrangeira (e porque não brasileira ${ }^{28}$ ) do lugar. Só podemos imaginar, com alegria, o susto que os lisboetas levarão quando os tapumes que hoje cercam o Museu não estiverem mais lá29.

O projeto original é composto por três volumes independentes: o pavilhão do museu, um edifício administrativo (anexo) e um de estacionamento, implantado na outra margem da via férrea ${ }^{30}$.

Já nos primeiros desenhos e na maquete de papel realizada pelo arquiteto vemos que há uma intenção clara de conectar o Museu com o outro lado da via férrea, onde há um parque muito utilizado pelos lisboetas nas margens do rio Tejo. Para realizar tal transposição, PMR sugere transferir a passarela de pedestres localizada a poucos metros dali, para conectá-la com o edifício do Museu. E ainda propõe que o arranque da passarela se dê não na calçada da grande avenida, mas dentro do edifício anexo, localizado na esquina da rua da Junqueira com a ladeira d'Ajuda.

Com este movimento, o arquiteto inclui o espaço do anexo como parte da travessia. O pedestre ganha a possibilidade de um novo caminho até o rio, que passa por dentro de uma construção sui genenris (como veremos a seguir), margeia a lateral do Museu - que possui uma abertura horizontal, pela qual ele pode ver de relance a exposição dos coches - e chega ao parque, tendo tido uma experiência inusitada.

Portanto, a implantação dos volumes do Museu no terreno é pensada também a partir de uma consciência das contingências daquele lugar: as particularidades do tecido urbano, da memória, e do valor da esquina.

Veremos agora como os dois volumes construídos se relacionam com os espaços internos e externos.

O pavilhão principal, onde ficará o acervo dos coches, ocupa a porção frontal do terreno, às margens da via férrea, e configura-se por um volume de 142 metros de comprimento e 48 de profundidade elevado do chão a (apenas) 4,5 metros de altura em relação à cota do térreo.

A estrutura principal do pavilhão - uma caixa metálica recoberta de placas de

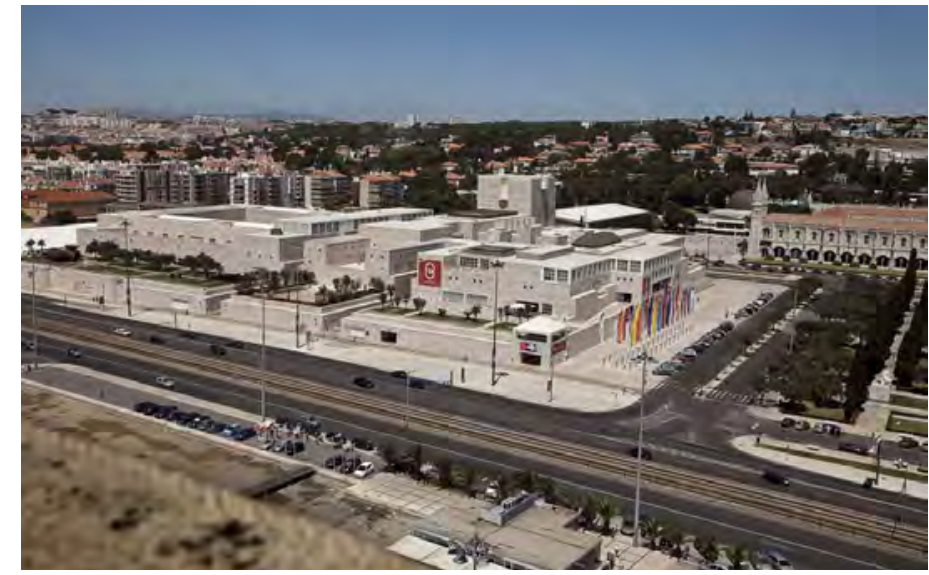

FIG 98

1989: CENTRO CULTURAL DE BELÉM. VITTÓRIO GREGOTTI
28 Quando visitei o Museu, os tapumes que fecham a obra ainda cercavam o terreno. No entanto, pelo que pude perceber em Lisboa ainda não existem lugares públicos semelhants à será a nova praça do Museu. As construções são na maioria fechadas no térreo, e esta fluidez, dada pela elevação das construções sobre pilotis, tão comum em nossa arquitetura moderna, trará vida nova à região.

29 Segundo Ana Vaz Milheiros em seu depoimento à Revista Projeto: “O museu de Paulo tem aquela grande massa, um discurso unitário, mas é parte do entorno. Ele conhece bem Lisboa, percebe como fomos construindo, ao logo do tempo, edifícios atrás dos muros.” In Revista Projeto Design, $\mathrm{n}^{\circ}$ 395, janeiro de 2013.

30 A ideia de realizar o estacionamento não era uma demanda do projeto, mas PMR ao visitar o lugar percebeu a de possibilidade incluir tal equipamento beneficiando não só os visitantes do Museu dos Coches mas das outras atrações do lugar também. E ao dispô-lo na outra margem da via férrea reforça a necessidade de se implantar a nova passarela. 


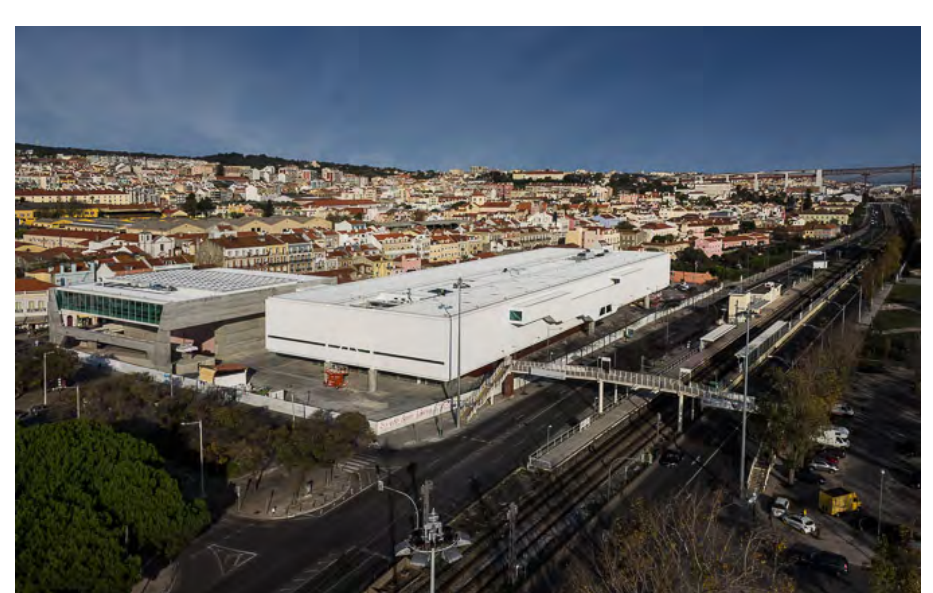

FIG 99

2008: MUSEU DOS COCHES

VISTA GERAL DO MUSEU.A PASSARELA QUE SAI DO ANEXO E ATRAVESSA A LINHA FERREA AINDA NAO FOI CONSTRUIIDA.

31 No atual Museu dos Coches as peças estão expostas em um grande salão onde tudo brilha, chão paredes e teto. Construído em 1786, por iniciativa de D. João VI (ainda infante), o edifico tinha a função de promover jogos equestres para desfrute da Família Real. http://www.museudoscoches.pt alumínio- se apoia num conjunto de pilares redondos dispostos nas faces externas do pavilhão. Nas faces menores, o arquiteto dispõe dois pilares, cujo eixo de implantação está desalinhado com os pilares que sustentam as vigas principais. Este desencontro cria, nos quatro cantos do pavilhão, um balanço estrutural que faz com que esta caixa de 142 metros de comprimento pareça flutuar no ar, ganhando uma surpreendente leveza.

O espaço interior do Museu divide-se em dois salões de pé direito duplo separados por uma faixa central, onde estão todas as instalações técnicas de manutenção dos coches, uma sala de exposições temporárias e circulações verticais.

O interior dos salões de exposição é um espaço homogêneo, todo branco, com paredes lisas e com poucas entradas de luz natural. Segundo o arquiteto, sua intenção era evitar qualquer menção a um possível cenário para os coches ${ }^{31}$, "para fazer brilhar aquilo que já é brilhante”.

Por esta faixa central de pé direito simples passam as passarelas que ligam o segundo andar do edifício anexo (onde está a administração) aos salões expositivos. Como no Cais das Artes, a passagem de um andar a outro se dá por um conjunto de escadas que está fora da projeção do volume, a tal “cristaleira”. Retoma-se a ideia de um passeio, agora feito por meio de passarelas soltas no vazio dos salões dos coches.

O edifício administrativo, o anexo, é, com o perdão do meu ânimo, uma pequena jóia! Está localizado bem na esquina, entre as ruas da Junqueira e da Ajuda, e portanto à ele dado a difícil tarefa de se relacionar diretamente com o entorno construído: a praça e o casario. Dentro dele estão localizados as salas de administração, um auditório, um restaurante com vista para o jardim dos Jerônimos, o arranque da passarela de pedestres e uma pequena ponte no segundo andar, que o conecta com o sistema de passarelas descrito acima.

Se a ideia inicial era a de acrescentar um acorde à sinfonia existente, é pelo edifício do anexo que este acorde toca. É por meio deste difício singular que ocorrem as principais relações urbanas entre o Museu e a cidade. O pavilhão de exposições, dada sua grande proporção, possui um caráter quase industrial, e nele não seria possível imprimir tal delicadeza.

Apesar do nome anexo, o edificio realiza-se como construção chave do projeto. Por ele faz-se a transição de escalas entre o casario delicado e antigo da rua da Junqueira e o imenso pavilhão de aço suspenso do chão.

Trata-se de uma volumetria singular, menos um edifício e mais um "amparo 


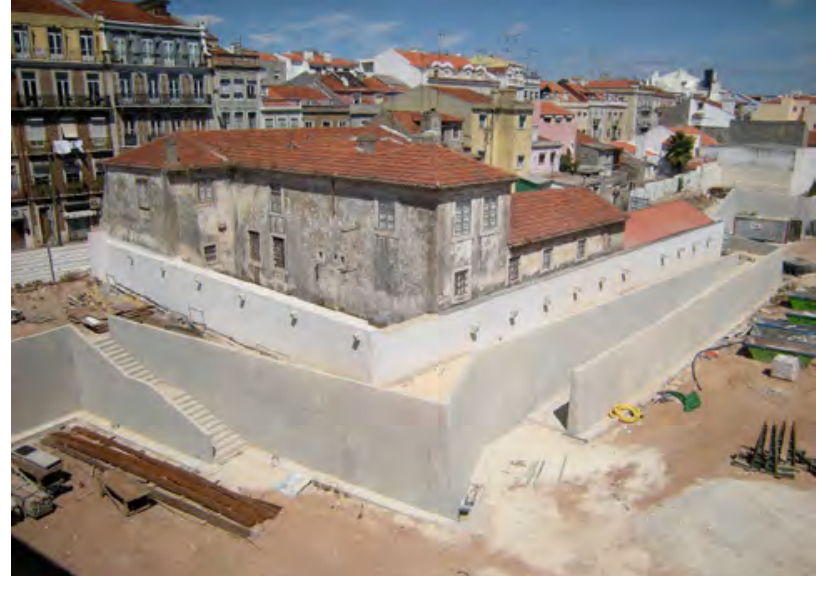

FIG 100

2011: CONFIGURAÇ̃̃O DOS FUNDOS DO LOTE.

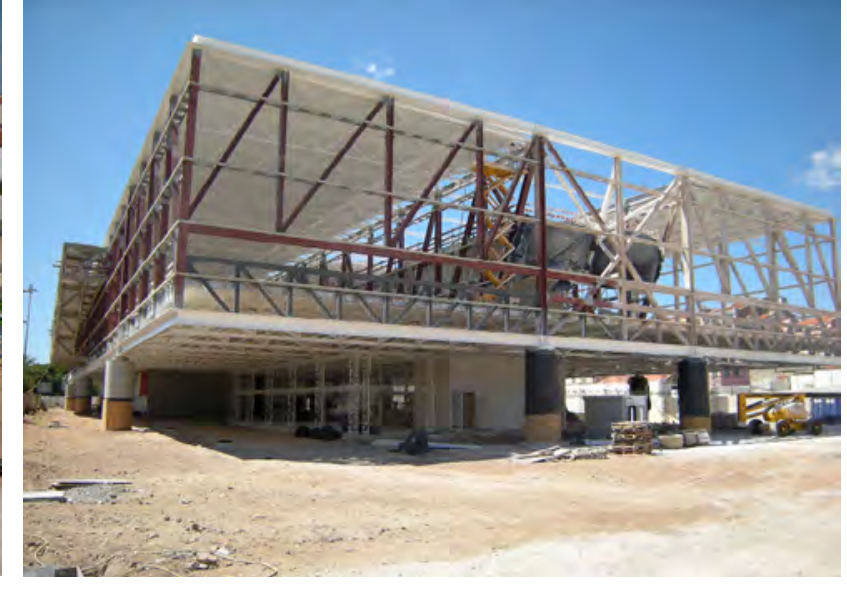

FIG 101

2011: PAVILHÃO DO MUSEU: BALANÇO ESTRUTURAL.

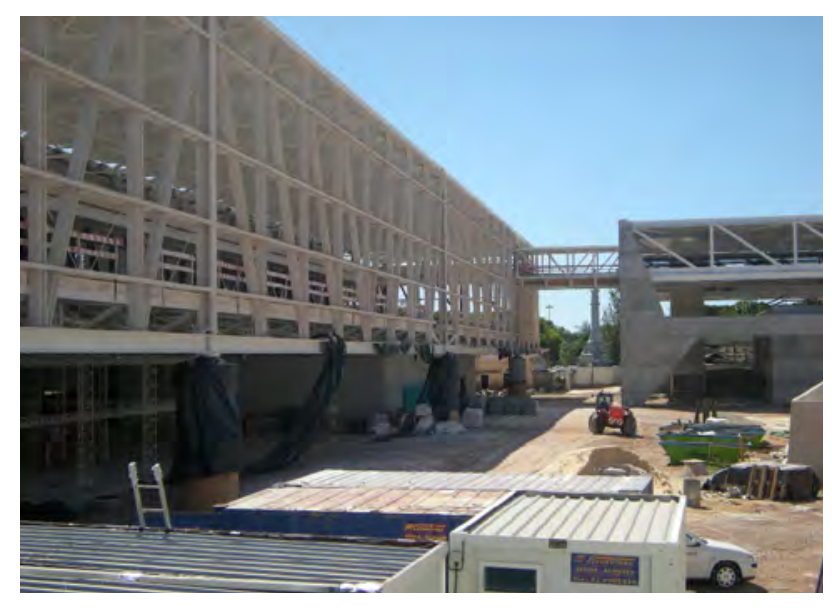

FIG 102

2011:VISTA DA PRAÇA: MUSEU E ANEXO LIGADOS POR PASSARELA AÉREA. 


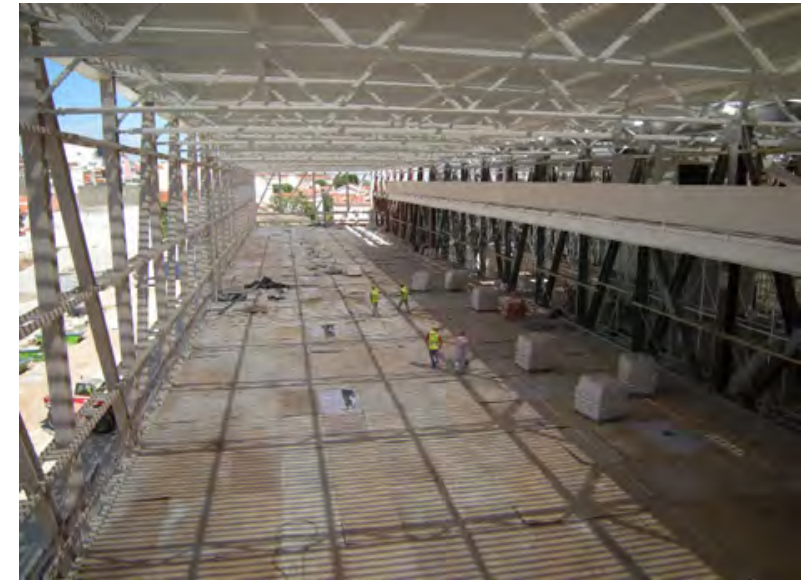

FIG 103

2011:VISTA INTERNA DO SALÃO DE EXPOSIÇÕES.Ã

DIREITA O VOLUME

DA ÁREA TÉCNICA.

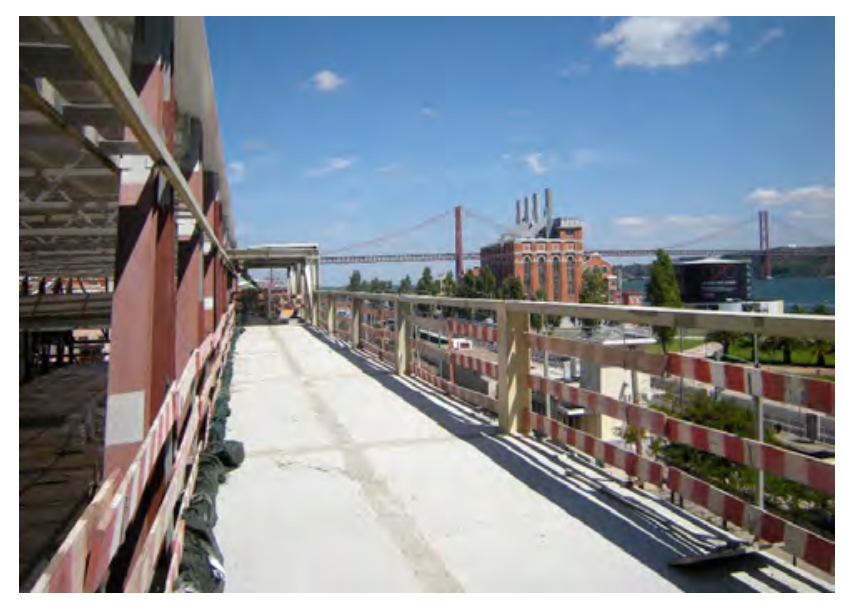

FIG 104

2011.VISTA SOBRE A "CRISTALERA" AINDA SEM FECHAMENTO A ESQUERDA O SALÃO DE EXPOSIÇŌES E Ã DIREITA VISTA SOBRE A CIDADE.

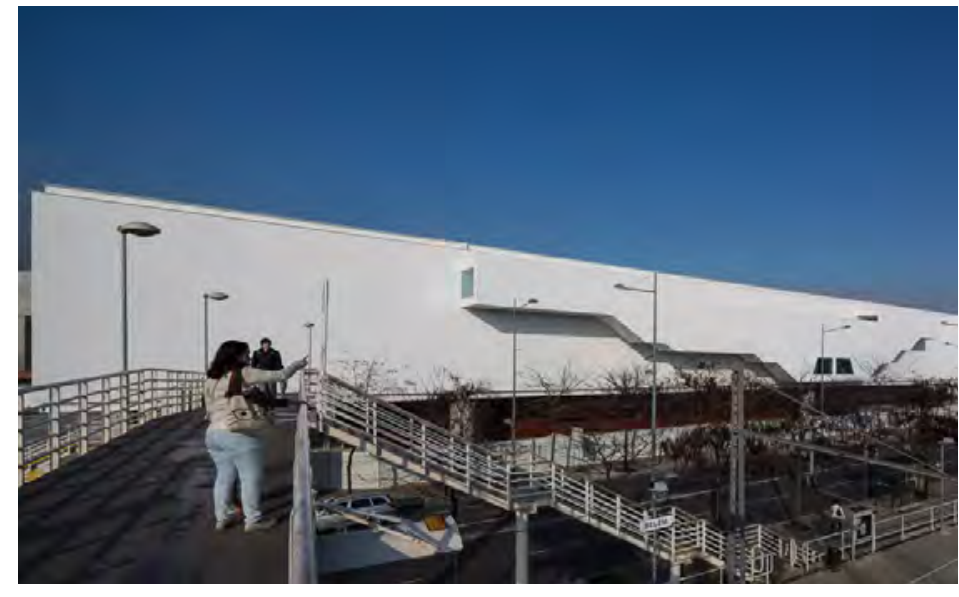

FIG 105

2012:VISTA PARA "CRISTALEIRA" A PARTIR DA PASSARELA EXISTENTE. 
estrutural”, como descreve PMR, conformado por dois contrafortes de concreto desenhados numa figura que nos remete ao projeto do Poupatempo - e uma cobertura de aço e vidro (o próprio teto da FAU-USP!).

É uma construção toda entreaberta, que não se fecha. Os “contrafortes", como denomina PMR os pilares das empenas laterais, encerram um cubo de concreto no seu interior, onde ficam os programas administrativos e o auditório. Este cubo não toca as extremidades do volume maior, nem na sua cobertura (onde há um espelho d'água) e assim cria um jogo encantador de cheios e vazios, luz da água refletida e sombra. É por um destes vazios que nasce o conjunto de rampas cuja entrada é independente e leva o pedestre da calçada da rua da Junqueira até o outro lado dos trilhos do trem, às margens do rio Tejo.

Há uma sensação de leveza ampliada pelo efeito da luz direta do sol, que passa pelos vidros da cobertura, reflete no espelho d'água interno e ocupa a porção central do espaço. O edifício congrega em um mesmo espaço experiências diversas, que não são nem exclusivas nem hierárquicas. É ao mesmo tempo passagem para o Museu, para a estação do trem, é lugar de contemplação e conversa com o vizinho.

O foyer do auditório do Museus, por exemplo, tem exatamente a mesma cota de nível das varandinhas das casas do outro lado da rua da Junqueira - que tem apenas cinco metros de largura - e é por ele que se dá a escala doméstica do espaço do Museu, como quem abre uma possibilidade de conversa com o outro lado. A varanda das casas e o foyer são espaços recíprocos, lugares de espera, de encontro e de contemplação.

Fica claro pela pureza das formas do volume do Museu que aquilo que move o pensamento do arquiteto vai muito além do prazer de realizar um belo artefato para receber a coleção dos coches, mas trata-se de uma tentativa de revelar uma cidade que já estava ali escondida debaixo da poeira. A obra cria uma nova ordem espacial que rompe com a configuração cartesiana da cidade existente e propõe outros meios de se relacionar com o espaço coletivo.

O vazio da praça é esse espaço de ruptura que quebra a regularidade do tecido urbano consolidado. Uma praça de faces irregulares, que oferece ao caminhante várias experiências: uma mais íntima, relacionada com o fundo do lote, recortado pelos jardins das pequenas casinhas; e outra de descanso na sombra do café, de curiosidade em ver o trabalho das oficinas de manutenção dos coches. Virtudes presentes na cidade, mas que ainda não haviam sido reveladas.



FIG 106

2012: ANEXO: INSERÇÃO URBANA

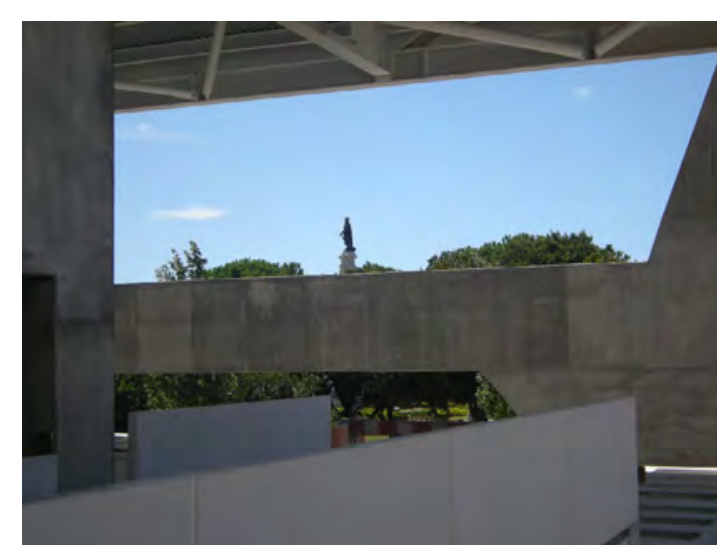

FIG 107

2011: ANEXO: VISTA PARA O JARDIM DOS JERÔNIMOS 


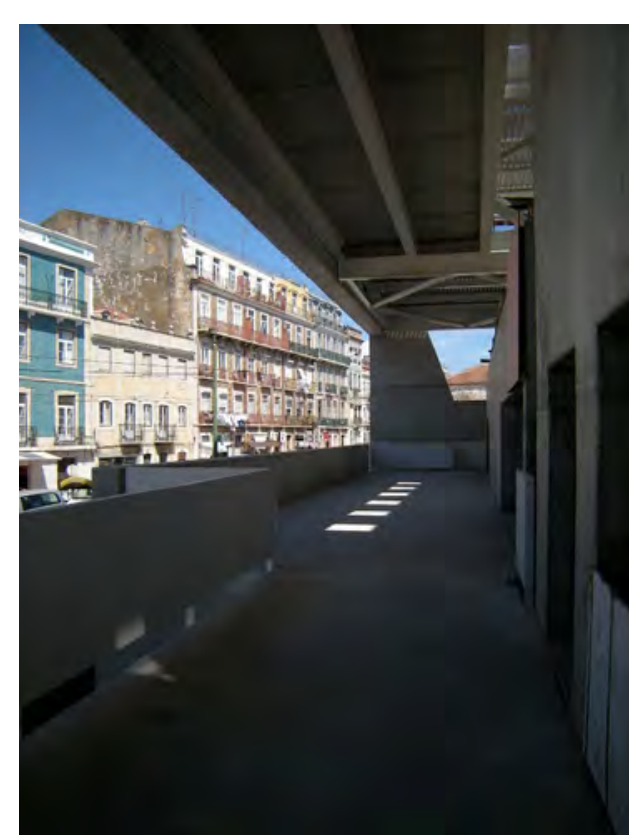

FIG 108

2011: ANEXO: FOYER DO TEATRO
O que o projeto determina claramente é que em primeiro plano está a constituição de um espaço público e em um plano seguinte, o museu. Ou seja, o desenho da praça ganha predominância sobre a visita ao acervo de coches.

Aqui, vê-se claramente que PMR quis constituir uma praça pública, conformada pela cidade já construída. No caso do Cais das Artes, a ideia é equivalente, mas nos parece que no caso de Vitória, o projeto chegou antes que a cidade.

O projeto do Museu dos Coches nos mostra que os contornos do território estabelecido pelo arquiteto, neste caso, se ampara nas condições urbanas pré-existentes do lugar, em relação ao espaço público, o sentido e importância de sua história e memória. Por outro lado é fácil perceber que os valores materiais do tecido urbano (gabaritos, recuos, cor, texturas) não são levados em conta no projeto: as longas empenas brancas do Museu, os pilares em “v” em concreto aparente do edifício anexo, o próprio uso dos pilotis, configuram um contraste evidente com as construções ao seu redor.

Vemos que esse modo de articular eixos de aproximação com o espaço urbano não é contextualista nem refratário em relação ao que há, trata-se de uma possibilidade de agir sobre o existente com base nas novas condições da cidade.

Nessa passagem da cidade mecânica para a digital, como descrevemos anteriormente, a relação entre o novo e o velho na cidade contemporânea midiática não pode ser a mesma da cidade moderna mecanizada. $\mathrm{O}$ arquiteto americano Peter Eisemann, em seu artigo “Unfolding events”, sugere que as novas estruturas urbanas e as já existentes sejam compreendidas de tal sorte que uma redefina a outra. Assim neste deslocamento, segundo Eisemann:

(...) o novo ao invés de ser entendido como fundamentalmente diferente do velho, seria visto ligeiramente como fora de foco em relação ao que existe. Esta condição fora-de-foco, permitiria uma visão embaçada, enevoada do todo, que seria novo e velho ao mesmo tempo. ${ }^{32}$

32 Para o autor, um modo possível de operar, ou se deslocar neste mundo "enevoado" é sob a forma da "dobra". A ideia de dobra, presente sobretudo nos estudos de Leibniz e Deleuze, é para Eisemann: "um contínuo formal que articula possíveis relações entre os eixos horizontais e verticais, entre figura e fundo, rompendo com as visão cartesiana da ordem espacial." Não vamos aqui estender a raciocínio sobre a "dobra", como modo de operar o espaço, mas vale destacar que se trata de uma reflexão importante, e atual, discutida sobretudo na obra de Gilles Deleuze e Rene Thom. EISEMANN, Peter. "Unfolding Events" in ZONE 6: Incorporations 1992. p. 422-427(tradução da autora).
Observando os dois Museus, agrada-nos a ideia de ver que suas estruturas, apesar de estarem dentro deste ambiente, sim, "fora de foco", têm uma relação de transformação recíproca com o lugar. Vem daí sua vitalidade.

Surpreende ainda, o fato de que em situações urbanas e programáticas tão díspares, o arquiteto tenha respondido com uma estratégia projetual tão similar; e que 
resultam em espaços urbanos completamente distintos. Isto porque podemos entender agora que em Vitória trata-se de uma ação sobre a paisagem, e em Lisboa de uma intervenção urbana.

Ao retomarmos os conceitos apresentados no início do capítulo, podemos admitir que o arquiteto tem uma consciência crítica sobre a constituição do território, em seus aspectos funcionais, culturais, e paisagísticos. Motivado também pelas novas funções da cidade contemporânea, recusa-se a tomar como dado de projeto referências estruturais que caracterizam um determinado lugar: o desenho das quadras, da malha viária, gabaritos.

O que poderia à primeira vista parecer simplesmente uma perda, ou um abandono de tais referências, é seu modo de configurar uma outra vida na mesma cidade, uma reorientação que dê conta de suas presentes exigências em novos parâmetros.

Não se trata de desprender o edifício do terreno para encontrar uma solução que poderia se repetir em vários lugares, mas de uma intervenção urbana ancorada no real presente da cidade. Neste sentido é uma ação concreta sobre o aqui e o agora.

Trata-se de uma arquitetura que não se realiza pela construção de artefatos feitos para brilhar, mas sim de instalações espaciais, urbanas, daquele que pensa o território não de modo analítico, como quem, colhe dados, resolve problemas, mas daquele que imagina, num misto de angústia e esperança, espaços que são capazes de transformar ou revelar as virtudes e a potência do lugar como abrigo para o habitat coletivo, para a vida do homem sobre este pequeno planeta.

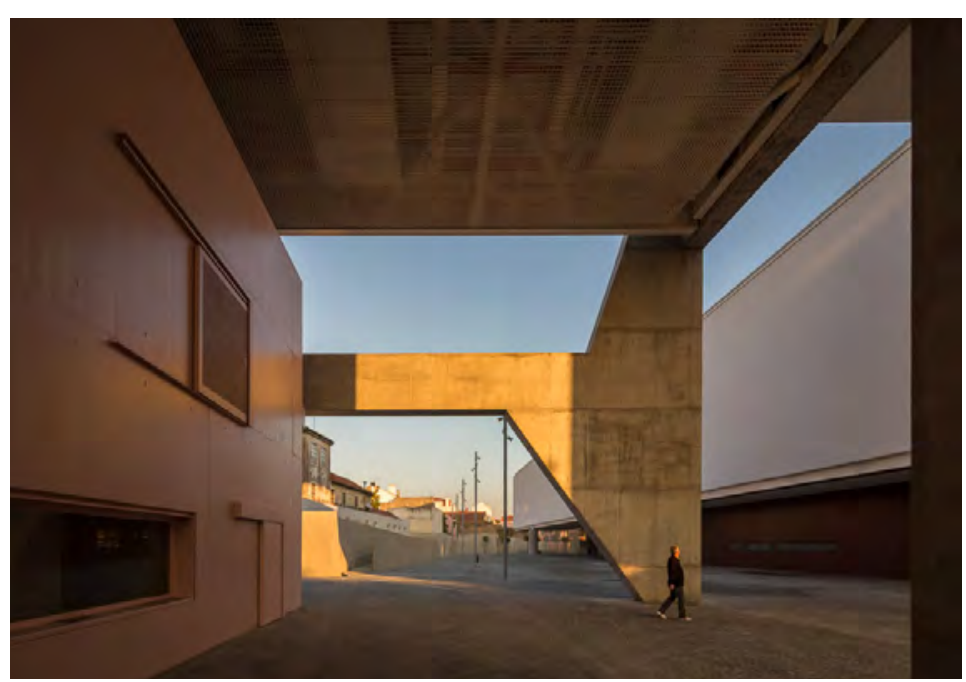

FIG 109

2012: ANEXO 


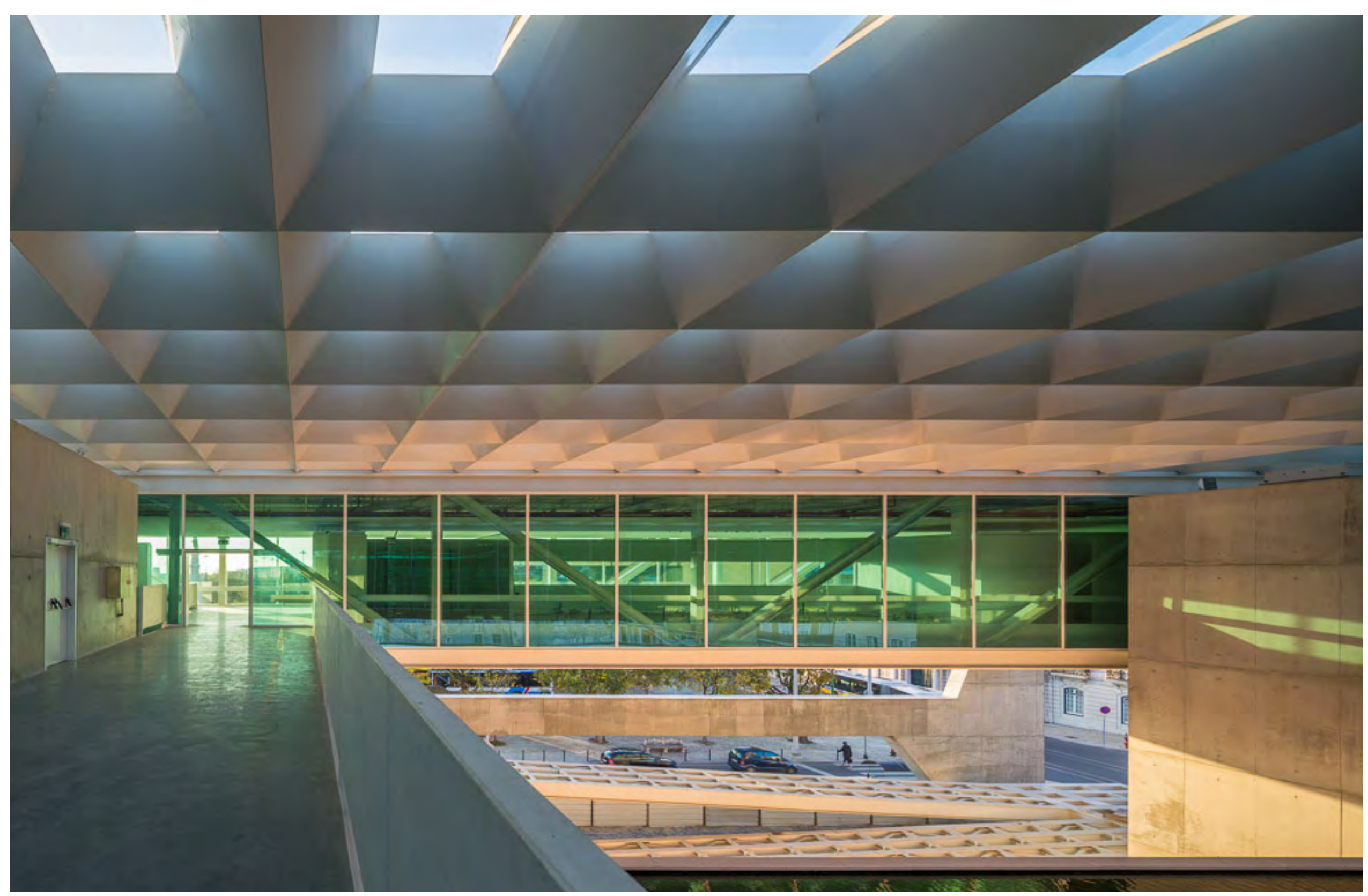




\section{SOBRE A FIGURA DO ANEXO NA ARQUITETURA}

O ANEXO É UMA CONSTRUÇÃO MUITO INTRIGANTE PARA PMR, POR ELA, SEGUNDO ELE, É QUE SE FAZ POSSÍVEL "VER O OUTRO", OU DESFRUTAR DAQUILO QUE SE FEZ. COMO VEMOS NO CROQUIS DO PROJETO PARA O RESERVATÓRIO DE URÂNIA. NO QUAL O VISITANTE VÊ NUM RECORTE PRECISO DADO PELA JANELA DO ANEXO PARTE DOS GIGANTES RESERVATÓRIOS D'ÁGUA. EM SUAS PALAVRAS:

“(...)QUANDO SE FAZ UMA CONSTRUÇÃO, DEVE IMAGINAR QUE, AO SAIR DESSA CONSTRUÇÃO OU DIRIGIR-SE DE DENTRO PARA FORA, MESMO QUE SEJA COM A VISÃO,ABRINDO UMA JANELA E OLHANDO, VOCÊ SEMPRE VÊ O OUTRO. MAS [A] IDÉIA DO ANEXO. E INTRIGANTE PORQUE DIVIDE EM DUAS PARTES UMA COISA SOD. DE ONDE UM VÊ O OUTRO, QUE SÃO O MESMO. ANEXO É COMO SE VOCÊ PREPARASSE O INTERLOCUTOR. PORTANTO, A FIGURA DO ANEXO NA AROUITETURA TEM. PARA MIM. UMA BELEZA, UM ENCANTO MUITO GRANDE (...)"

in: PIÑON, Helio. Paulo Mendes da Rocha, 2002. p. 41

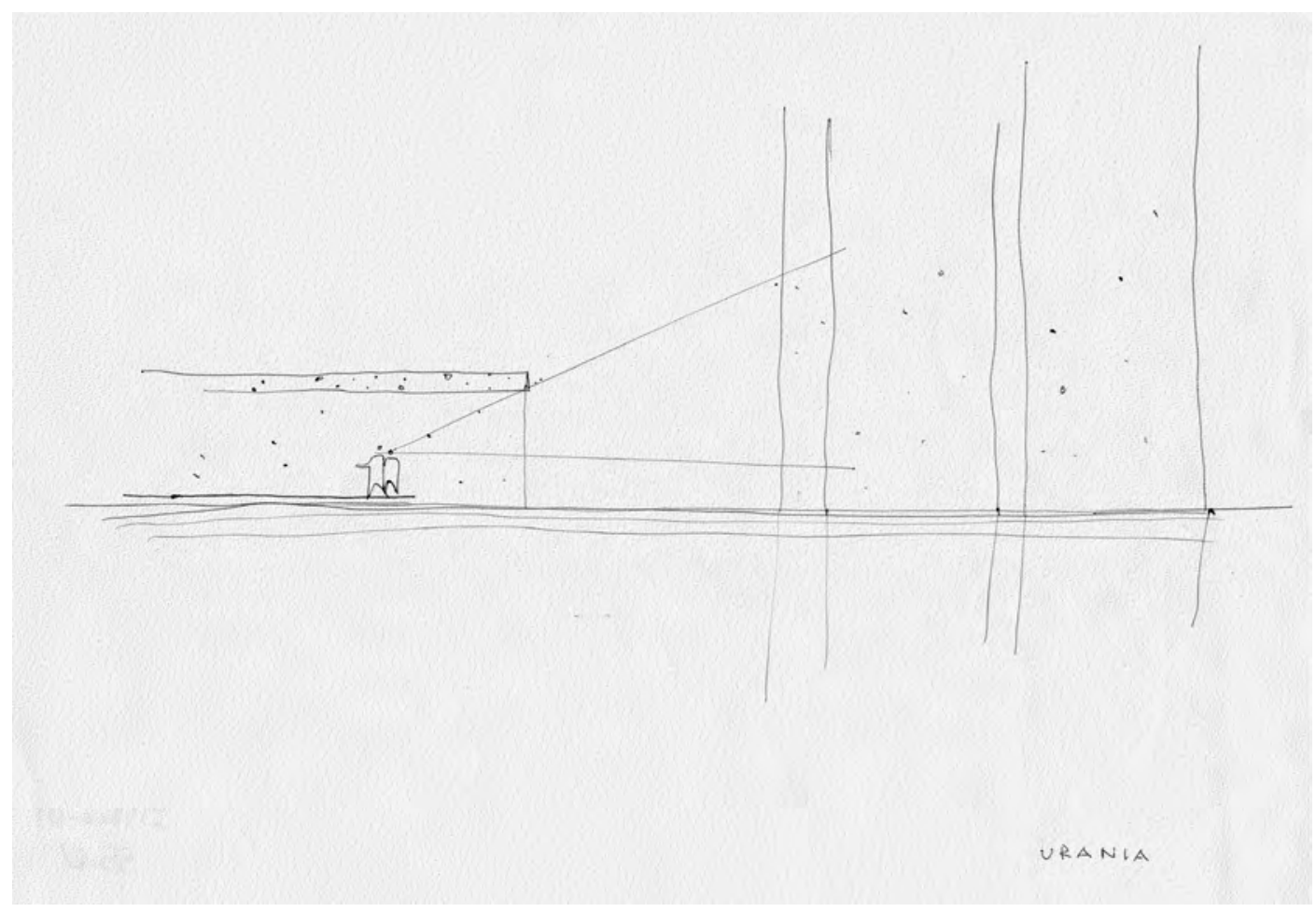

1968: RESERVATÓRIO DE ÁGUA PARA A CIDADE DE URÂNIA, SP.

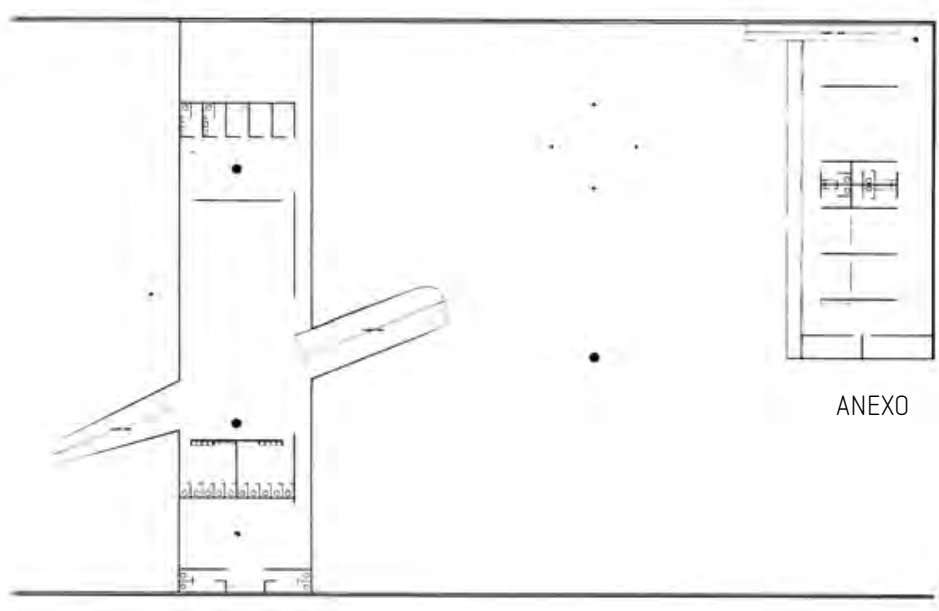

PLANTA DO SUB SOLO

S/ ESCALA

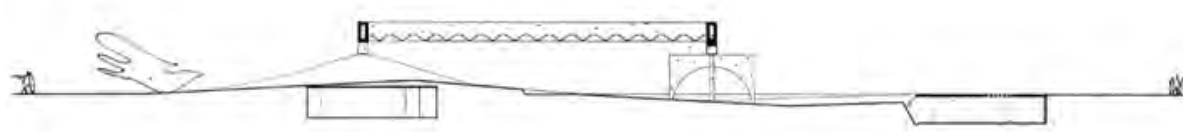

CORTE

S/ ESCALA

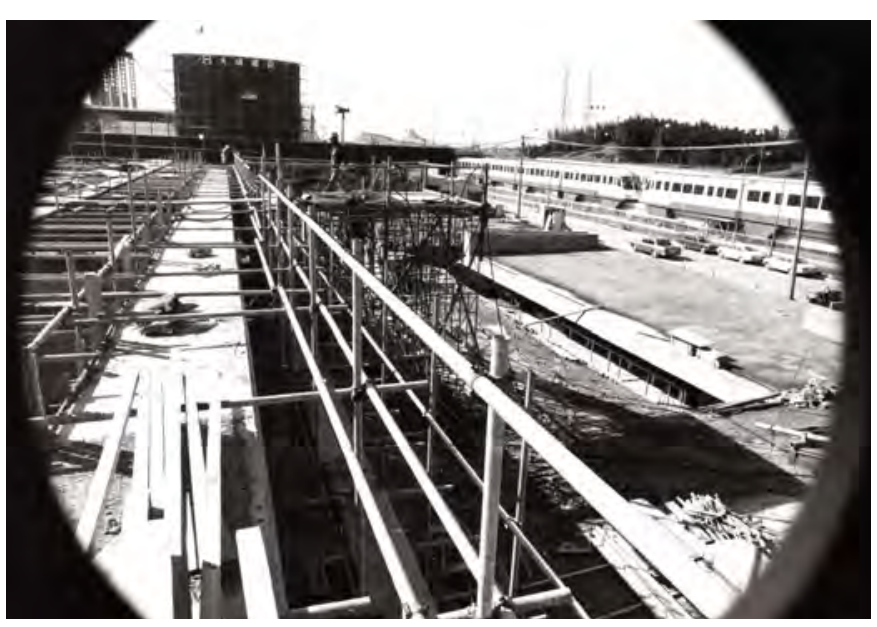

FIG 111

1970: PAVILHÃO DE EXPOSIÇ̃̃ES, OSAKA, JAPÃO.

FOTO DA OBRA: COM UM POUCO DE IMAGINAÇÃO PODEMOS VER A FRESTA DA JANELA DO ANEXO AO NIVEL DO CHÃO. O FOTOGRAFO ESTA SOBRE A COBERTURA QUE AINDA NÃO FORA CONCRETADA. 


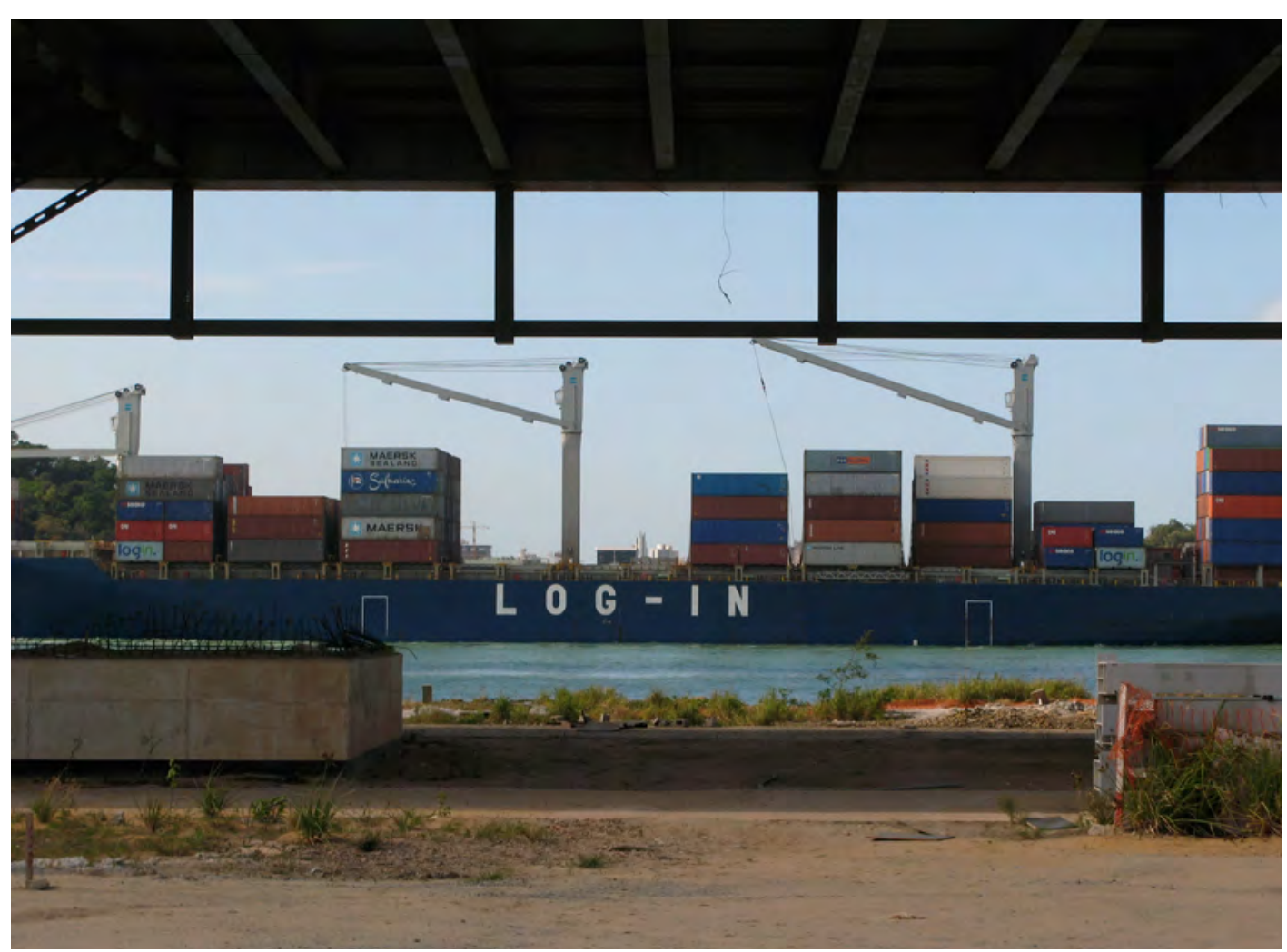

FIG 112

CAIS DAS ARTES

BAITA DO SUÁ, VITÓRA, ES

ANO DO PROJETO: 2007

ANO DO TÉRMINO DA OBRA: EM ANDAMENTO

ÁREA DO TERRENO: $21.850 \mathrm{M}^{2}$

ÁREA TOTAL MUSEU E ADMINISTRAÇÃO: $8.500 \mathrm{M}^{2}$

ÁREA TOTAL TEATRO: $14.000 \mathrm{M}^{2}$

PROJETO DE ESTRUTURA E FUNDAÇ̃̃ES: KURKDJIAN \& FRUCHTENGARTEN ENGENHEIROS ASSOCIADOS ENG. JORGE ZAVEN KURKDJIAN 

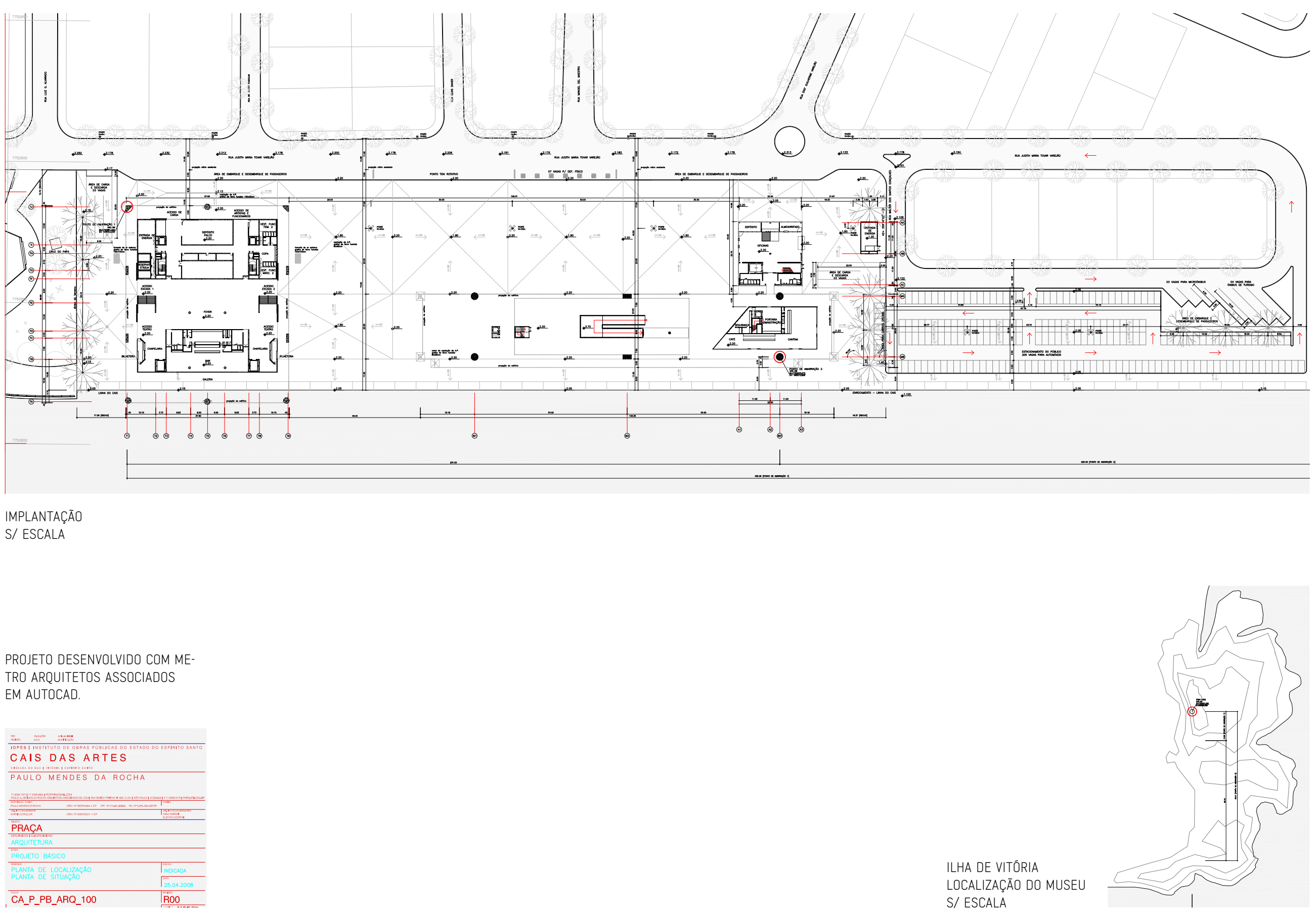

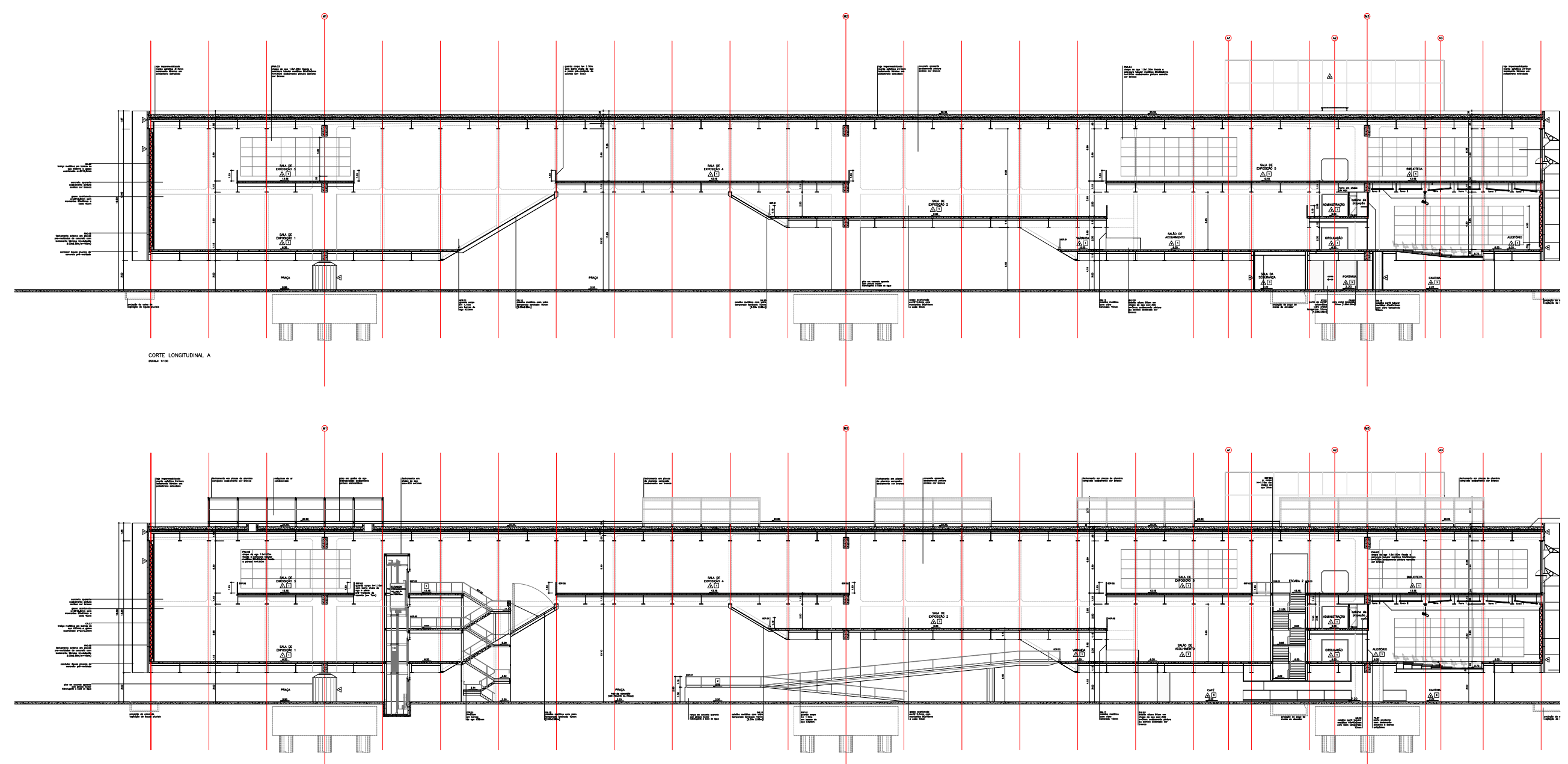


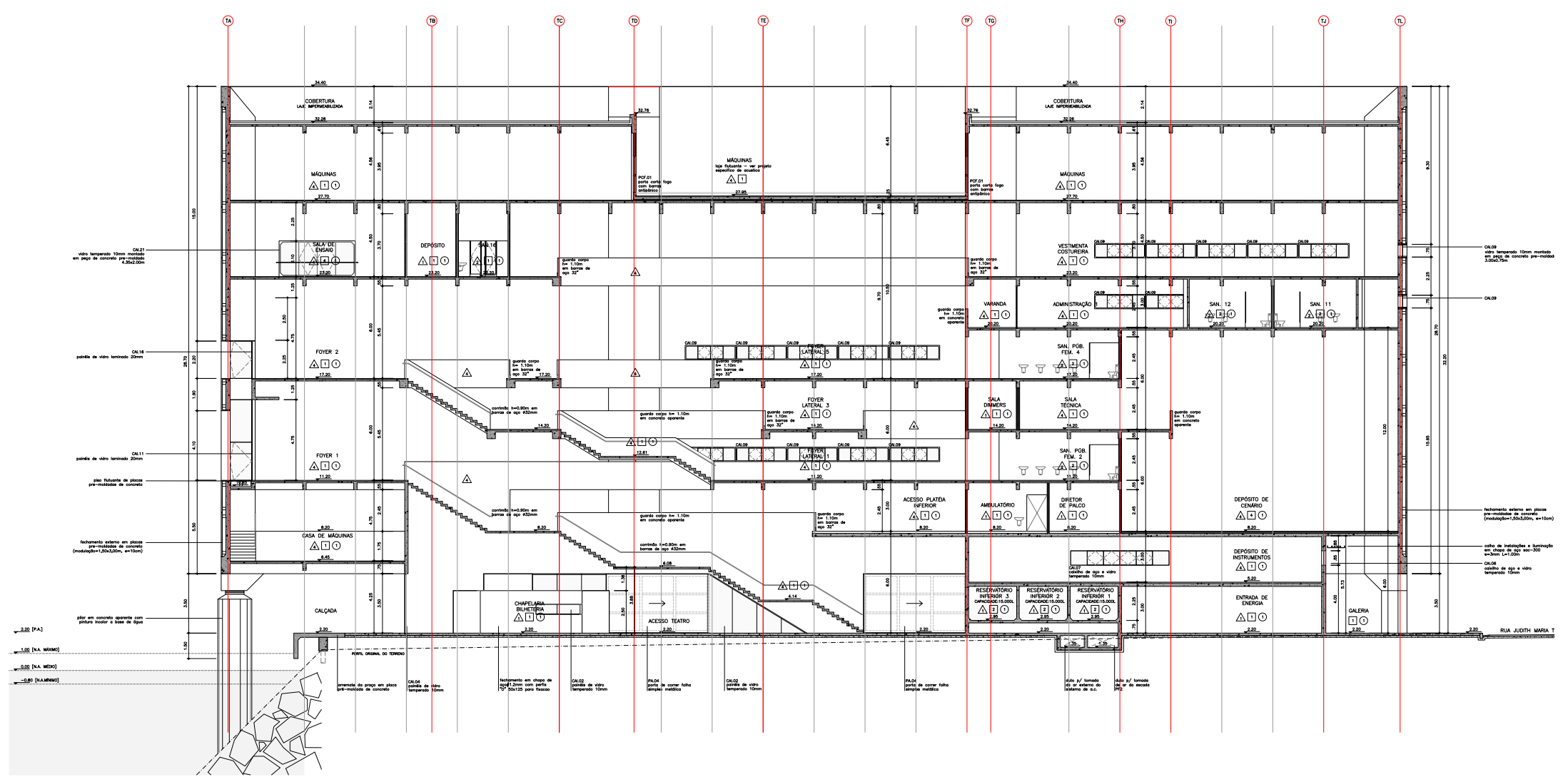




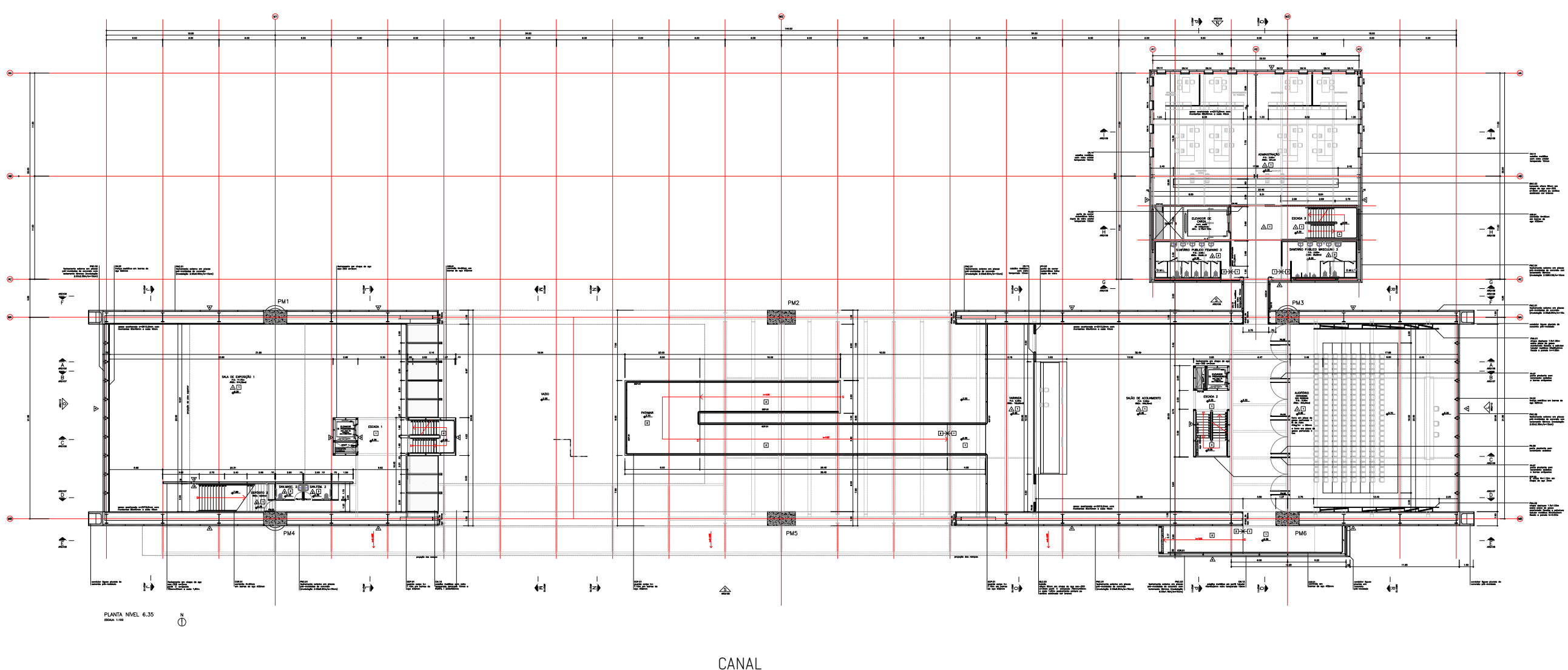




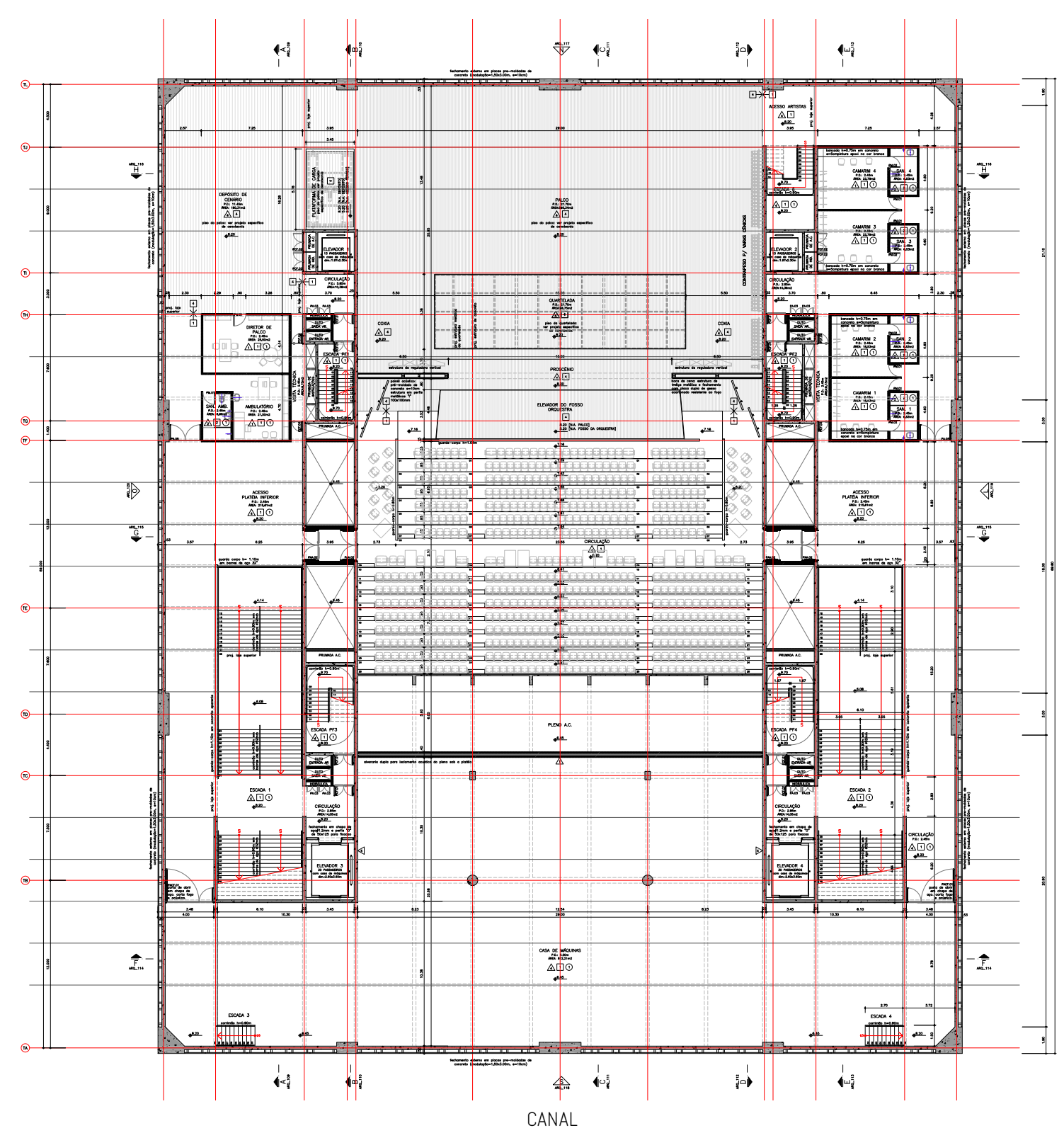

PLANTA DO TEATRO - NIVEL DO PALCO 


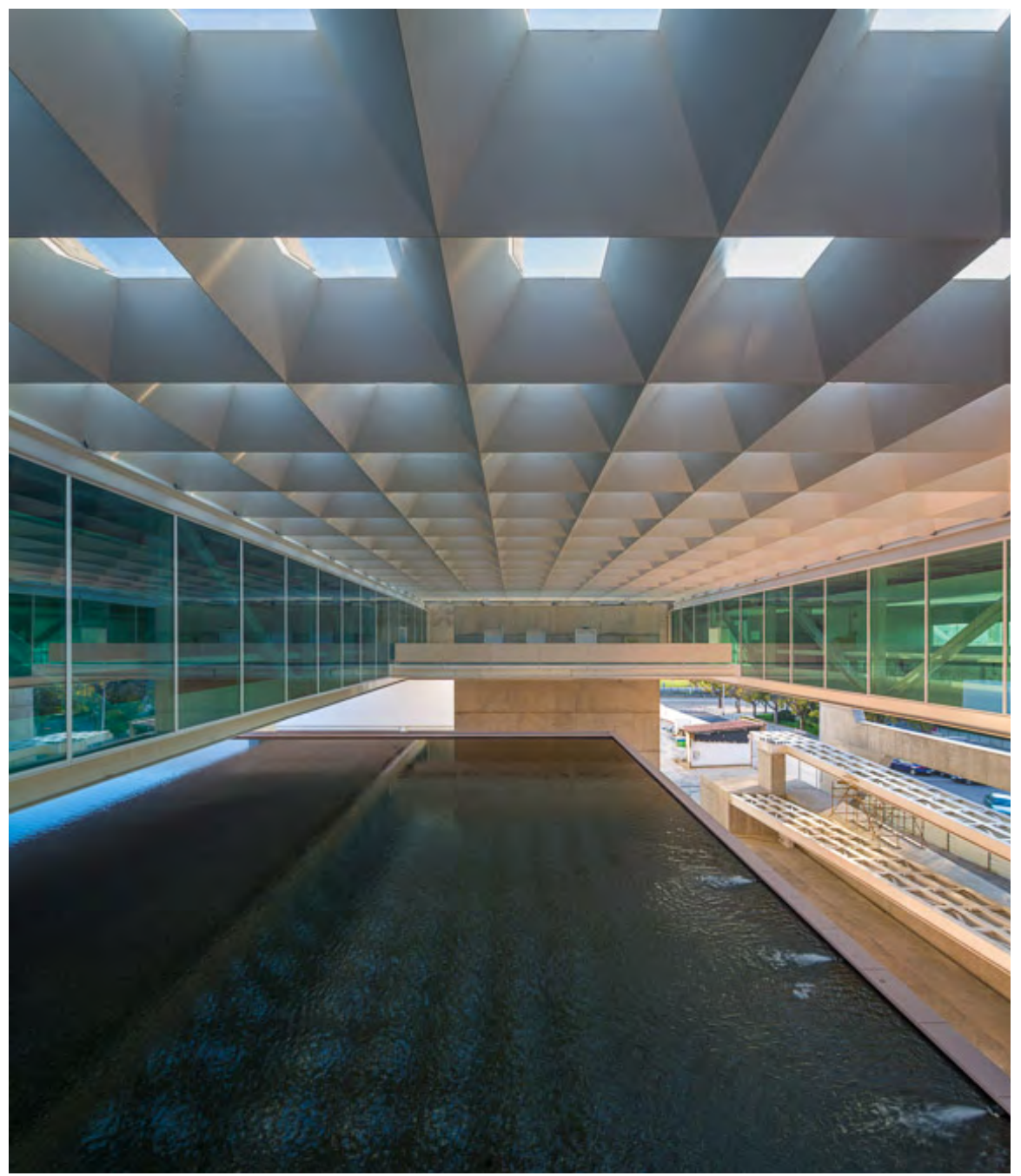

FIG 113

MUSEU DOS COCHES

LISBOA, PORTUGAL

ANO DO PROJETO: 2008

ANO DO TÉRMINO DA OBRA: 2012 (PRIMEIRA ETAPA)

ÁREA CONSTRUIIDA: $12.000 \mathrm{M} 2$

ÁREA DO TERRENO: $14.000 \mathrm{M} 2$

ESCRITÓRIO COLABORADOR: BAK GORDON ARQUITETOS E MMBB ARQUITETOS PROJETO DE FUNDAÇÕES, ESTRUTURAS, INSTALAÇÕES GERAIS: AFA CONSULT. ENG. RESPONSĀVEL: RUI FURTADO 

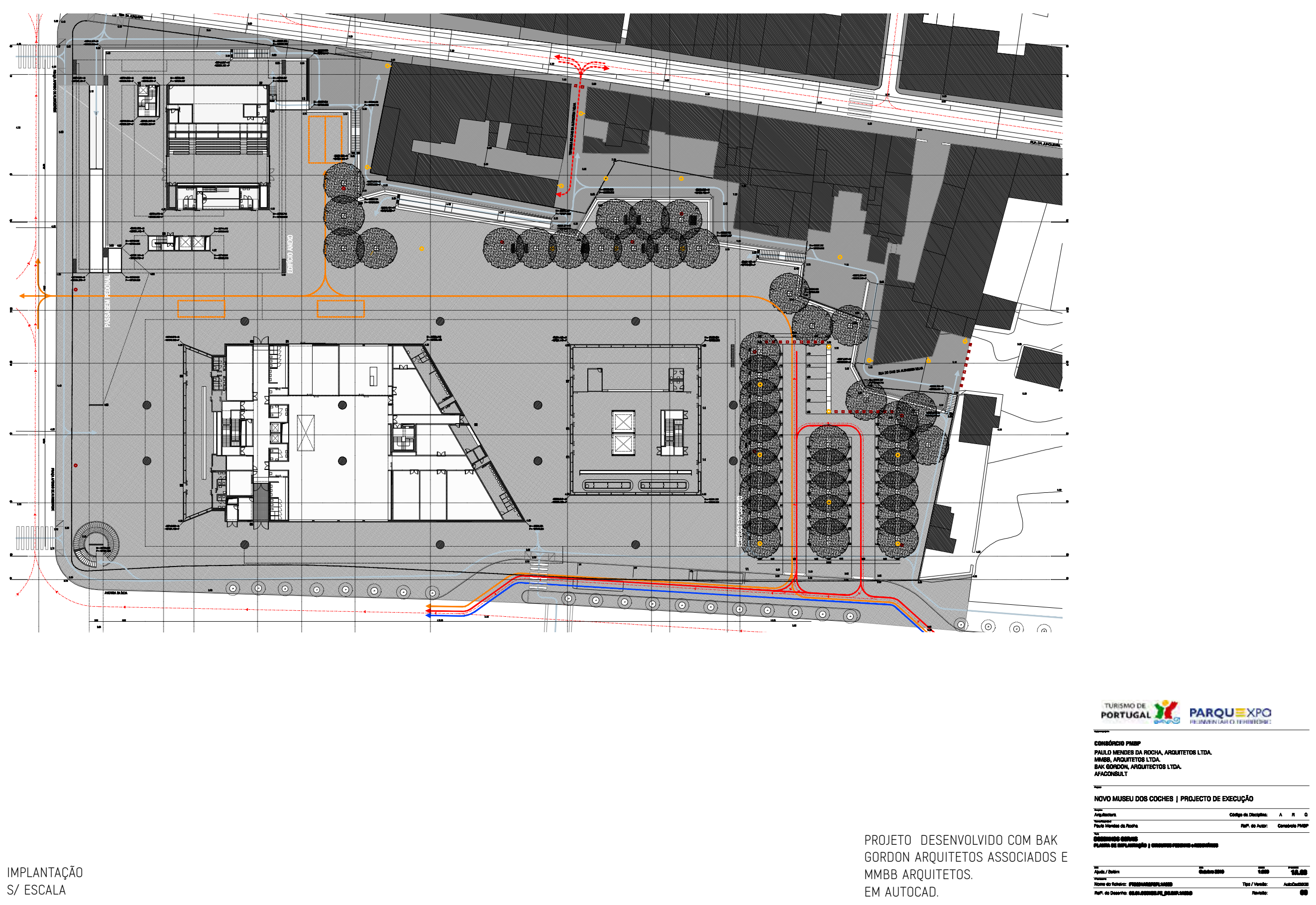


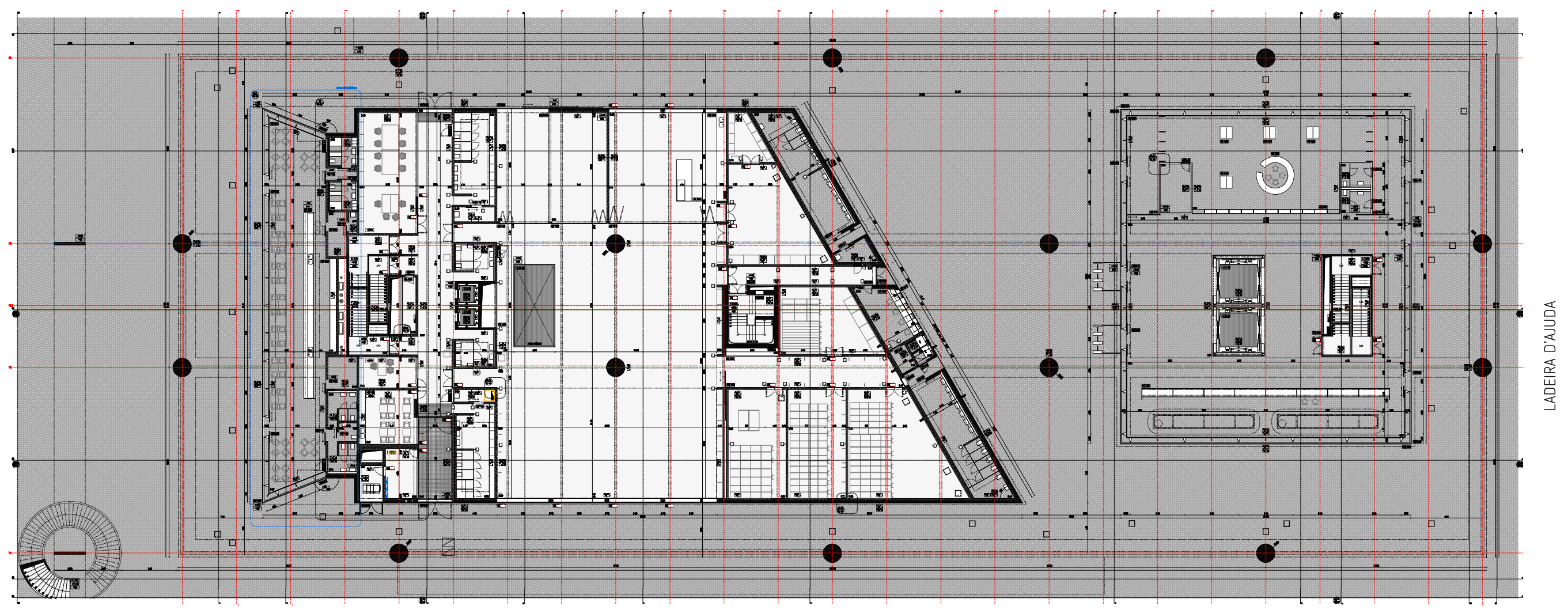

RUA DA JUNQUEIRA 


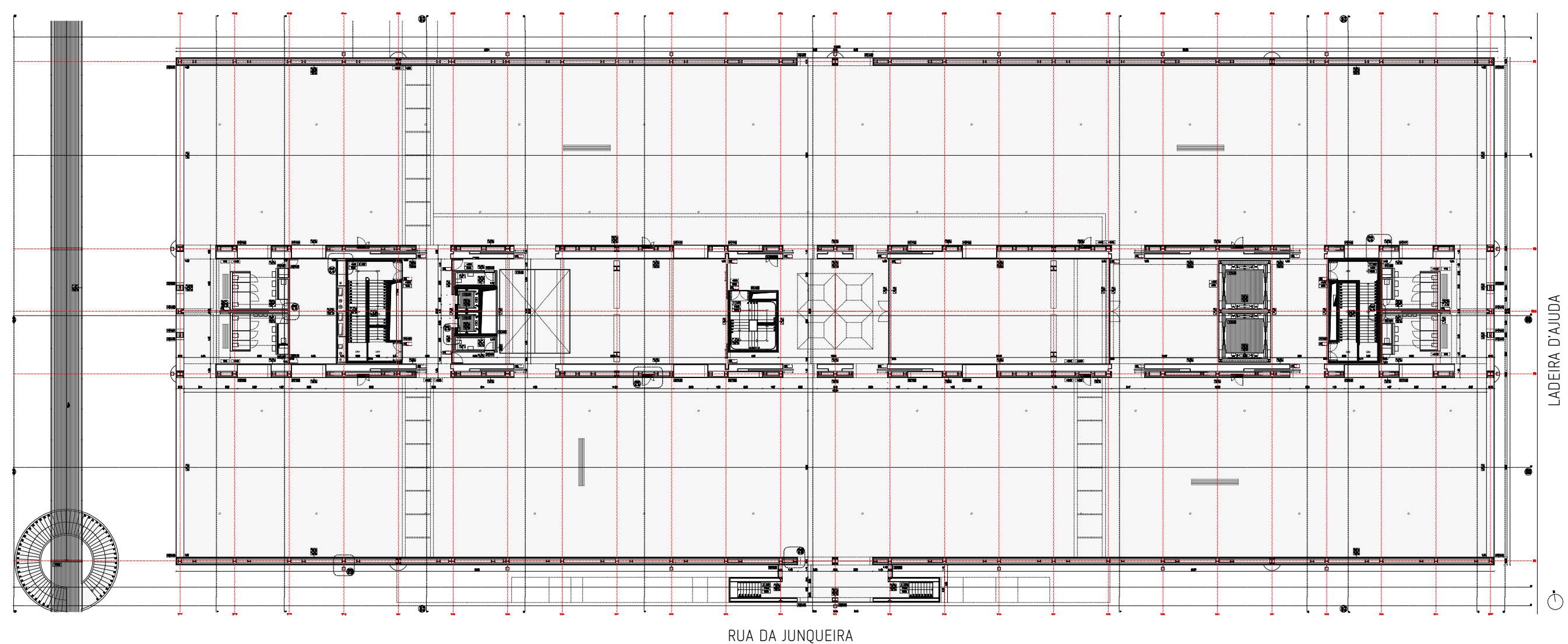




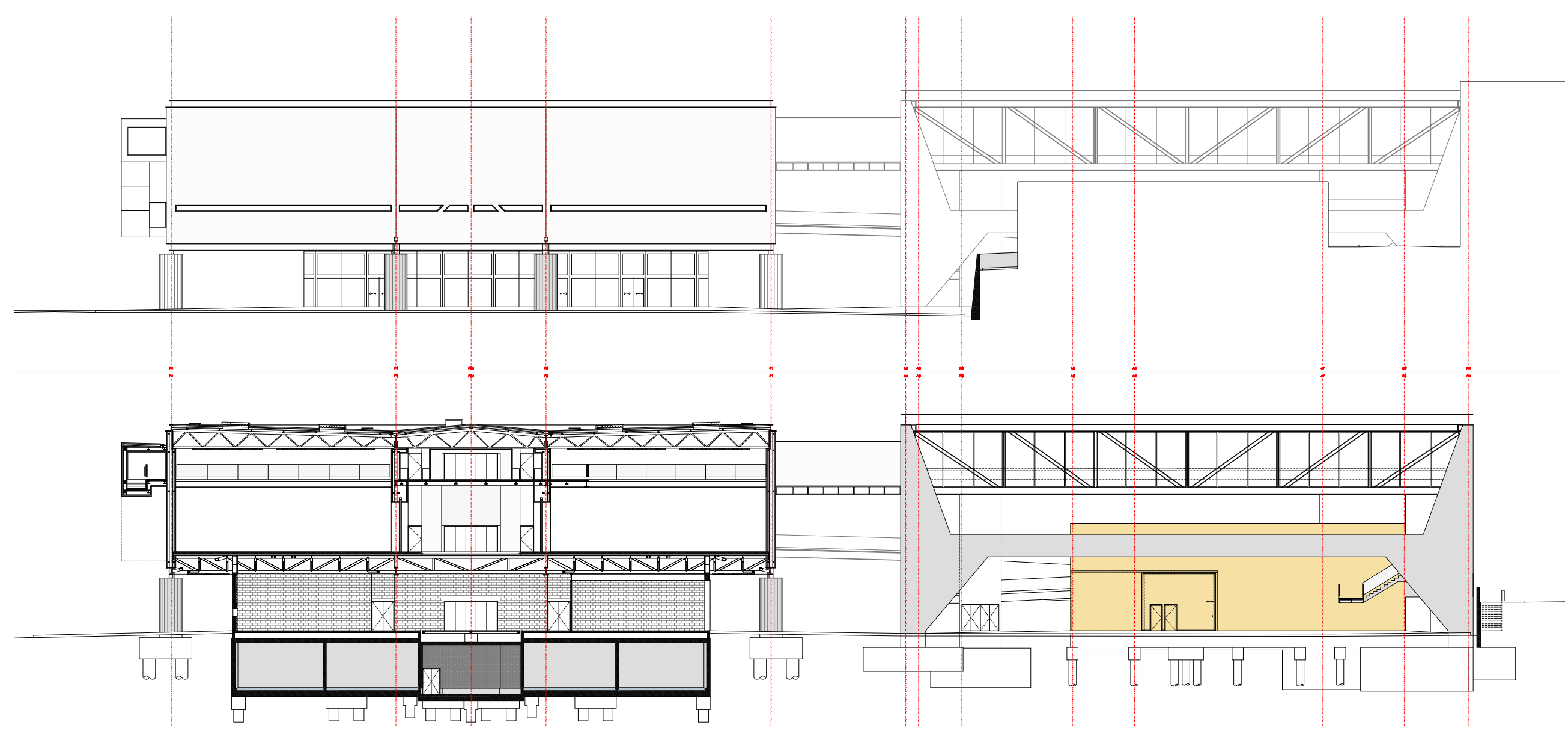




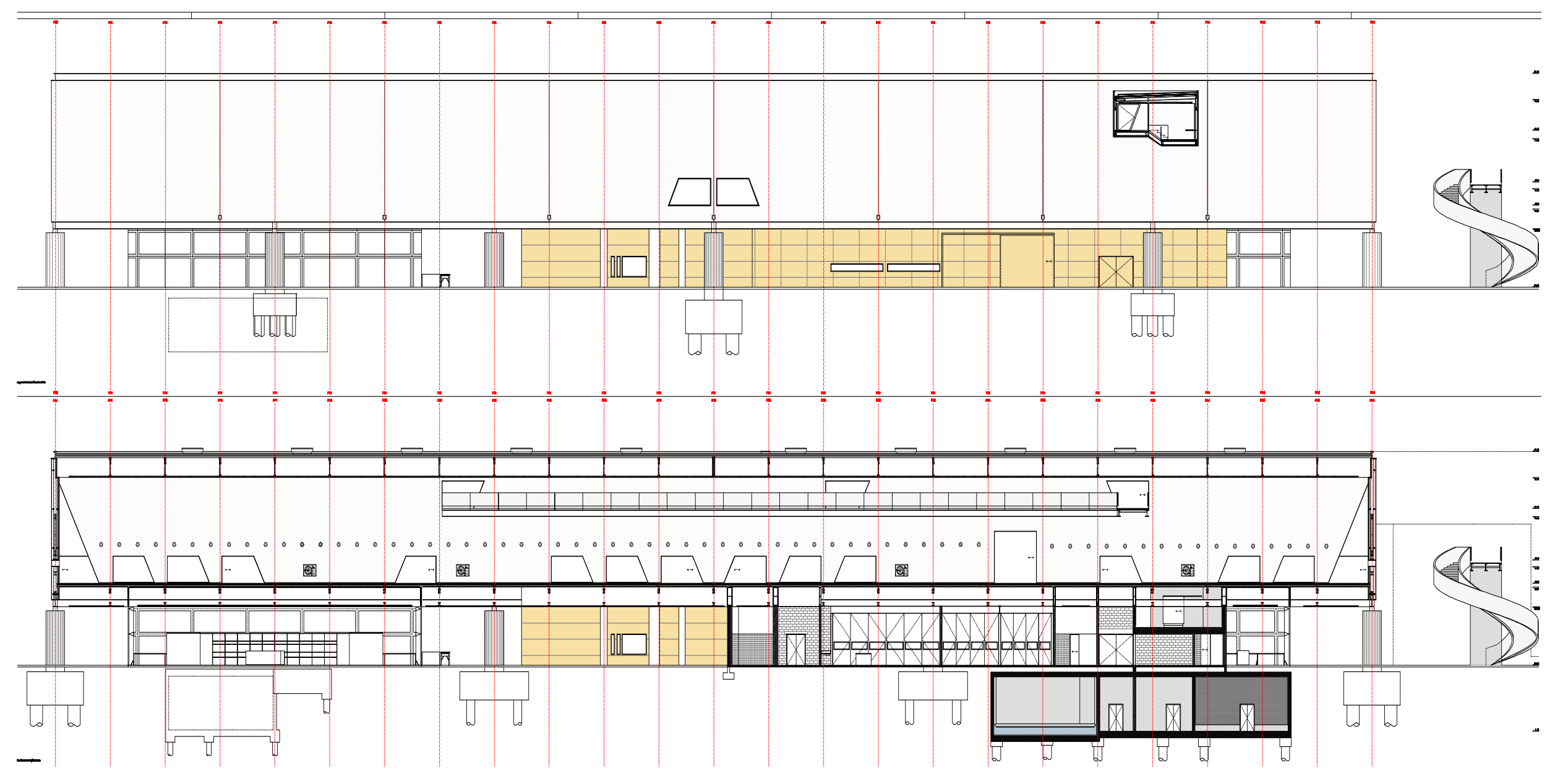

ELEVAÇÃO POSTERIOR DO MUSEU E CORTE LONGITUDINAL 


$$
\max
$$




\section{CONSIDERAÇÕES FINAIS}

\begin{abstract}
"a nossa existência(...) é consequência da existência de um desenho, ou seja a nossa existência é ela mesma um desenho, desde suas origens. E por isso que nós temos uma visão crítica das coisas que podemos estimar ou não. E que essas coisas são aproximações desses desenhos, mas que não são cristalizados e fixos, como se fossem tabu. Esse desenho esta permanentemente em andamento, em transformação. Mas tem uma raiz fundamental que seria mesmo a condição de vida e permanência no universo."1
\end{abstract}

Paulo Mendes da Rocha
1 PIÑÓN, Helio. Paulo Mendes da Rocha. p. 18.

PEDROSA, Mario. "Espaço e Arquitetura". in Dos murais de Portinari aos espaços de Brasília. São Paulo 1981. p. 252
Inicio minhas considerações finais com as palavras do arquiteto, para evidenciar em primeiro lugar que ele possui uma singular noção de desenho.

Verificamos também como seu trabalho gradualmente foi se afastando das questões particulares do objeto arquitetônico e se ampliando nas escalas do lote, da cidade, e enfim do território. Ao mesmo tempo PMR não estabelece um modo ou um "estilo" de fazer projetos: ginásios, casas, equipamentos urbanos, e museus, são projetos que estão em constante transformação, vivos, como um "work in progress".

Ao visitar as obras, ao sentir a ação do espaço construído sobre nós, entendemos também que a matéria prima do arquiteto não é em primeira instância o concreto bruto e aparente - apesar de termos aferido que o modo como PMR manuseia a matéria informa em grande parte seu fazer. É o espaço. Projetar é, para PMR, pensar nas possiblidades de transformação do espaço. $\mathrm{O}$ espaço como nos lembra Pedrosa citando Geoffrey Scott: “(...) é um nada , pura negação do que é sólido (...)”. ${ }^{2}$

Neste sentido como desenhar espaços? A reflexão do Capítulo II nos colocou em outro patamar em relação ao entendimento sobre a natureza do desenho no processo criativo. Entender o desenho como estrutura do pensamento foi fundamental para compreensão de como se dá a mediação entre o pensar e fazer.

No processo de projeção de PMR fica claro que o desenho e as maquetes de papel são suporte material dessa mediação. Foi possível portanto compreender que am- 
bos são a síntese da ideia que vai, durante o desenvolvimento do projeto, mudando de acordo com as contingências do trabalho, num processo continuo e não fragmentado, configurando uma totalidade onde ideia e espaço são ao final, uma coisa só. Portanto podemos concluir que trata-se de uma obra que se realiza pela dimensão do projeto, do espaço construído e o discurso.

O arquiteto constrói com suas mão as maquetes de papel, corta a madeira, prega o fio da linha de costura na mapoteca, gruda o papel manteiga na prancheta, desenha. Por tais ações vemos como a mão realiza um trabalho muito próximo do pensar, num processo de ação e reação quase que coincidentes num proceder relacional, acumulativo, incompleto, abre um modo de imaginar que permite inúmeras possibilidades criativas.

Nota-se que há um tempo fundamental nesse fazer. Um tempo, como nos ensinou Bergson, que não pode ser medido por uma unidade de medida de minutos e segundos, mas tempo que dura, acumula, muda, tempo de extensão transformadora.

Assim PMR chega à contemporaneidade, se reinventado em diálogo com a cidade.

Percebemos que o que move sua imaginação, ainda hoje, está numa dimensão que vai além do cotidiano da profissão, daquele que faz objetos de arquitetura. O que parece motivar PMR é como uma estrutura construída se instala e transforma o espaço urbano, o chão. Um chão, público, que une e sustenta nossa existência.

A propósito, em recente encontro entre arquitetos no $\mathrm{IAB}^{3}$ de São Paulo, PMR foi chamado para expor suas ideias sobre a contribuição do arquiteto para o desenvolvimento das cidades. Em sua fala, de tom otimista, destacou que a situação mundial em que nos encontramos, nos obriga a adquirir, de modo muito rápido, uma certa consciência sobre a natureza. Uma natureza por si inabitável, que precisa ser construída, projetada, levando-se em conta a sobrevivência e preservação dos recursos naturais. Segundo PMR são os arquitetos que tem o conhecimento peculiar desse modo de projeção e por isso, a profissão nunca foi tão necessária, teve tanto prestígio e importância como nos dias de atuais. ${ }^{4}$

Nessa nova era digital, onde os sentidos parecem estar um pouco "fora de foco", como sugere Eisemann ${ }^{5}$, impressiona a clareza com que PMR compreende o lugar da arquitetura no ambiente contemporâneo. Sua obra construída nos mostra como este pensamento transforma o espaço a partir de uma ideia precisa, que se realiza com o domínio da técnica e por uma poesia particular.

3 Instituto de Arquitetos do Brasil. Depoimento realizado por ocasião da tomada de posse da atual diretoria: 2012-2013.

4 HTTPS://vimeo.com/40199470.

5 “Blurring", como sugere Perter Eisemann em "Unfolding Events", 1992. 
Quando, jovens arquitetos são formados e se atualizam pelos meios digitais. Quando, se produz coisas em máquinas que não se sabe como funcionam, torna-se necessário rever os enquadramentos usuais do trabalho do arquiteto, numa condição urbana cada vez menos concreta e mais fluida. O desenho surge como questão relevante, no momento em que nos encontramos diante da inevitável questão da produção de projetos de arquitetura por meio do computador. Sem nostalgia, mas com espírito crítico é preciso perguntar: como se darão as novas mediações entre mão e mente no mundo digital? Como entender a ação do tempo sobre as coisas, se o tempo parece ter a duração de um clik?

$\mathrm{O}$ vigor e a nitidez com que a obra de PMR se relaciona com tais contingências, nessa realidade contemporânea - que Guilherme Wisnik mostra coberta pelo "nevoeiro" ${ }^{6}$ - nos deixam perceber com clareza que as razões do fazer de PMR permanecem ativas, mesmo sujeitas às mudanças de meio. O que nos indica que o nó da questão pode não estar na mudança em si mas no modo como nós arquitetos nos relacionamos com ela.

O mergulho no universo particular de ideias e construções de PMR estimula a reflexão que não cessa na formalidade de uma conclusão. Ao contrário, o estudo desta obra, inquieta, movimenta nossa imaginação, desdobra novos porquês, alarga o horizonte do campo ao qual nos dedicamos: inventar espaços.

6 WISNIK, Guilherme. Dentro do nevoeiro: diálogos cruzados entre arte e arquitetura contemporânea, São Paulo, 2012. p. 169 


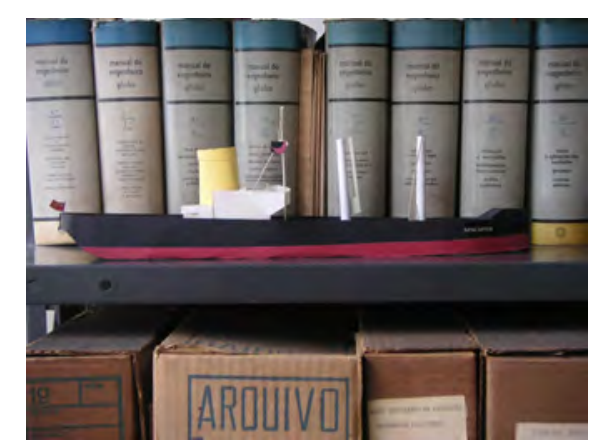

FIG 114

\section{REFERÊNCIAS BIBLIOGRÁFICAS}

ABBAGNANO, Nicola. Dicionário de filosofia. São Paulo, Ed. Martins Fontes, $3^{a}$ edição, 1998

ANDRADE, Mario. Aspectos das Artes Plásticas no Brasil - Do Desenho. São Paulo: Livraria Martins Fontes, 1965.

ACAYABA, Marlene Milan. Residências em São Paulo (1947-1975). São Paulo, Projeto Editora, 1986.

ANDRADE, Mario. Aspectos das Artes Plásticas no Brasil-Do Desenho. São Paulo: Livraria Martins Fontes, 1965.

ANSAY, Pierre, SCHOONBRODT, René. Penser la ville: choix de textes philosophiques. Bruxelas: Archives

ARANTES, Antonio Augusto. “A casa das Retortas”. Produzindo o passado. São Paulo, Brasiliense, 1984.

ARANTES, Otília B.F. O lugar da Arquitetura depois dos Modernos. São Paulo, Edusp, Studio Nobel, 1993.

, Otília B.F. Mário Pedrosa: itinerário crítico. São Paulo, Editora Página Aberta, 1991.

ARANTES, Pedro Fiori (org.) Sérgio Ferro: arquitetura e trabalho livre. São Paulo, Cosac Naifyy, 2006.

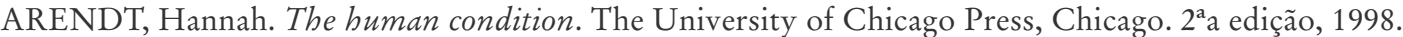

ARGAN, Giulio Carlo, trad. Marcos Bagno. Projeto e destino. São Paulo: Editora Ática,2004.

, Giulio Carlo. História da arte como história da cidade. São Paulo: Martins Fontes, 1995.

Giulio Carlo, trad. Denise Bottmann e Federico Carotti. Arte Moderna. São Paulo: Companhia das Letras, 1992.

Giulio Carlo. Walter Gropius e a Baubaus. Rio de Janeiro: José Olympio Editora, 2005.

ARTIGAS, Rosa (org.) Paulo Mendes da Rocha. São Paulo, Cosac Naify,2000.

, Rosa (org.) Paulo Mendes da Rocha 2. São Paulo, Cosac Naify,2007.

, Rosa (org). Paulo Mendes da Rocha: fifty years 1957-2007. Nova York, Rizzoli, 2007

ARTIGAS, Vilanova. Caminhos da arquitetura. São Paulo, CosacNaify, 2004

, João Batista Vilanova; Jose Tavares Correia de Lira e Rosa Artigas org. São Paulo, Cosac Naify, 2004.

, Vilanova. Coordenação Roberto Portugal Albuquerque. Cadernos dos Rabiscos originais - projeto do edifício da FAUUSP na Cidade Universitária. São Paulo, FAUUSP, 1998. BACHELARD Gaston. The poetics of space. Boston, Beacon Press, 1994.

BELlUZZO, Ana Maria. Carmela Gross. São Paulo, Cosac Naify Edições, 2000.

BENJAMIN, Walter. Magia e técnica, arte e política. Obras escolhidas. São Paulo, Ed. Brasiliense, 1985.

BERGSON, Henri. O pensamento e o movente. São Paulo, Martins Fontes, 2006.

BONDUKI, Nabil (org). Affonso Eduardo Reidy. São Paulo, Editorial Blau e Instituto Lina Bo e Pietro Maria Bardi, 2000.

BOLLNOW, Otto. Human Space. Londres, Hyphen Press, 2011

BREDENKAMP, Horst. "Frank Gehry and the Art of Drawing”.in Gehry Draws. Cambridge: The MIT Press, 2004. 
BRUAN, Yves. Arquitetura contemporânea no Brasil. São Paulo: Perspectiva, 1981.

BRUAND,Yves. “À margem do racionalismo: a corrente orgânica e brutalismo paulista”. Arquitetura contemporânea no Brasil. São Paulo, Perspectiva 1981.

BRUGGEN, Coosje van. Frank O. Gehry: El museo de Guggenheim Bilbao. Nova Nova York: The Solomon R. Guggenheim Foundation, 1997.

CARERI, Francesco. Walkscapes. El andar como practica estetica. Barcelona, Editorial Gustavo Gilli, 2002.

COHEN Jean Louis, MOELLER. G. Martin Jr. Ed. Liquid Stone. Nova York, Princeton Architectural Press, 2006.

CORBUSIER, Le. Vers une Architecture. Paris, Champs Flammarion, 1995.

CORBUSIER, Le. Precisões. São Paulo, Cosac Naify, 2004.

COSTA, Lucio. Arquitetura. Rio de Janeiro: Editora José Olympio, 2006.

, Lucio. Sobre uma arquitetura. Porto Alegre, UniRitter. $1^{\mathrm{a}}$ reimpressão em fac simile, 2007.

CORTE-LEAL, Eduardo. O triunfo da virtude origens do desenho arquitetônico. Lisboa, Livros Horizonte, 2001.

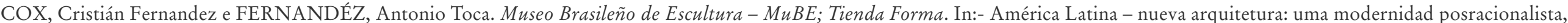

México, Ed. Gustavo Gilli, 1998.

DAGUERRE, Mercedes. Case latino Americane: casa Prata arcuschin San Paolo Brasile.Milão, Casabella, Modadori Publicitá, 2005.

DAL CO, Francesco; FORSTER, Kurt W. Frank O. Gehry - The complete works. Milão, Electra, 1998.

EVANS, Robin. The Projective Cast Arquitecture an its thres geometries. Cambridge, The MIT Press, 2000

EISEMANN, Peter. "Unfolding Events" in ZONE 6: Incorporations. CRARY, Jonathan e SANFORD Kwinter (ed). Cambridge, 1992.

FERRO, Sergio. “O canteiro e o desenho”. São Paulo, Projeto, 1979.

FICHER, Silvia e ACAYABA, Marlene Milan. “Tendências regionais após 1960”. Arquitetura moderna brasileira. São Paulo, Projeto Editora. 1982 , pgs.54,55 e 66.

FLUSSER Vilém, Petite philosophie du design. [essai]. Paris, Les editions circe-oxymoron, 2002.

FOCILlON, Henri. A vida das Formas seguido de Elogio da Mão. Edições 70: Lisboa, 2001.

FRAMPTON, Kenneth. Modern Architecture, a critical history. Londres: Thames and Hudson, 1985. $2^{\mathrm{a}}$ edição.

GIEDION, Siegfried. Affonso Eduardo Reidy - Bauten und Projekte.Sttutgart: Verlag Gerd Hatje, 1960.

, Siegfried. Space, time and architecture: the growth of a new tradition. Cambridge: Harvard University Press, 1973.

GREGOTTI, Vittorio. Território da arquitetura. Editora Perspectiva: São Paulo, $3^{a}$ edição, 2001.

HABERMAS, Jurgen. Mudança estrutural na esfera pública. RJ/SP: Tempo Brasileiro 1984.

HARVEY, David. The Condition of Postmodernity. Oxford: Blackwell Publishing,1990.

HUXTABLE, Ada Louise. The Unreal America Architecture and Illusion. Nova York: The New Press, 1997.

IWAMIZU, César Shundi. A estação rodoviária de Jaú e a dimensão urbana da arquitetura. FAU_USP, São Paulo, 2008.

JACOBS, Jane. Morte e vida de grandes cidades. São Paulo: Martins Fontes,2000.

JORGE, Luís Antônio. O espaço seco: Imaginário e poéticas da arquitetura moderna na América. São Paulo, FAU_USP. Tese de Doutorado, 1999.

KAHN, Louis. Essential Texts. Robert Twombly Ed. W.W Norton\&Company, Nova York, 2003.

KLEE, PAUL. Paul Klee Notebook. Jürg Spiller (ed). London; New York: Lund Humphries: George Wittenborn, 1969.

LE CORBUSIER. Vers une Architecture. Paris: Flammarion, 1995.

LINDSEY, Bruce. Digital Gehry: material resistance/digital construction. Bael;Berlin;Boston: Birkauser, 2001.

MARTINS, Carlos A.F. A constituição da trama narrativa da historiografia da arquitetura moderna brasileira. In. Revista da Pós São Paulo: FAUUSP, 1994.

, Carlos A.F. “Os desenhos da Arquitetura” in Catálogo da Exposição Os desenhos da Arquitetura como parte do projeto O desenho e suas abrangências Universidade de São Paulo,

São Paulo, 1995

, Carlos A.F. “"Hay algo de irracional...” - apuntes sobre la historiografia de la arquitectura brasileña”. Revista Block, número 4, dezembro. Buenos Aires, 1999.

MASSAO, Kamita. Vilanova Artigas. São Paulo: Cosac Naify, 2000.

MEYER, Regina, GROSTEIN Marta, BIDERMAN Ciro. São Paulo Metrópole. São Paulo Edusp, Imprensa Oficial, 2004.

MILHEIRO, Ana Vaz. “ Um edificio que se ajusta ao chão”. Projeto Design, no 395, janeiro 2013. São Paulo. p. 67

MONEO, Rafael. Inquietação teórica e estratégia projetual na obra de oito arquitetos contemporâneos. São Paulo: CosacNaify, 2009.

MONTANER, Josep Ma. \&VILLACMaria Isabel. Mendes da Rocha. Lisboa: Editorial Blau; Barcelona: Editorial Gustavo Gilli, 1996. 
MONTANER, Josep Maria e VILLAC, Maria Isabel. Mendes da Rocha. Barcelona e Lisboa, Gustavo Gili/ Blau, 1996.

, Josep Maria. Después Del movimiento moderno: arquitetura de la segunda mitad del siglo XX. Barcelona: Gustavo Gilli, 1993.

, Josep Maria. Museos para el nuevo siglo. Barcelona, Gustavo Gilli, 1995. pgs.90-91.

MORRIS, Robert. O tempo do espaço presente [1978], in G. Ferreira e C. Cotrim (org). Escrito de Artistas anos 60/70. Rio de Janeiro, Ed Jorge Zahar, 2006.

MOTTA Flávio. "Paulo Mendes da Rocha”, in Textos Informes. São Paulo. FAU-USP 2 edição ampliada, 1973.

, Flávio. "Arquitetura Brasileira para Expo-70”, in Textos Informes São Paulo, FAU-USP 20 edição ampliada, 1973.

, Flávio. Desenho e Emancipação. In "Sobre o Desenho". São Paulo: Centro de Estudos Brasileiros do GFAU USP, 1975.

NAVES, Rodrigo. A forma difícil. São Paulo: Editora Ática, 1996.

, Rodrigo. Amilcar de Castro. São Paulo: Cosac Naify, 1997.

, Rodrigo. O vento e o moinho. São Paulo, Editora Ática, 1996.

OTONDO, Catherine. "Espaços culturais na obra de Lina bo Bardi - o caso do MASP". Trabalho de Iniciação científica, orientador: Profa Dra Otilia Beatriz Fiori Arantes.

Faculdade de Arquitetura e Urbanismo da Universidade de São Paulo, 1992.

, Catherine. "São Paulo uma breve noticia daqui". Revista 1:100 no 45, Buenos Aires, junho 2008.

Catherine. "Você sempre entra por uma porta e sai por outra". São Paulo, PÓS - Revista do Programa de Pós-Graduação em Arquitetura e Urbanismo FAUUSP. nº 25, junho 2009.

, Catherine, e GOUVÊA José Paulo. Itinerários de Arquitectura, Paulo Mendes da Rocha. Córdoba, Fundacion Arquitectura Contemporânea. 2012.

, Catherine; BRAGA Juliana; GIMENEZ Carolina; GOUVEA José Paulo; SODRE João. PMR 29'-29 minutos com Paulo Mendes da Rocha. Curta metragem, 2010.

PEDROSA, Mario. Mundo, homem, arte em crise. São Paulo: Perspectiva, 1975.

PEDROSA, Mario. AMARAL, Aracy (org). Dos murais de Portinari aos espaços de Brasília. São Paulo, Editora Perspectiva, 1981.

PETERS, Ivana Franco. Contextura da criação arquitetônica; esboços e projetos. Tese de doutorado. Taubaté, PUC_SP .

PEVSNER, Nikolaus. Os Pioneiros do desenho Moderno: de William Morris a Walter Gropius. São Paulo: Martins Fontes, 1995.

PIÑÓN, Helio. Paulo Mendes da Rocha. São Paulo, Romano Guerra, 2002.

PUNTONI, Álvaro; PIRONDI Ciro: LATORRACA, Giancarlo \& ARTIGAS, Rosa Camargo. Vilanova Artigas: arquitetos brasileiros. São Paulo: Instituto Lina Bo Bardi e P.M. Bardi;

Fundação Vilanova Artigas, 1997.

RAFAEL de Urbino; organizador Luciano Migliaccio. Cartas sobre Arquitetura. Campinas, 2010.

REIS FILHO, Nestor. Quadro da Arquitetura no Brasil. São Paulo: ED Perspectiva, 1970.

ROBBINS Edward. Why architects draw. Cambridge: MIT Press, 1994.

ROCHA, Paulo Mendes da. "Edifícios escolares: escola técnica de Santos". Acrópole, São Paulo, n 377, julho 1970,pág. 35.

, Paulo Mendes da. "Perspectivas da arquitetura brasileira - recomendações para sua adequação aos trópicos". Arquitetura nos trópicos - Anais do I Seminário Nacional. Recife,

Fundação Joaquim Nabuco/Massangana, 1995, pgs.155-161.

, Paulo Mendes da. CARBONCINI, Anna (org.) "Morar no século XX”. A virada do século: reflexões sobre a passagem do milênio. São Paulo, Paz e Terra/Unesp/Secretaria de Estado da Cultura, 1987.

, Paulo Mendes da. Maquetes de papel.São Paulo, Cosac Naify, 2007.

, Paulo Mendes. Memorial de titulação: Concurso para provimento de cargo de Professor Titular. São Paulo: FAU-USP, 1998.

, Paulo Mendes. "Engendrando o Humano". Entrevista concedida à Revista Ide. São Paulo, $2^{\circ}$ semestre 1998.

, Paulo Mendes da. Encontros com Paulo Mendes da Rocha. Wisnik, Guilherme org, Rio de Janeiro, Becos do Azougue, 2012.

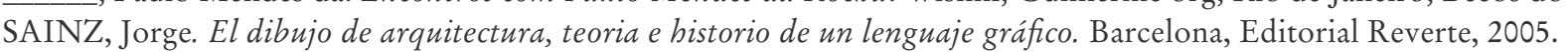

SANTOS. Cecilia Rodrigues. Caixa de surpresas. Revista Arquitetura e Urbanismo. São Paulo, 1993.

SANTOS, Milton. A natureza do Espaço: técnica e tempo, razão e emoção. São Paulo, Edusp, 2006.

, Milton, ... [et al.]. Territorio, territorios: ensaios sobre o ordenamento territorial. Rio de Janeiro, Lamparina, 2011.

SASSEN. Saskia. "A politica como lugar”. O Estado de São Paulo, 25 de dezembro, 2011.

SCHENK, Leandro Rodolfo. Os croquis na concepção arquitetônica. São Paulo, Annablume, 2010.

SENNETT, Richard. O artífice, trad. Clovis Marques Rio de Janeiro, Ed. Record, 2009.

, Richard. O declínio do homem publico: as tiranias da intimidade, trad. Lygia Araujo Watanabe. São Paulo, Companhia das Letras, 1988. 
SOLA-MORALES, Ignasi de. Territórios. Barcelona, Gustavo Gilli, 2002.

SOLOT, Denise Chini. Paulo Mendes da Rocha, Estrutura: o êxito da forma. Rio de Janeiro, Viana \& Mosley, 2004.

SPIRO, Annette (org). Paulo Mendes da Rocha Bauten und Projekte. Zurich, Verlag Nigglu AG, 2002.

TAFURI, Manfredo, DAL CO, Franceso. Modern Architecture. Nova York: Harry N. Abrams Inc., 1979.

TELLES Sophia S. Arquitetura Moderna no Brasil: o desenho da superfície. São Paulo: Departamento de Filosofia da Faculdade de Filosofia, Letras e Ciências Humanas da USP.

Dissertação de Mestrado, 1998.

, Sophia S. (ed.), Inventário da obra publicada de Paulo Mendes da Rocha. Campinas, Pontifícia Universidade Católica de Campinas, 1989.

Sophia da Silva. "Museu Brasileiro da Escultura". AU - Arquitetura E Urbanismo, São Paulo, ano IV, n¹7, abr./maio1990, pgs.51-53.

Sophia. "Documento: Paulo Mendes da Rocha”. AU - Arquitetura E Urbanismo, São Paulo, n60, jun/jul. 1995, p69-81.

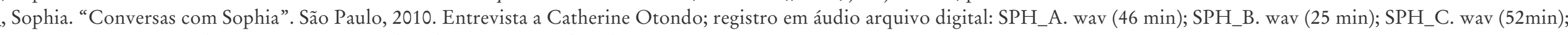

SPH_D. wav (44 min), gravados entre agosto e outubro de 2012. Material inédito.

TINEM, Nelci. O alvo do olhar estrangeiro - o Brasil na bistoriografia da arquitetura moderna. João Pessoa, Ed. Universitária, 2006. $2^{a}$ edição.

UNDERWOOD, David. Oscar Niemeyer e o modernismo de formas livres no Brasil. São Paulo, CosacNaify, 2002.

UTZON, Jørn, "Platforms and Plateaus: Ideas of a Danish Architect", in Zodiac 10. Milan, 1962.

VALÉRY, Paul. Introdução ao Método de Leonardo da Vinci. São Paulo: Editora 34. 1ª Reimpressão, 2006.

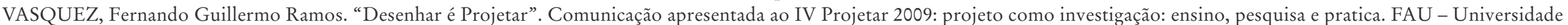

Presbiteriana Mackenzie, São Paulo, outubro, 2009.

VILLAC, Maria Isabel. La constuccion de La mirada. Naturaleza, Discurso y ciudad en La arquitectura de Paulo Archias Mendes da Rocha. Barcelona, Tese de doutorado. Universitat

Politécnica de Catalunya, UPC.

WISNIK, Guilherme. “ Nova cobertura da Praça Patriarca”. Revista Vitruvius, São Paulo. 03/12/2002. http://www.vitruvius.com.br

, Guilherme. "Arquitectura del territorio". Revista 2G, n 45. Barcelona: Editorial GGili, 2008.

Guilherme. "Entrevistas con los estúdios colaboradores de Paulo Mendes da Rocha”. Revista 2G. Revista 2G, nº 45. Barcelona: Editorial GGili, 2008.

, Guilherme. Estado crítico: à deriva nas cidades. São Paulo: Publifolha, 2009.

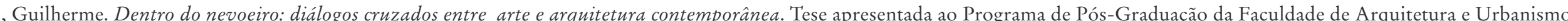

da Universidade de São Paulo. São Paulo, 2012.

WORMS, Frederic et RIQUIER, Camille. Lire Bergson. Paris, Quadrige/PUF, 2011.

XAVIER, Alberto (org.). Depoimento de uma geração. São Paulo: Cosac Naify, 2003.

XAVIER, Alberto; LEMOS, Carlos; CORONA, Eduardo. Arquitetura Moderna Paulistana. São Paulo, Editora Pini, 1983.

ZAERA, Alejandro. "Conversaciones con Frank O. Gehry”. In EL CROQUIS, 74/75. FRANK GEHRY 1991-1995. Madrid, El Croquis Editorial, 1995.

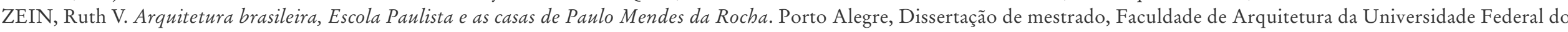
Rio Grande do Sul, 2000.

, Ruth Verde. “Pavilhão Oficial Do Brasil Expo-70 - Osaka, Japão, Museu De Arte Contemporânea - Usp - São Paulo, Conjunto Habitacional de Cumbica, Cecap Guarulhos”,

Projeto, Projeto Editores Associados, São Paulo, 1982, Edição Especial de 10 Anos, 1972/1982.

ZUMTHOR, Peter. Atmosferas. Barcelona, Gustavo Gilli, 2009.

, Peter. Pensar Arquitectura. Barcelona: Gustavo Gilli, 2009.

\section{SITES:}

http://www.frentetejo.pt/38/novo-museu-dos-coches.htm

http://www.geoportal.com.br

http://www.googlemaps.com.br

http://www.poupatempo.sp.gov.br/dados_est

http://www.vitruvius.com.br 


\section{CRÉDITOS DAS IMAGENS}

FIG 01

FIG 02

FIGS 03-04

FIG 05

FIG 06

FIGS 07-15

FIG 16

FIG 17

FIGS 18-2

FIG 22

FIG 23

FIG 24

FIG 25

FIG 26

FIGS 27-28

FIG 29

FIGS 30-34

FIG 35

FIGS 36-40

FIG 41

FIG 42

FIG 44

FIG 45

FIG 46

FIGS 47-52

FIG 53

FIGS 54-57

FIGS 58-59
RANCISCO GOMES DIAZ

RAFAEL DE URBINO IN CARTAS SOBRE AROUITETURA

KARINA SCUSSIATO PIMENTEL (Fundação Vilanova Artigas, Curitiba)

ACERVO PAULO MENDES DA ROCHA

JOSÉ MOSCARDI

ACERVO PAULO MENDES DA ROCHA

CATHERINE OTONDO

ACERVO CLUBE ATLÉTICO PAULISTANO

ACERVO PAULO MENDES DA ROCHA

JOSÉ PAULO GOUVÊA

ACERVO BIBLIOTECA FAU-USP

OSÉ PAULO GOUVÊA

ACERVO PAULO MENDES DA ROCHA

JOSÉ PAULO GOUVÊA

ACERVO PAULO MENDES DA ROCHA

NELSON KON

ACERVO PAULO MENDES DA ROCHA

ANNETTE SPIRO

ACERVO PAULO MENDES DA ROCHA

LEONARDO FINOTTI

WWW. PORTLAND.NET

WW SUBTILITAS.TUMBLR COM

CINTHIA YENDO

JOSÉ PAULO GOUVÊA

ANNETTE SPIRO

ACERVO PAULO MENDES DA ROCHA

JOSÉ PAULO GOUVÊA

ACERVO PAULO MENDES DA ROCHA

JOSÉ PAULO GOUVÊA

\begin{tabular}{ll} 
FIG 60 & ACERVO MMBB ARQUITETOS ASSOCIADOS \\
FIG 61 & GEOPORTAL.COM.BR \\
FIG 62 & GOOGLE MAPS \\
FIG 63 & NELSON KON \\
FIGS 64-65 & PEDRO KOK \\
FIGS 66-69 & CINTIA CARDOSO \\
FIGS 70-78 & ACERVO MMBB ARQUITETOS ASSOCIADOS \\
FIG 79 & ACERVO PAULO MENDES DA ROCHA \\
FIG 80 & LEONARDO FINOTTI \\
FIG 81 & JOSÉ PAULO GOUVÊA \\
FIGS 82-84 & CATHERINE OTONDO \\
FIG 85 & ACERVO PAULO MENDES DA ROCHA \\
FIG 86 & LEONARDO FINOTTI \\
FIGS 87-88 & JOSÉ PAULO GOUVÊA \\
FIG 89 & LEONARDO FINOTTI \\
FIGS 90-94 & CATHERINE OTONDO \\
FIG 95 & LEONARDO FINOTTI \\
FIG 96 & SITE MUSEU DOS COCHES \\
FIG 97 & ACERVO PAULO MENDES DA ROCHA \\
FIG 98 & SITE CENTRO CULTURAL DE BELEEM \\
FIG 99 & FERNANDO GUERRA \\
FIGS 100-104 & CATHERINE OTONDO \\
FIGS 105-106 & FERNANDO GUERRA \\
FIGS 107-108 & CATHERINE OTONDO \\
FIGS 109-110 & FERNANDO GUERRA \\
FIG 111 & ACERVO PAULO MENDES DA ROCHA \\
FIG 112 & CATHERINE OTONDO \\
FIG 113 & FERNANDO GUERRA \\
FIG 114 & CATHERINE OTONDO \\
\hline
\end{tabular}


VIII. ANEXO I

LISTA DE PROJETOS 1958-2011 
LISTA DE PROJETOS PAULO MENDES DA ROCHA 1957 a 2011

EP: ESTUDO PRELIMINAR: AP: ANTE PROJETO; PE: PROJETO EXECUTIVO

\begin{tabular}{|c|c|c|c|c|c|}
\hline $\begin{array}{l}\text { ANO do } \\
\text { PROJETO }\end{array}$ & $\mathrm{N}^{\circ}$ & $\begin{array}{l}\text { Nome do projeto/LOCAL } \\
\text { Equipe de trabalho }\end{array}$ & \multicolumn{2}{|c|}{ Descrição do material gráfico e digital } & Fase do trabalho \\
\hline 1957 & 1 & $\begin{array}{l}\text { Assembleia legislativa do Estado de Santa Catarina } \\
\text { Palācio Legislativo } \\
\text { Florianópolis, SC. } \\
\text { Equipe: Pedro Paulo Mello Saraiva e Alfredo Paesani. }\end{array}$ & \multicolumn{2}{|l|}{ Digital: } & $\begin{array}{l}\text { Concurso Nacional } 1^{\circ} \\
\text { premio }\end{array}$ \\
\hline \multirow[t]{2}{*}{1957} & \multirow[t]{2}{*}{2} & \multirow{2}{*}{$\begin{array}{l}\text { CHSA:Clube Hípico Santo Amaro } \\
\text { São Paulo, SP }\end{array}$} & Gaveta & Estudos & \multirow[t]{2}{*}{ AP } \\
\hline & & & & $\begin{array}{l}\text { Ante Projeto } \\
\text { Papel manteiga/lápis } \\
3 / 3 \text { A1 }\end{array}$ & \\
\hline 1957 & 3 & $\begin{array}{l}\text { Cadeira Paulistano } \\
\text { São Paulo, SP }\end{array}$ & & $\begin{array}{l}\text { Caixa de documentos } \\
\text { Arquivos dwg }\end{array}$ & \\
\hline \multirow[t]{2}{*}{1958} & \multirow[t]{2}{*}{4} & \multirow[t]{2}{*}{$\begin{array}{l}\text { Ginásio Paulistano: praça de esporte e piscinas } \\
\text { Rua Honduras 1.400, São Paulo, SP }\end{array}$} & Digital & $\begin{array}{l}6 \text { cortes digitalizados.jpg:1 corte.pdf:projeto } \\
\text { completo.dwg:ficha técnica.doc:memorial.doc } \\
8-9\end{array}$ & \multirow[t]{2}{*}{$\frac{}{2-3}=$} \\
\hline & & & $\begin{array}{l}\text { Ubo } \\
\text { Gaveta }\end{array}$ & & \\
\hline 1958 & 5 & $\begin{array}{l}\text { Escola primária do Clube Atlético Paulistano } \\
\text { Rua Honduras 1.400. São Paulo. SP }\end{array}$ & Tubo & Não foram encontrados os desenhos no tubo & \\
\hline \multirow[t]{2}{*}{1958} & \multirow[t]{2}{*}{6} & \multirow{2}{*}{$\begin{array}{l}\text { Hamburg-Sud: Sede da empresa } \\
\text { Santos, SP }\end{array}$} & Gaveta & Estudos & \multirow[t]{2}{*}{ PE } \\
\hline & & & & $\begin{array}{l}\text { EP } \\
\text { Papel Manteiga/lāpis } \\
\text { 2/2 Pranchas A1 } \\
\text { PE } \\
\text { Papel manteiga/lápis } \\
\text { 8/8 Pranchas A1 }\end{array}$ & \\
\hline 1960 & 7 & $\begin{array}{l}\text { Concessionária Volkswagen Brasilwagen } \\
\text { Conj. Nacional, São Paulo, SP }\end{array}$ & & Não foram encontrados os desenhos. & - \\
\hline 1960 & 8 & $\begin{array}{l}\text { Grupo Escolar Antonio Vilella Junior } \\
\text { Rua Francisco Teodoro, } 250 \text { Campinas, SP. }\end{array}$ & & Não foram encontrados os desenhos & \\
\hline
\end{tabular}




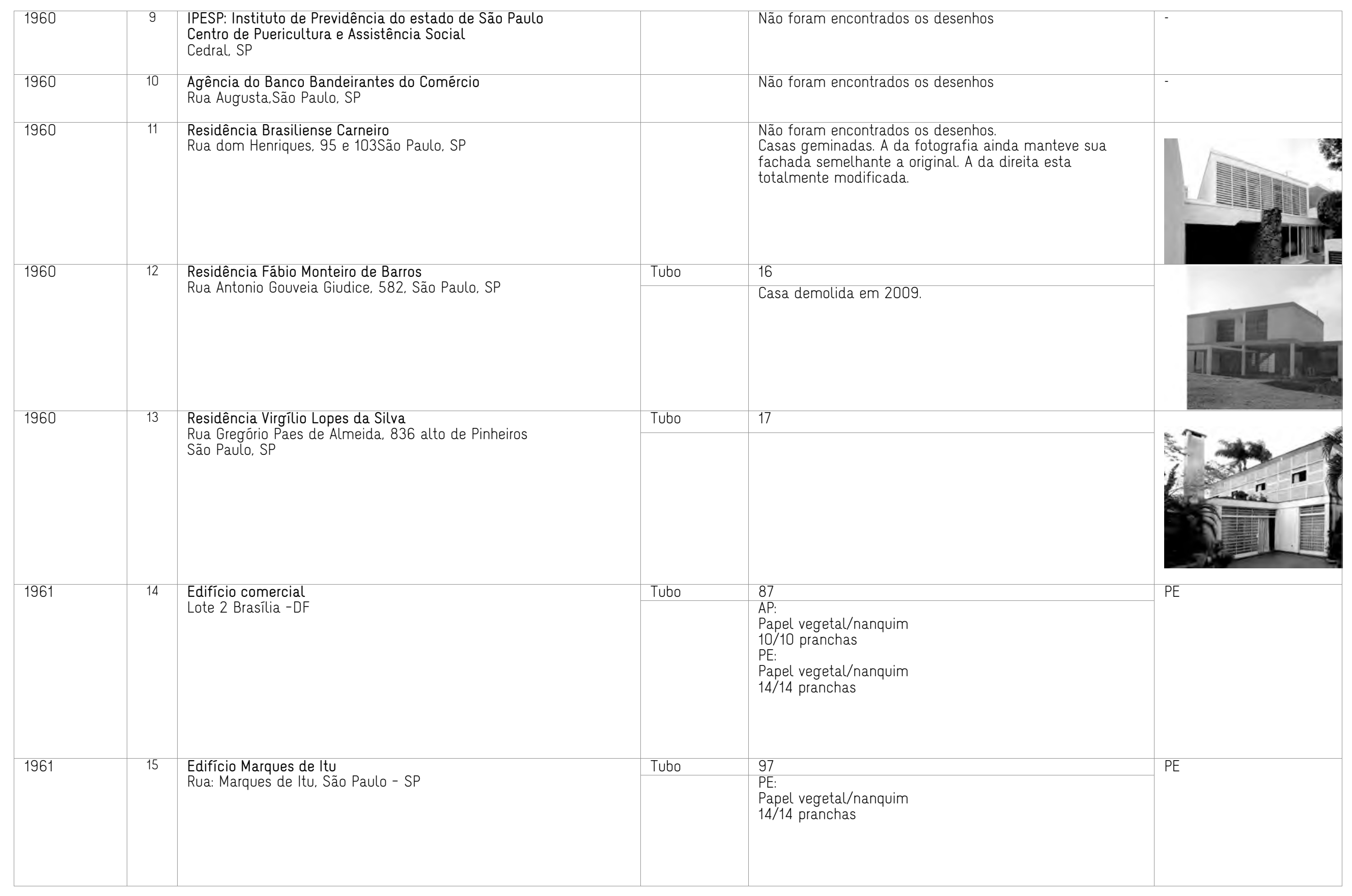




\begin{tabular}{|c|c|c|c|c|c|}
\hline 1961 & 16 & $\begin{array}{l}\text { Residência Heloisa Alves de Lima e Motta } \\
\text { Ilhabela - SP }\end{array}$ & Gaveta & $\begin{array}{l}\text { Casa de praia } \\
\text { Prefeitura } \\
\text { Papel vegetal/nanquim } \\
\text { Projeto Executivo } \\
\text { Papel vegetal/nanquim } \\
\text { 8/8 pranchas } \\
\text { 1978: Projeto Executivo } \\
\text { 3/3só não tem a folha } 1\end{array}$ & PE \\
\hline 1962 & 17 & $\begin{array}{l}\text { Faculdade de Antropologia e } \\
\text { Sociologia da USP } \\
\text { Cidade Universitāria, SP } \\
\text { Eng }^{\circ} \text { S. Mitsutani }\end{array}$ & $\begin{array}{l}\text { Digital } \\
\text { Tubo } \\
\text { Gaveta }\end{array}$ & $\begin{array}{l}9 \text { pranchas do projeto digitalizado.tif:ficha técnica.doc } \\
\text { 12:57(projeto de estrutura }\end{array}$ & PE \\
\hline 1962 & 18 & $\begin{array}{l}\text { Edifício de apartamentos } \\
\text { Av. Brigadeiro Luiz Antonio, São Paulo - SP }\end{array}$ & Gaveta & $\begin{array}{l}\text { Estudos } \\
\text { EP } \\
\text { Papel manteiga/lāpis (?) } \\
3 / 3 \text { pranchas A1 }\end{array}$ & EP \\
\hline 1962 & 19 & $\begin{array}{l}\text { Banco Leme Ferreira } \\
\text { Rua Marques de Itu,266, São Paulo, SP }\end{array}$ & & & EP \\
\hline 1962 & 20 & $\begin{array}{l}\text { Fórum de Avaré } \\
\text { Rua Paranā, 118, Avaré, SP } \\
\text { Equipe:Eduardo de Genaro e Newton Arakawa }\end{array}$ & Tubo & 96 & \\
\hline 1962 & 21 & $\begin{array}{l}\text { CNI - Confederação Nacional da Indústria } \\
\text { Brasília, DF } \\
\text { Equipe: Pedro Paulo de Mello Saraiva }\end{array}$ & Tubo & 3 e 48 & \\
\hline 1962 & 22 & $\begin{array}{l}\text { Escola Primária Sueli A. Mello (Vila Maria) } \\
\text { Rua Siqueira Campos, 845, São José dos Campos, SP }\end{array}$ & $\begin{array}{l}\text { Digital } \\
\text { Tubo }\end{array}$ & $\begin{array}{l}1 \text { foto P\&B do fim da obra:ficha técnica } \\
10\end{array}$ & \\
\hline 1962 & 23 & $\begin{array}{l}\text { Escola primária Taboão } \\
\text { Rua Nigéria, } 80 \\
\text { São Bernardo do Campo, SP }\end{array}$ & $\begin{array}{l}\text { Digital } \\
\text { Tubo } \\
\text { Gaveta }\end{array}$ & $\begin{array}{l}1 \text { foto P\&B da obra:ficha técnica.doc } \\
10\end{array}$ & \\
\hline
\end{tabular}




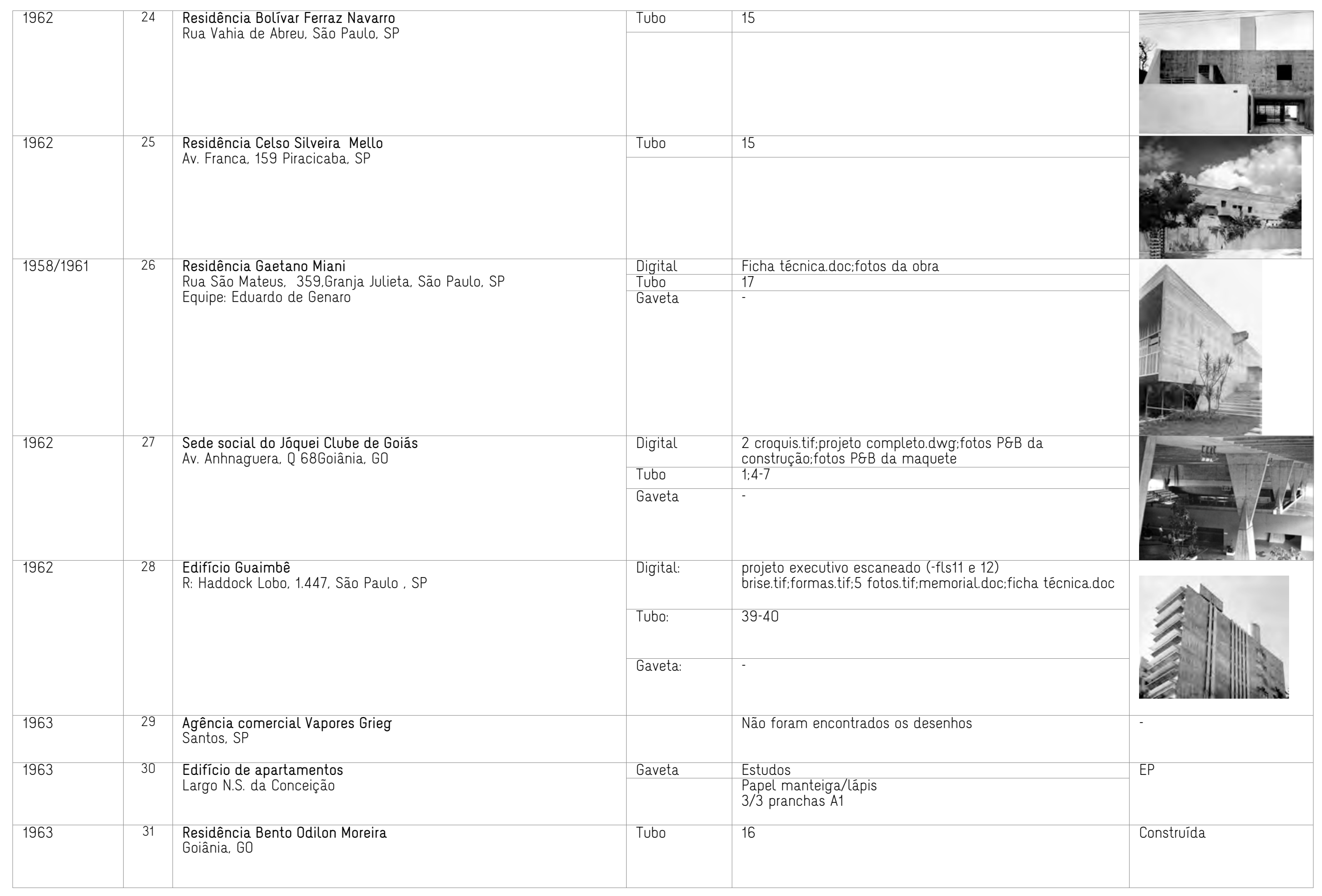




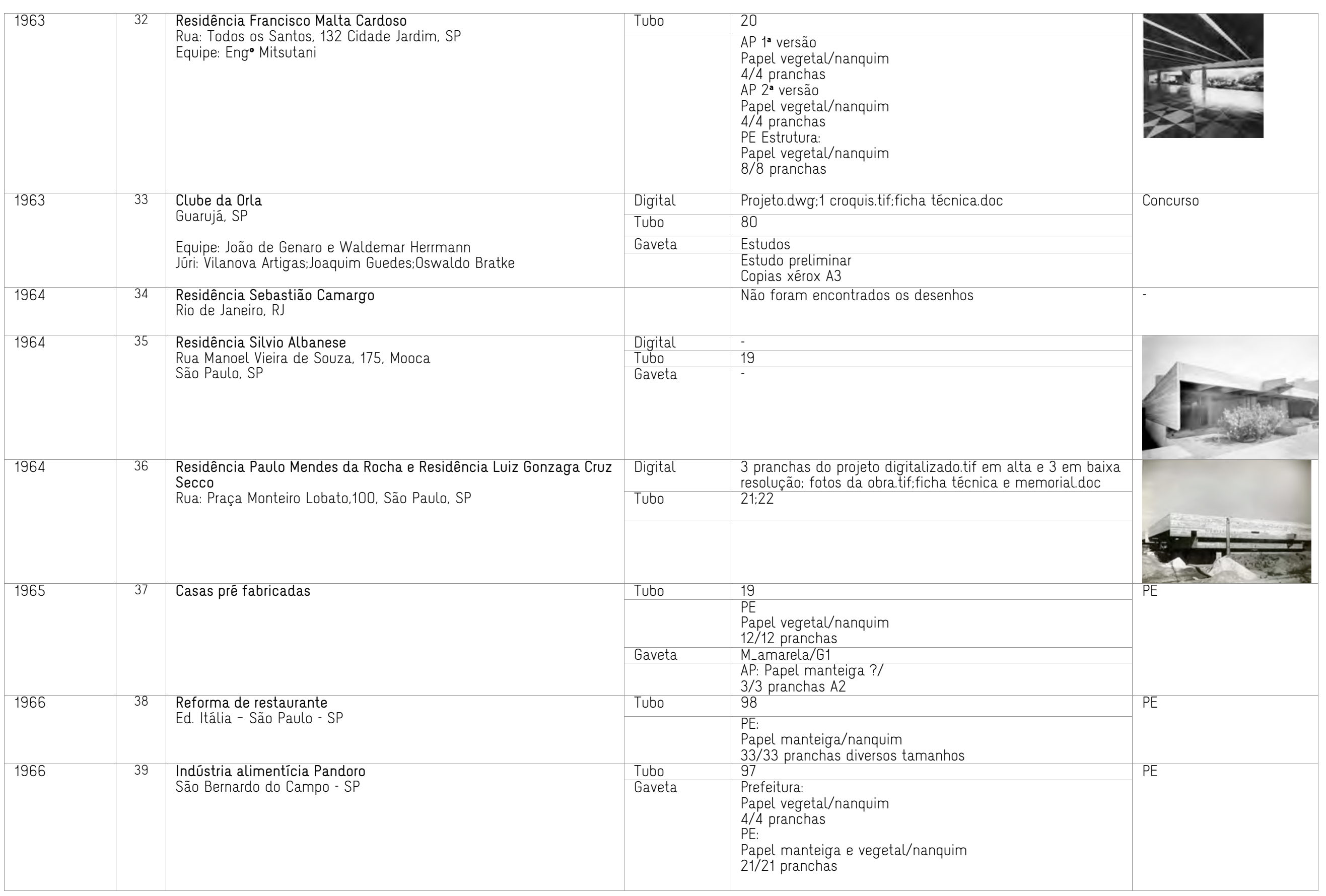




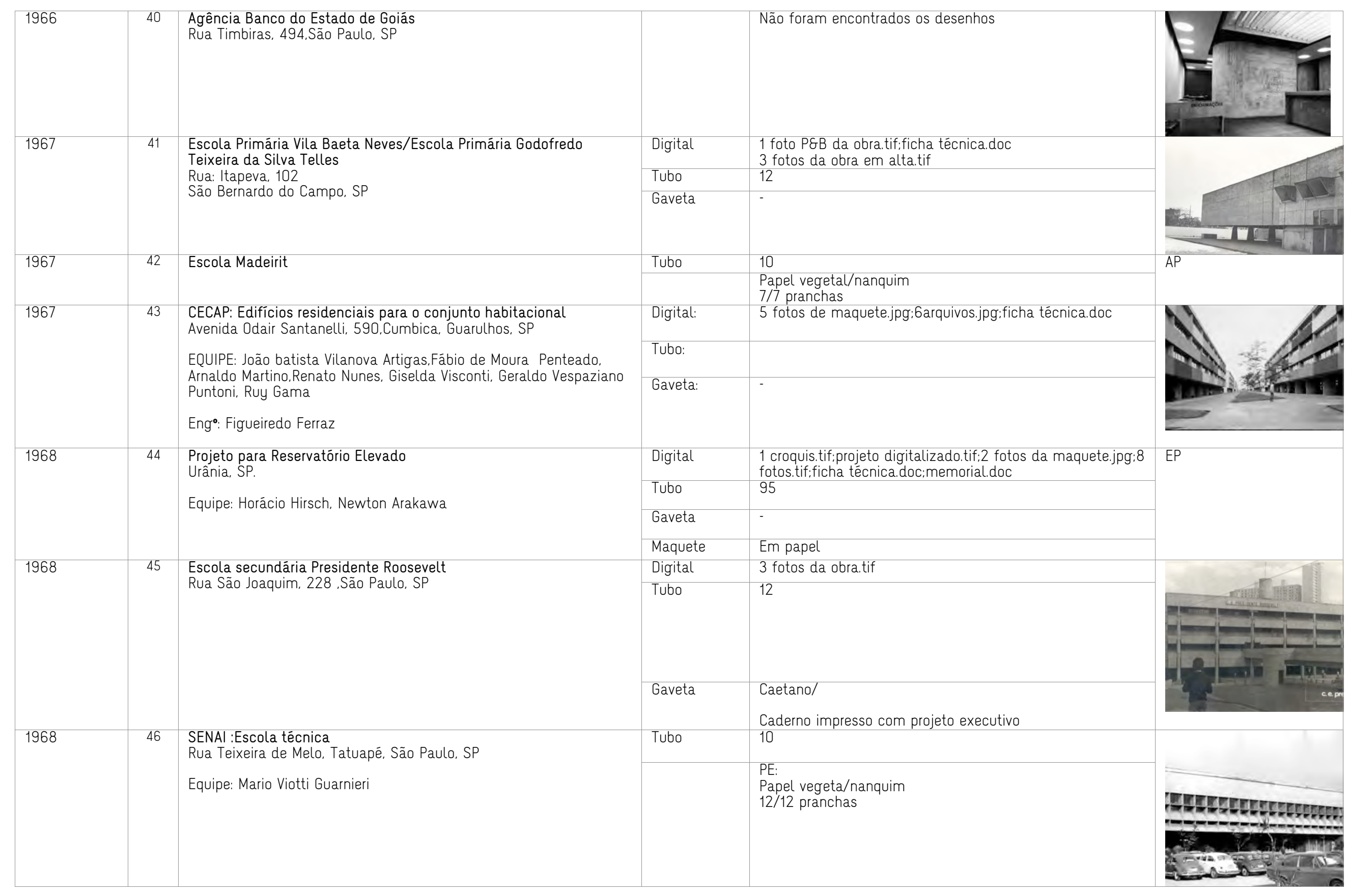




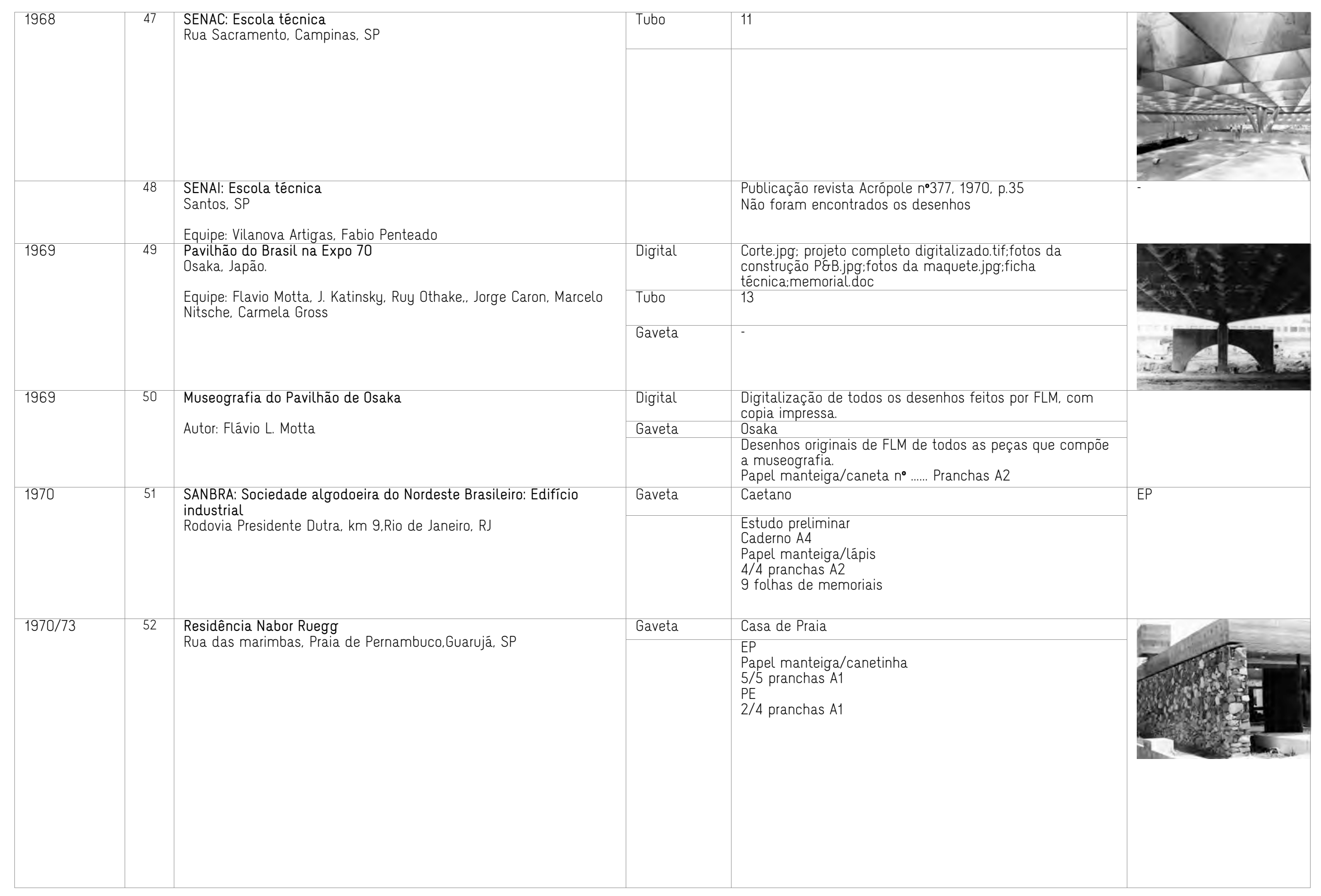




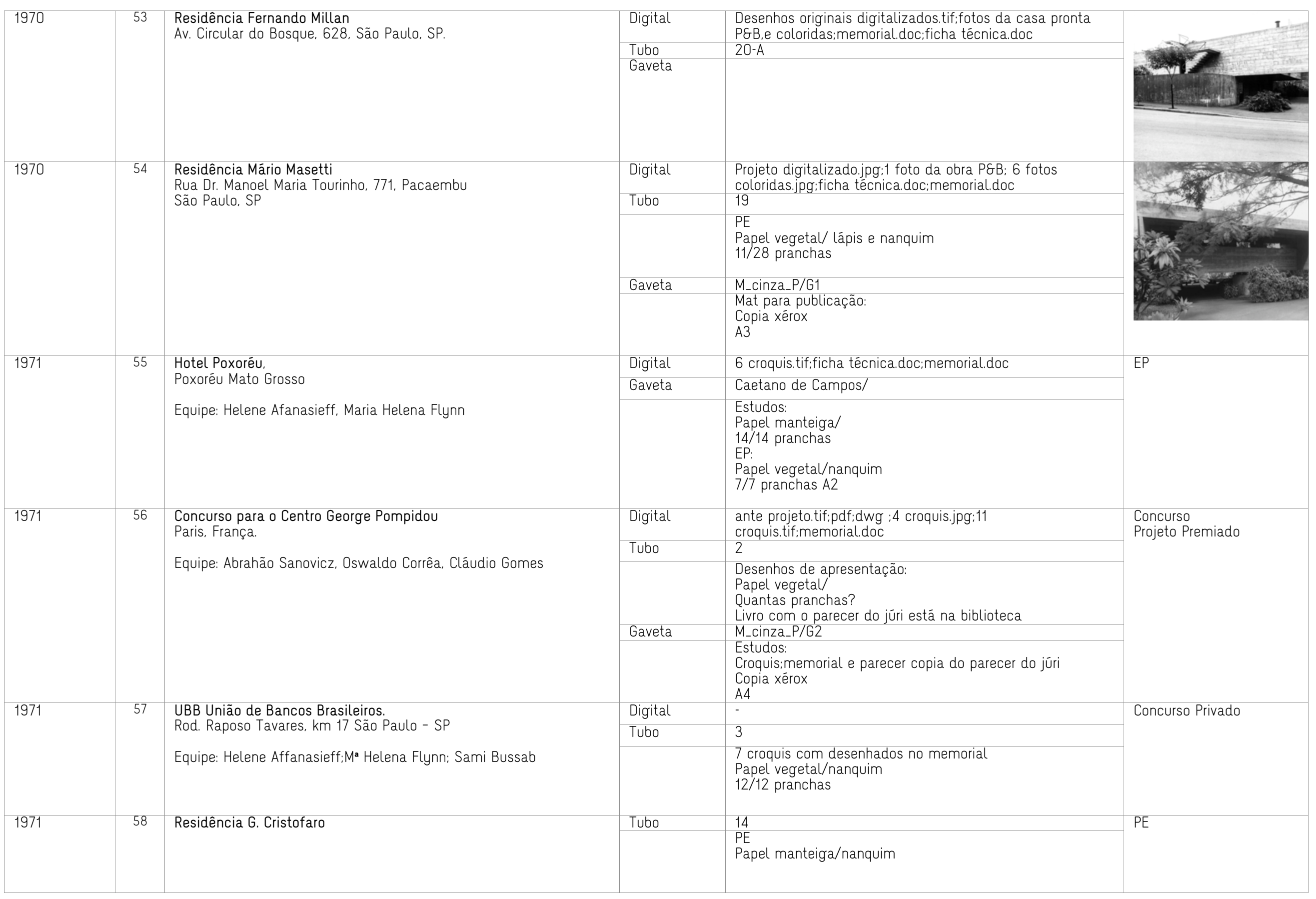




\begin{tabular}{|c|c|c|c|c|c|}
\hline \multirow[t]{2}{*}{1972} & \multirow[t]{2}{*}{59} & \multirow[t]{2}{*}{$\begin{array}{l}\text { Edifício Jauaperi - Formaespaço } \\
\text { Rua: Jauaperi, 176, São Paulo, SP }\end{array}$} & $\begin{array}{l}\text { Digital } \\
\text { Tubo }\end{array}$ & $\begin{array}{l}55 \\
\text { Croquis } \\
\text { Papel manteiga } \\
\text { AP: } \\
\text { Papel vegetal/nanquim } \\
11 / 11\end{array}$ & \multirow[t]{2}{*}{ Construído } \\
\hline & & & Gaveta & - & \\
\hline \multirow[t]{4}{*}{1972} & \multirow[t]{4}{*}{60} & \multirow[t]{4}{*}{$\begin{array}{l}\text { Educação Infantil Jardim Calux } \\
\text { Rua Âlvaro Guimarães, 350,São Bernardo do Campo, SP }\end{array}$} & Digital & $\begin{array}{l}6 \text { fotos da obra pronta (.tif):memorial.doc;ficha técnica.doc; } \\
1 \text { croquis }\end{array}$ & \\
\hline & & & Tubo & 10 & \\
\hline & & & & $\begin{array}{l}\text { AP } \\
\text { Papel vegetal/nanquim } \\
5 / 5 \text { pranchas } \\
\text { PE_ detalhes } \\
\text { Papel manteiga } \\
\text { 2/2 pranchas }\end{array}$ & \\
\hline & & & Gaveta & & \\
\hline \multirow[t]{2}{*}{1972} & \multirow[t]{2}{*}{61} & \multirow{2}{*}{$\begin{array}{l}\text { Residência James Francis King } \\
\text { Rua Angra dos Reis, } 1400 \\
\text { Chācara Flora, São Paulo, SP } \\
\text { Paisagismo: Eng. Rodolfo Gêiser e Ricardo Lobo de Andrade }\end{array}$} & $\begin{array}{l}\text { Digital } \\
\text { Tubo }\end{array}$ & $\begin{array}{l}3 \text { croquis.jpg:projeto digitalizado.jpg.tif } \\
18\end{array}$ & \\
\hline & & & Gaveta & & \\
\hline \multirow[t]{3}{*}{1972} & \multirow[t]{3}{*}{62} & \multirow{3}{*}{$\begin{array}{l}\text { Projeto de remodelação do centro da cidade de Santiago } \\
\text { Santiago, Chile } \\
\text { Equipe: Edgard Dente }\end{array}$} & Digital & 3 fotos da maquete.tif: memorial.doc:ficha técnica & \multirow[t]{3}{*}{ Concurso } \\
\hline & & & Tubo & 2 & \\
\hline & & & Maquete & $\begin{array}{l}\text { Papel vegetal/nanquim } \\
5 / 5 \text { folhas } \\
\text { Croquis de apresentação do projeto em copia heliográfica } \\
\text { Em papel }\end{array}$ & \\
\hline \multirow[t]{4}{*}{1973} & \multirow[t]{4}{*}{63} & $\begin{array}{l}\text { Estádio Serra Dourada } \\
\text { Goiânia, GO }\end{array}$ & Digital & $\begin{array}{l}\text { croquis a mão livre: fotos da obra:pronta:p\&b(tif:jpg); ficha } \\
\text { técnica.doc. }\end{array}$ & \\
\hline & & \multirow{3}{*}{$\begin{array}{l}\text { Equipe: Roberto Portugal, Maria helena Flynn, Roberto leme Ferreira, } \\
\text { Newton Arakawa, Ercules Turbiani, Eliane Galiardi }\end{array}$} & Tubo: & & \\
\hline & & & Gaveta: & M_cinza_P/G4 & \\
\hline & & & & $\begin{array}{l}\text { Croquis } \\
\text { Papel manteiga } \\
\text { A1 }\end{array}$ & \\
\hline 1973 & 64 & $\begin{array}{l}\text { la Bienal Internacional de Arquitetura:Projeto de exposição } \\
\text { Pavilhão da bienal, Pq. Do Ibirapuera,São Paulo, SP }\end{array}$ & & & Executado \\
\hline
\end{tabular}




\begin{tabular}{|c|c|c|c|c|c|}
\hline 1973 & 65 & Residência Lucia Francini & Gaveta & $\begin{array}{l}\text { Estudos } \\
\text { Estudo preliminar I } \\
\text { Papel manteiga/nanquim } \\
5 / 5 \text { pranchas A2 } \\
\text { Estudo preliminar II } \\
\text { Papel manteiga/nanquim } \\
7 / 7 \text { pranchas A2 }\end{array}$ & EP \\
\hline \multirow[t]{2}{*}{1973} & \multirow[t]{2}{*}{66} & \multirow{2}{*}{$\begin{array}{l}\text { Residência Lygia e Newton Isaac Carneiro } \\
\text { Rua João Carlos de Almeida, 494. Jardim Guarapiranga, São Paulo, } \\
\text { SP }\end{array}$} & \multirow[t]{2}{*}{ tubo } & 53 & \\
\hline & & & & $\begin{array}{l}\text { Fotos slides na biblioteca da FAU_USP } \\
\text { AP a lāpis }\end{array}$ & \\
\hline 1973 & 67 & $\begin{array}{l}\text { Residência Ignácio Gerber } \\
\text { Angra dos Reis, RJ }\end{array}$ & & Caixa de papelão na estante & \\
\hline 1973 & 68 & Residência Dalton Macedo Soares & Digital & 7 croquis.tif & \\
\hline & & $\begin{array}{l}\text { Rua Olegario Mariano, Morumbi } \\
\text { São Paulo, SP }\end{array}$ & Tubo & 22 & \\
\hline 1973 & 69 & $\begin{array}{l}\text { Residência Marcelo Nitsche } \\
\text { Rua Âlvares Florence, Butantã. São Paulo, SP }\end{array}$ & $\begin{array}{l}\text { Tubo } \\
\text { Gaveta }\end{array}$ & 18 & \\
\hline 1973 & 70 & $\begin{array}{l}\text { Residência Maria Alice Abbonanza } \\
\text { Rua: Caucaia do Alto. Serra da Cantareira - SP }\end{array}$ & Tubo & $\begin{array}{l}14 \\
\text { AP } \\
\text { Papel vegetal/nanquim } \\
4 / 4 \text { pranchas }\end{array}$ & AP \\
\hline
\end{tabular}




\begin{tabular}{|c|c|c|c|c|c|}
\hline \multirow[t]{3}{*}{1973} & \multirow[t]{3}{*}{71} & \multirow{3}{*}{$\begin{array}{l}\text { Casa Artêmio Furlan } \\
\text { Praia Lagoinha } \\
\text { Ubatuba, São Paulo }\end{array}$} & Tubo & 18 & \multirow{3}{*}{ in } \\
\hline & & & Gaveta & Casa de praia & \\
\hline & & & & $\begin{array}{l}\text { Ante Projeto } \\
\text { Papel manteiga/lápis } \\
7 / 7 \text { pranchas A1_mão livre }\end{array}$ & \\
\hline \multirow[t]{2}{*}{1973} & \multirow[t]{2}{*}{72} & \multirow[t]{2}{*}{ Residência Protótipo: Formaespaço } & Tubo & 33 & \multirow{2}{*}{ AP } \\
\hline & & & & $\begin{array}{l}\text { Papel vegetal/lápis } \\
6 / 6 \text { pranchas }\end{array}$ & \\
\hline \multirow[t]{2}{*}{1973} & \multirow[t]{2}{*}{73} & \multirow{2}{*}{ Chácara dos Bambus } & Gaveta & Estudos & \multirow[t]{2}{*}{ EP } \\
\hline & & & & $\begin{array}{l}\text { Estudo Preliminar } \\
\text { Papel manteiga/nanquim } \\
7 / 7 \text { pranchas } A 1\end{array}$ & \\
\hline \multirow[t]{2}{*}{1974} & \multirow[t]{2}{*}{74} & \multirow{2}{*}{$\begin{array}{l}\text { Centro Recreativo e Social de Ferrazópolis } \\
\text { São Bernardo do Campo (?) }\end{array}$} & Gaveta & Estudos & \multirow[t]{2}{*}{ EP } \\
\hline & & & & $\begin{array}{l}\text { EP I: } \\
\text { Papel vegetal/nanquim Copia heliográfica } \\
7 / 7 \text { pranchas } A O \\
\text { EP II: } \\
\text { Papel vegetal/nanquim } \\
3 / 3 \text { pranchas } A O \\
\text { Desenho a mao livre de canetinha hidrográfica }\end{array}$ & \\
\hline \multirow[t]{2}{*}{1974} & \multirow[t]{2}{*}{75} & \multirow{2}{*}{$\begin{array}{l}\text { Plano Urbanístico do rio Jaú } \\
\text { Jaú, SP } \\
\text { Equipe: Vilanova Artigas }\end{array}$} & & Não foram encontrados os desenhos & \multirow[t]{2}{*}{ EP } \\
\hline & & & & & \\
\hline \multirow[t]{2}{*}{1974} & \multirow[t]{2}{*}{76} & \multirow{2}{*}{$\begin{array}{l}\text { Parque da Grota } \\
\text { Bairro do Bexiga, São Paulo, SP } \\
\text { Equipe: Flávio Motta, Maria Ruth Sampaio:Benedito Lima de Toledo, } \\
\text { Christina de Castro Mello, Samuel Kerr, Koiti Mori, Klara Kaiser }\end{array}$} & Digital & 4 croquis.tif.jpg:ficha técnica.doc:memorial.doc & \multirow[t]{2}{*}{ Concurso } \\
\hline & & & Tubo & 29 & \\
\hline 1974 & 77 & Residência Carvalho Pinto & Tubo & $\begin{array}{l}38 \\
\text { EP } \\
\text { Caderno no papel manteiga/tinta }\end{array}$ & AP \\
\hline \multirow[t]{3}{*}{1974} & \multirow[t]{3}{*}{78} & \multirow{3}{*}{$\begin{array}{l}\text { TRANASA:Transmissões Mecânica Nacionais S.A.: } \\
\text { Rod. Fernão Dias, Guarulhos, SP }\end{array}$} & Tubo & 27 & \multirow{3}{*}{$\begin{array}{l}\text { Construído } \\
\text { Não encontrei imagem }\end{array}$} \\
\hline & & & Gaveta & Fotografias/gravuras & \\
\hline & & & & $\begin{array}{l}\text { AP: } \\
\text { Copia xérox } \\
\text { A2 } \\
\text { Fotos P\&B da maquete }\end{array}$ & \\
\hline \multirow[t]{3}{*}{1975} & \multirow[t]{3}{*}{79} & \multirow{3}{*}{$\begin{array}{l}\text { CECAP -Plano de urbanização: resisencial, escolas, comercio e lazer } \\
\text { Itatiba, SP } \\
\text { Equipe: Alfredo Paesani }\end{array}$} & Tubo & $23-26$ & \multirow[t]{3}{*}{ EP } \\
\hline & & & Gaveta & Caetano de Campos/ & \\
\hline & & & & $\begin{array}{l}\text { Papel manteiga/ } \\
4 \text { pranchas A2 } \\
\text { Memoriais } \\
\text { Desenhos no papel sulfite }\end{array}$ & \\
\hline
\end{tabular}




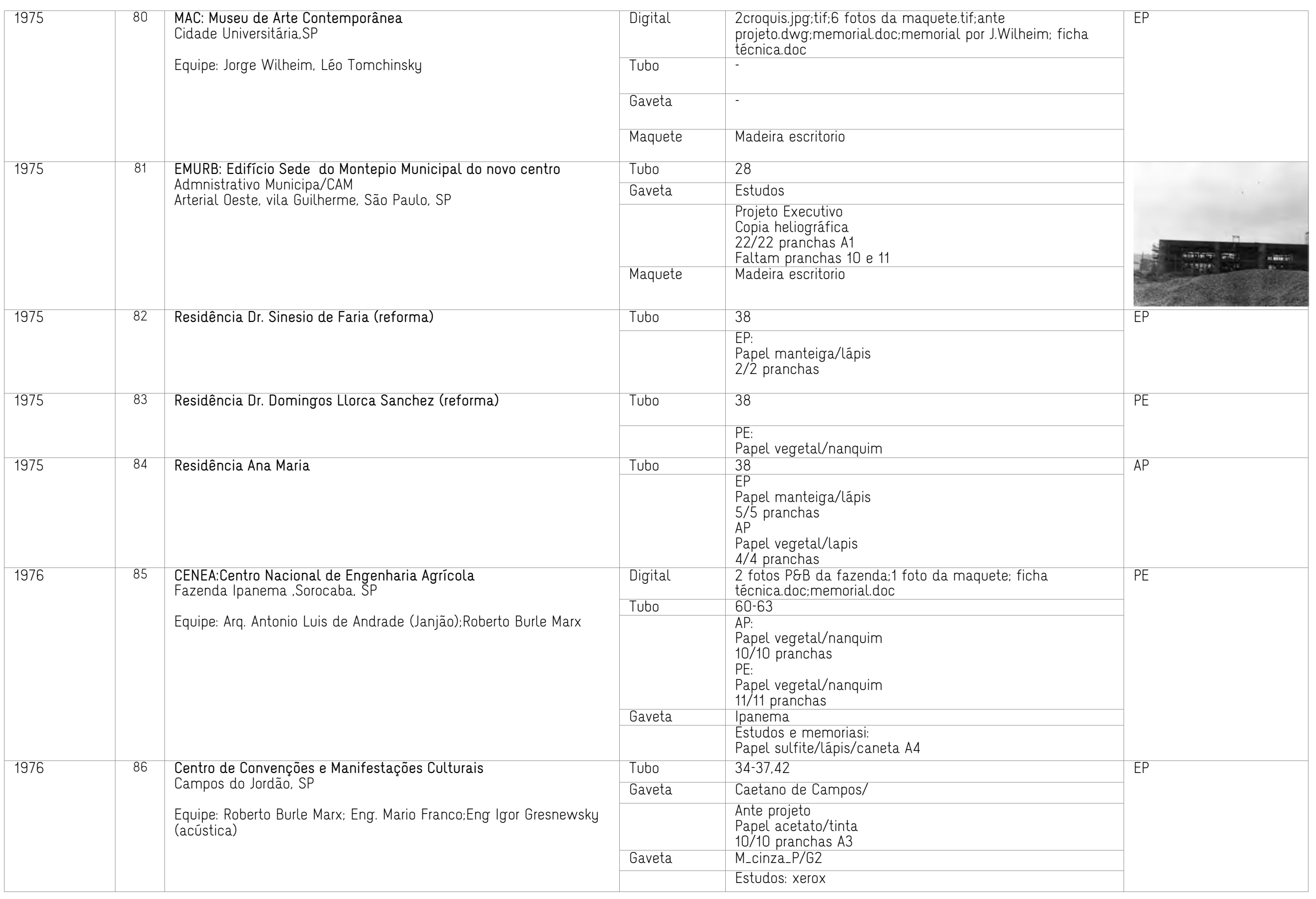




\begin{tabular}{|c|c|c|c|c|c|}
\hline 1976 & 87 & $\begin{array}{l}\text { EEPSG Vila Matilde } \\
\text { São Paulo, SP }\end{array}$ & & Não foram encontrados os desenhos & \\
\hline 1976 & 88 & $\begin{array}{l}\text { EEPSG Jardim Fraternidade } \\
\text { Campo Limpo, São Paulo, SP } \\
\text { Equipe:Alfredo Paesani }\end{array}$ & & Não foram encontrados os desenhos & \\
\hline 1976 & 89 & $\begin{array}{l}\text { Residência Antonio Junqueira de Azevedo, } \\
\text { Rua Guaonés,144, Jardim Guedala } \\
\text { São Paulo, SP } \\
\text { Equipe:Roberto Leme Ferreira }\end{array}$ & $\begin{array}{l}\text { Digital } \\
\text { Tubo }\end{array}$ & $\begin{array}{l}\text { Desenhos técnicos digitalizados.tif:6 fotos coloridas.jpg: } 5 \\
\text { fotos P\&B.tif:ficha técnica.doc:memorial.doc } \\
47\end{array}$ & (3) \\
\hline 1976 & 90 & $\begin{array}{l}\text { Instituto Caetano de Campos } \\
\text { Lg Nossa Senhora da Conceição,São Paulo, SP } \\
\text { Equipe: Abrahão Sanovicz }\end{array}$ & $\begin{array}{l}\text { Digital: } \\
\text { Tubo } \\
\text { Gaveta } \\
\text { Maquete }\end{array}$ & 3 croquis.tif: projeto.tif:memorial.doc; 5 fotos da maquete & Concurso \\
\hline 1977 & 91 & $\begin{array}{l}\text { Estação Rodoviária Interestadual } \\
\text { Cuiabá, MT } \\
\text { Equipe: Moacyr Freitas e Ercílio Gonçalves de Souza }\end{array}$ & $\begin{array}{l}\text { Digital } \\
\text { Tubo } \\
\text { Gaveta } \\
\text { Maquete }\end{array}$ & $\begin{array}{l}2 \text { fotos P\&B da maquete:memorial.doc; ficha técnica.doc } \\
44 \\
- \\
\text { Técnica mista }\end{array}$ & $\begin{array}{l}\text { Construída } \\
\text { Não foram encontradas } \\
\text { imagens }\end{array}$ \\
\hline 1977 & 92 & $\begin{array}{l}\text { Centro Universitário } \\
\text { Rondonópolis,MT }\end{array}$ & $\begin{array}{l}\text { Digital } \\
\text { Tubo } \\
\text { Gaveta }\end{array}$ & $\begin{array}{l}4 \text { fotos da maquete.jpg:1 foto da implantação_colagem } \\
84 \\
\text { M_amarela/rondonópolis } \\
\text { AP: } \\
\text { Papel vegetal/nanquim } \\
\text { A1 } \\
\text { Implantação } \\
\text { Colagem com papel seda }\end{array}$ & AP \\
\hline 1977 & 93 & $\begin{array}{l}\text { Casa das Retortas da Companhia de Gás de São Paulo } \\
\text { Rua do Gasômetro, Centro, SP } \\
\text { Equipe: Eduardo Colonelli }\end{array}$ & $\begin{array}{l}\text { Digital } \\
\text { Tubo } \\
\text { Gaveta }\end{array}$ & $\begin{array}{l}\text { Ficha técnica.doc:memorial.doc } \\
43 \\
\text { M_cinza_P/G4 } \\
\text { AP: } \\
\text { papel sulfite/copia } \\
9 \text { pranchas A2 }\end{array}$ & Construído parcialmente \\
\hline 1977 & 94 & $\begin{array}{l}\text { FUNBEC:Edifício de escritório } \\
\text { Rod Castelo Branco, km 22,Barueri, SP }\end{array}$ & $\begin{array}{l}\text { Digital } \\
\text { Tubo }\end{array}$ & $\begin{array}{l}105 \\
\text { EP:Croquis } \\
\text { Prefeitura } \\
\text { Papel vegetal/nanquim } \\
\text { AP: Papel vegetal/nanquim } \\
\text { PE:18/18 pranchas } \\
\text { Papel vegetal/nanquim }\end{array}$ & $\mathrm{PE}$ \\
\hline 1977 & 95 & $\begin{array}{l}\text { EEPSG Vila Heliópolis } \\
\text { São Paulo, SP }\end{array}$ & & Não foram encontrados os desenhos & - \\
\hline
\end{tabular}




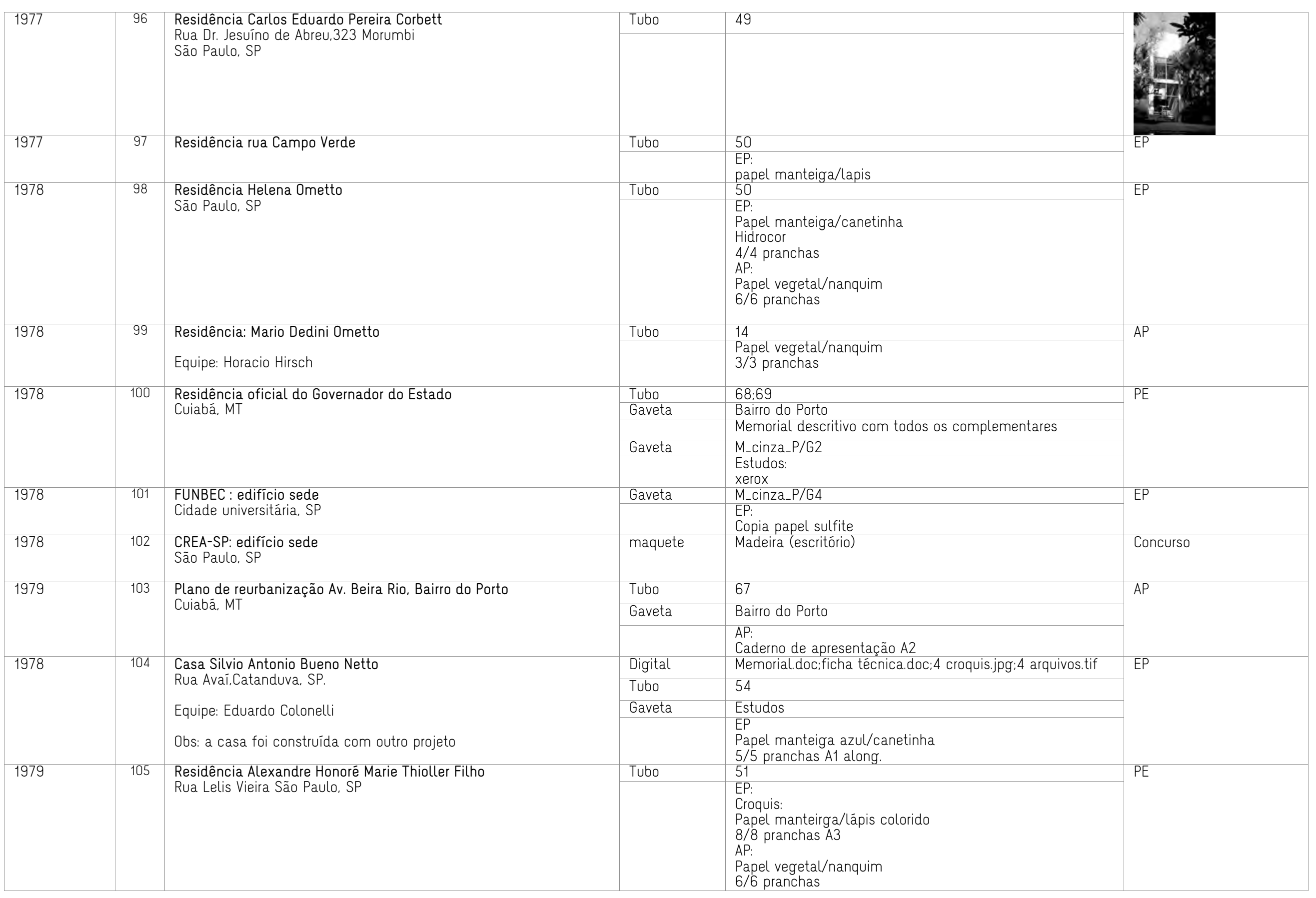




\begin{tabular}{|c|c|c|c|c|c|}
\hline & & & Maquete & $\begin{array}{l}\text { PE: } \\
\text { Arquitetura;estrutura;intalações } \\
\text { Madeira }\end{array}$ & \\
\hline \multirow[t]{2}{*}{1979} & \multirow[t]{2}{*}{106} & \multirow{2}{*}{$\begin{array}{l}\text { Residência Rodolfo Lara Campos } \\
\text { Rua Turquia - São Paulo SP }\end{array}$} & Tubo & 50 & \multirow[t]{2}{*}{ AP } \\
\hline & & & & $\begin{array}{l}\text { Papel vegetal/nanquim } \\
6 / 6 \text { pranchas }\end{array}$ & \\
\hline \multirow[t]{2}{*}{1979} & \multirow[t]{2}{*}{107} & \multirow{2}{*}{$\begin{array}{l}\text { Agencia Bancária Santos/Boqueirão } \\
\text { Av. Epitācio Pessoa, Santos, SP }\end{array}$} & Tubo & 50 & \multirow[t]{2}{*}{ EP } \\
\hline & & & & $\begin{array}{l}\text { EP } \\
\text { Papel manteiga/lápis } \\
5 / 5 \text { pranchas }\end{array}$ & \\
\hline \multirow[t]{4}{*}{1980} & \multirow[t]{4}{*}{108} & \multirow{4}{*}{$\begin{array}{l}\text { Cidade porto fluvial Tietê } \\
\text { Tietê. SP } \\
\text { Equipe: Paulo Archias Mendes da Rocha, Pedro Paulo de Mello } \\
\text { Saraiva, Alberto Rubens Botti, Giancarlo Gasperini }\end{array}$} & Digital & $\begin{array}{l}7 \text { croquis.tif: } 4 \text { fotos da maquete.tif:mapa digitalizado do } \\
\text { Estado de SP.tif:memorial port/inglês.doc;ficha técnica.doc }\end{array}$ & \multirow[t]{6}{*}{ AP } \\
\hline & & & Tubo & & \\
\hline & & & Gaveta & & \\
\hline & & & Maquete & Em aço. Hoje no Moma (Ny) & \\
\hline \multirow[t]{2}{*}{1980} & \multirow[t]{2}{*}{109} & \multirow{2}{*}{$\begin{array}{l}\text { Casa James Francis King } \\
\text { Ruas das Jabuticabeiras, praia de Pernambuco, Guarujā, SP }\end{array}$} & Gaveta & Casa da praia & \\
\hline & & & & $\begin{array}{l}\text { PE } \\
\text { Papel vegetal/lápis } \\
18 / 18 \text { pranchas .... } \\
\text { Detalhamento: } \\
\text { Projeto da cozinha } \\
\text { Papel manteiga/lāpis } \\
\text { 2/2 pranchas } \\
\text { Projeto Executivo da piscina } \\
\text { 1/1 Prancha }\end{array}$ & \\
\hline 1980 & 110 & $\begin{array}{l}\text { Laboratório Fleury } \\
\text { São Paulo, SP }\end{array}$ & Tubo & $30: 31$ & PE \\
\hline 1980 & 111 & $\begin{array}{l}\text { Agência Banespa S/A. } \\
\text { Teresina. Pl }\end{array}$ & Tubo & 56 & PE \\
\hline 1981 & 112 & $\begin{array}{l}\text { Estação Rodoviária Interestadual } \\
\text { Aguaī, SP }\end{array}$ & $\begin{array}{l}\text { Digital } \\
\text { Tubo }\end{array}$ & $\begin{array}{l}\text { Fotos P\&B da maquete } \\
75: 76\end{array}$ & \multirow{2}{*}{$\begin{array}{l}\text { Construído } \\
\text { Não foram encontradas } \\
\text { imagens } \\
\text { PE }\end{array}$} \\
\hline 1981 & 113 & $\begin{array}{l}\text { Estação Rodoviária Interestadual } \\
\text { Caraguatatuba, SP }\end{array}$ & $\begin{array}{l}\text { Digital } \\
\text { Tubo }\end{array}$ & $\begin{array}{l}2 \text { croquis.tif: } 1 \text { croquis.jpg:ficha técnica.doc } \\
75 ; 76\end{array}$ & \\
\hline 1981 & 114 & $\begin{array}{l}\text { Estádio Rudge Ramos } \\
\text { São Bernardo do Campo, SP }\end{array}$ & & Não foram encontrados os desenhos & - \\
\hline 1981 & 115 & $\begin{array}{l}\text { Estádio de Riacho Grande } \\
\text { São Bernardo do Campo. SP }\end{array}$ & & Não foram encontrados os desenhos & - \\
\hline 1981 & 116 & $\begin{array}{l}\text { Residência Haiyim Choedik } \\
\text { Rua Suécia, 53,São Paulo, SP }\end{array}$ & $\begin{array}{l}\text { Tubo } \\
\text { Maquete }\end{array}$ & $\begin{array}{l}32 \\
\text { Papel e madeira (?) } \\
\text { Foto da maquete }\end{array}$ & $\begin{array}{l}\text { Construída } \\
\text { Não foram encontradas } \\
\text { imagens }\end{array}$ \\
\hline
\end{tabular}




\begin{tabular}{|c|c|c|c|c|c|}
\hline 1982 & 117 & $\begin{array}{l}\text { SENAI :Centro de treinamento } \\
\text { Franca, SP }\end{array}$ & & Não foram encontrados os desenhos & - \\
\hline 1982 & 118 & Residência com 6 vigas & Gaveta & $\begin{array}{l}\text { M_cinza_P/G4 } \\
\text { Estudos: } \\
\text { Croquis } \\
\text { Papel manteiga/lápis } \\
1 \text { prancha AO }\end{array}$ & EP \\
\hline 1982 & 119 & $\begin{array}{l}\text { Residência Maurício Thomaz Bastos } \\
\text { Praia de Pernambuco, Guarujā, SP }\end{array}$ & Gaveta & $\begin{array}{l}\text { Estudos } \\
\text { EP: } \\
1 / 1 \text { prancha } A 1 \\
\text { AP: } \\
\text { Papel manteiga/nanquim } \\
4 / 4 \text { pranchas } A 1\end{array}$ & $\begin{array}{l}\text { Construído } \\
\text { Não foram encontradas } \\
\text { imagens }\end{array}$ \\
\hline 1983 & 120 & $\begin{array}{l}\text { Apt. Mario Masetti - reforma } \\
\text { Edifício Bahamas, São Paulo, SP }\end{array}$ & Gaveta & $\begin{array}{l}\text { Estudos } \\
\text { EP: } \\
\text { Papel manteiga/lápis } \\
8 \text { croquis } \\
\text { PE: } \\
\text { Papel vegetal/lapis } \\
\text { 4/4 pranchas A1 }\end{array}$ & EP \\
\hline 1983 & 121 & $\begin{array}{l}\text { Edifícios residenciais Costão das Tartarugas } \\
\text { Guarujāa, SP }\end{array}$ & & Não foram encontrados desenhos & - \\
\hline 1983 & 122 & $\begin{array}{l}\text { Residência Carlos Moreira Ferreira Montenegro } \\
\text { Jaú, SP }\end{array}$ & & Não foram encontrados desenhos & - \\
\hline 1984 & 123 & $\begin{array}{l}\text { Edifício de escritório Keiralla Sarham, } \\
\text { Rua Leopoldo Couto Magalhães Junior, } 132 \text { São Paulo, SP } \\
\text { Equipe: Eduardo Colonelli, Alexandre Delijaicov, Eduardo Aquino, } \\
\text { Geni Sugai, Rogério Marcondes Machado }\end{array}$ & $\begin{array}{l}\text { Digital: } \\
\text { Tubo }\end{array}$ & $\begin{array}{l}1 \text { croquis.jpg; projeto.dwg;6 fotos.jpg;4.psd } \\
64\end{array}$ & \\
\hline 1984- & 124 & $\begin{array}{l}\text { Edifício residencial Jaraguá } \\
\text { Praça Cidade da Paz, } 31 \text { Perdizes } \\
\text { São Paulo, SP } \\
\text { Equipe: Eduardo Colonelli, Alexandre Delijaicov, Eduardo Aquino, } \\
\text { Fernando Soares de Freitas, Geni Sugai, Marina Cobra, Rogério } \\
\text { Marcondes Machado }\end{array}$ & $\begin{array}{l}\text { Digital: } \\
\text { Tubo: }\end{array}$ & $\begin{array}{l}6 \text { croquis.jpg:projeto.dwg; } 3 \text { foto.tif (Nelson } \\
\text { Kon):memória.doc } \\
\text { 77:78 }\end{array}$ & \\
\hline 1984 & 125 & $\begin{array}{l}\text { Residência Maria Alice } \\
\text { Praia Barra do Una, SP }\end{array}$ & Gaveta & $\begin{array}{l}\text { Casa da praia } \\
\text { Estudo } \\
\text { Papel manteiga/lápis } \\
4 \text { pranchas A3 along. }\end{array}$ & EP \\
\hline
\end{tabular}




\begin{tabular}{|c|c|c|c|c|c|}
\hline 1984 & 126 & $\begin{array}{l}\text { CELTA - Construtora e Incorporadora: Protótipo de escola } \\
\text { Goiânia, GO }\end{array}$ & Gaveta & $\begin{array}{l}\text { M_cinza_P/G3 e G4 } \\
\text { Estudos: } \\
\text { Papel sulfite } \\
2 \text { folhas A4 } \\
\text { AP: } \\
\text { Papel manteiga/lápis } \\
\text { 2/2 pranchas }\end{array}$ & AP \\
\hline 1984 & 127 & $\begin{array}{l}\text { Biblioteca Pública do Rio de Janeiro } \\
\text { Rio de Janeiro, RJ } \\
\text { Equipe: Eduardo Colonelli, Eduardo Aquino }\end{array}$ & $\begin{array}{l}\text { Digital: } \\
\text { Tubo: } \\
\text { Gaveta }\end{array}$ & $\begin{array}{l}2 \text { croquis.jpg:3 croquis.tif:projeto } 8 \\
\text { pranchas.jpg:memorial.doc } \\
\text { M_cinza_P/G2 } \\
\text { Estudos: } \\
\text { Croquis/edital/memórias de cálculo } \\
\text { Original/copia } \\
\text { A4 }\end{array}$ & Concurso \\
\hline 1985 & 128 & $\begin{array}{l}\text { Terminal Rodoviário de Goiânia } \\
\text { Rua Quarenta e quatro. Setor Norte Goiânia, GO } \\
\text { Equipe: Luis Fernando Teixeira, Moacyr Paulista Cordeiro. O projeto } \\
\text { foi desenvolvido pelo escritōrio de arquitetura SUPLAN em Goiânia e } \\
\text { existem no escritório somente alguns croqui em gaveta e fotos no } \\
\text { arquivo suspenso. }\end{array}$ & & Não foram encontrados os desenhos & 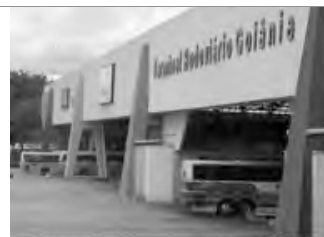 \\
\hline 1985 & 129 & Conjunto Habitacional Padre Bento & Gaveta & $\begin{array}{l}\text { M_cinza_P/G4 } \\
\text { EP: } \\
\text { papel manteiga/lápis cores } \\
\text { AP: } \\
\text { Papel manteiga/lápis } \\
6 / 6 \text { folhas A2 }\end{array}$ & $\mathrm{AP}$ \\
\hline 1985 & 130 & $\begin{array}{l}\text { Edifício de apartamentos Golden Hill } \\
\text { Alameda dos Aicás, São Paulo, SP }\end{array}$ & Tubo & 65 & $\begin{array}{l}\text { Não foram encontradas } \\
\text { imagens }\end{array}$ \\
\hline & 131 & $\begin{array}{l}\text { Agencia Regional } \\
\text { Itaquera - Guaianazes }\end{array}$ & Gaveta & $\begin{array}{l}\text { Fotografias/Gravuras } \\
6 \text { fotos P\&B da maquete }\end{array}$ & AP \\
\hline 1985 & 132 & $\begin{array}{l}\text { Agência Banco do Estado de São Paulo } \\
\text { Maringā. PR }\end{array}$ & Gaveta & $\begin{array}{l}\text { M_cinza_P/G4 } \\
\text { API: } \\
\text { Papel manteiga/lápis } \\
2 / 2 \text { pranchas } \\
\text { AP Il: } \\
\text { Papel manteiga/lápis } \\
\text { 2/2 pranchas }\end{array}$ & AP \\
\hline 1985 & 133 & $\begin{array}{l}\text { Residência Carlos Eduardo Lang } \\
\text { Alphaville - São Paulo, SP }\end{array}$ & Gaveta & $\begin{array}{l}\text { Estudos } \\
\text { EP } 2 \text { croquis a mão livre } \\
\text { AP Papel manteiga/lapis } \\
5 / 5 \text { pranchas AO_mao livre } \\
\text { Ante projeto II Papel manteiga/lápis } \\
7 / 7 \text { pranchas AO_régua }\end{array}$ & AP \\
\hline
\end{tabular}




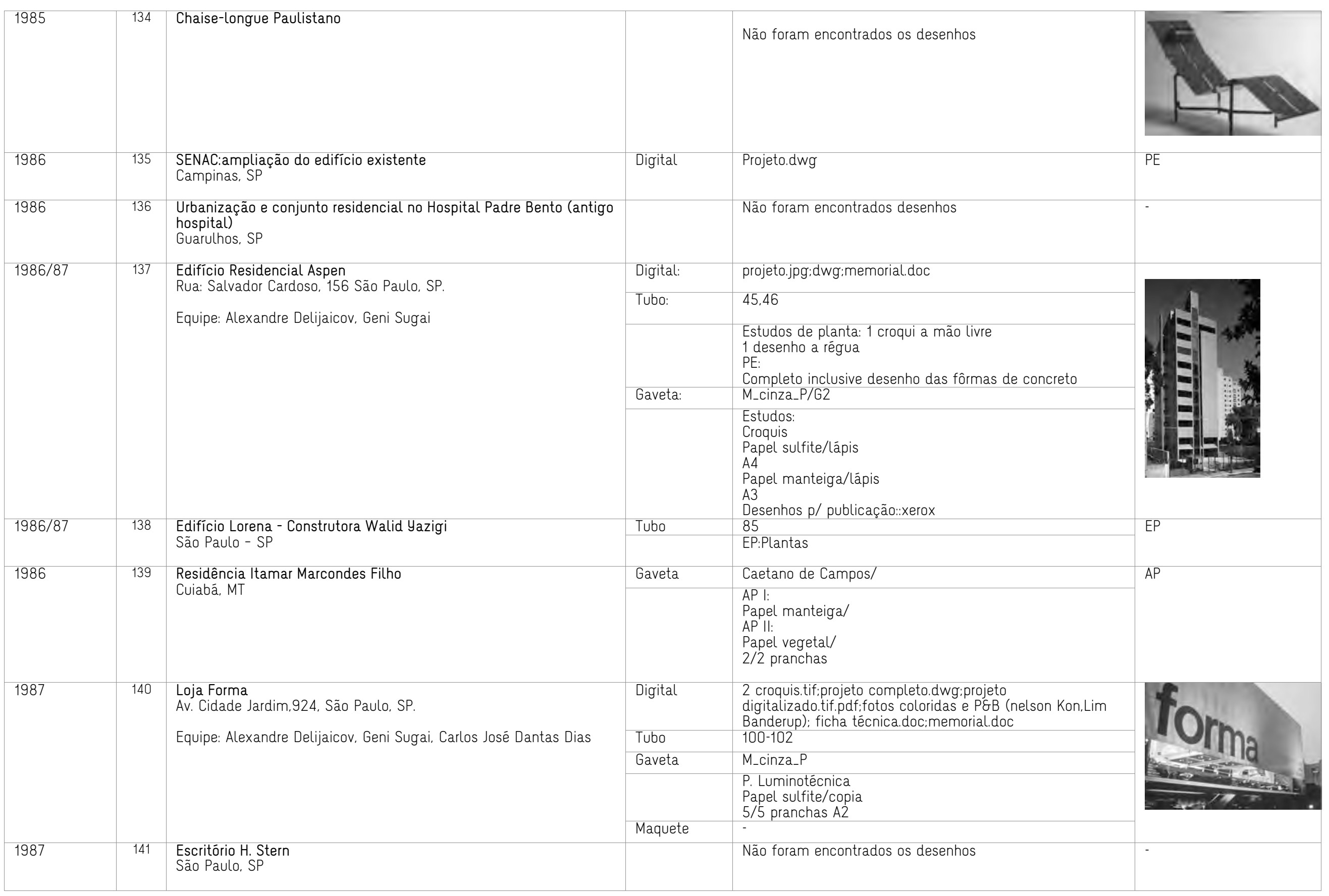




\begin{tabular}{|c|c|c|c|c|c|}
\hline 1987 & 142 & $\begin{array}{l}\text { SENAC: unidade Santo Amaro } \\
\text { Rua: Antonio Bento,381/393,São Paulo, SP }\end{array}$ & $\begin{array}{l}\text { Digital } \\
\text { Tubo }\end{array}$ & $\begin{array}{l}\text { 103:104 } \\
\text { EP: } \\
\text { Papel vegetal/nanquim } \\
\text { 7/7 pranchas } \\
\text { AP: } \\
\text { Papel vegetal/nanquim } \\
\text { 11/11 pranchas } \\
\text { Prefeitura: } \\
\text { 13/13 pranchas } \\
\text { EP II: 1988_novo terreno } \\
\text { Papel vegetal/nanquim } \\
\text { 4/4 pranchas } \\
\text { APII: } \\
\text { Papel vegetal/nanquim } \\
\text { 12/12 pranchas }\end{array}$ & $A P \mid$ e $\|$ \\
\hline 1988 & 143 & $\begin{array}{l}\text { Capela São Pedro } \\
\text { Palăcio do Governador,Campos de Jordão, SP } \\
\text { Equipe: Eduardo Colonelli, Alexandre Delijaicov, Geni Sugai, Carlos } \\
\text { José Dantas } \\
\text { Painel: Glauco Pinto de Moraes (1928, Passo Fundo, RS) }\end{array}$ & $\begin{array}{l}\text { Digital } \\
\text { Tubo }\end{array}$ & $\begin{array}{l}\text { Projeto digitalizado.tif } \\
\text { Croquis.tif } \\
74\end{array}$ & \\
\hline 1988 & 144 & $\begin{array}{l}\text { Biblioteca de Alexandria: UNESCO } \\
\text { Alexandria, Egito } \\
\text { Equipe: Alexandre Delijaicov, Geni Sugai, Álvaro Puntoni, Álvaro } \\
\text { Razuk, Ciro Pirondi, Francisco Rosa, Jorge Ricca Junior, Regina } \\
\text { Ferreira de Gouveia }\end{array}$ & $\begin{array}{l}\text { Digital: } \\
\text { Tubo: } \\
\text { Gaveta: }\end{array}$ & $\begin{array}{l}3 \text { croquis.tif: } 10 \text { fotos da maquete feita em esparadrapo:2 } \\
\text { memoriais em português e inglês.doc. } \\
66 \\
\text { M_cinza_P/G3 } \\
\begin{array}{l}\text { Copias dos desenhos de apresentação:memorial:fotos da } \\
\text { maquete }\end{array}\end{array}$ & Concurso \\
\hline 1988 & 145 & $\begin{array}{l}\text { MUBE: Museu Brasileiro de Escultura } \\
\text { Av. Europa. 218, São Paulo, SP } \\
\text { Equipe: Alexandre Delijaicov, Geni Sugai, Pedro Mendes da Rocha, } \\
\text { José Armênio, Carlos José Dantas Dias, Rogério Marcondes Machado, } \\
\text { Vera Domschke } \\
\text { Paisagismo: Roberto Burle Marx }\end{array}$ & $\begin{array}{l}\text { Digital } \\
\text { Tubo } \\
\text { Gaveta }\end{array}$ & $\begin{array}{l}23 \text { croquis.tig.jpg:planta Burle marx.jpg:Projeto executivo } \\
\text { completo em dwg:3 fotos coloridas da maquete:fotos da } \\
\text { obra Nelson Kon } \\
70-73 \\
\text { M_cinza_P/G2 } \\
\text { PE + complementares: } \\
\text { papel manteiga/lápis } \\
\text { Desenhos p/ publicação: } \\
\text { Estudos de variantes } \\
\text { Copia } \\
\text { A4 }\end{array}$ & \\
\hline 1988 & 146 & $\begin{array}{l}\text { Residência Maricatto } \\
\text { Praia do Guaecá - SP }\end{array}$ & $\begin{array}{l}\text { Gaveta } \\
\text { Tubo } 14\end{array}$ & $\begin{array}{l}\text { Casa da praia } \\
\text { Estudo preliminar } \\
\text { Papel manteiga/lápis } \\
5 / 5 \text { pranchas AO_mão livre }\end{array}$ & EP \\
\hline
\end{tabular}




\begin{tabular}{|c|c|c|c|c|c|}
\hline 1989 & 147 & $\begin{array}{l}\text { Residência Antonio Gerassi Neto } \\
\text { Rua Carlos Norberto de Souza Aranha, 409, São Paulo, SP } \\
\text { Equipe: Alexandre Delijaicov, Geni Sugai, Pedro Mendes da Rocha }\end{array}$ & $\begin{array}{l}\text { Digital } \\
\text { Tubo }\end{array}$ & $\begin{array}{l}\text { Projeto completo digitalizado:fotos da casa pronta:ficha } \\
\text { técnica.doc:memorial.doc } \\
\text { Gerassi possui um filme da obra onde se vê PMR } \\
\text { explicando o que esta acontecendo } \\
89\end{array}$ & (1) \\
\hline & & & Gaveta & - & \\
\hline 1990 & 148 & $\begin{array}{l}\text { Edifício de apartamentos - Construtora Yazigi } \\
\text { Praia Grande - SP }\end{array}$ & Tubo & $\begin{array}{l}109 \\
\text { Ante projeto } \\
\text { Papel manteiga/lápis } \\
7 / 7 \text { pranchas } \\
\text { Prefeitura } \\
\text { Papel vegetal/nanquim }\end{array}$ & AP \\
\hline 1990 & 149 & $\begin{array}{l}\text { Associação Atlética XI de Agosto: Edifício sede } \\
\text { São Paulo, SP } \\
\text { Equipe: Alexandre Delijaicov, Miriam Elwing.Pedro Mendes da Rocha }\end{array}$ & $\begin{array}{l}\text { Tubo } \\
\text { Gaveta }\end{array}$ & $\begin{array}{l}94 \\
\text { M_cinza_P/G3 } \\
\text { AP: Papel manteiga/lápis } \\
\text { 2/2 pranchas A2-along }\end{array}$ & AP \\
\hline 1990 & 150 & $\begin{array}{l}\text { Museu da UNICAMP } \\
\text { Campinas - SP } \\
\end{array}$ & Tubo & $\begin{array}{l}91 \\
\text { AP: Papel manteiga/lápis } \\
6 / 6 \text { pranchas A1 } \\
\text { AP II: Papel manteiga/lápis } \\
\text { 13/13 pranchas A1 }\end{array}$ & AP \\
\hline 1990 & 151 & $\begin{array}{l}\text { Conjunto habitacional Jardim São Luis I } \\
\text { São Paulo, SP }\end{array}$ & - & Não foram encontrados os desenhos & - \\
\hline 1990 & 152 & $\begin{array}{l}\text { Conjunto habitacional General Salgado } \\
\text { General Salgado, SP }\end{array}$ & & Não foram encontrados os desenhos & - \\
\hline 1990 & 153 & $\begin{array}{l}\text { Cenário: "Suor Angélica" } \\
\text { Teatro Municipal de São Paulo, SP } \\
\text { Equipe: Katia Pestada e Clauido Diaféria }\end{array}$ & Digital & 3 croquis & executado \\
\hline 1991 & 154 & $\begin{array}{l}\text { EEPSG Jardim dos Campeões e Delegacia de Ensino } \\
\text { Diadema. SP } \\
\text { Equipe: Alexandre Delijaicov }\end{array}$ & Tubo & 88 & PE \\
\hline 1991 & 155 & $\begin{array}{l}\text { EEPSG Jardim Novo Horizonte II } \\
\text { Carapicuíba, SP }\end{array}$ & Tubo & 92 & \\
\hline
\end{tabular}




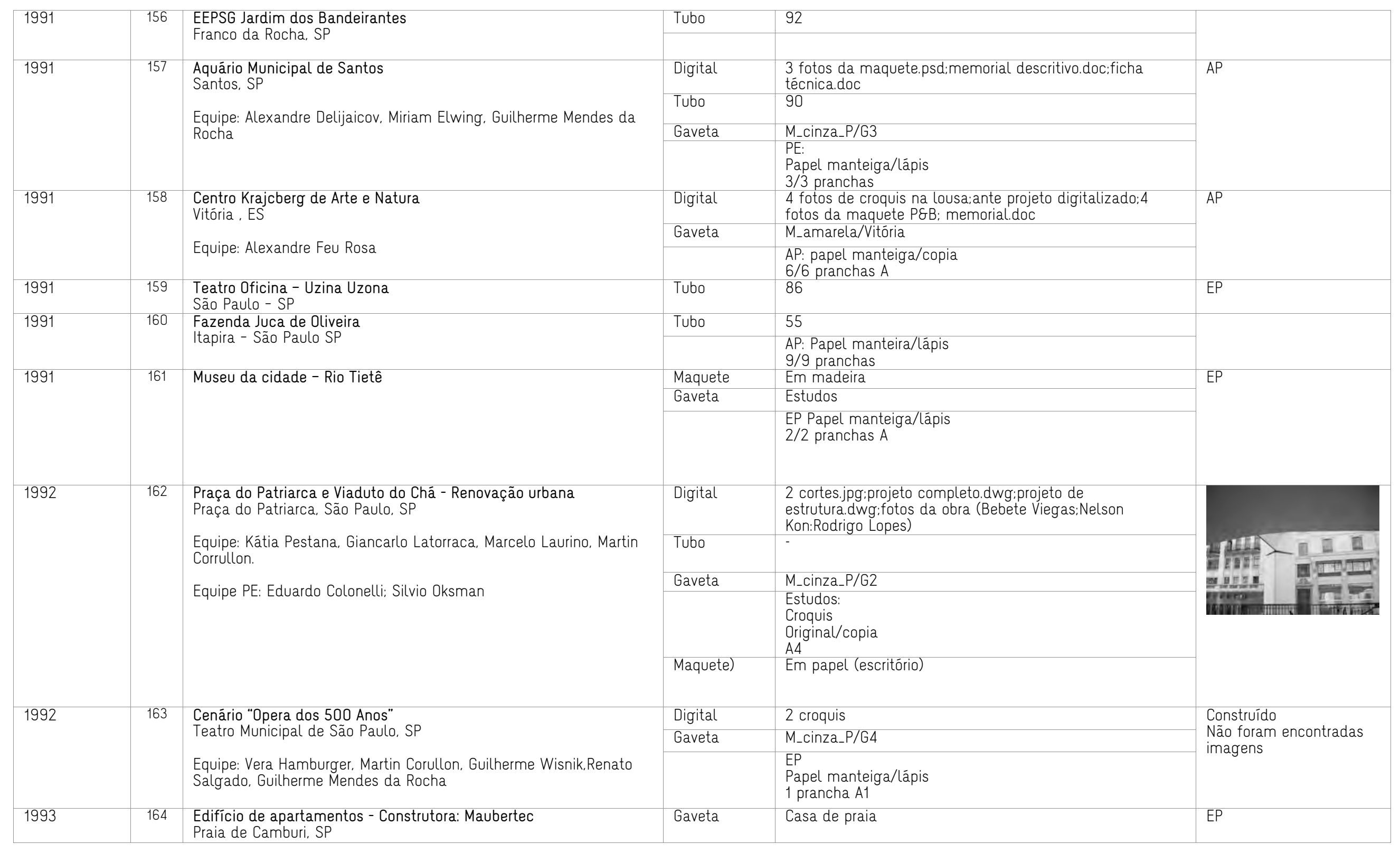




\begin{tabular}{|c|c|c|c|c|c|}
\hline & & & & $\begin{array}{l}\text { Estudo Preliminar } \\
\text { Papel sulfite/lápis } \\
9 \text { folhas A4_mão livre } \\
\text { Estudo Preliminar II } \\
\text { Papel sulfite/laapis } \\
\text { 3/3 pranchas A3_mão livre }\end{array}$ & \\
\hline \multirow[t]{2}{*}{1993} & \multirow[t]{2}{*}{165} & \multirow{2}{*}{$\begin{array}{l}\text { Banco do Estado do Espírito Santo } \\
\text { Vitória, ES }\end{array}$} & Gaveta & M_cinza_P/G4 & \multirow[t]{2}{*}{ EP } \\
\hline & & & & $\begin{array}{l}\text { Papel sulfite/copia } \\
5 / 5 \text { pranchas AO }\end{array}$ & \\
\hline \multirow[t]{3}{*}{1993} & \multirow[t]{3}{*}{166} & \multirow{3}{*}{$\begin{array}{l}\text { Plano urbanístico da Baía de Vitória } \\
\text { Vitória, ES } \\
\text { Equipe: Kátia Pestana, Giancarlo Latorraca }\end{array}$} & Digital & 5 croquis do projeto.tif & \multirow[t]{3}{*}{ EP } \\
\hline & & & Gaveta & M_cinza_P/G4 & \\
\hline & & & & $\begin{array}{l}\text { Papel manteiga/lápis } \\
7 / 7 \text { pranchas } \\
\text { A2 }\end{array}$ & \\
\hline \multirow[t]{2}{*}{1993} & \multirow[t]{2}{*}{167} & \multirow{2}{*}{$\begin{array}{l}\text { Pinacoteca do Estado - reestruturação } \\
\text { São Paulo, SP } \\
\text { Equipe: Eduardo Colonelli, Ana Paula Pontes, Marina Grinover, Silvio } \\
\text { Oksman... }\end{array}$} & Digital & $\begin{array}{l}6 \text { pranchas .dwg e pdf:levantamento.dwg:fotos do edifício } \\
\text { vazio (Ana P.Pontes):fotos da obra pronta (Nelson } \\
\text { Kon):ficha técnica.doc:memorial.doc;memorial em esp.doc }\end{array}$ & \multirow{2}{*}{$\frac{y}{2}=8$} \\
\hline & & & Gaveta & Publicações & \\
\hline \multirow[t]{4}{*}{1994} & \multirow[t]{4}{*}{168} & \multirow{4}{*}{$\begin{array}{l}\text { Corredor de ônibus Francisco Morato } \\
\text { Francisco Morato, SP } \\
\text { Equipe: MMBB }\end{array}$} & Digital: & Projeto.dwg:complementares.dwg & \multirow{4}{*}{ AP } \\
\hline & & & Tubo & - & \\
\hline & & & Gaveta & - & \\
\hline & & & Maquete: & Eletrônica: 23 imagens.tif; 4 em alta resolução.tif & \\
\hline \multirow[t]{2}{*}{1994} & \multirow[t]{2}{*}{169} & \multirow{2}{*}{$\begin{array}{l}\text { Cenário: "O homem sem qualidade" } \\
\text { Direção: Bia Lessa } \\
\text { Rio de Janeiro } \\
\text { Equipe: Jean Louis Le Blanc }\end{array}$} & Tubo & 81 & \multirow[t]{2}{*}{ Executado } \\
\hline & & & & $\begin{array}{l}\text { Croquis: } \\
\text { Papel manteiga e sulfite } \\
\text { PE: } \\
\text { Papel manteiga/lápis }\end{array}$ & \\
\hline \multirow[t]{2}{*}{1994} & \multirow[t]{2}{*}{170} & \multirow{2}{*}{$\begin{array}{l}\text { Cenário: "Futebol" } \\
\text { Direção Bia Lessa } \\
\text { Teatro Municipal - São Paulo - SP } \\
\text { Equipe: Martin Corullon }\end{array}$} & Tubo & 81 & \multirow[t]{2}{*}{ Construída } \\
\hline & & & & EP: Papel manteiga/lápis & \\
\hline 1995 & 171 & $\begin{array}{l}\text { Bienal de Fotojornalismo 1900-1995: História de ver: Oliviero } \\
\text { Toscani } \\
\text { Fundação Bienal de São Paulo, SP }\end{array}$ & & Não foram encontrados os desenhos & Executado \\
\hline \multirow[t]{4}{*}{ 1995/96 } & \multirow[t]{4}{*}{172} & \multirow{4}{*}{$\begin{array}{l}\text { Residência Mário Masetti } \\
\text { Fazenda da Cava, Cabreúva, SP }\end{array}$} & Digital & 5 croquis digitalizados & \\
\hline & & & Tubo & 107 & \\
\hline & & & & $\begin{array}{l}\text { Croquis } \\
\text { Projeto Executivo } \\
\text { Papel vegetal/nanquim } \\
\text { Detalhamento } \\
\text { Papel manteiga/lápis }\end{array}$ & \\
\hline & & & Maquete & Madeira & \\
\hline
\end{tabular}




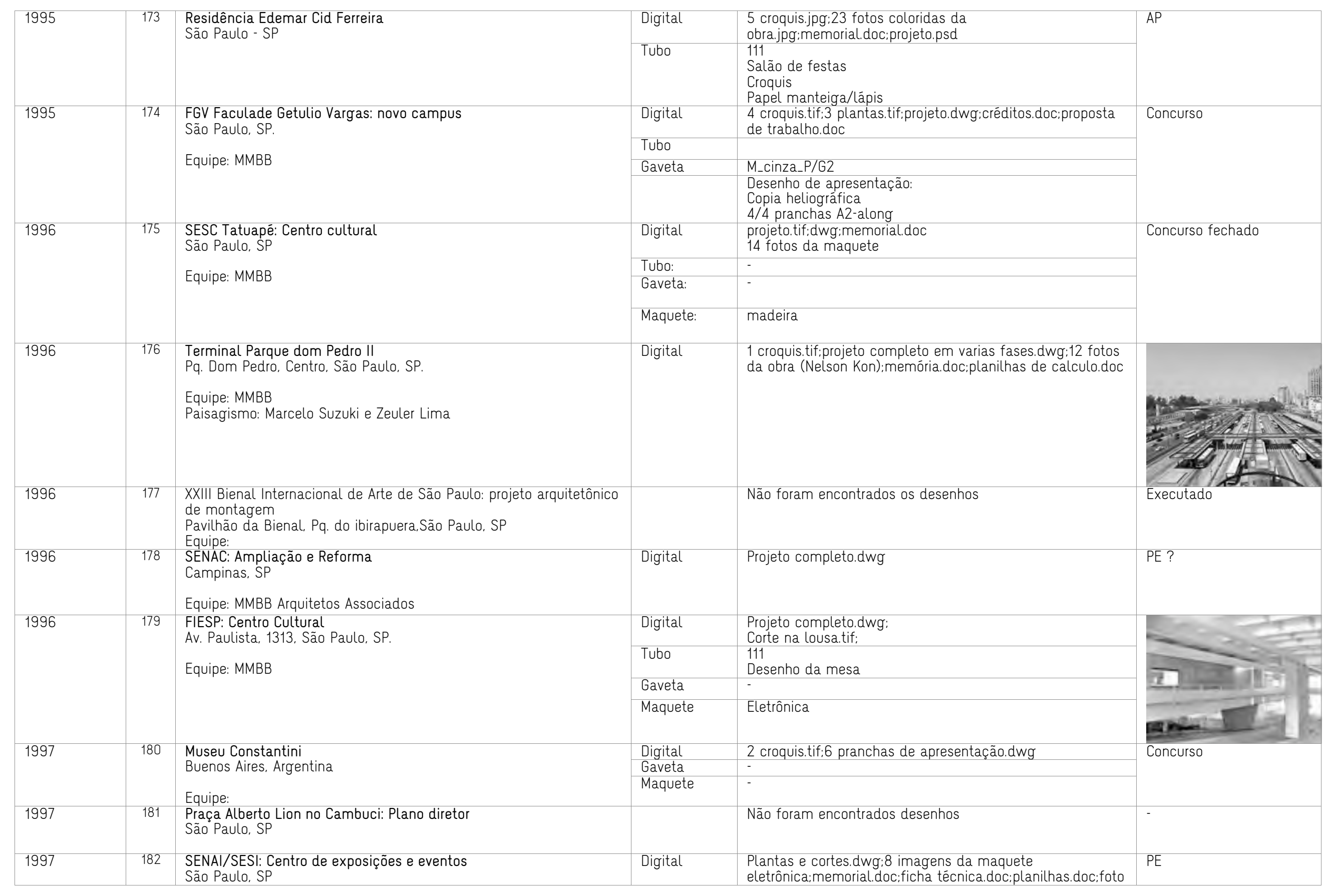




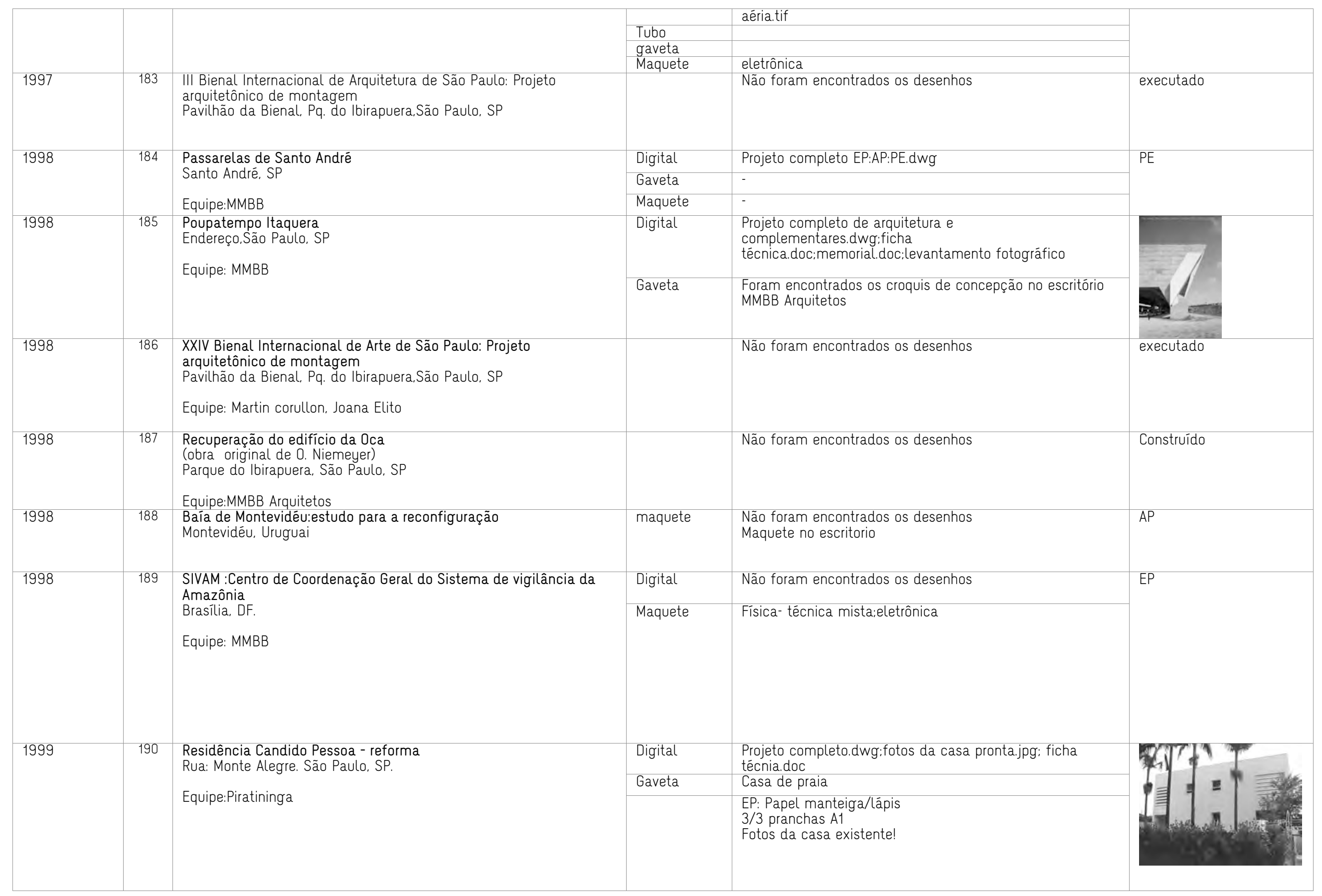




\begin{tabular}{|c|c|c|c|c|c|}
\hline 1999 & 191 & $\begin{array}{l}\text { "Corpo Público": Projeto arquitetônico para o desfile da M. Officer } \\
\text { São Paulo, SP } \\
\text { Equipe: Metro }\end{array}$ & Gaveta & $\begin{array}{l}\text { Papel manteita/sulfite } \\
3 / 3 \text { pranchas A1_mão livre }\end{array}$ & executado \\
\hline 1999 & 192 & $\begin{array}{l}\text { Clínica médica Miriam Mamber } \\
\text { São Paulo. SP } \\
\text { Equipe: Piratininga }\end{array}$ & & Não foram encontrados os desenhos & - \\
\hline 1999 & 193 & $\begin{array}{l}\text { Pavilhão do Mar } \\
\text { Caraguatatuba, SP } \\
\text { Equipe: MMBB } \\
\text { A segunda versão deste projeto foi feita no ano } 2000\end{array}$ & Maquete & $\begin{array}{l}\text { Ante projeto.dwg: fotos P\&B da maquete: foto aérea da } \\
\text { cidade:ficha técnica.doc;memorial.doc }\end{array}$ & AP \\
\hline 1999 & 194 & $\begin{array}{l}\text { Globo cabo s/a: projeto para desenvolvimento do Estudo Preliminar } \\
\text { de Reconfiguração Urbana da Ârea da "Associação de Empresas da } \\
\text { Chācara Santo Antônio" } \\
\text { São Paulo, SP } \\
\text { Equipe: MMBB }\end{array}$ & Digital & $\begin{array}{l}9 \text { fotos da maquete P\&B; 9coloridas.tif:ficha } \\
\text { técnica.doc;memorial.doc }\end{array}$ & EP \\
\hline 1999 & 195 & $\begin{array}{l}\text { Residência Sergio Moraes Abreu } \\
\text { Rua Laerte Assumpção esq. Cel. Bento Noronha } \\
\text { Equipe: Metro }\end{array}$ & & Não foram encontrados os desenhos & EP \\
\hline 1999 & 196 & $\begin{array}{l}\text { "Mostra do redescobrimento": projeto arquitetônico de montagem } \\
\text { Parque do lbirapuera, São Paulo, SP } \\
\text { Equipe: Metro }\end{array}$ & & Não foram encontrados os desenhos & - \\
\hline 2000 & 197 & $\begin{array}{l}\text { Recuperação dos espaços do Parque do Ibirapuera para instalação } \\
\text { da Exposição "Mostra do Redescobrimento" } \\
\text { Pavilhão da Bienal, Pq. do Ibirapuera. São Paulo, SP } \\
\text { Equipe: Metro e Guilherme Wisnik }\end{array}$ & & Não foram encontrados os desenhos & - \\
\hline 2000 & 198 & $\begin{array}{l}\text { Museus da USP } \\
\text { Cidade Universitária, SP } \\
\text { Equipe: MMBB e Piratininga }\end{array}$ & $\begin{array}{l}\text { Digital } \\
\text { Gaveta } \\
\text { Maquete }\end{array}$ & $\begin{array}{l}8 \text { croquis.jpg;estudo preliminar } 1 \text { e 2.dwg:memorial } \\
\text { descritivo;quadro de āreas } \\
- \\
\text { De papel }\end{array}$ & AP \\
\hline 2000 & 199 & $\begin{array}{l}\text { Jogos Olímpicos de 2008: le Boulevard du Sport: estudos para as } \\
\text { instalações dos em Paris } \\
\text { Paris.França. } \\
\text { Equipe: Alexandre Delijaicov: MMBB; Eduardo Argenton Colonelli; } \\
\text { Metro:Rastko Kovacevic; Roberto Klein; Silvio Oksman; Wellinton } \\
\text { Ricoy Torres }\end{array}$ & $\begin{array}{l}\text { Digital } \\
\text { Gaveta } \\
\text { Maquete }\end{array}$ & $\begin{array}{l}\text { Projeto completo.dwg.eps.jpg;apresentação.ppt:memorial } \\
\text { em francês.doc;croquis digitalizados }\end{array}$ & AP \\
\hline 2000 & 200 & $\begin{array}{l}\text { Portal para a cidade de São Roque } \\
\text { São Roque, SP }\end{array}$ & $\begin{array}{l}\text { Digital } \\
\text { Maquete }\end{array}$ & $\begin{array}{l}\text { Projeto completo.dwg; } 8 \text { fotos da maquete.tif; } 8 \text { jpg } \\
\text { De papel }\end{array}$ & EP \\
\hline
\end{tabular}




\begin{tabular}{|c|c|c|c|c|c|}
\hline \multirow[t]{2}{*}{2000} & \multirow[t]{2}{*}{201} & \multirow{2}{*}{$\begin{array}{l}\text { Paço Alfândega: projeto Completo de Arquitetura e Paisagismo de } \\
\text { Edifícios Garagem, deck e Salão de festas } \\
\text { Recife. PE. } \\
\text { Equipe: MMBB }\end{array}$} & Digital & $\begin{array}{l}\text { Projeto completo.dwg:19 fotos da maquete } \\
\text { P\&B.jpg:11imagnes da maquete eletrônica.jpg }\end{array}$ & \multirow[t]{2}{*}{ Construída } \\
\hline & & & Maquete & De papel;eletronica & \\
\hline 2000 & 202 & $\begin{array}{l}\text { Loja Dotto Import, Ltda. } \\
\text { Equipe: Metro }\end{array}$ & & Não foram encontrados os desenhos & - \\
\hline 2000 & 203 & $\begin{array}{l}\text { Pavilhão do Mar - } 2 \text { estudo } \\
\text { Caraguatatuba, SP } \\
\text { Equipe: MMBB }\end{array}$ & Digital & Não foram encontrados os desenhos & EP \\
\hline 2000 & 204 & $\begin{array}{l}\text { Museu da Língua Portuguesa: reestruturação espacial } \\
\text { Estação da Luz. São Paulo, SP } \\
\text { Equipe: Pedro Mendes da Rocha }\end{array}$ & Digital & Projeto completo.dwg;memorial.doc & \\
\hline 2000 & 205 & $\begin{array}{l}\text { Residência Isabella Prata } \\
\text { Rua Carlos Millan, São Paulo, SP } \\
\text { Equipe: Metro }\end{array}$ & $\begin{array}{l}\text { Digital } \\
\text { Gaveta }\end{array}$ & $\begin{array}{l}4 \text { croquis.tif:fotos coloridas da casa } \\
\text { M_amarela/Osaka } \\
\text { EP: Papel manteiga/lápis } \\
\text { Copias do projeto para publicação }\end{array}$ & \\
\hline 2000 & 206 & $\begin{array}{l}\text { Jogos Olímpicos de 2012: postulação da cidade de São Paulo } \\
\text { São Paulo. SP }\end{array}$ & Digital & $\begin{array}{l}18 \text { pranchas do Projeto apresentado.pdf : } 10 \text { imagens da } \\
\text { maquete eletrônica }\end{array}$ & \\
\hline & & Equipe: E. Colonelli, MMBB, Una Arq: Sergio Kipnis & Maquete & $\begin{array}{l}\text { Físicas em pva dos trechos dês. Por MMBB e Uma (estão } \\
\text { nos respec. escritōrios):maquete eletrônica }\end{array}$ & \\
\hline 2000 & 207 & $\begin{array}{l}\text { Residência Gabriel Douglas Zellmeister } \\
\text { São Paulo, SP } \\
\text { Equipe: Metro }\end{array}$ & & Não foram encontrados os desenhos & \\
\hline 2001 & 208 & $\begin{array}{l}\text { Deltametrópolis: Consultor do projeto } \\
\text { Holanda } \\
\text { Equipe: }\end{array}$ & Digital: & 9 croquis.tif:relatório.doc & EP \\
\hline
\end{tabular}




\begin{tabular}{|c|c|c|c|c|c|}
\hline 2001 & 209 & $\begin{array}{l}\text { Galeria Vermelho, } \\
\text { Rua Minas Gerais, } 350 \text { São Paulo, SP. } \\
\text { Equipe: Piratininga }\end{array}$ & Digital & $\begin{array}{l}6 \text { fotos da obra.tif } \\
\text { Não foram encontrados os desenhos }\end{array}$ & $y=\frac{1}{2}$ \\
\hline 2001 & 210 & $\begin{array}{l}\text { Casa Matriz } \\
\text { Av. Cidade jardim, São Paulo, SP } \\
\text { Equipe:Metro }\end{array}$ & Digital & Não foram encontrados os desenhos & \\
\hline 2001 & 211 & $\begin{array}{l}\text { Escola de Cinema Darcy Ribeiro: Instituto Brasileiro de Audiovisual } \\
\text { Rio de Janeiro, RJ } \\
\text { Equipe: Metro Arquitetos }\end{array}$ & Digital: & projeto executivo.dwg;levantamento.pdf & $\mathrm{PE}$ \\
\hline 2001 & 212 & $\begin{array}{l}\text { Monumento Rodoanel } \\
\text { São Paulo, SP }\end{array}$ & $\begin{array}{l}\text { Digital } \\
\text { Maquete }\end{array}$ & $\begin{array}{l}4 \text { croquis.jpg:1 prancha EP.dwg; } 7 \text { fotos P\&B da maquete.jpg } \\
\text { De papel }\end{array}$ & EP \\
\hline 2001 & 213 & $\begin{array}{l}\text { Centro de convenções do Eixo Tamanduateí } \\
\text { Santo André. SP } \\
\text { Equipe: MMBB }\end{array}$ & & Não foram encontrados os desenhos & - \\
\hline 2001 & 214 & $\begin{array}{l}\text { Reurbanização da área portuária de Recife } \\
\text { Recife. Pernambuco } \\
\text { Equipe: MMBB }\end{array}$ & digital & Arquivos em dwg & - \\
\hline 2001 & 215 & $\begin{array}{l}\text { Museu da Língua Portuguesa: edifício administrativo da Estação da } \\
\text { Luz } \\
\text { São Paulo, SP } \\
\text { Equipe: Pedro Mendes da Rocha }\end{array}$ & digital & Arquivos em dwg & $\sqrt{202}$ \\
\hline 2001 & 216 & $\begin{array}{l}\text { SESC } 24 \text { de Maio: Edifício cultural e esportivo } \\
\text { R: } 24 \text { de maio, São Paulo, SP } \\
\text { Equipe: MMBB }\end{array}$ & digital & Arquivos em dwg & Em obras \\
\hline 2002 & 217 & $\begin{array}{l}\text { Edifício Banco Safra - reforma } \\
\text { Av. Paulista. São Paulo. SP } \\
\text { Equipe: Eduardo Colonelli }\end{array}$ & & Não foram encontrados os desenhos & - \\
\hline 2002 & 218 & $\begin{array}{l}\text { FUSP:Centro de Ciência e Tecnologia da Fundação de Apoio à } \\
\text { Universidade } \\
\text { São Paulo, SP. } \\
\text { Equipe: Piratininga; Aflalo \&Gasperini: Zanettini Arquitetura: Espaço } \\
\text { Arch Design; Nestor Goulart Reis:Paulo Bruna Arquitetos Associados. }\end{array}$ & & Não foram encontrados os desenhos & - \\
\hline
\end{tabular}




\begin{tabular}{|c|c|c|c|c|c|}
\hline \multirow[t]{4}{*}{2003} & \multirow[t]{4}{*}{219} & \multirow{4}{*}{$\begin{array}{l}\text { Universidade de Vigo: ampliação e reordenação do Campus } \\
\text { Vigo, Espanha } \\
\text { Equipe: MMBB }\end{array}$} & Digital & 5 fotos da maquete.jpg & \multirow[t]{5}{*}{ PE parcial } \\
\hline & & & Gaveta & M_amarela/Vigo-Madrid & \\
\hline & & & & $\begin{array}{l}\text { EP: } \\
\text { Papel sulfite/lápis e caneta } \\
9 \text { folhas }\end{array}$ & \\
\hline & & & Maquete & $\begin{array}{l}\text { De papel } \\
\text { eletronica }\end{array}$ & \\
\hline 2003 & 220 & $\begin{array}{l}\text { EPAC:Escola Parque da Arte e da Ciência } \\
\text { Santo André. SP }\end{array}$ & Digital & $\begin{array}{l}\text { Projeto.dwg } \\
\text { Fotos da obra pronta (Nelson Kon) } \\
\text { Memorial descritivo.doc }\end{array}$ & \\
\hline 2003 & 221 & $\begin{array}{l}\text { Centro de ciência e Tecnologia para São Paulo, } \\
\text { Parque Estadual das fontes do Ipiranga. São Paulo, SP }\end{array}$ & & Não foram encontrados os desenhos & \\
\hline \multirow[t]{2}{*}{2003} & \multirow[t]{2}{*}{222} & \multirow{2}{*}{$\begin{array}{l}\text { Residência em antigo armazém. Torre Del Gallo } \\
\text { Florença, Itâlia } \\
\text { Equipe:MMBB }\end{array}$} & Digital & Não foram encontrados os desenhos & \multirow[t]{2}{*}{ EP } \\
\hline & & & maquete & Madeira e papel & \\
\hline 2004 & 223 & $\begin{array}{l}\text { Edifico de habitação em Vallecas } \\
\text { Esanche de Vallecas,Madrid. Espanha. } \\
\text { Equipe: Bellosillo y Associados, MMBB }\end{array}$ & Digital: & $\begin{array}{l}\text { projeto executivo.pdf; } 34 \text { fotos da obra pronta (Nelson Kon); } \\
\text { memorial.doc } \\
3 \text { fotos da obra:memorial.doc }\end{array}$ & \\
\hline \multirow[t]{2}{*}{2004} & \multirow[t]{2}{*}{224} & \multirow{2}{*}{$\begin{array}{l}\text { Galeria Leme } \\
\text { R:Agostinho Cantú, } 88 \text { São Paulo, SP } \\
\text { Equipe: Metro }\end{array}$} & Digital & Projeto.dwg & \multirow{2}{*}{$x^{2}$} \\
\hline & & & & & \\
\hline 2004 & 225 & $\begin{array}{l}\text { Museu Nacional de Belas Artes: ampliação e reforma } \\
\text { Rio de Janeiro, RJ } \\
\text { Equipe: Metro }\end{array}$ & Digital & 32 pranchas de apresentação.pdf: & $\mathrm{AP}$ \\
\hline 2005 & 226 & $\begin{array}{l}\text { Palácio dos Correios Argentino } \\
\text { Buenos Aires, Argentina }\end{array}$ & $\begin{array}{l}\text { Digital } \\
\text { Gaveta } \\
\text { Maquete }\end{array}$ & $\begin{array}{l}\text { Edital } 12 \text { pranchas.pdf:memorial.doc } \\
\text { Madeira pintada de branco }\end{array}$ & Concurso \\
\hline 2005 & 227 & $\begin{array}{l}\text { Capela de N.S. Da Conceição (Brennand) } \\
\text { Recife, Pernambuco } \\
\text { Equipe: Eduardo Colonelli }\end{array}$ & Digital & $\begin{array}{l}\text { Projeto.dwg } \\
\text { Fotos obra } \\
\text { Fotos da obra }\end{array}$ & Construído \\
\hline 2005 & 228 & $\begin{array}{l}\text { Casa Daros: adaptação do Educandário Santa Teresa para } \\
\text { implantação do centro cultural } \\
\text { Rio de Janeiro, RJ } \\
\text { Equipe: Pedro Mendes da Rocha }\end{array}$ & Digital & $\begin{array}{l}\text { Estudo preliminar.dwg: } 5 \text { croquis.jpg } \\
\text { Não foram encontrados os desenhos do PE }\end{array}$ & $\begin{array}{l}\text { Obra não respeitou } 0 \\
\text { projeto desenvolvido }\end{array}$ \\
\hline
\end{tabular}




\begin{tabular}{|c|c|c|c|c|c|}
\hline 2005 & 229 & $\begin{array}{l}\text { Ponte para a cidade de Vitória } \\
\text { Vitōria, ES } \\
\text { Equipe: }\end{array}$ & Digital & Projeto completo.doc:dwg:pdf & EP \\
\hline 2005 & 230 & $\begin{array}{l}\text { Estacionamento e reforma do salão de festas do Esporte Clube } \\
\text { Pinheiros } \\
\text { Rua Angelina Maffei Vita, } 493 \text { - Jardim Europa - São Paulo } \\
\text { Equipe: MMBB Arquitetos }\end{array}$ & & Não foram encontrados os desenhos & EP \\
\hline 2006 & 231 & $\begin{array}{l}\text { Concurso Internacional de projetos para o novo centro de justiça de } \\
\text { Trento. } \\
\text { Equipe: Maura Manzelle, Paulo Mendes da Rocha, Francesco } \\
\text { Magnani, Traudy Pelzel, Stefano Rocchetto, Andrea Lazzaroni. }\end{array}$ & $\begin{array}{l}\text { Digital } \\
\text { Maquete }\end{array}$ & $\begin{array}{l}\text { Projeto.pdf: } 3 \text { fotos da maquete.jpg } \\
\text { madeira }\end{array}$ & Concurso \\
\hline 2006 & 232 & $\begin{array}{l}\text { Parque do Engenho: Projeto Beira Rio } \\
\text { Piracicaba, SP } \\
\text { Equipe: Piratininga }\end{array}$ & Digital & Não foram encontrados os desenhos & EP \\
\hline 2006 & 233 & $\begin{array}{l}\text { Piscina Pública } \\
\text { Praça da República, São Paulo, SP }\end{array}$ & Digital: & proposta.doc:memorial.doc:projeto.pdf & EP \\
\hline 2006 & 234 & $\begin{array}{l}\text { Centro de convenções e Secretaria do Mar (ERSU) } \\
\text { Cagliari, Sardenha, Itália } \\
\text { Equipe: MMBB }\end{array}$ & Digital & $\begin{array}{l}7 \text { fotos aéreas do local coloridas.jpg } \\
14 \text { croquis }\end{array}$ & Estudos \\
\hline 2007 & 235 & $\begin{array}{l}\text { SESC: Centro Cultural Edifício Gloria } \\
\text { Vitória, ES } \\
\text { Equipe: Pedro Mendes da Rocha }\end{array}$ & & Não foram encontrados os desenhos & Concurso \\
\hline 2007 & 236 & $\begin{array}{l}\text { Museu de Vitória - primeiros estudos } \\
\text { Equipe: Metro }\end{array}$ & $\begin{array}{l}\text { Digital: } \\
\text { Gaveta } \\
\text { Maquete }\end{array}$ & $\begin{array}{l}\text { Apresentação do projeto, } 13 \text { pranchas.pdf } \\
3 \text { fotos da maquete P\&B } \\
\text { Casa da praia } \\
\text { EstudoSulfite/lápis e canetinha } \\
16 / 16 \text { A4 } \\
\text { De papel }\end{array}$ & EP \\
\hline 2007 & 237 & $\begin{array}{l}\text { Cais das Artes: Museu e Teatro de Vitória } \\
\text { Baia do Suá, Vitória - ES } \\
\text { Equipe: Metro Arquitetos }\end{array}$ & $\begin{array}{l}\text { Digital } \\
\text { Gaveta }\end{array}$ & $\begin{array}{l}\text { Projeto.dwg;apresentação do projeto.pdf:13 fotos coloridas } \\
\text { da maquete } \\
\text { M_amarela/vitoria } \\
\text { AP: } \\
\text { Papel sulfite/copia } \\
\text { 21/21 pranchas A3-along } \\
\text { 1.Papel com cargueiros em papel(escritório): PMR } \\
\text { 2.Maquete pvc em Londres(Zé Paulo); 3.Maquete em } \\
\text { madeira (Trivino) } \\
\text { 4. Modelo digital }\end{array}$ & \\
\hline 2008 & 238 & $\begin{array}{l}\text { Museu dos Coches } \\
\text { Lisboa, Portugal } \\
\text { Equipe: MMBB }\end{array}$ & $\begin{array}{l}\text { Digital } \\
\text { Maquete }\end{array}$ & Escritório & \\
\hline
\end{tabular}




\begin{tabular}{|c|c|c|c|c|c|}
\hline 2008 & 239 & $\begin{array}{l}\text { Pavilhão do Brasil em Xangai } \\
\text { Xangai,China } \\
\text { Equipe: Bia Lessa }\end{array}$ & & Croquis na lousa & Estudo \\
\hline 2006 & 240 & $\begin{array}{l}\text { Museu das Minas e do Metal } \\
\text { Praça da Liberdade, s/no } \\
\text { Belo Horizonte. MG } \\
\text { Equipe: Pedro Mendes da Rocha }\end{array}$ & digital & Não foram encontrados os desenhos & $\begin{array}{l}\text { Obra inaugurada em } 2010 \\
\text { Não foram encontradas } \\
\text { Imagens. }\end{array}$ \\
\hline 2008 & 241 & $\begin{array}{l}\text { Residência Teresa Genesini } \\
\text { Campos do Jordão - SP } \\
\text { Equipe: Eduardo Collonelli/Silvio Oksman }\end{array}$ & gaveta & $\begin{array}{l}\text { Papel: } \\
\text { Maquete de pvc: cliente levou } \\
\text { Não foram encontrados os desenhos }\end{array}$ & Em obras \\
\hline 2010 & 242 & $\begin{array}{l}\text { Museu dos Valores - Edifício Sede do Banco Central } \\
\text { SBS Quadra } 3 \text { Bloco B. Brasília / DF } \\
\text { Equipe: Pedro Mendes da Rocha }\end{array}$ & & Não foram encontrados os desenhos & Projeto em andamento \\
\hline 2010 & 243 & $\begin{array}{l}\text { Museu de Artes de Santos } \\
\text { Avenida Doutor Epitācio Pessoa, } 92 \\
\text { Equipe: Metro Arquitetos }\end{array}$ & Digital & Arquivos em dwg & AP \\
\hline 2010 & 244 & $\begin{array}{l}\text { Galeria Leme } 2 \\
\text { Equipe: Metro Arquitetos }\end{array}$ & Digital & Arquivos em dwg & $-\infty$ \\
\hline 2011 & 245 & $\begin{array}{l}\text { Casa na praia } \\
\text { Praia Escondida, Lima, Peru } \\
\text { Equipe: Metro Arquitetos }\end{array}$ & gaveta & Papel manteiga e lapis & AP \\
\hline 2011 & 246 & $\begin{array}{l}\text { Concurso Parque Olímpico } \\
\text { Rio de Janeiro, RJ } \\
\text { Equipe: arqto Bak Gordon, AfaConsult, Metro Arquitetos, MMBB } \\
\text { Arquitetos }\end{array}$ & digital & Projeto desenvolvido no escritório da metro & Concurso \\
\hline
\end{tabular}

\section{PROJETOS SEM DATA:}

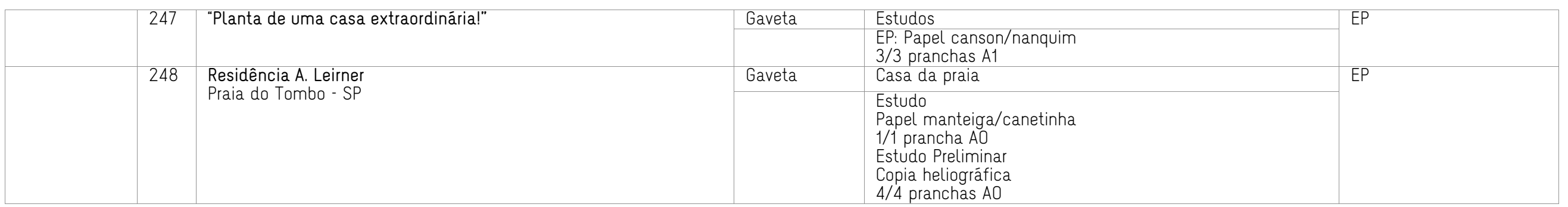




\begin{tabular}{|c|c|c|c|c|c|}
\hline & 249 & $\begin{array}{l}\text { Residência Selmi-Dei } \\
\text { Praia da enseada - Guarujā - SP }\end{array}$ & Gaveta & $\begin{array}{l}\text { Ante Projeto:Papel vegetal/nanquim } \\
2 / 2 \text { pranchas AO } \\
\text { Perspectiva a mão livre a canetinha }\end{array}$ & \\
\hline & \multirow[t]{2}{*}{250} & \multirow[t]{2}{*}{ Residência José Moura Gonçalves } & Tubo & 14 & \multirow[t]{2}{*}{ AP } \\
\hline & & & & $\begin{array}{l}\text { EP: Papel manteiga/canetinha } \\
\text { AP: Papel vegetal/lápis } \\
5 / 5 \text { pranchas }\end{array}$ & \\
\hline & \multirow[t]{2}{*}{251} & \multirow[t]{2}{*}{ Residência Dr. Edmundo de Freitas } & Tubo & 14 & \multirow[t]{2}{*}{ EP } \\
\hline & & & & $\begin{array}{l}\text { EP 1a versão:Papel manteiga/lápis } \\
4 / 4 \text { pranchas } \\
\text { EP } 2^{\mathbf{a}} \text { versão:Papel manteiga/lápis } \\
3 / 3 \text { pranchas }\end{array}$ & \\
\hline & \multirow[t]{2}{*}{252} & \multirow[t]{2}{*}{ Residência Salvatore Morisco } & Tubo & 14 & \multirow[t]{2}{*}{$\mathrm{AP}$} \\
\hline & & & & $\begin{array}{l}\text { EP: Papel manteiga/lápis } \\
3 / 3 \text { pranchas } \\
\text { AP:Papel manteiga/lápis } \\
5 / 5 \text { pranchas }\end{array}$ & \\
\hline & \multirow{2}{*}{253} & \multirow{2}{*}{$\begin{array}{l}\text { Residência no Guarujá } \\
\text { Guarujā. SP }\end{array}$} & Gaveta & M_cinza_P/G4 & \multirow[t]{2}{*}{ EP } \\
\hline & & & & $\begin{array}{l}\text { EP: Papel manteiga/lápis } \\
3 / 3 \text { pranchas } A O\end{array}$ & \\
\hline & \multirow[t]{2}{*}{254} & \multirow{2}{*}{$\begin{array}{l}\text { Duas residências } \\
\text { Av. Marguerita/R. Elisabeta }\end{array}$} & Tubo & 14 & \multirow{4}{*}{ Concurso } \\
\hline & & & & $\begin{array}{l}\text { AP: Papel manteiga/lápis } \\
5 / 5 \text { pranchas }\end{array}$ & \\
\hline & 255 & SESC - Rio de Janeiro & Tubo & 2 & \\
\hline & & & & $\begin{array}{l}\text { Papel vegetal/nanquim } \\
13 / 13 \text { pranchas } A O\end{array}$ & \\
\hline & \multirow[t]{2}{*}{256} & \multirow{2}{*}{$\begin{array}{l}\text { CNI SENAI SESI } \\
\text { Brasília, DF } \\
\text { Equipe:Pedro Paulo Melo Saraiva }\end{array}$} & Tubo & 3 & \multirow[t]{2}{*}{ AP } \\
\hline & & & & $\begin{array}{l}\text { AP:Papel vegetal/nanquim } \\
6 / 6 \text { pranchas }\end{array}$ & \\
\hline & \multirow[t]{2}{*}{257} & \multirow{2}{*}{$\begin{array}{l}\text { Banco Alfomares } \\
\text { Av. Paulista, São Paulo, SP }\end{array}$} & Tubo & 3 & \multirow[t]{2}{*}{ EP } \\
\hline & & & & $\begin{array}{l}\text { Papel vegetal/nanquim } \\
7 / 7 \text { pranchas }\end{array}$ & \\
\hline & \multirow[t]{2}{*}{258} & \multirow{2}{*}{$\begin{array}{l}\text { INL - Industria nacional de Locomotivas } \\
\text { Campo Limpo - São Paulo }\end{array}$} & Gaveta & Estudos & \multirow[t]{2}{*}{ AP } \\
\hline & & & & $\begin{array}{l}\text { Papel vegetal/nanquim } \\
4 / 4 \text { pranchas } A 1\end{array}$ & \\
\hline \multirow{9}{*}{1972} & \multirow[t]{2}{*}{259} & WESTINBRAS/AS & Gaveta & Estudos & \multirow[t]{2}{*}{ AP } \\
\hline & & $\begin{array}{l}\text { Equipe: João de Genaro } \\
\text { Eng. Joaquim Procópio Araújo }\end{array}$ & & $\begin{array}{l}\text { Papel vegetal/nanquim } \\
5 / 5 \text { pranchas } A 1\end{array}$ & \\
\hline & \multirow[t]{2}{*}{260} & \multirow{2}{*}{$\begin{array}{l}\text { SANBRA/SA } \\
\text { Jaguaré - São Paulo }\end{array}$} & Gaveta & Estudos & \multirow[t]{2}{*}{ AP } \\
\hline & & & & $\begin{array}{l}\text { Papel vegetal/nanquim } \\
6 / 6 \text { pranchas }\end{array}$ & \\
\hline & \multirow[t]{2}{*}{261} & \multirow{2}{*}{$\begin{array}{l}\text { COSIPA } \\
\text { Prōximo a Estação Piassaguera }\end{array}$} & Gaveta & Estudos & AP \\
\hline & & & & $\begin{array}{l}\text { Papel vegetal/nanquim } \\
8 / 8 \text { pranchas } A 1\end{array}$ & \\
\hline & 262 & SHT - Sociedade Harmonia de Tenis & Gaveta & Estudos & EP, Concurso? \\
\hline & & Rua Canadá - São Paulo - SP & & $\begin{array}{l}\text { Papel manteiga/lápis e nanquim } \\
6 / 6 \text { pranchas }\end{array}$ & \\
\hline & 263 & $\begin{array}{l}\text { SCSA - Santa Cândida Serviços e Automóveis S.A. } \\
\text { Araras - SP }\end{array}$ & Gaveta & Estudos & EP \\
\hline
\end{tabular}




\begin{tabular}{|c|c|c|c|c|}
\hline & & & $\begin{array}{l}\text { Papel manteiga/lápis } \\
4 / 4 \text { Pranchas } A 1\end{array}$ & \\
\hline \multirow{2}{*}{264} & \multirow{2}{*}{ FDS: Faculdade de Direito de Sorocaba } & Gaveta & Estudos & \multirow[t]{2}{*}{ AP } \\
\hline & & & $\begin{array}{l}\text { Papel vegetal/nanquim } \\
5 / 5 \text { Pranchas } A 1\end{array}$ & \\
\hline \multirow[t]{2}{*}{265} & \multirow{2}{*}{$\begin{array}{l}\text { FAPESP: nova sede } \\
\text { Rua da Consolação São Paulo - SP }\end{array}$} & Tubo & 79 & \multirow{2}{*}{ Concurso } \\
\hline & & & $\begin{array}{l}\text { Croquis: } \\
\text { Plantas } \\
\text { Desenho de apresentação: } \\
\text { Papel manteiga } \\
4 / 4 \text { pranchas }\end{array}$ & \\
\hline \multirow[t]{2}{*}{266} & \multirow[t]{2}{*}{ FPF: Estádio do Paraná } & Digital & 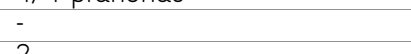 & \multirow[t]{2}{*}{ Concurso } \\
\hline & & Tubo & $\begin{array}{l}2 \\
\text { Papel vegetal/nanquim } \\
14 / 14 \text { folhas } A O\end{array}$ & \\
\hline \multirow[t]{2}{*}{267} & \multirow{2}{*}{$\begin{array}{l}\text { Edifício de apartamentos - Cia City } \\
\text { Conjunto Butantã } \\
\text { São Paulo - SP } \\
\text { Equipe: Renato L.M. Nunes }\end{array}$} & Tubo & 33 & \multirow[t]{2}{*}{ AP } \\
\hline & & & $\begin{array}{l}\text { Papel vegetal/nanquim } \\
13 / 13 \text { pranchas } A O\end{array}$ & \\
\hline 268 & $\begin{array}{l}\text { Edifício de apartamentos - Cia City } \\
\text { Conjunto Alto de Pinheiros } \\
\text { São Paulo - SP }\end{array}$ & Tubo & 33 & AP \\
\hline \multirow[t]{2}{*}{269} & \multirow[t]{2}{*}{$\begin{array}{l}\text { Edifício de apartamentos - Formaespaço } \\
\text { Av. Nove de Julho esq. rua Amauri }\end{array}$} & Tubo & 3 & \multirow[t]{2}{*}{ AP } \\
\hline & & & $\begin{array}{l}\text { Papel manteiga/nanquim } \\
5 / 5 \text { pranchas }\end{array}$ & \\
\hline \multirow[t]{2}{*}{270} & \multirow[t]{2}{*}{ Edifício de apartamentos - Forma Espaço } & Gaveta & Estudos & \multirow[t]{2}{*}{ AP } \\
\hline & & & Papel manteiga/ & \\
\hline \multirow[t]{2}{*}{271} & \multirow{2}{*}{$\begin{array}{l}\text { Edifício de apartamentos } \\
\text { Rua Bela Cintra } \\
\text { Proprietário: Flavio Pinho de Almeida }\end{array}$} & Gaveta & Estudos & \multirow[t]{2}{*}{ AP } \\
\hline & & & $\begin{array}{l}\text { Papel manteiga/nanquim } \\
6 / 6 \text { pranchas }\end{array}$ & \\
\hline \multirow[t]{2}{*}{272} & \multirow{2}{*}{$\begin{array}{l}\text { Edifício de apartamentos } \\
\text { Av. Francisco Bering ,Arpoador } \\
\text { Rio de Janeiro, RJ }\end{array}$} & Gaveta & Estudos & \multirow[t]{2}{*}{ EP } \\
\hline & & & $\begin{array}{l}\text { Papel vegetal/nanquim } \\
\text { Perspectiva a mão livre a lápis } \\
3 / 3 \text { Pranchas A1 }\end{array}$ & \\
\hline \multirow[t]{2}{*}{273} & \multirow[t]{2}{*}{ Edifício de apartamentos } & Gaveta & Estudos & \multirow[t]{2}{*}{ EP } \\
\hline & & & $\begin{array}{l}\text { Papel vegetal/nanquim } \\
\text { 4/4 Pranchas A1 }\end{array}$ & \\
\hline \multirow[t]{2}{*}{274} & \multirow{2}{*}{$\begin{array}{l}\text { Edifício RSL } 1 \\
\text { Rua São Luis, } 161 \text { esq. com D. José Gaspar }\end{array}$} & Gaveta & Estudos & \multirow[t]{2}{*}{ AP } \\
\hline & & & $\begin{array}{l}\text { Papel vegetal/nanquim } \\
6 / 6 \text { pranchas } \\
\text { Perspectiva a lápis AO }\end{array}$ & \\
\hline
\end{tabular}

Observações:

1. A Lista de projetos foi feita com base no curriculum de PMR, do levantamento de desenhos nas 4 mapotecas do escritório, nos tubos e nas caixas de papelão.

2.Ainda não foram feitos os levantamentos dos desenhos do arquiteto nos escritórios parceiros. 